UNIVERSIDADE DE SÃO PAULO

FACULDADE DE FILOSOFIA, LETRAS E CIÊNCIAS HUMANAS

DEPARTAMENTO DE LETRAS MODERNAS

PROGRAMA DE PÓS-GRADUAÇÃO EM LITERATURA ALEMÃ

\title{
ICONOFOTOLOGIA \\ DO BARROCO ALEMÃO
}

Antônio Jackson de Souza Brandão

Tese apresentada ao Programa de Pós-Graduação em Literatura Alemã, do Departamento de Letras Modernas da Faculdade de Filosofia, Letras e Ciências Humanas da Universidade de São Paulo, para obtenção do título de Doutor em Letras.

Orientadora: Prof ${ }^{\mathrm{a}} \mathrm{Dr}^{\mathrm{a}}$ Claudia Sibylle Dornbusch 


\section{Photo}

Lá está ela

na parede:

estática, imóvel, silenciosa...

Que bela!

Sou eu mesmo? Não creio ainda...

Como mudei!/ A pele lisa murchou

o cabelo negro

embranqueceu...

A sombra naquela parede/ é a mesma d'agora!

Agora... eu a vejo/ como me viu o fotógrafo outrora...

Mesmo ângulo,/ mesmo jeito... Meu irmão atrás brincando,/ minha mãe sorrindo, meu pai sentado,/ minhas tias...

Sou eu?!

Que festa naquele dia!/ Roupa nova, cabelo com brilhantinal tinha se ido a escarlatina...

Te olho agora/ buscando-me em ti: As lágrimas escorrem:/ sinto-te festa! sinto a alegria...

Foi-se a monotonia./ Da parede a tiro levo-a ao peito,/ me deito a contemplar-te agora: Por que choras? pergunta-me o eu ali/ estampado.

Receio responder. Calo-me.... Uma lágrima cai,/ sinto um ai! que sai do peito. Por que choro? Não sei.

Talvez porque ela esteja amarelada e eu... estou indo embora pra...?

Sei lá ... outra quimera.

São Paulo, 1/3/1992

(Brandão, 2001, p. 29) 
Dedico este trabalho:

a Deus que me deu coragem, saúde e persistência de levá-lo a cabo;

a Maria do Socorro de S. Brandão, minha mãe, que me ensinou o que é ter gana e lutar por aquilo em que se acredita;

a Gerardo Gomes Brandão, meu pai, que me abriu os olhos e o amor à fotografia, quando em nossas andanças;

à Emmanuelle Maria e à Isabella Maria, minhas filhas, pelo tempo que não Ihes dediquei durante sua execução;

à Vanessa Cassola, minha mulher, quando soube agüentar minhas noites perdidas com a pesquisa, além da contribuição inestimável no final;

a meus irmãos Ana Kátia e Geraldo pela constante confiança. 
Agradecimentos especiais a:

Claudia Sibylle Dornbusch por mais esse apoio, confiança e amizade acadêmica;

Mayra Rodrigues Gomes por suas ponderações;

Selma Meireles por seus apontamentos;

Walter König pelo valioso material oferecido. 


\title{
RESUMO
}

A presente Tese propõe uma nova abordagem da leitura de textos do período conhecido por Barroco e, para isso, fez-se necessário criar novos termos que correspondessem a essa expectativa: a iconofotologia e poemas fotográficos. Para que um leitor contemporâneo possa ler e compreender textos daquele período, teria de ter acesso a uma chave sígnica a que somente os leitores do Barroco tinham acesso: as iconologias. No entanto, esse referencial se perdeu, por isso temos de substituí-lo por um outro, a partir do acervo imagético-fotográfico de que dispomos hoje e que chamamos de iconofotológico. A partir dele, será possível lermos, sob o ponto de vista contemporâneo (não sob o ponto de vista seiscentista), os poemas que denominamos fotográficos.

\section{PALAVRAS-CHAVE}

Iconofotologia, poema fotográfico, Barroco alemão, iconologia, gênero emblemático

\begin{abstract}
The present Thesis intends to give a new approach to the reading of texts from the period known as Baroque and, for that, it was necessary to create new terms that corresponded to this expectation: the iconophotology and photographic poems. In order to enable a reader to read and understand texts of that period, he would have to have access to a signical key to which only readers of that moment had access: the iconologies. However, such reference has been lost; therefore, we have to replace it by another one, from the imagetic-photographic collection we have, which is called iconophotological. With this premise, it will be possible to read, under the contemporary point of view (not under the baroque point of view), the socalled photographic poems.
\end{abstract}

\section{KEY-WORDS}

Iconophotology, photographic poem, german Baroque, iconology, emblematic genre 


\section{SUMÁRIO}

\section{Parte I}

I. Prolegômenos para a Tese de doutoramento....................................... 8

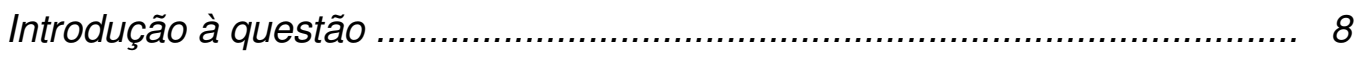

Do corpus e do método epistemológico ……………………………......... 29

Levantamento da questão ...................................................................... 33

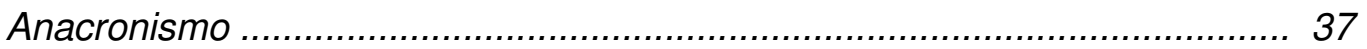

A técnica e a arte: a té $\chi v \eta$................................................................... 40

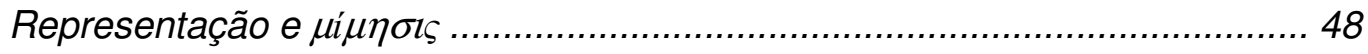

Imagem: zik

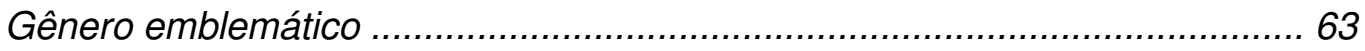

Aspectos da linguagem fotográfica ........................................................ 75

O $\lambda o ́ \gamma o \varsigma$ e a especificidade da linguagem poética ........................................... 92

II. Representação imagética no século XVII: leitura e interpretação ...... 104 Leituras pré-iconográfica, iconográfica e iconológica ................................ 104

\section{Parte II}

III. Constituição de um modelo iconofotológico .................................... 210

Rompimento do modelo epistemológico mimético ................................... 210

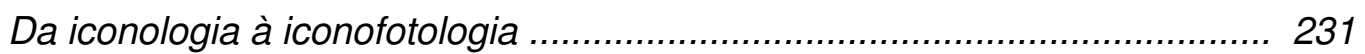

De um modelo iconofotológico ao poema fotográfico ................................ 270

IV. Da pintura à fotografia: encetamento do poema fotográfico ................ 290

Das iconologias paradigmáticas a uma iconofotologia particular ................ 290

V. Leituras iconofotológicas a partir da poética barroca alemã ............... 323

Guerra

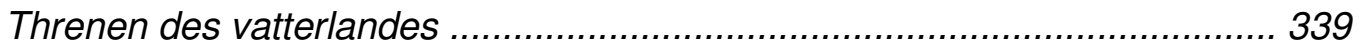

Catástrofes ................................................................................... 401

Die auff ein starckes Ungewitter erfolgte Stille ........................................ 401

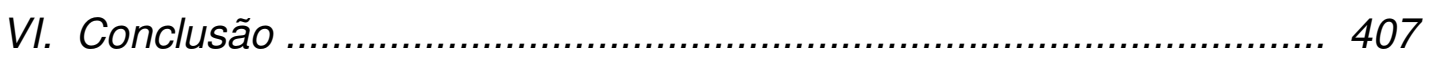

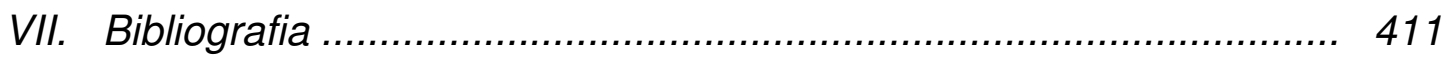

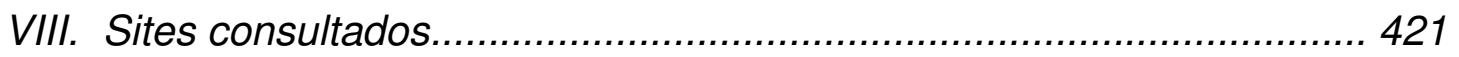




\section{PARTE I}




\section{PROLEGÔMENOS PARA A TESE DE DOUTORAMENTO}

Introdução à questão

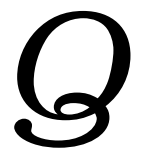

uando se diz que o futuro chegou com o século $X X I$, talvez possamos ter uma sensação semelhante a que passou o homem do final do século XIX em relação ao conceito de modernidade e a noção de velocidade. Em poucos anos, aquelas pessoas saíram da carruagem para vislumbrar as locomotivas e praticamente o primeiro vôo do avião: as distâncias se encurtaram e o mundo tornava-se cada vez menor. Houve também algo parecido em relação à reprodutibilidade da imagem, cuja fixação, por meio da $\tau \dot{\varepsilon} \chi v \eta^{1}$ - agora via fotografia -, começa a prescindir do pintor, levando-nos a uma posterior revolução no campo das artes pictóricas no século $\mathrm{XX}$, com os movimentos de vanguarda. Contudo, não se deve crer que os artistas plásticos, já no Renascimento, também não empregassem a própria $\tau \dot{z} \chi v \eta$ na reprodutibilidade imagética.

Isso fica claro quando, em 1435, Leon Battista Alberti expõe, em seu De pictura, justamente os mecanismos técnicos para se obter a ilusão de profundidade e de perspectiva por meio do intersector, um dispositivo criado por ele. Tal método transformou a arte ocidental e disseminou-se por toda a Europa, apesar de não ter sido esse o único procedimento desse tipo, já que muitos outros foram utilizados para esse fim, como a câmara escura. O pintor poderia, a partir dela, descobrir uma nova forma de ver a realidade, além de aprimorar sua busca por realismo, alcançado no período por meio das leis matemáticas da perspectiva linear; quando, a partir de um plano bidimensional, a pintura adquire a ilusão de um espaço tridimensional ${ }^{2}$. Dessa forma, e devido

\footnotetext{
${ }^{1}$ Quando nos referirmos à técnica com a acepção normalmente empregada hoje - sinônimo de tecnologia, resultado tecnológico - empregaremos o termo correspondente em português, técnica; quando seu emprego, porém, for em seu sentido mais abrangente, a partir da designação dos gregos como arte manual, habilidade (manual ou em coisas do espírito), conhecimento teórico, método, artifício, obra artística, tratado sobre arte, empregaremos o termo $\tau \dot{z} \chi v \eta$ (téchne).

${ }^{2}$ Alberti via na perspectiva um método infalível para a representação do visível. $A$ identidade entre o visível e o verdadeiro, refletia perfeitamente o espírito científico renascentista. A pintura deve formar-se como uma "janela" onde o espaço é enquadrado segundo princípios
} 


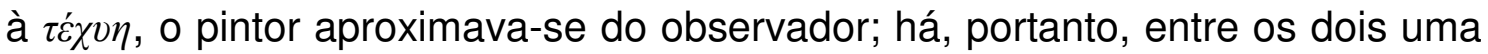
relação de intersubjetividade, quando este toma o lugar daquele e

se reúnem e partilham do mesmo olhar, a mesma relação entre o real e a imagem (...) e o mesmo tempo - uma passagem organizada entre o passado e 0 futuro a partir do eixo do presente. (Cf.: Couchot, 2003, p. 31).

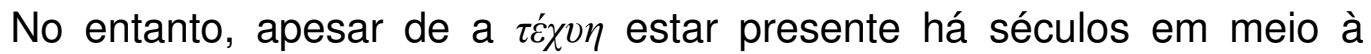
expressão artística, o advento da fotografia, por exemplo, nessa mesma esfera suscitou grandes polêmicas em alguns de seus membros. Baudelaire foi uma dessas vozes, pois via na fotografia uma imagem trivial e anteviu nela a supressão ou mesmo o corrompimento de algumas formas de arte (ibidem, p. 23) como a pintura, apesar de ele mesmo ter bebido dessa fonte. (Cf. Krauss, 2000 , p. 19) Flaubert, por sua vez, chamava Madame Bovary de um "retrato daguerreótipo da sociedade"; Zola, Georges Rodenbach, Breton, só para citar alguns, também utilizaram a fotografia direta ou indiretamente em parte de suas obras (Cf. Amelunxen, 1995, p. 225):

Die Literatur der Moderne seit Baudelaire ist wesentlich vom photographischen Dispositiv markiert, vieles ist in der Forschung des letzten Jahrhunderts bearbeitet worden, vieles liegt nach wie vor mangels methodologischer Prämissen brach. (Ibidem, p. 225)

[A Literatura do Modernismo, desde Baudelaire, é marcada, sem dúvida, pelo dispositivo fotográfico, muito foi trabalhado em pesquisa no último século $[X I X]$, porém muito ficou por fazer por falta de premissas metodológicas]

Baudelaire tinha sua razão: há mais de um século, dispensamos o serviço dos artistas plásticos e seu monopólio sobre a arte mimética; além disso, os reflexos da fotografia não se fizeram sentir somente na arte pictórica, no ulterior cinema, como também no habitus perceptivo do próprio homem. (Cf. Couchot, p. 33) A própria

literatura, por sua vez, também não deixou de sofrer os efeitos dessa revolução onto-iconológica que atingiu as imagens (...)? (Guimarães, 1997, p. 23)

quantitativos que diminuem a função discursiva em favor da autonomia do figurativo. (Schøllhammer, 2001, p. 35) 
Contudo, essa revolução de per si não é nenhuma novidade para o homo sapiens, visto que o domínio imagético é a origem do próprio homem enquanto ser racional. Assim, quando ele apreende e domina a utilização da imagem em benefício próprio, desenvolve suas habilidades intelectuais para poder nomear os elementos da natureza. Dessa forma, as próprias imagens possibilitariam, a posteriori (segundo a visão kantiana), a criação dos inúmeros sistemas lingüísticos existentes, não só para serem meras imagens em nossa consciência, mas para que pudessem ser fixados e corporificados a partir de elementos naturais via $\mu i ́ \mu \eta \sigma \varsigma$ (mímesis). Inicialmente, essas imagens restringiam-se a meros indícios rupestres que foram reestilizados, dando origem a imagens distintas daquelas primitivas que buscavam representar. Ocorre, portanto, a desaparição necessária daquilo que a funda, pois o traço de representação primeiro foi sendo elidido para tornar-se pura representação. (Cf. Foucault, 1966, p. 33) Com a escrita fonética - abstração total dos elementos da natureza por meio da consciência humana - o homem tem o domínio pleno do $\lambda o ́ \gamma o \varsigma$ (lógos) que dele se origina e se encarna em qualquer superfície que seu criador queira. No entanto, o eu estava fadado a não poder fugir mais de sua própria imagem e daquelas que criaria, como na construção de um texto:

Na medida em que o leitor cria os objetos da representação e constitui o sentido do texto (não de forma arbitrária, pois o processo de leitura é orientado pelas condições esquematizadas pelo texto, para a constituição do objeto imaginário) cria simultaneamente a si mesmo: o próprio sujeito-leitor é constituído nesse processo, já que é afetado pelo que produz. A leitura, nos diz magistralmente Wolfgand Iser, demonstra o quão pouco o sujeito é algo "dado", a leitura permite o "tornar-se consciente do sujeito". (Farinaccio, 2004, p. 19)

Resta ao homem, agora, reconhecer-se frente a um espelho, ter a consciência de saber quem é, de quem ou o que está a seu lado e, mais do que isso: ter a consciência de sua mortalidade, de sua finitude - cuja expressão artística é a noção de vanitas, que veremos posteriormente. Dessa 


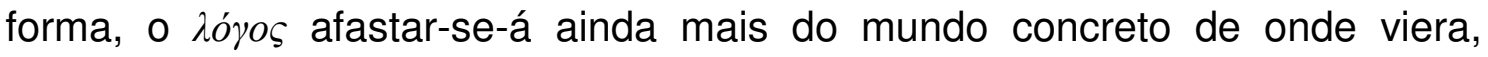
permeando-se de abstrações, com as quais o homem criaria um mundo mítico:

A palavra grega mythos (...) significa narrativa e, portanto, linguagem. Trata-se da palavra que narra a origem dos deuses, do mundo, dos homens, das técnicas (o fogo, a agricultura, a caça, a pesca, o artesanato, a guerra) e da vida do grupo social ou comunidade. Pronunciados em momentos especiais - os momentos sagrados ou de relação com o sagrado -, os mitos são mais do que uma simples narrativa. São a maneira pela qual, através das palavras, os seres humanos organizam a realidade e a interpretam. O mito tem o poder de fazer com que as coisas sejam tais como são ditas ou pronunciadas. (Chauí, 2000, pp. 137-138)

Com o mito, o homem cria a poesia, para explicar aquilo que sua ratio não conseguia explicitar; e, exatamente, por tentar demonstrar o indemonstrável, a poética vai diferenciar-se da linguagem corrente ${ }^{3}$, da objetividade do fluxo normal do mundo seja por meio de metáforas ${ }^{4}$, alegorias ${ }^{5}$ e musicalidade ${ }^{6}$ próprias; mantém-se, portanto, indiferente à linguagem em que se manifesta, demonstrando sua relação com o sacro: o próprio $\lambda o ́$ jos, para muitas civilizações, era somente utilizado pela casta sacerdotal, não visava à reprodução da realidade tão-somente, mas à verdade, tal como vemos na Bíblia. (Cf. Auerbach, 2004, p. 11)

O poeta sabe do poder que tem em suas mãos e para que essa verdade seja possível, despeja-nos, continuamente, imagens em seus poemas para que possamos viajar para outros mundos. Estes podem ser terras longínquas ou aquilo que temos arraigado dentro de nós mesmos, quando, por meio de sua evocação imagética, à semelhança de uma volição feérica, emergem de nossos pensamentos mais escondidos, pois

\footnotetext{
${ }^{3}$ Carone nos diz que isso é devido ao fato de que o poeta, ao fazer uma operação intelectual no caso o poetar - emprega uma expressão imprópria no lugar de outra por ele próprio já vivenciá-la metaforicamente. Dessa forma, o poeta não consegue submeter-se a nenhuma linguagem estabelecida, na medida em que a maneira dos outros não coincide com a sua. (Cf.: Carone, 1974, p. 38)

${ }^{4}$ Que, juntamente com os tropoi, liberam a carga poética que o mundo esconde e que a prosa mantém cativa. (Cohen, 1978, p. 43)

${ }^{5}$ Que veiculam idéias não de objetos e pessoas concretos e individuais (...), mas de noções gerais e abstratas como Fé, Luxúria, Sabedoria etc. (Panofsky, 2004, p. 51)

${ }^{6}$ Os acentos e as pausas constituem a parte mais antiga e mais puramente rítmica do metro; estão ainda próximos da pancada do tambor, da cerimônia ritual e dos calcanhares dançantes que batem no chão. (Paz, 2005, p. 15)
} 
As palavras, recorda Blondel, conservam no seu étimo e as frases guardam na sua estrutura resíduos da própria substância do pensamento, resíduos trazidos em metáforas, símbolos, alegorias e outros expedientes pitorescos da imaginação. Tais resíduos são esboços diversos de interpretações do mistério do pensamento. (Figueiredo, 1973, p. 94)

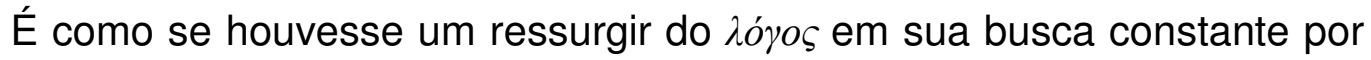
sua origem, quando ainda era efeito mimético puro da abstração primeira da natureza. Há, dessa forma, uma relação intrínseca entre a imagem e a palavra escrita: ambas provêm de uma fonte comum, a natureza, via $\mu i ́ \mu \eta \sigma \varsigma$, além de serem formas pessoais de ver o mundo e a realidade que nos cercam. Talvez resida exatamente aí o fato de a palavra escrita ser mais visual e tangível que a palavra acústica, exercendo um maior fascínio nas pessoas devido a sua materialidade. Saussure nos mostra, inclusive, que ela goza desse prestígio em relação à sua forma falada justamente por constituir-se de um objeto permanente e sólido, afinal as impressões visuais são mais nítidas e duradouras que as acústicas ${ }^{7}$. (Cf.: Saussure, 2006, p. 35)

A cultura seiscentista soube muito bem utilizar esses dois expedientes a relação iconológica - de forma ímpar, a ponto de sua utilização constituir um modelo epistemológico, permeando o pensamento europeu por meio de um gênero próprio: a emblemática (com suas modalidades: o emblema, a empresa, o hieróglifo, a divisa).

Utilizando meios plásticos, a cultura do século XVII pôde alcançar, com maior adequação, seus objetivos de propaganda. (...) se a arte da época se encontra animada por um espírito de propaganda e (...) a imagem é um recurso eficaz, é possível sustentar, como Argan, que "não se tenta conceituar a imagem, mas dar o conceito feito imagem"; isto é, proporcionar-Ihe a força, não mais demonstrativa, mas de apelo prático que é próprio da imagem. (Maravall, 1997, p. 389)

Por isso podemos dizer que em cada imagem poética dos Seiscentos haveria um emblema potencial, as pessoas daquele momento sentiam grande necessidade de explicar a palavra por meio de uma representação plástica (Cf.:

\footnotetext{
${ }^{7}$ A partir do Renascimento, pois a audição era o sentido predominante na Idade Média.
} 
Praz, 1989, p. 18), normalmente de forma alegórica, à moda dos hieróglifos egípcios que tinham de ser interpretados para que pudessem ser compreendidos; por isso hoje, quando se lêem poemas do Seiscentos, além do aparente estranhamento por eles transmitidos, devido ao anacronismo, devemos nos questionar se podemos acreditar que as imagens as quais evocam poderiam corresponder - ou não - àquelas sentidas e vivenciadas por um eu lírico, se não verdadeiras - um mero fingimento poético -, pelo menos hipotéticas, afinal poderiam, efetivamente, acontecer.

No entanto, quanto mais nos aprofundamos na poética daquele período, verificamos que o conceito estético de criação - calcada na expressão dos sentimentos do eu-, como nós o conhecemos hoje, era desconhecido pelos autores do Seiscentismo. Isso é fundamental para que possamos compreender esse período tão peculiar do gênero artístico humano:

Para nós o valor de uma obra reside em sua novidade: invenção de formas ou combinação das antigas de uma forma insólita, descoberta de mundos desconhecidos ou exploração de zonas ignoradas nos conhecidos; revelação, surpresas (...). Desde o Romantismo a obra há de ser única e inimitável. A história da arte e da literatura se desdobra como uma série de movimentos antagônicos: Romantismo, Realismo, Naturalismo, Simbolismo. Tradição não é continuidade e sim ruptura (...). (Paz, op. cit. pp. 133/134)

Dessa forma, nossa leitura é, evidentemente, diversa da leitura daquele período e de sua intencionalidade. Nosso conceito de arte é totalmente diverso, pois enquanto para nós a criação artística está voltada à expressão, cuja autonomia e individualidade são imprescindíveis; para os artistas do período conhecido por Barroco o mais importante era o conceito mimético; logo, a arte estava encapsulada na rigidez e na mecanicidade da pura imitação, cuja meta era a emulação.

É mais do que conhecida a tendência que havia no Humanismo de resgatar a Antigüidade clássica ${ }^{8}$. Apesar de esse resgate ter sido buscado em todas as artes - na poética, na arquitetura e na pintura -, ele não foi de todo

\footnotetext{
${ }^{8}$ Deve-se ter em mente, contudo, que tal resgate não foi exclusivo desse período, já que se deu durante grande parte da Idade Média, como veremos.
} 
possível, pois enquanto haviam chegado àquele momento muitos tratados retóricos e poéticos, aqueles que versavam sobre as artes plásticas, como a pintura, praticamente inexistiam. Dessa forma, a arte pictórica precisou se

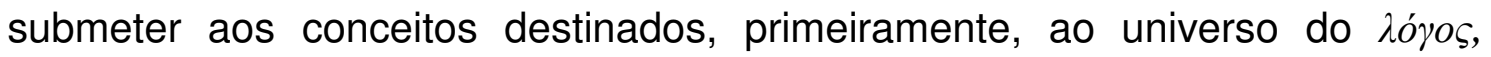
iniciando, portanto, a dependência da pintura em relação à poesia e a sua conceitualização imagética. Dessa forma,

o pintor se submete à tutela do logos em diversos âmbitos: como tradutor intersemiótico de conceitos da retórica e da poética (...) como teórico e realizador de uma pintura voltada (...) [à] representação da narração, isto é, do logos (...); deve ser um pictor doctus, cópia do doctus poeta (erudito, com uma larga bagagem de leitura): sem essa erudição ele não poderia corresponder à doutrina do decorum (...). [Ele] está submetido a um rigoroso código de regras sociais, de âmbito moral, político e religioso. (...) A pintura torna-se ilustração, um meio didático de atingir de modo mais imediato e descomplicado o que a escrita não consegue realizar; basta lembrar do papel fundamental atribuído a ela na era da Reforma e da Contra-Reforma. (Seligmann-Silva, in Lessing, 1998, p. 11)

Havia, portanto, nos Seiscentos, uma relação muito profunda entre a

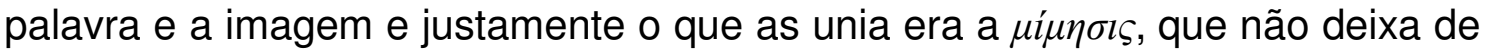
ser tradução, afinal um quadro era para ser lido, bem como um poema deveria ser visualizado, ou como disse Simônides de Ceos (557 a.C. - 467 a.C.): "A pintura é uma poesia muda; a poesia, uma pintura que fala". Dessa forma, há na concepção renascentista de arte - vista como $\tau \dot{\chi} \chi v \eta$ - a clara idéia de que todas as artes partem de um único pressuposto, a $\mu i \mu \eta \sigma ı \varsigma, ~ t e m o s, ~ p o r t a n t o$, uma transcodificação. É esse o momento em que há a preponderância do gênero emblemático cujo ápice se dá, justamente, no século XVII.

Apesar de a normatização da pintura ter sido calcada na do $\lambda o ́ \gamma o \varsigma, e$ aquela ser considerada inferior a este, o desenvolvimento da arte pictórica levou seus expoentes também a procurar fazer parte das chamadas artes liberais (ars liberae). A pintura quer deixar de ser a sombra da poesia e passa a procurar seu próprio espaço. Os pintores, no Renascimento, buscam, portanto, sua auto-afirmação, visto que, mesmo na Antigüidade - cuja estrutura social era escravocrata - persistia o preconceito em relação às ars mechanicae. Da 
Vinci foi um dos primeiros a querer inverter esta ordem estabelecida, a da preponderância da poesia sobre a pintura, afirmando que a imagem pictórica conseguia chegar mais rápido a seu objetivo de transcodificar uma idéia da natureza, via $\mu i ́ \mu \eta \sigma l \varsigma$, do que a leitura com a $\varepsilon v \alpha \dot{\alpha} \rho \varepsilon \varepsilon \alpha^{9}$ (enargeia, evidentia para os romanos). Verificar-se-á, posteriormente, uma mudança gradativa nessa vinculação, pois a partir do escopo técnico de algumas pinturas, alguns poetas passariam não só a imitar como também a emular os pintores (Cf.: Praz, 1982, p. 4), apesar de, em pleno Renascimento, a pintura ainda ter como mote o

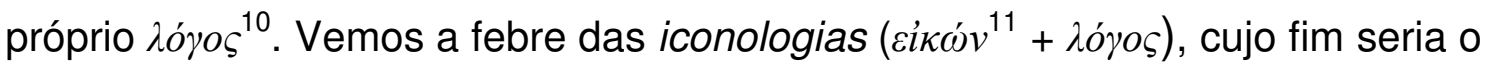
de despertar, naqueles que liam os quadros, as palavras que nelas estavam

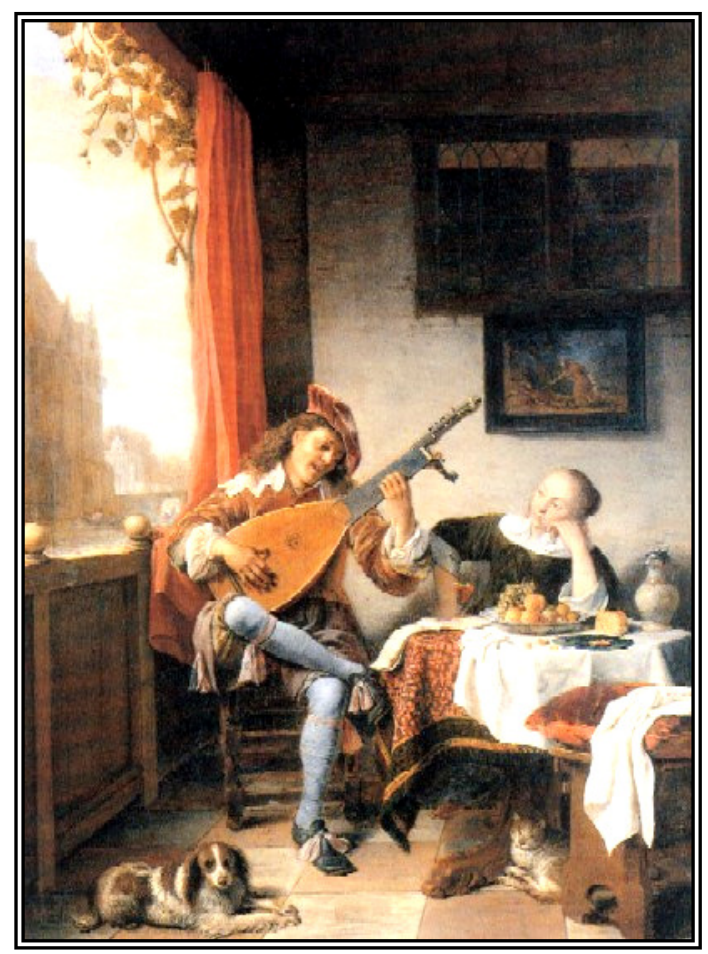

Figura 1 O tocador de alaúde, de Hendrick Sorgh , 1661. contidas, afinal

(...) a pintura quer ser lida, traduzida em comentários; quer voltar a ser texto. (Seligmann-Silva, op. cit. p. 11)

Evidencia-se, portanto, o preceito do ut pictura poesis ${ }^{12}$ que procurava exatamente estabelecer parâmetros nessa relação de tradução/comparação entre as artes.

O significado/emprego imagético que chegou a meados do século XVIII consistia numa convenção retórica a qual somente alguns iniciados aristocracia, membros do alto clero e, evidentemente, os artistas - saberiam decodificar. Dessa forma, seria

\footnotetext{
${ }^{9}$ A $\varepsilon v \alpha ́ \alpha \gamma \varepsilon l \alpha$ tinha por objetivo fazer do leitor uma espécie de espectador e produzir, vivamente, naqueles que se interessavam pela leitura os mesmos sentimentos que foram sentidos por quem esteve presente a um determinado acontecimento, ou seja, "por diante dos olhos".

${ }^{10}$ Carlos Ginzburg, por exemplo, mostra-nos a influência da obra de Ovídio na pintura de Ticiano que não a lera, provavelmente, no original, mas em vernáculo. (Cf.: Ginzburg, 1981, pp. 124-140)

11 Eikon.

${ }^{12}$ Esse preceito foi retirado de um verso de Horácio: Poesia é como pintura (ut pictura poesis); uma te cativa mais, se te deténs mais perto; outra, se te pões mais longe; esta prefere a penumbra; aquela quererá ser contemplada em plena luz, porque não teme o olhar penetrante do crítico; essa agradou uma vez; essa outra, dez vezes repetida, agradará sempre. (Horácio, 1981, p. 61)
} 
imprescindível o conhecimento de alguns teóricos - e de seus manuais - para que fossem fornecidas as pistas para esclarecer sua acepção e seu emprego: Horapolo, Alciato, Pierio Valeriano, Cesare Ripa, Laureatus, entre outros, afinal o homem do século XVII não se contentava apenas em apreciar imagens, queria torná-las hieróglifo, amalgamando-as à palavra de forma a materializar aquilo que Simônides de Ceos prognosticara. Além dos teóricos, de suas iconologias e livros de emblemas, a Bíblia também desempenharia, do mesmo modo, um papel preponderante na formação do corpus imagético do período: é dela, do $\lambda o ́ \gamma o \varsigma$ sagrado ali inserido/ emanado, de onde advém a visão teológica do mundo que nos impele a lê-la não como realidade, mas como verdade, chegando, inclusive, a utilizar de tirania. (Cf.: Auerbach, op. cit. pp. 10-12) Diante disso, pode-se compreender a noção do divino no âmago das pessoas dessa sociedade, para quem não se poderia esquecer de que Deus, para exercitar nossa sabedoria, semeou na natureza sinais que devemos decifrar (Cf.: Foucault, 1966, p. 55); ou como dizia Plotino: o mundo é a poesia de Deus (Cf.: Praz, 1989, p. 22), portanto caberia ao homem ler os sinais existentes não só no meio em que estavam inseridos como também na natureza que o cercava $^{13}$.

Apesar de a ação de Deus na sociedade humana ter sido relegada à simples fabulação, pelo menos para os iluministas, o poder imagético não perdeu sua força ${ }^{14}$; no entanto, o conceito de $\mu i \mu \eta \sigma \iota \varsigma$ passará a ser questionado e vai, pouco a pouco, sendo relegado, o que se processou de forma lenta e sucessiva desde o século XVIII e meados do XIX: não se aceitaria mais a

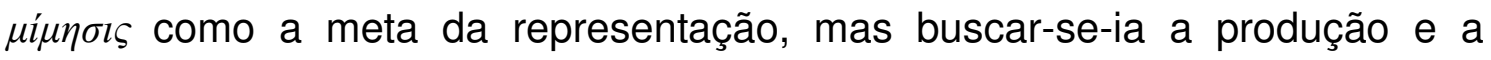
reprodução do espírito (Cf.: Duarte, 2001, p. 289) como refletiam os românticos alemães. Não se quer dizer com isso que a sociedade pós-romântica tenha se alijado das imagens ou que o mesmo tenha ocorrido em nossa sociedade: a diferença essencial é que as mesmas não mais passariam preceitos, juízos ou moralidades, afinal o ancien règime e sua rigidez social não existiam mais.

\footnotetext{
${ }^{13}$ No século XVII há o rompimento com divinatio do signo, ou seja, "se Deus ainda utiliza de sinais para nos falar através da natureza, serve-se de nosso conhecimento e dos nexos que se estabelecem entre as impressões para instaurar no nosso espírito uma relação de significação". (FOUCAULT, 1966, P. 87)

${ }^{14}$ As imagens podem não ter perdido sua força, no entanto, a Era de la Razón desdeño por absurdas las imágenes misteriosas. El acento ya no recae en el mensaje de misterio sino en el mensaje de la belleza (Ripa, 1987, p. 21), chega-se ao fim as imagens alegóricas e alegorizantes, o ciclo do gênero emblemático encerra-se.
} 
É manifesto que a influência imagética não tenha sido ignorada por nossa realidade contemporânea, como demonstra a grande preocupação com a imagem no início do século XX. Esta, no entanto, não só deixara de estar voltada à mera $\mu i \mu \eta \sigma \iota \varsigma$ (fig. 1), como também a estilhaçara por completo (fig. 2). A imagem pictórica, por exemplo, não teria mais como abandonar a imiscuição proporcionada pela imagem fotográfica. Poder-se-ia, inclusive, indagar que, à semelhança das iconologias dos séculos $\mathrm{XV}$ ao XVII, necessitaríamos também nós de compêndios ${ }^{15}$ para a interpretação dessas novas imagens pósfotográficas, exatamente porque não seria mais possível a instantaneidade na decodificação das mensagens pictográficas da arte moderna. Como essa não era prontamente decifrada pelo receptor, este, muitas vezes, a considerava uma não-mensagem, uma não-arte. Para os vanguardistas, a velocidade (Futurismo), a decomposição (Cubismo), a distorção (Expressionismo), o niilismo (Dadaísmo) ou a exploração do onírico e do inconsciente (Surrealismo) eram mais importantes do que a $\mu i \mu \eta \sigma \iota \varsigma$ da realidade visível. À semelhança de uma criança que começa a descobrir o corpo lentamente, parte a parte, a arte pictórica, finalmente, se volta para seu próprio aparato; descobre-se inteira quando se volta para si mesma, para suas próprias possibilidades e isso fica claro na incipiência desses movimentos vanguardistas, quando se tinha a impressão de que a arte só pretendia chocar, não transmitir dados e informações segundo os critérios da arte acadêmica. É exatamente esse choque que levava a uma tomada de consciência, fosse ela positiva (aceitando e renovando a arte) ou negativa (criticando e rebelando-se contra esse fazer artístico), ou seja, nunca levava a uma atitude passiva de apenas receber e decodificar o indecodificável, por mais obscuro que parecesse.

Não teria sido esse aparente obscurantismo da arte moderna o start para a redescoberta da arte barroca e da aproximação e interesse dos modernistas pela arte dos Seiscentos, também conhecida por ser obscura,

\footnotetext{
15 Evidentemente, não como a normatização do Classicismo, mas de uma forma intelectualizada e a que somente alguns membros da burguesia dominante teriam acesso, pois para o povo a arte moderna não representava arte: era-lhe ininteligível. A arte dita acadêmica prescindia de explicações para sua compreensão, no mais poder-se-ia perguntar o porquê de se utilizar essa ou aquela figura - representantes do povo em seus trabalhos diários, por exemplo; o mesmo não poderia ser dito da arte modernista, o que para muitos não era arte, ou como era dito no nazismo, uma arte degenerada.
} 
impermeável e inacessível, à semelhança da arte de vanguarda do início do século XX (fig. 2)?

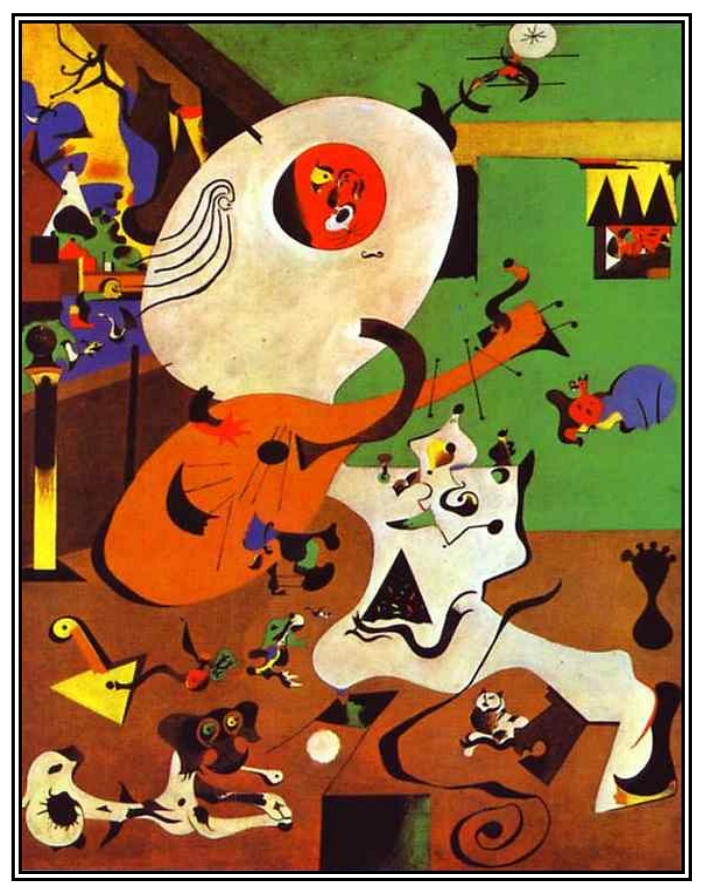

Figura 2: Interior holandês, de Joan Miró, 1928.

Baudelaire realmente tinha razão quando previra que a fotografia acabaria destituindo o pintor de seu papel de mentor do poder imagético, entretanto foi exatamente essa destituição que levou a arte pictórica a buscar uma nova mudança para que pudesse sobreviver, levando o artista a responder à trivialidade fotográfica (segundo o poeta francês) com a singularidade e com a novidade estética. Pode-se vislumbrar, dessa forma, um desenvolvimento contínuo na arte pictórica.

Contudo, decodificar o indecodificável já não interessa ao homem do século XXI. A mensagem imagética de hoje tem de estar em sua própria superfície, para que possamos compreendê-la em sua totalidade em apenas um relance, já não há mais tempo a perder com manuais, muito menos com literaturas consideradas ultrapassadas como a do Barroco. Hoje as imagens já têm de vir, praticamente, decodificadas para que os olhos do homem do século XXI não percam mais tempo; ou então, podemos dizer que elas são justamente o reverso disso: altamente codificadas, cristalizadas enquanto metáforas a ponto de não serem mais necessárias grandes reflexões acerca delas. No entanto, não se deve presumir que, sob o velame dessa despretensão, sejam facilmente decodificáveis, assim como o $\lambda o ́ \gamma o \varsigma$ que, eventualmente, as acompanham:

Quanto ao destinatário, ele não passa menos tempo a decodificar um slogan pelo fato de ser este mais curto; às vezes acontece o contrário. (Reboul, s/d, p. 46)

Estamos sob o domínio da velocidade sem limites e completamente inseridos na era da informação, afinal tudo nos é fornecido automaticamente: 
os dados chegam-nos a um clique do computador. Este se tornou um deus ex machina, pronto a nos auxiliar em todas as situações cotidianas por mais simples ou complicadas que possam parecer, mas que despendiam um tempo exageradamente longo (mesmo se a pretensão não fosse aprofundar-se no tema) com pesquisas devido à carência de informações para pessoas interessadas no assunto: basta pensar em uma simples consulta de dados a respeito de uma determinada doença, por exemplo. Na pré-internet, teríamos de ir a uma biblioteca para pesquisarmos, compilarmos e confrontarmos vários livros e publicações que, mesmo atualizados, estariam sempre defasados, quando conseguíssemos obter as informações necessárias! Além disso, o computador também revolucionou a relação do indivíduo com o coletivo, quando permitiu que este fornecesse àquele acesso ao mundo das informações via web, solucionando e minimizando cada vez mais o esforço humano. Ao modificar nossa relação com o coletivo, somos também influenciados, ou seja, o próprio indivíduo sofre transformações:

... o computador (...) não é mais meramente uma "máquina" à disposição do homem: ao revolucionar a práxis, ele não deixa, por conseguinte, de modificar nossa relação com nosso corpo, com nossa consciência individual e nossas relações com os outros. Um novo meio de comunicação de massa (...) implica a "modernização dos sentidos"; mudanças fundamentais da constituição do espaço/tempo e do que se entende por "subjetividade" conduzem, sem dúvida, a um redimensionamento profundo da cultura. (Farinaccio, 2004, p. 31)

Com o futuro e a enxurrada de novas transformações e aquisições provindas da técnica humana, mudaram-se vários conceitos e nossa forma de nos ver e interagir com o mundo que nos cerca. $O$ futuro chegou, basta pensarmos em um conceito e a internet faz o restante de forma quase instantânea em meio a bilhões de páginas a nosso dispor. É como se vivenciássemos um novo Quattrocento (Cf. Craia, 2003, p. 3), cuja revolução nos campos do saber humano foi tão intenso e operou profundas modificações sócio-econômico e culturais ${ }^{16}$. Que é, afinal, a informática, a nanotecnologia e a

\footnotetext{
${ }^{16}$ Em todos campos da $\tau \dot{x} \chi v \eta$ humana da filosofia, passando pela música, escultura, ciências, arquitetura e chegando à literatura e à pintura.
} 
genética senão a representação de um novo modo de ser, não mais o atributo de um deus ex machina, mas de um homo ex machina? E, assim como no Quattrocento italiano de Leonardo da Vinci, Botticelli e Rafael - os quais com o domínio das leis matemáticas inundaram a Europa com suas obras - suas imagens miméticas - e que levavam seus pares a ler nelas sinais diferentes daqueles que nós enxergamos; também nós, hoje, vemo-nos invadidos pelas imagens técnicas, sem as quais, provavelmente, ainda estaríamos longe de chegar ao futuro que tanto nos assombra pela rapidez dos acontecimentos, das imagens e das informações que temos diante de nós. $E$, para isso, foi imprescindível a gênese da imagem fotográfica, afinal foi ela que nos envolveu e dissipou a troca de informações, ao mudar nosso olhar frente ao mundo que nos cerca, afinal estávamos, desde o século $\mathrm{XV}$, sob o prisma da visão unilocular da qual nos libertamos.

Apesar do grande lugar ocupado pela técnica na sociedade, ela não é um fator determinante no campo artístico. A técnica predispõe, mas não determina, é preciso dizer e repetir. Uma nova técnica figurativa não conduz forçosamente a uma nova arte, mas faz surgir as condições para sua aparição. Ela modela a percepção, age sobre o imaginário, impõe uma lógica figurativa, uma visão de mundo. Mas no final das contas é ao criador somente que cabe exercer sua liberdade enquanto sujeito autônomo ante à autonomia da técnica, e de negociar entre o Nós e o $E U^{17}$. E essa liberdade se ganha. (Couchot, 2003, p. 19)

A partir daí, foi-nos possível ver o mundo com outros olhos, abarcá-lo e senti-lo multifacetadamente, abrindo-nos ao novo e encaminhando-nos em outras vias:

\footnotetext{
${ }^{17}$ Para Couchot, a atividade artística colocaria em jogo dois componentes do sujeito: de um lado, o sujeito-NÓS; de outro, o sujeito-EU. Aquele tende ao tecnicismo, à experiência tecnestésica; este, como expressão subjetiva, resiste ao tecnicismo, redefinindo sua própria identidade. Há neste embate um alargamento da noção de subjetividade que passa a ser não somente uma manifestação individual de um eu, egoísta ou narcisista, mas na sua oposição ao sujeito-NÓS, uma vez que não cessam de se afrontar, negociar, deslocar-se e de trocar de papéis. Cada arte (...) cada obra, corresponde a uma associação distintiva destes dois componentes do sujeito, uma tecnicidade figurativa e uma figura da subjetividade. (Ibidem, p. 17)
} 
(...) a representação não mais adota (...) as vias simbólicas do mito, do sagrado, da história, da linguagem, da cultura e da arte em que transitava e filtrava através do sujeito-EU, único senhor até então, da história. (Ibidem, p. 36)

Dessa forma, não mais interessa o deter-se, a observação e a análise seja da imagem ou da mensagem transmitida. Essas devem ser instantâneas, não há mais espaço para a reflexão e para a leitura: eis um dos paradigmas dos quais nos desprendemos, no futuro, em relação ao passado, quando deveríamos ler as mensagens inseridas numa imagem, para que obtivéssemos a totalidade de significações presentes nela.

Não se deve, no entanto, acreditar que tais mudanças são oriundas somente de nossos novos tempos loucos, visto que o próprio conceito de imagem mudou muito ao longo dos séculos, seja em seu conceito filosófico ${ }^{18}$ seja em sua expressão pictórica ${ }^{19}$. Ao referir-se à pintura, por exemplo, não se deve pensar em um pseudo purismo do trabalho artístico, quando um pintor num ato quase divino - retiraria do vazio sua criação sem nenhum apoio externo. Vimos que, na prática, não era assim que normalmente acontecia, pois desde o Renascimento, utilizava-se de instrumentos facilitadores e auxiliares ao olho humano, como a câmara escura, um dos fundamentos da fotografia, largamente utilizada pelos artistas durante os séculos XVII ao XIX para pintar paisagens.

En fin, desde el Renacimiento hasta bien entrado el siglo XIX puede comprobarse fácilmente un constante aumento en el empleo de medios auxiliares mecánicos, tendencia que encontró su auge en el siglo pasado [século XIX]. ¡Pero no sólo en la pintura! Existen bustos de principios del Renacimiento italiano que sin duda alguna fueron realizados a partir de vaciado en yeso de modelos vivos.

\section{(...)}

\footnotetext{
${ }_{18}^{18}$ Como se verifica na filosofia de Descartes, Leibniz, Humes, Husserl e Bergson.

${ }^{19}$ Ao longo dos séculos, houve momentos de oscilação e de perseguição da imagem tanto no Ocidente quanto no Oriente, entretanto tais ondas iconoclastas não conseguiram aboli-la, evidentemente, principalmente no Ocidente. Diversas culturas não admitiam nem admitem a utilização imagética em seus cultos à divindade, por exemplo. Para o Islamismo é proibido retratar o Profeta, da mesma forma os judeus sequer utilizam-se das vogais para indicar 0 nome de Deus, ou seja, nem mesmo a imagem verbal é-lhes permitida; mesmo no Cristianismo houve momentos de fúria contra as imagens, seja na Igreja Oriental, Ortodoxa, seja na Ocidental, a Romana, bem como nas protestantes, após o século XVI, conforme abordaremos adiante.
} 
En lo referente a la pintura, a partir del Renacimiento ha ido apareciendo todo un arsenal de aparatos ahorradores de trabajo y medios extra artísticos. De hecho, ya habría que incluir en este aparato a la perspectiva lineal, por lo menos en cuanto construida. (...) Y Giovanni Della Porta (1535-1615), por fin, recomienda para el dibujo el empleo de la cámara oscura. Son innumerables los que la han empleado desde entonces, con el fin de 'calcar' con su ayuda a la naturaleza (...). Los tecnólogos de la época, como Friedrich Risner y Athanasius Kircher (1602-1680), proporcionaron nuevos modelos de cámara oscura portátil. $Y$ desde 1657 incluso existe una manejable camera-box con dispositivo reflex. (Stelzer, 1981, pp. 16-17)

Vive-se, hoje, a dinamicidade sem precedentes dos meios de comunicação e da propagação da informação, cujo apogeu é, exatamente, a

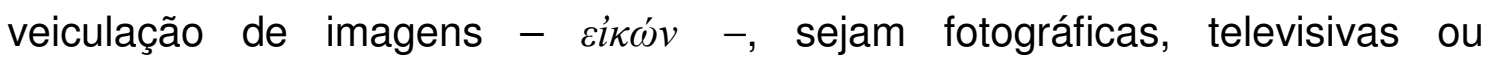
transmitidas por outros gêneros midiáticos. A televisão com suas imagens, por exemplo, não só acompanha os conflitos armados in loco, como também os transmite ao vivo. As fotografias, por sua vez, que antes se restringiam ao estúdio, chegaram à digital e agora são enviadas em segundos até mesmo por um aparelho celular; sua impressão - agora sequer se fala em revelação, já que esta se dá na hora, não é mais necessário o laboratório como intermediário - está ao alcance de todos e em casa.

A imagem técnica inunda todos os níveis da vida humana contemporânea e se difunde por grande parte das mídias presentes hoje, a ponto de ter imposto transformações profundas tanto nas formas de percepção e de sensibilidade humanas quanto em sua representação literária e pictórica. (Cf. Benjamim, 1985, passim) Cercados cada vez mais por uma grande quantidade de imagens, hoje é possível captá-las em tempo real a qualquer momento e em qualquer lugar, basta para isso apenas um clique, seja de uma câmera fotográfica, ou mesmo de um telefone móvel. Estes podem transmitir imagens em frações de segundos para qualquer parte do mundo - a imagem técnica impressiona-nos por sua velocidade de pensamento -, mas é justamente aí que reside sua efemeridade, sua condição imediatista, que fazem sua banalidade; não temos nenhum compromisso com elas, portanto são logo esquecidas. Talvez resida aí a trivialidade antevista por Baudelaire. No entanto, foi, entre outros aspectos, devido à imagem fotográfica que o século $X X$ 
vislumbrou uma revolução no campo das artes pictóricas, traduzidas pelos movimentos de vanguarda como o Impressionismo, Cubismo, Expressionismo, Dadaísmo, Surrealismo: a arte não está mais atrelada só a representações figurativas ${ }^{20}$. Picasso, por sua vez, assim se manifestou a respeito da relação processo/resultado fotográfico e artes pictóricas:

Quando você vê tudo o que é possível exprimir através da fotografia, descobre tudo o que não pode ficar por mais tempo no horizonte da representação pictural. Por que o artista continuaria a tratar de sujeitos que podem ser obtidos com tanta precisão pela objetiva de um aparelho de fotografia? Seria absurdo, não é? A fotografia chegou no momento certo para libertar a pintura de qualquer anedota, de qualquer literatura e até do sujeito. (Picasso, apud Dubois, 2006, p. 31)

Vê-se, portanto, o rompimento do conceito de imagem -

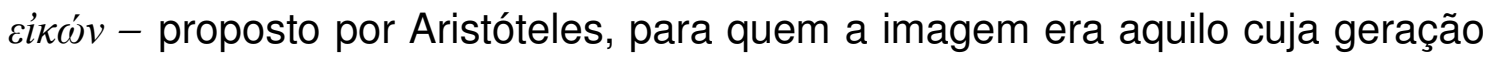

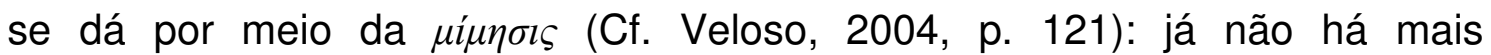
necessidade de imitar a natureza, afinal a máquina fotográfica faz isso via $\tau \dot{\varepsilon} \chi v \eta$.

A distribuição, portanto, é clara: à fotografia, a função documental, a referência, o concreto, o conteúdo; à pintura, a busca formal, a arte, o imaginário. (Dubois, ibidem, p. 32)

Alguns séculos antes, Lessing em seu Laocoonte ou sobre as fronteiras da Pintura e da Poesia (1766) havia estabelecido uma relação - dentro de suas proporções naturalmente -, entre a literatura e a pintura estabelecendo os limites de uma expressão artística em relação à outra. $\mathrm{O}$ objeto da pintura seria empregar um único momento da ação - deve renunciar, portanto, ao tempo -, escolhendo para isso a mais expressiva para fazer dela objeto pictórico, limitada que está pelo espaço; a poesia, por sua vez, por dispor da narrativa expõe os corpos por meio de suas ações no tempo.

\footnotetext{
${ }^{20}$ Representação enquanto paradigma epistemológico que permeou a cultura européia até meados do século XVIII e cujo pilar era exatamente a $\mu$ í $\mu \sigma \iota \varsigma$.
} 
(...) a pintura utiliza (...) meio ou signos totalmente diferentes dos da poesia: aquela (...) figuras e cores no espaço, (...) esta sons articulados no tempo (...). (Lessing, ibidem, p. 193)

Com a libertação mimética, obteve-se, portanto, aquilo que os

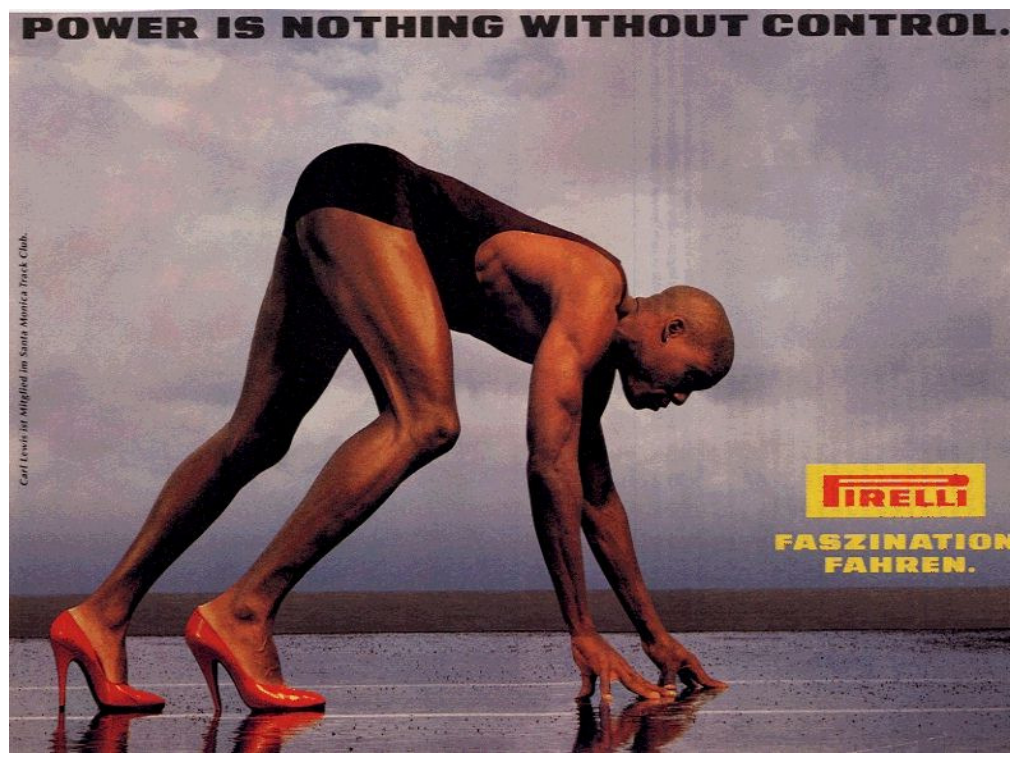

Figura 3: exemplo de oxímoro (o tropo a serviço da publicidade), quando há a exploração da contradição visual: "aqui a fusão é dos gêneros masculino $X$ feminino. $O$ universo de contradições evocado explora vários clichês destes dois opostos: força vs. graciosidade, simplicidade vs. sofisticação, rudeza versus beleza". Retirado de www.multiculturas.com/retorica/introd.htm românticos, no século XIX, tanto almejavam em sua revolução contra as amarras da

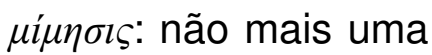
mera imitação da natureza, mas a revelação da verdade

\section{A} verdade expressa pela arte é (...) não a reprodução de um real qualquer, mas do absolutamente real ou do

real absoluto: da absoluta verdade. (Duarte (org), 2001, p. 294)

Não é exatamente essa a idéia que se tinha da fotografia até bem pouco tempo - sobretudo antes do processo digital ${ }^{21}$ - a de ser considerada a mais realista ${ }^{22}$ das artes miméticas (Cf.: Sontag, 1986, p. 53), imagem guardiã da verdade, ou mesmo a de perpetuação da realidade?

O trabalho da técnica é impor de forma crescente um efeito de "realidade" sobre os sinais ópticos, imprimir-Ihes a marca de uma homologia cada vez mais absoluta e fetichista com o objeto representado. (Machado, 1984, p. 27)

\footnotetext{
${ }^{21}$ Não se deve esquecer, contudo, de que desde seu início a fotografia era passível de manipulação, montagens e correções, ou seja, essa não é uma prerrogativa apenas do advento da fotografia digital e dos softwares fotográficos. No entanto, só depois desse acontecimento é que as pessoas atentaram para esse seu poder, antes restrito aos estúdios.

${ }_{22}$ Pierre Bourdieu, entretanto, nos diz que se a fotografia tem esse caráter de detentora da realidade e da objetividade é porque a sociedade sempre desejou isso.
} 
Para que a arte pictórica deveria preocupar-se em copiar fielmente a realidade se a fotografia já estava cumprindo esse papel? Abandonando a $\mu i ́ \mu \eta \sigma \iota \varsigma$, os movimentos vanguardistas vão além da técnica: adentram no reino

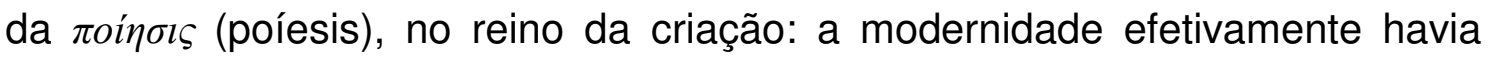
chegado.

Dessa forma, poderíamos inferir que ao fascínio do homem do século XIX quanto a seu conceito de velocidade e da reprodutibilidade mecânica da imagem, teríamos hoje a plenitude da $\tau \dot{\chi} \chi v \eta$ dessa reprodutibilidade e sua disseminação a uma velocidade inimaginada, nem mesmo há 30 anos. A fotografia, por exemplo, já se faz presente maciçamente na vida humana onde quer que estejamos, interagindo, muitas vezes, com o observador, da mesma forma que a realidade o teria feito. Exemplo desse cerco total é a linguagem publicitária que faz da imagem fotográfica parte intrínseca de sua estrutura juntamente com a palavra, afinal é inconteste a superioridade da imagem em relação à linguagem verbal, principalmente no que concerne à fixação de uma determinada idéia como na linguagem publicitária. (Cf. Reboul, s/d, p. 45) Temos, novamente (se é que podemos dizer que deixou de existir!), um emprego/argumentação icônico-lingüístico - nos moldes da emblemática seiscentista -, que não só leva o consumidor a convencer-se, consciente ou inconscientemente, da importância de um determinado produto, como lhe impõe valores, mitos, ideais e outras elaborações simbólicas, utilizando além dos recursos próprios da língua que lhe serve de veículo (Cf. Carvalho, 1998, p. 13) - e de seus recursos retóricos ${ }^{23}$ (figs. 3 e 4) - a inserção do elemento fotográfico, num amalgamento icônico-poético:

Sabemos que a ação sobre o outro (propaganda, prédica, sedução, publicidade, etc.) nunca deixou de alimentar-se no arsenal dos procedimentos 'poéticos', para não falar dos que os utilizam no discurso científico para fazer economia de uma demonstração. (Dubois, 1974, p. 42)

\footnotetext{
${ }^{23}$ Como nos diz Olivier Reboul em relação ao slogan e as funções da linguagem: a função poética aparece em qualquer slogan digno deste nome, pois o assunto de que ele trata é inseparável da maneira como o diz; todo o slogan é retórico (Reboul, s/d, p. 18), ou ainda quando o mesmo autor aborda o fato de um slogan ser ou não repetível quando aborda seu poder de satisfazer, de seduzir, de mostrar, de demonstrar, dizendo ser, antes de tudo um fator que já conhecemos: o estilo (...) que recorre aos procedimentos retóricos mais diversos, mas cujo caráter essencial é a concisão (ibidem, p. 51).
} 
Encontramos, portanto, combinadas nas propagandas contemporâneas não somente fotografias (imagens) como também chamadas concisas ${ }^{24}$ (slogans) numa tal contigüidade e num jogo tal que somos obrigados a decifrar a mensagem pretendida pela agência produtora. No entanto, essa decodificação circunscreve-se a grupos sociais específicos, já que nem todos conseguem (e podem) decodificá-las. Guardadas as proporções e os objetivos, é como se víssemos diante de nossos olhos o ressurgimento do gênero emblemático tão em voga no Seiscentismo, período em que a palavra buscava se tornar inteligível por meio da imagem, criando

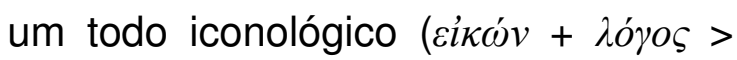
imagem + palavra) e alegórico. Praz nos remete a Schopenhauer, pois para este, por exemplo, a alegoria é legítima na literatura, mas inaceitável na pintura, por isso rejeita o emblema como pintura, esta seria apenas uma

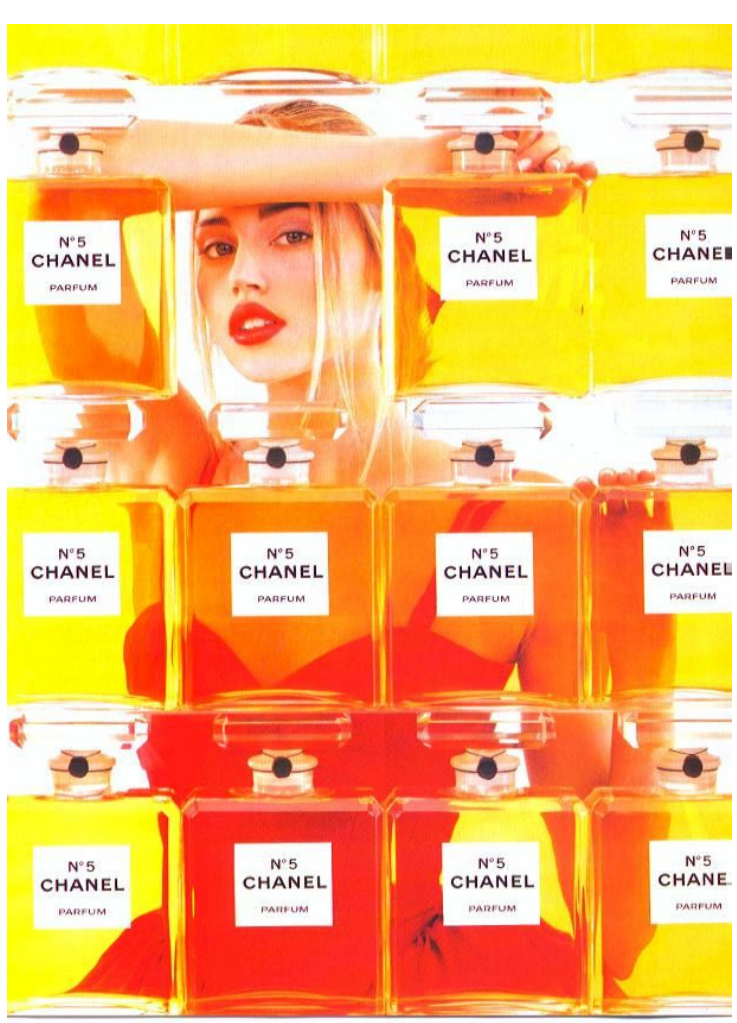

Figura 4: exemplo de policonia, quando se pode demonstrar a massificação da imagem que se quer vender (ibidem), o produto torna-se um objeto de desejo, um quase cí $\omega \lambda$ ov (eídolon). Retirado de www.multiculturas.com/retorica/introd.htm forma de a alegoria poética se tornar clara (identifica-se a alegoria poética via imagem). A pintura torna-se, portanto, parte da criação poética; e o poema, um potencial emblema. (Cf.: Praz, 1989, p.18)

Necesitado como estaba de certidumbres de los sentidos, el hombre del XVII no se detuvo en la mera apreciación fantástica de la imagen: quiso exteriorizarla, transponerla a un jeroglífico, a un emblema. Encontraba satisfacción en explicar la palabra añadiéndole una representación plástica. (Ibidem, p. 18) ${ }^{25}$

\footnotetext{
24 Houve momentos, no século passado, em que as propagandas possuíam textos demasiadamente longos, quando procuravam não só apresentar um produto, mas esmiuçá-lo. Era o estilo transamazônico nos dizeres de Ricardo Ramos (Cf. Marcondes, 1995, pp. 52-60).

${ }^{25}$ Praz cita W. J. Ong, em cujo ensaio From Allegory to the Diagram in the Renaissance Mind diz que a propensão a quadros alegóricos tem relação com o surgimento da imprensa e seus novos modos de comunicação do pensamento por meio de quadros e esquemas sinóticos. Esses acabavam reduzindo o verbal ao espacial, quando as palavras se tornavam mais claras
} 
Também é evidente que a relação propaganda/emblema possuía um papel primordial na manutenção do status quo social que, apesar de seu autoritarismo não só buscava calar - por meio da repressão física - como também atrair - principalmente em um período de tantos conflitos e guerras iminentes -, a colaboração de indivíduos dóceis. E o melhor meio para se lograr esse escopo é a persuasão (Cf.: Maravall, 1997, pp. 144-145), cujo principal artífice é a imagem:

Utilizando meios plásticos, a cultura do século XVII pôde alcançar, com maior adequação, seus objetivos de propaganda. Uma vez mais, é essencial remeter a eles para entender os aspectos dos Seiscentos que aqui consideramos. Se a arte da época se encontra animada por um espírito de propaganda e se isso implica que, para lograr seu objetivo, a imagem é um recurso eficaz, é possível sustentar, como Argan, que 'não se tenta conceituar a imagem, mas dar o conceito feito imagem'; isto é, proporcionar-Ihe a força, não mais demonstrativa, mas de apelo prático que é próprio da imagem. (ibidem, $\mathrm{p}$. 389)

Também nós, hoje, estamos sujeitos ao poder imagético, estamos cercados por ele, mas seu núcleo básico será agora a fotografia que cria, inclusive, uma realidade virtual que tende a substituir parcialmente o real para então dele se libertar. (Cf. Couchot, 2003, p. 19) Vivemos como se estivéssemos em dois mundos: o real, em que estão nossas imagens

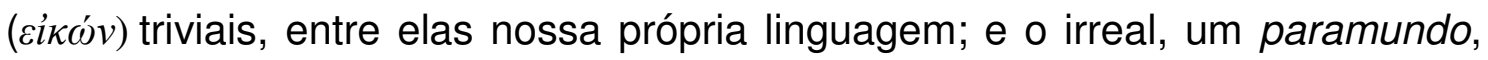
como se fosse um Eỉ $\omega \lambda \lambda$ ov (simulacro) que nos é imposto pelos meios midiáticos. Como não podemos nos libertar das imagens sob pena de perdermos nossa identidade como humanos, sua saturação, como vemos nos dias atuais por meio desse paramundo produzido por elas mesmas, nos conduz ao esvaziamento e à pobreza das significações (Cf. Guimarães, 1997, p. 22). Não há mais tempo a perder com a busca de possíveis significados para a mensagem exibida, ela deve valer-se por si mesma, transmitida no mesmo

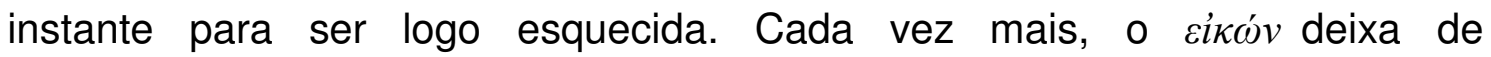
de los símbolos visuales en la verbalización, que marca la gran edad del cuadro simbólico, está testimoniada por el hecho de que fue una época marginal - una época en que la cultura verbal estaba transmutada en una cultura visual. (Praz, 1989, p. 59) 
reapresentar algo, a natureza por exemplo, pois já não se vale mais desse referencial que, praticamente, desaparece em meio a um mundo virtual e tecnicista. Essa facilitação e impregnação da imagem virtual influenciam todas as artes, entre elas, a própria literatura e o $\lambda o ́ \gamma o \varsigma$, seu gérmen fundador.

Diante desta nova realidade imagética em que estamos inseridos e cujo princípio motor teve grande participação da fotografia, move-nos o desejo de refletir, à base das teorias existentes, a possível relação existente entre um período tão rico em contrastes como o Seiscentismo ${ }^{26}$ e nossa contemporaneidade $^{27}$. Contudo, somos impelidos, obviamente, a fazer questionamentos cujas respostas serão objetos de estudo da presente tese:

a) Como fica a questão da representação, leitura e interpretação de textos literários não pertencentes ao momento que vivenciamos, mormente textos do século XVII, cujo referencial já era desconhecido menos de um século depois? Poder-se-ia afirmar que só o diacronismo seria responsável por tornar a literatura do século XVII tão distante de nós, ou o período conhecido por Barroco realmente é um momento de poetas incompreensíveis? ${ }^{28}$ Haveria, nesse vácuo, um elo perdido?

b) Como explicitado, em linhas gerais no início do trabalho, o período conhecido por Barroco foi de extrema iconofilia, sendo o ápice de uma série de transformações por que o homem da modernidade havia passado desde a Idade Média como, por exemplo, o predomínio da visão em detrimento da audição, advindo daí seu culto, quase obsessivo, à imagem. Esta passa a ter como paradigma o conjunto das iconologias que perpassaram o período e que influenciaram não só os pintores como também os poetas. A pintura, que havia conquistado o direito de ser uma arte liberal, possuía um status relevante nessa Weltanschauung, promiscuindo-se com a poética numa profunda protocooperação: a pintura baseando-se na estética poética e esta também se buscando naquela.

\footnotetext{
${ }^{26}$ À luz de um dos elementos mais caros àquela época: a imagem.

${ }^{27}$ Quando a mesma imagem já permeia todos os niveis e relações existentes.

${ }^{28}$ Marca preconceituosa legada por Croce, para quem o período era marcado por frígidas alegorias, de sobreposições apoéticas ou extrapoéticas (Ginzburg, 1991, p. 57), ou cujo sistema iconológico (emblemas, empresas e divisas) era um passatempo improfícuo como forma de enganar as pessoas do período (Cf. Praz, 1989, p. 23)
} 
No entanto, de que nos valem tais informações para nós, homens e mulheres do século XXI? Simplesmente, porque também nós estamos vivenciando esse momento de iconofilia à semelhança daquele momento, a ponto de termos criado, inclusive, uma supra-realidade convivendo com o real. Não queremos sequer afirmar, ou comentar aquilo que já se tornou trivial: chamar nosso momento de neo-barroco. Não é esse o objeto de estudo desta tese, pelo contrário, o que nos interessa é tão-somente o fascínio e o poder evocados que nossas sociedades extemporâneas têm em relação à imagem, apesar de o nosso paradigma imagético haver mudado: a pintura sai de cena ainda no século XX, quando adentramos ao mundo imagético da fotografia ${ }^{29}$. É possível estabelecermos uma afinidade entre a literatura e a fotografia, não no campo de uma possível inter-relação entre as duas (nos moldes do ut pictura poesis), mas no campo da recepção/leitura imagética que fazemos do mundo que nos cerca? É possível falarmos em poema fotográfico, ou mesmo em uma iconofotologia, quando não só haveria a

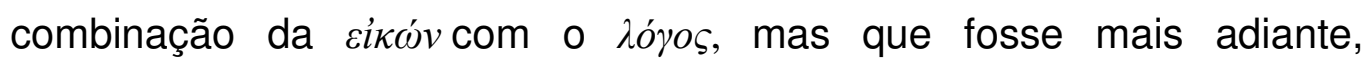
adentrasse no mundo da $\varphi \omega \tau o ́ \varsigma$ (photós) que nos proporciona a $\tau \dot{\varepsilon} \chi v \eta$ ?

${ }^{29}$ E a seus correlatos como o cinema, a televisão e os novos canais midiáticos que surgiram. 
Do corpus e do método epistemológico

Como já havíamos dito anteriormente, o objetivo desta tese é elaborar uma reflexão teórica em torno da recepção imagética de poemas que denominaremos fotográficos. Para isso, delimitaremos nossa análise com um corpus formado por poemas do Seiscentismo alemão ${ }^{30}$, para que possamos traçar paralelos a partir de seu enfoque imagético. Ao delimitarmos o objeto de estudo da presente tese fez-se necessária a escolha do corpus que o comporia. Estabeleceram-se, para isso, alguns critérios de escolha, a fim de permitir uma melhor abordagem de seus aspectos icônicos. Restringiu-se, a fortiori, o material a poemas do Seiscentismo alemão que tratassem de descrições, independentes de sua fôrma poética. Eventualmente, far-se-á necessária a utilização de poemas de outros períodos a título de ilustração, buscando, dessa forma, um efeito pedagógico.

Como não poderia deixar de ser, visto ser este um trabalho individual e subjetivo, não obstante sua proposta ser epistemológica, o material escolhido comportará certa arbitrariedade que, evidentemente, não trará prejuízos ao todo do trabalho, sobretudo porque grande parte dos autores aqui apresentados não faz parte do repertório conhecido no Brasil, ou seja, será mais do que uma escolha arbitrária: será uma apresentação ao público leitor brasileiro de obras de autores do Seiscentismo alemão, bem como de outros autores, tanto alemães quanto brasileiros, que nos servirão de suporte para o desenvolvimento da Tese aqui proposta.

Dentre a vastidão de poetas do período, priorizaram-se não só aqueles que tenham optado pela poesia sacra - esses servirão, principalmente, para corroborar aspectos iconológicos do período -, mas também os que tenham adentrado em outros gêneros poéticos - como o elegíaco ${ }^{31}$ ao tratarem de temas como conflitos ou tragédias. À primeira vista (segundo nossa acepção hodierna), esse fazer poético retrataria, somente, cenas da realidade de um eu

\footnotetext{
${ }^{30}$ Não se quer dizer que não possamos nos utilizar de textos de outras épocas que possam vir a corroborar nosso estudo, bem como confrontar momentos literários distintos com 0 Seiscentismo, objeto principal deste estudo.

${ }^{31}$ Mormente, orientados para o $\pi \alpha \dot{\theta} \theta 0 \varsigma$ (pathos) - cuja temática restringir-se-á ao lamento, à dor e à melancolia -, já que havia subgêneros como o moral, o bucólico e o erótico.
} 
lírico num determinado período. No entanto, como veremos, isso não existia naquele momento, mesmo que, sob nosso olhar, isso correspondesse a limitações impositivas. Essas, no entanto, faziam parte constante do fazer

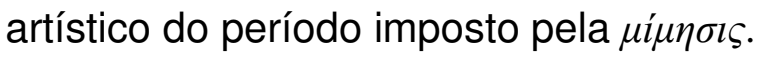

São, especificamente, esses poemas elegíacos que empregaremos para demonstrar aquilo que chamamos de poemas fotográficos, ou seja, textos que nos abrem diversas imagens para contemplação e que nos remetem a outras, fotográficas. Como veremos, a tese procurará demonstrar que a recepção icono-poética de períodos não só extemporâneos - em nosso caso de poemas do Seiscentismo alemão - mas também contemporâneos ao nosso, faz-se via fotografia, cujo acervo está inerente a todos nós.

Num primeiro momento, buscaram-se poemas que retratassem a visão de um eu lírico subordinado às preceptivas retóricas do período, mas cuja temática abordasse a guerra, afinal grande parte do século XVII alemão foi marcado pela Guerra dos Trinta Anos. Entretanto, ampliamos o espectro para poemas que retratassem aspectos imagéticos particulares dos Seiscentos como a representação de conceitos morais ou de lugares-comuns -, aqueles cujas imagens sofrem um efeito de refração diacrônica, ou seja, teriam um desvirtuamento do signo com o passar dos anos. Isso corroboraria, ainda mais, o intuito deste trabalho que é demonstrar a não possibilidade de uma leitura ipisis litteris desses textos (mesmo que essa seja feita de forma metafórica), pois não conseguiríamos depreender dos mesmos a totalidade das mensagens transmitidas.

Assim, o método que propomos é, a partir da compilação de textos, fazer uma comparação entre alguns deles em que haja mais do que similitude temática, mas imagens afins, revelando não suas particularidades praticamente inexistiam nesse período ${ }^{32}$-, mas sua confluência, pois essas imagens faziam parte do inconsciente coletivo daquela sociedade, normatizadas via iconologias e livros de emblema, os quais norteavam 0 pensamento e a arte daquele momento. Demonstraremos, com isso, a analogia icono-temática daqueles poetas e a confluência, em suas obras, entre o $\lambda o ́ o ́ c \varsigma$

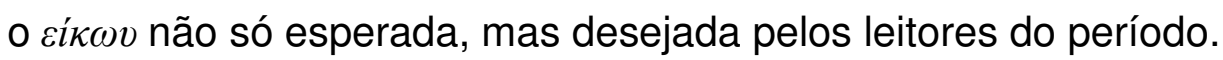

\footnotetext{
${ }^{32}$ Enquanto expressão de criatividade de um eu pessoal.
} 
Levantados esses conceitos retóricos e os significados de determinadas imagens para 0 homem seiscentista, temos $o$ início da segunda parte do trabalho. Esse consistirá em demonstrar que, por não dispormos mais desse múltiplo referencial, temos de redirecionar a leitura icônica para outros modelos que não os seiscentistas, mas aqueles que fomos construindo ao longo do século, cujo paradigma é a fotografia. Para isso, a leitura não será mais em relação às iconologias de que dispunham os artistas do XVII, mas o acervo fotográfico de que dispomos hoje, daí termos de recorrer a nossas iconofotologias que seriam, exatamente, o acervo de que nós dispomos hoje, não mais de cunho privado, direcionado a poucos, mas cuja abrangência é bem maior, visto que a imagem, hoje, acaba criando seu próprio paramundo, tal o seu domínio e penetração em todas as classes sociais, sendo que todos acabam sofrendo seus influxos.

Além do corpus poético, há o imagético que, como foi dito, será retirado das iconologias antigas, dos livros de emblemas, empresas e divisas de diversos autores dos séculos $\mathrm{XVI}$ ao XVII; e imagens de diversas fontes que abarquem os séculos XX e XXI, retiradas de periódicos, jornais e livros voltados à fotografia. 
Podem-se levantar muitas controvérsias, quando se propõe a fazer uma leitura intersemiótica entre duas artes, aparentemente distintas, como a literatura e a fotografia da forma pretendida nesta tese, apesar de ela reportarse à problemática da recepção imagética propiciada a leitores do século XXI, a partir de um fazer literário extemporâneo como a literatura barroca ${ }^{33}$. A nós, seus possíveis leitores, inseridos numa sociedade com profunda antipatia, indiferença e mesmo hostilidade ao ato de ler e cujos fundamentos podem tanto ser de ordem social como tecnológica, será exigido muito mais do que tempo, aplicação ou concentração - aparatos não condizentes com a vida atual -, mas conhecimentos prévios dos pressupostos que regiam esse fazer poético, cujo paradigma epistemológico era o conceito de representação.

É imprescindível, portanto, que abordemos, num primeiro momento, alguns conceitos que não só embasam como também perpassam essa epistéme ${ }^{34}$ seiscentista e sua possível relação com nosso tempo: $1^{\circ}$ ) a questão do anacronismo e sua relação com o fazer artístico; $2^{\circ}$ ) a abrangência do conceito de $\tau \dot{x} \chi v \eta^{35}$ que perpassa nossa acepção de técnica, além de fundamentar a correlação entre a $\tau \varepsilon^{\prime} \chi v \eta$ e o $\lambda o^{\gamma} \gamma o \varsigma$, afinal aquele é resultado deste, ou seja, são convergentes não colidentes; $3^{\circ}$ ) a abrangência do conceito de $\mu i ́ \mu \eta \sigma \iota \varsigma$ e de emulatio ${ }^{36}$ [emulação] inseridos dentro de um paradigma

\footnotetext{
${ }^{33}$ Apesar de os teóricos que estudam a arte do século XVII, inclusive este autor, não acharem apropriado a utilização do termo Barroco para designar a arte Seiscentista, a utilizaremos por uma questão básica: para nós pertencentes à cultura ibérica, a arte seiscentista pertence ao período que chamamos de Clássico - que corresponde o Classicismo, o Barroco e o Arcadismo -, no entanto para a arte literária alemã, o período clássico (Klassik) só existirá, com efeito, no século XIX com Goethe. Dessa forma, essa terminologia terá somente uso didático, daí a utilização dos dois termos ora para falar em uma arte seiscentista euro-latino-americana (Seiscentismo) ora para determinar a arte seiscentista alemã (Barock - Barroco), ou mesmo para evitar repetições desnecessárias.

${ }^{34}$ Não só no sentido de ciência, mas de arte, habilidade e conhecimento que permeavam o pensar seiscentista.

${ }^{35}$ Técnica: esta é apenas uma das várias acepções que a palavra possui para os gregos, como veremos, portanto está empregada, simplesmente, em caráter didático.

36 Aquilo que, pejorativamente, qualificaríamos como plágio (do grego $\pi \lambda \dot{\alpha}$ rıos: oblíquo, transversal). A esse respeito há uma querela que ainda hoje suscita dúvidas na própria literatura brasileira: o caso Gregório de Matos. Muito se falou de suas atitudes de plagiador, porém esses mesmos que o acusaram, esqueceram-se de ler que aquelas linhas pertenciam a uma realidade diferente da nossa na medida em que o "plágio" era prática comum da época, mesmo entre os maiores (Martins, 1987, v.1, p. 226). Ainda conforme Wilson Martins assinala, e com o que concordamos, não seria esse o motivo para se relegar o poeta baiano, mas o fato de serem ou não dele, efetivamente, os versos que lhe são atribuídos (Cf. ibidem, p. 227): sob o nome de Gregório de Matos poderemos compreender sem maiores prejuízos nem excessivas
} 
epistemológico constituído pela representação; $4^{\circ}$ ) demonstrar a abrangência do termo imagem, restringindo-o para os propósitos desta tese; 5) esclarecer 0 gênero emblemático, seu alcance e finalidades dentro da Weltanschauung seiscentista, demonstrando a relação estabelecida entre o $\lambda o ́ o$ o e a imagem, amplamente veiculados na sociedade seiscentista em todos seus níveis sociais ora exemplificando valores morais, religiosos e políticos (Cf.: Maravall, 1997, pp. 389-390), ora aliciando como cultura de massa, visando a um fim propagandístico $\left.{ }^{37} ; 6^{\circ}\right)$ a partir da orientação contemporânea do termo $\tau \dot{z} \chi v \eta$, expor que a fotografia não só é uma expressão artística, como também passível de ser cotejada com uma outra (no caso a literatura), afinal as diferentes artes são comparáveis (Jakobson, 2005, p. 119), mas para isso, esboçar a origem do processo fotográfico e os elementos epistemológicos que empregaremos nesta tese para o cotejamento com a poesia.

A gênese deste trabalho decorre de minha dissertação de mestrado, cujo tema fora a própria literatura barroca alema ${ }^{38}$, quando se abordaram os pressupostos sócio-culturais e políticos dos Seiscentos a partir de um corpus formado, em especial, pela obra lírica de Andreas Gryphius (1616 - 1664), autor mais expressivo do período, a partir dos modelos de representação da sociedade seiscentista. E, exatamente por estarmos separados há quatro séculos daquela Weltanschauung, a temática desta Tese pode causar estranheza, sobretudo porque ainda faltariam dois séculos - a partir daquele momento - para que a arte fotográfica iniciasse sua etapa final: a fixação da imagem no papel sensibilizado, apesar de o gérmen do processo fotográfico a câmara escura - já estar sendo, largamente, empregada por vários artistas do período.

hesitações, qualquer coisa como um poeta coletivo, uma espécie de constelação de poetas, em que os anônimos e desconhecidos se dissolvem na figura do epônimo e nele se transubstanciam para formar esse grande e imaginário poeta brasileiro do século XVII (ibidem, p. 227). Vale salientar, portanto, que essa Escola Gregório de Matos não fez nada que os grandes mestres do Seiscentismo não tenham feito, servindo-se, inclusive, como um tradutor no sentido de transformador, seja de Góngora ou Quevedo (Cf.: Campos, 1981, pp. 75-76).

37 Isso fica claro nos livros de emblemas e nas iconologias em moda na época. A respeito dessa manifestação, assim se expressa Maravall: (...) é próprio das sociedades nas quais se desenvolve uma cultura massiva de caráter dirigido apelar para a eficácia da imagem visual. $O$ Barroco (...) tinha de ser, pois, (...) uma cultura da imagem sensível. (Maravall, 1997, 389).

${ }^{38}$ A literatura barroca na Alemanha: Andreas Gryphius, representação, vanitas e guerra, 2003. 
Quando aludimos a qualquer expressão artística - sem levarmos em conta quaisquer teorias - devemos nos lembrar de que dificilmente houve unanimidade quanto ao tema inovação. Esta, pelo contrário, sempre leva a desgastes, tanto do lado revolucionário quanto do reacionário. O vencedor, no entanto, sempre é o objeto da disputa, no caso a expressão artística. Se hoje, por exemplo, reputamos à fotografia uma expressão artística e temos ciência de sua contribuição tanto para as artes pictóricas que a antecederam, quanto para aquelas que a sucederam como o cinema e a televisão, isso foi fruto de diversas incursões, resultados e imprecações. Pode-se corroborar a afirmação ao lermos a crítica de Baudelaire a essa nova expressão artística:

Estou convencido de que os progressos mal aplicados da fotografia contribuíram muito, como, aliás, todos os progressos puramente materiais, para o empobrecimento do gênio artístico francês já tão raro (...). Quando se permite que a fotografia substitua algumas das funções da arte, corre-se o risco de que ela logo a supere ou corrompa por inteiro graças à aliança natural que encontrará na idiotice da multidão. É necessário, portanto, que ela volte ao seu verdadeiro dever, que é o de servir ciências e artes, mas de maneira bem humilde como a tipografia e a estenografia, que não criaram nem substituirram a literatura. (...) Mas se the for permitido (...), que desgraça para nós! (Baudelaire, apud Dubois, 2006, p. 29)

Evidentemente, para aqueles que se dedicam à atividade arqueológica (Foucault, 1966, pp. 10-11) de resgatar as formas de expressão de uma época tão distante como o Seiscentismo, seria mais natural em um trabalho como este - em que uma das pontas está colocada no século XVII, momento em que o gênero emblemático atinge seu ápice e a pintura conhece grandes figuras como Velásquez, van Veermer, Rembrandt, Rubens, Caravaggio; e a outra, no século XXI - que esta leitura pudesse ser, no mínimo, entre a poesia e a pintura, afinal ambas estavam sujeitas às preceptivas do ut pictura poesis ${ }^{39}$, além de uma convivência, aparentemente, mútua, afinal

\footnotetext{
${ }^{39}$ Horácio, ao comparar em um verso - ut pictura poesis (poesia é como pintura) - a poesia com a pintura, não poderia imaginar que o mesmo se tornaria o lema de uma longa história de comparações e aproximações entre a poesia e as artes plásticas em inúmeros tratados de poesia e da pintura entre os século XVI ao XVIII. Afinal, desde a Antigüidade, relaciona-se a literatura às outras artes, pois todas tinham como pressuposto a $\mu i ́ \mu \eta \sigma \iota$.
} 
poesia e pintura têm marchado constantemente de mãos dadas, numa fraterna emulação de metas e meios de expressão.

(...) os pintores aceitavam de fato as sugestões dos escritores e obedeciam a esquemas inventados por eles na decoração de paredes e tetos, bem como na escolha de assuntos para pinturas isoladas. (Praz. 1982, p. 3)

Dizemos aparentemente devido aos paragoni ${ }^{40}$ que culminaram com a autoafirmação dos pintores como artistas (ars liberae) não como meros artesãos (ars mechanicae) ${ }^{41}$, cuja conceitualização veremos adiante. Também concordamos - até por comodidade - que a escolha mais natural para um trabalho como este fosse uma leitura intersemiótica entre a poesia e a pintura, ainda mais quando o período objeto deste estudo é a literatura dos Seiscentos, com toda sua interpenetração iconológica. É pertinente, portanto, afirmar que relacionar a poesia à fotografia demonstraria, além de uma pretensão, um grande anacronismo, por isso espero que possa me fazer compreender nesta empreitada.

\footnotetext{
${ }^{40}$ Muitas foram as discussões acerca da superioridade ou não da arte poética em relação à pintura. Leonardo da Vinci atribuía ao olhar um papel muito importante, buscando inverter a hierarquia tradicional que estabelecia a precedência da poesia sobre a pintura, ao argumentar sobre a imediaticidade e força dos signos da pintura (Cf.: Lessing, 1998, pp. 12-13). Além de Da Vinci, Cesare Ripa e Lessing entre outros, cria-se que a demonstração visual e pictórica era muito mais efetiva que qualquer instrução verbal, pois a pintura teria um poder maior que a poesia, não apenas por estar ligada ao sentido da visão, mas pela utilização de signos naturais, cuja energia não depende da educação. (Cf.: Brandão, 2003, p. 12)

${ }^{41}$ Vale salientar que o mesmo ocorreria em relação aos fotógrafos, que tiveram de demonstrar ser a fotografia também um gênero artístico.
} 
Não há dúvida de que trabalhar com expressões artísticas díspares e, além do mais, inseridas em intervalos temporais tão distantes possa parecer pretensão, loucura ou mesmo anacronismo, apesar disso, acreditamos que valha a pena a empreitada, por isso vamos ater-nos a um dos itens da enumeração acima: o anacronismo. Este termo além de designar imprecisão temporal, falta de conhecimento ou informação, foi - e é - largamente utilizado como recurso estilístico. Dessa forma, seu emprego pode tanto ser um lapso cultural - logo real -, quanto fictício - logo, intencional.

Determinados programas televisivos ou radiofônicos, quando se utilizam do desconhecimento de transeuntes para criar uma moção cômica, valem-se, muitas vezes, de situações anacrônicas reais: seja perguntando sobre o último filme de Leonardo da Vinci, seja sobre a repercussão do discurso de Gandhi a favor do desarmamento do Brasil. Nem sempre, contudo, a utilização de elementos anacrônicos tem a função de ridicularizar. Encontramos exemplos desse emprego nas novelas televisivas de época ou nos filmes, cujo enredo refere-se a personagens históricas.

Hoje, devido ao grande aprimoramento tecnológico agregado ao apuramento e espírito científico da História e da Arqueologia, buscam-se cada vez mais o realismo e a precisão

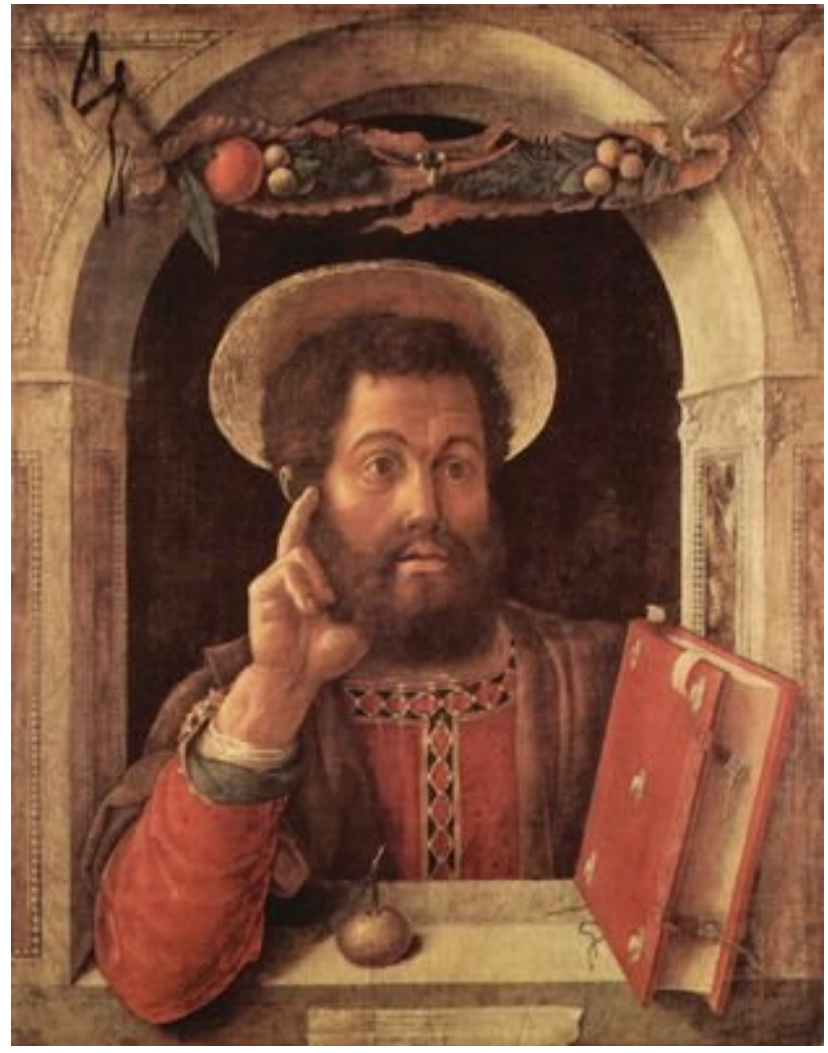

Figura 5: Evangelista São Marcos, de Andrea Mantegna, 1450 histórica nas grandes produções televisivas e cinematográficas. Estas contam, inclusive, com seus próprios consultores históricos, afinal queremos ver a realidade do passado, queremos 
visitá-lo e temos recursos para crermos nessa viagem: as técnicas digitais nos possibilitam assistir a batalhas e confrontos entre exércitos da Antigüidade com uma precisão de detalhes inimagináveis, inclusive sem a utilização de um número absurdo de figurantes como nos filmes épicos dos anos 50 do século $\mathrm{XX}$ (Ben Hur, por exemplo, contou com mais de oito mil figurantes!).

Não se deve presumir, evidentemente, que a utilização do anacronismo seja criação de nossa revolução tecnológica. $\mathrm{Na}$ arte pictórica medieval

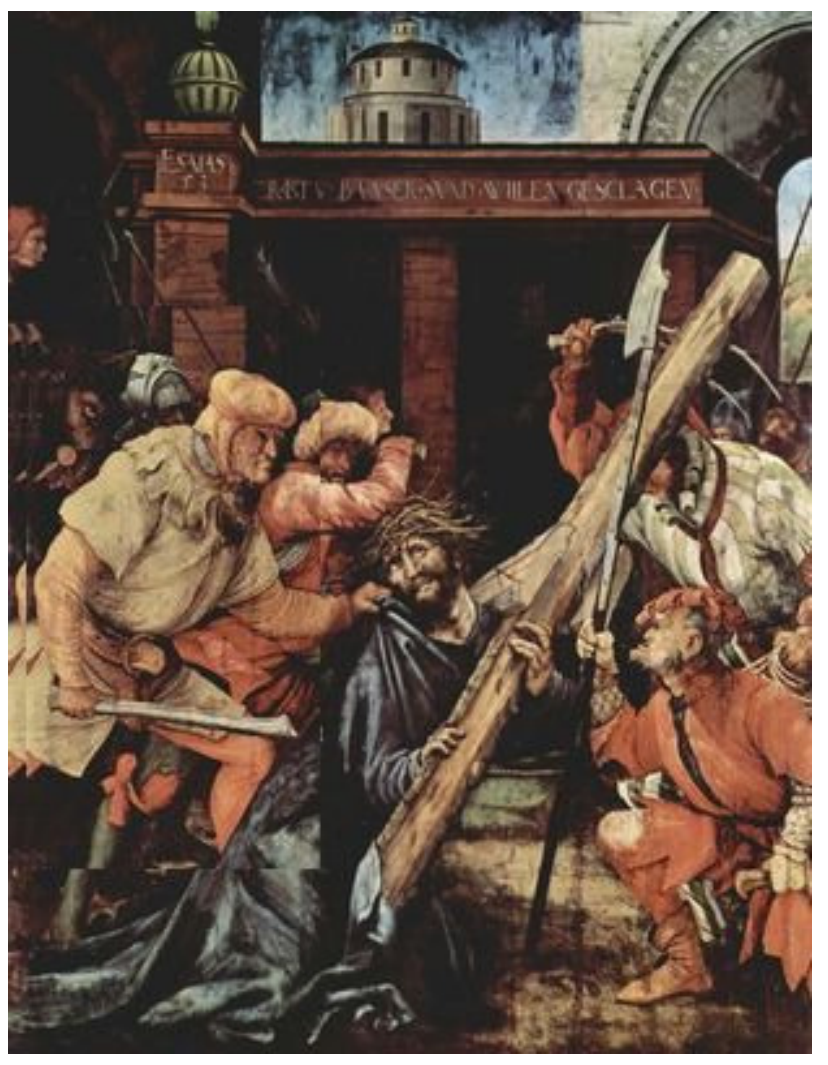

Figura 6: Cristo cai sob a cruz, de Mathias Grünewald, 1523/24 também era utilizado, segundo Panofsky:

(...) quando um iluminista gótico tem que ilustrar a estória de Laocoonte, este se torna um velho calvo e irado, em trajes contemporâneos $(\ldots)^{42}$. (Panofsky, 2004, p. 68)

A partir do Renascimento ${ }^{43}$, era uma tendência generalizada, chegando a meados do século XVIII, quando passa a ser depreciada. Para comprovar sua predisposição, basta que analisemos alguns quadros do período, não sendo necessários só os dos grandes mestres da pintura dos séculos XVI ao XVII como também os dos menos conhecidos. Inferimos que, na representação que esses artistas faziam do passado, seus retratados vestiam-se como se fossem seus contemporâneos.

\footnotetext{
42 Panofsky, à continuação, explica o porquê dessa utilização, quando nos informa que grande parte das descrições a que aqueles artistas tinham acesso eram fontes literárias, ou a modelos visuais presentes em monumentos clássicos. (Ibidem, pp. 68-71)

${ }^{43}$ Auerbach também tece comentários sobre a utilização do anacronismo na Idade Média com a introdução de elementos populares e em língua vernácula, o que, segundo o autor é perfeitamente normal: Também a transferência dos acontecimentos para um contexto contemporâneo, que, aos nossos olhos, é anacrônica, está perfeitamente em ordem. (Auerbach, 2004, p. 139 e Cf.: p.149).
} 
Onde estarão os soldados romanos (fig. 6) que levaram a cabo a crucificação ${ }^{44}$ de Cristo, no quadro de Grünewald? Por acaso os homens retratados parecem-se com aquilo que nós chamaríamos de soldados, ou seriam mercenários? Como seria, então, possível para nós, leitores não expertos na arte do século XVI, descobrirmos que a personagem retratada na fig. 5, no quadro de Mantegna (1431/1506), representa o evangelista Marcos se não fosse a legenda? Seria extremamente difícil, pois essa personagem está totalmente descontextualizada da época em que esteve inserida, a Palestina do século I da era cristã, parece-se até mesmo com um mercador veneziano (pelo menos é como o enxergo!). Que sensação teriam experimentado os leitores e mecenas renascentistas que encomendavam essas obras? Porventura, teriam tido a mesma sensação de perplexidade frente à obra pictórica à semelhança daquela que temos hoje? Será que eles encontravam-se ou reconheciam-se no seu santo de preferência, traduzidos, muitas vezes, a sua quase imagem e semelhança ${ }^{45}$ ?

Seguramente não seria devido ao anacronismo que desvalorizaríamos a obra de grandes pintores renascentistas como a do alemão Grünewald ou mesmo a de Mantegna, autor, dentre outras obras, da Lamentação sobre $o$ Cristo Morto (fig. 10), simplesmente por terem expressado o momento em que estavam inseridos. Apesar de ambos os pintores estarem separados não só espacial quanto temporalmente, respiraram a mesma atmosfera intelectual de sua época, pois como disse Mário Praz:

(...) há uma parecença geral entre todas as obras de arte de uma época, que limitações posteriores confirmam denunciando elementos heterogêneos; que há uma unidade latente ou manifesta nas produções do mesmo artista (...) (Praz, 1982, p. 55).

\footnotetext{
$\overline{44}$ Segundo Panofsky, a tradição iconográfica da crucificação pedia tanto a presença de civis quanto de militares, por isso a utilização de armaduras por parte dos soldados, ou seja, o anacronismo era tradição (cf.: Panofsky, op.cit. p. 225).

${ }_{45}$ Poderíamos imaginar, por exemplo, a inauguração da Igreja de São Francisco de Assis, em Ouro Preto, quando sua população reconhece na Virgem Assunta traços da mulata que vivia com o Mestre Ataíde, autor da grandiosa pintura em seu teto.
} 
O emprego/acepção de algumas palavras é tão comum em determinados períodos históricos que se torna difícil traçar um juízo claro a seu respeito por aqueles que as estão vivenciando - afinal sua definição é patente - ou por aqueles que, a posteriori, quiserem delas fazer objeto de estudo; exemplo disso é a palavra $\tau \dot{\chi} \chi v \eta$. Vários fatores podem concorrer para que isso ocorra e, entre eles, temos a polissemia assumida pelo termo no correr dos tempos. Dessa forma, um dos critérios mais utilizados para se fazer a distinção entre suas várias acepções é recorrer a sua origem etimológica. Evidentemente, não se pretende traçar aqui um critério diacrônico de um termo como $\tau \dot{z} \chi v \eta$ que muitos estudos demandou não só dos especialistas lingüistas como também dentro do âmbito da filosofia; entretanto, ser-nos-á profícuo fazer uma pequena digressão para que possamos chegar a compreender o porquê da dificuldade no emprego desse termo.

Ao falarmos em fotografia, duas das palavras que nos vem à mente são: técnica e tecnologia, principalmente agora com o advento da era digital e das inúmeras possibilidades que ela abriu nos campos da reprodutibilidade e manipulação imagética. Deparamo-nos com duas palavras cujo campo sígnico tem uma origem comum: o termo grego $\tau \dot{\chi} \chi v \eta$. Dessa forma, dois juízos parecem nos tomar: primeiramente, podemos ser impelidos a acreditar que a técnica seja resultado do atual progresso nos campos intelectual e científico, ou seja, somos propensos a acreditar que seja algo recente, de nossa modernidade ou da, muito propagada, pós-modernidade, como se fosse um membro estranho e desprendido da evolução humana (não no sentido ipsis litteris darwiniano, mas no de progresso); por outro lado, que a $\tau \dot{\varepsilon} \chi v \eta$ e as experiências artísticas ${ }^{46}$ pouco teriam em comum ou que não seria possível relacioná-las por estarem em campos opostos do fazer humano. Tal procedimento, porém, corresponderia ao conceito do anacronismo visto anteriormente que, num primeiro momento, poderia inclusive desqualificar uma

${ }^{46} \mathrm{O}$ artista poderia e deveria, inclusive, prescindir da técnica devido a seu gênio criador. 
possível inter-relação imagética entre a literatura e a fotografia, afinal esta seria uma expoente da técnica ${ }^{47}$, aquela da expressão artística.

No entanto, o liame entre arte e técnica praticamente não existe, pelo menos etimologicamente, já que a palavra arte - do latim $a r s^{48}$ - corresponde à palavra grega $\tau \dot{\chi} \chi v \eta$ que, muitas vezes, se traduz simplesmente por técnica, apesar das várias distinções que o termo acarretou (e acarreta). Não se pode,

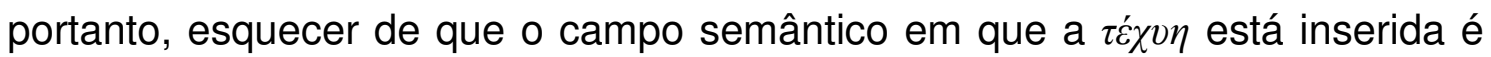
vasto, pois além de possuir muitas acepções (entre elas, de técnica que empregamos hoje sem ter a mesma conotação), está muito entremeada no todo humano, afinal a quase totalidade da história do homem, sua existência, sua libido, seu pathos primordial são abarcados por ela. (Cf.: Craia, 2003, p.16) Essa multiplicidade semântica decorre das próprias modificações que o termo sofreu na Grécia antiga, devido aos avanços da sociedade e da filosofia gregas: de uma sociedade agrícola ${ }^{49}$ e pré-socrática ao berço da racionalidade ocidental com a filosofia platônica e aristotélica.

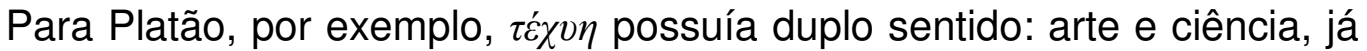

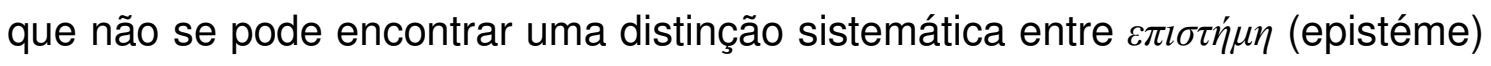
e $\tau \dot{\varepsilon} \chi v \eta$ (enquanto arte) por serem atividades humanas ordenadas e regradas. Quando o filósofo escreveu seus diálogos, as técnicas ${ }^{50}$ no mundo helênico

\footnotetext{
${ }^{47}$ Cujo dever seria, segundo Baudelaire, meramente o de servir às ciências e às outras artes, como já havíamos visto.

${ }_{48}$ Segundo Manuel Antônio de Castro, a tradução de $\tau \dot{\chi} \chi v \eta$ para ars foi especialmente problemática, pelo menos no que se refere à poética, já que essa tradução põe todo o acento na techné. Daí se entendeu a arte como a techné poetiké, mas o principal não estava mais na poíesis, como essência do agir, mas nos conhecimentos técnicos do fazer poesia, em que o fazer diz respeito às formas, à unidade orgânica. (Cf.: Castro, 2006)

49 Convém ressaltar esse caráter produtivo, do mundo do trabalho, principalmente na Grécia arcaica para que possamos ver que, naquele momento, segundo L. Bonilla (Cf. Bonilla, apud Garcia, 1997) havia uma grande consideração pelo trabalho. O trabalho agrícola, por exemplo, possuía, para a Grécia arcaica, um caráter religioso e moral: os agricultores eram queridos pelos deuses, pois enfrentavam as diversidades climáticas e tinham de se submeter diretamente às benesses divinas, portanto a agricultura não era uma $\tau \dot{\varepsilon} \chi v \eta$; outra era a visão em relação ao trabalho do artesão, visto como inferior, exerciam suas atividades em casa e, por não dependerem dos deuses, dependiam da própria $\tau \dot{z} \chi v \eta$ para sua atividade, algumas cidades gregas chegaram a privar-Ihes os direitos de cidadania, por exemplo. Por volta do século VI a.C., o interesse primordial dos filósofos gregos desviou-se desse mundo naturalista, cosmológico (período pré-socrático) para o da compreensão do homem, do seu comportamento e de sua moral, em que o interesse pela natureza integra-se com o do espírito;

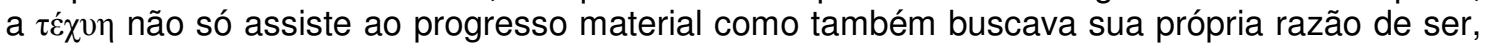
modificando-se o conceito de saber técnico, cujas primícias foram o aparecimento da pólis e a filosofia de Platão e Aristóteles.

${ }_{50}$ As técnicas industriais (artesania) produzem objetos, são produtivas; as intelectuais (matemática, astronomia) obtêm resultados por meio de aquisições intelectivas, são, portanto,
} 
estavam se desenvolvendo num ritmo crescente tanto de alcance quanto de complexidade, constituindo-se, inclusive, como nova e específica modalidade de saber. Vários fatores contribuíram para isso como os progressos da matemática e da medicina, bem como a constituição da polis, que fez emergir uma nova mentalidade que se destaca pelas formas de organização e dependentes das inovações técnicas. Dessa forma, a origem da pólis está intimamente ligada à criação da $\tau \dot{\varepsilon} \chi v \eta$ com a qual se concebe a politéia ${ }^{51}$ grega. Essa forma nova de rearranjo das relações políticas e sociais se opõe à individualidade familiar, já que essa nova forma de aglomeração humana necessitava de instituições novas (tribunais, assembléias, teatros) com as quais os cidadãos teriam atribuições próprias. Surge, dessa forma, a reflexão filosófica e o pensamento técnico como saber específico. (Cf.: Araújo, p. 17)

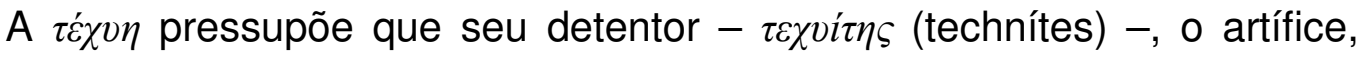

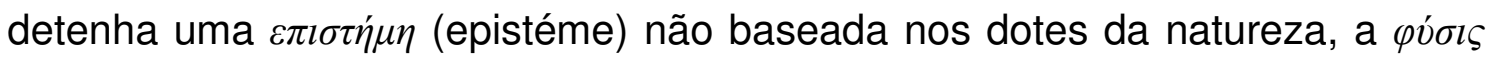
(phýsis ${ }^{52}$ ), o que torna possível sua transmissão a quem não detém essa técnica. Isso pressupõe, evidentemente, que tal conhecimento não tenha sido adquirido da mera empiria ${ }^{53}$, já que para o saber epistêmico é necessária a

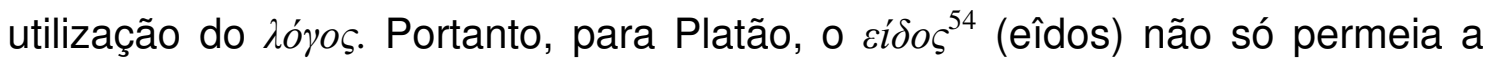

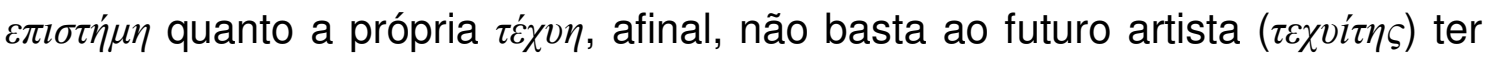

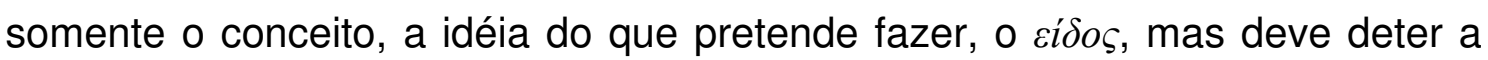

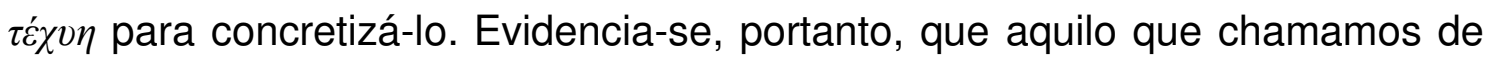
arte será resultado de um vislumbrar da obra - $\varepsilon i \delta o \varsigma$ - na mente do $\tau \varepsilon \chi v i ́ t \eta \varsigma$ (artífice) que, por meio da $\tau \dot{\chi} \chi v \eta$ - os processos necessários para sua execução e transmitidos via $\lambda o ́ \gamma o \varsigma$ - chegará ao resultado pretendido.

Enquanto para Platão arte e ciência eram correlatas, Aristóteles distingue os dois termos e será justamente esse o critério epistemológico que perdurará na cultura ocidental durante séculos. O estagirita nos diz que $\tau \dot{\varepsilon} \chi v \eta$ [arte] é semelhante à $\varepsilon \pi \imath \sigma \tau \eta \dot{\mu} \eta$, pois $\tau \dot{\varepsilon} \chi v \eta$ remete a um fazer adquirido por meio

teoréticas; as corporais (ginástica) possibilitam um estado físico não externo ao agente. (Cf. Araújo, p. 21)

${ }^{51}$ A constituição do Estado, o modo de vida dos cidadãos na Grécia antiga.

${ }^{52}$ A phýsis que consiste na natureza ou maneira de ser de uma coisa, ou seja, sua forma, sua condição natural, sua substância.

${ }^{53}$ A empiria terá uma conotação negativa para Platão, que a considerará privada de racionalidade ( $\alpha \lambda \circ \gamma \circ \varsigma)$.

${ }^{54} \mathrm{O}$ eîdos corresponde à idéia, ao conceito mental de alguma coisa. 
da empiria, afinal todo o conhecimento teórico dever estar embasado na experiência.

Y la experiencia [é $\mu \pi \varepsilon l \rho i \alpha \varsigma$ - empiria] parece, en cierto modo, semejante a la

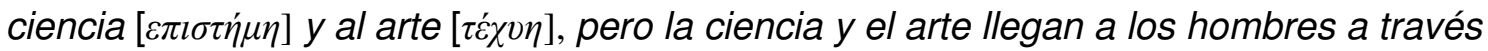
de la experiencia. Pues la experiencia hizo el arte (...). Nace el arte cuando de muchas observaciones experimentales surge una noción universal sobre los casos semejantes. (Aristóteles, 1987, pp. 4-5)

Por meio desta experiência, verifica-se que uma determinada droga tem o poder de curar certa enfermidade; no entanto, quando, a partir dessa verificação empírica, empregamos esse conhecimento a todas as pessoas, a

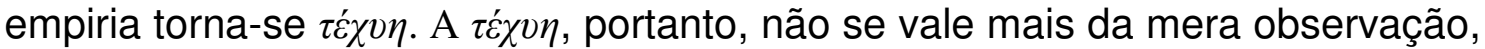
mas das causas e dos efeitos que essa proporciona na vida prática e, devido a isso, pode ser ensinada, e essa sua qualidade de ensinabilidade que a torna tão próxima à $\varepsilon \pi l \sigma \tau \eta \dot{\mu \eta}$.

Essa querela, portanto, estende-se até nossos dias e, em virtude de tal pluralidade conceitual não se chegou a um consenso suficientemente teórico acerca da técnica e suas implicações, principalmente no campo da filosofia. Estamos de tal maneira entranhados na e com a técnica que não nos damos mais conta de que por seu meio o homem não apenas criou instrumentos e meios para auxiliá-lo e maximizar sua aparente limitação, como também para que tivesse prazer frente àquilo que chamamos de estético: um poema, uma estátua, um quadro, um monumento; acabamos transformando aquilo que críamos ser o real numa realidade virtual:

A técnica é uma realidade tão poderosamente real - visível, palpável, audível, ubíqua - que a verdadeira realidade deixou de ser natural ou sobrenatural: a indústria é nossa paisagem, nosso céu e nosso inferno. Um templo maia, uma catedral medieval ou um palácio barroco eram alguma coisa mais do que monumentos: pontos sensíveis do espaço e do tempo, observatórios privilegiados de onde o homem poderia contemplar o mundo e o transmundo como um todo. Sua orientação corresponde a uma visão simbólica do universo; a forma e a disposição de suas partes abriam uma perspectiva plural, verdadeira encruzilhada de caminhos visuais: para cima e para baixo, na direção dos 
quatro pontos cardeais. Pontos de vista total sobre a totalidade. Essas obras não só eram uma visão do mundo, como estavam feitas segundo a sua imagem: eram uma representação da figura do universo, sua cópia ou seu símbolo. A técnica se interpõe entre nós e o mundo. (Paz, 2005, pp. 102-103)

A técnica, na acepção hodierna, vai além da conceitualização grega, não podendo ser considerada simplesmente decorrência da $\tau \dot{\varepsilon} \chi v \eta$, mas seu desdobramento em várias outras leituras da realidade que nos cerca, além da ruptura daquilo que considerávamos ininterruptível como a negação do mundo como imagem. Paz acrescenta que justamente devido a esse desaparecimento a técnica foi possível (Cf.: ibidem, p. 103):

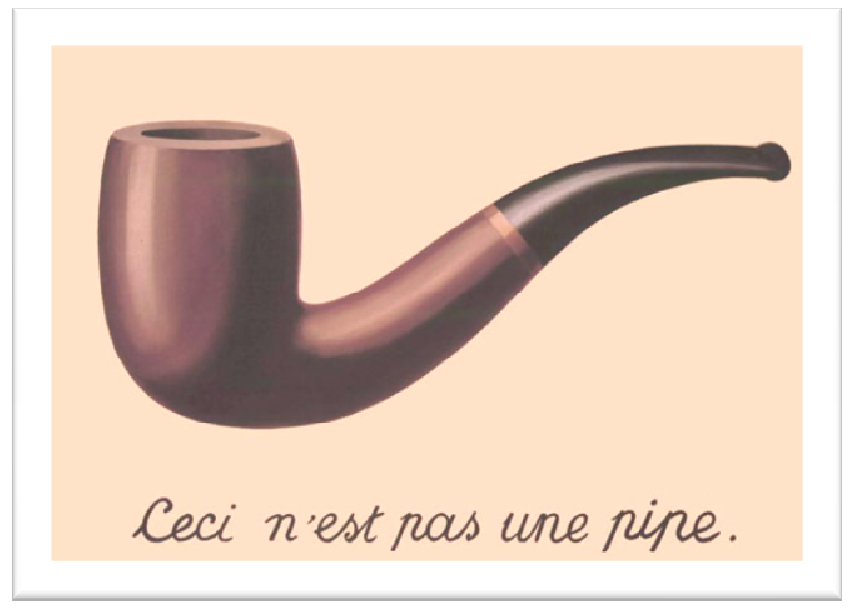

Figura 7: Le trahison des images, de René a Magritte, 1929.
As obras do passado eram réplicas do arquétipo cósmico no duplo sentido da palavra: cópias do modelo universal e resposta humana ao mundo (...). Símbolos do mundo e diálogo com o mundo: 0 primeiro por ser reprodução da imagem do universo; o segundo por ser o ponto de interseção

entre o homem e a realidade exterior. Essas obras eram uma linguagem: uma visão do mundo e uma ponte entre o homem e tudo que o rodeia e sustém. As construções da técnica - fábricas, aeroportos, planos de energia e outros grandiosos conjuntos - são absolutamente reais, mas não são presenças; não representam: são signos da ação e não imagens do mundo. (...) Não são obras, mas instrumentos(...).(ibidem, pp. 103104)

Essa implicação leva-nos a traçar um paralelo com uma das grandes descobertas/invenções do século XIX: a imagem fotográfica. A câmera como nova técnica proporcionou ao homem ver o que não via ou ver com outros olhos aquilo que acreditava conhecer e ver, enfim ter uma nova visão de mundo, segundo Proust (Cf.: Brassaï, 2005, p. 49) ou conhecer o que se esconde nos detalhes, nas minúcias, usando as palavras de Benjamim. (Cf.: 
Kothe, 1991, p. 222) No entanto, ainda falta à arte fotográfica não só uma teoria/filosofia abrangente como também uma tradição de crítica fotográfica. (Cf.: Sontag, 1986, p. 125) Isso se tornou imperativo, ainda mais agora com a facilidade dos meios digitais para captar e reproduzir as imagens. Para demonstrar, por exemplo, a aparente (ou não) dicotomia inerente a esse meio técnico de reprodutibilidade, basta inferir a facilidade de sua decodificação, ao se constatar como as pessoas se comportam frente às imagens fotográficas, quando inquiridas sobre a facilidade - ou não - para interpretá-las ou compreendê-las. Normalmente, respondem assertivamente. Flusser, por sua vez, nos diz que essas imagens são mais fáceis de serem decifradas só na aparência

Ontológicamente, las imágenes tradicionales significan fenómenos; las imágenes técnicas significan conceptos. Descifrar imágenes técnicas implica la lectura de su posición.

Con todo, es difícil descifrar las imágenes técnicas, pues aparentemente no necesitan ser descifradas. Su significado parece grabarse automáticamente sobre sus superficies como en las huellas digitales donde lo significado (el dedo) es la causa y la imagen (la huella) es el efecto. Parece como si el mundo significativo en las imágenes técnicas fuera la causa de ellas (...). el mundo refleja la luz solar y otras ondas luminosas que son captadas por superficies sensitivas - por medio de procesos ópticos, químicos y mecánicos - y el resultado es una imagen técnica. (...) Parece que aquello que vemos al contemplar las imágenes técnicas no son símbolos que necesiten descifrarse, sino indicios del mundo al que significan, y que podemos percibir este significado a través de ellas, aunque sea indirectamente. (Flusser, 1990, pp. 17-18)

Magritte já nos dissera isso em seu pseudo-emblema ${ }^{55}$ Trahison des images: o óbvio é que vemos na fig. 7 a representação mimética de um objeto ausente, apesar de se poder afirmar que se vê, efetivamente, um cachimbo, quando estaríamos vendo tinta, plasticamente ordenada em uma superfície, dando-nos a impressão de vermos o que, efetivamente, não estamos vendo.

\footnotetext{
${ }^{55}$ Utilizo pseudo pelo fato de Magritte, ao utilizar a representação lingüística juntamente com a pictórica, o faz não em vista da inter-relação/complementaridade sígnica como nos emblemas, mas da sua completa separação e divisão, com a condição de o enunciado contestar a identidade da figura (Almeida, 2006, p. 91)
} 
(...) teríamos, no continuum de configurações estéticas que coincidem com a modernidade, um fervilhar de investidas na relação entre imagem e texto, que culminaria em Magritte, com a proposta de uma não-relação que se afirma na presença dos elementos verbais e pictóricos, levando ao ápice o processo de separação entre representação plástica e lingüística. (Almeida, 2006, p. 92)

O que nos importa não é o fato de ser ou não verdadeiro, mas o de nos atingir, fazer com que nos deixemos levar por sua efração, assim como em

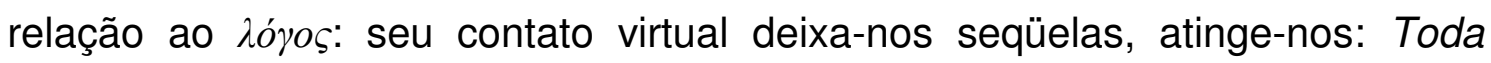
palavra é física, afeta imediatamente o corpo. (Deleuze, 2003, p. 90) Se assim somos tocados pelo $\lambda o ́ \gamma o \varsigma$ imaginemos quando este está junto à imagem, ainda mais a fotográfica com sua aparente realidade!

Além dessa sua pseudo-realidade, pode-se, com a imagem fotográfica, destacar e aprofundar a própria noção de belo dada por Aristóteles na Poética, para quem

(...) o belo reside na extensão e na ordem, razão por que não poderia ser belo um animal de extrema pequenez (pois se confunde a visão reduzida a um momento quase imperceptível), nem de extrema grandeza (pois a vista não pode abarcar o todo, mas escapa à visão dos espectadores a unidade e o todo (...). (Aristóteles, 1996, p. 38)

A fotografia nos permite jogar com a extensão, aumentando o diminuto ou diminuindo o avantajado, de forma que possamos - à moda dos gregos e seu ideal de proporção vinculado à matemática, à ordem e à simetria favorecer aquilo que chamamos, hoje, de prazer estético dado pelas $\tau \dot{\chi} \chi v \alpha l$ [artes] não utilitárias como a música, pintura, escultura e poesia, cuja busca é o saber em si mesmo ${ }^{56}$. Dizemos $\tau \dot{\varepsilon} \chi v \alpha l$, evidentemente, porque a arte $(\tau \dot{\varepsilon} \chi v \eta)$ para

\footnotetext{
56 É interessante o que nos diz Nussbaum a respeito das várias téxval: descubrimos varios tipos. En primer lugar están las téchnai claramente productivas, como la zapatería y la edificación (...). Un segundo grupo de artes, como la medicina, se distingue por la presencia de un fin vago, por ejemplo, la salud, que el lego puede considerar deseable y hacia el cual, como producto, se orienta la actividad del médico.(...) Por último están las artes cuyos fines son puramente internos: la danza, la flauta, el ejercicio atlético. Aquí no existe producto alguno; lo que se valora es la actividad en sí. Sin embargo, dado el carácter riguroso, preciso y enseñable de estas prácticas, no se duda en otorgarles el título de téchnai. (Nussbaum, 1995, pp. 147148)
} 
Aristóteles tinha uma acepção diversa da que temos hoje, possuía um sentido genérico; tanto poderia ser uma $\tau_{\varepsilon}^{\prime} \chi v \eta$ lógica, moral, retórica ou poética. $O$ sentido de belas-artes que temos hoje só surge em 1753 com a obra Aesthetica do filósofo alemão Alexander von Baumgarten, período em que vários estudos surgiram para sistematizar os vários gêneros artísticos e a arte começa a preterir o conceito de $\mu i ́ \mu \eta \sigma \iota$, , dominante no período objeto deste estudo, o Seiscentismo. 
Representação e $\mu i ́ \mu \eta \sigma \iota \varsigma$

A poética do século XVII não deve ser entendida como uma expressão de possíveis experiências pessoais de um eu lírico, conforme podemos compreendê-la no sentido contemporâneo, já que se baseia em formas, temas e conceitos preestabelecidos, mormente na filosofia e na retórica antigas. Esse alijamento desses conceitos tiveram início já no século XVIII, ampliaram-se no século XIX com o Romantismo, e aprofundaram-se no século XX com os movimento vanguardistas:

A experimentação levada a termo pelas vanguardas históricas no campo das artes implodiu de tal forma a noção de representação, que um travão pejorativo parece ter se the associado em definitivo. Parece sempre conservador falar-se em representação... (...) intitui-se uma tarefa permanente para a literatura desde então: colocar em crise as regras socioculturais da representação e evidenciar (...) o seu caráter inevitável de constructo, historicamente determinado. (Farinaccio, 2004, p. 10)

A literatura é, nos Seiscentos, uma representação retoricamente codificada, quando se verifica que o eu lírico individual cede espaço a um coletivo, seguindo os preceitos sociais vigentes, cujo eixo epistemológico orbitava em torno da $\mu \dot{\mu} \mu \eta \sigma \iota \varsigma ;$ não há, portanto, plágio, nem apelo à originalidade - no sentido romântico -, nem empiria, visto que todos os preceitos já estão determinados na fonte retórica dos auctores que devem ser imitados, pois não são somente fontes de saber, mas um tesouro da ciência e da filosofia da vida. (Cf.: CURTIUS, 1996, p. 95)

Para demonstrarmos em que consistia esse fazer artístico, devemos nos valer, exatamente, de como teóricos da contemporaneidade vêem a imitação pura. Teóricos como Wolfgang Iser (1926-2007),

Descarta a representação no sentido de mímesis-imitatio: o texto ficcional não reduplica algo pré-dado. O mundo apresentado no texto não designa um mundo existente, antes "deve ser tomado apenas como se fosse um mundo, embora não o 
seja" embora não designe um mundo existente, o mundo representado no texto está relacionado ao mundo empírico, na medida em que extrai dele os elemenos para a sua própria constituição." (Farinaccio, 2004, p. 17)

Assim, a empiria serve ao artista simplemente como fonte para sua arte, não como elemento essencial de onde ela provém. O mesmo serve para 0 psicologismo e para a força criadora da imaginação do artista, conceito que tem início apenas no século XVIII com Goethe, mas que inexistia nos Seiscentos:

a capacidade criadora do poeta é sentida aqui como a mesma força que atua na natureza externa. Goethe dirige-se ao "artistas capazes de criar" (schöpfungsvolle Künstler). Com Lenz ele sobe à plataforma: "A cada passo mais nos convencemos de que a força criadora no artista é o sentimento crescente das relações, das proporções e do necessário, e que só por meio delas nascerá uma obra autônoma, assim como outras criaturas nascem pela força do germe individual". Já o pré-romantismo inglês denomina "criadora" a força da imaginação poética, mas suas idéias diretrizes são o sentimento, o entusiasmo, a originalidade, o gênio. Só Goethe (...) encontrou na criatividade a palavra redentora que sobreleva a Natureza e a arte e associa o poeta às potências cosmogônicas. (Curtius, 1996, p. 484)

Pode-nos parecer estranho o fato de um conceito como força criativa do poeta ter sido desconhecido, algo que para nós já está profundamente enraizado. No entanto, os gregos sequer conheciam esse conceito, nem possuíam palavras para exprimir essa idéia:

A Antigüidade carecia desse conceito. A Hélade antiga colocava o poeta no círculo dos "homens divinos", ao lado de heróis, reis, arautos, sacerdotes e videntes. Chamam-se divinos porque estão acima do padrão humano. São favoritos dos deuses, intermediários entre eles e os homens. (...) Mas os gregos não conheciam o conceito da força criadora da imaginação. Não tinham plavras para exprimir essa idéia. O que os poetas expunham era inexato. Aristóteles louva Homero por haver ensinado aos poetas "o modo de dizer o que é falso". (ibidem, p. 485)

A genialidade individual - criação do Romantismo - era de somenos importância, pois o que importava era sua habilidade técnica - verossímil e 
retórica - no emprego das tópicas apropriadas e em seu emprego da $\mu i ́ \mu \eta \sigma \iota \varsigma$, já que,

Como se sabe, para ele a poesia era mimese, "imitação", e, na verdade, "imitação de homens que praticam alguma ação. A imitação pode apresentar as coisas como são, como parecem ou como deviam ser; não deve, portanto ser compreendida como cópia da natureza, mas como reprodução e transformação ou remodelagem. Mediante muitas interpretações, julgou-se poder atribuir ao atormentado texto o conceito de "visão criadora". (ibidem, p. 485)

Ao imitar, o poeta, por exemplo, busca a aemulatio, a superação operada tecnicamente, e é exatamente isso que o público, que também domina o sistema de prescrições do autor, espera encontrar: uma repetição, porém recontada de outra forma, pois é essa que lhe dará prazer.

As relações sociais são igualmente rígidas, não havendo o conceito contemporâneo de democracia, visto que tal sociedade está embasada nos privilégios e na demonstração de superioridade de um estamento sobre o outro. Assim, o tipo humano que melhor representa a racionalidade do momento é o discreto, ideal de excelência humana, cujos padrões eram o engenho, a prudência, a agudeza, a dissimulação honesta, o conhecimento de retórica, da poesia, de história e filosofia antigas. Tais qualidades eram imprescindíveis para se empregar as técnicas do decoro, norma de conveniência social em que se discernia o que é melhor para cada momento, cada situação, seja em termos éticos, retóricos ou políticos. O decoro estabelecia aquilo que deveria ser natural e habitual, impondo limites para a criação artística - mesmo que, para o homem do século XXI, possa parecer artificial ou incomum. Natural era, no período,

o eternamente humano; parecia que a tarefa máxima da poesia fosse dar expressão pura ao eternamente humano; e acreditava-se que o eternamente humano aparecesse de forma mais clara e sem mistura nas alturas isoladas da vida do que na baixa e confusa balbúrdia histórica. (Auerbach, 2004, p. 348)

Assim, será considerado natural - dentro do decoro estipulado no período - aquilo que comove o coração dos homens e suas paixões (Cf.: 
ibidem, p. 348), desde que se restrinja a um único segmento social: as classes mais elevadas, à aristocracia, à semelhança dos clássicos, como Homero:

(...) a vida, nos poemas homéricos, só se desenvolve na classe senhoril - tudo o que porventura viva além dela só participa de modo serviçal. A classe senhoril é ainda tão patriarcal, tão familiarizada com as atividades quotidianas da vida econômica, que às vezes se chega a esquecer seu caráter de classe. (...) Como estrutura social, este mundo é totalmente imóvel; as lutas só ocorrem entre diferentes grupos das classes senhoriais; de baixo nada surge. (ibidem, p. 18)

Além disso, o decoro estipulava, por exemplo, que cada gênero deveria ter seu próprio léxico. Mas quando as preceptivas dadas a determinado gênero não são empregadas seguindo tais normas, será indecoroso, como por exemplo, utilizar palavras obscenas no gênero trágico, o que não se aplica à comédia ou à farsa. Exemplo daquilo que se consideraria decoro, podemos retirar de Homero, quando este nos mostra a serviçal de Ulisses (transformado em um velho decrépito), reconhecendo-o por meio de uma cicatriz. Apesar de uma empregada estar na cena, revelando uma cena que seria do dia-a-dia,

Isto está longe, ainda, daquela regra da separação dos estilos que mais tarde se imporia quase por completo, e que estabelecia que a descrição realista do quotidiano era inconciliável com o sublime, e só teria lugar no cômico ou, em todo o caso, cuidadosamente estilizado, no idílico. (ibidem, p. 19)

Mesmo que se empregassem o estilo baixo, este não se destinava ao público em geral, já que seus autores esperavam dos leitores

uma formação social e literária à altura de compreender imediata e naturalmente todas as nuanças das infrações sociais, da vulgaridade do falar e do gosto. Por mais vulgar e grotesco que seja o assunto, a representação nada tem da grosseira comicidade das farsas populares. (ibidem, p. 40)

Assim, mesmo que os autores clássicos, por exemplo, empregassem o baixo estilo, esse não seria decodificado, se fosse possível, pela turba analfabeta, devido ao refinamento dos motivos empregados que não seria 
suportado por nenhum público popular. (Cf.: ibidem, p. 40) Assim, o baixo estilo da linguagem empregado pela elite

Não está destinado, certamente, ao riso de uma grande multidão, mas é o elegante condimento para o gosto de uma elite social e literária que observa as coisas de cima, impassível e fruidora (...). (ibidem, p. 40)

Esses aspectos do pensamento clássico internalizam-se no estilo social da sociedade seiscentista que se torna mecanicista, calcada numa disciplina e organização maior que a de outros períodos, apesar de seu aparente aspecto de desordem. (Cf.: Maravall, 1997, p. 126)

Para todos os momentos da vida, haverá sempre uma resposta com cada um sabendo exatamente qual é o seu papel no palco do mundo. A tópica do grande teatro do mundo converte-se em um instrumento imobilista da maior eficácia (ibidem, p. 255), por isso todo comportamento barroco tende a ser uma moral da acomodação (ibidem, p. 259), de manutenção de uma ordem fixa (Cf.: Auerbach, 2004, p. 296), já que os poderes sociais servem-se dela para montar mecanismos de contenção e coerção sociais. (Cf.: Maravall, 1997, p. 273)

A verossimilhança ${ }^{57}$, a partir dessa preceptiva, consistirá em representar aquilo que se acredita verdadeiro, segundo as determinações sociais do período, reproduzindo, na estrutura das obras, as motivações, explicações e prescrições próprias do gênero na qual está inserida, valendo-se do estilo e do léxico apropriados: ultrapassa-se aqui a verdade factual e adentra-se na contratual e na social.

Para que isso seja possível, é mister a utilização do engenho, força do intelecto que compreende dois talentos: perspicácia dialética e versatilidade retórica. Aquela penetra nas mais distantes e diminutas circunstâncias de cada assunto, esta confronta rapidamente todas essas circunstâncias entre si, ou

\footnotetext{
${ }^{57}$ Exemplo disso, é-nos fornecido por Auerbach a respeito do teatro clássico francês: Quando os círculos da corte e da melhor sociedade urbana começaram a se interessar pelo teatro, foram adotadas as regras das unidades dramáticas, sobretudo a partir de uma concepção da verossimilhança que hoje já não nos é habitual: achava-se inverossível que, durante as poucas horas de uma representação teatral, sobre o palco espacialmente limitado e distante só poucos passos do espectador, se desenrolassem acontecimentos muito distantes entre si no tempo e no espaço. Esta verossimilhança não se refere, pois, aos acontecimentos em si, mas à sua reprodução no palco, à possibilidade de ilusão cênica (...). (Auerbach, 2004, pp. 347-348)
} 
com o assunto. O resultado desse trabalho intelectual é a agudeza, modelo cultural de uma memória social de usos dos signos partilhada coletivamente, que definirá a hierarquização de uma retórica comportamental, bem como o esquema ordenador das práticas da representação do século XVII, seja nos livros de emblemas, de empresas, nas preceptivas retórico-poéticas, na poesia e na pintura, ou na codificação dos gêneros e estilos a que cada um pertence, adequando-os à grande variedade de tópicas, situações e comportamentos.

Nota-se que a Retórica aristotélica - a arte de falar, de construir o discurso artisticamente - terá um papel importante na vida do homem seiscentista, exatamente porque é uma arte de persuasão, exige técnica, método e conhecimento do público a quem o discurso destina-se. Para Aristóteles - que quis provar com sua obra que as rejeições de Platão à retórica eram infundadas, já que este a havia repudiado, como o fizera com a poética (Cf.: Curtius, 1994, p. 103)

a educação retórica, combinada com o ensino da lógica e da dialética, devia capacitar o discípulo a influenciar os ouvintes. E, dado o caso, também 'tornar mais forte a causa mais fraca'. (ibidem, p. 102)

Para que isso fosse possível, trata em sua Retórica, inclusive, da utilização de apotegmas. Estes seriam largamente utilizados pelos teóricos e pela poética dos Seiscentos, que encontravam nos poetas antigos centenas de versos que condensavam experiências psicológicas e regras de vida (cf.: ibidem, p. 95), quando serviram de base para muitos poemas.

Além de Aristóteles, Quintiliano terá grande influência no século XVII e sua obra Institutio Oratoria (95 A.D.), com doze volumes, considerada uma das melhores obras que nos legou a Antigüidade, é um tratado sobre a educação do homem. Para Quintiliano,

o homem ideal só pode ser orador, pois só a ele concedeu o Deus supremo e formador dos mundos o privilégio da fala. (ibidem, p. 104)

Dessa forma, a oratória está muito acima da astronomia, da matemática e de outras ciências (Cf. ibidem, p. 104), logo deve-se dar importância aos 
auctores e a seus apotegmas, chamados por ele de sentenças, que deviam ser "versos mnemônicos": para serem guardados de cor, colecionados e dispostos em ordem alfabética para facilmente serem consultados e empregados. (Cf. Curtius, 1994, p. 95)

A retórica terá uma grande abrangência no século XVII e dela fará grande utilização o artista, já que toda representação, codificada retoricamente, implicará seu profundo conhecimento, pois a arte do período será puramente mimética e sistêmica. Conheciam-se não só todas as cinco partes da retórica ${ }^{58}$, como as situações em que deveriam ser empregadas seus argumentos. Esses eram chamados de tótov - tópicas - em grego, e loci communes - lugarcomum - em latim. Empregavam-se, originalmente, na elaboração de discursos, entretanto

a poesia também impregnou-se de espírito retórico. A retórica perdeu, destarte, seu sentido primordial, sua razão de ser. Por outro lado, penetrou em todos os gêneros literários. (...) Assumem os topoi uma nova função: transformam-se em clichês de emprego universal na literatura e espalham-se por todos os terrenos da vida literária. (ibidem, p. 109)

O período também estará impregnado do elemento sacro. A divindade estará presente em tudo e em todas as relações, o que se evidencia na leitura que os artistas da época fazem da natureza: nela tudo tem um significado, até mesmo no ato de proclamar sermões, Deus se faz presente nas palavras proferidas; som e conceito estão intrinsecamente unidos, daí crer-se no esconjuro e na maldição. Temos uma interpretação teológica do mundo e esse é a própria representação do divino: tudo na natureza tem um significado e o significado das coisas não só é a Palavra de Deus (Cf.: Jöns, 1966, p. 31) como as coisas são portadoras dela. (ibidem, p. 32)

A Bíblia terá grande influência no período, por possuir tanto um senso espiritual como um místico - sensus espiritualis e mysticus -; difere, portanto,

\footnotetext{
${ }^{58}$ Como arte (ars), a retórica compreende cinco partes: inventio, dispositio, elocutio, memoria, actio; e formam o objeto da retórica (materia artis) três gêneros de eloqüência: o discurso forense (genus iudiciale), o discurso deliberativo (genus deliberativum) e o discurso laudatório ou solene (genus demonstrativum). Havia, entretanto, outros gêneros: o epitalâmio, a oração fúnebre, o discurso de aniversário, o de consolação, o de saudação, o de felicitação, entre outros.
} 
da literatura profana com seu sensus litteralis. Dessa forma, aquela com seu sentido alegórico ensina o significado da história da salvação à alma cristã; esta nos dá um acontecimento (ibidem, p. 30). Para Auerbach, o mundo da Bíblia não se contenta em ser uma realidade verdadeira, pretende ser o único mundo verdadeiro (Auerbach, 2004, p. 11), e devido a isso, condiciona uma exigência total e absoluta da verdade histórica:

A história de Abraão e Isaac não está melhor testificada do que a de Ulisses, Penélope e Euricléia; ambas são lendárias. Só que o narrador bíblico, o Eloísta tinha de acreditar na verdade objetiva da história da oferenda de Abraão (...). Tinha de acreditar nela apaixonadamente - ou então, deveria ser (...) um mentiroso consciente, não um mentiroso inofensivo como Homero, que mentia para agradar, mas um mentiroso político consciente das suas metas, que mentia no interesse de uma pretensão à autoridade absoluta. (ibidem, p. 11)

A alegoria que o sacro transmite deve ser, forçosamente, complexa e obscura, porque se consolida em complexos verbais que têm de ser imutáveis - à diferença de Homero, por exemplo, que nada oculta, nem há nenhum ensinamento num sentido hermético (ibidem, p. 10).

Dessa forma e diante de toda essa atmosfera do velame, seria fácil para o homem dos séculos XV, XVI e XVII aceitar teorias e ensinamentos que abordassem uma visão mais alegórica do mundo, por isso, acreditavam, a escrita alfabética teria menos condições de expressar o divino do que, por exemplo, os hieróglifos egípcios. (Benjamim, 1984, p. 197) Assim,

o desejo de assegurar o caráter sagrado da escrita - o conflito entre a validade sagrada e a inteligibilidade profana está sempre presente - impele essa escrita a complexos sinais, a hieróglifos. É o que se passa com o Barroco. Externamente e estilisticamente - na contundência das formas tipográficas como no exagero das metáforas - a palavra escrita tende à expressão visual. (ibidem, pp. 197-198)

A alegoria será então 
o esforço científico para o conhecimento da Palavra de Deus e, portanto, a base da Teologia (Jöns, 1966, p. 31)

que permeará todas as relações do período seiscentista, pois ela mesma,

embora uma convenção como qualquer escrita, era vista como criada, da mesma forma que a escrita sagrada. (Benjamim, 1997, p. 197) 
Falar em imagem seria o mesmo que falar em homo sapiens, pois ela está de tal forma inserida em nós que seria pouco provável imaginar a humanidade sem imagens, já que são meios de expressão da cultura humana desde antes de as pinturas rupestres aparecerem nas cavernas, milênios antes do aparecimento do registro fonético do hóros pela escrita. Diante de sua importância, evidentemente, houve muitas teorias a seu respeito no correr da humanidade que procuraram explicá-la mítica, lingüística, antropológica ou culturalmente.

Não se pretende nesta Tese, evidentemente, traçar as várias tendências que tentam explicá-la no correr da história humana, afinal não é esse o objeto deste estudo. Contudo, visto que uma parte do recorte que utilizaremos está inserida dentro do Seiscentismo ${ }^{59}$, e a outra dentro de nossa civilização dita pós-moderna ${ }^{60}$, é mister conhecer os critérios etimológicos que levaram não só à polissemia do termo, como também à utilização do termo nesse lapso temporal. Além disso, a própria importância do conceito imagem faz com que estabeleçamos alguns critérios para seu emprego nesta tese, como já havia sido feito com o termo $\tau \dot{\varepsilon} \chi v \eta$.

A imagem tanto pode ser a representação de uma realidade visível e sensível externa à consciência do homem (desenhos, pinturas, fotografias), quanto uma representação interna, mental (sonho, devaneios, pensamentos); ou ainda quando as realidades externas e internas funcionam como recurso lingüístico e o homem faz a associação inconsciente ou indireta de dois mundos ou duas realidades separadas no tempo e no espaço, como no texto literário. Vê-se, dessa forma, que elas podem tanto ser internas, dirigidas ao próprio intelecto de onde emanam; ou concebidas a partir de estímulos externos (como o próprio גóyos ao evocar algo: a palavra chocolate num outdoor, por exemplo, faz com que tenhamos vontade de comê-lo): vê-se,

\footnotetext{
59 Primeiro momento do que mais tarde se chamará a civilização da imagem, ou seja, a civilização moderna. (Argan, 2004, p. 51)

${ }^{60}$ Quando a imagem técnica domina e extrapola todos os meandros sociais.
} 
dessa forma que o $\lambda o ́ \gamma o \varsigma$ afeta nossos sentidos e percepção que temos do mundo a nossa volta, agindo, continuamente, com as imagens que evocam.

Há, portanto, a possibilidade de se reconstruir o visível e sensível via mente, quando se pretende criar um efeito de realidade e de verossimilhança com a realidade externa ao homem por meio de analogias e similitudes com padrões conhecidos. Normalmente, esse papel também pode ser oferecido pela literatura seja num texto poético ou num narrativo:

O conjunto de enunciados que formam uma imagem é, antes, um bloco de sensações, perceptos, afectos, paisagens e rostos, visões e devires. No trabalho de arte ou da literatura - escreveram Deleuze e Guattari - o que se conserva não é o material - seja o signo lingüístico, a pedra ou a cor -, o que se conserva em si é o percepto ou o afecto. (Guimarães, 1997, p. 63)

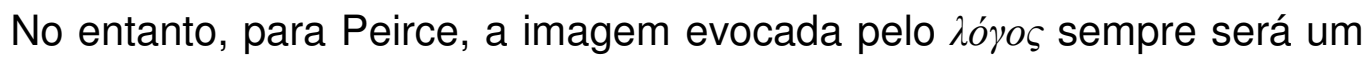
símbolo (a partir de sua tricotomia), já que

É aplicável a tudo o que possa concretizar a idéia ligada à palavra: em si mesmo não identifica essas coisas. Não nos mostra um pássaro, nem realiza diante de nossos olhos, uma doação ou um casamento, mas supõe que somos capazes de imaginar essas coisas, e a elas associar a palavra. (Peirce, 2005, p. 73)

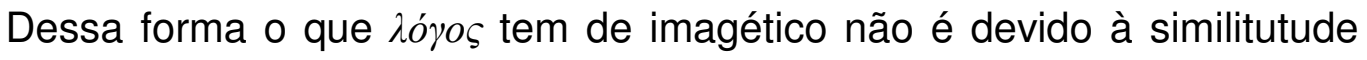
com o objeto que procura representar, mas pela conexão estabelecida na mente daqueles que utilizam a palavra, sem a qual essa conexão não existiria. (ibidem, p. 73) Assim, é necessário que haja uma vinculação entre os elementos do discurso para que possa haver a comunicação, ou seja, se o emissor transmite uma mensagem a um receptor sem que esse possa decodificar a mesma, aborta-se o entendimento, visto que a palavra/objeto não está amarrada a seu referente como no índice, com o qual está fisicamente conectado. (ibidem, p. 73) Isso se configura de modo claro em textos extemporâneos, quando, devido à alegorização, perde-se o referencial que deveria estar estabelecido entre o $\lambda o ́ \gamma o \varsigma$ e a imaginação que dele fazemos. 
A palavra imagem vem do latim - imago - cópia da realidade -; já para

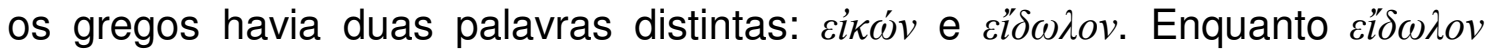
podemos traduzir como sombra, a silhueta de um morto, cuja essência enquanto ser Ihe falta (die Schattenbilder der Gestorbenen, denn es fehlt ihnen das Wesen selbst ${ }^{61}$ ); cópia (die Nachbildung); ou ainda, para os estóicos, imagem da alma; عikćv seria cópia que mantém similitude com algo; idéias mentais.

Diante das várias acepções que a palavra imagem pode ter, empregaremos nesta tese a palavra sikẃv, quando nos referirmos:

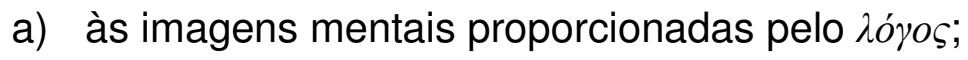

b) por aquelas que nos remetem a outras idéias mentais, ou conceitos retórico-literários.

Resulta daí a palavra ícone, que empregaremos num sentido positivo, como todo tipo de imagem, que podia ser tanto natural, como os reflexos da natureza, quanto artificial, como as pinturas, inclusive a fotografia.

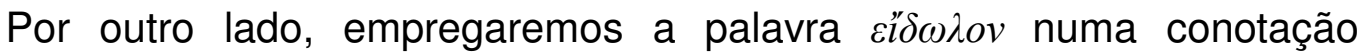
negativa, no sentido de

a) ídolo - com as acepções de simulacro ${ }^{62}$, fantasma, ou, por extensão, como objeto de desejo, de fetiche, à semelhança dos ídolos criados na Antigüidade para servirem de deuses, mas que deslocamos de lugar hoje, em nossa sociedade idolofílica (cf.: fig. 4);

b) idolatria $(\varepsilon i \delta \omega \lambda o v+\lambda \alpha \tau \rho \varepsilon i ́ \alpha)$, ou seja, culto à imagem.

Podemos justificar o emprego desses termos nesta tese, para tentarmos manter (artificialmente, é verdade) o empregado que os autores do período Barroco faziam, devido às questões religiosas suscitadas no período - a

\footnotetext{
61 Todas essas acepções foram retiradas de Pape: Griechisch-Deutsch, p. 25329.

${ }^{62}$ A idéia de simulacro remete a Platão e seu conceito de $\mu \dot{\mu} \mu \eta \sigma l \varsigma$. Segundo o filósofo, há uma oposição insuperável entre o mundo sensível e o mundo das Idéias e, para ilustrar o tema, empregou o conceito da caverna: o real, ao projetar-se na parede, traduz-se em irrealidade que as pessoas, em seu interior, crêem ser a realidade, afinal seus sentidos só teriam condições de alcançar simulacros. O real torna-se ideal, cujas Idéias - universais, imutáveis, eternas -, habitam o exterior e são inatingíveis pelos meros sentidos corporais; o mundo sensível, o irreal, não passa, portanto, de um teatro de sombras e reflexos. Por isso, para Platão, o fato de a

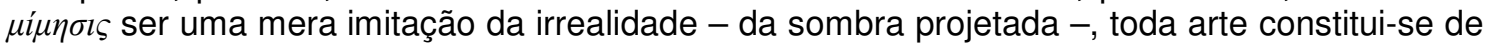
um desvio em relação à essência, uma falsidade, que aponta para o mero simulacro, do qual o mundo também faz parte, envolvido que está no mundo de aparências, por isso o ser humano não consegue atingir sua essência.
} 
questão da idolatria ou não dos católicos, ou da iconoclastia dos protestantes (para quem os católicos adoravam imagens, vendo-as, portanto como si̋ $\delta \lambda \nu v$ ) -, bem como à universalização de seu emprego imagético - via iconologias

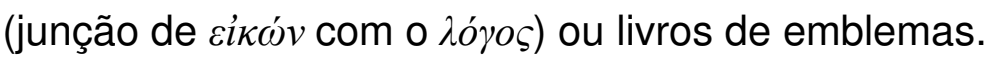

Num primeiro momento, as imagens tinham a função de tornar o mundo mais acessível ao homem, exatamente por serem mediações entre este e aquele. No entanto, vê-se, continuamente, que a imagem está, inclusive, se colocando no lugar do mundo de tal forma que o homem está vivendo em função das imagens que ele mesmo criou. (Cf.: Flusser, 1990, p. 12) Diante dessa relação unilateral, abre-se uma crise em nossa contemporaneidade, cujo epicentro é o próprio fazer imagético, já que

A cultura das imagens (e a transformação de toda a natureza tridimensional em planos e superfícies imagéticas) abre as portas para uma crise da visibilidade, dificultando aqui não apenas a percepção das facetas sombrias, mas até mesmo, por saturação, aquelas regiões iluminadas. Assim, como toda visibilidade carrega consigo a invisibilidade correspondente, também a inflação e a exacerbação das imagens agrega um desvalor à própria imagem, enfraquecendo sua força apelativa e tornando os olhares cada vez mais indiferentes, progressivamente cegos, pela incapacidade da visão crepuscular e pela univocidade saturadora das imagens iluminadas e iluminadoras. (Baitello, 2006, p. 2)

Não só o termo imagem é de tal forma abrangente, como também a polaridade representação visual x imaginação mental fez do termo, no correr dos séculos, objeto de várias opiniões. As imagens mentais, por exemplo, sempre foram valorizadas positivamente no Ocidente, seja como idéias ou modelos (desde Platão) ou como sonhos (desde Freud); entretanto, enquanto representação visual, há uma grande polarização nas diferentes culturas: uns vêem nas imagens a representação do divino, do tautológico; outros as proíbem, como o protestantismo cristão ou o islã. (Cf.: Santaella, 1998, pp. 3637)

Entretanto, apesar de todas as ondas iconoclastas, estamos cada vez mais submissos a elas, portanto é inegável que vivamos inseridos num mundo 
completamente imagético. O síkćv inundou todos os níveis da vida humana contemporânea e se dissipa por grande parte das mídias presentes hoje, a ponto de impor transformações profundas tanto nas formas de percepção e da sensibilidade humanas quanto em sua representação literária e pictórica. (Cf. Benjamim, 1985, passim)

Exatamente por sua constituição mental, e a despeito de seus empregos e controvérsias, a palavra imagem também possui um valor psicológico, pois sendo um produto imaginário, pode-se, por seu meio, representar toda forma verbal, frase ou conjunto de frases ditas pelo poeta e que, unidas, compõem um poema. (Cf. Paz, 2005, p. 37) Dentre essas imagens, podemos destacar as que representam um dos recursos estilísticos mais importantes para a criação poética, portanto verbal, e

que decorre da transfiguração da realidade em arte, ou melhor, do elemento real em figura ou imagem (Coelho, 1980, p. 75),

como as comparações, metáforas, símiles, jogos de palavras, paronomásias, símbolos, alegorias, mitos, fábulas etc.

Quaisquer que sejam as diferenças que as separam, todas têm em comum a preservação da pluralidade de significados da palavra sem quebrar a unidade sintática da frase ou do conjunto de frases. Cada imagem - ou cada poema composto de imagens - contém significados contrários ou díspares, aos quais abarca ou reconcilia sem suprimi-los. (Paz, 2005, p. 38)

Eis o que torna o poeta um realizador de mundos e de realidades novas, e cuja linguagem está muito distante da língua da ciência e de sua terminologia, pois ao subverter os princípios lógicos estabelecidos por essa mesma ciência, demonstra a incapacidade dessa em digerir o caráter contraditório da realidade (Cf.: Paz, 2005, p. 39); para isso o poeta cria suas respostas e as dos homens que por elas anseiam: isto pode ser aquilo; a tristeza, a alegria; a velhice, a juventude; o outono, a primavera. 
O poema não só proclama a coexistência dinâmica e necessária de seus contrários como a sua final identidade. E esta reconciliação (...) não implica redução nem transmutação da singularidade de cada termo (...). (ibidem, p. 40)

As imagens, enquanto realidades inseridas no mundo, continuam sendo aquilo que sempre foram - ou aquilo que acreditamos que sejam: mera arbitrariedade sígnica ${ }^{63}$, mera convenção da qual participamos sem podermos interferir -, não há, portanto, uma mudança de substância da res, quando o poeta diz que o céu é roxo, demonstrando tristeza, desesperança frente a um mundo que o oprime; ou, quando diz que as pérolas são lágrimas, se a convenção social a que pertencer assim opinar devido à tradição, por exemplo. Nem por isso, o céu deixará de ser, para a maioria das pessoas, azul, nem a pérola um material orgânico duro e esférico, produzido pelas ostras: eles não perdem sua essência pelo fato de os poetas os renomearem dessa ou daquela forma: eis o fantástico mundo da poética ligado ao da imagética ${ }^{64}$.

\footnotetext{
${ }^{63}$ Há, evidentemente, muita controvérsia quanto à arbitrariedade do signo imagético, conforme nos mostra Gombrich, quando este nos diz que a foto, por exemplo, não sendo uma réplica da realidade, seria, na verdade, uma transformação visual que deveria ser interpretada novamente por aquele que a observa: o aprendizado da leitura de uma fotografia parece ser completamente diferente daquele relativo a um sistema de código arbitrário. (...) 0 conseqüente contraste entre a natureza e convenção é falso. Trata-se muito mais de uma habilidade contínua que, para algumas pessoas, é naturalmente apreensível e, para outros, o é com grande dificuldade, o que faz com que ninguém dela se aproprie. (Santaella, 1998, p. 41) Ainda segundo o autor, a evolução humana dotou o homem do reconhecimento, assim como os animais, de imagens que lhe sejam vantajosas para sua própria sobrevivência, ou seja, a alguns objetos basta uma vaga semelhança com algo que possa nos fazer sobreviver para que possamos ser por eles atingidos. (Cf.: ibidem, p. 42) Não será o mesmo que sentimos, quando vemos a lua cheia alaranjada, na linha do horizonte, e temos a impressão de ela ser muito maior do que quando está branca? A cor laranja remete-nos a frutas (logo, a alimento), por isso que por menor que esteja presente num determinado meio, sempre estará próxima, pois teremos a impressão de ser muito maior do que, efetivamente, é.

64 À semelhança dos primeiros homens que, a partir da natureza, criaram novos signos, gérmen dos futuros sistemas lingüísticos e raiz motora de nossa dependência frente às próprias imagens artificias, das quais não podemos nos desprender.
} 
Gênero emblemático

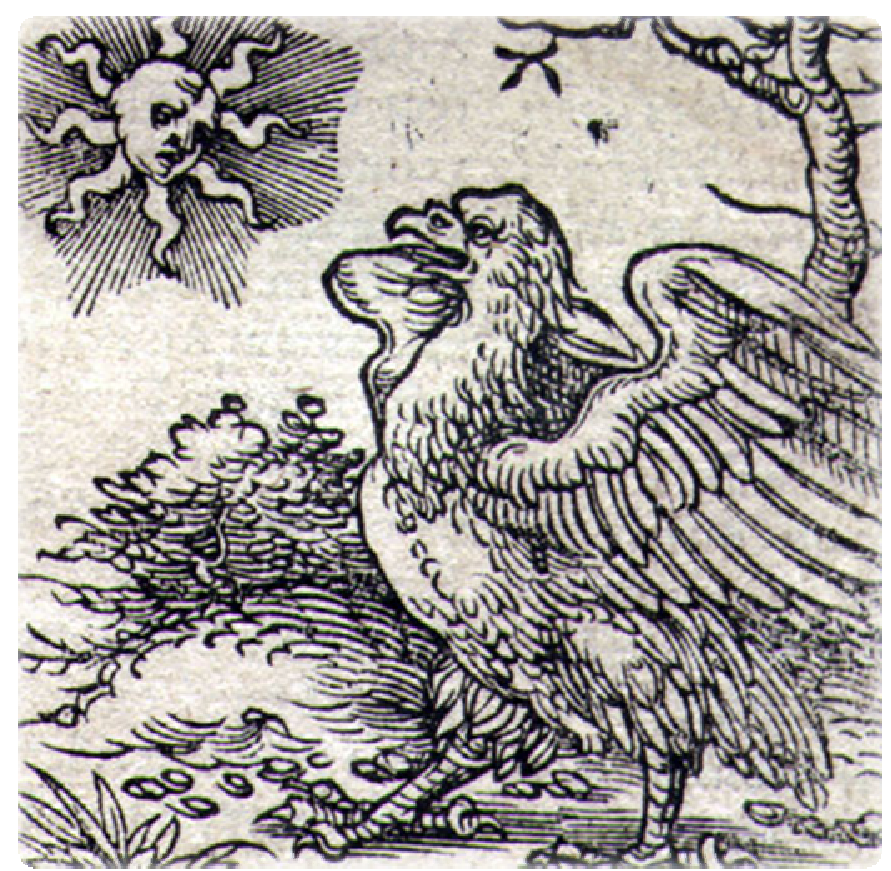

Figura 8: Segundo Horapolo, quando os egípcios queriam representar "Deus", "excelência", "sangue", "vitória", desenhavam um falcão:

Mediante el jeroglífico del halcón mirando hacia al sol, Horapolo nos propone este animal como imagen de la divinidad, la dignidad y la excelencia y de la victoria. (...)

La relación con la divinidad queda manifiesta por ser el único animal, a juicio del autor, que puede volar mirando al sol, y el astro, como es sabido y hemos dicho en otra parte, era para los egipcios y también para los platónicos, imagen de la dinidadd. (Horapolo, 1991, p.83)

Falar de emblema em uma sociedade em que - capital atingiu seu apogeu como a nossa, não deveria resultar em grande dificuldade, afinal estamos cercados de emblemas por todos os lados, simplesmente demos a eles outros nomes: marca $^{65}, \quad \operatorname{logotipo}^{66}$, logomarca...

Algumas marcas,

por exemplo, possuem, sozinhas, valores astronômicos como as da Coca-Cola (US\$ 65,3 bi), da Microsoft (US\$ 58 bi) ou da IBM (US\$ 57 bi). ${ }^{67}$ Isso corrobora o que havíamos dito, anteriormente, a respeito da linguagem publicitária, quando esta leva o consumidor a convencer-

\footnotetext{
${ }^{65}$ Marca é a representação simbólica de uma empresa ou entidade que permite identificá-la de imediato, podendo ser uma palavra que designa um produto, serviço ou a própria empresa. Pode-se representá-la via composição de um símbolo/imagem e/ou palavra/logotipo de forma individual ou combinada. O conceito de marca, entretanto, é bem mais abrangente do que pode demonstrar sua mera representação gráfica, já que se busca associar às marcas uma personalidade própria ou uma imagem/conceito mental, imputando-a na mente do consumidor, quando se pretende associar essa imagem à qualidade do produto. Para isso, adentra no campo do sígnico e do cultural, sendo, portanto, mais intangível do que tangível, pois cada consumidor possui sensações, experiências e percepções diferentes não só sobre a marca como também sobre o produto por ela identificado. Isso se deve, evidentemente, a vários fatores como a cultura, escolaridade e classe social a que pertence, fatos que devem ser observados pelas empresas de publicidade.

${ }^{66}$ Logotipo é a forma particular pela qual o nome de uma empresa - sua marca - é representada graficamente, seja pela escolha de um desenho e de uma fonte específica, ou somente um dos elementos. É uma assinatura institucional, devendo aparecer em todas as peças gráficas feitas para a empresa, portanto necessita seguir um padrão visual que a torna reconhecida onde quer que seja estampada.

${ }^{67}$ Segundo dados da Folha online de 27/07/2007.
} 
se da importância de determinados produtos, transformando-os em verdadeiros mitos, os novos $\varepsilon i \delta \omega \lambda \alpha$ a quem se deve prestar culto.

No entanto, a importância do poder imagético utilizado pela propaganda não é, seguramente, fruto de nossa sociedade, apesar de o campo de sua abrangência parecer-nos enorme. Para demonstrar isso, teríamos vários exemplos retirados da Antigüidade, basta nos ater a alguns: Alexandre Magno, para se fazer presente em todo seu vasto império, fez com que se espalhassem estátuas (imagens) suas por todo seu domínio: a corporificação de sua ausência; nem por isso eram menos respeitadas; tática semelhante fora utilizada por Otávio Augusto para impor seu poder de forma branda, unificando o Império Romano sob ele, seu imperador; que eram as grandes pirâmides, senão a demonstração do poder imagético - logo de propaganda -, que seus futuros moradores, os faraós, teriam tido em vida?

No entanto, maior que o poder imagético expresso por suas pirâmides e por seus colossais palácios, os egípcios, durante séculos, instigaram 0 Ocidente por sua forma de escrita, os hieróglifos, que fascinaram

os humanistas, como já havia acontecido com os gregos que, ao se depararem com tais ideogramas, os consideravam herméticos, inseridos num campo da especulação cosmogônica e da filosofia natural ou mesmo com significados psíquico-alegóricos, não os vendo como uma simples forma de linguagem que também poderia ser utilizada para e pelos sacerdotes. Sua representação imagética é, ao mesmo tempo, palavra e conceito, entretanto este não é aberto a todos, é obscuro, necessita-se, portanto, de interpretação, pois como afirmava Plotino: os egípcios não se utilizavam de argumentos discursivos, pois haviam descoberto uma forma de sintetizar as idéias por meio das imagens.

Para muitos teóricos do Humanismo, a tradição grega e a hebraico-cristã nos remete ao Egito, já que Platão, Pitágoras e Moisés aprenderam com ela; mesmo Jesus, segundo Pico della Mirandola, ocultara seu conhecimento em torno da verdade, como os egípcios e outros povos. Tal consideração estendeu-se a toda cultura e pensamento ocidentais, por isso a obra de Horapolo, Hieroglyphica, desfrutou de grande prestígio no período - tornando-se, portanto, obrigatória a todos que quisessem utilizar-se dos hieróglifos -, pois, cria-se, era o único testemunho herdado 
daquele momento que visava à análise e ao comentário de sua simbologia (...). (Brandão, 2003, pp. 49-50)

Uma das chaves sígnicas, portanto, para se compreender 0 Barroco é, justamente, deslumbramento propiciado pela obra de Horapolo $^{68}$, provável egípcio que, no século IV, teria des-cifrado os enigmas contidos nos hieróglifos, revelando seus mistérios. Ao ser descoberto pelos humanistas, serve de inspiração para a criação do gênero emblemático. No entanto, da mesma maneira que os Hieroglyphica foram o prenúncio desse gênero, a obra levou-o ao descrédito, já no século XVIII, diante do crivo racionalista do Século das Luzes, pois a mesma nada acrescentava

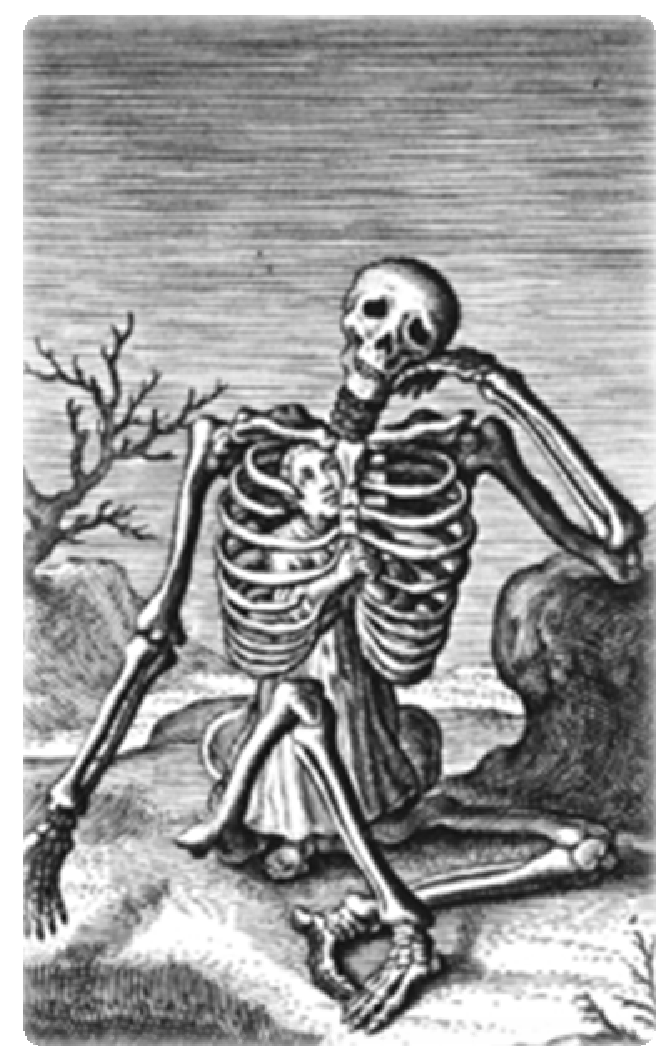

Figura 9a: Exemplo do corpo do emblema 38, de Hermann Hugo, de 1624.

no campo da filologia, mas no do fantástico, como demonstram os comentários de seu possível autor ao manipular o conteúdo semântico dos hieróglifos, que seria, a posteriori, desmistificado por Champollion. (ibidem, p. 50)

Não obstante o fato de as explicações contidas na obra Hieroglyphica serem ou não falsas, essas tiveram participação significativa na constituição do gênero emblemático (Cf.: Praz, 1989, p. 24) e no repertório imagético do

${ }^{68}$ Há um artigo de Gonzáles de Zárate que aborda de maneira clara o explicitado: La mentalidad ilustrada del siglo XVIII comenzó a cuestionar estos importantes códigos de información para artistas e intelectuales, comprendió que el fundamento del Emblema era netamente fantástico por cuanto partía de premisas falsas apuntadas por Horapollo, figura enigmática que compuso la Hieroglyphica hacia el siglo IV, obra que llegaría a Florencia en el $X V$ y que estimuló las mentes más preclaras del Humanismo dando origen a esta literatura que hemos Ilamado Emblemática. Tal y como nos cuenta Chastel y refrenda Wittkower, los eruditos del XVI entendieron que el sabio egipcio había conseguido descifrar la sabiduría de los pueblos del Nilo que de forma oculta había quedado reflejada en un lenguaje visual o escritura jeroglífica. Los estudios de Champollión derrumbaron tales premisas y pusieron de relieve que el Horapollo tan sólo sirvió para excitar la fantasía poética de sus seguidores (...). (Gonzáles de Zárate, 1999, pp. 256-257) 
período, cujo ápice dar-se-á, exatamente, nos Seiscentos. Apesar do modismo advindo com a obra de Horapolo e sua influência no incipiente gênero, pode-se dizer que a concepção de uma onda emblemática seja anterior a ela, afinal permeava a mentalidade iconográfica dos primeiros cristãos, ou mesmo o homem do medievo com seus bestiários, lapidários e alegorias. (ibidem, p. 16)

A palavra emblema vem do grego $\varepsilon \mu \beta \lambda \eta \mu \alpha$ e pode significar a parte da lança onde se encravava o ferro; algo embutido; ou mosaico. Temos, exatamente, isso: um amalgamento logo-icônico que, à semelhança do mosaico, não pode ser visto num relance como uma mensagem que se abre e é logo descartada - como as imagens de nossa contemporaneidade, as quais não passam de um embrulho que, ao ser rasgado, é posto fora e de que ninguém se lembrará -, senão a imagem desprender-se-ia de seu invólucro e se tornaria um borrão disforme, perdendo sua significação. Para isso, tem de ser lida e relida, degustada, apreciada, para assim - por meio do engenho ${ }^{69}$ ser decodificada e dar prazer. Vê-se, dessa forma, que traz sempre embutida em si mais do que uma imagem cercada de palavras que tentam se explicar mutuamente, já que se propunham a levar a mudanças comportamentais devido a seus preceitos morais.

Tendo como marco inicial a publicação, em 1531, do livro Emblematum liber, do humanista italiano Andrea Alciati que, ao praticar um exercício próprio do momento - tradução e imitação -, compôs uma antologia com 99 epigramas latinos, cuja inspiração fora o livro de Horapolo. Ao ser publicado, acrescentaram-se ilustrações para melhor explicar o conteúdo dos epigramas: sua repercussão fora enorme, como demonstraram suas várias reedições (mais de 150) e as constantes imitações por outros autores. Também vale salientar que, apesar da aparente novidade, já era muito popular, na França, no

\footnotetext{
${ }^{69}$ Força do intelecto que compreende dois talentos: perspicácia dialética e versatilidade retórica. Aquela penetra nas mais distantes e diminutas circunstâncias de cada assunto, esta confronta rapidamente todas essas circunstâncias entre si, ou com o assunto. $O$ resultado desse trabalho intelectual é a agudeza, "modelo cultural de uma memória social de usos dos signos partilhada coletivamente", que definirá a hierarquização de uma retórica comportamental, bem como o esquema ordenador das práticas da representação do século $X V I I$, seja nos livros de emblemas, de empresas, nas preceptivas retórico-poéticas, na poesia e na pintura, ou na codificação dos gêneros e estilos a que cada um pertence, adequando-os à grande variedade de tópicas, situações e comportamentos.(Brandão, 2003, pp. 44-45)
} 
final da Idade Média, uma literatura parecida com o emblema, visto que motes (divisas) eram, freqüentemente, explicados por alegorias.

A moda de se empregar imagens para explicar epigramas propaga-se, rapidamente, na Itália, e foi decisiva para o desenvolvimento do gênero emblemático - com suas diferentes modalidades: empresa, emblema e divisa ${ }^{70}$ e cada uma delas destinada a diferentes leitores, apesar de possuírem a mesma constituição logo-imagética.

Seu êxito consistia em um casamento perfeito para as aspirações de grupos intelectuais do período, já que, naquele momento, se buscava uma linguagem universal e, acreditava-se, a melhor forma para que isso fosse possível seria por meio de imagens. Estas teriam esse poder de comunicação por serem acessíveis a todos, trilhando o caminho dos hieróglifos egípcios. Dessa forma, e munidos com essa nova possibilidade de comunicação, transmitir-se-iam regras de conduta para todos os seres humanos.

Evidentemente, um fator primordial para o sucesso do gênero deveu-se à imprensa, que estendeu o mote emblemático para outros âmbitos que não o moral e o didático. Vê-se, portanto, emblemas que tratam de temas religiosos, do amor, da flora, da fauna, da mitologia; tampouco, restringiu-se ao círculo católico, como demonstram os inúmeros livros de emblemas protestantes. Outro aspecto que vale ressaltar é que o gênero não se restringiu ao veículo livro, mas a grandes obras pictóricas utilizadas em cortejos reais, de exéquias, em festas de cunho religioso ou popular, mas que, infelizmente, se perderam por não terem sido registradas.

\footnotetext{
${ }^{70}$ Convém ressaltar algumas características que possuem o emblema e a empresa, devido às confusões que podem causar. Enquanto admitem-se várias imagens em um mesmo emblema - figuras históricas ou fabulosas, materiais ou artificiosas, verdadeiras ou quiméricas inclusive a representação do corpo humano, a empresa ou divisa é composta de um número reduzido de imagens, além de não admitir a representação total do corpo humano, havendo só a possibilidade de se representar membros isolados do corpo: pernas, braços, troncos, mãos, pés. A intencionalidade do emblema é de caráter geral, relaciona-se à vida humana como um todo, não vela o que quer dizer: é direto, claro, nunca encobre o que declara; a empresa possui um emprego particular, sutil, engenhosa, por isso enigmática.
} 


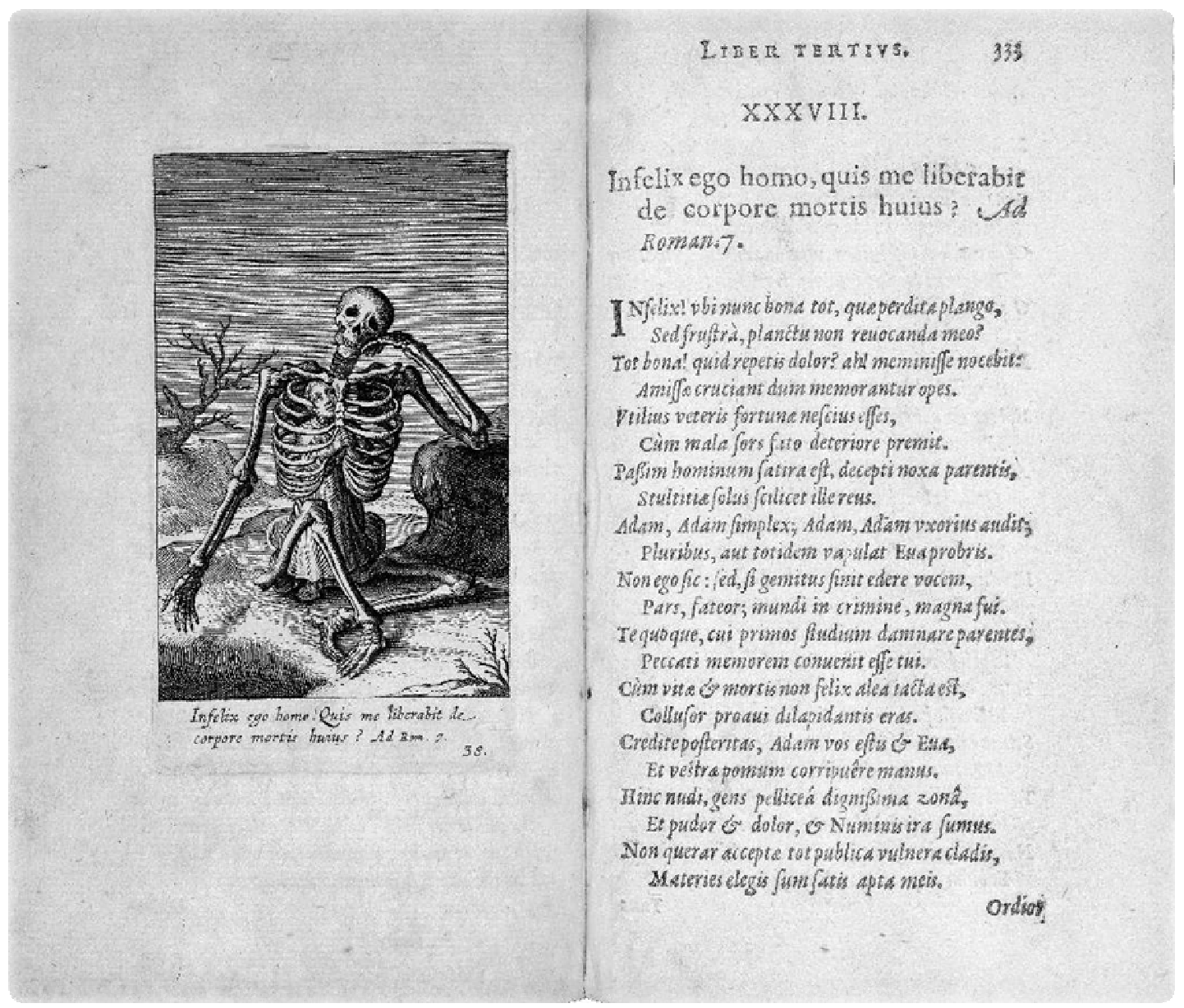

Figura 9b: Facsímile do emblema 38, de Hermann Hugo, onde se vê o corpo - a imagem -, o mote em latim - Infelix ego homo, quis me liberabit de corpore mortis huius (Infeliz de mim! Quem me libertará deste corpo de morte? (Rm 7, 24) -, e a alma - o texto epigramático - que neste emblema estende-se por dez páginas.

Os emblemas possuíam uma estrutura tripartite constituída por:

a) uma imagem - que era seu corpo e que deveria ser fixada na memória dos leitores, pois ela passava os preceitos morais que 0 autor desejava transmitir;

b) um mote, a inscriptio, - normalmente uma sentença aguda escrita em latim, com a qual o leitor era direcionado a determinada leitura da imagem;

c) um epigrama, ou texto explicativo, - que buscava relacionar o corpo com o mote do emblema, clarificando a relação existente, era, portanto, sua alma.

Um emblema, portanto, é um meio multisígnico, que busca em sua hermenêutica muito mais do que a interpretação de sua alma, afinal retoma sua 
vocação ao alegórico, ao filosófico, à particularização de uma Weltanschauung, além de prévios conhecimentos/conceitos teológicos, retóricos, pedagógicos, estéticos (dentro de nossa acepção hodierna, evidente) e históricos, sem os quais se torna quase impossível abarcar toda sua carga sígnica: deve-se ter em mente que muitos poetas e teóricos do XVII, por exemplo, eram polímatas cujo conhecimento era multifacetado -, além dissso, ainda não havia a idéia de especialização. Além desses elementos, confluem para dificultar sua interpretação o anacronismo - e, como foi possível demonstrar, esse não seria o único e maior problema - bem como o idioma empregado - normalmente o latim, mas também se empregavam a língua vernácula do autor, ou ainda vários idiomas concomitantes.

Para lermos um emblema com sua multissignificação, portanto, faz-se necessário lê-lo como a um mosaico, cujas partes auxiliam para a compreensão do todo: as palavras como pequenas pedras vão aclarando os conceitos presentes na imagem que, apesar de, muitas vezes, ser clara, é-nos obscura. Corpo e alma se completam à medida que vamos relacionando-os, e a imagem conceitual torna-se presente.

Ao lermos o emblema do padre jesuíta Hermann Hugo (1588-1629), nosso exemplo da figura 9, é possível vermos a imagem de uma pessoa dentro de um esqueleto que parece estar descansando, ou inquirindo-nos acerca de algo; e, logo abaixo do corpo do emblema vemos a seguinte inscriptio, em latim, que dirigirá nossa leitura: Infelix ego homo, quis me liberabit de corpore mortis huius?, retirada da Carta de São Paulo aos Romanos: Infeliz de mim! Quem me libertará deste corpo de morte? ( $\mathrm{Rm} 7,24){ }^{71}$ Com isso, podemos inferir que a pessoa que está dentro do esqueleto está clamando para sair de lá por algum motivo, talvez medo, pavor... por estar presa e não ter como sair. Mas, quem a pôs lá dentro?

Ao lermos o capítulo em que o versículo está inserido, vemos São Paulo exortando a comunidade de Roma a compreender que a antiga Lei - a Lei de Moisés, ou seja, os preceitos religiosos do povo hebreu a que pertencia - era justa, quando, por exemplo, o fez compreender (via consciência) o conceito de

\footnotetext{
${ }^{71}$ Todas as citações bíblicas utilizadas neste trabalho foram tiradas da Bíblia Sagrada: Edição Pastoral. São Paulo, Edições Paulinas, 1990.
} 
pecado e de suas implicações. No entanto, ao ter consciência do mesmo, não só não conseguiu abandoná-lo, como se torna escravo dele

Porque o pecado aproveitou a ocasião do mandamento, me seduziu e, através dele, me matou. $(\mathrm{Rm} 7,11)$

O apóstolo continua sua epístola, dizendo que aquilo que era para ser bom para ele - a consciência do mal, do pecado -, simplemente se transformou em morte, visto que seu resultado foi contrário. No entanto, ele frisa, tal fato não foi devido à Lei, mas ao pecado que reside nele mesmo:

Foi o pecado que fez isso. Pois o pecado, através do que é bom produziu em mim a morte, a fim de que o pecado por meio do mandamento aparecesse em toda a sua gravidade. $(\mathrm{Rm} 7,13 \mathrm{~b})$

Vê-se, à continuação, que São Paulo - diríamos num jogo conceptista apresenta esse pecado interno como algo que vem do egoísmo humano e, portanto, deve ser extirpado do homem, mas isso somente foi possível quando o $\lambda o ́ \gamma o \varsigma$ divino se encarna e, ao assumir a própria condição humana, arranca de seu interior o egoísmo por meio de sua morte e ressurreição. Essa seria a diferença entre os que acreditam na Lei e aqueles que acreditam em Jesus Cristo. São Paulo, portanto, em seu jogo dialético, mostra a seus destinatários quem é que pode libertá-los da morte interior - do egoísmo -, um corpo estranho dentro de outro, mas que, no fundo, é o próprio íntimo da pessoa.

À continuação, a alma do emblema vai levando-nos a tentar compreender por que a pessoa clama, já que está de mãos postas em sinal de prece e de clemência. Há várias citações retiradas do Livro dos Salmos como o 38, 102 e o 118, além do livro de Jó.

O eu lírico do Salmo 38 clama a Javé que não lance sobre ele a fúria de sua justiça devido a seus pecados, já que além dos sofrimentos que pesam sobre ele externamente, há também aqueles que Ihe pesam em sua cabeça. Provavelmente, demonstra estar com uma grave doença como a hanseníase sinal externo de pecado para os hebreus, sujeito ao isolamento do meio 
comunitário -, por isso é perseguido e apontado pelos outros: ele torna-se, portanto, sua própria prisão, devendo abandonar tudo, é um impuro. Entretanto, apesar de declarar-se culpado (SI 38, 19), afirma que não são justas as acusações de seus detratores (SI 38, 20-21); suplicando por socorro, pede que Javé abrande seu sofrimento:

Vem socorrer-me depressa, meu Senhor, minha salvação! (SI 38, 23)

O livro de Jó vem completar a idéia do salmista, pois em seu sofrimento sente-se sufocado por dores, pede antes a morte do que a permanência de tal situação. Se ele pecou, por que Javé não lhe mostra, não o perdoa? Por que fazer tanta conta do que ele é e faz?

O que é o homem, para fazerdes tanto caso dele, para fixares tua atenção sobre ele, a ponto de examiná-lo a cada manhã e testá-lo a cada momento? Por que não paras de me espionar, deixando-me ao menos engolir saliva? (Jó 7, 17-19)

Ao lermos, rapidamente, alguns detalhes da imagem ${ }^{72}$, poderemos verificar que aquilo que ela nos transmite lembra o que já fora dito na alma do emblema, já que os textos falam de morte e temos sua representação na figura do esqueleto. Mas, além dessa imagem lúgubre, vemos a de uma menina (ela está de vestido) que está inserida dentro do esqueleto, cujas costelas servem de grades para mantê-la presa. É possível verificar também que ela dirige seu olhar aos céus, suplicando para sair daquele corpo de morte - que sequer é um corpo - que a mantém prisioneira; está de mãos postas, segurando o esterno tétrico de sua prisão da mesma maneira como o prisioneiro segura nas grades da prisão que o mantém cativo... Chama-nos a atenção a posição adotada pelo esqueleto: sentado, pernas cruzadas, mão esquerda segurando a cabeça que está um pouco abaixada, a outra espalmada para frente; e tudo isso, em um ambiente inóspito.

\footnotetext{
72 Mais adiante, onde trataremos da representação imagética no século XVII, trataremos de uma forma pormenorizada os diversos tipos de leitura que teremos de ter numa análise como essa, a partir dos preceitos de Panofsky.
} 
Apesar de sua prisão, a menina não demonstra desespero como poderíamos, num primeiro momento, pensar. Pelo contrário, seu rosto demonstra-nos a serenidade de quem confia e crê em uma força maior do que ela. Seus olhos dirigindo-se ao céu representam, segundo a Iconologia de Cesare Ripa (1555-1622) ${ }^{73}$, oração:

Se pinta con los ojos alzados hacia el Cielo, porque las cosas que se piden en la Oración deben relacionarse precisamente con la que es nuestra verdadera patria, y no con las cosas de la tierra, donde somos peregrinos. (Ripa, 1987, v. 2, p. 159)

$(\ldots)$

(...) con los ojos vueltos hacie al Cielo mostrándose con ello el conocimiento de sí mismo que engendra la humildad, así como el conocimiento de cuanto a Dios se refiere, que engendra la confianza; enseñándonos con ello que en lo que respecta al pedir no debemos ser ni tan humildes que desesperemos, ni tan confiados que no nos asalten las dudas a causa de las faltas y pecados cometidos. (ibidem, p. 159)

Vemos que a menina - na verdade a representação da alma humana não demonstra medo devido a sua confiança em Deus, pois sabe que Ele virá em seu socorro prontamente, afinal ele não pára de nos espiar a todo momento, conforme havíamos lido em Jó. Além disso, São Paulo disse-nos que, ao sermos batizados, morreríamos em Cristo, mas como ele ressucitou, ressucitaríamos também com ele, dessa forma,

Se Cristo está em vocês, o corpo está morto por causa do pecado, e o Espírito é vida por causa da justiça. Se o Espírito daquele que ressucitou Jesus dos mortos habita em vocês, aquele que ressucitou Cristo dos mortos dará a vida também para os corpos mortais de vocês, por meio do seu Espírito que habita vocês. (Rm 8, 10-11)

Aqui, portanto, começamos a fechar o cerco para a compreensão do todo emblemático passado por Hermann Hugo: o esqueleto é, na verdade, o próprio corpo morto pelo pecado, mas resgatado por Deus devido ao Espírito que habita a alma - no caso a menina - daqueles que conseguiram dominar seus instintos egoístas:

\footnotetext{
${ }^{73}$ A principal obra de Ripa é Iconologia de 1593, manual iconográfico com figuras alegóricas e mitológicas, empregada como manual para grande parte dos artistas do período barroco.
} 
Se vocês vivem segundo os instintos egoístas, vocês morrerão; mas se com a ajuda do Espírito fazem morrer as obras do corpo, vocês viverão. $(\mathrm{Rm} 8,13)$

Para isso se faz necessária a meditação, o buscar-se, o refletir profundamente sobre sua existência e abandonar o homem velho para se revestir do novo:

Vocês devem deixar de viver como viviam antes, como homem velho que se corrompe com paixões enganadoras. $E$ preciso que vocês se renovem pela transformação espiritual da inteligência. (Ef 4, 22-23)

Depreende-se que o esqueleto não passa do homem velho que tem de morrer (ou já está morto se já foi tocado pela graça) para que o novo - a criança - possa tomar seu lugar. Isso explica a própria atitude do esqueleto, já que segurar a bochecha com a mão esquerda representa, para Ripa, meditação:

Estará reposando la mejilla encima de la mano del brazo izquierdo, plegándose este último sobre la rodilla del mismo lado, en actitud pensativa. (...)

La actitud en que aparece, sujetándose el rostro, significa la gravedad y profundidad de pensamientos en que ocupa su mente, ejercitándose precisamente en aquelllas cosas necesarias e imprescindibles para actuar con la mayor justeza $y$ perfección, evitando al azar y las acciones caprichosas. (Ripa, 1987, pp. 63-64)

Alciato não poderia ter feito uma melhor escolha para o nome de sua obra e do conseqüente gênero resultante dela, pois foi por meio desse mosaico de informações, saberes e conhecimentos que a imagem quis transformar-se em uma linguagem universal; e, mesmo apesar de sua relativa brevidade, o gênero emblemático influenciou grandes nomes da literatura e da pintura até nossos dias, como veremos adiante. O tempo não pára, outros valores mais alto se alevantam, assim como a $\tau \dot{\varepsilon} \chi v \eta$ que faz morrer o velho para o novo poder chegar: entretanto, o que parece morte é um novo renascer da fênix; o novo, 
uma nova forma em mosaico de ver o mundo: a partir de suas minúcias e dos detalhes antes não percebidos, mas propiciados pela fotografia. 
Aspectos da linguagem fotográfica

Deus disse: "Que exista a luz!" E a luz começou a existir. Deus viu que a luz era boa. E Deus separou a luz das trevas: à luz Deus chamou "dia", e às trevas chamou "noite". (Gn 1,3-4)

Benjamim falou-nos do pensamento que, incansável, não pára de perseguir as coisas e, nessa perseguição, considera seu objeto sob os mais variados ângulos possíveis. À semelhança de um mosaico (Cf. Benjamim, 1986, p. 50) que, para ser vislumbrado, necessita da contemplação não da parte, a qual sequer se relaciona intrinsecamente e que está em contigüidade, mas do todo. Este não passa da alternância entre o fragmento e o vazio do encaixe. Ambos, porém, não são excludentes, completam-se na obra, assim como a luz e a escuridão que, em seu ciclo, é o princípio do agir, do pensamento, da arte, da vida, enfim de tudo,

A obra universal da LUZ é a morada de todas as coisas. Trata-se de uma ENERGEIA, uma operação ontológica que põe tudo em obra, por constituir em tudo o que, antes de ser, já sempre era ser (...), Boécio traduziu para o latim uma expressão corrente na Idade Média: quod quid erat esse. (Leão, 2006, p. 64.)

A luz para os gregos possuía a qualidade de encetar toda a criação; para nós, a mesma luz, via fotografia, abriu a oportunidade não só de conhecermos essa mesma criação como também irmos além, de penetrarmos em suas minúcias, em seus detalhes, permitindo-nos jogar com a extensão das coisas: aumentando o diminuto ou diminuindo o avantajado, favorecendo o que chamamos de prazer estético ${ }^{74}$, oferecido pela técnica fotográfica que nos permitiu vislumbrar

mundos imagéticos que se escondem no pequeno detalhe, suficientemente significativos e ocultos para encontrarem abrigo nos estados de devaneio, mas tendo

\footnotetext{
${ }^{74}$ Este é dado, ainda segundo os gregos, pelas $\tau \dot{\chi} \chi v \alpha ı$ não utilitárias música, dança, pintura, escultura, poesia: aquí no existe producto alguno; lo que se valora es la actividad em si. (Nussmann, 1995, p. 147)
} 
agora se tornado grandes e formuláveis, capazes de fazer com que a diferença entre técnica e magia seja visível como uma variável de natureza histórica. (Benjamin, 1991, p. 222)

Distanciando-nos da peça do mosaico, conseguimos vê-lo na totalidade. A fotografia fez, exatamente, o contrário, tornou possível conhecer o outro lado das coisas por sua aproximação. É como se, de repente, nos fosse possível conhecer o outro lado da lua, o mesmo que, devido à ausência de luz, ainda desconhecemos. No entanto, para que o sonho de perpassar não só pequenos mundos - antes desconhecidos, já que não percebidos - como também a nós próprios - nossas particularidades, nossa face oculta que teimamos em não nos revelar - fosse possível, foi necessário aprender a dominar a luz; à diferença do fogo dado por Prometeu, agora essa foi uma conquista do próprio homo sapiens com auxílio de suas $\tau \dot{\chi} \chi v \alpha u$. Por meio delas e sujeitando a luz (como se Prometeu também a tivesse entregado), o homem criou o processo fotográfico ( $\varphi \omega \tau o ́ \varsigma$ - luz; $\gamma \rho \alpha \varphi \eta ́$ - escrita, linha, processo), concretizando um sonho perseguido há muito pela humanidade: o de poder reproduzir e fixar aquilo que o olho vê na natureza, cujo início remonta à própria humanidade. Quando o homem primitivo, utilizando-se da luz de tochas nas cavernas escuras, decalcava suas mãos nas paredes à semelhança das sombras produzidas pela luz, é como se antevissem a criação de fotogramas ${ }^{75}$ (Cf.: Dubois, 2006, pp. 67-71); ou mesmo no início da pintura que, segundo Plínio, tem origem na fixação do contorno humano também a partir de sua sombra ${ }^{76}$.

Pode-se compreender porque, apesar de o processo fotográfico só ter sido possível em sua totalidade na primeira metade do século XIX, a fotografia

existierte in Gestalt von Plänen und Projekten, nicht zuletzt aber auch von Phantasien, Träumen und Mythen. Die Pläne und Projekte gehören ebenso wie die Vorarbeiten und Vorstufen zur Erfindung der Photographie in den Bereich der Technikund Wissenschaftsgeschichte und interessieren den Literaturwissenschaftler nur mittelbar. Aber für Träume, Phantasien und Mythen ist die Literatur und ihre Wissenschaft zuständig.

${ }^{75}$ Fotografias realizadas sem a utilização de um aparelho fotográfico, quando se colocam objetos diretamente sobre o papel sensível, expondo-os à luz.

${ }^{76}$ Vale conferir a fábula contada a esse respeito pelo mesmo Plínio. (Cf. Dubois, op. cit. pp. 117-118) 
Lange bevor sich die Physiker und Chemiker der Idee der Photographie bemächtigten, begegnen wir dieser in literarischen Zeugnissen. (Koppen, 1987, pp. 15-16)

[existia na forma de planos e projetos, e para não esquecer também em fantasias, sonhos e mitos. Os planos e projetos faziam parte inclusive da preparação e das etapas iniciais em direção à invenção da fotografia no campo da história da técnica e da ciência, e interessavam, só indiretamente, à ciência literária. Mas a ciência literária é competente em sonhos, fantasias e mitos. Muito antes de os físicos e químicos apossarem-se da idéia da fotografia, nós a conhecíamos nos testemunhos literários.]

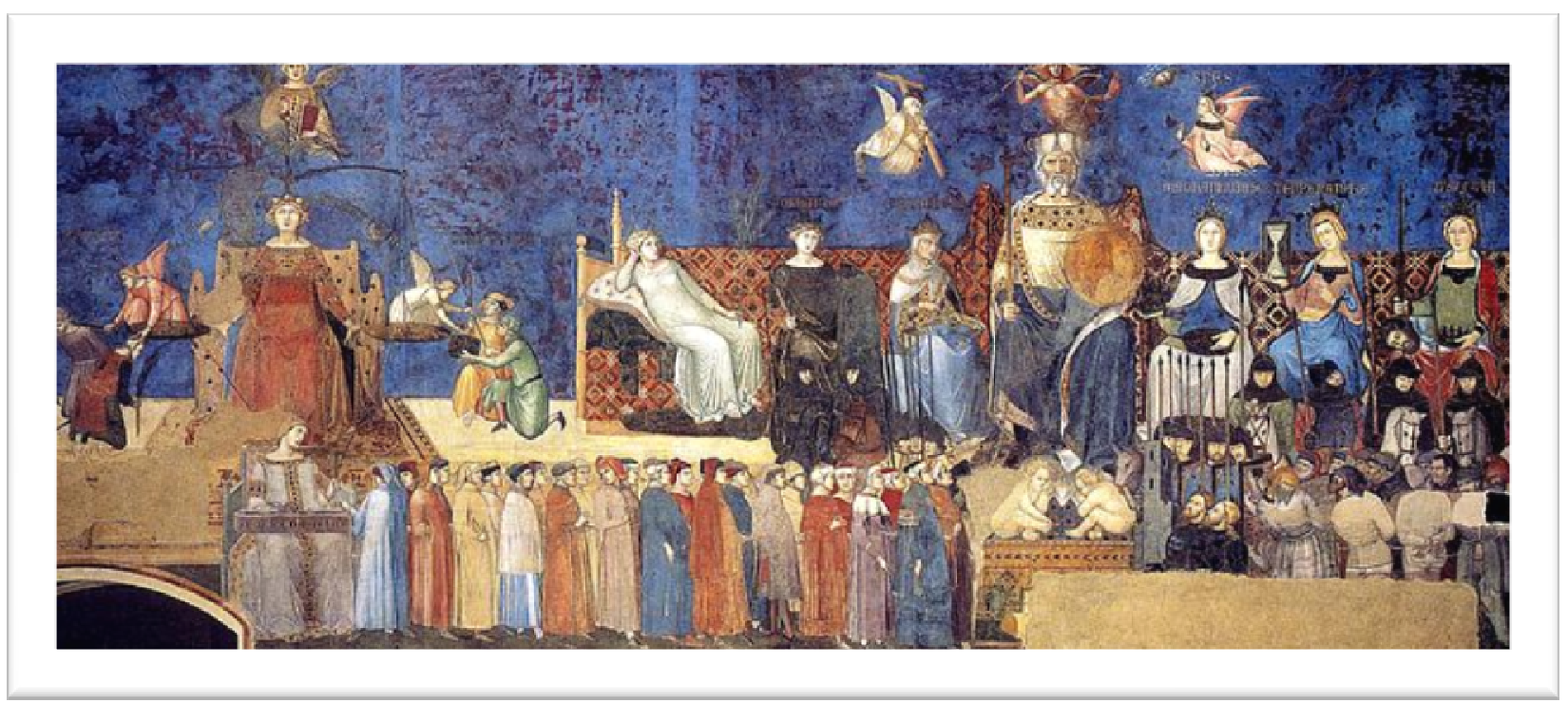

Figura 10: Alegoria do Bom Governo, de Ambrogio Lorenzetti, 1337/40.

Exemplo desse indício literário acerca da reprodutibilidade imagética já havia sido preconizado no mundo mítico grego a partir da história de Narciso que, segundo Koppen, é visto hoje somente sob o prisma de uma interpretação psicológica e psicanalítica, mas que antes dessas leituras permitia uma associação à imagem especular, afinal o espelho é a primeira reprodução imagética da realidade. (Cf. ibidem, pp. 16-17)

Deve-se ter em mente, quando falamos em anseio da humanidade, que o surgimento da fotografia deveu-se a um conjunto de fatores e de conhecimentos esparsos adquiridos no correr dos séculos, em áreas distintas do conhecimento: física, química, filosofia e artes, portanto sua invenção 
(...) não pode ser confundida [simplesmente] com a descoberta das placas sensíveis à luz e por isso a data de 1826 (quando Nièpce registra ou fixa a imagem na chapa fotográfica pela primeira vez) é arbitrária para designar o nascimento do processo. A fixação fotoquímica dos sinais de luz é apenas uma das técnicas constitutivas da fotografia; a câmara fotográfica, porém, já estava inventada desde o Renascimento, quando proliferou sob a forma de aparelhos construídos sob o princípio da câmara obscura (...). (Machado, 1984, p. 30)

E é justamente no Renascimento, período em que grandes transformações sócio-econômicas e sociais ocorrem, que a arte pictórica rompe a teoria dogmática que a relegava a um plano secundário - as artes mecânicas (ars mechanicae) - em relação às chamadas artes liberais (ars liberae $)^{77}$. Mais do que isso, a virtù visiva passa a ocupar o lugar que pertencia ao ouvido: Deus falava ao homem medieval sobretudo pelo ouvido ${ }^{78}$, agora Deus fala por meio de imagens.

Essa mudança de enfoque deveu-se, sobretudo, ao avanço do campo pictórico e à adequação do fazer artístico às ciências, renovando não só a arte medieval como também modificando seu ponto de vista em relação à imagem que tinham diante de si. Os teóricos do período, como Alberti, enfatizavam a necessidade de centralizar a narrativa pictórica como princípio básico do perspectivismo - na arte medieval aceitava-se uma seqüência narrativa dentro de um mesmo quadro (fig. 10):

Alberti destacou a perfeição do perspectivismo como método infalível para representar o visível. $A$ identidade entre $o$ visível e o verdadeiro refletia perfeitamente $o$

\footnotetext{
77 Tal conceituação remonta ao primeiro século de nossa era, quando as chamadas artes liberais designavam aquelas dignas dos homens livres em contraposição às mecânicas, próprias do trabalhador manual. O filósofo romano Varrão havia classificado as artes liberais como nove: gramática, retórica, lógica, aritmética, geometria, astronomia, música, arquitetura e medicina. No séc. V d.C., Marciano Capela em seu As Núpcias de Mercúrio com a Filologia reduzia a sete as ars liberae: gramática, retórica, lógica, aritmética, geometria, astronomia e música, quando eliminou a arquitetura e a medicina. Dessa forma, a pintura, a escultura e a arquitetura (só para citar as que consideramos arte) foram relegadas a um plano inferior por séculos. E, finalmente no século VI, Isidoro em seu Etymologiae (550) e Casiodro com seu Institutiones divinarum et humanorum lectionum (562), dividiram-nas em duas categorias: 0 trivium e o quadrivium, este corresponderia a aritmética, geometria, astronomia e música, aquele a gramática, dialética e retórica. Portanto, havia se instaurado, de modo incipiente, a divisão que chegaria até nós entre as ciências matemáticas e as filosóficas. Daí teremos a

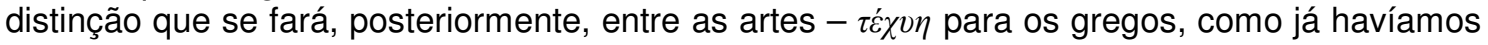
dito - que visam à arte (ao belo) e à técnica (utilidade).

${ }^{78} \mathrm{O}$ contato com imagens era restrito a membros do clero e a alguns nobres.
} 
espírito científico renascentista. A pintura deve formar-se como uma "janela" onde o espaço é enquadrado segundo princípios quantitativos que diminuem a função discursiva em favor da autonomia do figurativo. Assim, a perspectiva se estabelece na confiança numa posição escópica estável do sujeito contemplador (...). (Schøllhammer, 2001, p. 35)

Dessa forma, a obra de arte renascentista insistirá numa perspectiva unilocular, a partir de um único ponto de vista (fig. 11): um ponto de fuga, que permanecerá na sociedade ocidental durante séculos e também influirá na própria fotografia. A obsessão criada pelo Renascimento em torno da concepção e do efeito de realismo imagético vai além de uma mera representação:

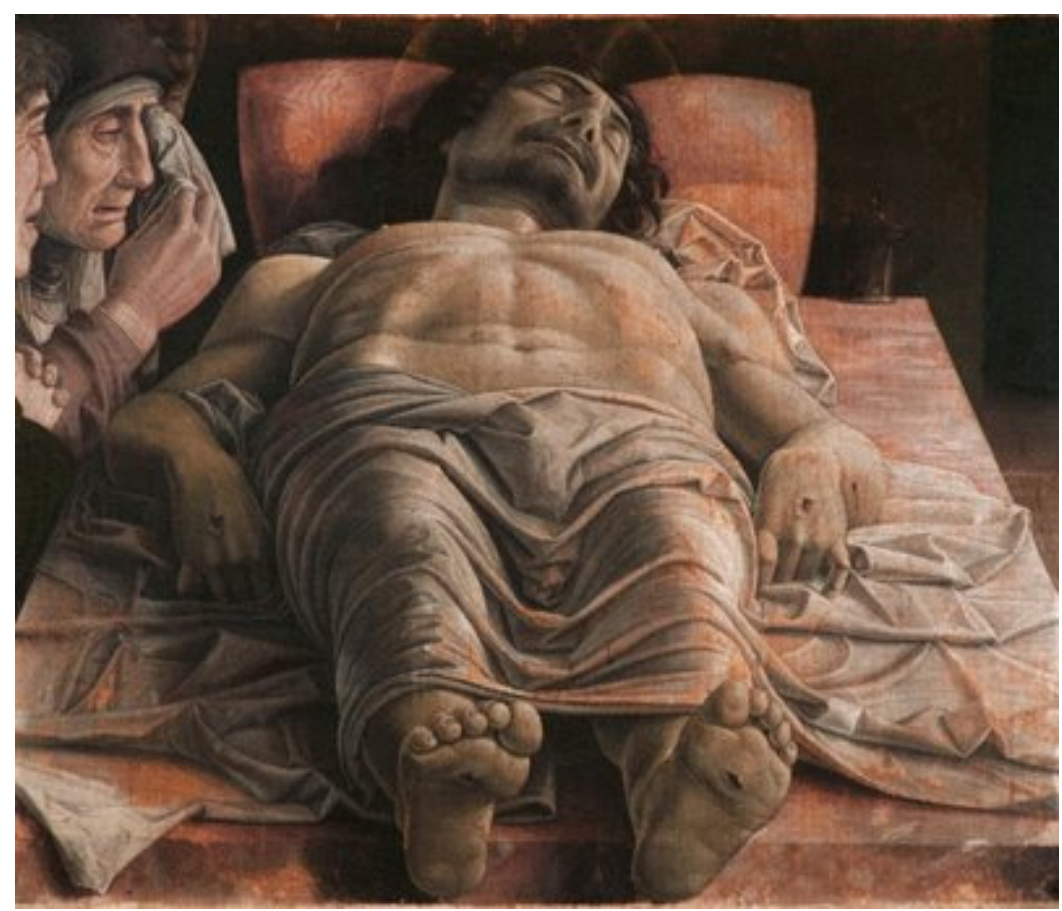

Figura 11: Lamentação a Cristo Morto, de Andrea Mantegna, 1480.

Não se tratava apenas (...) de buscar recursos para representar o "real", no sentido de que todo e qualquer sistema de signos busca de alguma forma se referir a algo "real": a estratégia renascentista visava suprimir - ou pelo menos reprimir - a própria representação, na medida em que esse analogon buscado deveria ter espessura e densidade suficientes para se fazer passar pelo próprio "real".

Na verdade, mais que analogia, o que a imagem figurativa buscou esse tempo todo foi uma homologia absoluta, a identidade perfeita entre o signo e o designado. (Machado, op. cit. p. 27) 


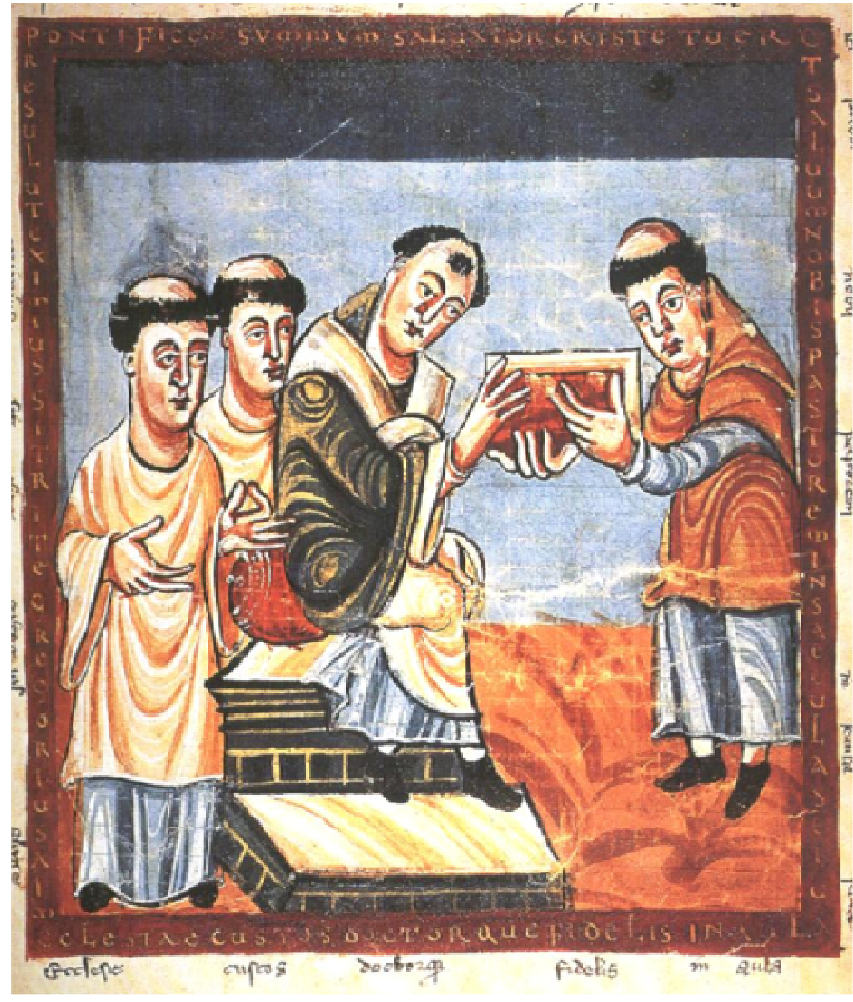

Figura 12: miniatura que ilustra o Livro do Louvor à Santa Cruz,
Tal concepção era impensável no mundo medieval, cujas obras planas ${ }^{79}$ se baseavam, entre outros aspectos, no hieratismo, na frontalidade, na isocefalia, na isodactilia, na falta de perspectiva e de profundidade (fig. 12). Prevalecia, naquele momento, não só a interpretação metafísica da estrutura do corpo humano ${ }^{80}$ (Panofsky, op. cit., p. 128), como também

do séc. IX.

as especulações cosmológicas, centradas nas correspondências por Deus ordenadas entre o homem e o universo, (...) [quando] as proporções do ser humano são explicadas pelo plano harmonioso da criação divina. (ibidem, p.129)

A arte medieval, portanto, era pura simbologia, expressando a visão de um mundo teocrático e mágico; na renascentista, há um outro ponto de vista: por meio das leis matemáticas da perspectiva linear, o plano bidimensional da pintura adquire a ilusão de um espaço tridimensional a partir de um único ponto de fuga. Assim, a introdução dessa terceira dimensão é que permitia ver a cena simulando distância, volume e massa. Busca-se criar um efeito de realidade vista pelos olhos, um quase naturalismo, não no sentido de um gênero, ou de um momento literário, mas no de busca da perfeição daquilo que é imitado:

\footnotetext{
${ }^{79}$ A arte medieval é designada como uma arte plana (flächenhaft), apesar disso há figuras consideradas perspectivadas, contudo por não se apoiarem por meios ópticos não nos passam essa impressão. ( Cf.: Panofsky, op. cit. pp. 108-109)

80 Era, por exemplo, a partir do rosto que se mediam as dimensões do corpo, isso porque ele é sede da expressão espiritual; para os clássicos todo o corpo possuía igual interesse, não havendo, portanto, nenhuma especificidade em relação a uma parte determinada. (Cf. ibidem, pp. 110-112)
} 
basado en el profundo deseo humano de una reproducción objetiva del entorno en su totalidad o en sus aspectos parciales. Así, por tanto, el naturalista no puede 'estilizar' (...) apartarse de la visión natural por medio de un método configurador, una expresión subjetiva del temperamento o un acto de abstracción idealizador. Por todo ello, desde siempre se ha puesto en duda que pueda existir un 'arte' naturalista. (Stelzer, 1981, p. 16)

Antes de esse naturalismo ter sido materializado pela fotografia considerada num primeiro momento a mais mimética das artes -, perpassando, efetivamente, a imaginação daqueles teóricos, e concretizando-se por meio da

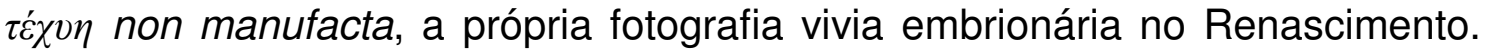
Dessa forma, quando a fotografia se materializa, cinco séculos de busca pela perfeição estética concretizaram-se e a própria fotografia recebe como herança grande parte do universo virtual criado pela própria Renascença (Cf.: Grieco, 2006, p. 105). A partir de então, a arte pictórica estaria liberada para trilhar outros caminhos, como a quebra do perspectivismo, do realismo, da linearidade da luz. Em suma, a fotografia

libertou as artes plásticas de sua obsessão por semelhança. Pois a pintura esforçava-se, no fundo em vão, em nos iludir, e essa ilusão bastava à arte (...) [agora] a fotografia e o cinema (...) satisfazem definitivamente e em sua própria essência a obsessão do realismo. (Bazin, apud Dubois, 2006, p. 31)

Num primeiro momento, é mister conhecer algumas propriedades físicas da luz - sua propagação, reflexão, refração e absorção -, bem como as propriedades ópticas e o emprego da câmara escura e, para concluir, o avanço tecnológico que culminou com a imagem e a fotografia digitais ${ }^{81}$.

\footnotetext{
${ }^{81}$ Pode-se perguntar o porquê da falta de uma abordagem em relação à química, por exemplo. A resposta é direta: não interessa a este trabalho tal abordagem, pois trabalharemos com 0 produto final, ou seja, a foto enquanto objeto. Além disso, diante da nova realidade em que estamos inseridos, podemos, inclusive, preteri-la, visto que deixou de ser parte intrínseca do processo fotográfico que sequer necessita mais de uma revelação: sabemos o resultado na hora. O trabalho, portanto, limitar-se-á à câmara escura, já que esta tese focará a recepção imagética no século XVII e seus sistemas de representação, cujo desenvolvimento foi contíguo ao da própria câmara, poderíamos, inclusive, estabelecer uma relação somente a partir desse ponto.
} 
A luz é uma forma de energia eletromagnética ${ }^{82}$ radiante $^{83}$ e pode ser transmitida de duas formas: ou em linha reta - como o laser - ou de forma ondulatória - quando há um simples transporte de energia, não de matéria, já que para sua transmissão não é necessário um meio material para seu deslocamento. Assim, se a luz solar incide sobre um determinado corpo, dependendo do comprimento de sua onda, pode ser que algumas ondas sejam absorvidas, refratadas e refletidas ${ }^{84}$ (fig. 13), principalmente se essa superfície for lisa como o vidro ou a água.

É-nos importante tal abordagem, não só para compreendermos a logicidade da luz e sua captação pelo processo fotográfico, como também para apropriarmo-nos desses conceitos físicos - refração e reflexão -, seguindo o conceito do lingüista russo Valentin N. Volochinov (1895-1936). Para este, a realidade material da ideologia são os signos que constituem a base de todo sistema de representação, porém

essa "representação" das coisas se dá de forma dupla e contraditória: os signos, ao mesmo tempo, refletem e refratam a realidade visada pela representação.(...) Resulta daí que o fenômeno da refração nos impede de obter uma reprodução "fiel" dos sinais luminosos, já que ele os "deforma" ou os "transfigura" de acordo com a natureza do material cristalino interposto em seu percurso. (...) Mas por que o signo modifica? Exatamente porque ele não é uma entidade autônoma, que "aponta para", ou "representa" os fenômenos do mundo com inocência, sem quaisquer mediações. (Machado, 1984, pp. 20-21)

\footnotetext{
${ }^{82}$ Ondas produzidas pela oscilação e aceleração de uma carga elétrica e que possuem componentes elétricos e magnéticos.

${ }^{83}$ Dependendo de sua freqüência (o que determina as diferentes sensações de cor da luz), o espectro magnético (série de cores semelhantes às do arco-íris: violeta, azul verde, amarelo, laranja e vermelho, em que cada cor corresponde a uma freqüência diferente) compõe-se de raios gama, raios $\mathrm{X}$, radiação ultravioleta, a luz (visível a olho nu), os raios infravermelhos, as microondas e as ondas de rádio.

${ }^{84}$ Segundo a física teórica, haveria um objeto ideal que absorveria toda a radiação que chegasse a sua superfície sem que a mesma pudesse ser refletida: o corpo negro.
} 


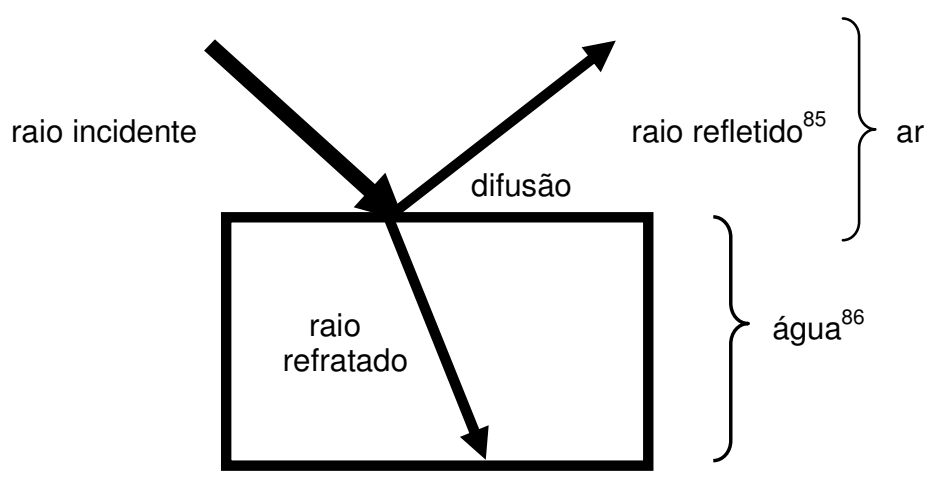

Figura 13: a reflexão e refração do raio luminoso

A concretude sígnica se dá por meio de alguém e de instrumentos que se interpõem entre a realidade representada e o signo que quer ser sua representação, além dos sinais externos e concretos dessa representação,

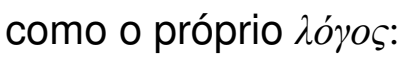

a palavra é o único signo que pode ser exteriorizado por qualquer indivíduo que tenha pulmões e cordas vocais, já que a produção dos demais sistemas de signos pressupõe a propriedade privada dos meios de produção (as tintas, o pincel, o instrumento musical, a câmera fotográfica, os aparelhos de gravação e toda a demais parafernália mecânico/eletrônica da ideologia industrializada) e a aquisição nem sempre democrática de know-how para operar instrumentos e códigos. (Ibidem, pp. 25-26)

Esses signos, porém, ao mediarem o mundo e o hóyos, por exemplo, acabam refratando-se: querem dizer sem, contudo, ser possível fazê-lo plenamente. Algo semelhante a essa situação ocorre, quando tentamos expor nossas sensações - aquelas apreendidas ao nos deparar com situações que fujam de nosso controle -, diante de uma paisagem, diante de algo que consideremos injustiça - a imagem de pessoas famélicas, o sofrimento de uma

\footnotetext{
${ }^{85}$ Temos a reflexão regular - quando um feixe de luz incide numa superfície lisa e é refletido para a mesma direção de onde veio - como a ocorrido num espelho ou num lago; e a difusão (ou reflexão difusa da luz) - quando o feixe de luz incide sobre uma superfície rugosa e é refletida em todas as direções - como a madeira, os tecidos, as paredes.

${ }_{86}$ Dependendo do meio em que penetra, a luz se refrata, isto é, muda sua trajetória original. Isso fica claro, quando vemos, por exemplo, a luz incindindo sobre a água.
} 
criança ou de um idoso que chora -, enfim descrever nossas emoções, aquilo que sentimos por algo ou por alguém, mas não conseguimos. O próprio tempo nos demonstra isso, quando determinado signo se perde em seus meandros e quando tentamos utilizá-lo de modo anacrônico: refrata-se de seu conceito proposto originalmente, levando-nos a ver aquilo que, efetivamente, não corresponde com à representação pretendida: aquilo que visualizamos não é sua totalidade sígnica.

Se é possível apropriar-nos dos termos refletir e refratar para descrever esses fenômenos lingüísticos devido à dinamicidade da linguagem verbal humana, valendo-nos da conceitualização da física, o mesmo se torna claro em relação à fotografia, uma vez que a câmera reflete (por meio de seu pseudoespelho que é a película) e refrata (por meio das objetivas que reorientam o sentido da informação luminosa) o mundo (Cf. Ibidem, p. 26), a partir da propagação retilínea da luz.

É exatamente pelo fato de ser retilínea que se opera a inversão imagética dentro da câmara escura ${ }^{87}$ : os raios luminosos, ao penetrarem pelo orifício $^{88}$ da câmara, fazem-no em linha reta, por isso a imagem surgida em seu interior fica invertida no anteparo.

\footnotetext{
87 Não se sabe quem foi o criador da câmara, nem mesmo seu descobridor. O certo é que Aristóteles (384-322 a.C.) descreveu seu mecanismo ao observar a imagem do sol, no momento de um eclipse, sendo projetada no solo, quando sua luz passava por um orifício de uma folha de árvore. Deve-se, entretanto, a Al Hassan ibn al Haitham (965-1039), erudito árabe conhecido por Al-Hazen, a construção efetiva da câmara escura, da qual se serviu para a observação de eclipses solares (Schreiber, 1969, p. 14), sem, contudo, afirmar ter sido seu descobridor. (Stelzer, 1981, p. 13) Durante a Idade Média, a câmara escura foi objeto de análise e observação de muitos estudiosos como o monge inglês Roger Bacon (1214-1294) (Schreiber, 1969, pp.18-19) e o erudito judeu Levi ben Gerson (1288-1344), porém sua utilização restringiu-se somente à área de observação, principalmente de ocorrências celestes como os eclipses.

${ }^{88}$ Leonardo da Vinci fará uma inequívoca descrição do orifício da câmara, mais que uma descrição: um verdadeiro tratado sobre a correlação desse com o olho humano. Ele via na câmara escura mais do que um mero objeto de observação, um aparelho primitivo ou um artifício qualquer (Cf.: ibidem, p. 21), como demonstram observações em seu diário - que só seria descoberto e publicado em 1797 - e sua antevisão da fotografia: Wer möchte es für möglich halten, da $\beta$ ein so kleiner Raum die Bilder des ganzen Weltalls zu fassen vermag! $O$ großartiges Geschehen! Welcher Verstand könnte diese Naturerscheinung wohl ergründen? Welche Sprache könnte ein solches Wunder erklären? Gewi $\beta$ keine. Das veranla $\beta t$ das menschlische Vorstellungsvermögen zur Betrachtung des Göttlichen. Hier werden alle Gestalten, hier werden alle Farben, hier werden alle Bilder der Teile des Weltalls in einem Punkt zusammengedrängt. - Oh, welcher Punkt ist so wunderbar? - Das sind die Wunder: nämlich, da $\beta$ schon verlorene, in einem so kleinen Raum verschmolzene Formen bei seiner Erweiterung wiederhervorgeholt und neu gebildet werden können. Wie ist es möglich, da $\beta$ aus verschwommenen Ursachen so klare und deutliche Wirkungen hervorgehen können wie diese Bilder (...)? (ibidem, p. 22)
} 
Leonardo da Vinci maravilhava-se com a câmara escura a ponto de se perguntar: Que língua poderia explicar tamanha maravilha? Com essa pergunta quase ontológica, da Vinci revela sua opção pelo olhar, pelas artes visuais, pictóricas, em detrimento da arte literária e procura

inverter a hierarquia tradicional que estabelecia a precedência da poesia sobre a pintura, argumentando em termos da maior imediaticidade e força dos 'signos' da pintura. (Seligmann-Silva, 1998, p.12)

Da Vinci considerava a visão, a virtù visiva, o sentido mais nobre, muito

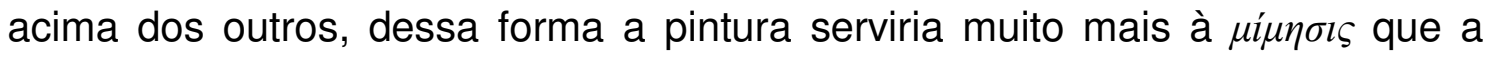
poesia, já que aquela é muito mais próxima da realidade do que esta: a pintura não necessita de interpretação, é direta, objetiva, universal; as palavras, pelo contrário, estão divididas em línguas diferentes, logo necessitam de tradução de uma para outra, não sendo, portanto, universais ${ }^{89}$. Para da Vinci, as palavras podem levar-nos à imaginação, mas esta se perde logo, ao ser substituída por outra; diferente de uma tela, cuja imagem permanece. A partir dessas considerações, podemos entender seu deslumbramento pela câmara escura e a grande possibilidade que se abre para as artes miméticas, principalmente no auxílio ao desenho e à pintura. Entretanto, ainda seriam necessários alguns aperfeiçoamentos para orientar a passagem dos raios de luz pelo orifício da câmara escura, obtendo-se, dessa maneira, maior nitidez ${ }^{90}$.

Em 1550, Girolamo Cardano (1501-1576) publicou De Subtilitate, em que faz uma descrição da câmara escura bastante conhecida ${ }^{91}$ e teve um

\footnotetext{
${ }^{89}$ Vide a questão da arbitrariedade proposta por Saussure. (Saussure, 2006, p. 81)

${ }^{90}$ Aqueles pesquisadores verificaram que o orifício da câmara tinha de ser menor, mas até isso se tornou um empecilho, visto que um orifício pequeno deixa passar pouca luz, tornando a imagem fraca, assim quanto menor o orifício, menor o brilho com um orifício bem pequeno, os raios de luz convergem e formam uma imagem nítida, porém a pequena quantidade de luz faz com que a imagem fique fraca. Dessa forma, a opção seria aumentar o orifício, pois mais raios de luz passariam e deixariam a imagem mais forte, porém, esses não estariam tão ordenados e formariam uma imagem desfocada: aumentando o orifício, fortalece-se proporcionalmente a imagem, visto que há um aumento da passagem da luz, entretanto não há uma convergência de todos os raios, tornando a imagem desfocada. Esse problema ainda seria resolvido no século XVI, já que surgiram muitos teóricos que aprimoraram a técnica e o emprego da câmara escura. Entre eles podemos citar Girolamo Cardano (1501-1576) - matemático, médico e filósofo de Pádua -, Daniello Barbaro (1514-1570), de Veneza, e Giovanni Battista della Porta (1541-1615), de Nápoles.

${ }_{11}$ Willst du sehen, was auf der Straße vor sich geht, so mußt du bei hellem Sonnenlicht die Läden deines Fensters schließen nachdem du in die Läden eine Linse aus Glas eingesetzt hast. Die durch die Öffnung geworfenen Bilder erscheinen dann auf der gegenüberliegenden Wand,
} 
papel importante em seu aprimoramento ao sugerir a utilização de uma lente junto ao orifício da mesma, o que permitiu aumentar seu emprego, obtendo, dessa forma, uma imagem mais clara e nítida: com a utilização de uma lente biconvexa, é possível aproveitar ao máximo a luz e o foco é obtido pela refração dos raios de luz na lente, que são convergidos para formar uma imagem clara e nítida ${ }^{92}$.

Havia ainda um outro problema surgido para a efetiva utilização da câmara escura pelos artistas: como manter a regularidade do foco? A resposta foi dada por Daniello Barbaro (1514-1570) em seu livro La pratica della prospettiva, de 1568, quando menciona que com a variação do diâmetro do orifício seria possível melhorar a nitidez da imagem ${ }^{93}$. Vemos assim surgir um sistema que, ao aumentar ou diminuir o orifício, tornaria possível uma melhor focalização do objeto que se queria reproduzir. Quanto mais fechado o orifício, maior seria a possibilidade de focalizar dois objetos diferentes pela lente: surge

doch sind ihre Farben schwach... (Schreiber, 1969, p. 24) [Se tu queres ver o que está ocorrendo na rua, então precisas fechar as venezianas de tua janela num dia de sol claro, depois disso colocas uma lente de vidro nas venezianas. As imagens que são projetadas através do orifício aparecerão na parede oposta, apesar de suas cores serem fracas...]

${ }_{92}$ Isso foi possível graças à capacidade de refração do vidro, que converge os raios luminosos refletidos pelo objeto, fazendo com que cada ponto luminoso do objeto correspondesse a um ponto da imagem refletida, fazendo, portanto, uma imagem puntiforme.

${ }_{93}$ Wenn ihr sehen wollt, wie die Natur die Gegenstände abbildet, nicht nur den Umriß des Ganzen und seiner Teile, sondern auch in Farbe, Schatten und Ähnlichkeit, so müßt ihr ein Loch in einen Fensterladen des Raumes machen, in dem ihr beobachten wollt. Das Loch hat die Größe eines Brillenglases, das von der Art sein muß, wie es ein alter Mann braucht, also bikonvex, nicht konkav wie die Gläser der Kurzsichtigen. Das Glas wird in dem Loch befestigt. Alle Fenster und Türen werden geschlossen, damit das Licht nur durch die Lochöffnung einfallen kann, dann hält man gegenüber der Linse, in einem ganz bestimmten Abstand, ein Blatt Papier und sieht so alles scharf abgebildet, was sich auf der Straße abspielt. Auf dem Blatt werdet ihr dann die Formen sehen, wie sie sind, die Abstufungen der Schatten und Farben, die Bewegungen, die Wolken und die Wellen des Wassers, die fliegenden Vögel und alles das, wenn die Sonne hell und schön scheint, weil im Sonnen Licht die Bilder am deutlichsten werden. Für diesen Versuch sollte man nur die besten Gläser verwenden. Auch muß das Linsenglas so weit abgedeckt werden, daß nur eine kleine Öffnung in der Mitte frei bleibt, dann wird das erhaltene Bild noch getreuer mit der Wirklichkeit übereinstimmen. (ibidem, p. 25) [Se quereis ver como a natureza retrata os objetos, não só o contorno do todo e de suas partes, mas também suas cores, sombras e semelhanças, então precisais fazer um orifício em uma veneziana da janela do cômodo no qual quereis observá-las. O orifício tem o tamanho de uma lente de óculos e precisa ser como a que um homem idoso utiliza, ou seja, biconvexa e não côncava como as lentes dos míopes. O vidro precisa estar firme no orifício. Todas as janela e portas deverão estão fechadas, a fim de que a luz só possa incidir pelo orifício aberto. Então se mantém no lado oposto à lente, em uma distância correta, uma folha de papel e vê retratado, dessa forma, nitidamente, o que se passa na rua. Na folha vereis então as formas como elas são, as matizes das sombras e cores, os movimentos, as nuvens e as ondas da água, os pássaros voando e todo o resto se o sol estiver brilhando claro e bonito, já que com a luz do sol as imagens se tornam mais nítidas. Para esse experimento deve-se utilizar somente as melhores lentes. A lente de vidro também precisa ser coberta de modo que só um pequeno orifício fique livre no meio, então a imagem obtida será ainda mais fiel e condizente com a realidade.] 
o diafragma ( $\delta l \alpha ́ \varphi \rho \alpha \gamma \mu \alpha$ - barreira). A partir de então, os avanços da câmara escura não pararam mais ${ }^{94}$ : a arte também não seria mais a mesma e com ela nosso olhar em relação ao mundo que nos cerca:

Beginning in the late 1500s the figure of the camera obscura begins to assume a preeminent importance in delimiting and defining the relations between observer and world. Within several decades the camera obscura is no longer one of many instruments or visual options but instead the compulsory site from which vision can be conceived or represented. Above all it indicates the appearance of a new model of subjectivity, the hegemony of a new subject-effect. First of all the camera obscura performs an operation of individuation; that is, it necessary defines an observer as isolated, enclosed, and autonomous within its dark confines. (Crary, 1992, pp. 38-39)

Assim, devido às novas técnicas alcançadas dentro do ambiente da física, e com condições satisfatórias de controlar a câmara escura via escolha de lentes, diafragmas e a facilidade das câmaras portáteis, houve uma generalização de sua utilização, principalmente por artistas, nos séculos ulteriores. Nos séculos XVIII e XIX, já havia toda uma indústria de instrumentos auxiliares para os pintores e mesmo no século XIX, encontramo-nos em um momento em que para muitos artistas bem como para o público, o "ideal" em arte consistia na reprodução não ideal, mas na reprodução puramente naturalista, fiel à natureza. Pouco antes do advento da fotografia encontramos

\footnotetext{
${ }^{94}$ Cito alguns: 1573 - o astrônomo e matemático italiano Egnatio Danti sugere a utilização de um espelho côncavo para reinverter a imagem da câmara escura em sua obra La perspecttiva di Euclide; 1580 - o alemão Friedrich Reiner descreve uma câmara escura portátil, apesar de seu livro Optics somente ter sido publicado após sua morte, em 1606; 1620 - o astrônomo alemão Johann Kepler utiliza uma câmara escura em forma de tenda, em que havia uma lente e um espelho que direcionava a imagem para um tabuleiro, a fim de que o mesmo fizesse desenhos topográficos durante uma viagem à Alta Áustria; 1636 - o professor de matemática Daniel Schwenter descreve em seu livro Deliciae physico-mathematicae um sistema de lentes que combinavam três distâncias focais diferentes; 1646 - o padre alemão Athanasius Kircher descreve em sua obra Ars Magna lucis et umbrae uma câmara escura em forma de liteira; 1665 - o italiano Antonio Canaletto utiliza um sistema de lentes intercambiáveis em sua câmara escura como meio auxiliar para a realização de desenhos panorâmicos; 1676 - o professor de matemática Johann Christoph Sturm ilustra em sua obra Collegium Experimentale sive curiosum uma câmara escura cujo espelho interno inclinado a $45^{\circ}$ refletia luz vinda da lente para um pergaminho azeitado colocado horizontalmente; além disso, havia uma carapuça preta que funcionava como pára-sol, melhorando a qualidade da visualização da imagem; 1685 - o monge alemão Johann Zahn ilustrou em sua obra Oculis Artificialis teledioptricus vários tipos de câmaras portáteis como o tipo reflex, com $23 \mathrm{~cm}$ de altura e $60 \mathrm{~cm}$ de largura. Assim, a câmara escura chegou à perfeição, já que o sistema de Zahn já era muito parecida com a das câmaras fotográficas atuais: a luz, depois de atravessar a lente, refletia-se em um espelho plano e a imagem se formava sobre um vidro polido.
} 
quadros que já oferecem a impressão de serem verdadeiras fotografias em preto e branco. (Cf.: Stelzer, 1981, pp. 18-19)

Não obstante, os influxos da $\tau \dot{\chi} \chi v \eta$ e o fato de a imagem sempre estar condicionada historicamente, mesmo que sob uma ótica racional e cientificista, ela ainda se apoiaria, durante anos, no real, no palpável, cuja busca ainda seria a contigüidade; mesmo e apesar de que ainda estivéssemos condicionados a vê-la partir do olho de um indivíduo como lá no princípio, na formação incipiente do $\lambda o ́ \gamma o \varsigma$ humano, quando se

buscava a objetividade, porém de uma forma subjetiva, pois tudo não passava de uma retratação daquilo que os olhos de um determinado "escriba" viam; logo, era uma forma particular de visão transmitida a um outro e desse a todo um conjunto de indivíduos de um mesmo segmento social. (Brandão, 2003, p. 8)

Mesmo quando o Cubismo quebra o perspectivismo albertiano, ainda assim havia algo no mundo a ser retratado; assistiríamos a inúmeras outras correntes vanguardistas com suas novas especulações em torno da arte, da imagem, mas mesmo assim veríamos o continuísmo da aderência ao real, pouco importa que haja estilização, abstração: querem estilizar dados de um mundo palpável, querem abstrair elementos de um mundo real, possível, mesmo que onírico. No entanto, o futuro nos proporcionou mais do que uma nova maneira de ver as coisas, uma nova representação: a simulação.

Pode-se estabelecer uma confluência entre a revolução cibernética ${ }^{95}$, pela qual estamos passando, e a do Renascimento, vetor básico para o olhar

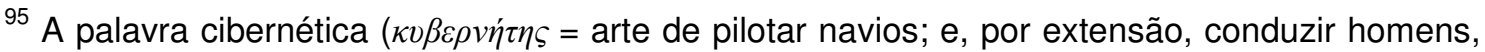
ou mesmo a arte de governar) foi um termo cunhado pelo matemático estadunidense Nobert Wiener que a reinventou, em 1948, cuja base técnica é a ciência do controle e da comunicação no animal e na máquina. 'A finalidade da cibernética, ele dirá, é desenvolver uma linguagem $e$ técnicas que nos permitam efetivamente atacar o problema da regulação das comunicações em geral, e também de encontrar um repertório conveniente de idéias e de técnicas para classificar suas manifestações particulares segundo certos conceitos'. No coração desse repertório reside a noção de informação. (Couchot, 2003, p. 95) No entanto, a cibernética tem servido de base para uma série de termos (entropia, comunicação, feedback, robô, etc.) $e$ expressões (inteligência artificial, realidade virtual, engenharia genética, cérebro artificial, redes neurais, etc.). Também é pedagógica na medida em que possibilita, através de princípios científicos de comunicação e controle, otimizar as relações entre dois sistemas: o que pretende ensinar (sistemas docente) e o que deve aprender (sistema discente). (Sangiorgi, 1991, p. 18)
} 
ocidental durante séculos: a matemática. Como visto, uma das principais diferenças entre a arte renascentista e a medieval foi a representação de cenas tridimensionais na tela e, para que isso fosse possível, foi necessário o domínio das leis geométricas de representação visual. Já a baliza de nossa revolução principia ainda no século XIX, quando George Boole (1815-1864) fundamenta a lógica binária ${ }^{96}$, demonstrando que os processos de raciocínio do cotidiano podem ser representados em termos de lógica formal e em termos matemáticos. Esses são, grosso modo, o princípio do processo digital, quando tudo o que está a nosso redor é reduzido a dois dígitos: 0 e 1. Eis que regressamos ao mundo da ratio, agora mais impessoal do que nunca, pois já não somos mais intermediados pelo humano, mas pelo não humano.

Ambos andam lado a lado, confundindo-nos continuamente, pois já não sabemos o que é ou parece ser: se já vivíamos inseridos num mar de imagens em sua forma analógica ${ }^{97}$ e seu caráter mecânico, ainda mais agora devido ao processo digital. Isso, evidentemente, trouxe suas implicações: mesmo na concretude espacial trazida pelo Renascimento, sua individualidade e perspectiva egoísta e unilocular, havia o contato físico, o tete à tete, mesmo que o gênio ficasse em sua redoma escura em busca da perfeição estética; agora, o que vemos é a certeza total da ubiqüidade (não era somente Deus que era ubíquo?): podemos estar em todos os lugares, mas não estamos em lugar nenhum! Esvaímo-nos num eterno continuum de zeros e uns, para os quais não há individualidade, diferença, prazer e originalidade estéticos: o dígito binário não distingue uma foto artística da trivial, um quadro de da Vinci ou os rabiscos de uma criança, muito menos Bach de uma banda

\footnotetext{
96 Pode-se explicar a teoria de Boole da seguinte maneira: supondo que uma pessoa vai a uma festa, queira dançar, mas está sem um parceiro. No local, há pessoas que dançam, outras que não dançam: não se pode fazer as duas ao mesmo tempo. A pessoa procurada terá de ser um homem ou uma mulher. Para Boole, o que há na festa são conjuntos de pessoas: o de homens $(H)$ e de mulheres $(M)$, além disso, há pessoas que dançam $(D)$ e que querem dançar (Q). O par masculino deveria satisfazer duas condições: ser mulher e também querer dançar. Boole vê aí a importância do conectivo $e$ (and) que liga essas duas condições, atribuindo-lhe o símbolo n; representa, dessa forma, esse conjunto de pares como $\mathrm{M} \cap \mathrm{Q}$. No entanto, nem todos da sala podem desejar dançar, mas conversar com alguém que pode ser tanto $M$ quanto $\mathrm{H}$, já que ambos estão na sala. Aqui Boole mostra-nos a importância de outro conectivo ou (or), atribuindo-lhe o símbolo $\cup$. Dessa forma, $\mathrm{H} \cup \mathrm{M}$, na lógica algébrica de Boole, inclui todos os homens e mulheres presentes na sala. Dessa forma, as variáveis sempre serão duas: sim/não, verdadeiro/falso, $1 / 0$.

${ }^{97}$ Nada mais do que o processo tradicional de obtenção da imagem fotográfica, resultante de um processo físico-químico: a luz que passa pela lente e ao atingir o negativo fotográfico provoca a sensibilização dos sais de prata na película fílmica.
} 
adolescente... é esse esvair-se que rompe a magia da fotografia, pois de sagrada passa a ser profana; de esperada, aguardada com ansiedade anterevelação, é vista na hora, apagada, refeita, retocada via softwares de manipulação de imagens acessíveis a todos. Vemos, portanto, a banalização total: rompe-se, completamente, a contigüidade, o índice:

a imagem que aparece sobre a tela não possui mais, tecnicamente, nenhuma relação direta com qualquer realidade preexistente. Mesmo quando se trata de uma imagem ou objeto numerizado, pois a numerização rompe esta ligação - esta espécie de cordão umbilical - entre a imagem e o real. São números e somente números expressos sob a forma binária na memória e nos circuitos do computador que preexistem a esta imagem e a engendram, entre o real e a simulação se interpõe uma operação computacional e algorítmica. A imagem numérica não é mais o registro de um traço deixado por um objeto preexistente pertencente ao mundo real (...); ela é o resultado de um processo em que a luz é substituída pelo cálculo, a matéria e a energia pelo tratamento da informação. Enquanto as imagens fundadas sobre a representação são testemunhos de uma forte aderência ao real, indissociáveis de uma realidade preexistente no espaço e no tempo, tanto quanto de uma vontade obsessional de escapar à sua atração, a relação da imagem numérica ao real obedece a uma outra lógica. (Couchot, op. cit. pp. 163-164)

Perdendo sua condição indicial, é como se a fotografia digital deixasse de existir enquanto objeto/espelho do real e passasse a representar um outro mundo, já que a própria visão também deixa de transmitir a certeza: que é real (diríamos, indicial, calcado na certeza de um referente contíguo) que é irreal (criação virtual, sem indicialidade)? A fotografia digital torna-se um novo Cubismo, pois também passa a construir imagens do mundo e, não simplesmente, representá-lo, reproduzi-lo: eis a concretização de um novo paramundo, com a quebra definitiva da coerência do espaço figurativo: a arte pictórica não seria mais a mesma com o advento do Cubismo - e seu rompimento com o modelo albertiano -; a fotografia analógica - cujo processo (término/começo) inicia-se com Nièpce - também não seria mais a mesma com a digital.

Não se vê agora, como se enxergava no início do século $X X$. Tal relação, evidentemente, não se restrigiria apenas às imagens em si, mas a 
todas as outras que estão a nossa volta, inclusive, as proporcionadas pelo $\lambda o ́ \gamma o \varsigma$. 


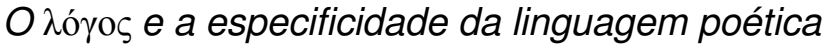

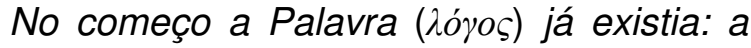
Palavra estava voltada para Deus, e a palavra era Deus. No começo ela estava voltada para Deus. Tudo foi feito por meio dela, e de tudo o que existe, nada foi feito sem ela. Nela estava a vida e, a vida era a luz dos homens. Essa luz brilha nas trevas $e$ as trevas não podem apagá-la. (Jo 1,1-5)

Diante das palavras de São João, vemo-nos diante de duas realidades distintas: primeiro, ele afirma que Jesus Cristo é o $\lambda o ́ \gamma o \varsigma$ de Deus, não uma simples palavra proveniente da boca divina, mas a Palavra enquanto essência da divindade que dela parte e a ela retorna num eterno continuum; segundo, o $\lambda o ́$ yo por não ser apenas uma palavra, um sopro divino, mas a própria Palavra divina, produz um efeito, uma realização: a criação - nada foi feito sem ela. Um artesão, por exemplo, impõe à matéria - terra, pedra, madeira - a forma desejada, por meio de um ato, mas que fora antes concebido por sua mente criadora $^{98}$. (Cf. Santo Agostinho, 1996, p. 315) Da mesma forma o גóyos divino conhecia sua criação antes mesmo de tê-la efetivado, entrevendo-a desde todo o sempre (ibidem, p. 314), esperando, simplesmente, o momento do fiat...

Assim, o $\lambda o ́ \gamma o \varsigma$ divino assume uma importância fundamental, não só porque personifica a divindade incorpórea, tornando-se visível na obra que cria, como também por originar a vida com seu sopro divino. Dessa forma, não há criação sem o $\lambda o ́ \gamma o \varsigma$ e é nele que a vida se abastece, continuamente, com sua luz; já que, sem essa luz, a vida não poderia existir e o caos continuaria em meio às trevas: enquanto a luz ainda não existia, o que era a presença das trevas, senão sua ausência? (ibidem, p. 344) Mas, fez-se a luz e a partir dela todas as criaturas para, finalmente, se chegar ao homem. Assim, já que para Deus "não há diferença nenhuma entre o dizer e o criar", Deus e seu sopro

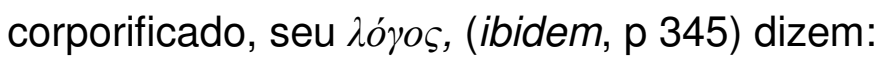

Façamos o homem à nossa imagem e semelhança. (Gn 1,26)

${ }^{98}$ Aquilo que já havíamos visto e que para Platão se chama sídos. 
À imagem e semelhança de Deus o homem foi criado e mesmo não tendo participado da criação, visto ser uma mera criatura, isso não foi impedimento para que pudesse participar nela com seu ato de nomear, manifestando também seu dom de criar:

Então Javé Deus formou do solo todas as feras e todas as aves do céu. E as apresentou ao homem para ver com que nome ele as chamaria: cada ser vivo levaria o nome que o homem the desse. O homem deu então nome a todos os animais (Gn 2,19-20).

O homem nomeia. Também ele fez uso do $\lambda o ́ \gamma o s$, mas de seu próprio $\lambda o ́$ os, o homem deixa de ser uma mera criatura, passa a ser como um deus. Era uma nomeação incipiente, o homem ainda não travava batalhas com sua própria criação. Portanto, na nomeação adamítica ele ainda não precisava lutar

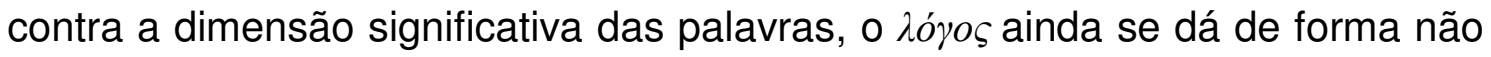
intencional (Cf.: Benjamim, 1984, p. 59): temos de um lado a coisa - res -; de outro, o nome. Esse é, efetivamente, o nascimento do homem: quando ele sai de sua mudez de argila, de sua animalidade, de sua proto-infância e passa a ser; sai da escuridão em que se encontrava para ver a luz de sua própria dupla criação. Transformamo-nos verdadeiramente em homens e igualamo-nos à divindade por meio da nomeação que fazemos das coisas do mundo, por meio

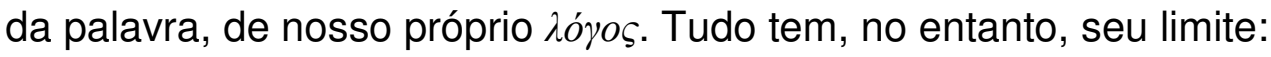

Você pode comer de todas as árvores do jardim. Mas você não pode comer da árvore do conhecimento do bem e do mal, porque no dia em que dela comer, com certeza, você morrerá. $(\mathrm{Gn} 1,16)$

Ao dominar o uso da palavra, o homem quis ir além de si mesmo, pois realmente acreditou que poderia ser como um deus. Sua visão de mundo já não era a mesma, nem seria mais o mesmo: a tentação de possuir o poder do $\lambda o ́ \gamma o \varsigma$ foi maior que a ordem divina, por isso a serpente soube explorar seu conhecimento do $\lambda o ́$ yos humano, para dele tirar proveito: 
De modo algum vocês morrerão. Mas Deus sabe que, no dia em que vocês comerem o fruto, os olhos de vocês vão se abrir, e vocês se tornarão como deuses, conhecedores do bem e do mal. (Gn 3,5)

Mas a palavra realmente abriu os olhos do homem: efetivamente ele se dá conta de uma única verdade fundamental: ele não é um deus, nem sua existência é perene, mas efêmera. Além disso, só há uma verdade suprema: a morte, já que nenhum animal tem a consciência de que terá um fim. Sua divindade não veio, nem a imortalidade, mas o dissabor da consciência de saber que se é mortal. Pior do que isso é ter consciência dessa finitude a partir de um universo infinito que seu próprio $\lambda o ́ \gamma o \varsigma$ the aferiu. Não obstante, o

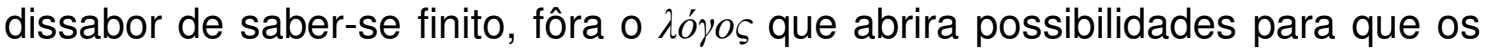
homens enchessem e submetessem a terra, dominassem os peixes do mar, as aves do céu e todos os seres vivos que rastejam sobre toda a terra. (Cf.: Gn 1, 28) A natureza é dominada e sujeitada por um ser fadado ao fracasso, entretanto foi justamente por meio do poder que o $\lambda o ́ \gamma o \varsigma$ conferiu ao homem que essa sujeição foi possível.

Passaram-se séculos, as linguagens se efetivaram e o emprego do $\lambda o ́ \gamma o \varsigma$ se concretizou e com ele o jogo que essa concretização possibilitou como o de criar mundos paralelos, cujo princípio norteador fora a imagem. Por meio da imaginação, o homem não só pode dominar a si mesmo, a seus semelhantes, ao mundo físico, como também ir além daquilo que a própria natureza lhe forneceu, adentrar ao metafísico: poder voar, misturar-se aos deuses, fazer-se invisível, vencer feras, ser imortal, enfim criar tudo aquilo que sua limitação mortal impossibilitava-o de fazer: eis porque a literatura - em especial a poesia - tem um papel fundamental para a criação do mítico, do onírico, do humano. Isso porque

toda imagem aproxima ou conjuga realidades opostas, indiferentes ou distanciadas entre si. Isto é, submete à unidade a pluralidade do real. (Paz, 2005, p. 38)

Afinal, essa é a grande possibilidade que o $\lambda o ́ \gamma o \varsigma$ nos deu e, de modo especial, por meio da poesia, pois 
O poema não diz o que é e sim o que poderia ser. Seu reino não é o do ser, mas o do "impossível verossímil" de Aristóteles.

Apesar desta sentença adversa os poetas se obstinam em afirmar que a imagem revela o que é e o que poderia ser. E ainda mais: dizem que a imagem recria o ser. (ibidem, pp. 38-39)

É mister que estabeleçamos os limites daquilo que julgamos ser o objeto poema para que possamos, a posteriori, abordar a relação que julgamos pertinente entre o $\lambda o ́ \gamma o \varsigma$ e a imagem, a fim de definirmos nosso conceito de iconofotologia e de poema fotográfico.

A poética tornou-se objeto de estudos epistemológicos em todos os níveis da civilização humana, quando se buscou explicitá-la à luz de sua sociedade, no entanto várias lacunas foram sendo deixadas, inclusive na própria civilização grega, da qual somos herdeiros. Aristóteles dá-nos prova dessa aparente imprecisão ao nos legar a Poética, pois sequer se aprofundou em temas como $\pi o i ́ n \sigma \varsigma^{99}$ ou $\mu i ́ \mu \eta \sigma \iota \varsigma^{100}$ que, para nós, seriam cruciais para a compreensão do ato poético, como sugeriria o nome de sua obra. Isso, porém, é perfeitamente plausível devido ao fato de não ter sido o único a fazer tal abordagem em seu tempo, afinal já era um tema que vinha sendo abordado por sua cultura antes mesmo de seu mestre Platão; ou, então, por seu emprego/acepção ser tão comum que o estagirita não necessitasse traçar um juízo claro a seu respeito, afinal eram conceitos recorrentes.

Decorridos vários séculos, também nós poderemos ter dificuldades em expor, claramente, aquilo que entendemos por poética, não só por ter seu enfoque sofrido modificações no correr dos anos, como também por termos hoje a idéia de que tudo possa ser poético ${ }^{101}$ : da pintura, passando pela

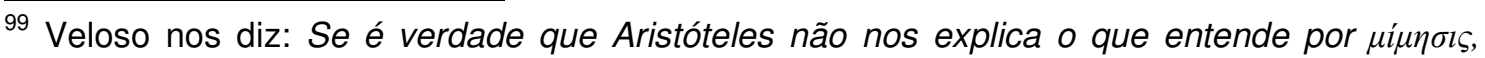

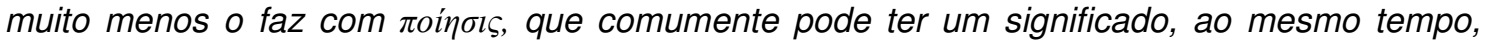
mais estreito e mais amplo do que ele Ihe atribui, ou seja, respectivamente, a composição de versos e todo tipo de produção. (Veloso, 2004, p. 122)

100 Veloso, a esse respeito, cita Barnes: What is "imitation"? Aristotle offers no explanation. Presumably he supposed that this audience would be familiar with the term - perhaps from their reading of Plato. (Ibidem, p. 74)

${ }^{101}$ Voltamos a utilizar o conceito inicial proposto pelos gregos de $\pi$ oin $\sigma \iota \varsigma$ - criação, ação.
} 
fotografia, cinema, escultura e chegando, finalmente, ao próprio fazer poético ${ }^{102}$ enquanto expressão lingüística.

Portanto, faz-se necessário restringir, claramente, o que consideramos texto poético, pois o conceito que temos de poesia hoje, difere daquele que os clássicos possuíam - incluindo aí os Seiscentos, objeto deste estudo -, sobretudo no que se refere ao fato poético e sua relação à visão ordenadora do mundo, que permeavam de modo claro a aristocracia dominante, mas que seria distinta daquela que surgiria com a burguesia, da qual somos herdeiros. Vemos, de um lado, a aristocracia com suas regras de conduta bem definidas, imóveis, estamentais; de outro, mutatis mutandis, a burguesia e seus ideais libertários, seja na ordem política - destruição do ancien régime -, na social com sua ascensão ao poder político -, seja na artística - com a ruptura do modo mimético de ver o mundo.

Poderíamos inferir que a poesia é o reflexo especular da linguagem humana, pois além de apresentar os dois níveis da linguagem - o fônico e o semântico -, também reflete parte daquilo que o homem carrega dentro de si, mesmo que de forma não consciente, e que é expresso por meio do $\lambda o ́ \gamma o \varsigma$. Exemplo dessa extrapolação é a não linearidade que a poesia assume, quando comparada à prosa, ou seja, à semelhança das imagens que se nos apresentam no pensamento, como nos relances de memória com seu pulsar contínuo e o fato de esse não possuir um ritmo constante, o mesmo ritmo que encontramos no poema e que constitui sua parte intrínseca:

O ritmo é inseparável da frase; não é composto só de palavras soltas, nem é só medida ou quantidade silábica, acentos e pausas: é imagem e sentido. Ritmo, imagem e significado se apresentam simultaneamente em uma unidade indivisível e compacta: a frase poética, o verso. (Paz, 2005, p. 13)

Esse pulsar demonstrado pelo ritmo do poema dá-nos prova de sua existência ímpar, una, como um coração pulsante provando sua existência.

\footnotetext{
102 Cohen nos fala a respeito: Não cremos que o fenômeno poético se limite às fronteiras da literatura e que seja lícito indagar-Ihe as causas entre os seres da natureza ou as circunstâncias da vida. É perfeitamente possível esboçar uma poética geral que procuraria os traços comuns a todos os objetos, artísticos ou naturais, suscetíveis de provocar a emoção poética. (Cohen, 1978, pp. 11-12)
} 
Evidentemente, o ritmo faz parte de toda linguagem verbal, porém é

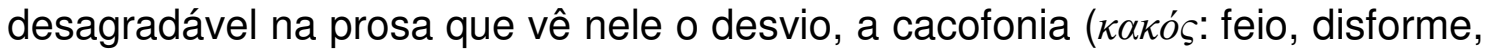
defeituoso), cujos exemplos são parequema, paliptoto, epizeuxe, eco, entre outros.

Sem ritmo, não há poema (...). O ritmo é condição do poema, enquanto que é inessencial para a prosa. Pela violência da razão, as palavras se desprendem do ritmo; essa violência racional sustenta a prosa, impedindo-a de cair na corrente da fala onde não regem as leis do discurso e sim as de atração e repulsão. (Ibidem, pp. 11-12)

A ratio, portanto, inibe o ritmo, prende-o, torna-o artificial, quebra a liberdade de expressão, a alegria e a espontaneidade humanas, e é exatamente ela que permeia a prosa em detrimento da poesia. Com ela, buscase ordenar a explosão de pensamentos, das imagens que nos saltam de nossa memória de forma desorganizada. Ao inibir a utilização dos tropoi, por exemplo, mostra-nos que quer se perpetuar como verdade única e indivisível, mas que se apaga nos corredores da história. Tal particularidade intempestiva da prosa, acaba, no entanto, tornando-a instantânea: eis o que a torna fugaz. Cohen cita Paul Valéry, para quem uma das características básicas da prosa é, exatamente, o fato de, ao ser compreendida, desaparecer e ser substituída pelos conceitos que propôs comunicar:

A linguagem comum permanece como linguagem somente quando não desempenha sua função - que é a de produzir tais impressões idéias, atos, etc. (...) Tão logo, porém, compreendamos o que diz, a linguagem é substituída em nossas mentes pelo que significou; a linguagem propriamente não dura. A qualidade específica da linguagem poética, por outro lado, é a de durar. (Cohen, 1975, p. 103)

No entanto, para que o poema possa durar, o poeta deve tecê-lo de tal forma que não the basta criar quaisquer imagens, mas imagens vivazes; não basta imitar, mas proporcionar prazer não só no ato de imitar como também no de visualizar e identificar o que foi imitado (Cf.: Aristóteles, 1996, p. 33), eis a grande diferença entre o poeta e o prosador. Segundo Lessing, este se contenta tão-somente com a clareza e a nitidez do que é transmitido, o poeta jamais: 
Antes, ele [o poeta] quer tornar tão vivazes as idéias que ele desperta em nós, de modo que, na velocidade, nós acreditemos sentir as impressões sensiveis dos seus objetos e deixemos de ter consciência, nesse momento de ilusão, do meio que ele utilizou para isso, ou seja, das suas palavras. (Lessing, 1998, p. 203)

Para que tais imagens produzidas via $\lambda o ́ \gamma o \varsigma$ efetivem-se e que perdurem não depende, exclusivamente, do pulsar intempestivo do inconsciente de um eu lírico criativo, se este não conseguir atingir os leitores. Estes têm de ser tocados, e aquele tem de conseguir ativar certas disposições da consciência (Iser, 1999, p. 9) do leitor, a fim de que entrem em uma mesma sintonia e, a partir dessa relação, levem ao prazer mencionado por Aristóteles na Poética. Iser assim se expressa a esse respeito:

(...) a leitura só se torna um prazer no momento em que nossa produtividade entra em jogo, ou seja, quando os textos nos oferecem a possibilidade de exercer nossas capacidades. (Ibidem, p. 10)

E é devido a essa nossa participação que o poema se torna memorável

Não na acepção estática de documento ou propriedade pública, mas na acepção dinâmica de recriação individual. (Levin, 1975, p. 14)

Eis a dinamicidade da poesia: o fato de poder ser criada e recriada continuamente, não importando o momento em que estamos inseridos, eis o grande jogo que nos possibilita o hójos: o fato de podermos criar e termos prazer em visualizar outra criação, ou de imiscuir-nos em nossa própria e na de outrem. O fato de ser fênix dá à obra poética seu valor de monumento:

O poema (...) não morre por ter vivido; foi expressamente ideado para nascer de novo de suas cinzas e tornar-se, infindavelmente, o que acabou de ser. A poesia pode ser reconhecida por esta propriedade: a de que tende a fazer-se reproduzir em sua própria forma; estimulando-nos a reconstruí-lo identicamente. (Valéry, apud ibidem, p. 104)

Para a poesia, o tempo é um mero detalhe, alheio ao fazer artístico. O poeta, por sua vez, esvai-se em seu próprio tempo: implacavelmente, todos 
temos de desaparecer, ninguém foge a essa realidade, daí o carpe diem horaciano, cujo reflexo é o próprio modo de pensar a literatura no mundo clássico (como veremos adiante): viver o presente, o momento, por isso

Homero (...) não conhece segundos planos. O que ele nos narra é sempre somente presente, e preenche completamente a cena e a consciência do leitor. (Auerbach, op. cit, p. 3)

Para Husserl, o presente é um sempre estender-se, cujo resultado seria o passado e o futuro e, ao absorver sucessivamente o passado e o futuro nesse ato contínuo, quase infinito (apesar de não sê-lo, pois essas duas pontas do presente - passado e futuro - jamais se encontrarão) cada vez mais estarão distantes entre si. (Cf. Deleuze, 2003, pp. 63-65) A obra, porém, permanece, repete-se a cada nova leitura - a despeito de seu autor - e nos conduz, por meio da leitura, a seu contínuo presente:

Os amores de Safo, e a própria Safo, são irrepetíveis e pertencem à história; mas seu poema está vivo, é um fragmento temporal que, graças ao ritmo, pode reencarnar-se indefinidamente. Faço mal em chamá-lo fragmento, pois é um mundo completo em si mesmo, tempo único, arquétipo, que já não é passado nem futuro, mas presente. E esta virtude de ser para sempre presente, por obra da qual o poeta escapa à sucessão e à história, liga-o inexoravelmente à história. Se é presente, só existe neste agora e aqui de sua presença entre os homens. Para ser presente o poema necessita fazer-se presente entre os homens, encarnar na história. Como toda criação humana, o poema é um produto histórico, filho do tempo e de um lugar; mas também é algo que transcende o histórico, no princípio do princípio. (Paz, op. cit., p. 53)

Transcendendo o histórico, o poema nos mostra que a sua história é paralela à nossa, constituindo-se um todo não só temporal como espacial. Vemos a alternância entre uma contínua protensão e retenção, ou seja, um presente contínuo cujos influxos saltam aos olhos durante a leitura, levandonos a interagir com o texto, tornando-nos partícipes do mesmo por meio de nossas próprias impressões, de nossas próprias percepções: 
(...) nos representamos a percepção como uma visão fotográfica das coisas, que seria tomada de um ponto determinado com um aparelho especial, no caso os órgãos de percepção, e que se desenvolveria a seguir na substância cerebral por não se sabe qual processo de elaboração química e psíquica. Mas como não ver que a fotografia, se fotografia existe, já foi obtida, já foi tirada, no próprio interior das coisas e de todos os pontos do espaço? (Bergson, 1999, p. 36)

Nossa consciência escolherá, a partir de vários pontos instados num poema, um único para que, a partir desse, possa tentar compreender o todo que se nos apresenta diante de nós e que possa despertar, em nossa memória, as correlações necessárias para que possamos adentrar no objeto textual, cuja diferença do correlato perceptivo é o fato de somente podermos estar adiante, nunca inseridos. No entanto, podemos nos questionar: em qual dos pontos do texto poético isso poderia advir, se o poema é um todo

visual (imagens suscitadas pelo texto), sonoro (tipografia: recitação mental) e espiritual (significados intuitivos, conceitos emotivos? (Paz, op. cit. p. 26)

Por que fragmentos desse mundo completo que caracteriza o poema deveríamos/poderíamos começar? Ou então, podemos ir além: sob que aspecto histórico devemos nos centrar? A partir de uma visão sincrônica ou diacrônica?

Retomemos as palavras de Paz que nos servirão de ponto de partida:

Para ser presente o poema necessita fazer-se presente entre os homens, encarnar na história.

Cada momento histórico, porém, possui suas particularidades, seus avanços e retrocessos em relação a determinados aspectos, sejam sociais, culturais $^{103}$ ou econômicos, por isso a leitura que fazemos de um momento e

103 Pode-se questionar tal afirmação, no entanto, quando vislumbramos o ocorrido na Alemanha nazista em relação aos movimentos vanguardistas e o culto aos modelos clássicos de uma forma totalmente artificiosa, podemos pensar em um retrocesso do fazer artístico. Não se deveria negar, simplesmente, o valor de um pseudo-classicismo se o mesmo surgisse do meio artístico como parte de sua expressão, mas a forma pretensiosa como foi imposto pelo Reich, afinal a arte ariana não surgiu da experiência artística nem de seu meio, mas da mente de um pequeno grupo, encabeçado pelo Führer, para quem a expressão artística surgida do meio artístico no início do século XX era uma arte degenerada, portanto deveria ser abolida. 
de um espaço específicos pode sempre ser diversa daquela que havia em determinado contexto. Com nosso avanço no campo social, surgiu o lugarcomum: não ser politicamente correto. Exemplo disso são as rinhas de galo ou as touradas, mas o que dizer das rinhas de homens no Império Romano, quando não só as autoridades como também o povo inebriavam-se com 0 sangue derramado? Por isso,

Die Kultur einer Epoche zu verstehen ist nur möglich, wenn wir das durchgehende, alles durchpulsende Lebensgesetz finden, es als alles durchformendes Strukturprinzip aufzeigen. (...) Nicht von einer abstrakten Idee können wir ausgehen; Kultur muß als lebendiges Geschehen, als Lebensäußerung des Volkskörpers geschaut werden, Leben ist immer Leben des Menschen. (...) Gewiß ist der Besitzbürger des 19. Jahrhundertes etwas anderes als der Bildungsbürger des 18.; aber das sind nur abkürzende Benennungen, die nicht im Wirtschaftlichen oder Gesellschaftlichen ihren eigentlichen Grund haben, sondern im Seelischen (...). (Kindermann, s/d, p. 1)

[Entender a cultura de uma época só é possível se encontrarmos a lei vital e pulsante que tudo permeia, mostrando-a como princípio estrutural que tudo forma. (...) Não podemos partir de uma idéia abstrata; a cultura deve ser entendida como ação viva, como expressão viva do corpo popular; a vida é sempre a vida de pessoas. (...) Certamente, a burguesia do século XIX, centrada na propriedade, não é igual à burguesia do século XVIII, centrada na Bildung; mas essas são apenas definições resumidas, que não se originam, realmente, na esfera econômica ou social, mas na esfera espiritual (...).]

As máquinas, no advento da modernidade, levavam o temor a alguns, enquanto outros se maravilhavam com elas; os futuristas tomavam-nas como mote de seu fazer artístico; no entanto, elas passaram a ser, numa época próxima à nossa, pesadelo para aqueles que, em virtude de seu desenvolvimento e da robótica, temiam por seus empregos. O avião, por exemplo, parecia ser o grande impulso à união dos povos: tornou-se a grande arma de destruição entre os mesmos e, com seu ronco, levava o caos e a morte em tempos de guerra (ou não, como se viu com o WTC em Nova York).

A guerra, por sinal, sempre foi um mote poético no tempo em que as armas alimentavam o sonho de grandes impérios e a certeza de se obterem glória, prestígio e imortalidade. Contudo, quando não bastavam mais o 
domínio, a submissão, a sujeição dos povos, principalmente no momento em que a pax temporária instalava-se, monumentos deveriam ser erguidos para tornar sempre vivas essas lembranças. Não haveria, contudo, a necessidade de que esses marcos fossem apenas de pedras, poderiam ser transcritos para que todos pudessem saber das glórias passadas: palimpsestos que pudessem apagar as derrocadas e somente mostrar os momentos de vitória e esperança de homens que além de homens, são soldados:

Os soldados não são como homens - eis a lição que aprendi de uma vida entre guerreiros. Essa lição fez-me considerar altamente suspeitas todas as teorias e representações da guerra que a colocam no mesmo pé de outras atividades humanas. A guerra está indiscutivelmente ligada à economia, à diplomacia e à política como demonstram os teóricos. Mas a ligação não significa identidade ou mesmo semelhança. A guerra é completamente diferente da diplomacia ou da política porque precisa ser travada por homens cujos valores e habilidades não são os dos políticos e diplomatas. São valores de um mundo à parte, um mundo muito antigo, que existe paralelamente ao mundo do cotidiano, mas não pertence a ele. Ambos os mundos se alternam ao longo do tempo, e o do guerreiro acerta o pé com o do civil. Mas o segue à distância. Essa distância nunca pode ser eliminada, pois a cultura do guerreiro jamais pode ser a da própria civilização. Todas as civilizações devem suas origens ao guerreiro; suas culturas nutrem os guerreiros que as defendem, e as diferenças entre elas farão os guerreiros de uma muito diferentes externamente dos da outra. (Keegan, 2006, pp. 16-17)

Poderíamos aproveitar a imagem do soldado levantada para tentarmos estabelecer uma analogia entre o mesmo e o poema, para que pudéssemos tentar compreender as vicissitudes enfrentadas, hoje, pelo mote poético nesta época alheia à leitura. Poderíamos inferir que o elo que os une é o fato de ambos serem e estarem alheios àquilo que reconhecemos como padrão normal $^{104}$. O soldado, por exemplo, vive em um mundo paralelo ao mundo do cotidiano, quando é obrigado a pôr a descoberto os instintos mais primitivos do homo sapiens; disposições que foram, século após século, condenadas por

\footnotetext{
${ }^{104}$ Quando se diz normal, por exemplo, está se pensando na regularidade do restante da sociedade, para quem a hierarquia, por exemplo, é uma imposição exagerada e descabida, apesar de indispensável ao fato de se estar soldado; ou a disposição das palavras no papel em versos ou a métrica, por exemplo, um mero jogo sem sentido nem propósito, utilizados por poeta, simplemente, para complicar a leitura, mas sem os quais o pulsar poético não existiria.
} 
filósofos, profetas e religiões, que afirmavam ser a ratio aquilo que nos diferenciava dos animais. Algo parecido pode ser dito do poema, afinal este também põe a descoberto o interior do homem, quando se vê que imagens saltam da memória, inclusive as que queriam ficar veladas, num impulso que não se dá de forma organizada nem ordeira, mas conturbada e desorganizada. Para que essa fuga seja possível, deve-se menosprezar a ratio: eis por que a poesia desvirtua-se daquilo que se considera norma (a linguagem corrente).

O poema, dessa forma, também vive em um paramundo, ou como nos diz Paz: em um mundo completo em si mesmo (Paz, 2005, p. 53). Prova disso é o fato de a prosa ser considerada a linguagem normal, corrente; logo, tendo-a como modelo, pode-se considerar o poema um desvio, um erro, apesar de voluntário (Cf.: Cohen, op. cit., pp. 15-16), além disso, vive em seu próprio tempo sem, contudo, interferir, diretamente, no tempo histórico:

O poema é um tempo arquetípico; (...) que se encarna na experiência concreta de um povo, um grupo ou uma seita. Esta possibilidade de encarnar-se entre os homens torna-o manancial, fonte: o poema dá de beber a água de um perpétuo presente que é, também, o mais remoto passado e o futuro mais imediato. (Paz, 2005, p. 54)

Não é à toa que os livros sagrados das grandes religiões do homem foram escritos em versos, e é desse manancial que pessoas no mundo inteiro se servem para relacionarem-se entre si, com o meio em que estão inseridos, com suas divindades, em suma, para viver.

Como se não bastasse o fato de ser fonte e manter seu próprio tempo, o poema passa a ser espelho do mundo real em que está inserido, e, como tal, reflete-o por meio da inversão: ele é, mas para sê-lo mais, tem-se de invertê-lo para que a visualização seja maior, seja completa e mais nítida, ou seja, devese manter distância, para que se possa abarcar o mundo refletido em profundidade. Assim, para enxergar de forma clara a realidade e o presente em que se está inserido, é necessário estar distante, para que se possa discernir melhor e mais claro, caso contrário o que se verá são emanações de nossa subjetividade latente. 


\section{REPRESENTAÇÃO IMAGÉTICA NO SÉCULO XVII: LEITURA E INTERPRETAÇÃO}

Leituras pré-iconográfica, iconográfica e iconológica

$D$ ara se compreender uma mensagem é necessário que os dois
elementos da comunicação - o emissor e o receptor - possuam, evidentemente, um código comum, para que se possam estabelecer relações mínimas de compreensão. Isso não é válido somente ao se fazer uso da linguagem verbal, mas também para toda comunicação humana, seja por meio de gestos, sinais, olhares ou imagens. No entanto, devido à dinamicidade da língua, à arbitrariedade do signo lingüístico e ao fato de este também não ser uma entidade estanque, apesar de convencional, a língua não consegue se defender dos deslocamentos imputados ao signo lingüístico (Cf. Saussure, 2006, p. 90), sofrendo mutações no correr dos tempos. Dessa forma, uma palavra não só poderá sofrer acréscimos ou supressões de fonemas ou letras (modificando seu significante) ${ }^{105}$ como poderá também ter um deslocamento da

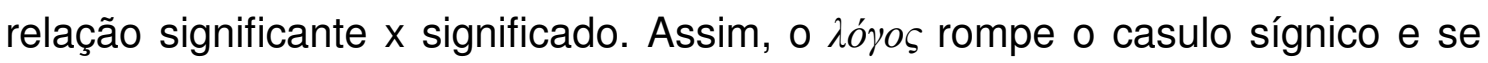
abre a outras especulações.

Conforme afirma Saussure, esse rompimento se dá, primeiramente, por meio da fala, pois para o lingüista suíço, toda modificação diacrônica da língua é ocasionada justamente por ela (Cf.: ibidem, p. 115), quando alguns indivíduos de uma comunidade fazem dessa alteração a norma ${ }^{106}$; porém, essa relação não é percebida pela consciência coletiva (Cf.: ibidem, p. 116) de imediato, afinal essas alterações nunca se efetuam em bloco, mas em elementos, digamos, aleatórios dentro do sistema que é a língua. (Cf.: ibidem, p. 102)

A arte, enquanto expressão de uma coletividade, também se deixa influenciar pelas mudanças de postura da própria sociedade em que está

\footnotetext{
${ }^{105}$ Saussure comenta a esse respeito quando fala da regularidade das mudanças fonéticas (Cf.: Saussure, op. cit. p.167 ss.)

${ }^{106}$ Algo parecido com o sentido do lingüista Coseriu, que propôs um acréscimo à dicotomia saussuriana, cuja tricotomia vai do mais concreto (fala, uso individual da norma) ao mais abstrato (língua, sistema funcional), passando por um grau intermediário: a norma (uso coletivo da língua).
} 
inserida, bem como da influência do tempo que, implacável, tudo modifica, inclusive a relação entre a própria arte e seu artífice. Este se torna um representante dos anseios de sua sociedade, na medida em que não só externa os anseios de sua Weltanschauung, como também serve de elo entre os homens e sua divindade. Não se quer dizer, contudo, que os artistas sempre desfrutaram de boa reputação, inclusive na base da sociedade ocidental, a

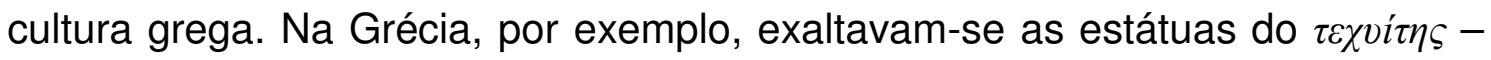
como Fídias -, porém este era menosprezado por ser um mero artífice, alguém que apenas domina a $\tau \dot{x} \chi v \eta$ mecânica. Afinal não é porque a obra oferecia prazer que os artífices deveriam ser dignos de estima, pelo contrário: dificilmente passaria na cabeça dos jovens das famílias tradicionais a vontade

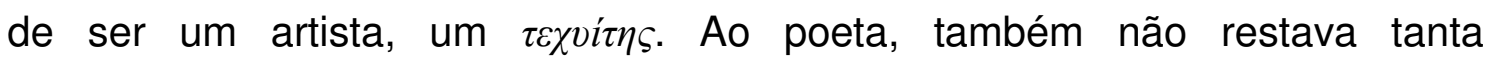
consideração, pelo contrário, da mesma forma que os artífices, sua obra era exaltada, o poeta não. Isso devido ao fato de que a obra poética não dependia das próprias faculdades do poeta, mas da inspiração ${ }^{107}$, ou seja, o poeta não era filtro do meio em que estava, mas da divindade a que estava submetido.

Se a inspiração para Platão em $A$ República era sinal de falta de conhecimento próprio, do jogo dos deuses em relação aos homens, cujo fim é o encantamento e a distância das coisas sérias, mas não conduz à sabedoria e a virtude, pois envolve o homem num mundo onírico e irreal; o mesmo não pode ser dito dos românticos, seu extremo oposto. ${ }^{108}$ Para os românticos, a finalidade da poesia era elevá-la a sublime fonte donde ela emana, isto é, Deus, porque o poeta sem religião e sem moral é como o veneno derramado na fonte (Gonçalves de Magalhães, apud, Martins, 1977/78, v. II, 546 p.), ou

\footnotetext{
${ }^{107}$ Pode-se dizer, portanto, que o resultado do processo artístico provém de dois saberes: de um lado o saber racional ou técnico, de outro o irracional que provém da inspiração. Quando o artífice constrói um navio, utiliza de seus conhecimentos adquiridos via $\tau \dot{z} \chi v \eta$ juntamente com a razão, no entanto, como a inspiração proveria de outrem e não de capacidades próprias, essa escaparia do domínio da razão.

${ }_{108}$ Evidentemente o salto é gigantesco, entretanto ilustra duas visões bem particulares de mundo: se em uma - na grega - vigora a aristocracia, cujos princípios serviram de base para grande parte da sociedade ocidental, com sua visão - para nossos dias - excludente e princípio social estamental; na outra, temos a incipiência do fato burguês, quando se instaura uma outra realidade sócio-econômica e cultural no ocidente. Dessa forma, se avançarmos alguns séculos e desde o ponto de vista literário, também poderíamos ter duas visões diferentes, dois extremos: de um lado o Classicismo - inserido também no continuísmo aristocrático - que visava àquela realidade extemporânea; de outro o Romantismo - com sua visão burguesa. Esta, porém, teve a necessidade de um intermezzo que foi o Arcadismo tentativa, digamos, infantil de a burguesia se apropriar dos conhecimentos clássicos da moribunda aristocracia - para, finalmente, aflorar um novo e dinâmico correr literário que veríamos posteriormente, quando as amarras do mimetismo foram desatadas.
} 
seja, tais poetas eram o sinal de sua superioridade frente aos outros homens: 0 poeta quando canta, não é um mortal, mas o 'Arcanjo da justiça eterna' (ibidem, p. 223), mais que um elo com o divino, ele próprio tem participação nessa vida divina via sua criação: ele cria, seu $\lambda o ́ \gamma o \varsigma$ transcende, tem vida.

A afinidade entre o poeta e o divino também se modificou, de forma profunda, na arte moderna. Se no Romantismo o poeta estaria um degrau acima dos meros mortais, agora o artista é o próprio deus e sua obra, objeto de veneração, já que Deus, o simbólico, o mítico são, simplesmente, ignorados pela nova expressão artística:

Toda a história da arte no ocidente, especialmente a partir do Renascimento, conta e mostra os recuos sucessivos do sagrado em proveito de uma autonomia vivida como uma liberação cada vez maior dos constrangimentos religiosos e morais. Mas com a arte moderna, o momento originário ao qual a obra remete não é definitivamente mais aquele da criação (nem aquele do ato sacrificial que funda a unidade simbólica da comunidade); é aquele do ato de figuração em si mesmo. Ato que remete, efetivamente, a uma 'presença real', mas que nada tem de divino, de mítico, de mitológico, de histórico, mas nada de

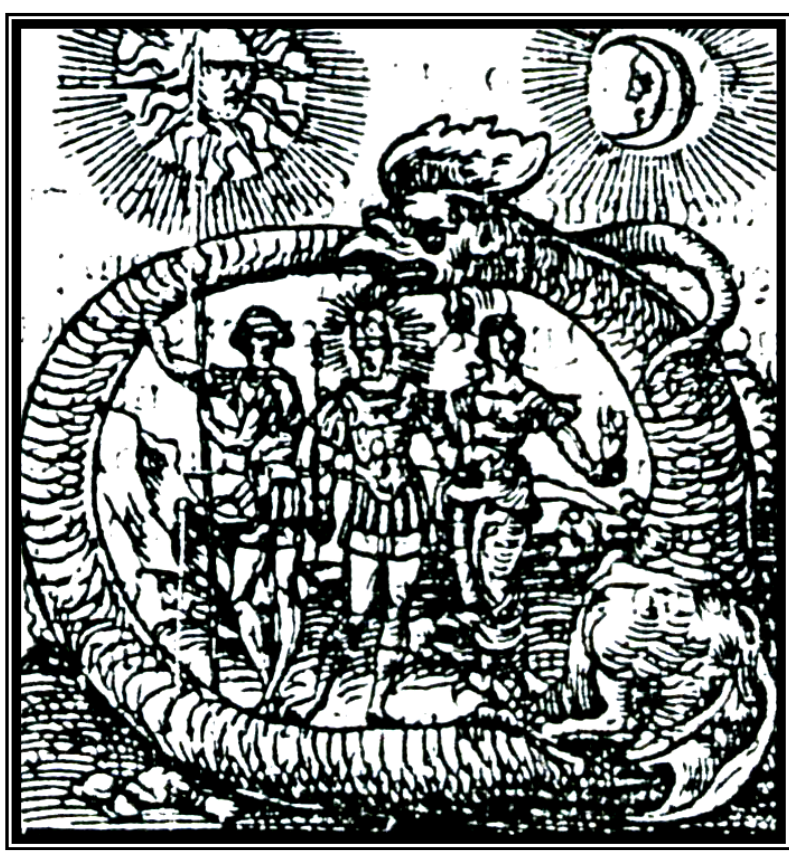

Figura 14-Hieróglifo 1 : A eternidade, de Horapolo. transcendente, já que ela nada mais é que a presença do artista, desmesuradamente expandida, perfeitamente soberana, mas imanente e fechada sobre si mesma. (Couchot, op. cit., pp. 145-146)

Ao abandonar o mítico, a obra de arte cria um fosso imensurável entre si e o público, ou seja, esse rompimento que deveria ser passageiro, curto, momentos de explosão, de tempestade como as vanguardas devem ser, para que se efetue a posterior bonança, ou seja, seu aprimoramento, não ocorreu, pelo contrário; estende-se num eterno continuum: 
Se a imitação se torna simples repetição, o diálogo cessa e a tradição se petrifica; e do mesmo modo, se a modernidade não faz a crítica de si mesma, se não se postula como ruptura e só é uma prolongação do 'moderno', a tradição se imobiliza. Isto é o que sucede com grande parte da chamada 'vanguarda'. A razão é clara: a idéia de modernidade começa a perder sua vitalidade. (Paz, op. cit., p. 134)

O artista de mero artífice, de mero instrumento, tornou-se divino, superior à obra, ou nas palavras de Harold Rosenberg, grande demais para a arte (Rosenberg, apud Couchot, op. cit., p. 126), ou ainda o próprio demiurgo, utilizando o conceito platônico; a obra artística, uma fênix que tem de perpetuar-se, indefinidamente, enquanto expressão solitária e única, à semelhança do primeiro hieróglifo mostrado por Horapolo (fig. 14), segundo o qual os egípcios, quando queriam designar eternidade, representavam um basilisco mordendo, continuamente, sua própria cauda: eis a arte moderna. Livre das preceptivas miméticas, torna-se, no entanto, refém de uma procura ininterrupta por originalidade numa perpetuação massificante, quando é obrigada a se manter num eterno vanguardismo, logo numa contínua rejeição ao passadiço. No entanto, ao esvaziar-se de toda ligação com o passado, inclusive com o sagrado, a arte imagética, por exemplo, apaga toda sua significação fundamental que era, exatamente, dar ao homem acesso ao ininteligível, à mítica realidade; ou, ainda, o prazer estético que a fruição das obras nos proporcionava, como o de reconhecer nela seu original (Cf.:

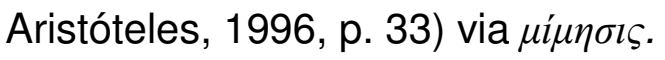

No entanto, ao apagar tais elementos, sacraliza-se ${ }^{109}$ a ruptura entre 0 deus artista e seus fiéis, já que esses não conseguem acompanhar essa nova

\footnotetext{
${ }^{109}$ Couchot nos diz que: A vanguarda responde por artifícios à dessacralização dos rituais provocados pelas mídias de massa e pela sua tecnologização que suprime o caráter único das obras de arte. Trata-se de reinventar o sagrado ou substitui-lo por qualquer coisa que dê a ilusão dele, ainda que o negando. Também a arte moderna (...) é assombrada pelo sagrado. Mas este (...) toma as formas simbólicas de substituição. Uma dessas formas é a presença do artista, de sua pessoa, que tende a se confundir com a obra e busca atribuir-lhe sua unicidade de indivíduo (...). (Couchot, op. cit., p. 148)

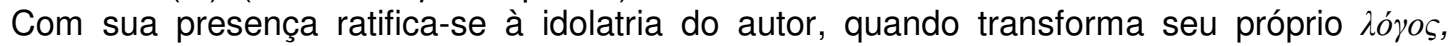
enquanto emanação do Ser, em obra, tentando-se assemelhar ao hóyos divino. No entanto, nem sempre essa tomada de lugar do divino alcança seus objetivos e, por isso, o artista tem de buscar outros meios para que possam satisfazer o anseio de seus fiéis como a utilização da ciência e da técnica. A ciência, todavia, é utilizada não pelo que é ou representa, mas por aquilo que não é como a magia e o mistério: a arte então se torna uma ciência, mas uma ciência inverificável, um conhecimento revelado, um evangelho. (Ibidem, p. 148)
} 
religião, presos que ainda estão a antigos conceitos. Da mesma forma que esses fiéis são desprezados pelos deuses neófitos, estes ignoram a relação intrínseca estabelecida pelo signo. Apesar de este em um poema sofrer deslocamentos metafóricos em seus constituintes, suas imagens dão prazer, afinal ainda representam o mundo de onde provieram e este ainda é acessível aos pobres mortais. Entretanto, vemos seu esvaziamento, continuamente, nas várias tendências artísticas da pós-modernidade, sua desconstrução sígnica, inclusive do próprio $\lambda o ́ \gamma o \varsigma$, impedindo a relação irremediável entre obra e leitor. Iser nos fala que a relação entre o leitor e o texto, por exemplo, caracteriza-se por um envolvimento direto e por se transcenderem justamente por esse envolvimento. (Cf.: Iser, op. cit,. pp. 12-13) No entanto, como podemos nos envolver quando o que temos diante de nós parece não nos dizer absolutamente nada?

Sem alegria, sem prazer num mundo polissêmico e repleto de cacossemia: muitas vezes sentimo-nos assim diante do mundo que nos rodeia. A relação do homem com o mundo mudou, o mesmo serve em relação ao divino e consigo mesmo; também mudou sua relação com a arte e com aquilo que consideramos arte. Dessa forma, como podemos acreditar que seja possível simplesmente abrir um livro de outras épocas, ler e absorver tudo com os olhos que temos hoje, se muitas das verdades e daquela Weltanschauung não nos dizem nada mais? Entramos no futuro, por isso necessitamos de uma máquina do tempo para poder compreender qual 0 valor das imagens/conceitos presentes no imaginário seiscentista para que possamos confrontá-lo com aquilo que nós mesmos cremos hoje; para essa viagem é mister conhecer sua iconografia e iconologia, para que também nós não nos percamos na polissemia daquele momento.

Para a análise das obras pictóricas presentes nesta tese, vamos utilizar os preceitos oferecidos pelo teórico de arte alemão Erwin Panofsky (18921968), para quem é possível identificar três níveis no tema ou significado de uma obra de arte, a fim de que possamos compreender seus conceitos de iconografia e iconologia: 
a) tema primário ou natural (descrição pré-iconográfica): identificação das formas básicas ${ }^{110}$ de uma expressão artística, tendo por base nossa experiência prática: cores, linhas e volumes; materiais identificados com as formas animadas ou inanimadas (homens, animais, plantas, objetos etc) como bronze, madeira, pedra; percepção de alguns modos de expressão - alegria, tristeza, raiva;

b) tema secundário ou convencional (descrição iconográfica): ligação de motivos artísticos e suas combinações com assuntos ou conceitos que podem ser reconhecidos como portadores de significados, como as alegorias; pressupõe, portanto, familiaridade com temas ou conceitos específicos (imagens católicas retratadas com uma palma nas mãos representam martírio, por exemplo), ou seja, demanda busca de conhecimentos prévios para sua interpretação ${ }^{111}$;

c) significado intrínseco ou conteúdo (descrição iconológica): apreensão de princípios subjacentes que revelam a atitude básica de uma nação, de um período, classe social, crença religiosa ou filosófica (Panofsky, op. cit., p. 52), dessa forma requer mais do que familiaridade com determinados conceitos, ou, como diz Panosfky, temos de ter uma faculdade mental comparável à de um clínico nos seus diagnósticos. (Ibidem, p. 62) Deve-se, portanto, buscar as respostas para possíveis questionamentos na obra, não apenas e exclusivamente em uma única, mas no grupo de obras, a que devota sua atenção, com base no que pensa ser o significado intrínseco de tantos outros documentos da civilização historicamente relacionados a esta obra ou grupo de obras quantos conseguir: de documentos que testemunhem as tendências políticas, poéticas, religiosas, filosóficas e sociais da personalidade, período ou país sob investigação. (Ibidem, p. 63)

A partir desses pressupostos, definiremos o que entendemos por iconografia e iconologia, para que possamos dar continuidade a este trabalho. Como a própria origem etimológica nos deixa antever, a palavra iconografia já

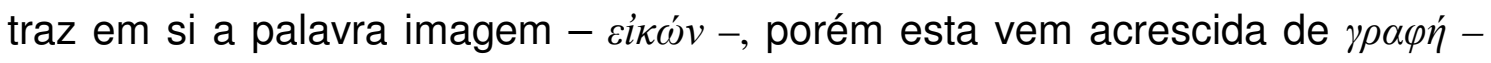

\footnotetext{
110 Puras para Panofsky.

${ }^{111}$ No entanto, tal conhecimento prévio pode não garantir a totalidade da interpretação, já que podem haver variáveis de percurso, conforme exemplo dado por Panofsky acerca da pseudofigura de João Batista degolado. (Cf. Ibidem, pp. 59-62)
} 
escrita, ou seja, implica em si um método basicamente descritivo e estatístico. A preocupação da iconografia é a de descrever e classificar imagens, portanto

é um estudo limitado e, como que ancilar, que nos informa quando e onde temas específicos foram visualizados por quais motivos específicos. Diz-nos quando e onde o Cristo crucificado usava uma tanga ou uma veste comprida; quando e onde foi Ele pregado à Cruz, e se com quatro ou três cravos; como o Vício e a Virtude eram representados nos diferentes séculos e ambientes. (Cf. Panofsky, op. cit., p. 53)

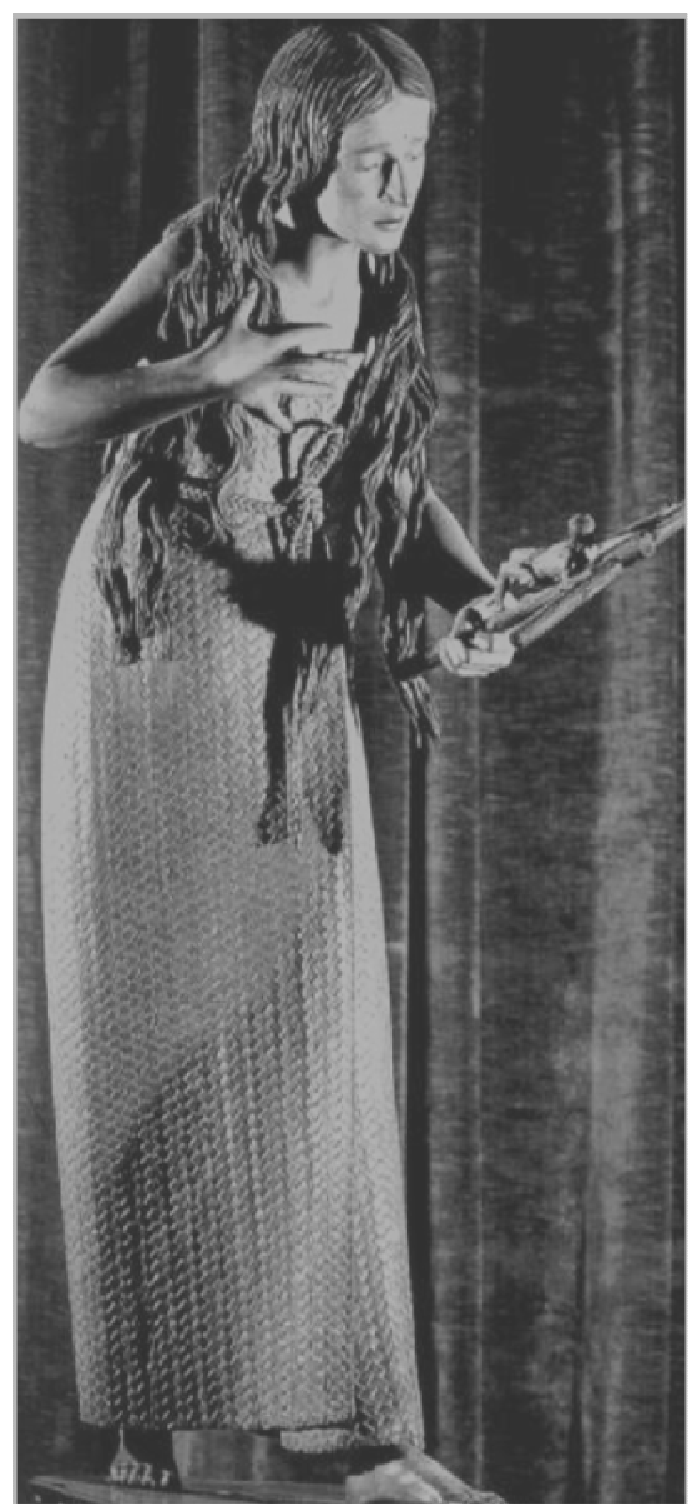

Figura 15: Maria Madalena, de Pedro de Mena, 1664 
Enquanto a iconografia paira sobre a superfície da obra artística, a iconologia vai mais fundo, dirige-se ao método interpretativo e, exatamente, por adentrar no mundo do $\lambda o ́ \gamma o \varsigma$, que cria a racionalidade, o mundo mítico, o mundo da poesia, o mesmo que vai além da linguagem comum e entra no mundo mágico das abstrações alegóricas e metafóricas à procura que está da ordenação do caos da formação do eu individual, a partir de sua consciência. É como se o $\lambda o ́$ jos saísse à busca de sua cara metade que se perdeu na natureza (quando ele ainda pertencia a ela) e tivesse adquirido corporeidade via $\mu і \mu \eta \sigma \iota \varsigma$. Esse é o maravilhoso mundo da iconologia, pois

sempre que a iconografia for tirada de seu isolamento e integrada em qualquer outro método histórico, psicológico ou crítico, que tentemos usar para resolver o enigma da esfinge. (Ibidem, p. 54)

A mesma que aparece diante de nós e nos pergunta: quem sou eu? Que represento para você? Estou no lugar de quem ou de quê? Decifra-me ou devoro-te! ${ }^{112}$ Dessa forma, a iconologia ultrapassa a mera análise superficial e incide com a síntese, convertendo-se em parte integral do estudo da arte, uma vez que não se limita ao mero levantamento estatístico preliminar. Faz-se necessário, portanto, muito mais do que ver e conhecer as iconologias existentes no século XVII, buscar sua relação com o homem dos Seiscentos e a interferência que esse sistema teria em nossa compreensão daquele mundo, a partir de sua relação estabelecida entre a palavra e a imagem.

Há uma imagem (fig. 15), que consideramos uma das mais belas do Barroco, exatamente por, aparentemente, não corresponder ao lugar-comum que temos das imagens do período, obra do escultor espanhol Pedro de Mena (1628-1688), que nos servirá para iniciarmos esta viagem pelo mundo dos Seiscentos.

\footnotetext{
${ }^{112}$ A citação refere-se à tragédia de Sófocles, Édipo Rei, quando a esfinge dirige-se a Édipo com a seguinte pergunta/enigma: Qual é o ser que, tendo uma única voz, ora caminha com dois pés, ora com três, ou ainda com quatro, e que é tanto mais fraco quantos mais pés tiver? Prontamente respondida por Édipo: o homem. Para Cesare Ripa, todas as alegorias deveriam ser nomeadas, entretanto ao retirar-lhe o nome, ela se torna um enigma.
} 
Sem nos ater ao nome da obra, mas somente a uma descrição direta do que podemos ver, ou seja, fazendo nossa descrição pré-iconográfica, é possível levantarmos alguns aspectos da imagem:

a) Temos uma imagem esculpida na madeira;

b) Uma mulher, recurvada, cujos olhos estão fixos em direção a um crucifixo;

c) Seu rosto transmite um aspecto grave, de dor ou sofrimento; possui cabelos longos, desgrenhados;

d) Sua mão direita está direcionada ao peito; sua mão esquerda segura o crucifixo;

e) Está com um vestido reto, longo, cingido com uma corda em laço;

f) Pernas separadas, a esquerda na frente, a outra atrás; pés descalços.

Além do aspecto da beleza plástica evocada e das características descritas acima, a obra não nos passaria nada além do exposto, afinal não há nada nela que poderia nos chamar a atenção. Talvez a singularidade da cor do vestido (lembra aspectos dourados) que sequer o é, pois podemos verificar, próximo aos pés, que parece mais uma túnica cingida por uma corda do que, propriamente, um vestido, que seria uma peça única.

Ao passarmos para a análise iconográfica, estamos propensos a constatar que a imagem tenha um cunho religioso, devido, evidentemente, ao crucifixo na mão esquerda da mulher, que o segura firmemente, demonstrando um devoto sentimento. Logo observamos que essa mulher não é qualquer mulher, mas uma que, segundo os Evangelhos, seguiu Jesus de perto. Sabemos isso devido ao título da obra: Maria Madalena. Inclusive foi uma das mulheres que estiveram ao pé da cruz juntamente com Maria, mãe de Jesus, e o apóstolo São João (Mt 27,56, Mc 15,40, Lc 23,49, Jo 19, 25) além disso, foi a primeira testemunha ocular da Ressurreição de Cristo (Mt 27,55-56; Mc 15,4041, Lc 23,49, Jo 19,25).

Poderíamos, inclusive, conjecturar que 0 ato de segurar o crucifixo poderia ser uma alusão a sua presença na crucificação de Jesus, algo como 
uma rememoração de um ato consumado e presenciado que o artista quis imputar-Ihe. Imagem retratada pelo poeta Angelus Silesius (1624-1664) ${ }^{113} \mathrm{em}$

\section{Ans Kreuze Christi}

Schau, deine Sünden sinds, die Christum, unsern Gott,

So unbarmherzig verdammen bis in Tod.

Jedoch verzweifle nicht, bist du nur Magdalen,

So kannst du seliglich bei seinem Kreuze stehn.

(Silesius. Cherubinischer Wandersmann, p. 605

[À cruz de Cristo

Veja, são estes teus pecados, que o Cristo, nosso Deus,/ tão cruelmente condenaram à morte./ No entanto, não te desesperes, tu és Madalena apenas,/ Assim tu podes ficar próximo a sua cruz.]

Talvez resida aí a alusão encontrada em Lc 7, 36-50, quando uma mulher, também pecadora, dirige-se a Jesus e lava-lhe os pés com suas lágrimas, secando-os com seus cabelos e cobrindo-os de beijos e perfume. Ainda conforme Silesius:

\section{Von Maria Magdalena}

Maria kommt zum Herrn, voll Leids und voller Schmerzen,

Sie bittet um Genad und tut doch ihren Mund

Mit keinem Wörtlein auf; wie macht sies ihm denn kund?

Mit ihrer Tränen Fall und dem zerknirschten Herzen.

(Silesius, op. cit., p. 883)

[De Maria Madalena

Maria vem ao Senhor, repleta de sofrimentos e de dores,/ Ela pediu por misericórdia e sua boca/ Não se abriu com nenhuma palavrinha; como ela se fez entender?/ Com a queda de suas lágrimas e o coração esmagado]

Pode-se demonstrar que o ato de ter o crucifixo na mão, representasse que a retratada não quisesse se esquecer daquele ato, quando se projetariam

${ }^{113}$ Pseudônimo de Johannes Scheffler, poeta alemão. 
suas lembranças por meio de um objeto concreto. No entanto, teríamos aí um anacronismo: a utilização de crucifixos (a cruz juntamente com a representação de Cristo morto) apareceria na iconologia cristã por volta do século $\mathrm{V}$, logo Maria Madalena já estaria morta há muito tempo. Por que então o olhar grave, se Jesus, apesar de sua morte, havia ressuscitado e estava vivo, sendo ela, inclusive, a primeira testemunha ocular? Aqui, temos de voltar aos Evangelhos, que nos dizem que Maria Madalena foi uma mulher de quem Jesus havia expulsado sete ${ }^{114}$ demônios. (Lc 8, 2; Mc 16,9) Quem sabe resida aí a resposta para a sisudez de sua expressão: a lembrança - e a conseqüente tristeza - por ter cometido muitos pecados. Não há, nos Evangelhos, nenhuma informação sobre esses, no entanto no imaginário popular só poderiam ter sido os da concupiscência, por isso é, muitas vezes, retratada como uma prostituta arrependida que chora por seus pecados.

Não há, entretanto, nenhuma menção nominal à Maria Madalena, cita-se tão somente uma mulher. Teríamos mais uma resposta para nossos questionamentos: os cabelos desgrenhados. Talvez fosse uma representação do ato nos pés do Mestre que o autor quisesse destacar ou de sua antiga

\footnotetext{
${ }^{114}$ Havia, desde a Antigüidade, uma obsessão pelos números que perpassa a Idade Média e chega a meados do século XVIII. Curtius nos diz, por exemplo, que um dos textos bíblicos mais citados durante a Idade Média fora retirado do livro da Sabedoria: Mas tudo dispuseste com medida, número e peso. (Sb, 11,21) Provavelmente, sua origem remonta ao século I a. C., em Alexandria, já que alguns elementos fornecem provas de que tal fórmula era, originalmente, grega como atestam Sófocles, Górgias e Platão. (Cf.: Curtius, 1996, pp. 616-617) Através desse versículo, o número foi santificado como fator constitutivo da obra divina da criação. Adquiriu dignidade metafísica. Este é o motivo grandioso da composição numérica na literatura. (ibidem, p. 617) Dessa forma, se o plano de Deus era aritmético, o escritor deveria deixar-se guiar também pelos números, que haviam se tornado (para o homem medieval), símbolos da ordem divina. O número sete, por sua vez, era importante na tradição judaico-cristã cuja origem estava - provavelmente entre outras - na observação das quatro fases da lua, que se modificam a cada sete dias. A partir daí, os hebreus passaram a associar o número sete a um período completo, passando a ser sinônimo de plenitude, totalidade e, com um matiz teológico, a totalidade querida por Deus. Assim, a ordem do tempo estava baseada no sete (o sábado, dia sagrado, chegava a cada sete dias; o candelabro do Templo tinha sete braços; daí, a associação que o Cristianismo incipiente fizera com o mesmo número ao associá-lo como resultado da soma dos quatro elementos naturais criados por Deus - terra, água, fogo e ar com o três - número das pessoas da Santíssima Trindade). O verbo hebraico jurar, por exemplo, vem da raiz hebraica que designa a palavra sete, talvez seja uma forma de se ter por testemunha a ligação que há entre os sete poderes do céu e da terra. Pedro fala a Jesus (Mt 18, 21-22) se ele tinha de perdoar somente sete vezes - ou seja, completamente -; Jesus, porém, para reforçar essa idéia, diz a Pedro para não perdoar sete vezes, mas setenta vezes sete. Setenta é uma combinação do sete e do dez. Se o sete era a plenitude e a totalidade, o dez (a origem estava nos dez dedos da mão; também é a soma de três - número da Santíssima Trindade - e sete é o da totalidade, da plenitude; também pode ser o sinal da aliança entre a divindade e sua criação).
} 
profissão: vemos hoje que ainda há a perpetuação dessa idéia generalizada da prostituição de Maria Madalena, seja nos livros que querem tratar cientificamente, do assunto, seja no imaginário transmitido pelo cinema, por exemplo.

Ao empreendermos a interpretação iconológica, verificaremos que o simples emprego dos textos evangélicos não é capaz de nos auxiliar na análise total da obra, pois veremos que a diferença estará em detalhes que nos passam despercebidos, como veremos demonstrado abaixo:

Nós, leitores do século XXI, vemos na obra:

mulher com rosto de aspecto grave

vestido reto, longo e cingido com uma corda em laço

Os leitores do século XVII viam como Sinal de Penitência (Buße), segundo a Iconologia de Cesare Ripa:

mujer extenuada, de rostro macilento, revestida con ropas tristísimas $y$ pobres (Ripa, 1987, p. 190, v. 2)

Nós, leitores do século XXI, vemos na obra:

olhos fixos em direção a um crucifixo

Os leitores do século XVII viam como Sinal de Penitência (Buße), segundo a Iconologia de Cesare Ripa:

mujer macilente (...) sosteniendo un azote con la diestra y una cruz con la diestra, hacia la cual está mirando fijamente (ibidem, 1987, p. 192, v. 2) 
Nós, leitores do século XXI, vemos na obra:

mão direita em direção ao peito

Os leitores do século XVII viam como Sinal de Amor a Deus (Liebe zu Gott), segundo a Iconologia de Cesare Ripa:

con la diestra ha de mostrar su pecho (Ibidem, 1987, p. 89, v. 1)

Nós, leitores do século XXI, vemos na obra:

mão direita em direção ao peito

Os leitores do século XVII viam como Sinal de Arrependimento dos pecados (Bereuen der Sünden), segundo a Iconologia de Cesare Ripa:

aparecerá arrodillado, golpeándose el pecho con la diestra, y con la cabeza algo inclinada (Ibidem, 1987, p. 112, v. 1)

Nós, leitores do século XXI, vemos na obra:

mão esquerda segurando um crucifixo

Os leitores do século XVII viam como Sinal de Obediência (Gehorsam), segundo a Iconologia de Cesare Ripa:

mujer de rostro noble y muy modesto revestida con hábito religioso, que sostendrá con la izquierda un Crucifijo (Ibidem, 1987, p. 136, v. 1) 
Nós, leitores do século XXI, vemos na obra:

mão esquerda segurando um crucifixo

Os leitores do século XVII viam como Sinal de Fé Cristã (Christiliche Glaube), segundo a Iconologia de Cesare Ripa:

mujer que aparece puesta en pie (...). Con la siniestra sostendrá una Cruz (Ibidem, 1987, p. 401, v.1)

Ripa publicou sua Iconologia em 1593 e, da mesma forma que a obra de Alciati, alcançou várias edições em várias línguas, tornando-se uma referência não só para pintores, escultores, como também para poetas que dela se serviram. Sua fonte de inspiração remonta à Idade Média que, por sua vez, ancorava-se na Antigüidade Clássica, incluindo aí a arte egípcia ${ }^{115}$. Ripa não foi o único a utilizar essa prática de compilação da alegorização, mas teve o mérito de estabelecer, a partir de sua obra, uma metodologia, um sistema, permitindo a compilação de representações alegóricas para artistas, inclusive em ordem alfabética, quando se facilitava a escolha dos conceitos/alegorias que queriam ser abordadas por um artista. Contudo, nem todos os conceitos tratados por ele possuíam representações pictóricas, mas, nem por isso, deixavam de possuir farto material de consulta das inúmeras fontes de onde provieram.

Ao representar algo para dar a idéia de um outro algo, a alegoria adentra no reino do metafórico e do simbólico, ora velando uma verdade, ora demonstrando engenho e refinamento presentes em determinada camada social. Podemos verificar essas duas tendências, por exemplo, no seio do Cristianismo, quando seu emprego generalizou-se em dois momentos bem

\footnotetext{
${ }^{115}$ Deve-se à descoberta do livro de Horapolo, publicado em Veneza, em 1505, o fascínio que havia, no período, pela cultura egípcia, pelos hieróglifos e pela simbologia que continham.
} 
distintos $^{116}$ : durante a perseguição do Império Romano e após a Reforma. São João, ao escrever o Apocalipse, dirige-se à incipiente Igreja que sofria perseguições na Ásia Menor, por isso suas palavras visavam não só a doutrinar, mas também a reconfortar, no entanto teve de mascarar suas palavras por meio de imagens que não fossem acessíveis àqueles a quem elas não eram dirigidas, utilizando alegorias e simbologias próprias, como a gematria $^{117}$ :

Vi, então, uma Besta que subia do mar. Tinha dez chifres e sete cabeças. Em cima dos chifres havia dez diademas, e nomes blasfemos sobre as cabeças. A Besta que eu via parecia uma pantera. Os pés eram de urso, e a boca era de leão. (...) Aqui é preciso entender; quem é esperto, calcule o número da Besta; é um número de homem; o número é seiscentos e sessenta e seis. (Ap 13, 1-2, 18)

Evidentemente, textos assim se dirigiam a leitores coetânos, delimitados por língua, cultura e referencial comum. Como é um texto supra-doutrinário, na medida em que também pretende servir de reconforto em momentos de tribulação $^{118}$, busca animar, revelando que essa situação de angústia terminaria em breve, por isso exorta à confiança, pois Roma, a Besta que subia do $\operatorname{mar}^{119}(. .$.$) - expandindo-se, centripetamente, não só estaria cercada pelas$

\footnotetext{
${ }^{116}$ Não que não houvesse havido alegorização em outros momentos - basta verificar sua utilização nas tópicas utilizadas no período, muitas vezes de caráter helenizante bem como nos bestiários medievais -, no entanto ela foi preeminente nesses períodos de instabilidade. $\mathrm{Na}$ Idade Média, por exemplo, a Patrística submeteu os autores profanos, tanto quanto a Bíblia, à interpretação alegórica, e via neles sábios ou 'filósofos'. (Curtius, op. cit. p. 89)

${ }_{117}$ Método que consiste em revelar velando, ou seja, utiliza-se da particularidade de algumas línguas - o hebraico, o grego, o latim - cujas letras também representavam números, quando, para encobrir um conceito, uma idéia ou um nome, se utilizava de letras não em seu emprego fonológico, mas aritmético. Dessa forma, e dentro de um determinado contexto, somente alguns intérpretes poderiam compreender uma determinada mensagem. Por exemplo, num texto grego, poder-se-iam inserir palavras/códigos a partir dos números hebraicos, fazendo uma transposição entre os dois sistemas de escrita.

${ }^{118}$ Há uma semelhança muito grande entre o texto de S. João e o Livro de Daniel, tanto pelas imagens evocadas - Quatro enormes feras surgiram do meio do mar (...). A primeira parecia um leão com asas de águia. (...) uma segunda parecia um urso. (...) Depois vi uma outra fera parecida com pantera. (...) Vi uma quarta (...). Era (...) diferente das outras feras, porque tinha dez chifres. (Dn 7, 3-7) - quanto pela exortação para não se deixarem vencer pela perseguição por que os hebreus estavam passando no tempo de Antíoco IV Epífanes. Cada uma dessas imagens representaria um Império: o leão seria o babilônico; o urso, o medo; o leopardo, o persa; o quarto, o de Alexandre Magno.

${ }_{119}$ Vir do mar significava para os hebreus o reino do mal, da desordem, do caos, das forças que se opõe a Deus e à felicidade do homem; o mesmo vemos no livro de Daniel citado na nota anterior.
} 
águas do Mar Tirreno, do Adriático, do Jônico, como também de todo o Mediterrâneo $^{120}$ ou, no auge do Império, ao Mare Nostrum - e tinha sete cabeças - as sete colinas que rodeavam seu núcleo primitivo: Capitólio, Quirinal, Viminal, Esquilino, Celio, Aventino e Palatino -, render-se-ia a Cristo. O mesmo também se aplicaria à palavra Besta e a seu número correspondente que, segundo estudiosos, era simplesmente a forma gemátrica para o nome, em grego, do Imperador Nero (37-68), primeiro perseguidor dos cristãos. ${ }^{121}$ A alegoria fez e faz parte do Cristianismo desde seu início - seguindo, inclusive, 0 paradigma hebreu bíblico -, ultrapassa a era apostólica e adentra na arte proto-cristã: esta perpassa o domínio puro do $\lambda o ́ \gamma o \varsigma$ e utiliza alegorias pictóricas que aquela, ainda muito ligada a tradições

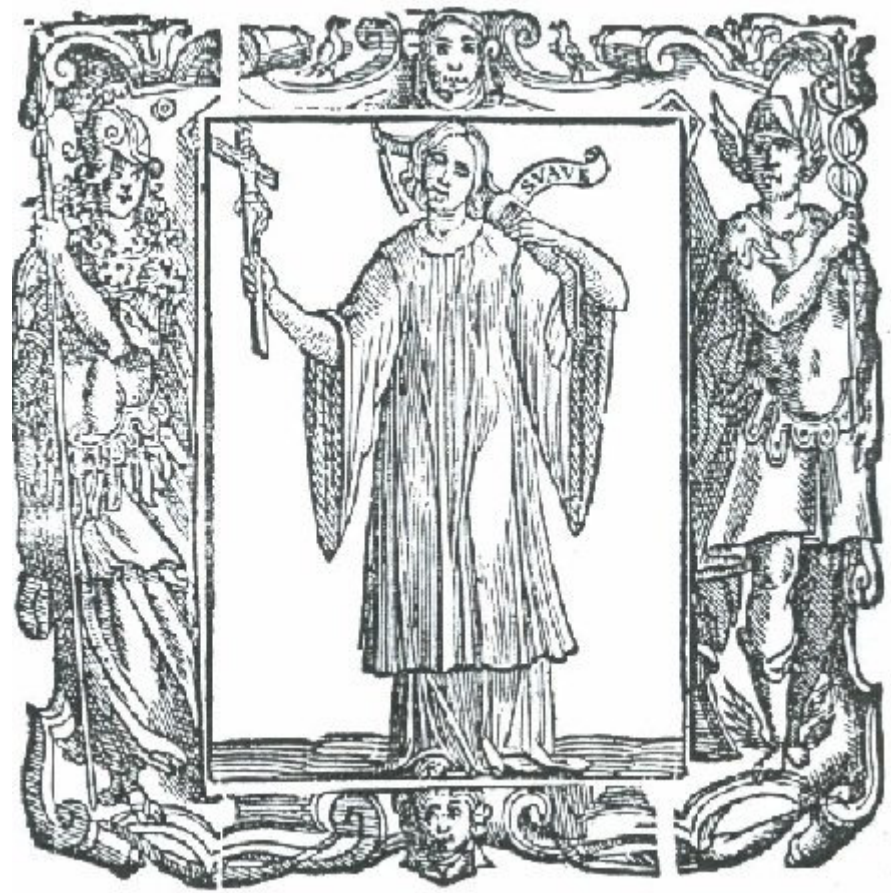

Figura 16: Obediência, de Cesare Ripa. (op. cit., p. 137) hebraicas, limitava ${ }^{122}$. Da mesma forma que a literatura epistolar e doutrinária, a arte pictórica ${ }^{123}$ das catacumbas também era impregnada por alegorias: vários símbolos alegóricos eram utilizados em seu interior, entre eles o

\footnotetext{
${ }^{120}$ Segundo os topônimos utilizados hoje.

${ }^{121}$ A leitura dessa passagem numa leitura sincrônica como a da contemporaneidade, fá-nos buscar explicações descontextualizadas e fora dos propósitos da concepção original que era, apesar da aparente obscuridade simbólica, direta e clara; evidentemente, para os leitores do período a quem era dirigida, afinal a alegoria existe antes mesmo de sua normatização via

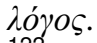

${ }_{122}$ Exemplo disso é a eterna querela pós-Reforma entre católicos e protestantes, quando estes dizem que aqueles adoram ídolos e, para isso, recorrem a Ex 20, 4-5 "Não faça para você ídolos, nenhuma representação daquilo que no céu ou na terra, ou nas águas que estão debaixo da terra. Não se prostre diante desses deuses, nem sirva a eles"; ou ainda a Dt 5, 8-9, onde se vê o mesmo preceito: Não faça ídolos para você, nenhuma representação do que existe no céu, na terra ou nas águas que estão debaixo da terra.

${ }^{123}$ Apesar de aqueles artistas não possuírem técnicas precisas; por isso, essas pinturas eram simples e, normalmente, revelavam a origem social de seus executores: escravos, pessoas simples do povo, pois o Cristianismo ainda não havia se consolidado entre a gente culta e entre os grandes artistas do momento.
} 
peixe $^{124}$, a âncora ${ }^{125}$, a pomba com um ramo de oliveira no bico ${ }^{126}$, o lírio ${ }^{127}$, o cacho de uvas, o trigo ${ }^{128}$. Santo Agostinho em seu Civitas Dei referenda, inclusive, que a Bíblia deveria ser lida de forma alegórica: No Velho Testamento, o Novo Testamento está dissimulado; no Novo Testamento, o Velho Testamento é revelado ${ }^{129}$, afinal ao homem não era permitido o conhecimento literal das Escrituras, esse deveria vir por meio de um segundo sentido, para que pudesse se aproximar da Verdade divina sem, contudo, chegar à sua totalidade ${ }^{130}$. S. Tomás de Aquino, por sua vez, vê uma tríplice função da imagem: como instrumento de informação, ou seja, para instruir os que não sabem ler; como ajuda para a memória dos mistérios da salvação e como estímulo para devoção. (Zilles, 1997, p. 554)

Outro grande momento da alegorização da Igreja foi a Contra-Reforma, quando, após o Concílio de Trento, a obra de arte assume um papel importantíssimo na reconquista do espaço perdido pelo catolicismo, que tinha agora de lutar contra o ataque iconoclasta advindo da Reforma, tentando disciplinar o movimento artístico cristão ${ }^{131}$. A arte teria de atingir a consciência

\footnotetext{
${ }^{124} \mathrm{O}$ peixe, por exemplo, é um dos símbolos mais antigos de que o Cristianismo fez uso, empregado devido ao fato de a palavra grega $\imath \chi \theta \dot{s} \varsigma$ ( $I X \Theta Y \Sigma$ em maiúsculo), ichthys,

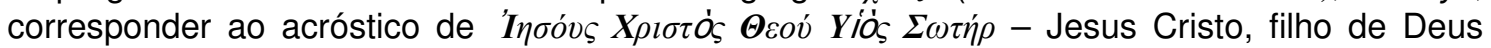
Salvador.

${ }^{125}$ A âncora representava a firmeza e a confiança na fé em meio a adversidades, baseava-se também nas metáforas náuticas, empregadas desde a Antigüidade.

${ }^{126}$ A pomba com o ramo de oliveira no bico era uma alusão a Noé que, em meio ao dilúvio, a solta para verificar se havia terra firme; significa, portanto, esperança e confiança.

${ }_{127}$ O lírio branco é, desde a antigüidade, a representação da pureza, beleza e também da morte. É possível também ver seu emprego em Mt 6,28-Olhem como crescem os lírios do campo: eles não trabalham nem fiam.

${ }^{128} \mathrm{O}$ trigo e a uva representam o pão e o vinho utilizados desde o início do Cristianismo, pois rememoram a última ceia de Jesus. Vale salientar que a cruz, enquanto símbolo não era empregado no início do Cristianismo, provavelmente por retratar mais ignomínia - era para isso que era empregada no Império Romano - que instrumento salvífico, por isso não eram empregadas nessa fase proto-cristã.

${ }_{129}$ Auerbach chama isso de Interpretação Figural, que ocorre quando se estabelece uma relação entre dois acontecimentos ou duas pessoas, na qual um deles não só se significa a si mesmo, mas também ao outro e este último compreende ou completa o outro. (...) quanto mais educados no sentido antigo, quanto mais aprofundados na cultura antiga estivessem os escritores dos tempos patrísticos, tanto mais eles deviam sentir a necessidade de verter 0 conteúdo do Cristianismo numa forma que não fosse só mera tradução, mas uma adaptação às suas próprias tradições conceituais e expressivas. Também aqui Santo Agostinho serve como exemplo (...). (Auerbach, op. cit., pp. 62-63)

${ }_{130}^{130}$ Algo próximo ao "Mito da Caverna" de Platão (República, livro VII).

131 A Contra-Reforma, por exemplo, condena a utilização do nu, limitando, inclusive, sua exibição ao público. Essa ficava reservada à elite e eram representações mitológicas, cujo repertório já era repleto de temas e formas decifráveis por uma clientela internacional (Ginzburg, op. cit., pp. 122-123); o mesmo se deu com a representação de Maria como a Virgem do Leite.
} 
de quem a percebesse, não de forma racional, mas que apelasse para os sentidos, restabelecendo uma relação, freqüentemente afrouxada ou rompida, entre a lgreja e a massa de fiéis que, em muitos casos, sequer existia (Cf.: Ginzburg, 1991, p. 121). Sabia-se da função decisiva das imagens, de sua função de idiotarum libri (Livro dos ignorantes) desde Gregório Magno (540604): O que para os leitores a escrita é, para os olhos dos não-instruídos, o é a imagem, pois até os ignorantes vêem nela o que devem imitar, lendo nela

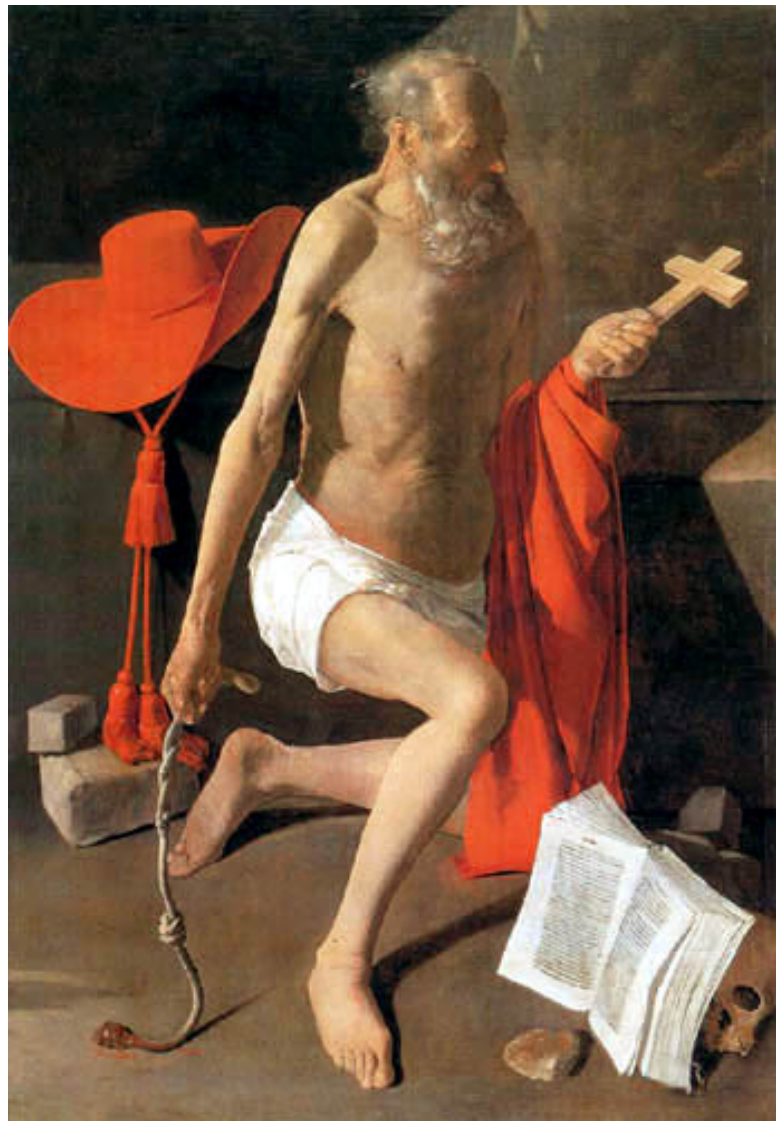

Figura 17: São Jerônimo Penitente, de Georges de la Tour, 1624-1650

inclusive os que não sabem ler (Zilles, op. cit. p. 555). A imagem, portanto, adquiriu valor complementar ao da palavra e dos sacramentos ao abrir não só aos incultos como à elite o acesso ao desconhecido, à divindade e aos preceitos morais, além de servir como atividade pedagógica, à medida que rememoram os mistérios da salvação em torno da pessoa de Jesus, dos apóstolos e da Virgem Maria ${ }^{132}$.

Evidentemente, quando a Reforma demonstra sua tendência iconoclasta - indo contra uma tradição que já se arraigara dentro do catolicismo ${ }^{133}$ há séculos e cujas origens, pode-se inferir, remontam ao Império Romano - e apela não só para a abolição

\footnotetext{
132 Tanto na Igreja do Ocidente quanto na do Oriente, ratificado pelo Concílio de Nicéia, em 787, quando se reconhece ao ícone o direito à veneração, não à adoração: Na trilha da doutrina divinamente inspirada dos nossos Santos Padres e da tradição da lgreja, que sabemos ser a tradição do Espírito Santo que habita nela, definimos com toda a certeza e acerto que as veneráveis e santas imagens, bem como as representações da cruz preciosa e vivificante, sejam elas pintadas, de mosaico ou de qualquer outra matéria apropriada, devem ser colocadas nas santas igrejas de Deus, sobre os utensílios e as vestes sacras, sobre paredes e em quadros, nas casas e nos caminhos, tanto da imagem de Nosso Senhor, Deus e Salvador, Jesus Cristo, quanto da de Nossa Senhora, a puríssima e santíssima Mãe de Deus, dos santos anjos, de todos os santos e dos justos. (Zilles, p. 550)

${ }^{133}$ Houve, no interior da igreja, momentos de iconoclastia anteriores à Reforma, principalmente na Igreja oriental, quando o imperador bizantino Leão III começou uma campanha contra as imagens e ordenou sua destruição. Os bispos levantaram-se contra a proibição, inclusive o
} 
imagética do culto, mas também pela recusa da alegorização e pela interpretação literal das Escrituras -, a Igreja Católica enxerga nisso uma debilidade que deveria ser explorada, pois ao optar pela iconoclastia, a Reforma abre mão de um poderoso e eficaz recurso: a imagem; que, por sua vez, será maciçamente empregada pela Igreja Católica, mormente no século XVII, reconquistando por seu meio muitos dos fiéis que perdera um século antes.

Uma das iconografias de Ripa que representa a obediência (fig. 16) mostra-nos, à semelhança da obra de Mena, uma mulher com um crucifixo em uma das mãos ${ }^{134}$ e na outra o julgo com a palavra suave. Evidentemente, levantar-se-ão questionamentos sobre as diferenças entre a figura alegórica e a obra do espanhol, mas aqui reside uma grande alteração entre a criação artística naquele momento - calcada na $\mu i \mu \eta \sigma ı \varsigma$ - e a que entendemos hoje voltada à originalidade. Naquele momento, cada mudança de expressão do rosto representava ou uma virtude ou um vício; o mesmo vale para a posição das mãos e dos pés; da roupa que se veste; daquilo que se tem nas mãos ou próximo a si; enfim, tudo possui uma significação que tem de ser lida juntamente com a imagem e em sua totalidade. A representação do rosto na alegoria da fig. 14, por exemplo, difere daquela verificada na obra de Mena. $\mathrm{Na}$ de Ripa vemos a placidez, que é o submeter-se de per si à vontade dos outros - daí a obediência - advinda, principalmente, da gente nobre (Ripa, op. cit. v. 2, pp. 136-137); enquanto que na de Mena, vemos a tristeza e a melancolia. Esta, por sinal, ainda para Ripa, é uma manifestação da contrição, uma das três partes de que se compõe a penitência juntamente com a contenção e a reparação. Daí seu ar lastimoso, doloroso, de arrependimento. O mesmo podese inferir em relação à posição do crucifixo nas mãos das duas personagens: cada uma delas tem-no numa mão diferente, afinal cada uma tem uma leitura diferente: a mão direita voltada ao peito deve ser lida como arrependimento dos pecados - o que Mena nos quis passar -, já a mão esquerda segurando o

papa Gregório II (715-731) condenou a iconoclastia do imperador, apesar de esse prosseguir sua luta contra as imagens. Fato que perdurou até o século IX (843), quando se restabelece, definitivamente, a utilização dos ícones no culto.

${ }^{134}$ Apesar de o texto dizer que a mulher segurará o crucifixo com a mão esquerda, na imagem a vemos com a mão direita. A imagem não deve estar invertida, pois a palavra svave está legível. 
crucifixo, a obediência no seguimento da doutrina, e a fé cristã. A posição de Mena lembra-nos o emblema que temos na fig. 18 (da Ichonographia Emblematica Triplicus Ad Deum Tri-Unum, da Província Carmelita da Baviera, de 1779), na qual vemos a representação da penitência oferecida por Ripa (item $b$ ), só que agora a mulher tem na mão direita um cilício, à semelhança do São Jerônimo, do francês Georges de La Tour (fig. 17).

Evidentemente, esses conceitos/imagens perpassaram 0 gênero emblemático e adentraram no poético, imiscuindo-se: as palavras de Simônides de Ceos concretizam-se, tornam-se uma realidade inconteste: a obra pictórica dos Seiscentos deveria ser realmente lida, por isso o artista inundava-a com elementos que, para nós, no século XXI, pouco ou nada representam; afinal, vemos tais cenas representadas sob o ponto de vista estético e não sob o retórico/convencional, por isso simplesmente enxergamos em seus detalhes - que falam - meros adornos, enfeites, elementos deslocados ou expressivos como a mão no peito de Madalena. $\mathrm{O}$ mesmo vale para a poesia, pois as imagens poéticas utilizadas por grande parte dos autores do Seiscentismo trabalham com a técnica

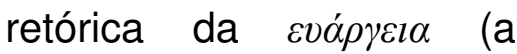
evidentia latina), sendo que prescindem das palavras que as evocam - via seu apagamento -, criando um todo imagético, que tinha de ser visualizado: o $\lambda \dot{o} \gamma o \varsigma$

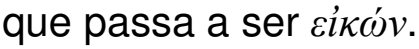

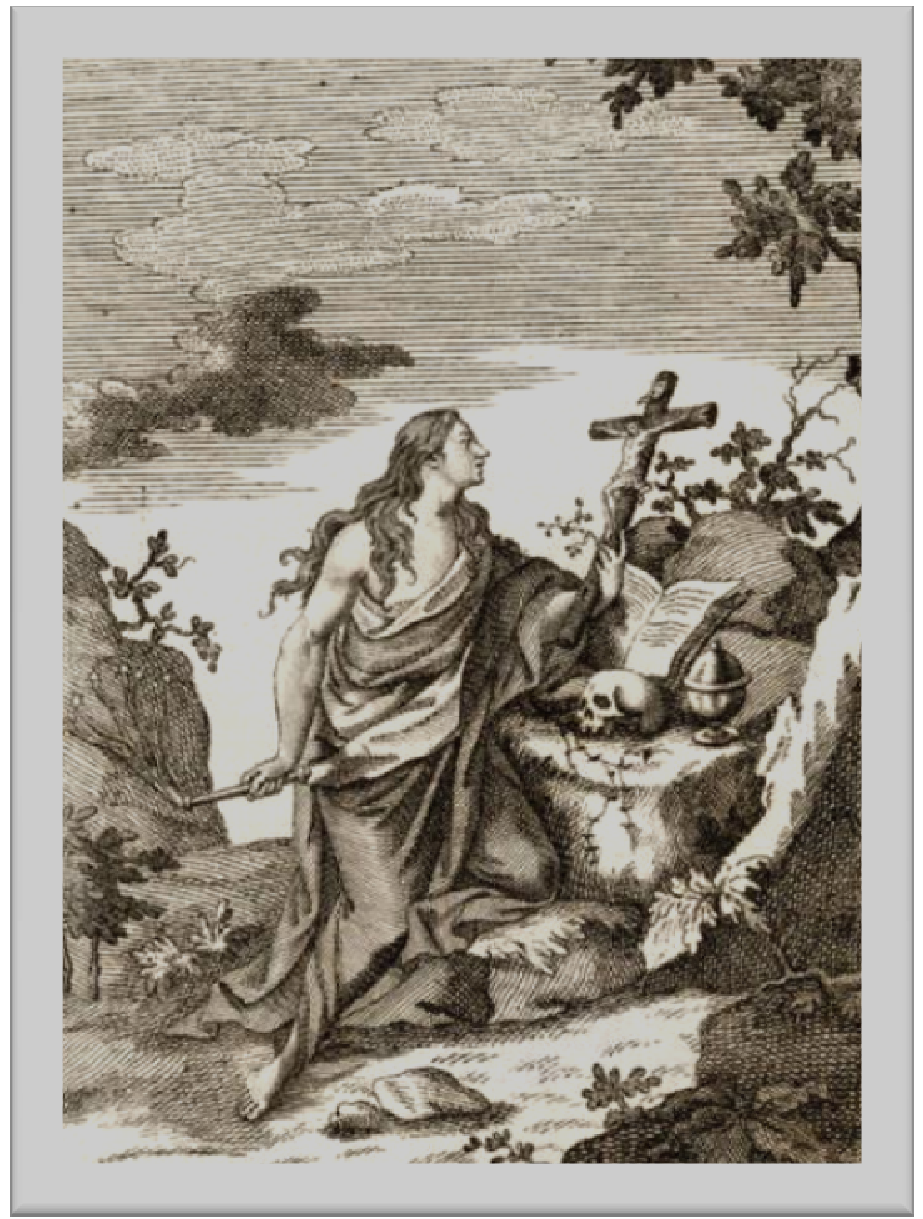

Figura 18: Penitência, da Iconographia Emblematica ao Deus Trino, 1779.

Portanto, verificaremos alguns exemplos de imagens/conceitos anteriormente abordados a partir de alguns elementos pictóricos e 
emblemáticos -, agora por meio de poemas de diversos autores do Seiscentismo alemão, para que possamos nos familiarizar com os mesmos e com a projeção imagética que os leitores dos Seiscentos faziam.

Penitência (Buße)

\section{Angelus Silesius}

Die Christenheit verwundert sich

Ob deiner tiefen Buße,

$D a ß$ du so frei und offentlich

Dem Herren fielst zu Fuße

(Silesius. Cherubinischer Wandersmann, p. 228)

[A cristandade admira-se de tua profunda penitência/ já que caíste tão livre e publicamente aos pés do Senhor]

\section{Simon Dach}

Der Herr ist dir versühnt, er hat mit dir Gedult,

Vnd schätzt die Busse mehr als alle deine Schuld

(Dach. Geistliche Lieder. Trostgedichte. p. 456)

[O Senhor expiou-te, Ele tem paciência contigo/ E considera a penitência mais que toda tua culpa.]

Pecado, penitência, lágrimas (Sünde, Buße, Weine)

\section{Angelus Silesius}
a)
Die geistlichen Jahreszeiten

Der Winter ist die Sünd, die Buße Frühlingszeit,

Der Sommer Gnadenstand, der Herbst Vollkommenheit.

(Silesius. Cherubinischer Wandersmann, p. 142)

[As estações espirituais

O inverno é o pecado; a penitência, a primavera,/ O verão, estado de graça; o outono, perfeição.] 
b) Ans Kreuze Christi

Schau, deine Sünden sinds, die Christum, unsern Gott,

So unbarmherzig verdammen bis in Tod.

Jedoch verzweifle nicht, bist du nur Magdalen,

So kannst du seliglich bei seinem Kreuze stehn.

(Silesius. Cherubinischer Wandersmann, p. 605)

[À cruz de Cristo

Veja, são estes teus pecados, o Cristo Nosso Deus,/ tão cruelmente condenaram à morte. No entanto, não te desesperes, tu és Madalena apenas,/ Assim tu podes ficar próximo à sua cruz)

\section{Paul Gerhardt}

Ach, wein auch du, o Menschenkind,

Und traure über deine Sünd;

Halt doch von deinen Lastern ein

Und mache dich durch Buße rein.

(Gerhardt, op. cit, p 123).

[Ah! Chora tu também, oh criança humana,/ Pranteia sobre teu pecado;/ têm , afinal, domínio de teus vícios/ e purifica-te por meio de penitência.]

Arrependimento dos pecados (Das Bereuen der Sünden)

\section{Angelus Silesius}

a) Laß mich nur solche Gnad und Huld,

Wie Magdalen, erlangen

Und Ablaß meiner Sünd und Schuld

Aus deinem Mund empfangen.

(Silesius, op. cit. p. 177)

[Deixa-me somente alcançar, como Madalena,/ Graça e mercê, e receber/ De meus pecados e culpa/ O perdão de tua boca]

b) Du Balsamritz, du Rosentür,

Du reicher Mund, durch den sich mir

Mein Heilstrom ausgegossen.

Ach, wasch doch ab und schweif geschwind 


\section{Von meiner Brust weg alle Sünd.}

(Ibidem, p. 508)

[Tu fissura balsâmica, tu porta de rosas,/ Tu rica boca, por cujo meio/ Verte-se-me o rio da salvação./ Ah, então lava e afasta, rapidamente,/ De meu peito todo pecado.]

\section{Sigmund von Birken}

a) Ach die Ursach war auch ich, Ich und meine Sünde:

Diese hat gemartert dich, Nicht das Heidgesinde. Jesu, lehr bedenken mich Diß mit Buß und Reue; Hilf, daß ich mit Sünde dich Martre nicht aufs neue.

(Birken, Geistliche Lieder, p. 92)

[Ai! eu também fui a causa/ Eu e meu pecado/ Que te martirizou,/ Não a coorte pagã./ Jesus, lembra-me desse ensinamento/ Com penitência e arrependimento;/ Ajuda que não te martirize de novo com pecados.]

b) O Grosser Gott, ich klage dir mit Reu

Die Ungedult, so mich besessen,

Die wider dich sich setzet ohne Scheu

Dir Gnaden denket abzupressen,

Die für und für

Den deinen hier

Nach meinem Willen will abmessen.

(Ibidem, p. 23)

[Ó grande Deus, lamento diante de Ti, arrependido/ A impaciência que me possui,/ Que se coloca contra Ti, sem pudor/ Tencionando tirar misericórdia de Ti,/ Que sempre/ com os Teus aqui/ Quer se medir pela minha vontade.]

\section{Angelus Silesius}


Ich will dich lieben, meine Krone,

Ich will dich lieben, meinen Gott,

Ich will dich lieben ohne Lohne

Auch in der allergrößten Not.

Ich will dich lieben, schönstes Licht,

Bis mir das Herze bricht

(Silesius, op. cit., p. 48)

[Eu quero amar-te, minha coroa,/ Eu quero amar-te, meu Deus,/ Eu quero amar-te sem soldo/ Mesmo na maior penúria,/ Eu quero amar-te, lindíssima luz,/ Até romper meu coração.]

\section{Gerhard Tersteegen}

Gott lieben ist der Seelen Leben,

Gott lieben ist der Sinne Tod;

Lieb Gott, doch liebe nichts daneben,

Sonst schmeckst du nicht dies Himmelbrot!

(Tersteegen, p. 635)

[Amar Deus é vida da alma,/ Amar Deus é morte dos sentidos;/ Deus amar,/ Ama a Deus, mas não ame nada além disso, / Senão não provarás esse pão do céu.]

Obediência (Gehorsam)

\section{Paul Gerhardt}

Dem Meer und Wind

Gehorsam sind,

Gibst sich zum Dienst und wird ein Knecht der Sünder.

Du, Gottes Sohn,

Wirst Erd und Ton,

Gering und schwach wie wir und unsre Kinder.

(Gerhardt: Gedichte, p.17)

[Ao mar e ao vento/ Sois obedientes,/ Dai-te ao serviço e tornas-te servo dos pecadores./ Tu, filho de Deus,/ Tornas-te terra e barro,/ Ínfimo e fraco como nós e nossos filhos]

\section{Simon Dach}


a) Wir kommen alle gleich

Gebohren in ein Reich,

Da niemand sich muß sperren.

Doch Gott gehorsam seyn,

Dies machet uns allein

Zu unsern eignen Herren.

(Dach. Geistliche Lieder. Trostgedichte. p. 605)

[Chegamos todos, igualmente/ Nascidos em um Reino,/ Em que ninguém será barrado./ Mas ser obediente a Deus,/ É isso que, apenas,/ Nos faz senhores de nós.]

b) Was that er nach der Zeit nicht überall für Zeichen,

Es muste die Natur ihm stets gehorsam weichen,

Er macht' aus Wasser Wein und in der Hungers-Noht

Fünff tausent Männer satt, und hatte sieben Brodt,

Hat aber Hunger selbst wol viertzig Tag erlitten,

Mit Blösse, Kält' und Durst und Dürfftigkeit gestritten (...).

(Ibidem, p. 392).

[O que ele, no tempo não realizou com sinais,/ Sempre a natureza, obediente, teve que ceder diante dele,/ De água, fez vinho e na miséria da fome/ Saciou cinco mil homens tendo sete pães/ Mas Ele próprio sofreu com a fome por quarenta dias/ Tendo lutado contra a nudez, frio e sede e privação.]

Os textos poéticos verificados são apenas alguns exemplos de conceitos/imagens que, evidentemente não foram empregados somente nos Seiscentos, mas em outros períodos literários, contudo a cvó $\rho \gamma \varepsilon l \alpha$, a imagem que salta diante de nossos olhos, foi o diferencial maior, pois no período em questão, voltado a um conceito mimético não à originalidade, buscava-a como um dos objetivos da descrição. (Cf. Seligmann-Silva, in Laooconte, 1998, pp. 59-60). Quando, por exemplo, Clemens Brentano (1778/1842) utiliza conceitos semelhantes aos empregados no período barroco, a realidade e a Weltanschauung da Europa já eram outras, a $\mu i \mu \eta \sigma l \varsigma$ era relegada ao limbo pictórico. A pintura, por exemplo, não queria mais ser uma arte a reapresentar o mundo na tela, ou seja, sua função não seria mais a de ser um simulacro do real, mas o de apresentar na tela um mundo como tal, o da expressão. 
Lentamente vemos que, na arte, a representação cede seu espaço à apresentação. (Cf. Couchot, op. cit., p. 52)

Assim se expressa Brentano - poeta romântico alemão de ascendência italiana - acerca dos conceitos Buße e Sünd:

\section{Clemens Brentano ${ }^{135}$}

a) Wann abends uns die braune Nacht

Im Schatten schwarz verkleidet,

Und ich dann meine Sünd' betracht,

Groß Not mein Herz erleidet.

Von lauter Leid, von Traurigkeit,

Mein Augen mir fast rinnen,

Zu'n Sternen auf (...)

(Brentano. Ausgewählte Gedichte, p. 566.).

[Quando a parda noite ao ocaso/ reveste-nos em sombras escuras,/ E então eu contemplo meus pecados/ Meu coração sofre grandes infortúnios./ Quase meus olhos de ruidoso sofrimento e de tristeza se vertem/ em direção às estrelas.]

b) Du mußt wohl Buße üben,

Weil du die Blicke senkst.

(Ibidem, p. 163)

[Tu bem precisas exercitar a penitência, pois abaixas tua mirada.]

Nesse caso, todo o referencial emblemático pouco tinha a dizer a este poeta, as imagens evocadas já não faziam parte intrínseca da sociedade em que estava inserido. O mesmo pode ser dito do poema de Luise Hensel (17981876), contemporânea de Clemens Brentano ${ }^{136}$, sobre Maria Madalena. Vale a pena lermos e visualizarmos suas imagens:

\footnotetext{
${ }^{135}$ Vale salientar que a religiosidade vista em Brentano começa a se formar quando o poeta reconverte-se ao catolicismo em 1817, provavelmente após o contato que manteve com a mística estigmatizada Anna Katharina Emmerich, sobre quem escreveu Das bittere Leiden unsers Herrn Jesu Christi. Nach den Betrachtungen der Gottseligen Anna Katharina Emmerich, 1833

${ }^{136}$ Por quem, inclusive, o poeta foi apaixonado.
} 
An St. Maria Magdalena

(Am Morgen der ersten Beichte)

Erfleh' mit Lieb' und Thränen,

Du strenge Büßerin,

Daß ich mit reinem Sehnen

Nach Jesu strebe hin!

Daß ich zu Seinen Füßen

Verzeihung mög' erflehn,

In Thränen ganz zerfließen,

In Reue ganz vergehn.

Ich hab' Ihn viel gekränket

Und hab' es wohl gewußt;

Mein Herz hab' ich ertränket

In Erden-Schmerz und -Lust.

Ich hab' Ihn oft vergessen,

Den ich doch früh erkannt,

Und habe ganz vermessen

Mich von Ihm abgewandt.

O, gieb mir Deine Reue

Und Deine Thränenfluth,

$O$, gieb mir Deine Treue

Und Deiner Liebe Gluth,

Bis Er mir neues Leben

Mit diesen Worten giebt:

"Geh' hin, dir ist vergeben,

Weil du so viel geliebt.«

(Hensel, Lieder, p. 226)

[A Santa Maria Madalena (Na manhã da primeira confissão)

Implora com amor e lágrimas, / Tu, austera penitente; / Que eu com puro desejo/ A Jesus almeje! / Que eu a Seus pés/ Perdão queira implorar, / Em lágrimas me derramar inteira, / Em arrependimento sofrer inteira./ Eu O magoei muito/ E bem sabia disso;/ Meu coração afoguei/ Em dor e prazer mundanos./ Muitas vezes $O$ esqueci,/ Esse que cedo reconheci,/ E d'Ele me afastei abruptamente./ Oh, dá-me teu arrependimento/ $E$ teu regato de lágrimas/ Oh, dá-me tua fidelidade/ E a chama de teu amor,/ Até Ele me dar nova vida/ Com essas palavras:/ "Vá, estás perdoada,/ Porque muito amaste".] 
Vemos que o eu lírico diz Erfleh' mit Lieb' und Thränen, no entanto ao empregar Tränen não haveria, necessariamente, uma outra acepção que não fosse o pesar e a tristeza, talvez por também ter pecado, ou considerar-se pecador. A partir desse modo de sentir-se, pode-se estabelecer a correlação entre a palavra Thränen e o título (dedicatória?) da obra, cujo mote se baseia na passagem bíblica em que Maria Madalena, supostamente, teria lavado os pés de Jesus com suas lágrimas e secando-os com seus cabelos para, com esse gesto, suplicar (erflehen) perdão por seus pecados. Não há nada além dessa correlação entre o eu lírico e a personagem retratada, ou seja, o eu lírico sabe que se cair aos pés de Jesus (zu Seinen Füßen) com contrição e amor, cuja exterioridade são as lágrimas, alcançará seu intento, assim como Maria Madalena também o lograra. Dessa forma, Thränen seria a demonstração sincera da vontade que o eu lírico tem de ser perdoado, é a sua verdade, sua necessidade; provavelmente, isso se dê por meio de um padre (Am Morgen der ersten Beichte), quando também ouvirá as palavras que o Mestre dirigiu à mulher que Ihe lavou os pés: Geh' hin, dir ist vergeben, weil du so viel geliebt.

Não se trata, portanto, de uma mera imitação do texto bíblico ou de textos de períodos anteriores, com a mesma temática, mas da aproximação/identificação do eu lírico com a figura bíblica, quando enxerga nela um modelo a ser seguido (enquanto um eu que busca se espelhar num outro eu), não um paradigma a ser imitado (enquanto modelo epistemológico, nos moldes da literatura seiscentista). Por isso, dizemos que não há nada além disso, ou seja, as lágrimas podem ser, efetivamente, lágrimas, porque a poesia

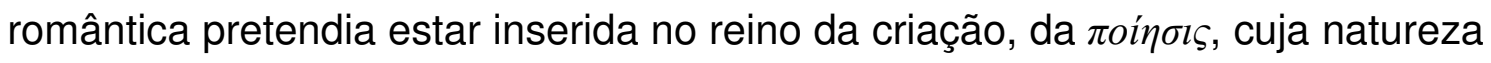
é unicamente realidade (Novalis, apud Duarte, op. cit., p. 293) nem que para isso tenha de, a partir dessa realidade, recriá-la (Cf.: Paz, op. cit., p.50); desse modo, dirigia-se contra a concepção mecânica da $\mu i ́ \mu \eta \sigma ı \varsigma$, da representação enquanto modelo epistemológico do fazer artístico. Vemos que esse eu reflete sua experiência diante do mundo, mas não se preocupa tão-somente com um outro eu-paradigma, com a imitação de conceitos preestabelecidos nem mesmo da natureza. Essa imitação difere do conceito de Einbildungskraft (na verdade, capacidade/força da imaginação) - de Fichte - quando para descrever o processo poiético criativo de um Eu substantivado em 
contraposição a um não-Eu, o filósofo opta por excluir da subjetividade a própria natureza (Cf.: ibidem, p. 292). Talvez por isso Novalis, por sua vez, visse na representação verdadeira, perfeita a fonte da superstição e do erro (Novalis, apud Seligmann-Silva, 2004, p. 98), pois essa não expressa a verdade de um eu diante da força auto-poiética proporcionada pela poesia que, para os românticos, não quer ser a reprodução de um real qualquer, mas da absoluta verdade. (Cf.: Ibidem, p. 294) Essa, ao apoiar-se na experiência poética - que não difere da identificação com a 'realidade da realidade' expressa-se e comunica-se pela imagem (Paz, op. cit. p.50) evocada e emanada no poema via $\lambda o ́ \gamma o \varsigma$, transmutando o homem e convertendo-o, ele mesmo, em imagem: eis o momento de agraciamento, de reconciliação consigo mesmo, pois quando se faz imagem, faz-se o outro (Ibidem, p. 50): o eu lírico torna-se Madalena, ela escuta o que ela quer ouvir, já que no Evangelho de Lucas temos: Dir sind deine Sünden vergeben.(...) Dein glaube hat dir geholfen; geh hin in Frieden! (Lc 7, 48 e 50) ${ }^{137}$, não Geh' hin, dir ist vergeben, Weil du so viel geliebt: eis o que nunca aconteceria, por exemplo, no Seiscentismo, quando inexistia a originalidade cometida por Hensel.

As lágrimas podem não ser lágrimas, principalmente quando tratamos de modelos literários não voltados à originalidade como os do Seiscentismo, bem como ser representadas por outras imagens/conceitos, cuja significação perpassa o conceito de tristeza/alegria relacionados com o ato de lacrimejar. Pode-se exemplificar isso com a imagem de Pedro Mena, considerada anteriormente, em cuja significação podia-se ler Sündenbekenntnis und die Lossprechung als Reinigungsbad der Seele ${ }^{138}$. (Biedermann, 1999, p. 115) 0 ato em si da purgação dos pecados resultaria em lágrimas como resultado exterior do Reue von Befleckungen ${ }^{139}$ (ibidem, p. 115), perpassando, portanto, a tristeza como emoção: não há aqui a perda de algo ou de alguém de que se gostava, não é o resultado do egoísmo, da insegurança, da baixa autoestima, da inveja ou da desilusão - podendo ser, evidentemente, a causa primeira do pecado, cujo resultado tenham sido elas próprias -, mas o

${ }^{137} \mathrm{Na}$ edição alemã traduzida de Martinho Lutero. Na edição brasileira, que optamos, está: Seus pecados estão perdoados (...) Sua fé salvou você. Vá em paz!.

${ }_{138}$ Conhecimento do pecado e a absolvição como banho de purgação da alma.

${ }^{139}$ Arrependimento das manchas (máculas). 
resultado da limpeza da alma que, arrependida e perdoada, é levada à compunção. Por ter essa expressividade e essa dimensão, nem sempre a palavra lágrima foi utilizada pelos poetas daquele momento, pois buscavamse formas mais engenhosas, como a utilização da palavra pérola. Podemos citar muitos exemplos:

\section{Benjamim Neukirch}

Noch wie die mutter selbst aus ihrer hertzens-see

Das saltz der thränen läst als rundte perlen fliessen.

(Neukirch. Gedichte, p. 121)

[Ainda como a própria mãe deixa escorrer de seu coração-mar o sal das lágrimas como pérolas arredondadas.]

\section{Daniel Caspar von Lohenstein}

So weinen sie vor leid/ daß sich ein theil entfernen

Von liebes-ästen soll. Die göldnen wiesen-sternen/

Der erde gelbes haar/ die edlen blumen fühl'n

Der liebe zauber-werck in ihren wurtzeln spiel'n/

Die perlen ihres thaus sind bittre liebes-thränen;

Der kräfftige geruch ist ihr verliebtes sehnen/

Und ihrer seuffzen hauch: der farbe purpur-blut

Auff ihren knospen ist die lichte liebes-glut.

(Lohenstein. Gedichte, p. 80)

[Então choram de dor/ que precisam se afastar um pouco/ Dos ramos do amor. As estrelasprado/ do cabelo dourado da Terra/ As nobres flores sentem/ A obra da magia do amor em suas raízes brincam/ As pérolas de seu orvalho são lágrimas de amor amargas;/ O forte odor é da cor púrpura/ Sobre os botões é a suave brasa do amor.]

\section{Johann Klaj}

Ich habe nun gesungen/

was mein versprechen war/

Ach hätt ich soviel Zungen 


\author{
Als augenblick im Jahr/ \\ Soviel deß Staubs der Sonnen/ \\ der Tropffen in den Bronnen \\ der Sternen an den Blauen/ \\ der Perlen in den Tauen/ \\ deß Wildes in den Wäldern
}

(Klaj. Redeoratorien, p. 445)

[Eu cantei agora/ o que era minha promessa/ Tivesse eu tantas línguas/ quanto um ano tem momentos/ Tanta poeira do sol/ dos pingos na fonte das estrelas no azul/ das pérolas no orvalho/ da caça nas florestas.]

\title{
Christian Hoffmann von Hoffmannswaldau
}

a) Der wunder-starcke safft/ der süsse thau der seelen/

So um rubinen fleußt/ und hier auff perlen steht/

Gibt deutlich zu verstehn/ daß in der augen hölen

Die reitzung öffters schläfft/ hier memahls

(Hoffmannswaldau. Gedichte aus Neukirchs Anthologie Bd. 1, p. 98)

[O sumo forte e milagroso/ doce orvalho das almas/ que corre em volta dos rubis/ e aqui está sobre pérolas/ Mostra claramente/ que nas órbitas do olho/ o estímulo, muitas vezes dorme/ aqui, nunca.]

b) Die thränen stehen dir wie perlen im gesichte/

Und fliessen wie crystall durch wangen/ mund und brust

(Hoffmannswaldau. Gedichte aus Neukirchs Anthologie Bd. 2, p. 11)

[As lágrimas estão em seu rosto como pérolas/ e correm como cristal pelas faces,/ por boca e peito.]

c) Vor Freuden tritt mir itzt das Wasser ins Gesichte, Und rollet unvermerckt wie Perlen ums Papier

(Hoffmannswaldau: Sinnreiche Heldenbriefe, p. 79)

[De alegria sobe-me a água ao rosto,/ e rola despercebido pelo papel como pérolas.] 


\section{Andreas Gryphius}

Der ists durch den sich Gott mit Menschen wil verbinden/

Diß ist der Perlen-Thau/ der frischen Morgenröth:

Der die verwelckte Seel erfrischt/ was liegt/ erhöht.

Diß ist der Trost durch den wir Muth im Zagen finden:

(Gryphius. Sonette, p. 329)

[É através dele que Deus quer se unir ao homem/ É o orvalho de pérolas/ da fresca aurora matinal:/ Que refresca a alma murcha/ que o que está deitado/ ergue./ É o consolo pelo qual encontramos coragem no desespero.]

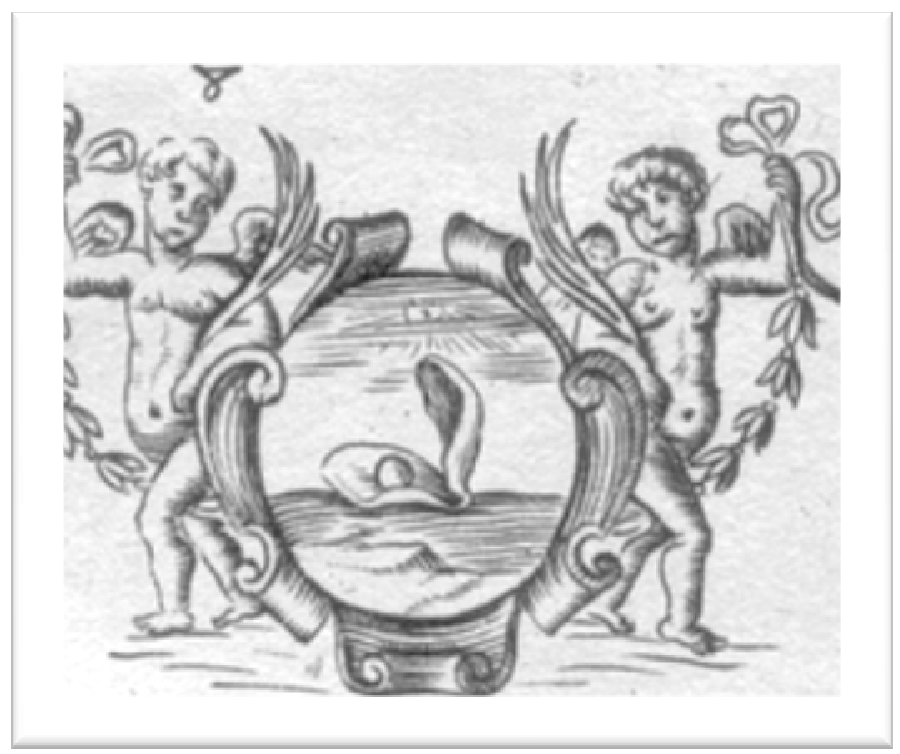

Figura 19: Une perle das sa cocque au dessous du soleil, de Daniel de la Feuille, 1691.

\section{Catharina Regina von Greiffenberg}

Du wurdest von dem Bach der Trübsal sehr geweicht / und littest stöß' und schläg' / O Jammer! von den bösen.

Solch köstlich Wasser labt das fast-verschmachte Herz: dein Perlen-Blut-Safft stillt / der Seelen Sündenschmerz.

(Greiffenberg. Geistliche Sonnette: Lieder und Gedichte, p. 199)

[Foste muito marcado pelo riacho da tristeza/ e sofreste golpes e ataques/ Ó tristeza! Pelos maus./ Tal saborosa água refestela o coração/ quase fenecido:/ teu sumo de sangue e pérolas sacia/ a dor pecaminosa das almas.] 
A fascinação pelas pérolas remonta à Antigüidade ${ }^{140}$ e devido a sua pureza e origem misteriosas, muitas civilizações tentaram explicar sua procedência: uns acreditavam ser ou uma gota de orvalho ou uma lágrima da lua que caía dentro da ostra; um presente dos deuses mandado à terra; e, por representar pureza, muitos povos utilizavam-nas nos mortos para demonstrar sua inocência na vida post mortem, à semelhança da moeda de Caronte. Dessa forma, não é difícil compreender o porquê de a pérola ter se tornado uma alegoria da pureza, simbolizada pelas lágrimas via purgação como dito anteriormente, tendo utilizada, inclusive, na alegoria cristã:

Es gibt eine Muschel im Meer, die heißt Purpurmuschel. Sie steigt vom Meeresgrunde auf..., öffnet ihren Mund und trinkt den himmlischen Tau und den Strahl der Sonne (conforme a fig. 19), des Mondes und der Sterne und bringt so die Perle zustande aus den oberen Lichtern... Die beiden Schalen der Muscheln werden verglichen mit dem Alten und dem Neuen Testament, die Perle mit unserem Heiland Jesus Christus. (Biedermann, 1999, p. 826)

[Há uma ostra no mar chamada de ostra púrpura. Ela sobe do fundo do mar... abre sua boca e bebe do orvalho do céu e o raio de sol, da lua e das estrelas e então faz a pérola a partir das luzes do alto... Ambas as conchas da ostra podem ser comparadas ao Velho e ao Novo Testamento, a pérola com nosso Salvador Jesus Cristo.]

Vale salientar, no entanto, que a palavra pérola como utilização alegórica perpassa o Seiscentismo e adentra no Romantismo alemão, demonstrando, provavelmente, sua força imagética cristalizada:

\section{Achim von Arnim}

a) Kinder, ja nicht zu ihr dränget,

Perlen deuten ja auf Thränen

Ja die Hand nicht aus dem Kahne

In dem kühlen Wasser hänget (...)

(Arnim. Ausgewählte Gedichte, p. 25.)

[Crianças, não ide até ela,/ pérolas apontam para lágrimas/ Do barco não pendurem/ a mão na fresca água.]

\footnotetext{
${ }^{140}$ Não só a que consideramos clássica, como os gregos, romanos, inclusive a egípcia, mas também de vários outros povos como os chineses, os hindus, os persas.
} 
b) Da meine Thränen an den Perlen glänzen,

Der alten Fabelsage innre Wahrheit,

Daß jene Perlen Thränen sind der Meeresgeister,

Die ahnend großes Unheil uns verkünden.

(ibidem, p. 488)

[Quando minhas lágrimas em pérolas brilham/ A verdade interna da velha fábula,/ De que aquelas lágrimas são pérolas dos espíritos marinhos,/ Que como prenúncio, nos anunciam grande infortúnio.]

\title{
Clemens Brentano
}

\author{
Halt, halt, ihr scheinend Perlen klar, \\ Ihr tausend Licht und Fackel, \\ Halt, halt, ihr wohlgezündte Schar, \\ Ihr Feur und Flamm' ohn' Makel,
}

(Brentano. Ausgewählte Gedichte, p. 566)

[Parem, parem pérolas claras e reluzentes,/ Mil luzes e tochas/ Parem, parem, turba incendiada,/ Fogo e chama sem mácula.]

\section{Joseph von Eichendorff}

Da löst' sie Kranz und Spangen,

Und über ihr Angesicht

Perlen und Tränen rannen,

Man unterschied sie nicht.

(Eichendorff. Gedichte (Ausgabe 1841), p. 603)

[Eis que solta guirlanda e fivelas/ E sobre o rosto/ Escorriam pérolas e lágrimas,/ Não se poderia diferenciá-las.]

\section{Friedrich Rückert}

Rosengeschmeide

Die Rose meiner Liebe,

Der keine Sonne scheint;

Daß sie nicht schmucklos bliebe, 
Hat Perlen sich geweint.

Sie trägt als Brustgeschmeide

Der Thränen Perlenschnur.

Des Schmuckes mich entkleide

Die hohe Sonne nur.

Die Perlen alle wollen

Vergehn vor Ungeduld,

Bis sie zergehen sollen

An Blicken deiner Huld.

(Rückert. Wanderung, p. 88)

[Enfeite de rosas

A rosa do meu amor,/ Para quem nenhum sol brilha;/ Para que não ficasse desonrada,/ Chorou pérolas./ Como enfeite no peito, colar de pérolas de lágrimas/ Que o enfeite me tire/ Apenas 0 sol a pino./ As pérolas todas querem/ fenecer de impaciência/ Até se dissolverem/ Diante dos olhares de tua benevolência.]

Quando passa a ser empregado, esporadicamente, em momentos literários ulteriores ${ }^{141}$ :

\title{
Otto Julius Bierbaum
}

\author{
Denn aus Gold sind deine Lippen, - seltsam, \\ Bernsteingoldig deine Augen, - seltsam, \\ Und dein Nabel eine weiße Perle.
}

(Bierbaum. Ausgewählte Gedichte, p. 49)

[Pois de ouro são teus lábios - curioso,/ De ouro-resina teus olhos, curioso,/ E teu umbigo uma pérola branca.]

\section{Luise Büchner}

Ihr ganzes Wesen funkelt,

\footnotetext{
${ }^{141}$ Ada Christen, pseudônimo de Christiane Rosalia Friederik, utiliza esse conceito em Einer do livro Lieder einer Verloren (Canções de uma perdida), de 1868. Há, na obra, vários poemas, cujo campo semântico gravita em torno do verbo weinen (chorar), talvez resulte daí sua utilização, não representando, a meu ver, uso corrente naquele momento.
} 


\section{Ein blitzender Demant - \\ Jolanthe ist der Perle \\ Anmuth'gem Schmuck verwandt.}

(Büchner. Frauenherz, p.152)

[Todo o seu ser resplandece,/ Como um diamante que brilha/ Jolanta parente é/ Do enfeite belo da pérola.]

\section{Richard Dehmel}

Was glühst du, Rubin, von versunkenen Stunden?

Was blickst du, Perle, so bleich im Gold?

(Dehmel. Aber die Liebe, p.190)

[Por que ardes, rubi, lembrando horas passadas?/ Por que miras, pérola, tão pálida em meio ao ouro?]

\section{Franz Grillparzer}

Die Perle hat doch auch kein Ohr,

Der Demant keinen Mund,

Der Blick des Goldes winkend nur

Gibt Wunsch nach Freiheit kund.

(Grillparzer. Gedichte, p. 354)

[Mas a pérola também não tem ouvido,/ O diamante não tem boca,/ Apenas o olhar do ouro, que acena,/ Noticia o desejo de liberdade.]

\section{Heinrich Heine}

Mein Herz gleicht ganz dem Meere,

Hat Sturm und Ebb' und Flut,

Und manche schöne Perle

In seiner Tiefe ruht.

(Heine. Buch der Lieder, p. 193)

[Meu coração parece o mar,/ Tem tempestade, maré baixa e alta,/ E uma ou outra pérola/ Repousa em sua profundeza.] 


\section{Johann Gottfried Herder}

Die schönste Perle blinkt auf seinem Angesichte,

Der Mühe Lohn, o mehr als Kronen werth!

(Herder. Gedichte, p. 53)

[A mais bela pérola brilha em sua face,/ a recompensa pelo esforço, mais vale, ó que coroas!]

Além de ser empregada parafraseando a passagem bíblica: Não dêem aos cães o que é santo, nem atirem pérolas aos porcos ${ }^{142}$; eles poderiam pisálas com os pés e, virando-se, despedaçar vocês (Mt 7,6), conforme os exemplos:

\section{Ada Christen}

Alle Herzen, alle Menschen

Hatten sich von mir gewandt,

Und mit Abscheu alle Lippen

Meinen Namen bald genannt.

Da kam Einer, sah in's Antlitz,

In das thränenblasse mir:

„Unter Schweinen, « sprach er traurig,

„Fand die Perle ich an Dir. «

(Christen. Lieder einer Verlorenen, p. 31)

[Todos os corações, todos os homens/ Afastavam-se de mim,/ E com repulsa todos os lábios/ Pronunciavam meu nome./ Eis que veio um, olhou-me na face/ Que estava pálida de lágrimas:/ "Entre porcos", disse, triste,/ Encontrei a pérola em ti".]

O dia 26 de dezembro de 2004 ficará marcado na história da humanidade como o dia em que o mar não só avançou em direção a terra,

${ }^{142} \mathrm{Na}$ tradução de Lutero é utilizado Säue (porcas) não Schweine (porcos). 
como também varreu a vida de quase trezentas mil pessoas. Evidentemente, não que esse tenha sido o maior ou o pior tsunami por que a humanidade passou, mas as cenas foram vistas in loco por muitas pessoas ao redor do globo e ao mesmo tempo. Todos nós vimos pessoas atônitas, desesperadas, sem saber o que fazer: não havia, no entanto, nada a fazer. Muitas nunca imaginariam que o espetáculo que estavam presenciando - as ondas no quebra mar - seria o último: seguiu-se uma verdadeira hecatombe.

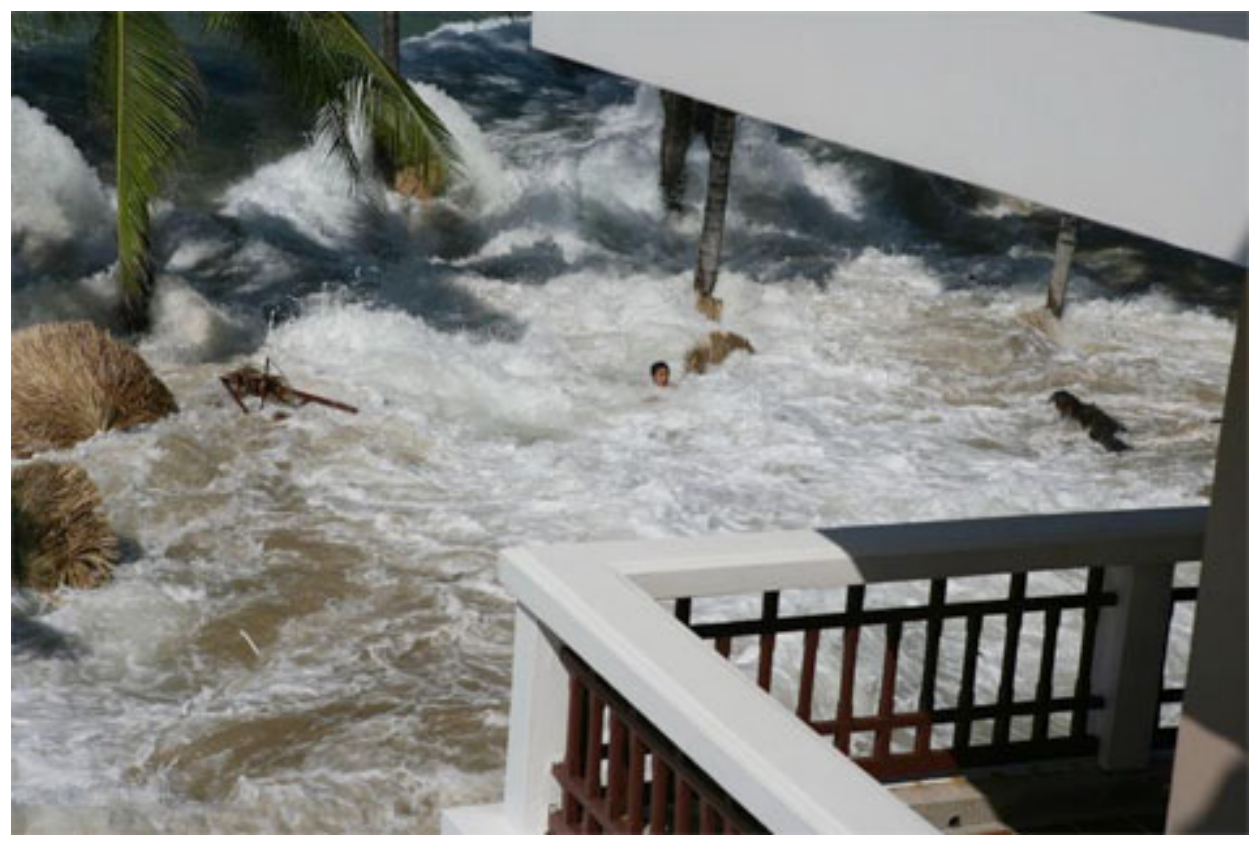

Foto 1: Sheraton Grande Laguna Phuket, Tailândia, s/n, 2004

A televisão bombardeou-nos com muitas imagens, com muitas cenas que chegavam a todo o momento e que nos impressionavam: como foi possível isso? Diante de tanta tecnologia, como aceitar que uma tragédia dessas não pudesse ter sido, pelo menos, prenunciada com algumas horas de antecedência?

Estávamos no final do ano, tempo em que as pessoas, normalmente, reúnemse com a família, com os amigos e querem, via catarse, esquecer os problemas e preocupações do ano que se encerra, por meio da festa, da alegria, preparando-se para um novo ano. Ainda estávamos comemorando, quando vimos que o pior estava acontecendo no outro lado do mundo: não queremos nos lembrar de que também somos suscetíveis a esses acontecimentos, de que a vida está ligada por um pequeno fio que nos prende, mas que pode se romper com facilidade. Fazemos questão de não nos lembrarmos de nossa pequenez, afinal já conquistamos muito: o homem vive quase cem anos, a 
medicina está cada vez mais adiantada, a tecnologia nos cerca de todos os lados - inclusive para nos mostrar que, apesar de todas essas conquistas humanas, ainda somos fracos e nossa força é nada diante da força da natureza a que estamos submetidos. Eis que a fotografia nos prova tal fato: sim, realmente a cena aconteceu; sim, realmente, isso pode nos acontecer.

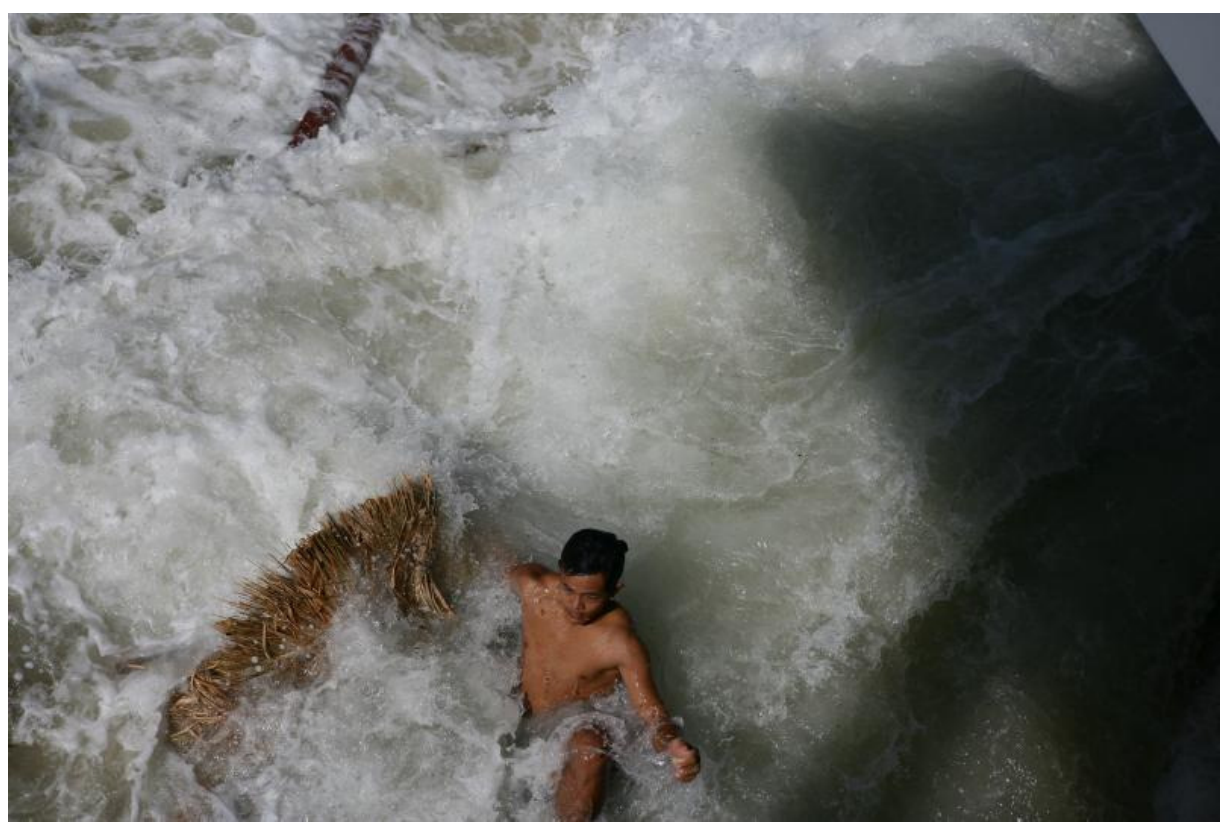

Foto 2: Sheraton Grande Laguna Phuket, Tailândia, s/n, 2004.

O homem das fotos 1 e 2 está sendo arrastado pela força da água que avança sobre um hotel de luxo em meio a ilhas de pessoas miseráveis que não têm acesso às benesses da $\tau \dot{\chi} \chi v \eta$. O pior é que essas imagens exigem de nós que vejamos outras e mais outras, não nos contentamos com uma, todas chamam, literalmente, nossa atenção. Sabemos e queremos que venham mais e, à semelhança do fototropismo vegetal, tornamo-nos iconotrópicos: sentimos necessidade de mais e mais imagens para podermos (tentar) saciar nosso apetite voraz por elas, mesmo que isso tenha um sabor de indigestão nas festas de fim de ano.

Essas imagens tecnológicas não querem, a priori, nos transmitir preceitos morais $^{143}$; apesar de nos transmitir $\pi \dot{\alpha} \theta o \varsigma$ [pathos], sentimos emoção

\footnotetext{
${ }^{143}$ Até poderíamos vê-los ou mesmo utilizá-los hoje, quando, ao ver tais imagens, falássemos a respeito do efeito estufa, do problema da elevação do nível dos mares, mesmo que não haja nenhuma relação com o tsunami - o fato retratado -, que é devido a fatores externos ao
} 
ao vê-las, somos impelidos a pensar nas crianças, nos velhos e na situação desesperadora que pessoas como nós experimentaram, no entanto estamos longe dos acontecimentos e não nos deixamos (nem queremos) influenciar além desse $\pi \alpha ́ \theta o \varsigma$ inicial - por eles: tentamos fingir que isso só acontece com os outros, em países pobres e longínquos, pois a catástrofe não nos reconhece; buscamos, portanto, relegá-la sempre ao outro: ao outro mundo, às outras pessoas e, dessa forma, não só não tememos a morte, como fingimos que ela não existe e que estamos a salvo dela - pelo menos podemos retardála ao máximo - devido à técnica ${ }^{144}$. Até o momento em que ela se acerca de nós e mostra-nos seus dentes: trememos e vemos que também nós somos mortais: não há para onde fugir, as ondas se acercam de nós e nos levam. É exatamente isso que vemos na foto 2: um homem sendo arrastado pela força implacável das águas do mar que avançaram sobre tudo, inclusive sobre ele; não é possível fazermos nenhuma outra leitura dela a não ser essa. O que vemos na foto é um acontecimento em seus dois recortes: o temporal e o espacial. A fotografia, enquanto recorte temporal, reduz o tempo não só a um ponto como também o perpassa, perpetuando aquilo que aconteceu somente uma vez (Cf. Dubois, op. cit., p. 174): a cena se perpetuará num continuum enquanto minha memória dela se lembrar, enquanto fizer parte do acervo que tenho em mim, bem como de minhas experiências. No entanto, o fotógrafo ao utilizar seu ato, muitas vezes de forma violenta ${ }^{145}$, retém um plano do real em detrimento do que está à sua volta, usando seu poder de corte (Cf.ibidem, p. 178): não é o que vemos nessa foto, pelo contrário, é como se o fotógrafo tentasse salvar o homem que ali estava, arrancando-o da força da natureza.

Uma mesma leitura não seria possível, evidentemente, nas obras do Seiscentismo, como a retratada na fig. 20 que, só na aparência, lembraria a temática da foto 2. A leitura que devemos fazer aqui tem de ser alegórica, já homem como, por exemplo, deslocamentos tectônicos na plataforma submarina ou quando placas mais densas deslizam sobre as menos densas (continentais).

${ }^{144}$ Como veremos, essa era uma visão totalmente antagônica à do homem seiscentista, que fazia sempre questão de colocar a finitude, a morte diante de si, como demonstram as obras do período. Só para citar dois exemplos literários temos: Quevedo ao escrever: comigo levo a terra e a morte (Cf. Maravall, op. cit. p. 269), e Gryphius: Hier schawt der schwartze Todt zu beyden Augen au $\beta$ [Aqui a morte negra espreita com ambos os olhos] (Gryphius, op. cit. p. 8).

${ }_{145}$ Como um caçador ou como um predador que caça exatamente o que quer e despreza o restante. Susan Sontag faz uma análise interessante quando compara a câmera fotográfica com as armas em um safári. 
que, à diferença da foto em questão, estão inseridos aqui vários preceitos moralizantes; ou seja, vemos exatamente aquilo que não vemos. Além disso, a passagem não se refere nem é dirigido a um eu individual, mas a um eu coletivo que se encontrava na imagem e buscava seguir seus preceitos moralizantes. Para demonstrar isso é mister que façamos uma análise da mesma e suas implicações no modo de ver daqueles que se deixavam influenciar por elas.

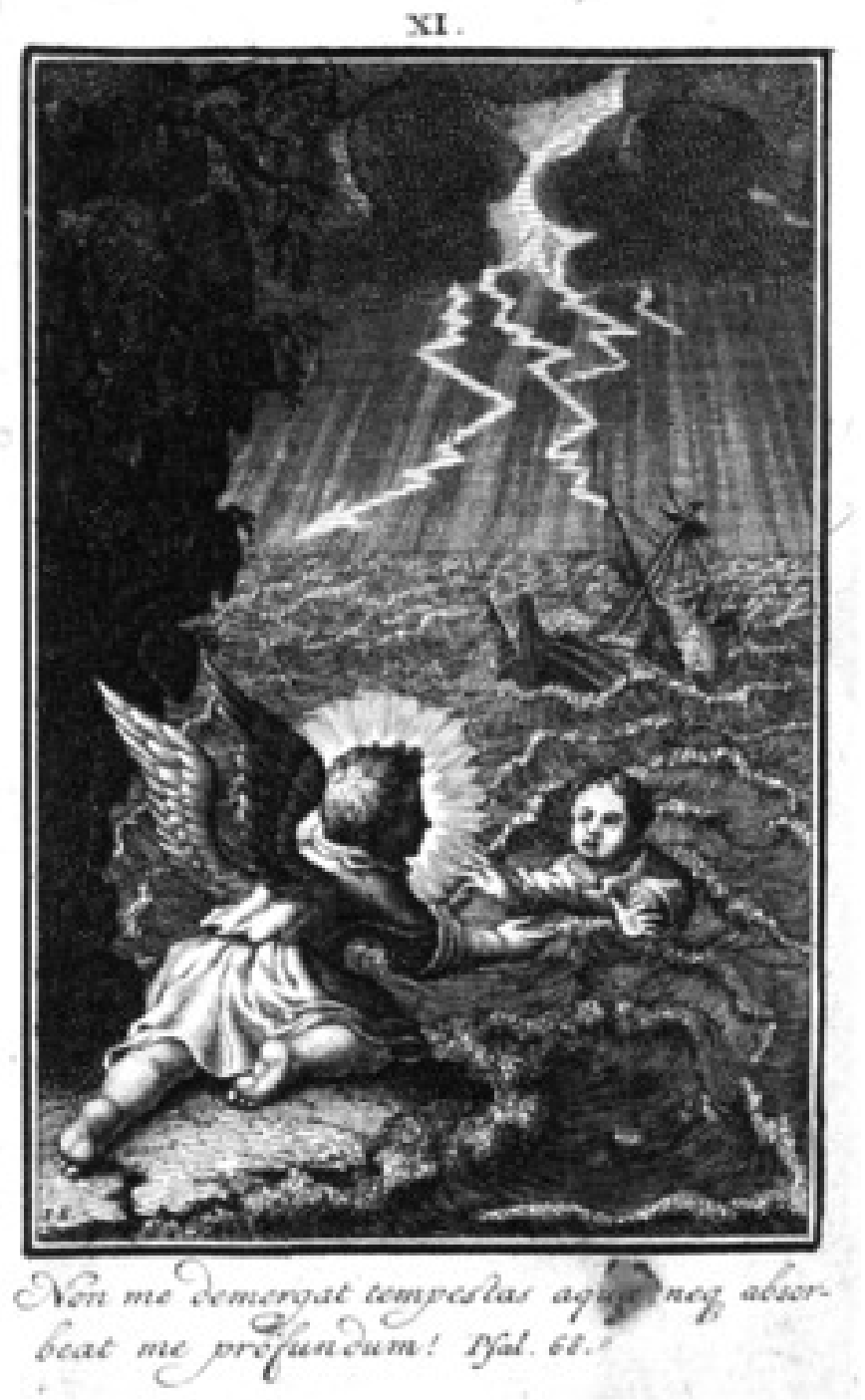

Figura 20: Emblema XI Non me degart tempestas aquae, de Jan Suderman, de 1724.

$\mathrm{Na}$ leitura pré-iconográfica desse emblema, podemos levantar alguns aspectos imagéticos: 
a) Vemos uma criança que, aparentemente, foi vítima de um naufrágio, porém o que chama a atenção é o fato de ela estar sozinha e distante do navio em que estava;

b) Vemos que a criança é auxiliada por um anjo da guarda (essa é a imagem que me vem, quando vejo uma criança em apuros e junto a ela um anjo), talvez resida aí o fato miraculoso de seu salvamento;

c) É possível vermos uma gigantesca tempestade que se precipita, demonstrada pelos raios que cortam o céu, pelas nuvens escuras e pelo mar agitado;

d) Vemos um navio afundando.

À semelhança da escultura de Mena, ao passarmos para nossa análise iconográfica, também somos impelidos a analisar a figura a partir de uma conotação religiosa, visto que, diante de uma desventura como um naufrágio, vê-se apenas uma criança à deriva que, aparentemente, se salva de forma miraculosa, por meio de um anjo que lhe dá a mão. Aliado a esse fato, vê-se escrito no corpo do emblema uma passagem em latim que diz: Non me demergat tempestas aquæ, neque absorbeat me profundum! e, à continuação, Psal. 68. A passagem bíblica serve, portanto, de mote para a imagem emblemática:

Salva-me, ó Deus, pois a água está chegando ao meu pescoço. Estou afundando no lodo profundo, sem nada que me segure; vou afundando no mais fundo das águas, e a correnteza me arrastando... Esgotei-me de tanto gritar, minha garganta queima e meus olhos se consomem, esperando por meu Deus. (...) Que a correnteza não me arraste, nem o lodo profundo me engula, e que o poço não feche sobre mim a sua boca. (SI 69, 1-4 e 16)

Mas, um acontecimento nos chama a atenção: o fato de a personagem retratada ser uma criança, além de seu afogamento. Se estivesse se afogando, não deveria estar com as mãos espalmadas em direção ao anjo, mas acima da cabeça (talvez como o homem da foto 2 que as têm retesadas - apesar de só nos ser possível ver uma - tentando se agarrar a algo), debatendo-se para tentar se salvar, se é que isso seria possível em meio a uma tempestade 
dessas proporções e, ainda mais para uma criança; além disso, onde estariam as outras pessoas do navio? Estariam todas mortas? Não há como responder a isso com base na gravura: não temos elementos para isso, a não ser a imagem em si e o mote bíblico. Esse, por sua vez, se refere a um homem adulto, conforme podemos inferir lendo o texto até seu final. Então, surge-nos, novamente, a pergunta: por que uma criança? Pergunta cuja resposta não pode ser dada nem com uma análise preliminar - na leitura pré-iconográfica -, nem mesmo em nossa análise iconográfica, pois faltam-nos elementos iconológicos para poder abarcar toda sua significação imagética.

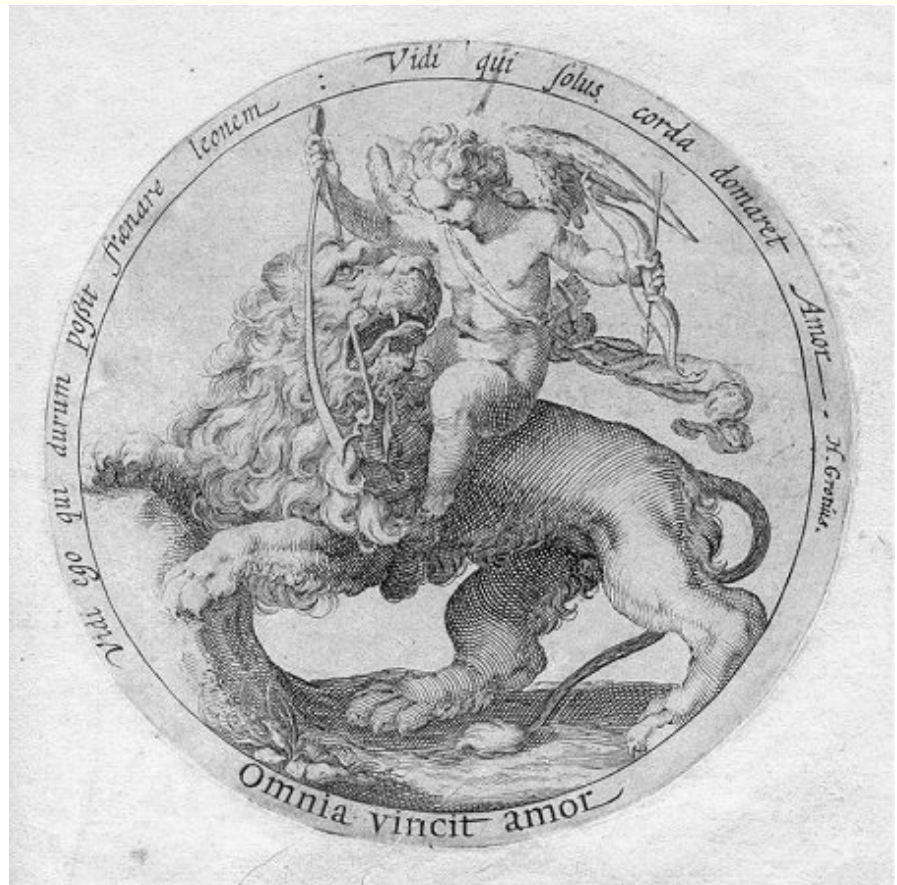

Figura 21: Omnia vincit Amor [O Amor vence tudo], emblema de Daniel Heinsius, de 1607.
Para compreender o porquê do anjo e da criança que se afoga, temos de conhecer a tradição emblemática holandesa, pois foi, exatamente, na Holanda onde floresceram os chamados emblemas amorosos, que se tornaram destaque na literatura nacional daquele país, quando seus emblemistas resgataram, da Antigüidade,

metáforas desgastadas e deram-lhe um novo viço. Nesse resgate, ressurge a figura do Cupido, quando Daniel Heinsius publica, em Amsterdã, seu Emblemata Amatoria, cujo primeiro emblema retrata o deus-menino sobre um leão (fig. 21), além de trazer um hemistíquio de Virgílio: Omnia vincit Amor.

A esse respeito, Angelus Silesius assim se expressa ao esboçar um paralelo entre o Cupido e o Menino Jesus:

Cupido, blindes Kind,

Pack dich hinweg geschwind

Mit deinen Narrenpfeilen! 


\section{Du sollst mein Herz \\ Mit deinem Scherz \\ Nunmehr nicht übereilen.}

(Angelus Silesius, Heilige Seelenlust oder geistliche Hirtenlieder, p. 97)

[Cupido, cega criança,/ Sai daqui, rápido/ com suas flechas bobas!/ O meu coração/ Com tua dor/ Não mais surpreenderás.]

Heinsius, desse modo, não só fez escola, como também dela mesma bebeu $^{146}$, pois vários outros emblemistas também tiveram como mote o Cupido, tamanha havia sido a aceitação da obra, afinal, fixara em forma pictórica conceitos que haviam sido o repertório da poesia lírica durante muito tempo (Praz, 1989, p. 114): é possível

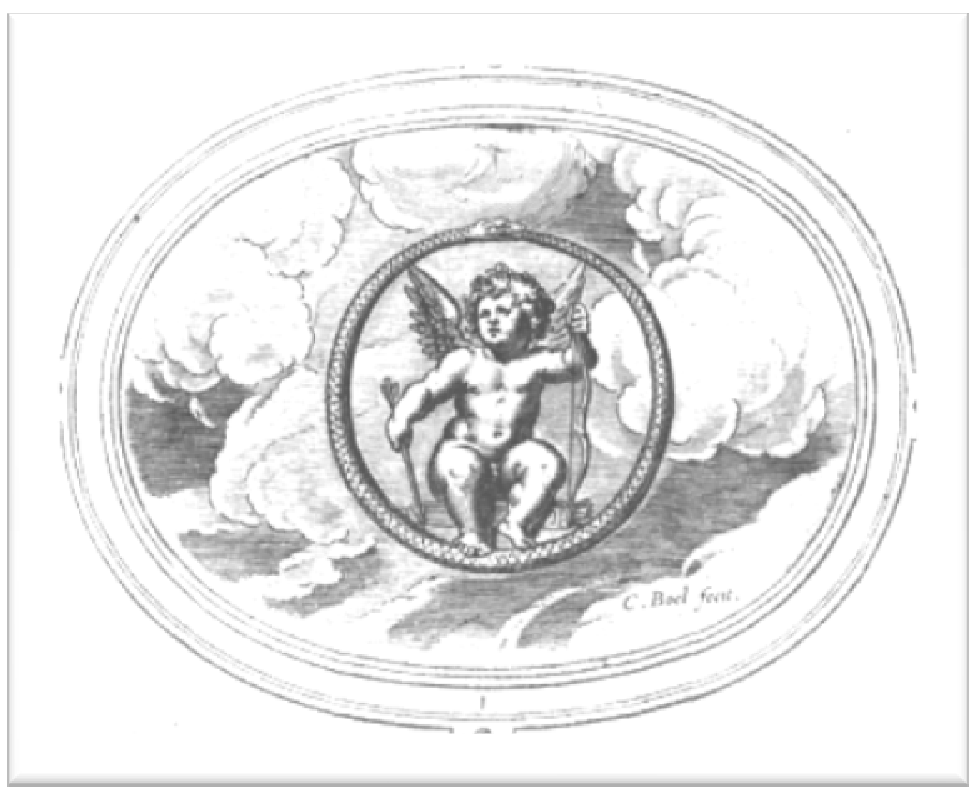

Figura 22: Amor Aeternus, de OttoVaenius, 1608. ler, em seus emblemas, sobretudo Petrarca e com ele toda a tradição dos poetas latinos, em especial Ovídio, cuja influência havia assegurado a transmissão dos conceitos clássicos do amor durante a Idade Média. (Cf.: ibidem, p. 114)

Temos na fig. 22, por exemplo, o primeiro emblema do livro Amorum emblemata de Otto Vaenius, um dos que seguiram os passos de Heinsius em busca do Amor profano, ou poderíamos dizer, do Amor pagão. Nele vemos o Cupido flutuando por entre nuvens e cercado por uma serpente que morde a própria cauda, cujo significado, visto anteriormente, é eternidade. Vaenius utiliza versos de Sêneca na subscriptio desse emblema:

\footnotetext{
${ }^{146}$ Vemos isso quando Hensius, em sua obra de 1613, utiliza o estilo de Vaenius: em vez dos medalhões redondos rodeados de inscrições, encontramos marcos ovalados sem inscrição alguma (Praz, ibidem, p. 115), conforme a figura 20.
} 


\section{AMOR AETERNVS \\ Nulla dies, tempúsue potest dissoluere amorem, \\ Néue est, perpetuus sit nisi, verus Amor, \\ Annulus hoc anguisque tibi curuatus in orbem, \\ Temporis æterni signa vetusta, notant.}

[Nenhum dia ou tempo pode acabar com o amor e o amor não é real se não eterno. A aliança de casamento e a serpente arqueam-se num círculo, tempo de eternidade, é um sinal disso para você.]

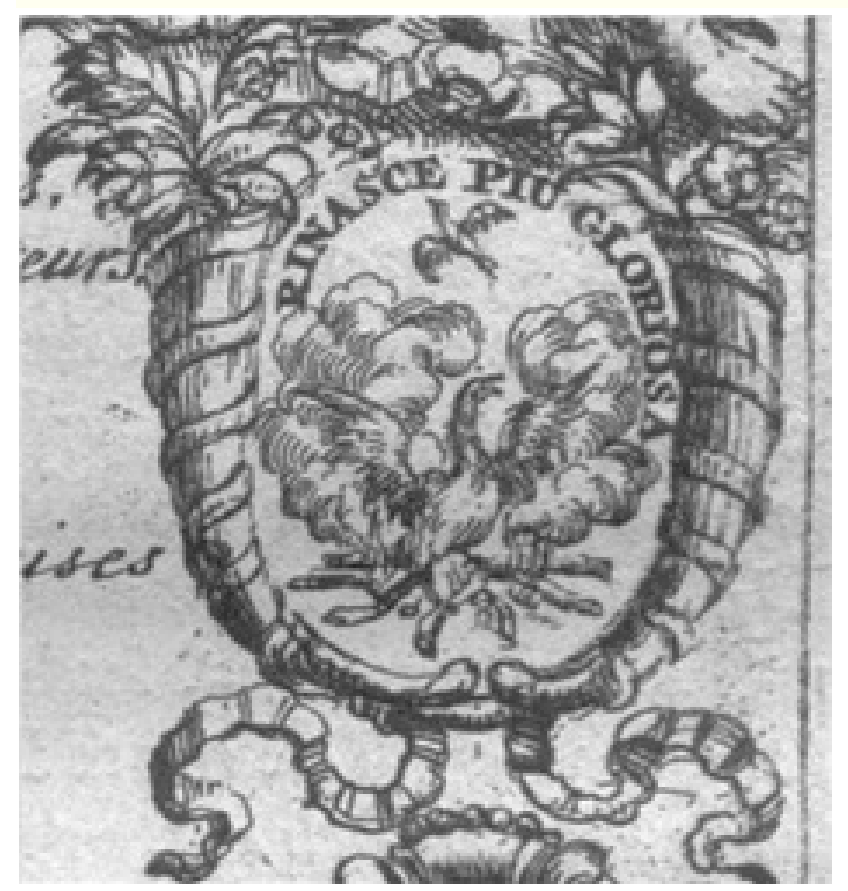

Figura 23: Rinasce piu gloriosa, de Daniel de la Feuille, 1691.
Greiffenberg, para nos falar da eternidade do amor, utiliza-se da imagem de Cristo associada à imagem da fênix:

\section{Auf dem Stroh die}

Ewig Liebe brennt und flammet liechter loh /

zündet solches doch

nicht an. Solten wir nit auch anheben /

\section{und als rechte}

Christen-Fönix / uns verbrennen Heilig froh?

(Greiffenberg, op. cit. p. 168)

[O Eterno Amor queima na palha e a chama arde mais luz/ mas nada se acende. Será que nós não devemos começar e como o reto Cristo-Fênix nos queimar felizes de santidade?]

Assim, o amor de Cristo é cotejado à figura mitológica da fênix por dois fatores indissociáveis: esta não só ressurge das cinzas, como também necessita do fogo para manter seu perpétuo continuum; Cristo não só ressuscitou em meio às cinzas da humanidade - cuja morte representou e perpassou -, como também o fez devido a seu amor por essa mesma 
humanidade; e, devido a sua mesma ressurreição, seu amor Rinasce più glorioso, inflamando o coração daqueles que acreditam nessa verdade de forma contínua e perene.

Esse Amor eterno e flamejante teria, portanto, como prenúncio - sua interpretação figural - a sarça ardente no deserto ( $E \times 2,2)$ : não há como fugir de seu calor que queima sem se consumir mesmo que sejamos palha, mesmo que não queiramos dar o primeiro passo como Moisés, daí o questionamento do eu lírico: Solten wir nit auch anheben/ und als rechte Christen-Fönix / uns verbrennen Heilig froh?

Além de Catharina Greiffenberg, essa imagem também pode ser encontrada em:

\section{Angelus Silesius:}

a) Entzünd mein Herz, o keusches Feur,

Mit deiner heilgen Brunst,

O Speise, komme mir zur Steur

Mit deiner Lieb und Gunst.

Zünd an, verbrenn, vermehr die Glut,

O Jesu, höchst gewünschtes Gut,

Daß ich, dein Phönix, sterb.

(Angelus Silesius. Heilige Seelen/ust oder geistliche

Hirtenlieder, p. 499)

[Inflama meu coração, ó fogo casto/ Com teu fervor sagrado/ Ó alimento, vem a mim/ Com teu amor e favor/ Com teu amor e favor/ Acende, queima, multiplica a brasa/ Ó Jesus, bem altamente desejado,/ Para que eu, teu fênix, morra.]

b) Ein Phönix soll man sein

Ich will ein Phönix sein und mich in Gott verbrennen,

Damit mich nur nichts mehr von ihme könne trennen.

(Angelus Silesius. Cherubinischer Wandersmann, p. 477)

[Deve-se ser uma fênix

Quero ser uma fênix e consumir-me em Deus/Para que nada mais d'Ele me possa separar] 


\section{Sigmund von Birken}

Christen wie der Phönix sterben,

Werden lebend in dem Grab.

Wer im Sternenhaus will erben,

Muß die Erde legen ab.

Wann die Sonne eilt der Ruh'

In den Wintertagen zu,

Sie läßt nach dem Untergehen

In der andern Welt sich sehen.

(Birken. Gedichte, p. 20)

[Cristãos como a fênix morrem/ Tornam-se vivas no túmulo./ Aquele que quiser herdar no lar das estrelas/ Deve abdicar da Terra./ Quando o sol em direção da paz/ Se dirigie nos dias de inverno,/ Ele, depois de se pôr,/ Mostra-se no outro mundo.]

\section{Friedrich von Logau}

Wo Phönix etwa wohnt, wohnt, glaub ich, auch das Glücke,

Von dem man nach dem Ohr und nichts weiß nach dem

[Blicke.

ledoch ich weiß den Ort, wo Glücke macht Bestand,

Den aber niemand kennt, biß dieser wird verbrant.

(Logau. Sinngedichte, p. 351)

[Ali, onde mora a fênix, creio que também mora a felicidade/ Da qual se sabe de ouvido, mas não pelo olhar./ mas eu conheço o lugar onde a felicidade é perene,/ Mas que ninguém conhece até que queime.]

\section{Daniel Caspar von Lohenstein}

Hier find die seele den tod und das leben/

Auffgang und untergang/ wiegen und grab.

Hier wird die glut ihr zur speise gegeben/

Und was sie nehret/ das zehret sie ab.

Gleichwie der Phönix von neuem auch lebet/

Wenn er sich zwischen die flammen begräbet.

(Lohenstein. Gedichte, p. 106) 
[Aqui a alma encontra a morte e a vida/ Ascensão e queda/ berço e túmulo./ Aqui a brasa lhe serve de alimento./ E o que alimenta, a consome./ Assim como a fênix renasce/ Quando entre chamas se enterra]

Apesar de sua relação com o fogo, a fênix deve ser vista por representar a eternidade da alma e a ressurreição de Cristo, pois ela mesma ergue-se das cinzas após três dias. Vale salientar que, muitas vezes na iconografia cristã, a fênix é representada, inclusive, pelo pelicano. Esta ave também é muito simbólica, pois cria-se que, quando não havia como alimentar suas crias, o pelicano arrancava com o próprio bico parte de seu peito para dar-Ihes seu sangue. Dessa forma, torna-se símbolo do sacrifício de Cristo assim como o do amor dos pais aos filhos. Angelus Silesius expressa dessa forma essa relação entre o sangue do pelicano e sua relação com o de Cristo:

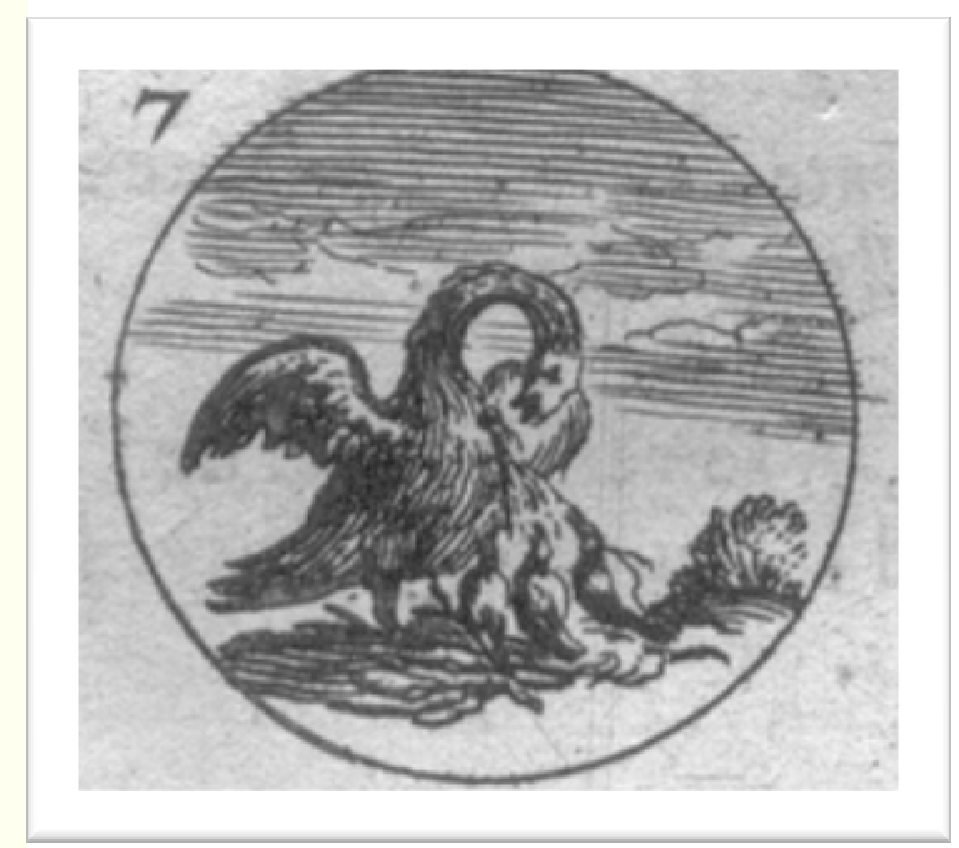

Figura 24 Un Pelican donnant à manger à ses perits, de Daniel de la Feulille, de 1691. 


\section{An den Sünder}

Wach auf, du toter Christ, schau, unser Pelikan

Sprengt dich mit seinem Blut und Herzenswasser an.

Empfängst du dieses recht mit aufgetanem Mund,

So bist du augenblicks lebendig und gesund.

(Angelus Silesius. Cherubinischer Wandersmann, p. 607)

[Ao pecador

Acorda, cristão, vê, nosso pelicano/ Te molha com seu sangue e água do coração./ Se a recebes de boca bem aberta,/ Tornas-te vivo e saudável]

A representação do elemento fogo não pertence à fênix, mas a outro animal: a salamandra. Ripa apresenta-nos o elemento fogo da seguinte maneira:

Mujer que con ambas manos sostiene una vasija que contiene fuego. $A$ un lado se pondrá una Salamandra, que aparece en medio de una hoguera, y al lado contrario un Fénix que también ha de estar ardiendo, sobre el cual se ha de ver un Sol resplandeciente. (Ripa, op. cit., pp. 304-305)

Dessa forma, não podemos ler "salamandra" como um mero anfíbio, mas a tradição simbólica nos faz vê-la como

ein Elementarwesen, das im Element Feuer wohnt, damit dieses nicht unbelebt und unbehütet sei. (...) Sie sind dem Volksglauben zufolge nicht Dämonen, sondern von Gott bestellte Hüter des Elements. (Biedermann, op. cit., p. 920)

[um ser elementar que reside no elemento fogo, para que este não fique inerte e desprotegido. (...) Segundo a crença popular, não são demônios, mas protetores dos elementos empossados por Deus]

Ou, segundo Horapolo, representava o homem não queimado pelo fogo (cf.: Horapolo, op. cit., pp. 253-255). Essa acepção faz com que o conceito recebesse contornos cristãos e morais como o amor à constância, quando a Patrística interpretou a constância com que a salamandra enfrenta o fogo com o exemplo dos mártires (Cf.: ibidem, p. 254) nos primórdios do cristianismo, ou 
ainda uma alusão ao livro de Daniel, que conta a história de três jovens lançados na fornalha por ordem do rei Nabucodonosor. (Dn 3, 21 e 94)

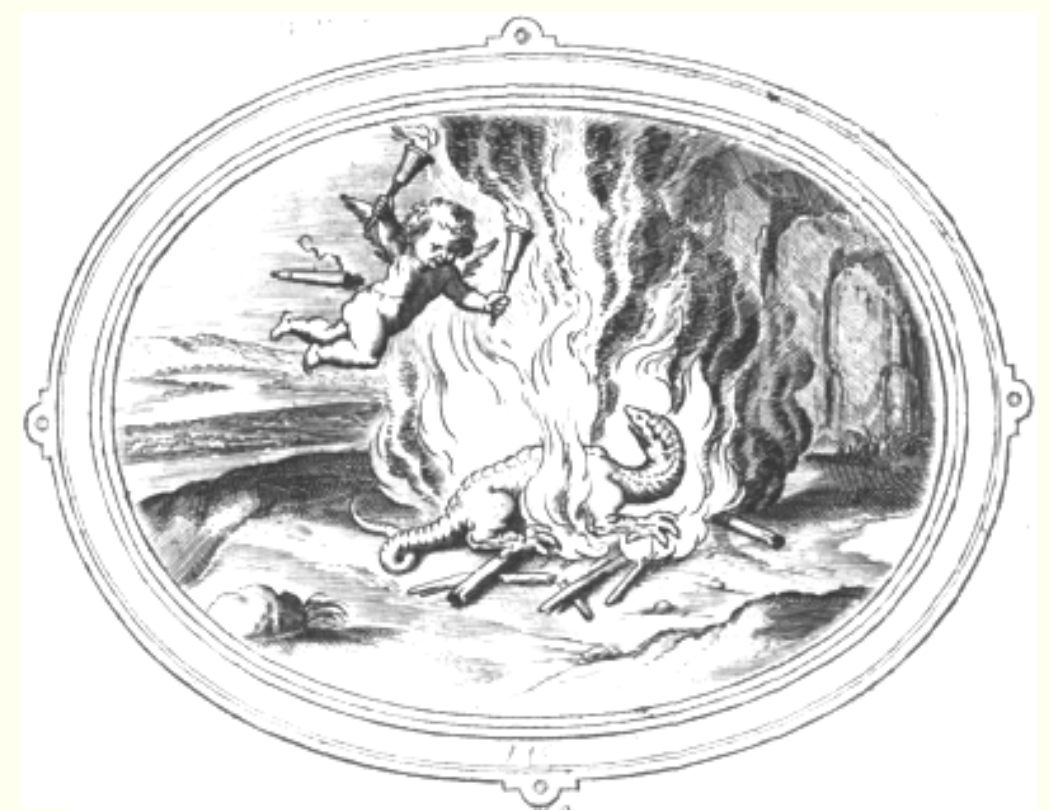

Figura 25, Mea vita per ignem, emblema de OttoVaenius, 1608.

A salamandra também foi empregada pelos poetas alemães do Seiscentismo, como podemos demonstrar:

\section{Angelus Silesius}

Im Wasser lebt der Fisch, die Pflanzen in der Erden,

Der Vogel in der Luft, die Sonn im Firmament,

Der Salamander muß im Feur erhalten werden,

Im Herzen Jesu ich als meinem Element.

(Angelus Silesius, op. cit., p. 847) .

[Na água vive o peixe, as plantas, na terra,/ O pássaro, no ar; o sol, no firmamento,/ A salamandra deve se manter no fogo,/ E no coração de Jesus, eu, como eu meu elemento.]

\section{Christian Hoffmann von Hoffmannswaldau}

a) Du zeigst mir unverstellt die reinen liebes-flammen/

Das feuer/ das durch dich auch mich zugleiche brennt.

Es reimt sich in der welt doch nichts so wohl zusammen/

Als wenn sich eine brunst der andern freundin nennt.

In dieser wollen wir als Salamander leben/ 
Die tugend trägt uns stets ihr reines öle zu:

(Hoffmannswaldau, op. cit., v. 1, p. 55)

[Mostra-me sem disfarce as puras chamas do amor/ $O$ fogo, que através de ti também me queimou/ Nada no mundo rima tanto quanto um incêndio se irmana a outro./ Neste, queremos viver como salamandra/ A virtude sempre nos traz seu óleo puro (...)]

b) Befrage selbst das heisse licht/

Das aus den hellen augen bricht/

Was feuer es in mir erwecket?

Es schmeltzt der seelen hartes eiß/

Und machet Salamander heiß/

Und ich soll seyn unangestecket?

(ibidem, p. 156)

[Perguntas, tu mesmo, à luz quente/ Que brota dos olhos claros/ Que fogo desperta em mim?/ Derrrete o duro gelo das almas/ E esquenta salamandras/ e eu deixaria de me contaminar?]

\section{Benjamin Neukirch}

Was aber bringen uns die thränen endlich ein?

Ein Christ muß in der glut wie Salamander seyn/

Und wie ein palmen-baum auch in der kälte grünen.

Nach sonne folget blitz/ nach regen sonnenschein;

So strahlt des himmels gunst auch wieder nach der pein/

Und läst die thränen offt uns zum ergetzen dienen.

(Neukirch, op. cit., p. 128)

[Mas, enfim, o que nos trazem as lágrimas?/ O cristão na chama deve ser como a salamandra/ e como a palmeira verdejante no frio./ Ao sol segue-se o raio/ após a chuva, o sol/ Assim também a benevolência celeste se mostra após a dor.]

Ao depararmo-nos com a fig. 25, podemos nos surpreender e questionar o aspecto angelical do Cupido, pois temos a impressão de que o mesmo está ateando fogo a um animal: vemos nas mãos do pequeno deus alado duas tochas e, sob o mesmo uma salamandra (mais parece a imagem de um 
dragão!) inserida dentro de labaredas. Tal imagem pode parecer-nos absurda, afinal nos é difícil dissociar a imagem do Amor da que temos pertencente à iconologia cristã, quando anjos crianças têm um aspecto angelical e bom - à semelhança do que vemos na fig. 20 - , o que pode surpreender aqueles que vêem essas imagens pela primeira vez. Como pode um anjo agir dessa maneira? Mais uma vez, verificamos que, para analisarmos essas imagens e os textos poéticos do período, temos de adentrar, necessariamente, em seu campo iconológico, caso contrário, devido ao ruído, a mensagem não será decodificada. Dessa forma, antes de prosseguirmos nossa análise imagética do Amor pagão, queremos exemplificar possíveis ruídos, para isso vamos contrapor fotos ${ }^{147}$ de um lado e emblemas de outro para que, en passant ${ }^{148}$, possamos verificar como nossa realidade interfere na recepção imagética do XVII:

a)

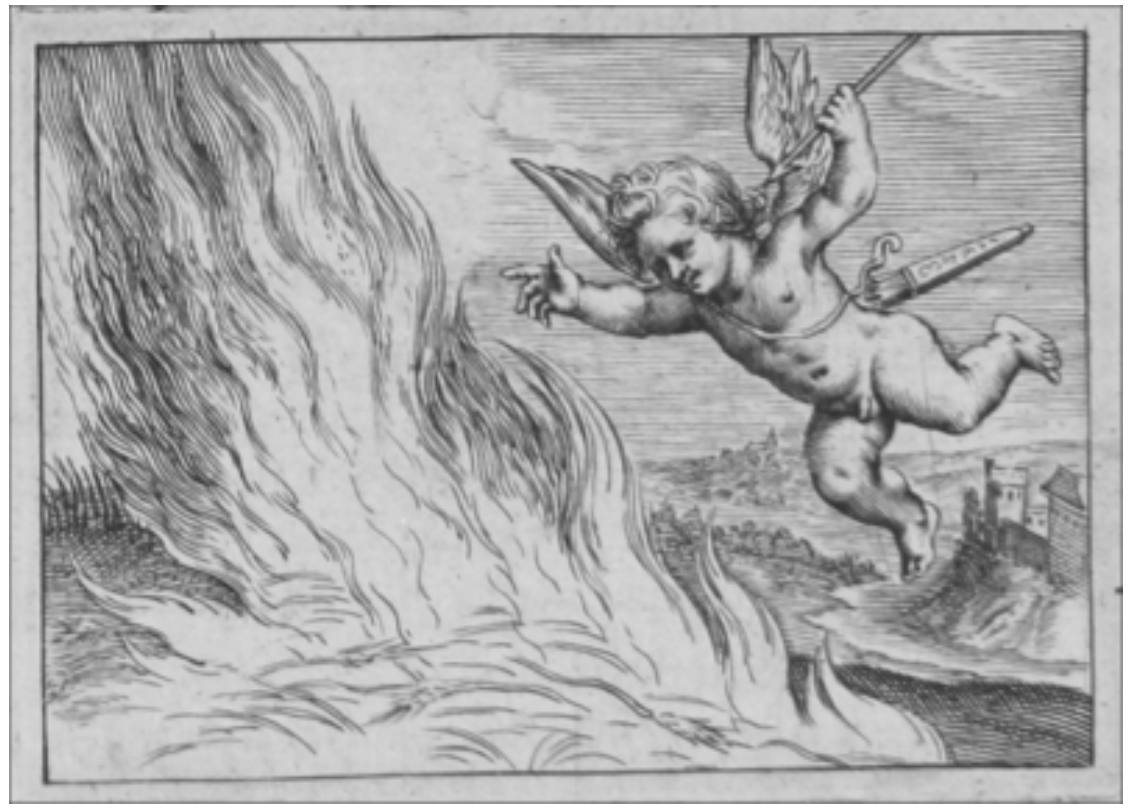

Figura 26: Quod cito fit, cito perit $^{149}$, de Otto Vaenius, de 1618

\footnotetext{
${ }^{147}$ Como vemos o mundo hoje, nosso paradigma imagético

148 Digo de passagem, pois essa será uma análise ulterior dentro da tese.

${ }^{149} \mathrm{O}$ que chega rapidamente, morre rapidamente.
} 


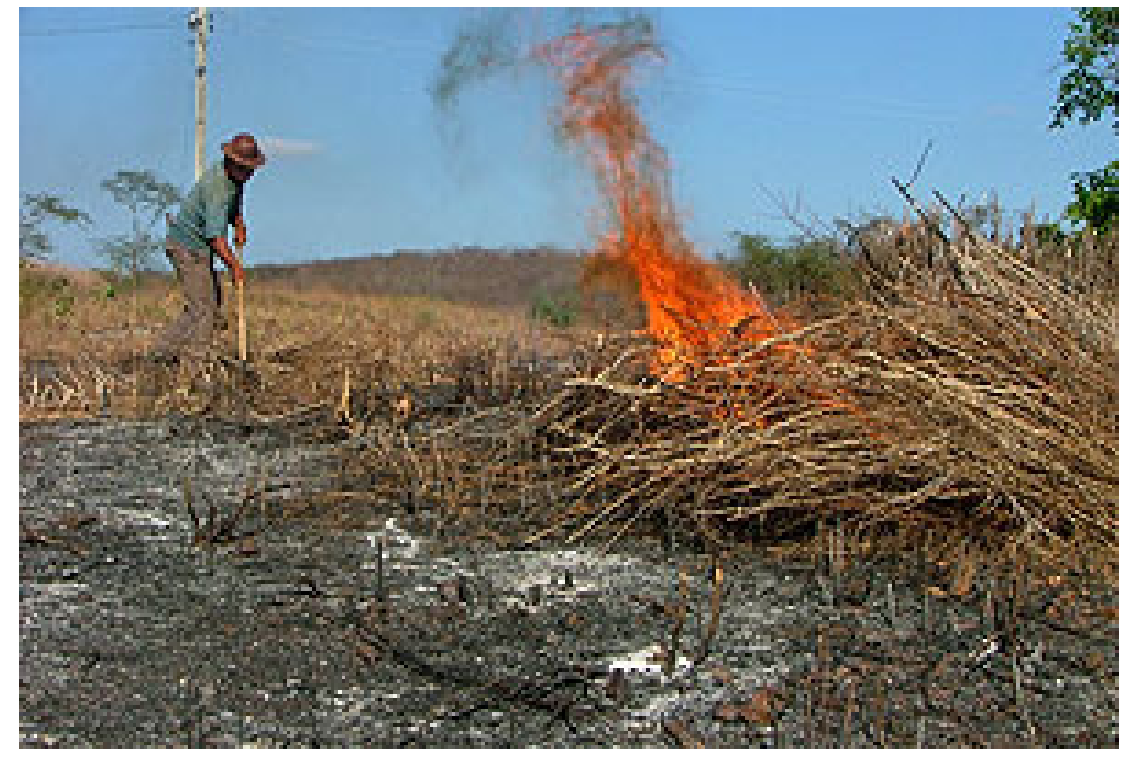

Foto 3: Queimada, de Marcos Cirano, s/d

Hoje, certamente, veríamos com restrições o emblema de Vaenius (fig. 26), pois seria até possível - dentro de uma linha especulativa - relacioná-lo a uma defesa das queimadas, afinal vemos um anjo ateando fogo no capim seco (mesmo não estando com tochas nas mãos, não evidencia tristeza, ou pesar, mas um prazer quase mórbido com a cena); ou seja, pode-se levar a crer numa pseudo-aceitação da divindade - representada pelo anjo - nesse ato. Isso, no entanto, demonstraria o que chamamos de politicamente incorreto, algo parecido com o exposto na foto 3 , quando um homem executa essa atividade, infelizmente, banal no interior brasileiro, quando se ateia fogo para preparar o solo após a colheita, para uma nova semeadura ou ainda preparar pasto para o gado. Nossa consciência atual de sobrevivência - deixou de ser uma mera preocupação ecológica - não admite mais esse ato, muito menos o exposto por um ser não humano como o representado na fig. 26. Há, é evidente, a legenda que nos diz Quod cito fit, cito perit, no entanto a grande maioria das pessoas não lê mais latim, logo seu efeito é-nos inócuo.

Seria factível uma analogia entre as duas imagens como a descrita acima? Evidentemente não. Vemos duas realidades dessemelhantes não só temporal quanto culturalmente: essa consciência ecológica, só para atermo-nos a um aspecto hodierno abordado (o da foto), é algo muito recente na sociedade humana - sempre acreditamos que poderíamos sujeitar e dominar a terra, só 
nos esquecemos de um mero detalhe: tudo acaba, inclusive o planeta em que estamos inseridos; Vaenius, por exemplo, nunca poderia ter proposto algo que fosse a favor ou contra o que chamamos de queimada, sua preocupação era mostrar a fugacidade da paixão, louca e repentina: Quod cito fit, cito perit. Assim como a paixão humana vem como um fogo abrasador, queimando o coração do homem; assim, ele vai embora, como o fogo na palha, daí a utilização do Cupido para essa representação. Ripa, por sua vez, ao descrever o Amor, cita-nos Sêneca:

Tiene en los hombros alas/y armadas las manos con arco y con saetas,/ y en un haz, bien sujetas/ lleva las llamas que por el universo/ va luego esparciendo, hasta el punto de que con su ardor/ todo corazón enciende./ Y siendo en muy poco diferente del humano uso, de Vulcano y de Venus ha nacido/ ostentando en el Cielo el más sublime estado./ Amor es vicio de la mente insana:/ cuando se mueve de su esfera propia/ incendia el ánimo, y nace en sus verdes años/ a edad en la que mucho puede, aunque ve poco./ El ocio lo alimenta, y la lascivia humana,/ mientras se mantiene lejana/ la mala suerte con sus graves daños/ desplegando sus tristes alas, y mientras la buena y feliz (fortuna) está presente/ trayendo consigo cuanto tiene en su rico seno./ Mas si ésta viene a menos/ cuando el ciego deseo al mal consiente, / el fuego que antes ardía enteramente se extingue,/ perdiendo pronto amor toda su fuerza. (Sêneca, apud Ripa, op. cit,p. 94)

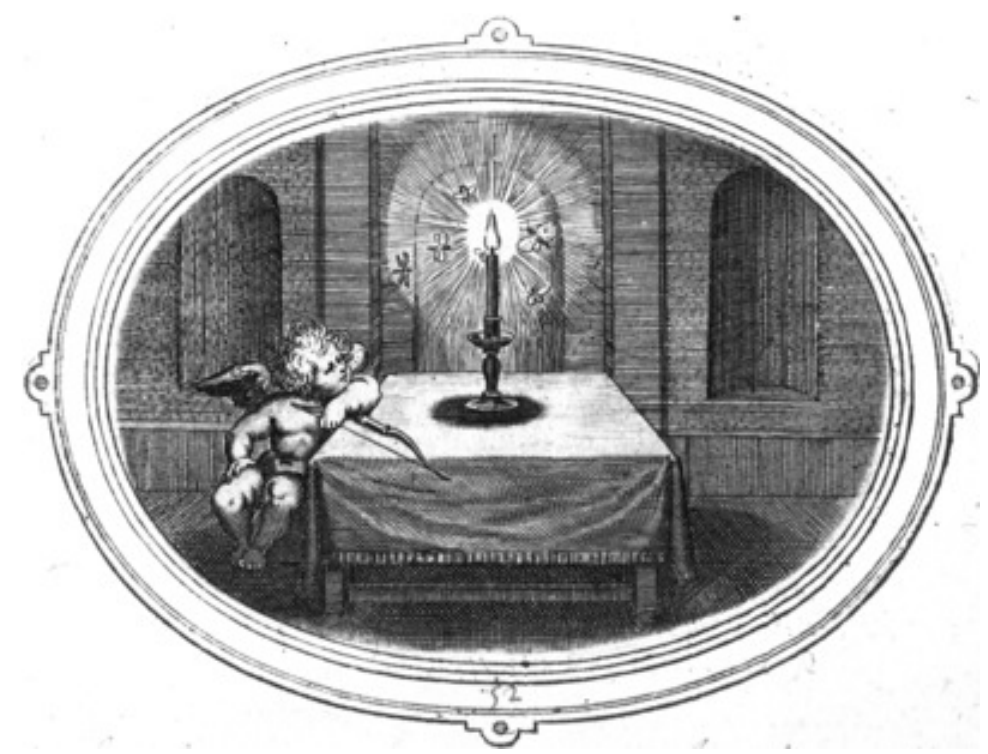

Figura 27: Emblema 52, Breve \& damnosa voluptas, de Otto Vaenius, 1608
El fuego que antes ardía enteramente se extingue, perdiendo pronto amor toda su fuerza: essa é a acepção do emblema de Vaenius, ou seja, o fogo sequer é fogo, mas o desejo espalhado pelo universo cujo calor incendeia 0 coração dos homens. Dessa forma vemos uma

relação estabelecida entre o fogo que consome rapidamente a palha com a 
própria brevidade da felicidade, fato muito explorado nos Seiscentos de várias maneiras como na relação estabelecida entre a vela e os mosquitos que, inebriados pela luz, morrem pela atração fatal desta ${ }^{150}$. Vaenius nos mostra essa relação prazer/dor, em seu emblema 52 (na fig. 27), sob o olhar atento do Amor e cuja subscriptio diz:

\section{BREVIS ET DAMNOSA VOLVPTAS.}

Lumina delectant culices, perimuntaque petita;

Sic nobis spes est optima caussa mali.

Qui circumuolitat deceptus Amoris ad ignis,

Numquid naturam papilionis habet?

[Pernilongos amam a luz, mas morrem quando dela se aproximam. Do mesmo modo nossa maior esperança é a causa de nossa desgraça. Quem decide voar para o fogo do amor,ele não se assemelhará a uma mariposa?]

b)

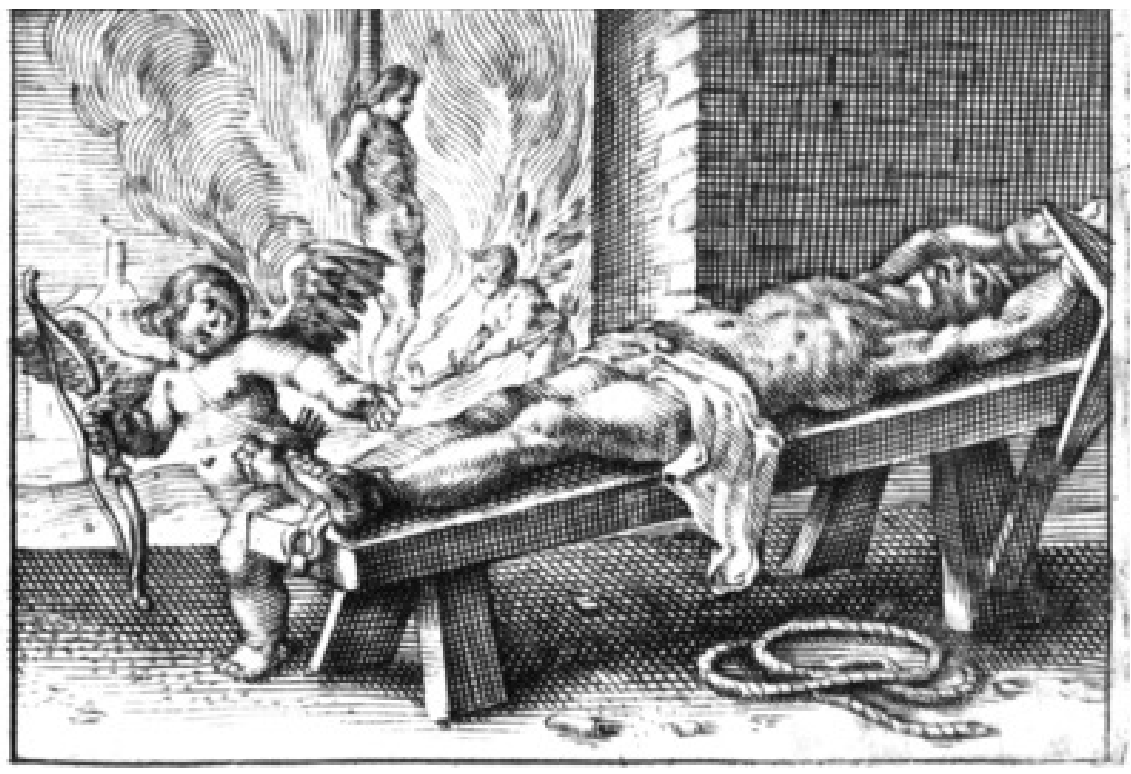

Figura 28: Emblema 10, In poeanam vivo, de Daniël Heinsius, de 1616.

\footnotetext{
150 Vale salientar que esse conceito/imagem será empregado por muitos outros momentos literários, não sendo, portanto exclusivo do período ora abordado.
} 


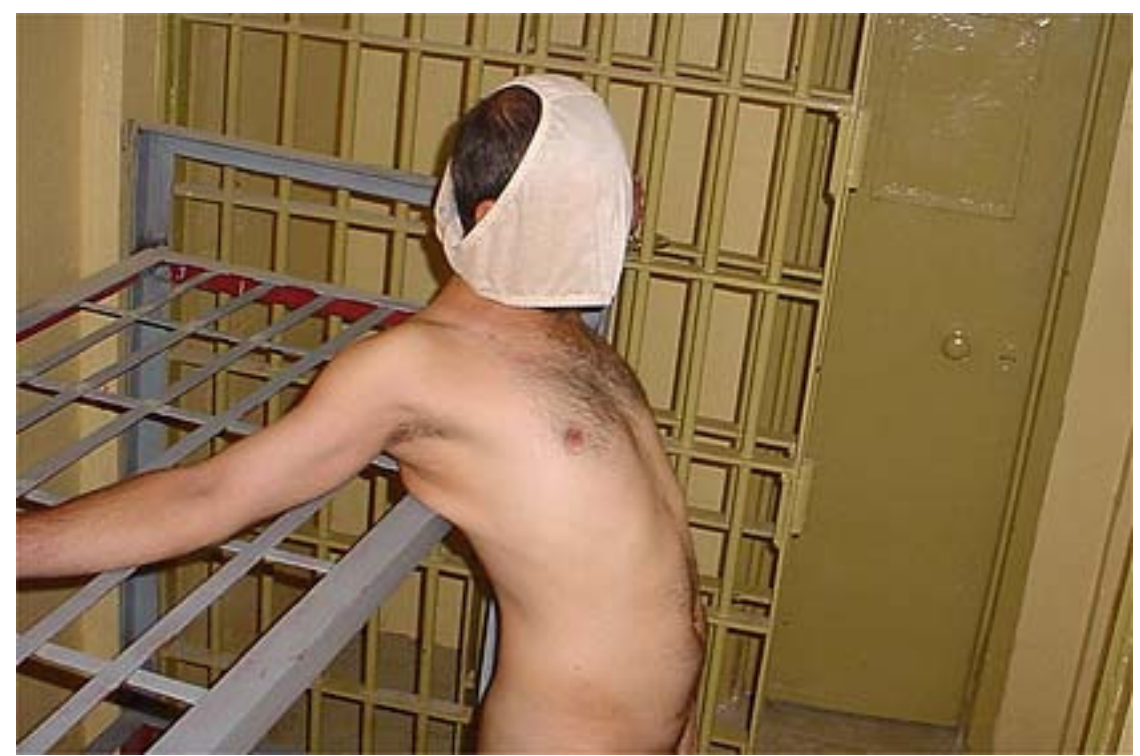

Foto 4: Tortura em Abu Ghraib, s/a/d

Mais chocante seria o outro emblema (fig. 28), quando não só vemos um homem sendo torturado, como também um outro sendo queimado vivo, e o pior é que, em ambos os casos, os torturadores são anjos (Cupidos). Não pude deixar de rememorar, a partir desse emblema, as torturas sofridas pelos prisioneiros iraquianos na prisão de Abu Ghraib, quando os anjos libertadores estadunidenses livrariam o país do demônio Saddam e torturaram, de forma vil (como se houvesse outra forma de tortura), prisioneiros de guerra como o da foto 4. Logicamente, isso não passa de uma mera associação, para encontrarmos aqui um ponto em comum: o emprego metafórico da palavra anjo. Nem os estadunidenses são os auto-propagados anjos da justiça nem os anjos torturadores são anjos na acepção cristã. No caso do emblema de Heinsius temos, na verdade, uma auto imputação da tortura, visto que o amor nos tortura na medida em que nos tornamos seus prisioneiros, quando nos apaixonamos, daí os Cupidos serem os torturadores, afinal são eles que nos flecham com as setas do amor. Muito diferente da foto, pois nessa vemos não uma auto imputação - como se fosse possível escolher quando e como ser flechado -, pelo contrário, a partir de dados concretos da cultura dos subjugados (mundo islâmico), imputam-se torturas de ordem sexual e moral. A tortura poderia não ser real: não há sangue, nem equimoses, mas vê-se um tormento de ordem ética, busca-se a humilhação, a subjugação dos que já estão subjugados. 
Hoffmannswaldau, em seu Er ist unglückselig [Ele é um desgraçado], cita inclusive a tortura em um poema, não a decorrente do amor, mas a da alma atormentada pelo sentimento de nulidade diante da vida e de sua efêmera condição:

Die schmertzen sind mein tranck/ das unglück meine kost.

Ich muß auff folter-bäncken sitzen/

Und auff den schweren stab des jammers mich nur stützen.

(Hoffmannswaldau, Gedichte aus Neukirchs Anthologie, p. 149)

[As dores são minha bebida, a infelicidade minha comida. Preciso me sentar na cadeira de tortura e somente no pesado bastão do pranto me escorar.]

O mesmo sentimento que, provavelmente, os que são torturados sentem diante da dor, da nulidade diante de sua total impotência diante de sua fraqueza:

Ich unglückseliger! warum bin ich gebohren?

(...)

Mein leib ist ein spital/ darinn der geist muß krancken;

Ich bin ein ebenbild der bleichen traurigkeit

(...) (ibidem)

[Desgraçado eu! Por que nasci? (...) Meu corpo é um hospital, em que o espírito precisa adoecer; Eu sou um retrato da pálida tristeza (...)]

Em 1615, Vaenius publica Amoris Divini Emblemata e põe freio nas diabruras do Cupido, que passa não mais a representar o deus grego e sua relação com os homens, ora benfazendo-os ora torturando-os, mas assume 0 papel do Amor Divino, ou seja, o deus pagão é retirado da cena: o cristianismo entrava no palco novamente. Tal acontecimento não era novo, já o havíamos visto desde a Patrística, quando sob os escombros do paganismo os Padres da Igreja alicerçaram as bases da nova religião: 


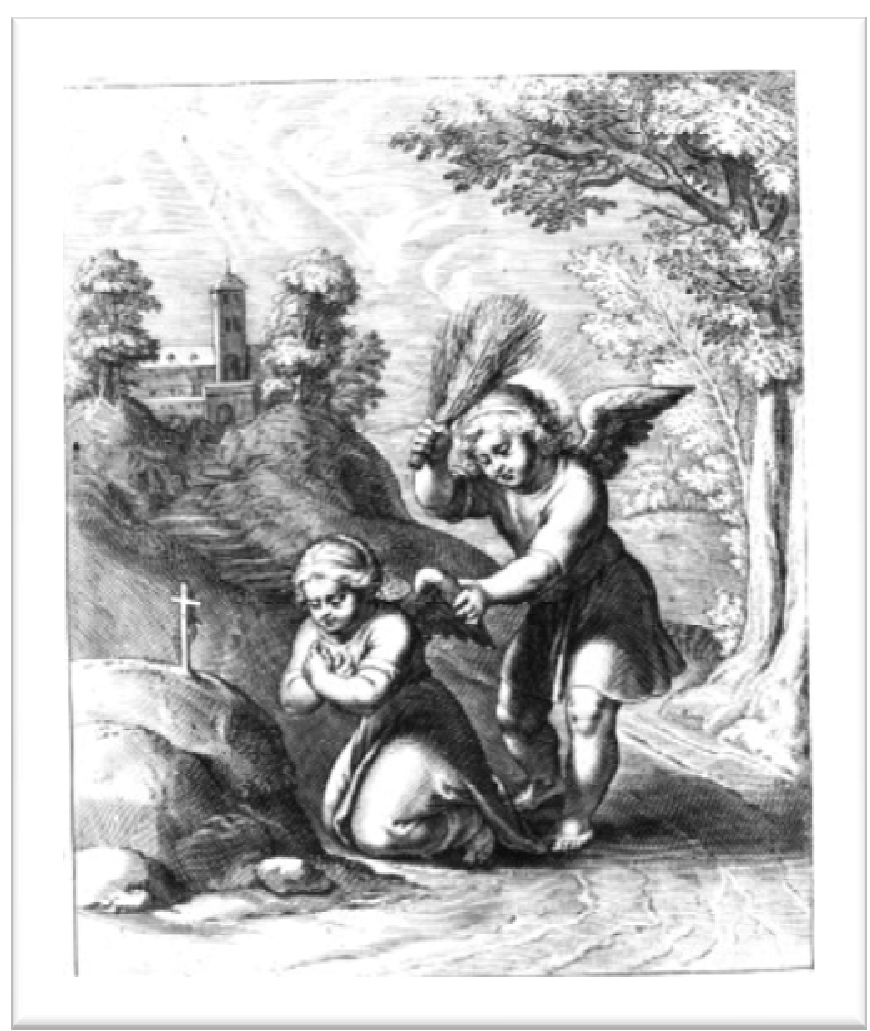

Figura 29: Emblema 28, Amoris flagellum dulce, de Otto Vaenius, de 1615.

Quanto mais educados no sentido antigo, quanto mais aprofundados na cultura antiga estivessem os escritores cristãos dos tempos patrísticos, tanto mais eles deviam sentir a necessidade de verter 0 conteúdo do Cristianismo numa forma que não fosse só mera tradução, mas adaptação às suas próprias tradições conceituais e expressivas. (Auerbach, op. cit., p. 63)

Poder-se-á dizer que o mesmo aconteceu com os emblemas de Vaenius, ou utilizando as palavras de Praz: Ovidio há sido sucedido por San Agustín. (Praz, 1989, p. 151). Vemos, por exemplo, na fig. 29, o Amor divino - representado pelo anjo em pé e vestido que leva em uma das mãos um ramo que servirá de açoite - e um outro anjo que, na realidade, representará a alma humana. Vemos, agora, que o tormento, a pena, o castigo são representados como Amoris flagellum dulce ${ }^{151}$ : o amor divino mostra-nos que o sofrimento pode ser doce, aprazível, que é possível sofrer sem dor, visão bem diferente da que havíamos visto, anteriormente, em relação ao Amor pagão. Na subscriptio desse emblema vemos a alusão à correção dada pelos pais a seus filhos:

A vezes importa al hijo

Mas el azote del padre,

Que el regaço de la madre.

${ }^{151} \mathrm{O}$ chicote do amor é doce. 


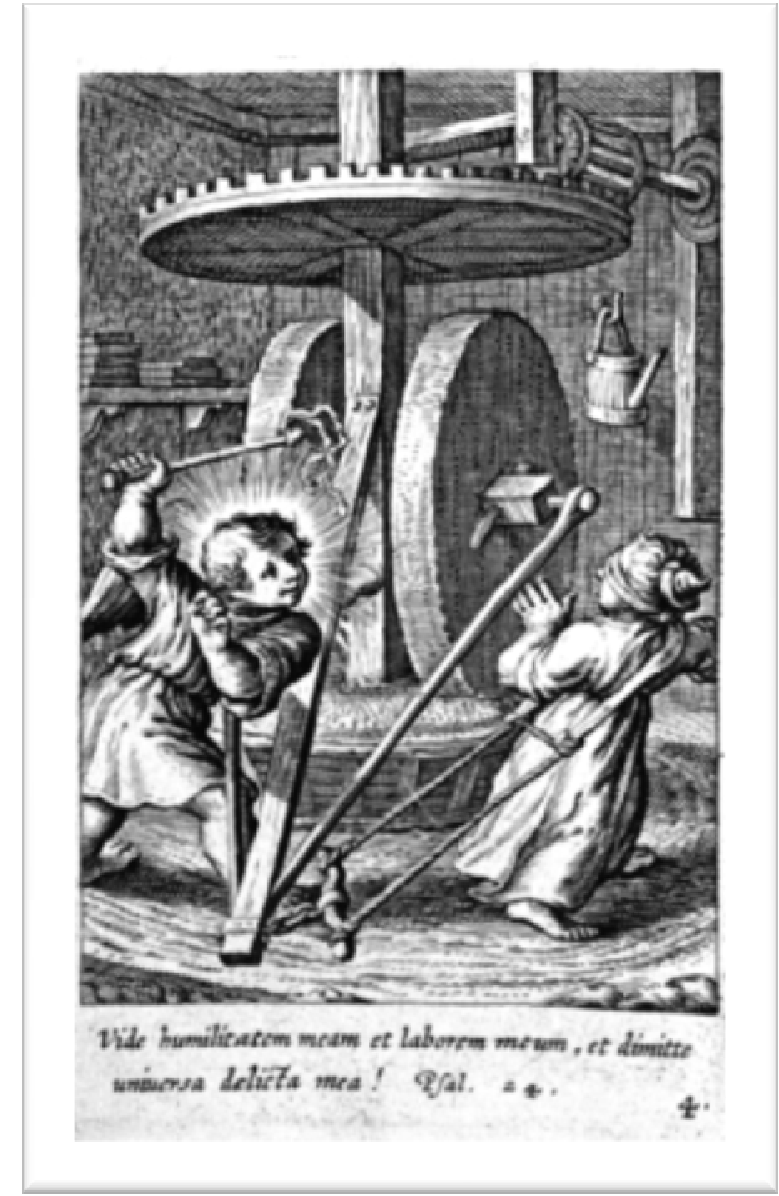

Figura 30: Emblema 4 Vide humilitatem meam, de Justus de Harduwijn , 1629.

meam $^{152}$.

Silesius assim se expressa:
Justus de Harduwijn em seu Goddelycke wenschen (1629), mostra-nos a punição dada à alma pecadora em seu emblema 4 que também não é vista como tormento, mas como forma de se perdoar os pecados (fig. 30), cujo mote está no salmo 25:

Olha minha fadiga e miséria, e perdoa meus pecados todos. (SI, 25, 18)

Dessa forma, o emblema não deve ser visto como representação de uma mera punição, mas como uma troca: por meio da resignação da alma, esta purga seus pecados, daí seu mote: Vide humilitatem

\section{Mittel zur Heiligkeit}

Dein Geist sei aufgespannt, dein Herze leer und rein,

Demütig deine Seel, so wirst du heilig sein.

(Angelus Silesius, Cherubinischer Wandersmann, p. 701)

[Meio para a santidade

Teu espírito esteja aberto, teu coração vazio e limpo, Tua alma, humilde, então serás santo]

Simon Dach não só fala em demütig (humilde) como também em ergiebet (resigna-se) diante do sofrimento:

152 Veja minha humilhação. 


\begin{abstract}
Dieß alles thust du auch bey mir,
Was bin ich wieder schuldig dir?

Ein Hertz was dich nur liebet,

Und dir allein

In Lieb und Pein
\end{abstract}

Demütig sich ergiebet.

(Dach, Geistliche Lieder. Trostgedichte. S. 462

[Isso tudo também o fazes comigo/ O que te devo, novamente?/ Um coração que apenas te ama/ e a ti apenas/Em amor e sofrimento/ humilde se entrega.]

Portanto, ao retornarmos à fig. 20, poderemos observar que o anjo representado no emblema XI de Jan Suderman ${ }^{153}$ não é um mensageiro divino, um guardião individual ou ainda uma criatura celestial, mas, na realidade, o próprio Amor Divino que estende suas mãos em auxílio de uma criança. Essas mesmas mãos não se dirigem apenas a uma criança isolada em meio a um naufrágio e com risco iminente de afogamento, mas a toda alma humana que, desprotegida, se assemelha à criança que tem de ser levada pelo braço. Esta não está cercada pelas águas do mar, mas pela vida em tribulação, e por isso não há outras pessoas: só ela, pois o destino de sua vida the pertence, ou melhor, pertence a Deus que Ihe concede o livre-arbítrio para buscá-lo e abrirIhe as mãos para que possa aceitar seu pedido de perdão. Daí as mãos abertas e espalmadas em direção ao Amor Divino que a aceita e a acolhe como a criança que corre de encontro ao pai após o dia inteiro ter permanecido no jardim da infância.

${ }_{153}$ Que possui, exatamente, a mesma forma do emblema XI de Hermannus Hugo, de 1624; do XI de Justus de Harduwijn, de 1629; demonstrando também que a relação que tinham de plágio era bem diversa da que temos hoje, como já havíamos dito anteriormente. 
Freqüentemente utilizadas nas literaturas do Renascimento e do Barroco, as metáforas náuticas são uma tradição que remonta à Antigüidade clássica, perpassa a patrística e as alegorias bíblicas medievais e mantém-se por um longo tempo (Cf.: Curtius, 1996, p. 178), inclusive transcorrendo o período barroco, como nos poemas românticos, mormente aqueles cuja conotação é religiosa como alguns poemas de Achim von Arnim e mesmo seu cunhado, Clemens Brentano.

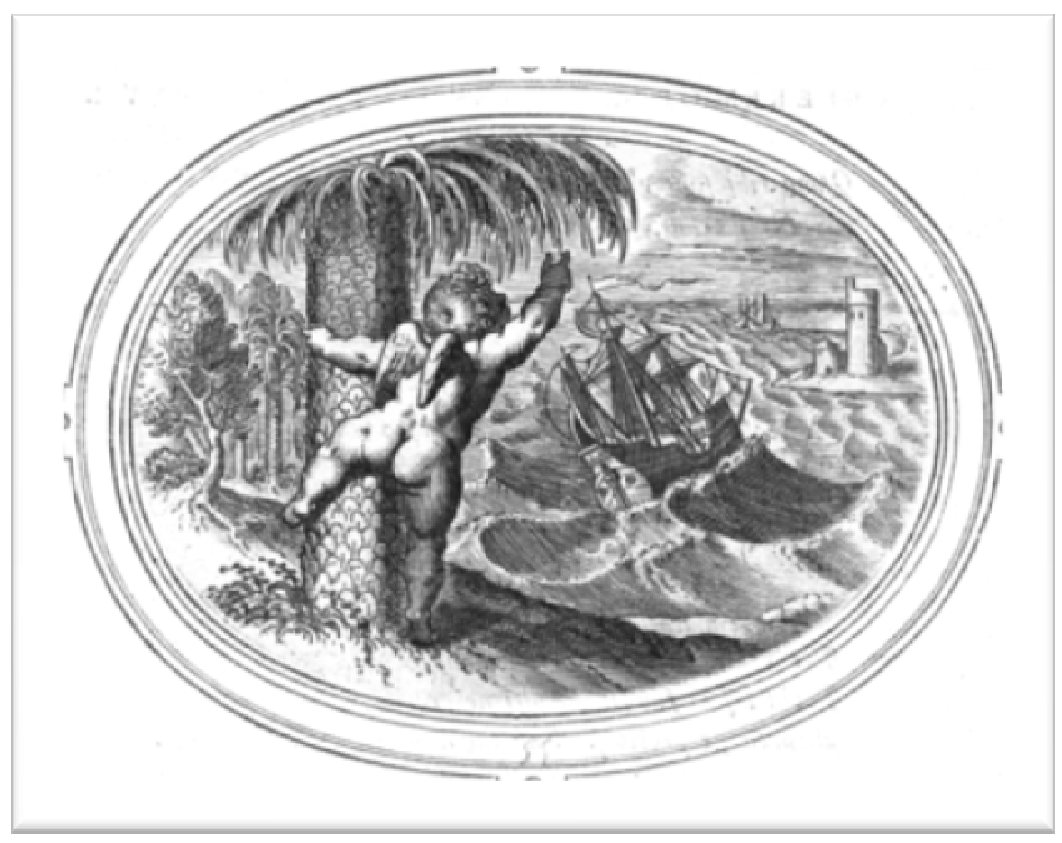

Figura 31: Emblema 55, Finis coronat opus de Otto Vaenius, 1608. 
A tradição emblemática foi inundada pela imagem do navio sendo castigado pelos ventos e pelo mar tormentoso em sua busca por segurança em

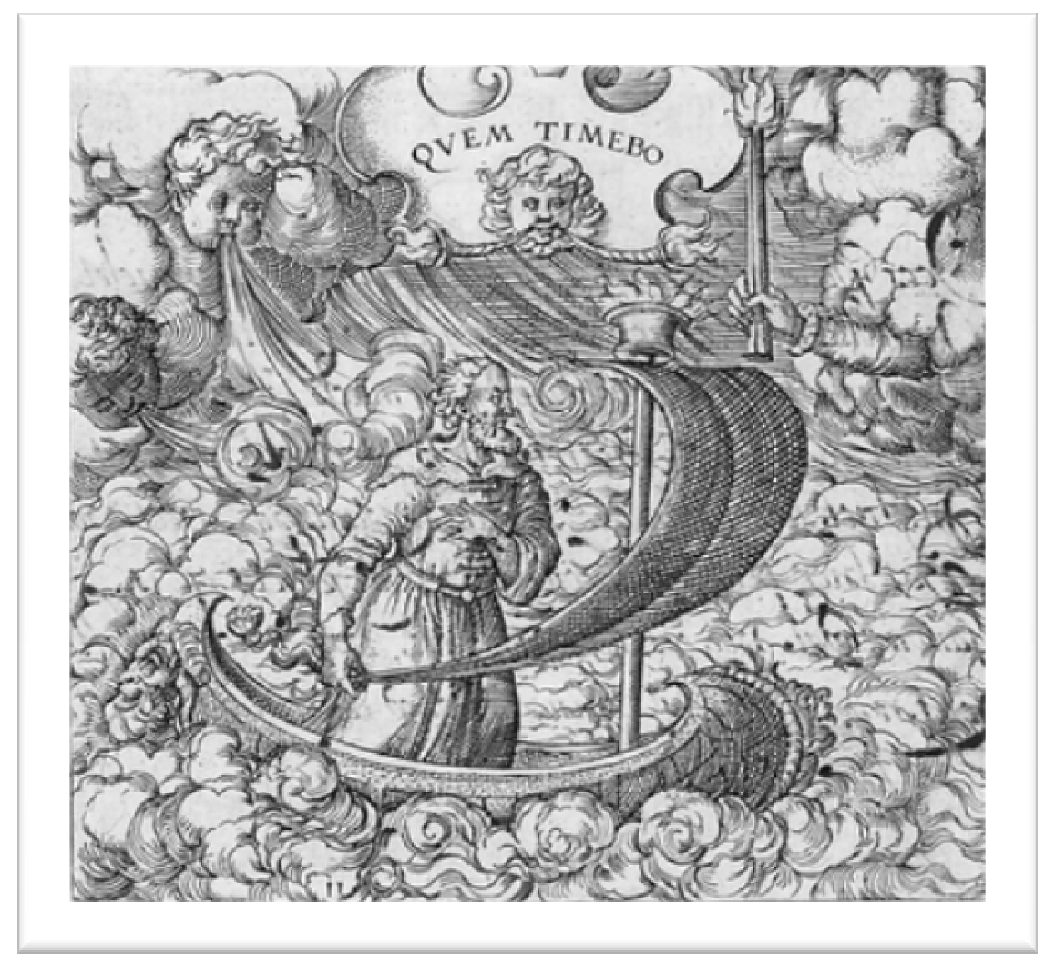

Figura 32, Emblema 11, Quem timebo?, de Georgette de Montenay, 1615.

meio à agitação do mar de borrasca; o navio no mar em meio a tempestades e obstáculos e que não consegue alcançar o porto a que se dirige ou a outro próximo, pode se considerar perdido, afinal seu destino seria, pelo menos, o de sua segurança. A nau pode nos mostrar a vida do homem no mundo, cercada por sofrimentos e preocupações por todos os lados - como o navio está pelas águas do mar - e cujo fim é o Porto, o encontro com a morte, quando prestará contas daquilo que fez ao Criador: Finis coronat opus (fig. 31). É o momento em que nossos atos em vida coroarão ou não nossa existência. Apesar de Vaenius nos falar do Amor, o mesmo pode se referir à existência humana, visto que esse conceito/imagem será largamente empregado não só na emblemática, como na poética do período. Podemos ver isso na subscriptio de seu emblema 55:

Ni ratis optatum varijs iactata procellis/Obtineat portum, tum perijße puta

[Se um navio é dirigido ao redor de todos os tipos de tormentas e não se aproxima ao porto que é sua esperança, pode-se considerá-lo perdido]. 
Alciato, em seu emblema 43, mostra-nos a mesma imagem, referindo-se ao Estado:

\section{Spes próxima}

Innumeris agitur Respublica nostra procellis,

Et spes venturae sola salutis adest:

Non secus ac navis medio circum aequore, venti

Quam rapiunt, salsis iamque fatiscit aquis.

Quod si Helenae adveniant, lucentia sidera, fratres:

Amissos animos spes bona restituit.

[Our state is shaken by innumerable storms, and there is only one hope for its future safety; just like a ship in the middle of the sea which the winds grasp, it now breaks up in the briny water. But if the brothers of Helen, shining stars, appear, good hope restores those downcast spirits.]

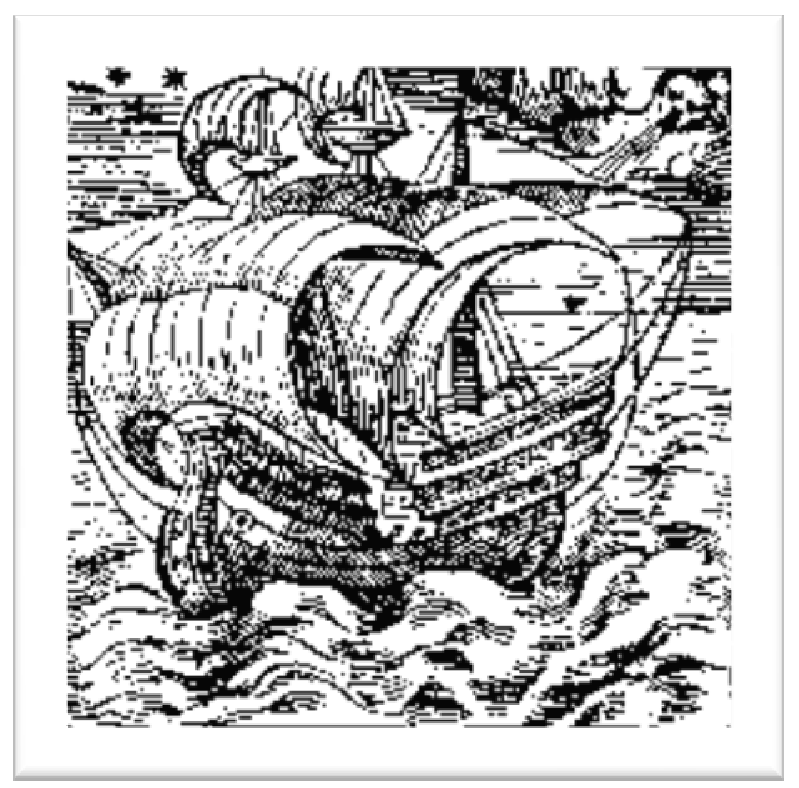

A confiança ${ }^{154}$ em Deus deverá ser plena, devemos nos abandonar à Divina Providência para que, por seu intermédio, possamos chegar ao Porto de

\footnotetext{
${ }^{154}$ Ripa demonstra a confiança como uma mujer (...) que sostiene com ambas manos uma nave. (...) Se pinta con la nave entre las manos por ser signo de confianza, pues con los navíos arriesgan los navegantes atravesar las ondas del mar, las cuales, con sólo su perpetuo movimiento, parece que amenazan con arruinar y dar muerte y exterminio al hombre que, abandonado la tierra, sale fuera de sus límites naturales.(Ripa, op. cit.v. I, p. 212)
} 
nossa vida, para isso devemos nos deixar guiar pelas mãos divinas, representada por uma mão nos céus que segura uma tocha à semelhança de um farol que guia para o local mais seguro. Vemos isso, no gênero emblemático, claramente explicitado pela francesa Georgette de Montenay, uma das únicas mulheres a dedicar-se ao gênero e, além disso, de confissão protestante, em seu emblema 11 (fig. 30), cujo título é Quem timebo? [A quem temerei? SI 27,1] Vemos um homem (independe de quem seja) em uma barca que é açoitada por ventos e em meio a uma grande tempestade, mas que demonstra sua confiança e fé em Deus, conforme nos demonstra sua mão esquerda em seu peito. (Ripa, op. cit., p. 403)

Há na poética do Barroco alemão inúmeros exemplos do emprego do conceito/imagem Schiff [navio] como curso da vida em alto mar em meio a perigos e atribulações que devem ser vencidas para que se possa chegar com segurança ao Port [porto], seu destino final.

Schiff (navio)

\section{Hoffmann von Hoffmannswaldau}

Ich bin ein schiff der liebes-see/

Das wind und wetter plaget/

Dem unglück/ hoffnung/ furcht und weh/

Durch mast und segel jaget.

Hier zeiget sich

Kein port für mich/

Dieweil ich itzt muß meiden

(Hoffmannswaldau, Gedichte aus Neukirchs Anthologie, Bd. 1, p. 121)

[Sou um navio do mar de amor/ Assolado pelos vento e por tempestades/ que desgraça/ esperança/ temor e dor/ Mande por mastros e velas./ Aqui não se mostra Nenhum porto para $\mathrm{mim} /$ Que agora devo evitar]

\section{Angelus Silesius}

a) Ich schiff ohn Zagen auf dem Meer

In allem Ungewitter.

Fliegt gleich mein Schifflein hin und her 
Vom Nordwind, dem Zerrütter,

Fahr ich doch fort und seh ihn an,

Den Leitstern, was ich kann.

(Angelus Silesius, Heilige Seelenlust oder geistliche Hirtenlieder, p. 458)

[Eu navio destemido no mar/ Em todas as tempestades./ Voa meu barquinho para lá e para cá/ Pelo vento norte, o abalador,/ continuo e olho para ela,/ Estrela-guiia, enquanto puder.]

b) Ich werde zwar oft schwach und müd

Und bin sehr abgeschlagen,

Weil aber er mich an sich zieht,

So acht ich keine Plagen.

Mein Schifflein wird noch wohl bestehn

Und in den Port eingehn.

(Ibidem, p. 459)

[É verdade, às vezes, fico fraco e cansado/ E bastante esgotado,/ Mas por ele me puxar para si/ Não ligo para pragas. / Meu naviozinho deve agüentar / E entrar no porto.]

\section{Sigmund von Birken}

Die Wellen hier wallen,

Mein Schifflein anfallen.

Sie wollen mich senken,

Im Welt Meer ertränken.

Mein Segel ich wende,

Zur Sternen-Anlände.

O Himmel! zu dir

Steht meine Begier.

(Birken, Geistliche Lieder, p. 135)

[As ondas aqui rolam/ Atacam meu naviozinho/ Querem me afundar/ Me afogar no mar do mundo./ Viro minha vela/ Para as estrelas./ Ó céu! A ti / Destinam-se meus desejos.]

\section{Simon Dach}

Über Wunsch und über Hoffen

Sind wir dieses, was wir sind. 
Daß auch uns die Noht getroffen,

Tobt die Ost-See durch den Wind,

Sind die all' in Angst und Pein,

Die in einem Schiffe seyn.

(Dach, Gedichte an das kurfürstliche Haus, p. 220)

[Sobre desejo e esperança/ Somos o que somos./ Que também a nós a necessidade atinja,/ O Mar Báltico passa pelo vento,/ Com medo e dor ficam todos,/ Os que estão num navio.]

\section{Quirinus Kuhlmann}

Mein Gott, mein Gott! Schau meine Trübsal an!

Ich sehe um und um nichts als nur lauter wasser!

Ob Ost und Nord mit mir zu schiffe gehen,

Und gros dein werk, das täglich mir vorlauffet!

Doch stehe ich mit Ost und Nord in Noth,

Bis an den gürtel recht in hauptgefahr und wellen.

Ich weist nicht mehr vor meiner nässe rath,

Mit der mein Weis und Blau so häuffig wird gefeuchtet.

Di flutten steigen hoch! Mein Schif zeucht mehr und mehr!

Das es di höchste zeit in grösser eil zufahren.

(Kuhlmann, Der Kühlpsalter, Bd. 2, p. 536)

[Meu Deus, meu Deus! Vê minha tristeza!/ Em minha volta só vejo água! Leste ou norte no navio comigo/ Grande tua obra que, diariamente, se me apresenta!/ Mas com Leste e Norte estava em apuros, Até a cintura em perigo e ondas./ Não sabia o que fazer de tão molhado./ Pela água que molha meu branco e azul!/ As marés sobem! Meu barco sofre cada vez mais!/ Que se dirija com rapidez no maior tempo.]

\section{Andreas Gryphius}

a) Wie ohne Ruh'

Ein Schifflein wird bald her/ bald hin geschimissen:

So setzt uns zu

Der sorgenSturm/ wir werden hingerissen

Auff dises Lebens Schmertzenvollen See.

(Gryphius, p.195) 
[Assim sem descanso, o barquinho é jogado para lá e para cá: ataca-nos a tormenta dos problemas, somos arrastados para o mar de dores dessa vida.]

b) Mein offt bestürmbtes Schiff der grimmen Winde Spil

Der frechen Wellen Baal/ das schir die Flutt getrrennet/

Das vber Klip auff Klip'/ vndt Schaum/ vndt Sandt gerennet;

Komt vor der Zeit an Port/ den meine Seele wil,

Gott Lob! Der rauhe Sturm führt durch die wüste See

Der rasend-tollen Welt/ wo immer neues Weh

Und Leid auf Angst sich Häufft/ wo auf das harte Knallen

Der Donner/ alle Wind in Flack und Seile Fallen/

von kaum erkennter Klipp' und seicht-verdecktem Sand;

Mein Schiff (zwar vor der Zeit) doch an das liebe Land.

(Gryphius, Sonette, Bd 1, p. 61)

[Meu barco várias vezes atacado pelo jogo voraz dos ventos; o baile das ondas que dividem as águas; que passou por encostas e espuma e areia, chega ao porto antes do tempo; o porto que minh'alma quer.

Louvado seja Deus! A tempestade rude leva-nos pelo mar revolto do mundo loucoirado, onde a dor sempre renovada e sofrimento e medo se acumulam, onde após o estouro do trovão, todo o vento cai nas ondas e velas diante de quase imperceptíveis encostas e areias levemente cobertas. Meu barco (antes do tempo, é verdade) chega à terra amada.]

Jöns, a respeito desse soneto de Gryphius nos diz:

Das Schiff bedeudetet den Leib, das stürmische Meer die Welt; Hafen und Land sind Sinnbilder des Endes der von calamitates und vielleicht auch errores erfüllten Lebensfahrt, wo der Geist den Leib und damit das Zeitliche verläßt. Der „Port“ ist zwar der „Port des Todes“, aber in christlichem Sinn Erlösung von der Qual und Unruhe des Irdischen und zugleich den Eingang in die Ewigkeit, das „Vaterland“. (Jöns, 1966, p. 198) 
[O navio significa o corpo, o mar tempestuoso, o mundo; o porto e a terra são imagens do fim da viagem da vida repleta de calamidades e também de erros, em que o espírito abandona 0 corpo e com ele a vida temporal. O "porto" é, precisamente, o "porto da morte", mas, no sentido cristão, a solução do martírio e desassossego do mundano e, ao mesmo tempo, a entrada na eternidade, a "pátria".]

Após ter vencido o mar de vicissitudes - tormentos, tempestades, ventos contrários -, resta ao navio chegar a seu Porto seguro. O homem chega, portanto, à consumação de sua jornada. Podemos ver exemplos dessa chegada na emblemática, na fig. 31, quando vemos um homem que aponta

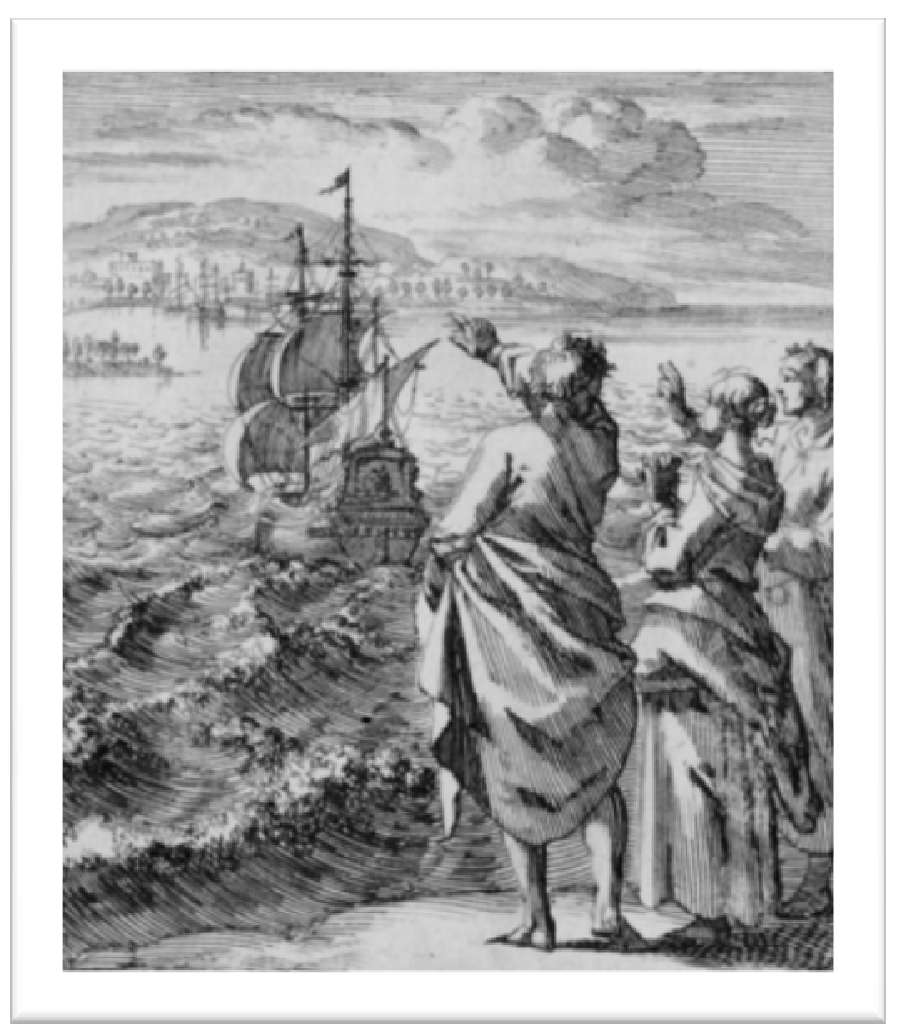
para um navio que está chegando a seu destino. Entre as interpretações dadas a esse emblema, está o fato de as pessoas que acenam hesitarem ir ao outro lado, talvez por medo do desconhecido ou o receio do que possam lá encontrar. Não receia a morte aquele que não cometeu crimes, que não pecou, pois está livre para se defrontar com seu julgamento e ver Cristo face a face.

Figura 33, Emblema 10 Aan d'overkant, is 't zalig land., de Pieter Huygen, 1689.

Port (porto)

\section{Angelus Silesius}

a) Ich lasse Donner, Hagel, Blitz

Und alles auf mich stürmen,

Schau nur nach meines Sternes Sitz

An seines Himmels Türmen.

Ich fahr voll Hoffnung nach dem Port,

Denn Jesus zeucht mich fort.

(Angelus Silesius, Heilige Seelenlust oder geistliche Hirtenlieder, p. 458) 
[Deixo trovão, granizo e raio/ E tudo mais cair sobre mim,/Vê só a sede de minha estrela/ nas torres de seu céu./ Vou cheio de esperança ao porto/ Pois Jesus me leva.]

b) Es stürmt kein Wind in diesem Port

Und innerhalb der Brucken,

Der Blumen feind, der strenge Nord,

Darf hier nicht einmal mucken.

Es facht und webelt nur allein

Wie spielend durcheinander

Ein tausendkühles Lüftelein

Mit lieblichem Gewander.

(Angelus Silesius, Sinnliche Beschreibung der vier letzten Dinge,

p. 74)

[Nenhum vento sopra nesse porto/ $E$ em meio às pontes,/ os inimigos das flores, e o Norte vigoroso,/ Não pode nem para aqui/ Sopra e esvoaça sozinho/ Como que brincando, revolto,/ Um arzinho fusco/ com roupagem adorável.]

\section{Catharina Regina von Greiffenberg}

a) Wann nur mein Schiff erlangt / den viel gewünschten Port /

(Ich mein / ein gutes End) mein hie geführtes Leben /

So bin ich schon vergnügt / und kan mich freuen dort.

Doch kan ein gutes End allein die Tugend geben /

als die es selber ist. Werd' ich in sie versetzt /

so bin ich alles Leids und stürmens reich ergetzt.

(Greiffenberg, Geistliche Sonnette, Lieder und Gedichte, p. 95)

[Quando meu navio alcançar o porto tão desejado/ (Digo: um bom fim) minha vida que levo aqui/ Estou feliz e me alegro lá./ Mas só um bom fim pode me dar a virtude/ do que ela mesma. Se nela me coloco/ fico feliz com todo sofrimento e tormenta.]

b) Gleich wie der Wolken last in tropfen sich verlieret: also mein Vnglück auch durch Thränen Regenfällt. als Haubt Plejaden / sie zu feuchten sind bestellt / der Gottes Güte Land das hülff-blüh dann gebteret. Diß quälend Wellen-Meer an wunsches Port offt führet. Der Buße Muschel Perl in seinem schoß es hält / 
zu dem die Amber sich / das Ruf-Gebet / gesellt.

Offt man darinnen mich / gleich als im Felsen / spüret:

Sonst treibt die Wasserkunst offt grosses Räderwerck.

(ibidem, p. 100)

[Como as nuvens se perdem em gotas:/ minha desgraça em chuva de lágrima cai/ como plêiades centrais, feitas para umedecer/ que a bondade divina ajude a florescer a tem/ Esse mar de ondas tormentosas leva ao porto do desejo./ A pérola da concha da penitência mantém em seu colo/ ao qual o âmbar se junta com a prece-clamor./ Muitas vezes, ali, me sinto como na rocha:/ Senão a arte das água faz grandes obras.]

c) Die Seeligkeit der Geist in diesen Segel wehet / der in den Hafen bringt das Schiff mit Pfeiles-eil. Ich bin bereit im Port / und mein Port ist in mir / auch mitten in dem Meer: was darf die Flut mich scherzen?

(ibidem, p. 117)

[A felicidade do espírito sopra nessa vela/ que leva o navio ao porto como uma flecha./ Estou pronto no porto e meu porto está em mim/ também em meio ao mar: o que a maré me fará?]

\section{Andreas Gryphius}

Der schnelle Tag ist hin/ die Nacht schwingt jhre fahn/

Vnd führt die Sternen auff. Der Menschen müde scharen

Verlassen feld vnd werck/ Wo Thier vnd Vögel waren

Trawrt jtzt die Einsamkeit. Wie ist die zeit verthan!

Der port naht mehr vnd mehr sich/ zu der glieder Kahn.

(Gryphius, Sonette, p. 108)

[O breve dia se foi, a noite agita sua flâmula/ E tráz as estrelas cansadas/ Deixam campo e o trabalho, onde estiveram animais e pássaros/ Agora está a solidão em luto. Como se gastou o tempo!/ O porto se aproxima cada vez mais do barco, de seus membros.] 
Além de Port essa segurança buscada pelo homem também pode ser alcançada pelo Fels [rochedo] que, da mesma forma que pode ser destruidor em meio a uma tempestade, pode ser a salvação em meio à amplidão do mar, ou seja, é o refúgio que a alma procura, é o encontro com o próprio Deus:

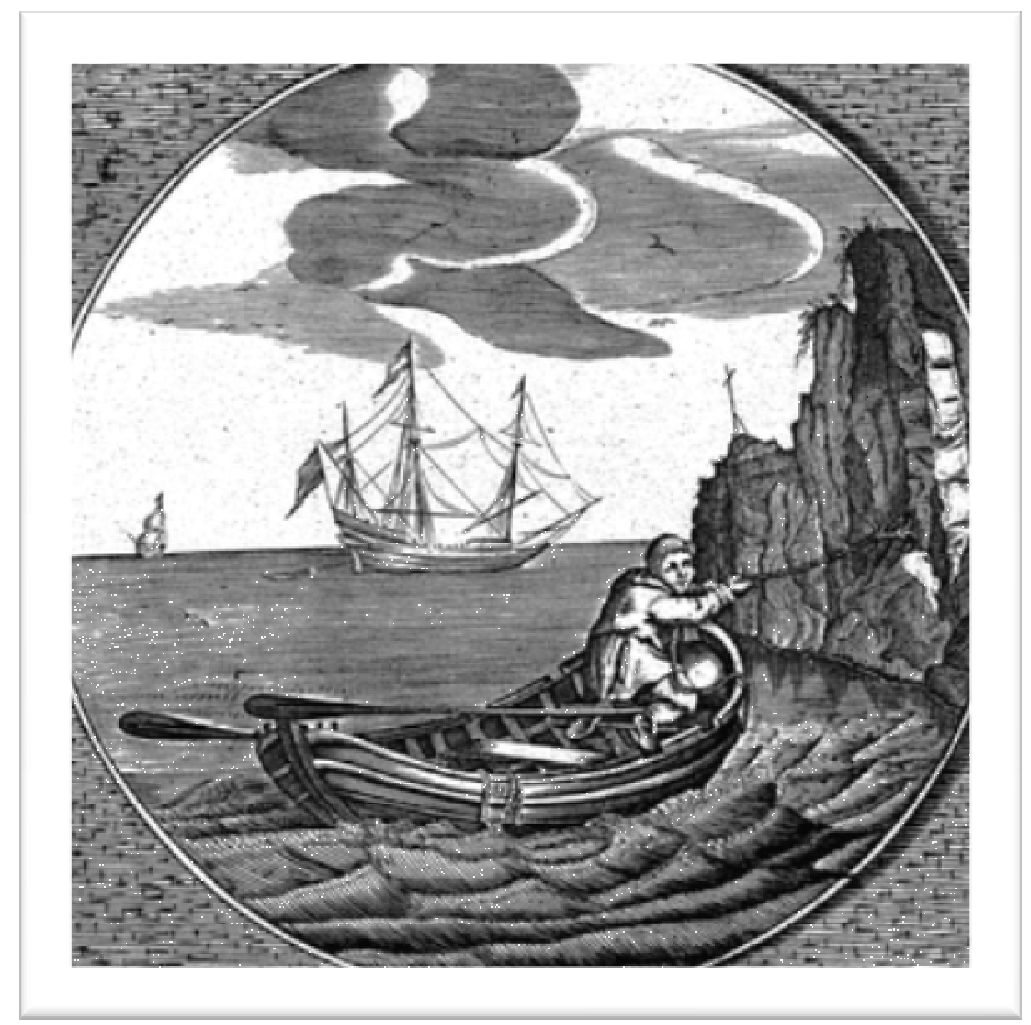

Figura 34: Emblema 20, Dum trahimus, trahimur, de Jacob Cats, de 1627.

Eu te amo Javé. Tu és minha força! Javé, meu rochedo, minha fortaleza, meu libertador: meu Deus, rocha minha, meu refúgio, meu escudo, força que me salva, meu baluarte! (SI 18, 1-3)

O holandês Jacob Cats (1577-1660) mostra-nos isso em seu emblema 20 da obra Sinne- en minnebeelden, de 1627 (fig. 34), quando vemos um marinheiro que se agarra a um rochedo com a ajuda de uma âncora. Por outro lado, uma imagem parecida é utilizada por Georgette de Montenay, quando nos mostra no mote de seu emblema 60: Invia virtuti nulla est via, ou seja, que não 
há nenhum caminho fechado para a virtude (fig. 35). Vê-se um soldado demolindo um rochedo em que há uma estátua personificando a virtude, apesar das ondas do mar. O mesmo podemos dizer da fig. 18, quando vemos que a alma humana estende as mãos para o Amor Divino que está, a sua espera, ao lado de um rochedo, algo parecido com o que nos diz Angelus Silesius:

\section{Christus ist wie ein Fels}

\section{Wer sich an Christum stößt, er ist ein Felsenstein,}

Zerschellt; wer ihn ergreift, kann ewig sicher sein.

(Angelus Silesius, Cherubinischer Wandersmann, S. 1086)

[Cristo é um rochedo

Quem se chocar com Cristo que é um rochedo/ Estilhaçar-se-á; quem acolhê-lo, terá segurança eterna.]

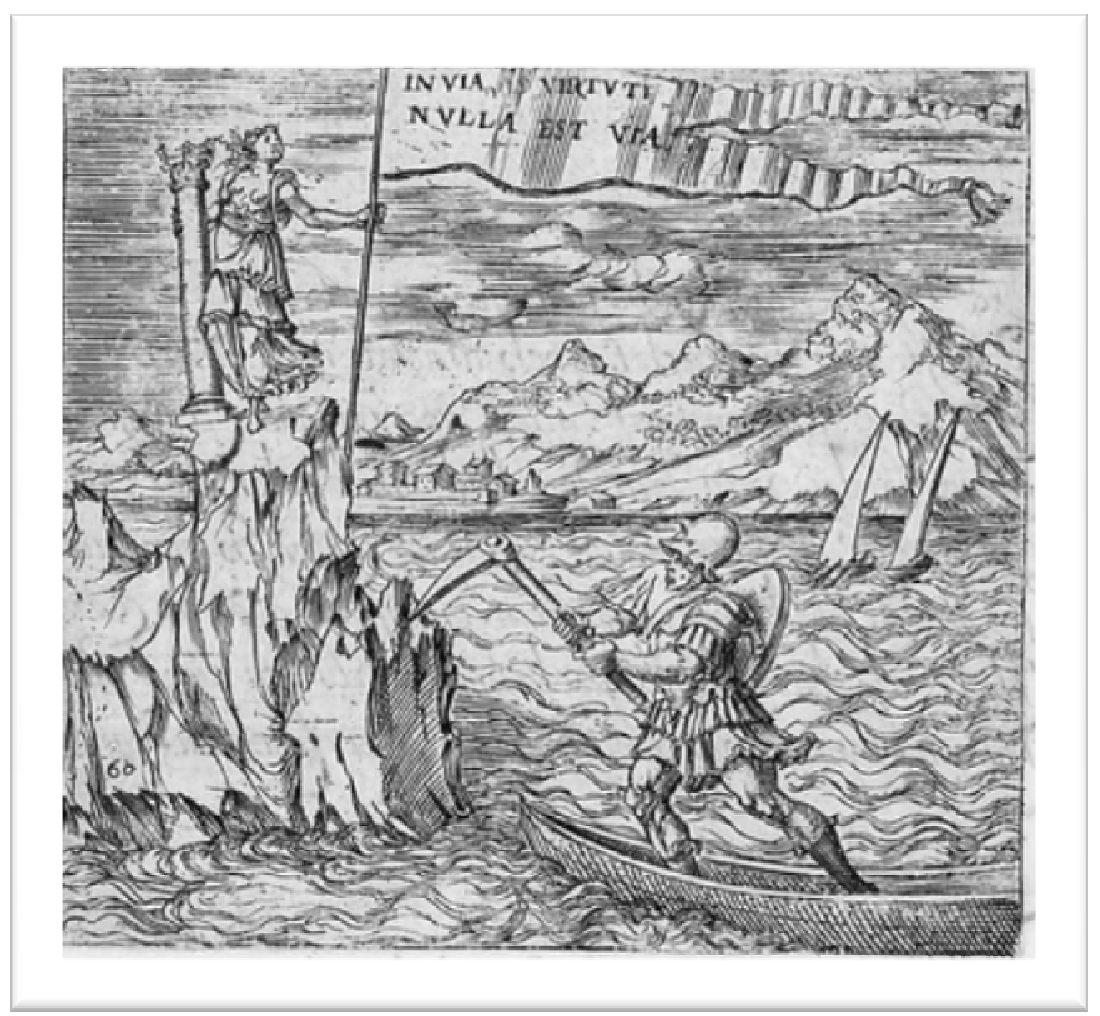

Figura 35: Emblema 60, Invia virtuti nulla est via, de Gerogette de montenay, de 1615. 


\title{
Paul Fleming
}

\author{
Arzt, ich bin krank nach dir. Du Brunnen Israel, \\ dein kräftigs Wasser löscht den Durst der matten Seel'. \\ Auch dein Blut, Osterlam, hat meine Tür errötet,
}

die zu dem Herzen geht. Ich steife mich auf dich, du mein Hort, du mein Fels. Belebe, Leben, mich.

Dein Tod hat meinen Tod, du Todes Tod getötet.

(Fleming, Deutsche Gedichte, p. 872)

[Médico, estou doente, ansiando por ti. Tu, fonte de Israel,/ Tua água poderosa sacia a sede de minha alma enfraquecida./ Também teu sangue; Cordeiro da Páscoa, tingiu de vermelho a minha porta./ que leva a meu coração. Apóio-me em ti,/ meu refúgio, meu rochedo. Vida, dáme vida./ Tua morte a minha morte matou, Tu, morte da morte.]

\section{Paul Gerhardt}

\author{
Mein Volk kommt aus dem Weinen, \\ Sein Feind kommt aus der Ruh, \\ Ihr tausend flieht vor einem, \\ Wie geht das immer zu? \\ Ihr Herr, ihr Fels und Leben, \\ Ist weg aus ihrem Zelt, \\ Er hat sie übergeben \\ Zur Flucht ins freie Feld.
}

(Gerhardt, Gedichte, p. 534)

[Meu povo vem do choro,/ Seu inimigo vem da calma,/ Vós, milhares, fugis de um só,/ Como pode ser isso?/ Seu Senhor, seu rochedo e vida,/ Foi-se de sua tenda./ Entregou-os à fuga/ Para os campos livres.] 
Vanitas

- $\quad$ Vanitas vanitatum dixit Ecclesiastes vanitas vanitatum omnia vanitas

- $\quad \mu \alpha \tau \alpha l o \tau \eta \varsigma \mu \alpha \tau \alpha l o \tau \eta \tau \omega v \varepsilon l \pi \varepsilon v$ o $\varepsilon \kappa \kappa \lambda \eta \sigma l \alpha \sigma \tau \eta \varsigma \mu \alpha \tau \alpha l o \tau \eta \varsigma \mu \alpha \tau \alpha l o \tau \eta \tau \omega v$ $\tau \alpha \pi \alpha v \tau \alpha \mu \alpha \tau \alpha l o \tau \eta \varsigma$

- $\quad$ ¡Vanidad de vanidades! - dice Cohélet -, jvanidad de vanidades, todo vanidad!

- Windhauch, Windhauch, sagte Kohelet, Windhauch, Windhauch, das ist alles Windhauch

- Vanity of vanities, saith the Preacher, vanity of vanities; all [is] vanity.

- $\quad$ Vanité des vanités, dit l'Ecclésiaste, vanité des vanités, tout est vanité.

- $\quad$ Ó suprema fugacidade, diz Coélet, ó suprema fugacidade! Tudo é fugaz!

$(\operatorname{Ecl} 1,2)^{155}$

Uma das palavras/conceitos mais empregadas no século XVII foi, seguramente, a que diz respeito ao texto bíblico acima, retirado do livro do Eclesiastes. Não importa qual a língua falada - latim, grego, castelhano, alemão, inglês, francês, português -, a posição social - se nobre, se clérigo, se burguês, se povo -, o grau de cultura - instruído, culto, doutor, medíocre, ou mesmo analfabeto como a grande maioria -, inclusive a orientação religiosa se católico ou protestante -, afinal todos se deixavam influenciar não só pela palavra vanitas como por tudo aquilo que se representava a partir desse conceito: independente se o meio escolhido fosse o pictórico, o escultórico ou o poético.

A vanitas deixa de ser uma mera palavra para tornar-se um gênero em que se imiscuíam as expressões artísticas do século XVII, quando se demonstrava a relação conflituosa do homem com a morte, herança do $\lambda o ́ \gamma o \varsigma$, afinal por seu meio tivemos a consciência de nossa finitude e com ela a angústia de nossa mortalidade. Enquanto expressão artística, lembra-nos as naturezas-mortas, no entanto às frutas, aos animais são acrescidas - quando não substituídas - outras imagens que eram plenamente decodificadas pelo homem seiscentista, mas que para nós podem causar estranheza.

Como já iniciamos nosso trabalho a partir da imagem escultórica barroca - a obra de Pedro Mena - vamos agora ingressar no reino pictórico propriamente dito e analisá-lo à luz dos modelos preestabelecidos no período,

\footnotetext{
${ }^{155}$ As citações foram retiradas do site www.bibliacatolica.com.br, cujas versões são, em ordem, Vulgata Latina, Septuaginta, La Santa Biblia, Die Bibel, Bible: King James version, Bible de Jérusalem, Bíblia Sagrada: Edição Pastoral.
} 
comparando-os não só com obras emblemáticas do período, como também com textos poéticos que trabalhavam com temas afins. Para isso, valemo-nos de uma obra do artísta plástico holandês David Bailly (1584-1657) bastante singular, que nos fornecerá muitos elementos para uma análise mais abrangente desse tema tão caro ao período seiscentista que é a vanitas. Da mesma forma que a obra de Mena, iniciaremos nossa análise a partir de nossa

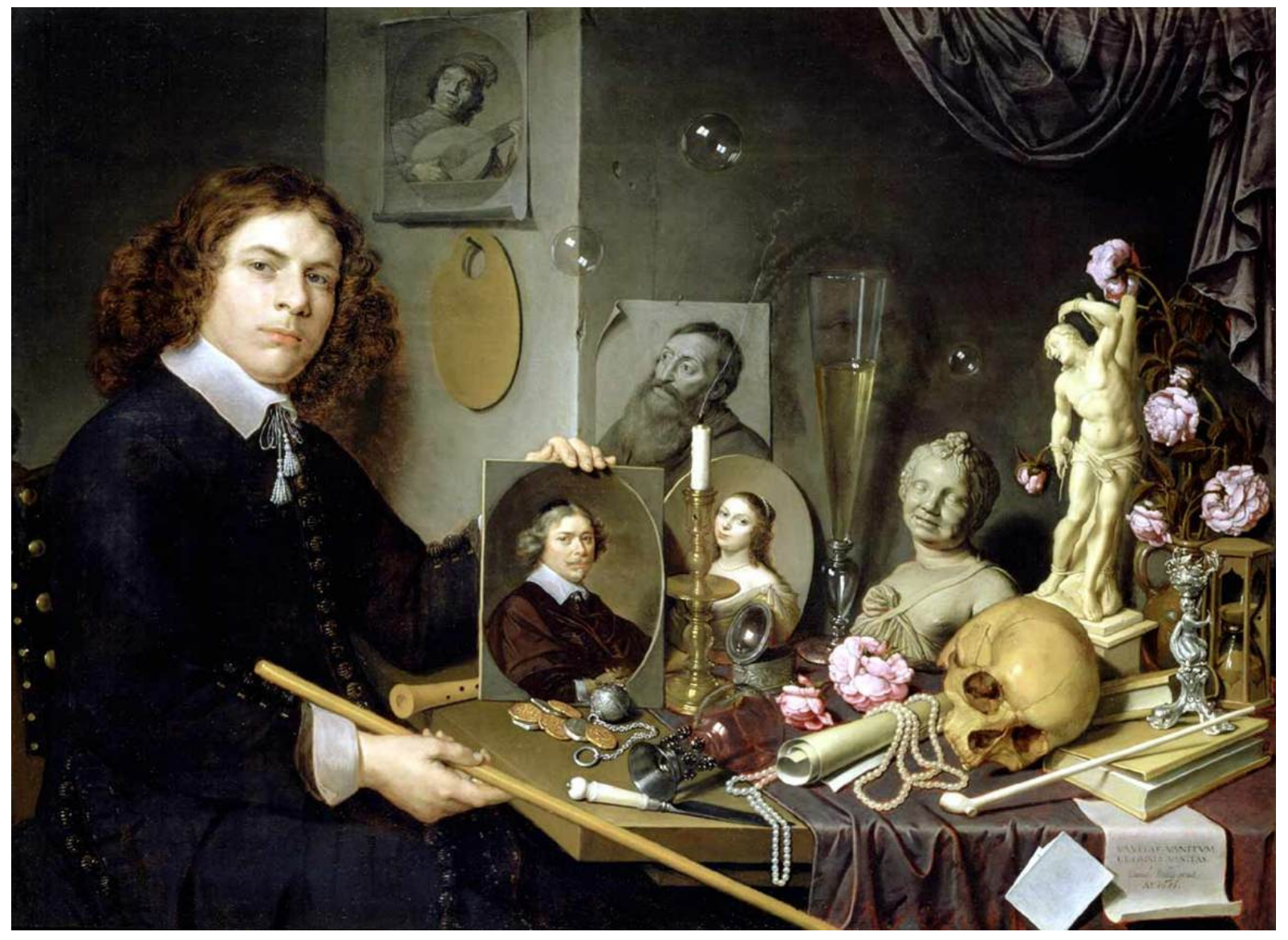

Figura 36 Auto-retrato com símbolos da vanitas, de David Bailly, 1651

descrição pré-iconográfica:

a) Temos um quadro riquíssimo em detalhes;

b) Vemos um jovem com roupas escuras, sentado numa cadeira embotoada, segurando um bastão na mão direita e mostrando-nos um retrato de uma pessoa idosa;

c) O jovem, sentado a uma mesa repleta de objetos, tem um rosto em que se vê altivez, mesclada com orgulho: talvez o quadro que tenha nas mãos tenha sido pintado por ele, já que vemos uma palheta pendurada na parede a seu lado; 
d) Vemos que a mesa está coberta com uma toalha de tom escuro, no entanto parte dela está levantada. Nesta, vemos alguns objetos além do quadro exibido: um cálice de vinho deitado, moedas, um relógio de pulso, uma flauta e uma faca, provavelmente para abrir envelopes;

e) Sobre a toalha temos: um colar de pérolas; um crânio; um castiçal cuja vela fora apagada há instantes; duas flores murchas; uma vasilha de água - parecida com uma taça de espumante, mas que, provavelmente, é um receptáculo para água que será misturado à tinta -; um quadro de mulher; um busto de um menino; dois livros; uma ampulheta; uma pequena imagem que nos lembra São Sebastião atado a uma árvore; um vaso com flores murchas; uma piteira longa; uma caixinha, aparentemente de prata; sob um livro e caindo fora da mesa algo que parece ser um bilhete dobrado e um papel aberto com os dizeres: Vanitas Vanitatum et Omnia Vanitas;

f) No canto direito do quadro podemos ver uma cortina de cor escura levantada;

g) Acima do quadro de mulher vemos uma gravura de homem; e, nessa mesma parede, um vulto de mulher toma parte da parede;

h) É possível ver, no ambiente, bolhas de sabão flutuando no ar;

i) Há, na parede onde a palheta está pendurada, um quadro onde vemos um trovador.

Ao passarmos a nossa análise iconográfica, verificamos que, à diferença de grande parte das imagens vistas até aqui, a de Bailly não nos remete, pelo menos aparentemente, a nenhuma conotação de cunho religioso - como a representação de temas bíblicos ou hagiográficos - por um motivo singular em relação aos demais países europeus de então: a prosperidade econômica da sociedade holandesa. Ao não se restringir ao clero nem à nobreza, mas a uma forte classe média urbana, a arte do país praticamente desconheceu o mecenato eclesiástico e cortesão - quem mais encomendava esse tipo de obras -, resultando em poucos quadros com temas bíblicos e devocionários, daí o predomínio das representações da vida cotidiana, aquilo que, comumente, era chamado de paisagem vista da janela (fig.1). Diante dessa 
falta de motes religiosos ${ }^{156}$, pelo menos na temática pictórica seiscentista, é possível questionar a possível imagem de São Sebastião, por nos parecer fora de propósito, visto que as roupas do jovem que está sentado insinuam que o mesmo era protestante ${ }^{157}$, logo iconoclasta.

Além desse aspecto, são facilmente perceptíveis na obra imagens que demonstram a fugacidade do tempo, logo da vida, como a vela apagada, o crânio, a ampulheta, as flores murchas: imagens/símbolos mais conhecidos da vanitas - que não passavam de lugares-comuns utilizados por grande parte dos pintores do período -, conforme o título da pintura quer nos passar. As flores, por exemplo, enquanto representação da vanitas não são uma criação barroca, mas remontam à tradição bíblica:

Todo ser humano é erva e toda sua beleza é como a flor do campo: a erva seca, a flor murcha, quando sobre elas sopra o vento de Javé; a erva seca, a flor murcha, mas a palavra do nosso Deus se realiza sempre. (Is 40,6-8)

Mesmo no Novo Testamento há demonstração da efemeridade da flor:

Olhem como crescem os lírios do campo: eles não trabalham nem fiam. Porém eu Ihes digo: nem o rei Salomão, em toda a sua glória, jamais se vestiu como um deles. Ora, se Deus assim veste a erva do campo, que hoje existe e amanhã é queimada no forno (...). (Mt 6, 28-30)

A ampulheta e o relógio de bolso, devido à natureza de seu emprego, corroboraram a passagem do tempo e nossa escravidão em relação a ele. $O$ mesmo pode ser dito a respeito do crânio que é, de per si, o resultado da morte, sua forma mais visível, ou seria o resultado futuro das duas personagens retratadas no quadro? O resultado do presente (velho), passado (jovem) e futuro (caveira)? Vemos, dessa forma, o jogo de Bailly em relação a

\footnotetext{
${ }^{156}$ Evidentemente estamos nos referindo aos pintores holandeses protestantes - que eram a maioria por sinal -, pois não podemos nos esquecer dos católicos como Rubens, van Veermer (convertido ao catolicismo, mas que não explorou temas religiosos em seus quadros).

${ }^{157}$ Mas, por que protestante? Porque, apesar do enriquecimento da burguesia holandesa reformada com o comércio ultramarino, ela buscava conservar um estilo simples e prático das classes comerciantes e, evidentemente, devido a preceitos religiosos, utilizavam uma indumentária escura, contrastando com a riqueza de detalhes da aristocracia católica.
} 
seu auto-retrato, quando este nos é mostrado com arrogância (ou seria prepotência?) pelo próprio Bailly jovem - característica normal da juventude, repleta de hormônios e ganas de auto-suficiência que o pintor soube muito bem representar - em contraste com o Bailly velho - representado num quadro dentro do quadro - que demonstra serenidade e aceitação - características próprias da idade madura. Dessa forma, a vanitas é posta em destaque a partir do próprio eu criador, quando nos mostra o resultado da fugacidade da vida em si mesmo: eu era isso, eu fui assim; agora, sou assim.

Visualizamos com esse jogo nosso desejo de nos vermos, perpetuamente, nas várias etapas de nossa vida, mas que melhor forma para isso que o próprio ato fotográfico? Ou mesmo se todos pudéssemos ser artistas e nos auto-retratar em várias fases de nossa vida à semelhança de Rubens e pudéssemos ver como o tempo agiu em nós no correr dos anos, entretanto se isso nos fosse possível, sempre nos veríamos de forma diversa daquilo que os outros vêem. O espelho sempre nos trai, visto que o que vemos é sempre presente, não vemos nada demais, não vemos mudanças, não sentimos as mudanças até que um amigo nosso chega a nossa casa e vê num porta-retrato alguém e nos pergunta quem é, desconhecendo tratar-se de nós.

Não obstante o fato de não haver uma temática religiosa no quadro, há um versículo do Eclesiastes no canto direito da obra - VANITAS VANITATUM ET OMNIA VANITAS - que nos deve remeter a uma leitura sob um prisma religioso e nos aprofunda o próprio conceito de vanitas, do qual faz parte. Dessa maneira, supõe-se que a obra tenha como viés o texto bíblico que nos questiona logo no início:

Que proveito tira o homem de todo o trabalho com que se fadiga debaixo do sol? (Ecl 1,3)

Mais que uma pergunta ontológica, o que vemos a seguir é uma série de fenômenos naturais que sempre se repetem sem a interferência humana, num continuum cíclico natural:

Geração vai, geração vem, e a terra permanece sempre a mesma. O sol se levanta, o sol se põe (...). O vento sopra para o sul, depois para o norte (...). Todos os 
rios correm para o mar, e o mar nunca transborda (...). O que aconteceu, de novo acontecerá; e o que se fez, de novo será feito: debaixo do sol não há novidade. (...) Ninguém se lembra dos antigos, e aqueles que existem não serão lembrados pelos que virão depois deles. (Ecl 1, 4-11)

Temos no capítulo inicial uma verdadeira síntese daquilo que será abordado pelo livro, apontando, conseqüentemente, a inutilidade de todo o esforço humano; e isso só foi percebido, segundo o eu bíblico, após o mesmo ter investigado e pesquisado muito a partir da luz da sabedoria (Cf.: Ecl 1,1315). A conclusão a que chegou foi uma: tudo é fugaz, uma corrida atrás do vento $(\mathrm{Ecl} 1,14)$; ele tem consciência de ter adquirido ciência e sabedoria; decide ir além e se propõe também a conhecer a tolice e a loucura, mas conclui que

Também isso é correr atrás do vento, porque onde há muita sabedoria, há muita tristeza, e onde há mais conhecimento, há também mais sofrimento. (Ecl 1, 1618)

Diante disso, parte em busca de experimentar a alegria, de conhecer o prazer, entrega-se à bebida, no entanto também descobre neles a fugacidade. Não satisfeito, procura realizar grandes obras:

Construí palácios (...), plantei vinhas, fiz jardins e pomares (...) construí reservatórios de água (...). Comprei escravos (...), tive muitos criados (...). Possuí muitos rebanhos (...). Acumulei prata e ouro (...). Arranjei cantores e cantoras e delícias dos homens - princesas em grande número.

Não recusei nada do que meus olhos pediam, e nunca privei o meu coração de nenhum prazer. Sabia desfrutar de todo o meu trabalho (...).

Então examinei todas as obras que havia feito e o trabalho que elas tinham custado para mim. E concluí que tudo é fugaz e uma corrida atrás do vento, e que não há nada de permanente debaixo do sol. (Ecl 2, 3-12)

Sim, apesar de tudo o que o eu bíblico ter feito ser fugaz e ter um fim, há ainda algo que o deixa satisfeito: possuir sabedoria. Mas, mesmo assim, examina-a e compara-a à insensatez e, nessa comparação, vê que a vantagem 
da sabedoria em relação à insensatez é a mesma da luz sobre as trevas, afinal o sábio tem os olhos abertos, e o insensato caminha na escuridão, porém tanto o sábio quanto o insensato

têm o mesmo destino. Então pensei: "Vou ter o mesmo destino que o insensato! Para que me tornar sábio?" E concluí que também isso é fugaz. De fato, a lembrança do sábio desaparece para sempre, como a do insensato, bem logo tudo ficará esquecido: o sábio morre da mesma forma que o insensato. (Ecl 2, 14-16)

O eu bíblico perde, portanto, não só sua esperança como também alimenta o ódio pela vida, afinal tudo sob o sol o desagradou: nada permanece, a não ser o desalento de ter se fatigado duramente para ter de deixar aos outros, que nada fizeram, o resultado de seu suor:

Detesto todo o trabalho com que me afadigo debaixo do sol, porque devo deixar tudo para o homem que virá depois de mim. (...) ele será dono de tudo o que eu fiz debaixo do sol com a minha fadiga e sabedoria. Também isso é fugaz. Então fiquei com o coração desesperado por causa de todo o trabalho com que me afadiguei debaixo do sol. (...) E depois tem que deixar seus bens para outro que nada se afadigou.

Então, que proveito resta para o homem de todo o trabalho e esforço mental com que se afadigou debaixo do sol?(...) seus dias todos são dolorosos, a sua tarefa é penosa, e até a noite ele não pode repousar. (Ecl 2, 18-23)

O Eclesiastes pertence aos chamados livros sapienciais e por mais pessimista que pareça, o eu bíblico mostra-se crítico, lúcido e realista, mesmo que de forma inconformista, quanto ao ritmo da vida e da impotência do homem, face à realidade inexorável da morte. Ao buscar a mesma dinamicidade da vida, o eu bíblico faz emprego de antinomias, paradoxos, enigmas, repetições, a fim de nos demonstrar sua máxima: tudo é fugaz!

Ao vermos a obra de Bailly e a confrontarmos com o texto bíblico, fica difícil estabelecermos, de forma direta, uma correspondência, por isso é mister irmos além e procurarmos as respostas na análise dos elementos iconológicos da pintura para que nos forneçam as respostas para uma análise mais 
abrangente. Dessa forma, retiraremos do quadro alguns elementos para analisá-los individualmente, a fim de podermos cotejá-los com outras expressões artísticas - sejam quadros, emblemas ou estátuas - e textos poéticos do Seiscentismo alemão que abordem a mesma imagem/conceito.

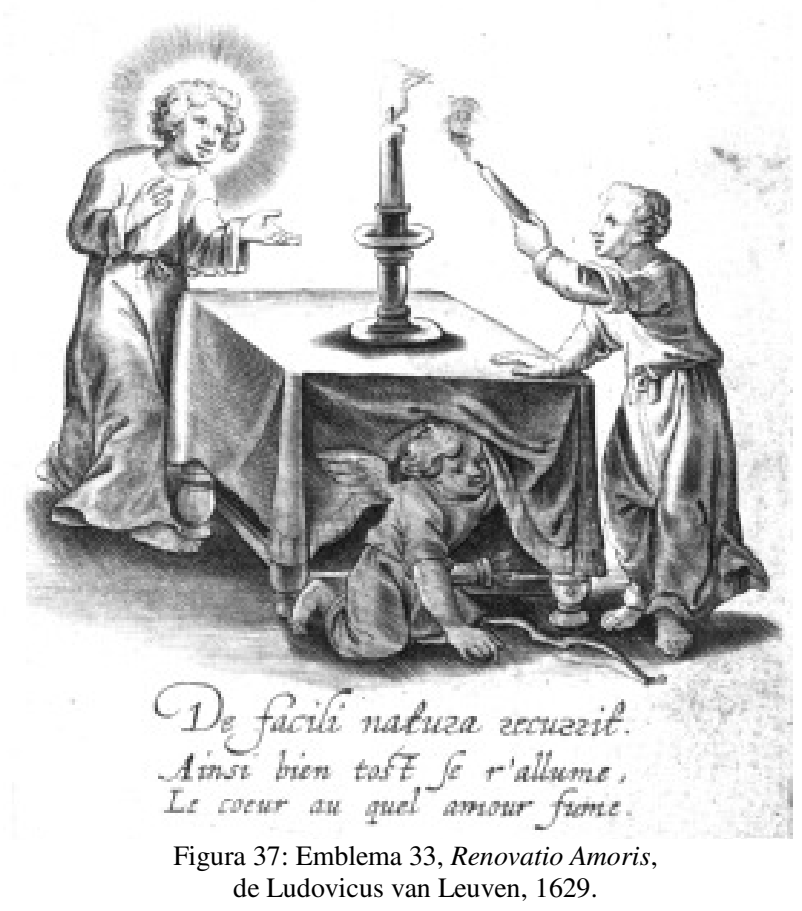

pelo círio; as outras velas simbolizam as pessoas que têm de passar essa boa nova para as outras (fig. 37), não só renovando a esperança na Boa Nova do Ressucitado como também demonstrando ser ele mesmo luz do mundo:

Vocês são a luz do mundo. (...) que a luz de vocês brilhe diante dos homens, para que eles vejam as boas obras que vocês fazem (...). (Mt 5, 14-16) 
A emblemática tratará do tema como na obra Amoris divini et humani antipathiae, de 1628 (fig. 38), quando vemos duas crianças: uma com um livro provavelmente a Bíblia que, por meio da interpretação figural, predizia a vinda do Messias - a outra segura uma tocha e um turíbulo. Ambas dirigem - olhar para um círculo

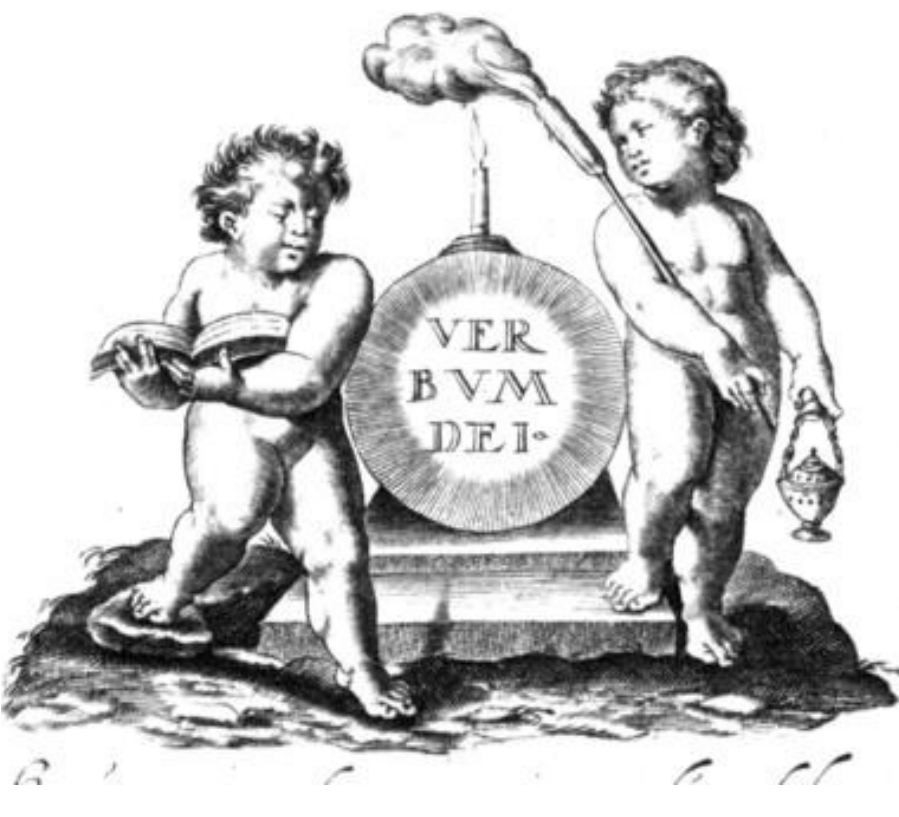

Figura 38: Emblema 49, Exiccatur foenum, et cadit flos, anônimo, 1628. luminoso, sobre o qual vemos uma vela acesa, em que está escrito: Verbum Dei: para São João além de $\lambda o ́ \gamma o \varsigma$ Jesus é Luz:

Nela estava a vida, e a vida era a luz dos homens. Essa luz brilha nas trevas, e as trevas não conseguiram apagá-la. (Jo 1, 4-5)

Jesus é o Verbo de Deus, por isso uma criança tem o turíbulo em sua mão, pois o incenso tem de ser oferecido à Divindade, a Cristo ressucitado, que ilumina mesmo os que já se foram (fig. 39:

Outrora vocês eram trevas, mas agora são luz no Senhor. Por isso comportemse como filhos da luz. (...) Não participem das obras estéreis das trevas (...), tudo o que é denunciado, torna-se manifesto pela luz, pois tudo o que se torna manifesto é luz. É por isso que se diz: "Desperte, você que está dormindo. Levante-se dentre os mortos, e Cristo o iluminará." (Ef 5, 8,14)

A vela acesa é a Luz Divina que ilumina e dá a vida, no entanto quando está apagada é sinal de morte, de fim, como vemos na fig. 39: a chama da esperança/vida está apagada, os mortos esperam-no: vemos a cova, os crânios, a pá e a picareta. Quem pode revertar isso é Cristo, ao acender a vela, 
quebrando, momentaneamente, o domínio da morte, trazendo-nos, de novo, ao reino fatídico da vanitas. Assim como Deus dá a vida, ele pode tirá-la com seu sopro divino, o mesmo sopro que faz respirar é aquele que nos faz inertes (fig 38). Eis a idéia expressa na obra de Bailly, eis como os leitores do XVII liam a vela apagada: basta o vento para apagá-la, mesmo que ela tenha sido luz, mesmo que sejamos filhos da luz, esta tem de regressar de onde veio: a escuridão da morte que, para aqueles que crêem não é o fim, mas o renascimento, pois

fomos sepultados com Ele na morte, para que, assim como Cristo foi ressucitado dos mortos por meio da glória do Pai, assim também nós possamos caminhar numa vida nova. (Rm 6, 4)

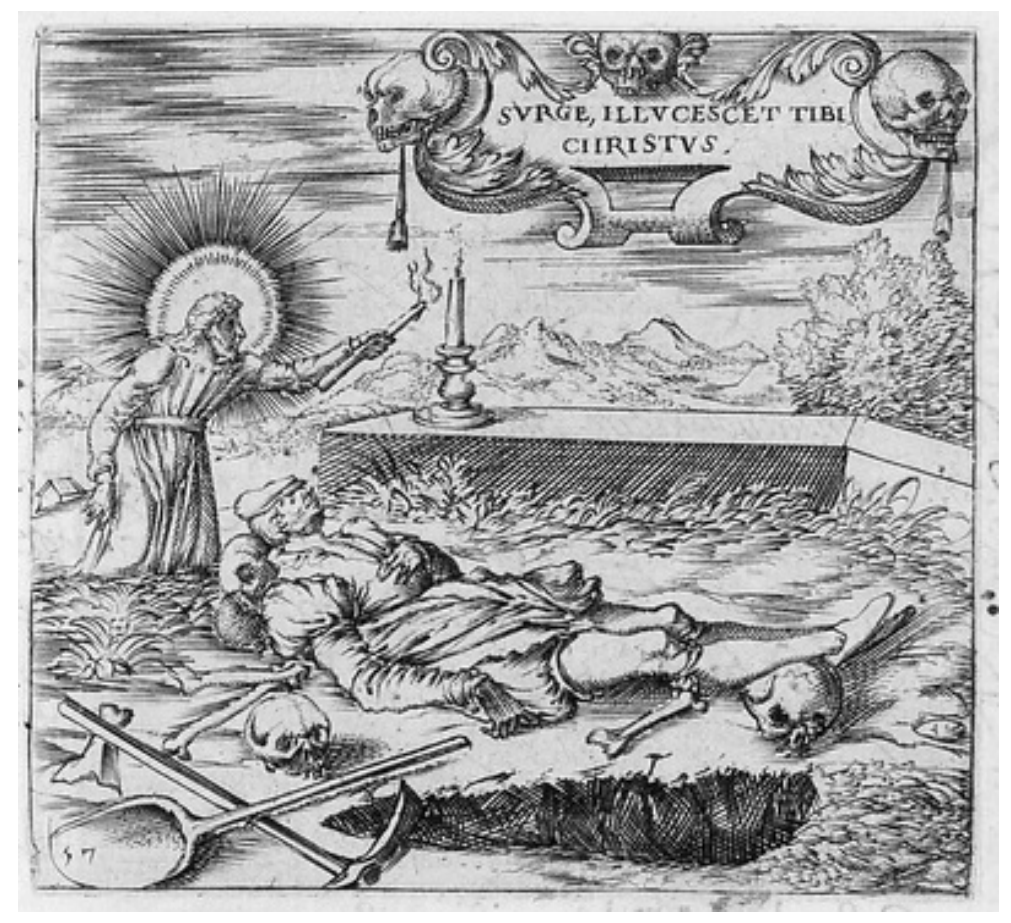

Figura 39: Emblema 57, Surge, illucescet tibi Christus, Gerogete de Montenay, 1615.

Temos, a seguir, alguns exemplos de como os poetas do Seiscentismo alemão trabalharam com esse conceito/imagem: 


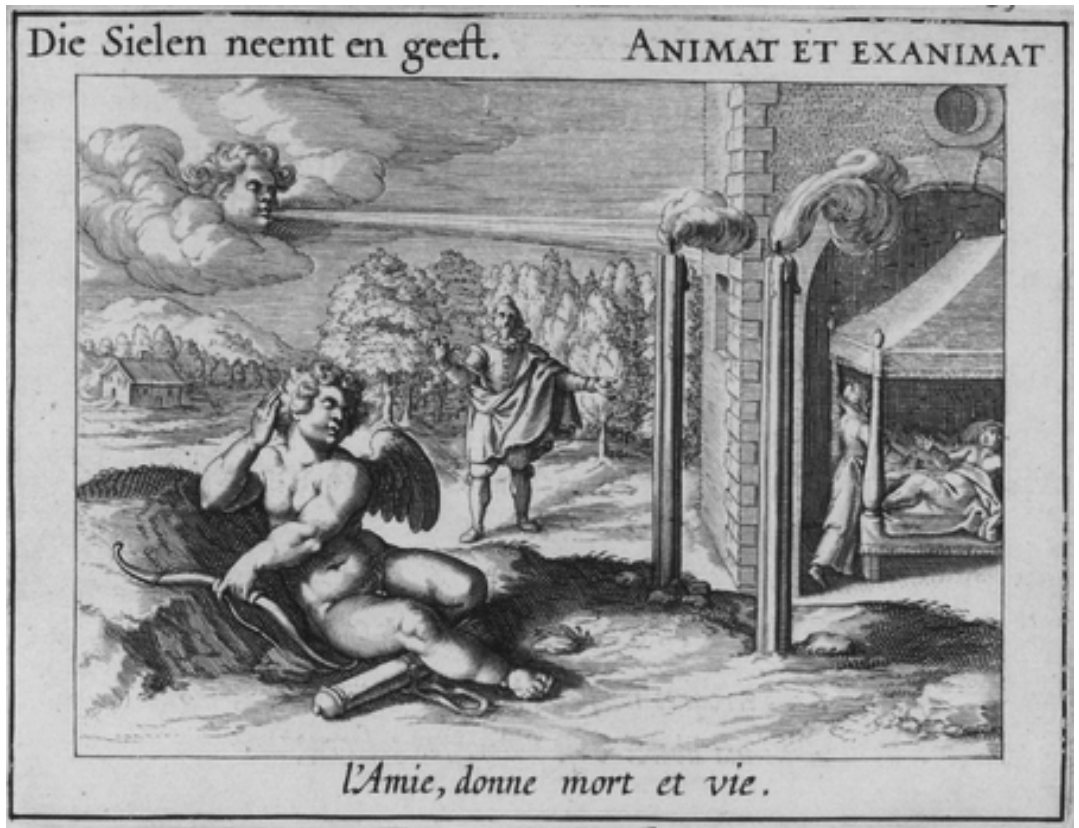

Figura 40: Emblema 26, Die sielen neemt en gheeft, de Pieter Cornelisz, 1611.

\section{Andreas Gryphius}

\section{Ein bald verschmeltzer Schnee und abgebrannte Kerzen}

(Gryphius, 1963, v. 1, p. 9)

[Uma neve logo derretida/ e velas queimadas]

\section{Catharina von Greiffenberg}

a) Herzen / Kerzen /Geistes glänzen / kan bekränzen / wann die Erden /muß zu Staub und Aschen werden

(Greiffenberg, op. cit., p. 444)

[Corações, velas,o brilho do espírito podem coroar/ quando a terra deverá tornar-se pó e cinzas]

b) Streit' / inm zu Lob / mit dir: daß nicht nur Blut austreibet / besonder Geist und Krafft / verbrenn die Lebens-Kerz in seiner treuen Brunst. Denk / löblich ist der Sieg / wann nur mein Gott geehrt / wann ich schon unter lieg.

(ibidem, p. 107) 
[Luta, em honra d'Ele, contigo: para que não corra apenas sangue/ espírito especial e força consomem a vela da vida/ em seu fiel ardor. Pensa, louvável é a vitória/ se meu Deus for louvado, quando eu já estiver lá embaixo.]

Moedas

As moedas, evidentemente, simbolizam a fortuna, a ostentação, a riqueza, enfim o dinheiro. Este nos pode vir do esforço do trabalho - portanto, abençoado por Deus -; e da manutenção/perpetuação da opressão dos maiores sobre os menores, ou seja, do pecado, enquanto desvio das normas morais estabelecidas por uma sociedade e ratificadas por sua divindade cobiça, luxúria, tirania, enfim formas que desagradariam a Deus, mas não a Satanás, por exemplo. Essa idéia será recorrente no Seiscentismo, visto que o domínio do dinheiro - devido ao poder que a própria burguesia estava assumindo - era cada vez maior, instaurando o domínio do capitalismo como regulador social.

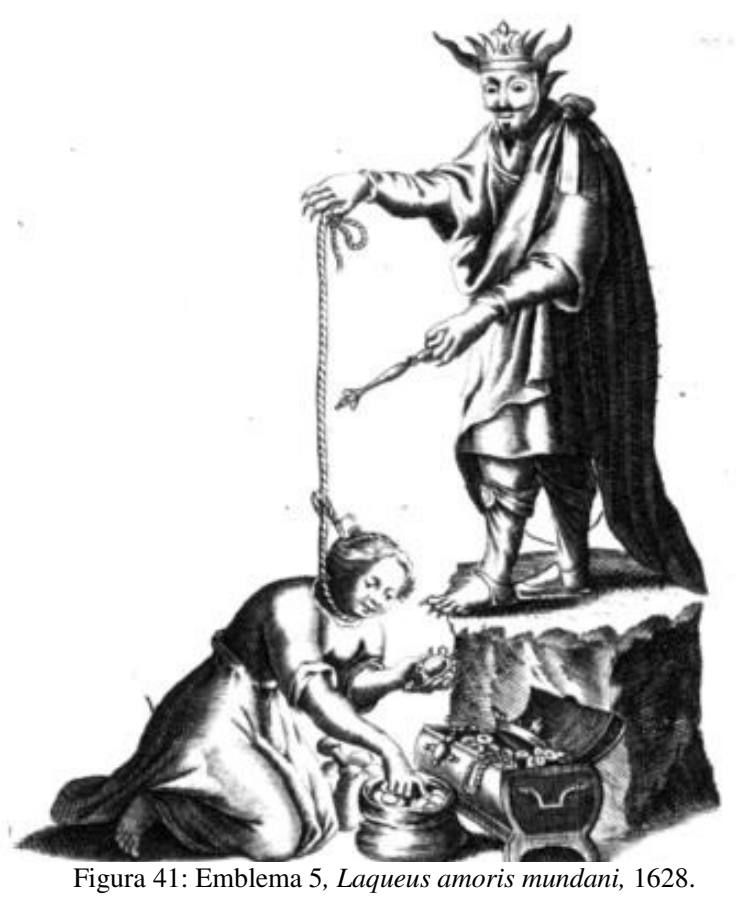

A emblemática empregará a imagem/conceito da moeda sob diversos parâmetros: como forma de o homem se escravizar por 
desejos insensatos e perniciosos, que fazem os homens afundarem na ruína e perdição. Porque a raiz de todos os males é o amor ao dinheiro. Por causa dessa ânsia de dinheiro, alguns se afastam da fé e afligem a si mesmos com muitos tormentos. (1Tim 6, 9-10)

\section{Observamos isso} na figura 41, quando vemos uma pessoa ajoelhada - em sinal de adoração - diante do dinheiro, mas na realidade ajoelha-se diante do Demônio. Escravizado, o homem

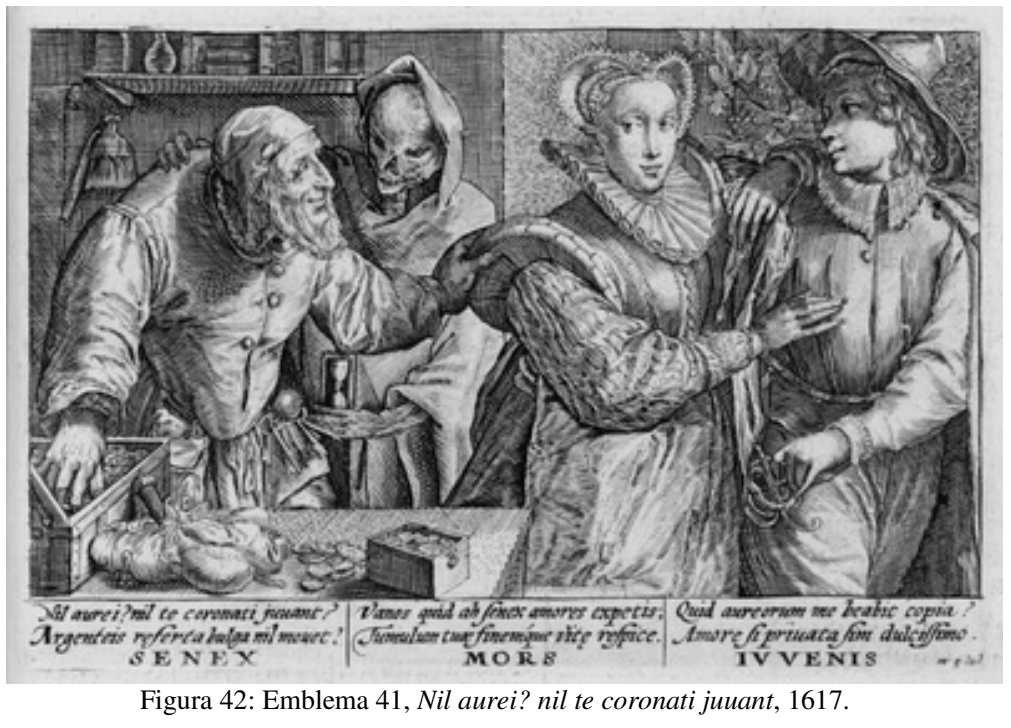
se sujeita a tudo, atado - simbolizado pela corda enlaçada ao pescoço do subjugado - que está aos bens terrenos e sob o domínio do Príncipe do mundo, Satanás - por isso, a coroa, o cetro e o manto -, que o leva aonde quer, privando-o da graça de Deus, a quem abandona.

O dinheiro quer poder comprar tudo, inclusive a felicidade e o amor, de modo que aqueles que o têm, acreditam poder comprar a afeição dos outros (fig 42).

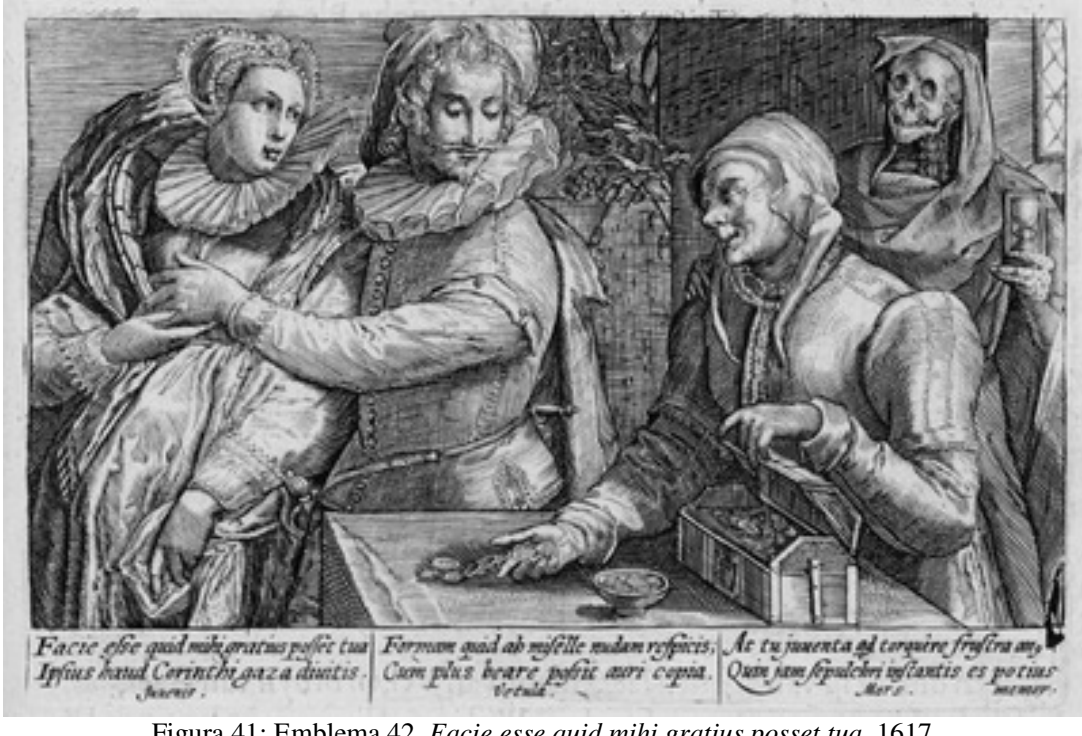

Figura 41: Emblema 42, Facie esse quid mihi gratius posset tua, 1617.
A emblemática nos mostra isso quando vemos um velho tentando comprar o amor de uma jovem ao exibir-lhe sua riqueza, simbolizada pela urna de moedas 
que tem diante de si, mas que recebe o desprezo dela, que prefere um rapaz de sua própria idade. Ao lado do ancião vemos a caveira simbolizando a morte e trazendo a ampulheta, mostrando-nos que seu tempo chegará em breve. 0 mesmo vale para as mulheres que querem se aproveitar da situação como na fig. 43. A morte, à espreita, dizendo que o tempo é curto. Mas tempo de quem? De quem compra, de quem é comprado, ou da riqueza que com a mesma facilidade com que vem, vai embora? Dessa forma, a citação direta de fortuna - moedas de ouro e prata, objetos preciosos - representa a vanitas, pois são bens efêmeros que, por mais que os possuamos, não poderemos levar para o outro mundo.

Apesar dessa conotação negativa, as moedas também podem simbolizar a pureza e isso só é possível no fogo (fig. 44), pois é ali que se comprova sua qualidade. De maneira semelhante, a fé e a constância - a Deus, ao amor, a um ideal -, também segundo preceitos bíblicos, é provada na adversidade:

Meu filho, se você se apresenta para servir ao Senhor, prepare-se para a provação. (...) aceite tudo o que the acontecer, e seja paciente nas situações dolorosas, porque o ouro é provado no fogo e as pessoas escolhidas, no forno da humilhação. (Eclo 2, 1,4-5)

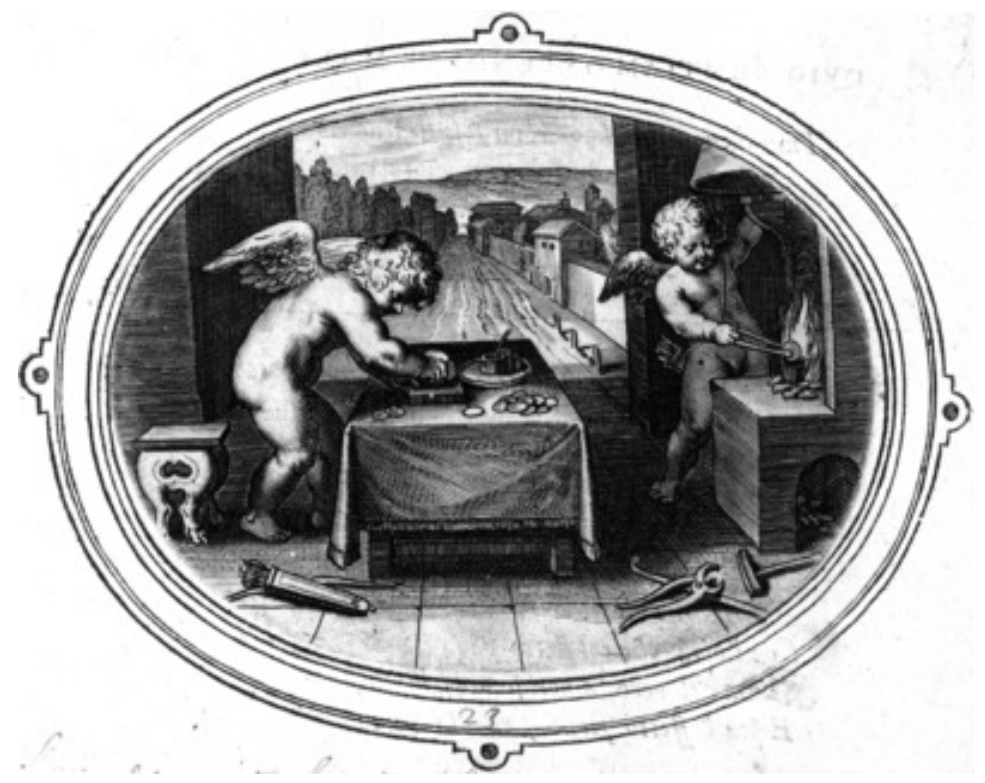

Figura 44: Emblema 23, Amor certus in re incerta cernitur, de Otto Vaenius, 1608. 
Temos, a seguir, alguns exemplos de como os poetas do Seiscentismo alemão trabalharam com esse conceito/imagem:

\section{Paul Fleming}

Lies Rosen, Münze, Klee, Borrag und Quendel aus, mach für mein Haupt und Hand mir einen Kranz und Strauß/ und hauch' ein Lüftlein drein (...)

(Fleming. Deutsche Gedichte. p. 941)

[Escolha rosas, moedas, trevo, borragem, tomilho/ faça para minha cabeça e mão uma grinalda e um ramalhete e sopre um arzinho dentro]

\section{Angelus Silesius}

Die Seel ist Gottes Bild

Das Bildnis Gottes ist der Seelen eingeprägt,

Wohl dem, der solche Münz in reiner Leinwand trägt.

(Angelus Silesius, Cherubinischer Wandersmann, p. 641)

[A alma é a imagem de Deus/ A representação de Deus está cunhada nas almas,/Bemaventurado aquele que traz uma moeda em uma tela pura.]

\section{Sigmund von Birken}

Du hast uns zur Münz geschlagen

Und dich selbst in uns geprägt.

(Birken. Geistliche Lieder. p. 108)

[Tu nos fizeste moeda,/ E te cunhaste em nós]

Bolhas de sabão

Bolhas de sabão são por sua própria natureza frágeis e fugazes, por isso também representam a vanitas; foram, portanto, não só exploradas pela 
emblemática (fig. 45 e 46), como também pela poética do período. Justus de Harduwijn explora o conceito/imagem em seu emblema 20, quando vemos 0 Amor Sagrado cobrindo os olhos da Alma humana para que esta não visse a personificação da vanitas (futilidade, inutilidade). O título desse emblema provém do livro dos Salmos:

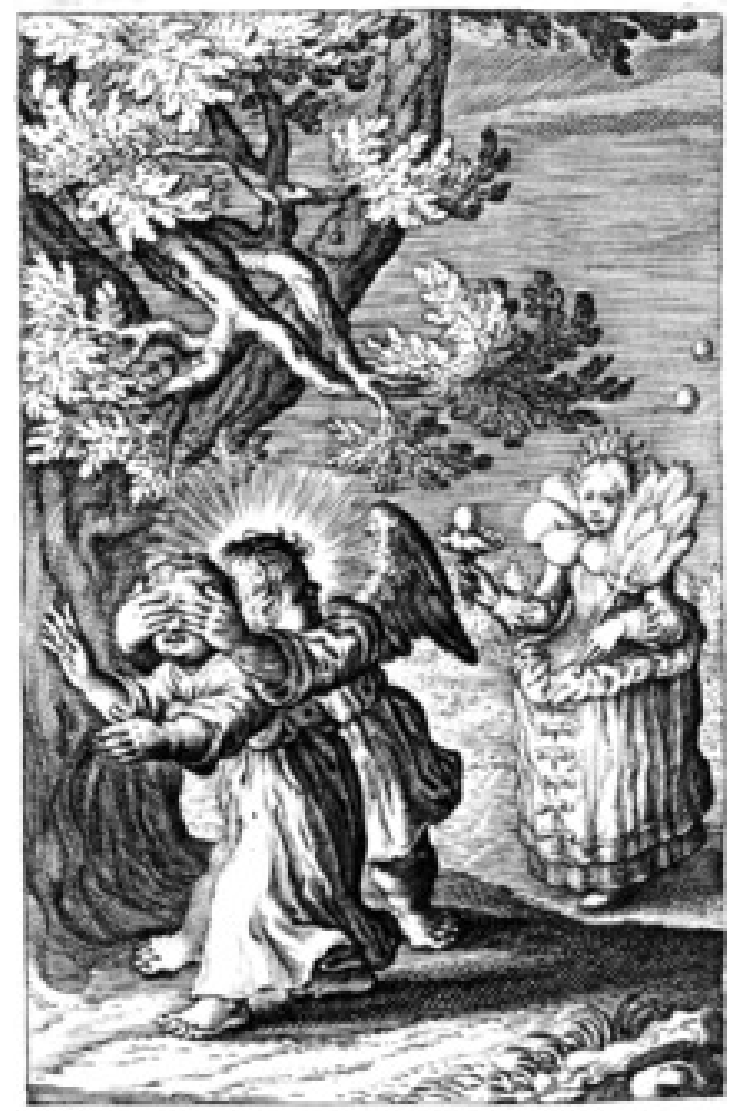

Figura 45: Emblema 20, Auerte oculos meos ne vide, de Justus de Harduwijn, 1629
Evita que meus olhos vejam o que é inútil, dá-me vida, pela tua palavra. (SI 119, 37)

Mais expressivo, no entanto, é o emblema Homo bulla [homem bolha] que retrata exatamente a efemeridade do homem, quando este é, metaforicamente, uma bolha cujo resultado é o crânio sob a criança que brinca de fazer bolhas de sabão. Além destas há também outras evidências da vanitas, como a fumaça que se lança no ar e a flor.

Temos, a seguir, alguns exemplos de como os poetas do Seiscentismo alemão trabalharam com esse conceito/imagem:

\section{Angelus Silesius}

Wie eine Blum und Wasserblas/

In einem Hui verderben (...)

(Angelus Silesius, Sinnliche Beschreibung der vier letzten Dinge. p. 8) 
[Como uma flor e uma bolha de água/ desaparecem com um vento]

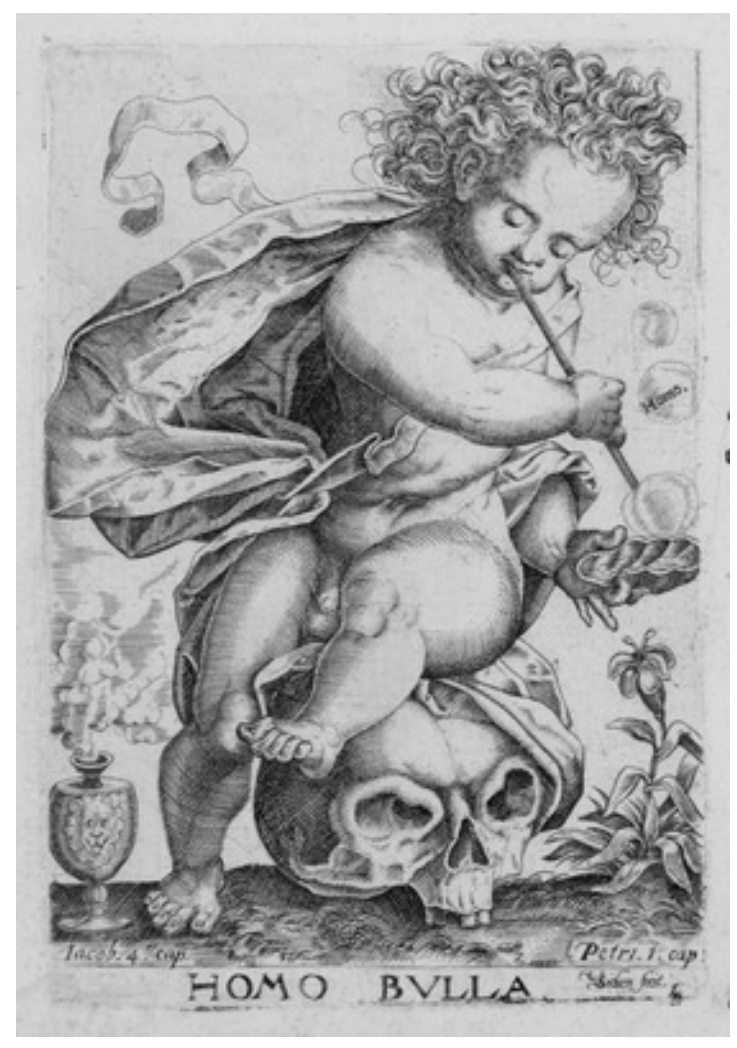

Figura 46: Emblema 49, Homo bulla, anônimo, 1617.

\section{Andreas Gryphius}

Solt denn die Wasserblaß/der leichte Mensch bestehn.

[Afinal, deve o leve homem ser como a bolha de água?]

\section{Simon Dach}

Die eine Wasserblaß, ein Dampff, ein schneller Wind,

Ein Ball, ein Mährlein, Traum, Schnee, Rauch und Schatten sind.

(Dach. Geistliche Lieder. Trostgedichte. p. 415)

[Que uma bolha de água, um vapor, um vento rápido/ um baile, um matunguinho, sonho, neve, fumaça e sombras são.] 
O crânio, os ossos ou todo o esqueleto são, sem dúvida, os elementos de maior impacto referentes à temática da vanitas: é o resultado visível da ação da efemeridade da vida e de seu triunfo. Várias foram as representações da morte na emblemática, como a em que vemos um esqueleto, em atitude imperiosa montada sobre um crocodilo (fig. 47). É interessante a dupla significação desse emblema, pois se a morte pode ser considerada negativa,

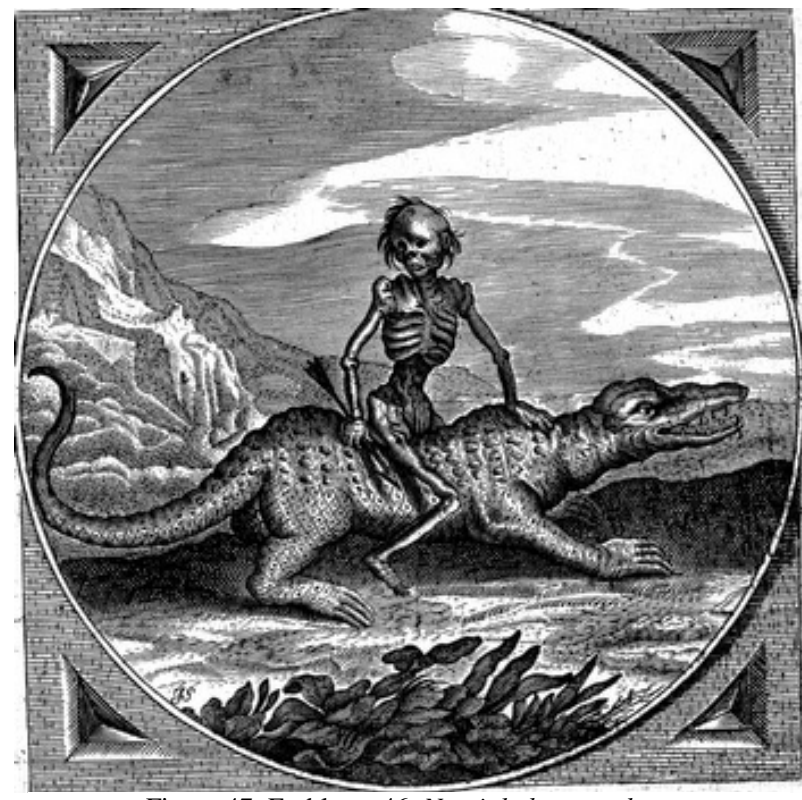

Figura 47: Emblema 46, Nescit habere modum, de Jacob Cats, 1627. visto que arranca, destrói e nos reduz a cinzas, o crocodilo, devido a sua ferocidade, corrobora a própria imagem da morte. Horapolo afirma que, para os egípcios, representava fúria e proliferação. Os antigos viam-no como próprio símbolo da maldade, sendo venerado inclusive pelos egípcios como um deus, pelo medo que

inspirava. (Cf. Horapolo, 1991, p. 160) O emprego das duas imagens, talvez, remeta também não somente ao fato da ferocidade de ambos (da morte e do crocodilo), mas pelo fato de ambos se proliferarem muito, ou seja, do mesmo modo com que o crocodilo traz a morte:

Por su extrema rapacidade (...) fue jeroglífico de la ruína y destrucción, pues es muy peligroso y su mordisco incurable (ibidem, p. 160)

Além da morte, traz também a vida, pois os antigos (Aristóteles, Plutarco, Eliano) viam no crocodilo a qualidade de se proliferar muito, já que o mesmo chega a pôr mais de sessenta ovos de cada vez: eis que nosso emblema chega a ser mais um jogo barroco, um paradoxo imagético conceitual. Afinal, que é a morte senão o renascer das cinzas em seu perpétuo 
continuum, quando a matéria morta se incorpora na matéria viva? Que melhor representação para a morte que a de reproduzir-se indefinidamente ${ }^{158}$, numa época marcada por contínuas guerras como a dos Trinta Anos, que não parava de ceifar vidas numa proliferação de destruição quase sem fim?

Conforme nos
mostra Maravall, a
familiarização com a
violência decorrente do
espetáculo cotidiano da
repressão e da guerra
(Maravall, 1997, p. 268)
contribuiu não só para a
inclinaçãor pela
crueldade ${ }^{159,} \quad$ como
também orientava todo o
delineamento patético e
pessimista do Barroco, a
fim de pôr às claras a condição humana para

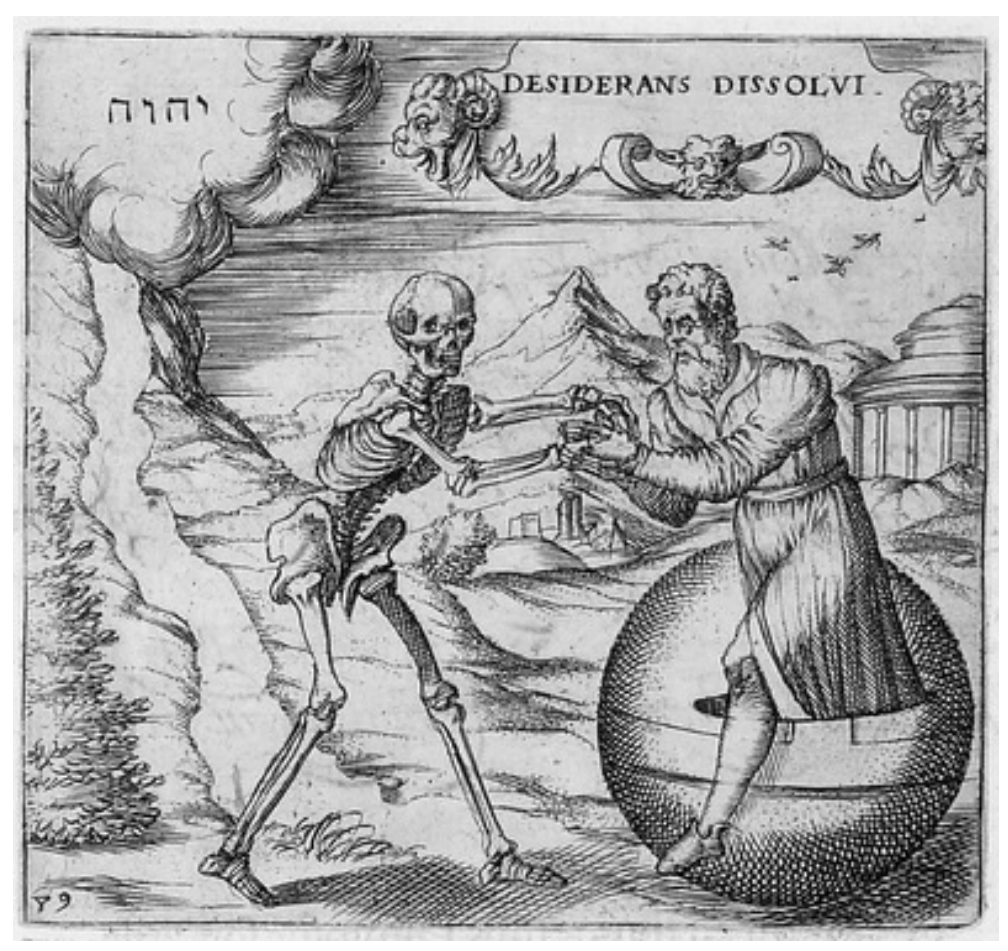

Figura 48: Emblema 89, Desiderans dissolvi, Georgete de Montenay, 1615.

dominá-la, contê-la e dirigi-la (ibidem, p. 268). Contudo, essa obsessão mórbida não é fruto exclusivo do século XVII, nem mesmo da centúria anterior, remontando à Idade Média - tendo em vista, evidentemente, a cultura cristã -, o que se tem é uma diferença na abordagem. Na Idade Média, por exemplo, a morte era vista a partir de um pensamento teológico e coletivo, como o visto nas danças de esqueletos ${ }^{160}$ (fig. 48) que, não correspondia à idéia escatológica cristã do Juízo Final:

\footnotetext{
${ }^{158}$ Por isso Ripa também nos mostra o crocodilo em sua representação da luxúria, quando se vê uma mulher desnuda sentada sobre um crocodilo, porque ya decían los Egipcios que dicho animal era símbolo de Lujuria, en atención a su caracter fecundísimo, pues en efecto engendra muchos hijos; $y(. .$.$) es de tan contagiosa libinosidad que, según se cree comúnmente, atando$ al brazo diestro los dientes de su mandíbula superior, pueden excitar y provocar nuestra lujuria. (Ripa, op. cit. v. II, p. 34)

${ }_{59}$ Refletida, muitas vezes, nas Trauerspiele como a Sophie de Hallmann, em que, após o martírio imposto a uma cristã e a suas filhas, suas cabeças, decapitadas, são exibidas no palco como em um banquete dos mortos (Cf.: Benjamin, op. cit. p. 242). Gryphius também utilizava cadáveres e mortes no palco; o mesmo expediente também era encontrado nos palcos espanhóis (Cf. Maravall, op. cit., p. 267).

${ }^{160}$ Vale salientar a diferença que há entre a dança de esqueletos e a dança macabra: na primeira temos a representação que se dá somente entre esqueletos, ou seja, a morte já havia
} 
Não fiquem admirados com isso, porque vai chegar a hora em que todos os mortos que estão nos túmulos ouvirão a voz do Filho, e sairão dos túmulos: aqueles que fizeram o bem, vão ressucitar para a vida; os que praticaram o mal, vão ressucitar para a condenação. (Jo 5,28)

E que será mote para muitos poemas seiscentistas como alguns de Silesius:

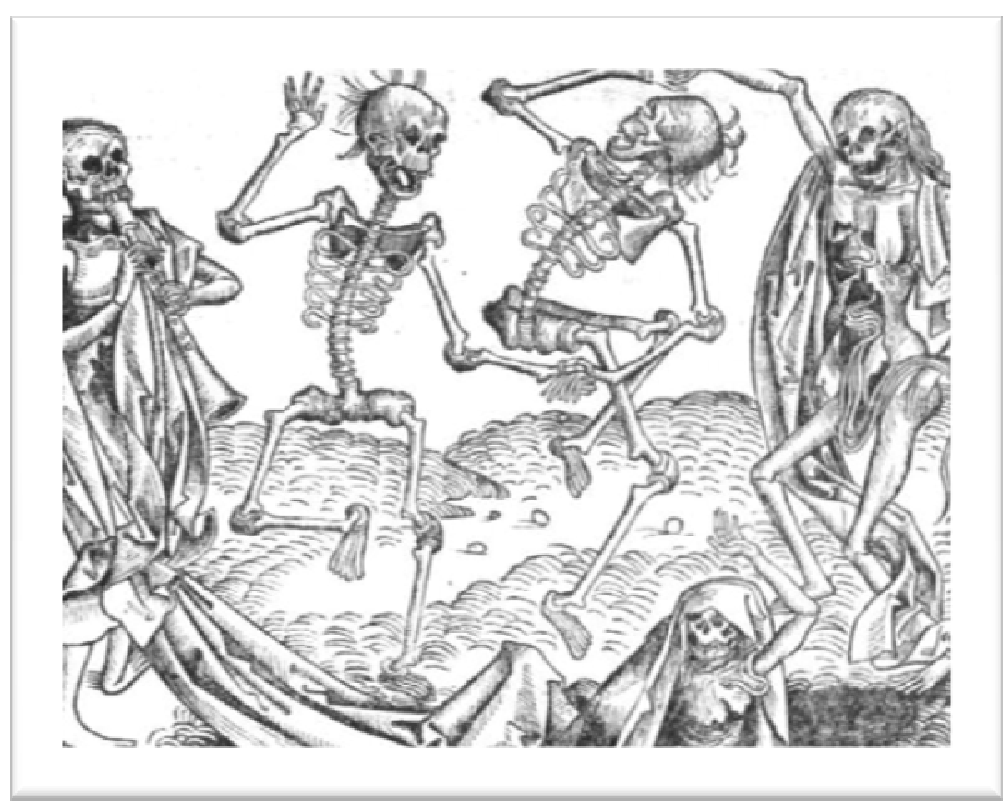

Figura 49: gravura do livro Liber Chronicum, de Hartmann Schedel, 1493.

Die Gräber alle tun sich auf,

Die Särge, die zerspringen,

Das Meer muß mit dem schnellsten lauf

Die Toten wieder bringen.

(Angelus Silesius, Sinnliche Beschreibung der vier letzten Dinge, p. 13)

[Todos os túmulos se abrem,/ Os caixões, que se esfacelam,/ O mar, com a mais rápida correnteza,/ Deve trazer de volta os mortos.]

sido instaurada e - segundo uma superstição medieval - os mortos chamam uns aos outros para, de forma burlesca, imitar os vivos antes de ir buscá-los; na outra, os mortos - esqueletos - estão acompanhadas de pessoas vivas, cf. a série de gravuras de Hans Holbein, $A$ dança macabra. 
No século XVII, o individual cede ainda mais espaço para o coletivo, afetando diretamente o eu que já vivia atormentado por graves conflitos sociais. É como se essa subversão generalizada penetrasse em cada um e fosse repassada ao todo coletivo, por isso era preciso operar com recursos psicológicos, excitá-los, conduzi-los (Maravall, 1997, p. 268), em suma, canalizá-los para que pudessem ser empregados a partir de um sentido ascético-religioso - o tu és pó e ao pó hás de tornar - ou mesmo social e político - faça o que mando senão esse será seu destino. Isso seria perfeitamente possível, visto ser essa a realidade presenciada por todos diante do fétido odor de morte que se espalhou pela Europa durante a Guerra dos Trinta Anos. Além disso, ninguém está protegido da morte, esta não escolhe suas vítimas pela posição social, por sua inteligência, por suas posses, afinal todos são convocados a seu chamado e convidados a entrar no barco que os levará para o outro lado do rio (fig. 50).

À medida que os Estados nacionais se consolidam no século XVII e o Absolutismo se mostra como seu unificador, verse-á que a realidade, representada no emblema 98 de Vaenius (fig. 50) se torna cada vez mais clara, pois vemos ali que todos, sem exceção, se verão diante da morte, principalmente em tempo de guerra (representada

pelas labaredas e pela

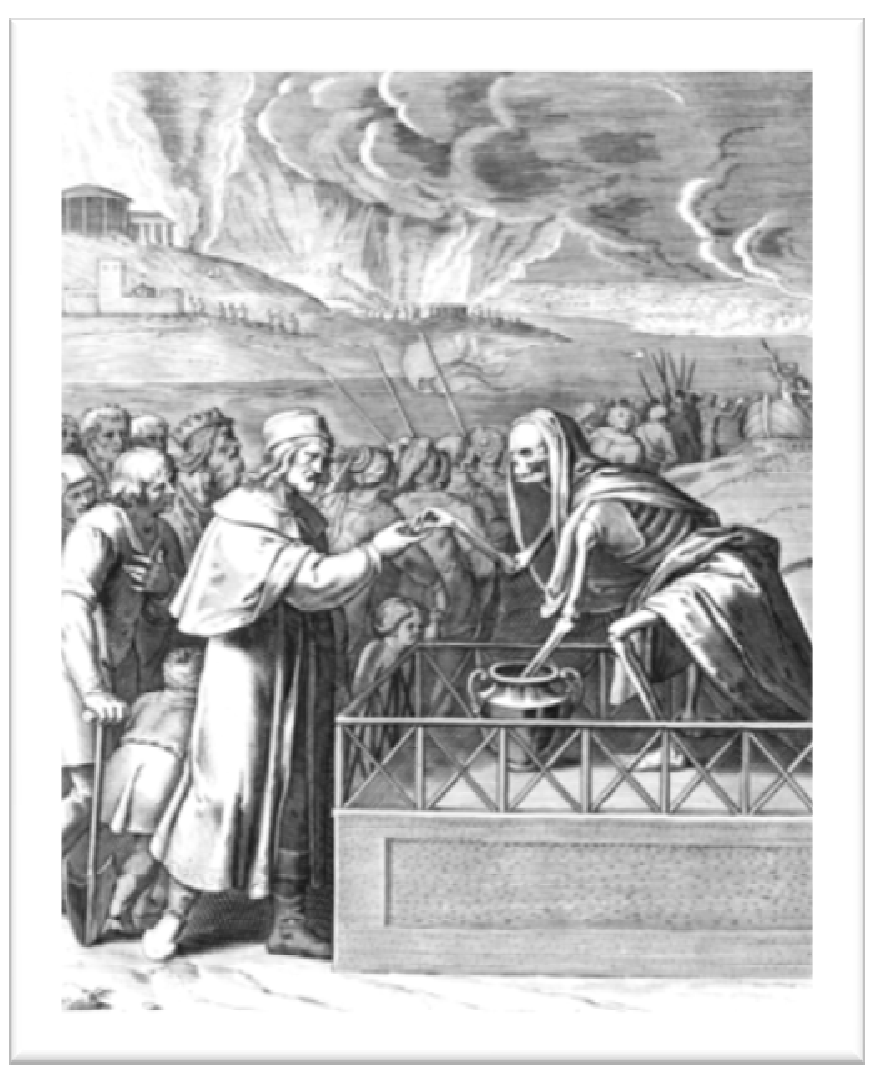

Figura 50: Emblema 98, Mortis certitudo, de Otto Vaenius, 1612. fumaça) seja o rei (representado com a coroa), seja o camponês (que traz a pá como instrumento de trabalho). Convém lembrarmos que a guerra, por exemplo, naquele período era encargo da nobreza: eram os reis, os príncipes e 
os nobres que se dirigiam para o front $^{161}$, fato que começa a mudar com o desenvolvimento do capitalismo, quando nobres enviam prepostos em seu lugar em troca de pagamento. A relação que podemos estabelecer entre a consolidação dos Estados nacionais, as guerras e a morte é o fato de que ocorre, no período, um fenômeno de violência coletiva, a contínua guerra de Estado contra Estado (Maravall, op. cit., p. 270), cuja precipitação fora no século anterior, mas que se converte em uma conflagração generalizada e permanente. (ibidem, p. 270) ${ }^{162}$

Podemos ver também na emblemática, formas mais brandas de retratação da morte e de sua relação com os homens como a apresentada no emblema 89, Desiderans dissolvi, Georgete de Montenay (fig. 48), quando se pode ver a morte convidar, acolher e retirar o homem do mundo - cuja representação é-nos dada pelo globo de onde o homem se retira - pelas mãos.

Temos, a seguir, alguns exemplos de como os poetas do Seiscentismo alemão trabalharam com esse conceito/imagem:

\section{Andreas Gryphius}

a) Der jtzt so pocht vnd trotzt/ läst vbrig Asch vnd Bein

(Gryphius, Sonette, p. 11)

[Que agora palpita e teima/ então restará pó e osso]

b) Nichts wird als Haut vñ Bein mehr an mir vbrig funden.

(Ibidem, p. 12)

\footnotetext{
${ }^{161}$ Tivemos na Guerra dos Trinta Anos, por exemplo, a morte de Gustavo Adolfo, rei da Suécia, cuja morte destruiu o sonho sueco de ser uma potência européia. O mesmo ocorrera a Portugal, quando D. Sebastião morre na batalha de Alcácer-Quibir, levando o país à penumbra da História durante quase um século.

162 Vale a pena a leitura de Maravall (p. 271), quando o mesmo nos mostra que o homem seiscentista acreditava que os bens naturais - alimentos, por exemplo - possuíssem um volume quantitativamente inalterável, ou seja, para que uma sociedade pudesse obter algo - e saciar-se - teria, forçosamente, de retirar de uma outra e isso, naturalmente, seria à custa de conflitos. Poderíamos, inclusive, fazer uma analogia com a idéia do Lebensraum de Hitler que cria ter necessidade de ir à busca do espaço vital, tomando de outros países aquilo que, segundo ele, a Alemanha já não poderia comportar para a saciedade de seu povo, como terra e mão-de-obra farta, inclusive escrava.
} 
[Nada se encontrará em mim além de pele e osso]

c) Ich finde meistens nichts vor mir/

Als gantz entfleischete Gerippe!

Hirnscheitel sonder Haar vnd Zier/

Antlitzer sonder Naß' vnd Lippe

Vnd Haupter sonder Haut vnd Ohr/

Gesichter sonder Stirn vnd Wangen/

Die Leffzen sind in nichts vergangen/

Noch wenig Zähne ragen vor.

(Gryphius, Vermischte Gedichte, p. 10)

[Geralmente, nada encontro em mim/ Além de ossos descarnados!/ Crânio sem cabelos e adornos/ Face sem nariz e lábios/ E cabeça sem pele nem orelhas/Sem testa, nem faces/ Os lábios transformaram-se em nada/ Só poucos dentes sobresaem.]

d) Schau wie die lebenden Gerippe

Mit tieffen Augen dir nachsehn/

Wie sie mit gantz verschrumpter Lippe/

(ibidem, p. 44)

[Olha como os esqueletos vivos/Te miram com os olhos profundos/ Como com lábios murchos]

\section{Berthold Brockes}

Es riß ein gräßliches Gekrach,

Wodurch des gantzen Hauptes Knochen.

(Brockes. Irdisches Vergnügen in Gott, p. 692)

[Rompe-se um estrondo terrível,/ por meio de todos os ossos do crânio]

\section{Simon Dach}

Trägt man den Sarg hinein,

Den Ewer Fleisch vnd Bein,

Was? Ewer Hertz sol füllen?

Seh ich, o grosses Leid!

Ein schwartzes Trawer-Kleid

Euch beyd' vmbhüllen? 
(Dach, Geistliche Lieder. Trostgedichte, p. 169)

[Traz-se no caixão/ Tua carne e teus ossos,/ O quê? Teu coração deve sentir?/ Vejo, ó grande sofrimento!/ Uma roupa negra de luto/ Envolvê-los ambos?]

\title{
Johann Klaj
}

\author{
Was war damals an dir/O du Zier der Künste/ \\ übrig/ als der abgefleischte Leib/ das von Haut \\ und Beinen zusammengeflikte Gerippe/geäderte Arme/ \\ gebrochene Augen/ eingefallene Wangen/ \\ die gehemmete Zunge/ und zerstimlete Worte?
}

(Klaj, Redeoratorien, p. 549)

[O que outrora restava em ti, ó tu adorno das artes/ além do corpo descarnado/ o esqueleto de pele e osso remendado, braços de veias/ olhos virados, faces caídas/ a língua travada/ e as palavras mutiladas?]

Ampulheta

A ampulheta e o relógio de bolso, além de evocarem a velocidade fágica do tempo, dão-nos consciência da degradação da matéria e da vida, representada pela perda do viço, pelo enrugamento no rosto, pelas gretas nos cantos da parede não representam, portanto, a morte em si:

Sanduhr oder Stundenglas, nicht in erster Linie ein Symbol des Todes, sondern der Vergänglichkeit und des Verrinnens der Zeit, was naturgemäß auch ein »memento mori« (gedenke des Todes, bzw. der unaufhaltsam näherrückenden Todesstunde) mit einschließt. Das Stundenglas gehört in erster Linie zu den Attributen des Zeitgottes Chronos oder Aion. Da das Zeitmeßgerät immer wieder umgedreht werden muß, um funktionieren zu können, läßt es sich auch mit einem Weltbild zyklischer Zeitabläufe in Einklang bringen, also mit der "ewigen Wiederkehr" kosmischer Situationen. (Biedermann, op. cit. p. 928)

[Ampulheta ou vidro das horas, que primeiramente não é símbolo da morte, mas da efemeridade e do correr do tempo, o que, portanto, engloba também um memento mori (lembra-te da morte, ou da chegada inexorável da morte). A ampulheta primeiramente faz parte dos atributos do deus do tempo, Cronos ou Aion. Já que a ampulheta deve ser virada 
continuamente para que funcione, ela pode ser associada a uma imagem do mundo com decursos cículicos do tempo, ou seja, com o eterno retorno de situações cósmicas.]

A subscriptio do emblema 12 (fig. 51), retirada do livro de Jó, demonstranos que o fim do eu-bíblico está próximo:

Como são poucos os dias da minha vida! Deixa-me, para que eu possa respirar um pouco, antes que eu me vá para nunca mais voltar, para o país da treva e da sombra da morte, para o país onde a aurora é noite negra, onde a sombra da morte cobre a confusão, e onde a claridade é escuridão. (Jó 10, 20-22)

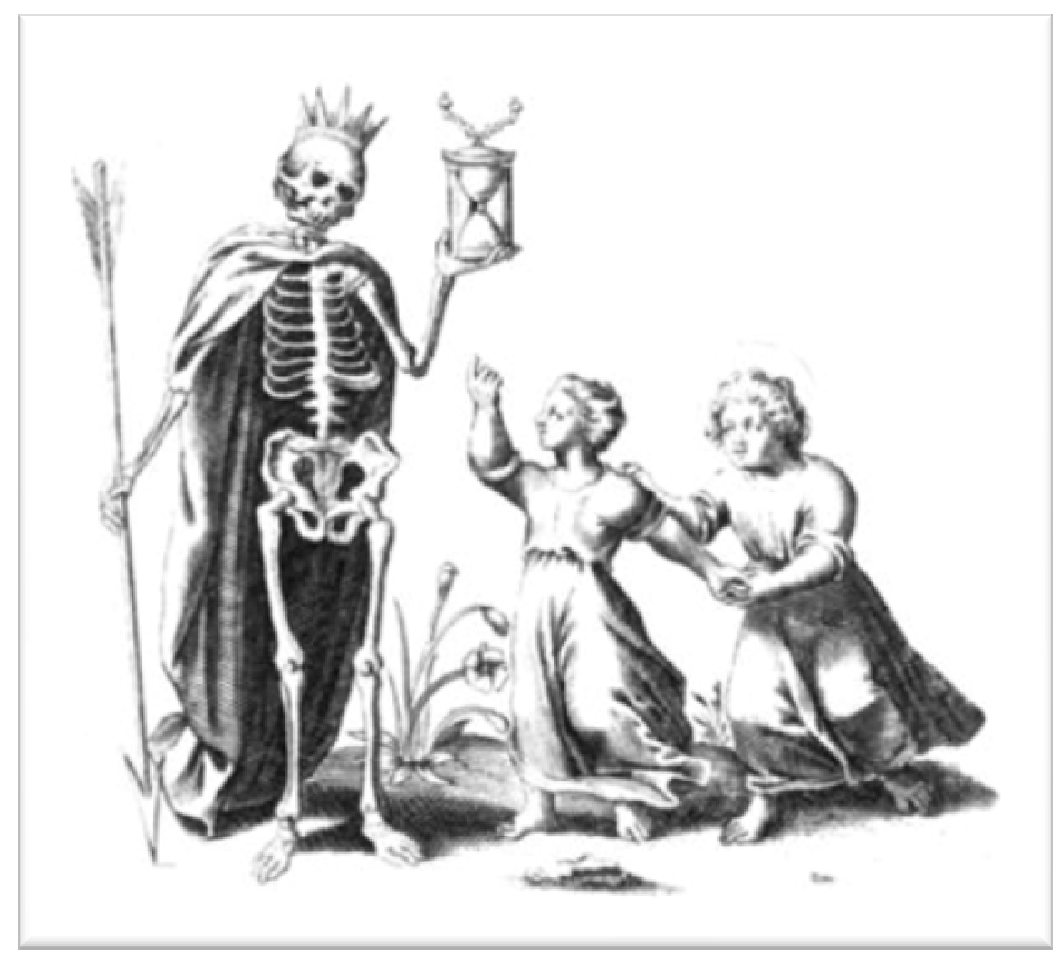

Figura 51: Emblema 12, Antipathia amoris et mortis, anônimo, 1628.

Dessa forma, uma das intenções da utilização emblemática da ampulheta é demonstrar que, apesar de o termo estar próximo, é possível ainda ter uma chance (respirar um pouco) e buscar não só a conversão dos pecados, como também a virtude:

Als Aufforderung zur Tugend soll das Sanduhr-Symbol an die Mäßigkeit erinnern, damit die dem Menschen zugemessene Zeit nicht durch Ausschweifungen willkürlich abgekürzt werde. Die heiligen Asketen Ambrosius und Magdalena werden mit der Sanduhr dargestellt. (Biedermann, op. cit., p. 928) 
[Como estímulo à virtude, o símbolo da ampulheta deve lembrar a medida. Para que o tempo concedido ao homem não seja encurtado, voluntariamente, por excessos. Os ascetas Santo Ambrósio e Madalena são representados por meio da ampulheta.]

Gryphius assim nos fala:

\author{
Uber eine Sand-Uhr \\ Der Sand der deine Zeit kan in dem Glaß abtheilen/ \\ Weist uns/ wie wir der Grufft/ der Hand voll Sand/ zueilen
}

(Gryphius, 1963, v. 2, p. 206)

[Sobre uma ampulheta

A areia no vidro teu tempo pode dividir/ nos mostra que da cova nos aproximamos, da mão cheia de areia]

As flores não só agradam e dão prazer a nossos olhos, como também por seu meio é possível perceber como a beleza se esvai em tão pouco tempo, o maravilhoso odor em breve lembra a morte e seu domínio. Evidentemente, a idéia primeira é a de representar o novo; vemos isso, por exemplo, na fig. 51, por isso está junto à criança que brinca de forma despreocupada. No entanto, e devido a isso, representa também a vanitas, já que o viço esvai-se de forma fugaz. Sua origem não se encontra no Seiscentismo, mas na Bíblia:

Os dias do homem são como a relva, ele floresce como a flor do campo. RoçaIhe um vento, e já não existe. (SI 103,15-16)

Dentre as flores, a rosa merece um destaque especial, visto ser um dos temas recorrentes na poética dos Seiscentos, devido a seu frescor enquanto botão, à sua beleza ímpar e ao fato de ser rodeada por espinhos, cuja conotação será largamente empregada por poetas de todas as épocas. Gryphius assim se expressa a seu respeito: 
Kein Stand/ kein Ort/ kein Mensch/ ist seines Creutzes frey/

Wo schöne Rosen Blühn/ stehn scharffe Dorn darbey.

[Nenhuma classe, nenhum lugar, nenhum homem está livre de sua cruz. Onde florescem belas rosas, estão os espinhos agudos.]

A vida na terra é comparada a rosa rodeada de espinhos:

\author{
Mit Thränen grüssen wir \\ In Thränen lebt man hir: \\ Mit Thränen gibt man gute Nacht! \\ Was ist der Erden Saal? \\ Ein herber Thränen-Thal! \\ Wie Rosen die wir zihn. \\ Auff Dörnern nur verblühn.
}

[Saudamos com lágrimas e em lágrimas se vive aqui: com lágrimas se dá boa-noite! O que é o salão da terra? Um amargo vale de lágrimas, assim como as rosas que cultivamos: só florescem com espinhos]

Os espinhos, dentro da tradição cristã ocidental, remetem à coroa ${ }^{163}$ recebida por Cristo durante seu martírio, tendo, portanto, várias conotações negativas em relação à condição humana. Segundo Ambrósio (séc. IV d.C.), a rosa rodeada de espinhos representava a condição humana após a expulsão do homem do paraíso, significaria Welt Wollust (prazer mundano). (Cf.: JÖNS, 1966, p. 120) Esse é justamente o nome do soneto cujos versos (Kein Stand...) foram transcritos acima: Der Welt Wollust ist nimer ohne Schmerzen [O prazer do mundo jamais é sem dor]. Ambrósio recorreu ao Gênesis:

\footnotetext{
${ }^{163}$ Quando se fala em coroa de espinhos esquece-se, normalmente, do duplo caráter negativo desse ato dentro do mundo judaico. Primeiro, 0 ato pode ser visto como uma afronta/humilhação do homem judeu supliciado que diziam ser rei, porém não era aceito como tal por aqueles que o condenaram, logo atingiria a todos os presentes: eis seu rei - havia dito Pilatos; segundo, os antigos reis hebreus não recebiam coroa, eram ungidos com óleo, seria portanto a constatação de uma pantomima da humilhação com seu gran finale: o fato de a mesma não ser de ouro, mas de espinhos, logo o rosto do futuro supliciado estaria eclipsado lembrando Gregório de Matos - devido ao sangue que jorrava dessas feridas.
} 
A terra produzirá para você espinhos e ervas daninhas, e você comerá a erva dos campos. Você comerá seu pão com o suor do seu rosto, até que volte para a terra, pois dela foi tirado. Você é pó, e ao pó retornará. (Gn 3, 18-19)

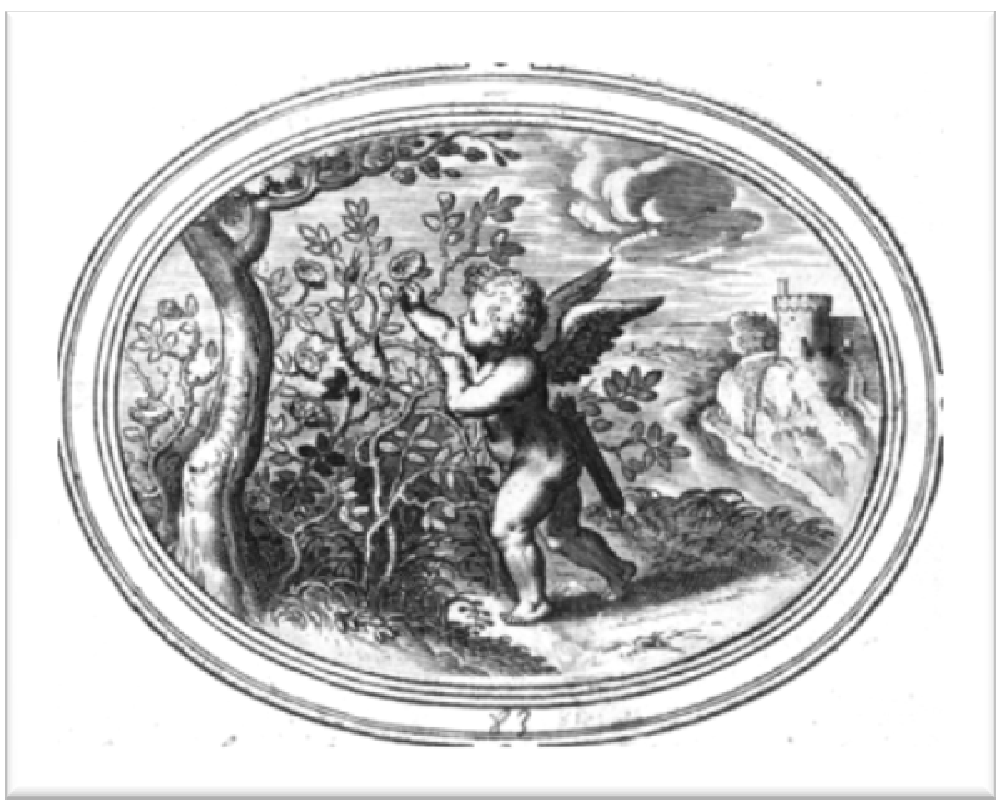

Figura 52: Emblema 81, Armat spina rosas, mella tegunt apes, de Otto Vaenius, 1608.

Ripa mostranos os espinhos para retratar a compunção:

Tiene los ojos vueltos hacia el Cielo y vierte copiosas lágrimas, llevando en la cabeza una corona de punzantes espinas. Sostiene con la izquierda un corazón, coronado de espinas igualmente (...).

Tiene además dos coronas de espinas (...) [y] representa la culpa contraída por el pecado; culpa que sin cesar punza y remuerde la conciencia, quedando simbolizada por la corona que en la cabeza lleva. (Ripa, op. cit. p. 205-206)

Gryphius também compara a rosa com Cristo, especificamente como se fosse seu cetro, ou seja, sua autoridade:

\section{(...) er wird der Armen Recht/}

der müden tröster seyn/ er wird was krum' ist schlecht/ was dunckel offenbar/ was langsam eilends schlichten er ist den Rosen gleich/ sein Zepter stärckt und bricht gleich wie ein Rosen-Zweig wol reucht/ und hefftig sticht.

[(...) ele será consolador do direito dos pobres e dos cansados; ele melhorará o que está torto e mau; tornará claro que está escuro; o que é lento, será apressado. Ele é como as rosas: seu cetro fortalece e quebra; assim como um galho de rosa é perfumado e fere com intensidade.] 
Cristo é visto aqui como soberano imparcial, misericordioso e justo, daí a correspondência feita com a rosa, que exala perfume refrescante, mas possui espinhos que podem ferir. No emblema 211, sobre as rosas, Picinelli havia

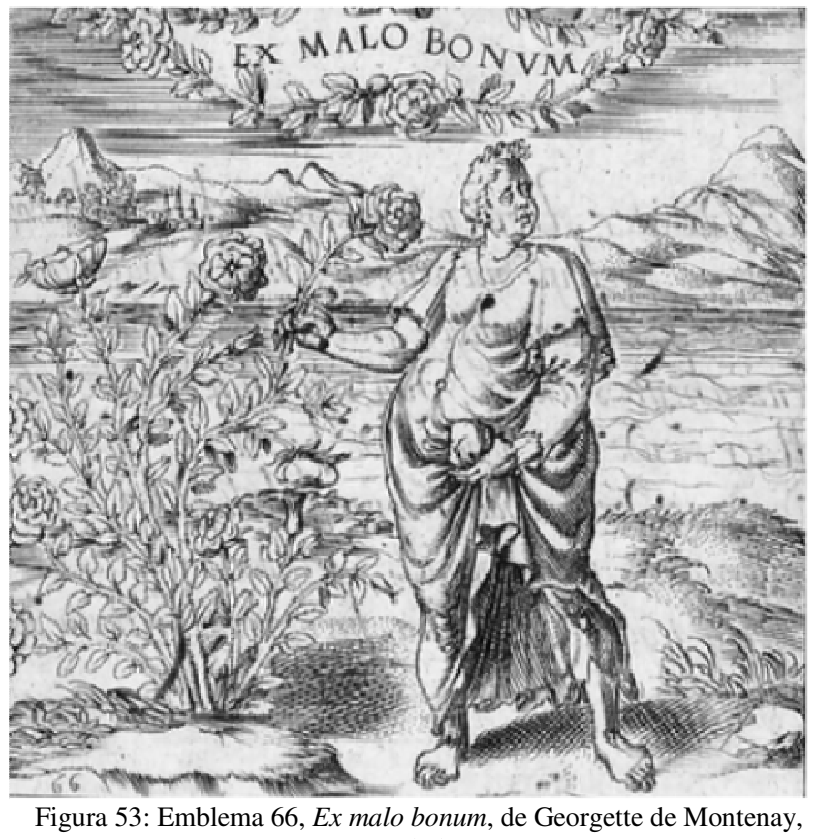
1615 . expressado como mote: Pungit \& recreat; quando se referiu à natureza de Deus, essa característica da rosa significava Justitia \& Misericordia. (Cf.: JÖNS, op. cit. p. 124); Georgette de Montenay, por sua vez, em seu emblema 66 Ex malo bonum [Do mal ao bom], também se refere ao espinho da rosa, quando vemos uma mulher colhendo uma ${ }^{164}$ (fig. 53), afirmando-nos de seu poder de acalmar o peso do jugo, utilizando a figura do boi em seu trabalho de arado.

Temos, a seguir, alguns exemplos de como os poetas do Seiscentismo alemão trabalharam com esse conceito/imagem:

\section{Angelus Silesius}

Des Fleisches Schönheit und ihr Ruhm/

Scheint mir wie eine blasse Blum

(Angelus Silesius, Heilige Seelenlust oder geistliche

Hirtenlieder, p. 141)

\footnotetext{
${ }^{164}$ Esse emblema, por sinal, faz-me lembrar de várias fotos de pessoas simples em seus pequenos jardins, quando fazem questão de se fotografar segurando rosas ou outras flores.
} 
[A beleza carnal e sua glória/ parece-me como uma pálida flor]

\section{Andreas Gryphius}

a) Mag auch an Schönheit was/ der Blum zu gleichen seyn?

(Ibidem, p. 17)

[Também desejaria ser comparado à beleza da flor?]

b) Als eine wiesen blum/ die man nicht wiederfindt.

(ibidem, p. 34)

[Como uma flor do campo que não se reencontra]

Vanitas, vanitatum et omnia vanitas

\section{SIGMUND VON BIRKEN}

Hier Weh, dort Wohl; hier Leid und dorten Freud;

Hier Eitelkeit und dorten Ewigkeit

(Birken. Geistliche Lieder, p. 42.)

[Aqui dor, lá bem; aqui sofrimento e lá alegria; Aqui vaidade e lá eternidade]

\section{ANGELUS SILESIUS}

a) Wie bin ich zugerichtet!/ O Eitelkeit, o Sündenwust,/

(Angelus Silesius. Heilige Seelenlust oder geistliche Hirtenlieder. p. 321)

[Em que estado estou! Oh vaidade, oh deserto de pecados!]

b) O Tod, o Eitelkeit, was denkst du dich so groß!

(Ibidem. p. 520.) 
[Oh morte, oh vaidade que te imaginas tão grande!]

\section{SIMON DACH}

Hier ist das Reich der Eitelkeit,/Hie herschen Unfall, Glück und Zeit,

(Dach. Geistliche Lieder. Trostgedichte. p. 491)

[Aqui é o reino da vaidade, aqui reina infelicidade, sorte e tempo]

\section{ANDREAS GRYPHIUS}

Ich seh' wohin ich seh/ nur Eitelkeit auff Erden/

Was dieser heute bawt/ reist jener morgen ein

(Gryphius, 1963, v.1, p. 7)

[Para onde olho, só vaidade na terra vejo/ O que este hoje constrói, aquele amanhã destrói]

O pintor se retrata jovem exibindo-se quando idoso. Na realidade, a relação deveria inversa, ou seja, o homem maduro é que teria de apresentar o jovem, já que a maturidade seria seu tempo presente. Vê-se, portanto, a passagem do tempo e da juventude (apesar do jogo realizado pelo artista).

\section{ANDREAS GRYPHIUS}

Ich bin nicht/ der ich war/ Die kräffte sind verschwunden!/

Die Glieder sind verdort wie ein verbrandter Grauß/

(Gryphius: Sonette, p. 12 )

[Eu não sou o que era/ As forças desapareceram!/Os membros estão murchos como um horror queimado] 


\section{SIMON DACH}

Ich bin alt und matt/ Vnd des Lebens satt.

(Dach: Geistliche Lieder. Trostgedichte., S. 369)

[ Estou velho e fraco/ e cansado da vida] 
PARTE II 


\section{CONSTITUIÇÃO DE UM MODELO ICONOFOTOLÓGICO}

Rompimento do modelo epistemológico mimético (iconológico e emblemático)

omper barreiras: uma das principais qualidades do homem, seja
transportando pedras gigantescas - para construir pirâmides - seja superando a velocidade do som - numa aeronave. Exemplos não faltam, o próprio homem pode ser considerado uma barreira superada dentro da natureza: tinha tudo para não vingar dentro da evolução, no entanto o $\lambda o ́ \gamma o \varsigma$ aliado à $\tau \varepsilon ́ \chi v \eta$ foram nosso diferencial. Entretanto, a barreira transposta que nos importa não está no passado remoto, tampouco no tão próximo, mas refere-se ao rompimento da $\mu$ ím esboçar-se, de forma incipiente, já no século XVIII, aprimorando-se no século XIX, e efetivando-se no século XX.

A partir dessa ruptura, caberia ao artista demonstrar seu gênio criador e verificar-se-ia um deslocamento da obra artística - de mimética para expressiva -, tanto na arte pictórica quanto na poética; além disso, selar-se-ia a relação estabelecida por essas duas artes, cujo princípio norteador foi o Ut pictura poesis. Este foi posto em xeque, já no século XVIII, por Lessing em sua obra Laocoonte: ou sobre as fronteiras da pintura e da poesia, quando, ao demarcar as fronteiras entre poesia e pintura, antecipa o rompimento entre as duas. O relacionamento entre essas expressões artísticas havia sido harmônico desde o Renascimento, tendo como manifestação as iconologias e o gênero emblemático ${ }^{165}$.

Lessing delimita o campo de atuação tanto da imagem quanto da escrita a dois aspectos não intercambiáveis: o tempo e o espaço. Aquele ficaria a cargo da poesia, este da pintura que

pode utilizar apenas um único momento da ação nas suas composições coexistentes. Deve, portanto, escolher o momento mais expressivo a partir do qual se

\footnotetext{
${ }^{165}$ Evidentemente, a relação entre poesia e pintura não tem início no Renascimento, mas na Antigüidade.
} 
torna mais compreensível o que já se passou e o que se seguirá. (Lessing, 1998, p. 194)

Sendo necessário, destarte,

renunciar totalmente ao tempo: ações progressivas não podem, enquanto progressivas, fazer parte dos seus objetos, mas ela tem que se contentar com ações uma ao lado da outra ou com meros corpos que sugerem uma ação através das suas posições. (ibidem, p. 190)

Por seu lado, à escrita caberia desenvolver as ações, ou segundo Lessing, expor os corpos por seu meio (Cf.: ibidem, p. 193), quando as ações vão sendo pintadas à medida que o leitor vai lendo (Cf.: ibidem, p. 195), em um ato contínuo de protensão e retenção, afinal não somos capazes de apreender um texto num só momento (Iser, 1999, p. 11) como um todo perceptível à semelhança de um objeto qualquer:

Enquanto o objeto da percepção se evidencia como um todo, o texto apenas pode ser apreendido como "objeto" em fases consecutivas da leitura. Em relação ao objeto da percepção, sempre nos encontramos diante dele, ao passo que, no tocante ao texto, estamos dentro deste. (Ibidem, p. 12)

Desde fins do século XVIII, portanto, o conceito de $\mu i ́ \mu \eta \sigma \iota \varsigma$ já estava sendo abolido e recusado pelos jovens românticos alemães que visavam não só à plena liberdade na criação artística como também a uma nova afirmação da arte, não mais voltada, especificamente, à mera imitação da natureza, mas à produção e à reprodução do espírito. Friedrich Wilhelm Schelling (17751854), por sua vez, propõe não a negação total do princípio mimético, mas sua transformação (Cf.: Gonçalves in Duarte (org.), 2001, pp. 289-293); Friedrich Schlegel (1772-1829), por sua vez, via no Romantismo uma transformação estética definitiva, cujo sentido principal seria o de libertar a arte não só de sua função mimética em relação à natureza, mas também de sua forma inferior de apreensão da verdade 
a partir da consolidação da idéia de que a arte é produzida por uma subjetividade necessariamente livre e naturalmente criadora, ao mesmo tempo intelectual e intuitiva, consciente e inconsciente de e em sua criação artística. (ibidem, p. 289)

Quanto mais as artes - a pictográfica e a poética - distanciavam-se, mais procuravam independência uma da outra. Já no século XIX, vemos, em relação à pintura, que

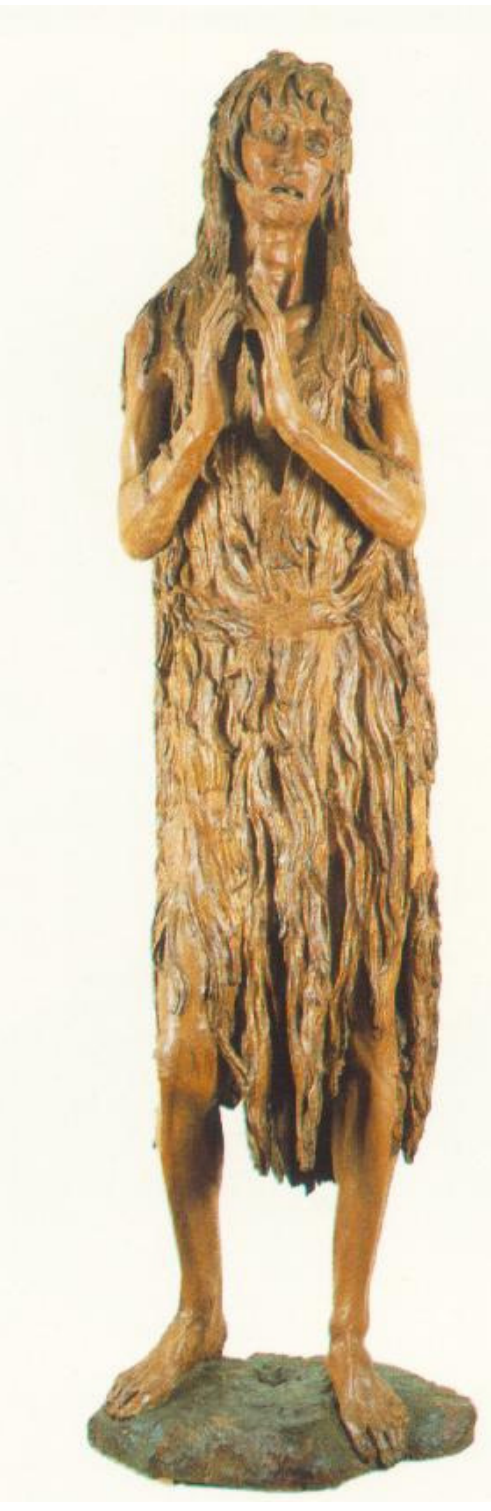

Figura 54: Santa Maria Madalena, de Donatello, (1453-55)

se inicia um verdadeiro exorcismo de todos os elementos literários e figurativos no processo que se inicia com o Impressionismo e que culmina na pintura abstrata e/ou conceitual. Através da ruptura com a tradição convencional de linguagem $e$ textualidade (iconografia) os pintores das diferentes tendências modernistas se concentram no desenvolvimento do puramente visual. (Schøllhammer, 2001, pp. 30-31)

Simultaneamente, verificar-se-ão a quebra do domínio mimético na arte e o distanciamento da obra artística dos modelos preestabelecidos pelos tratados iconológicos e emblemáticos. Estes foram, simplemente, esquecidos, resultando daí o fato de a obra artística barroca ter sido considerada obscura, já que era repleta de detalhes poluidores e desnecessários. Entretanto, 0 que se considera supérfluo nesse fazer artístico, corresponderia, exatamente, ao desconhecimento de sua codificação, ou seja, ao óbvio vácuo cultural diacrônico perpetrado pelo tempo.

Para ilustrar esse ostracismo a que se relegaram esses fazeres artísticos e prosseguirmos com o objeto desta Tese, temos de retornar ao exemplo dado na Parte I, à obra de Pedro Mena. 
Tendo-a como mote ${ }^{166}$, poderemos compará-la a algumas obras que tratam do mesmo objeto (a representação de Santa Maria Madalena), quando será possível visualizarmos diferentes abordagens desse tema no correr dos séculos. Dessa forma, perceber-se-á que teremos diante de nós:

a) uma representação distanciada daquilo que consideramos hoje como real ${ }^{167}$ ou natural, apesar de dar-nos a impressão de serem únicas e originais, se comparadas a outras de um momento diferente daquele. No entanto, se a cotejarmos com outras do mesmo período, surpreender-nos-emos com a similitude entre ela e suas contemporâneas, devido a certa regularidade com que os artistas do período abordavam temas afins. Certifica-se, dessa maneira, que essas obras não eram singulares, tampouco originais (basta analisarmos a pose e a indumentária empregadas pelos artistas do período em várias de suas imagens): esses tinham de seguir regras específicas de representação, definidas por manuais e tratados preestabelecidos, resultando em obras artísticas, por vezes, análogas: modificavam-se as feições do representado, não o modo de representação ${ }^{168}$;

b) um total desconhecimento das preceptivas retóricas auferidas por aquelas obras da sociedade em que se inseriam, mas que mesmo sendo simplesmente ignoradas, serviriam, em alguns casos, inclusive como adorno pictórico, como se vê com e emprego do crânio na fig. $55^{169}$.

\footnotetext{
${ }^{166}$ Apesar de a mesma não ser aquilo que, segundo o lugar-comum, poderíamos considerar como modelo de arte barroca.

${ }^{167} \mathrm{Na}$ medida em que obras similares possuíam uma representação análoga. Não poderíamos dizer, entretanto, que não houvesse verossimilhança naquelas obras, mas certa artificialidade, principalmente na obra escultórica, devido à utilização de expressões similares em diferentes obras, dando-nos a impressão de uma constante repetição: mudavam-se, simplemente, os nomes das obras, daí o porquê de aquilo que consideramos real hoje diferir muito do que se considerava real no século XVII.

${ }_{168}$ Conforme havia sido ilustrado, anteriormente, para exemplificar o conceito de penitência, quando comparamos as representações entre Maria Madalena e São Jerônimo. Apesar de isso ser claro na obra pictórica, fica muito mais evidente na obra escultórica, quando se deve ler a legenda para se saber de quem se trata.

${ }^{169}$ Nos moldes dos lugares-comuns, cujo significado primeiro se perde no tempo, apesar de sua constante utilização.
} 
Na fig. 54, obra escultórica renascentista do italiano Donatello ${ }^{170}$ (13861466), Maria Madalena é-nos apresentada como uma mulher velha, de rostro macilento, revestida com ropas tristísimas y pobres (...), mirando atentamente a los Cielos (Ripa, 1987, p. 190): sinal de penitência para a Iconologia de Ripa.

No entanto, suas mãos, à diferença da obra de Mena, estão juntas, por isso podem indicar-nos:

a) A terceira Bem-aventurança (ibidem, v. 1, p. 150): Felizes de vocês que agora choram, porque hão de rir (Lc 6, 21b). Já que ela, agora velha, pode receber a recompensa que tanto almeja: reencontrar-

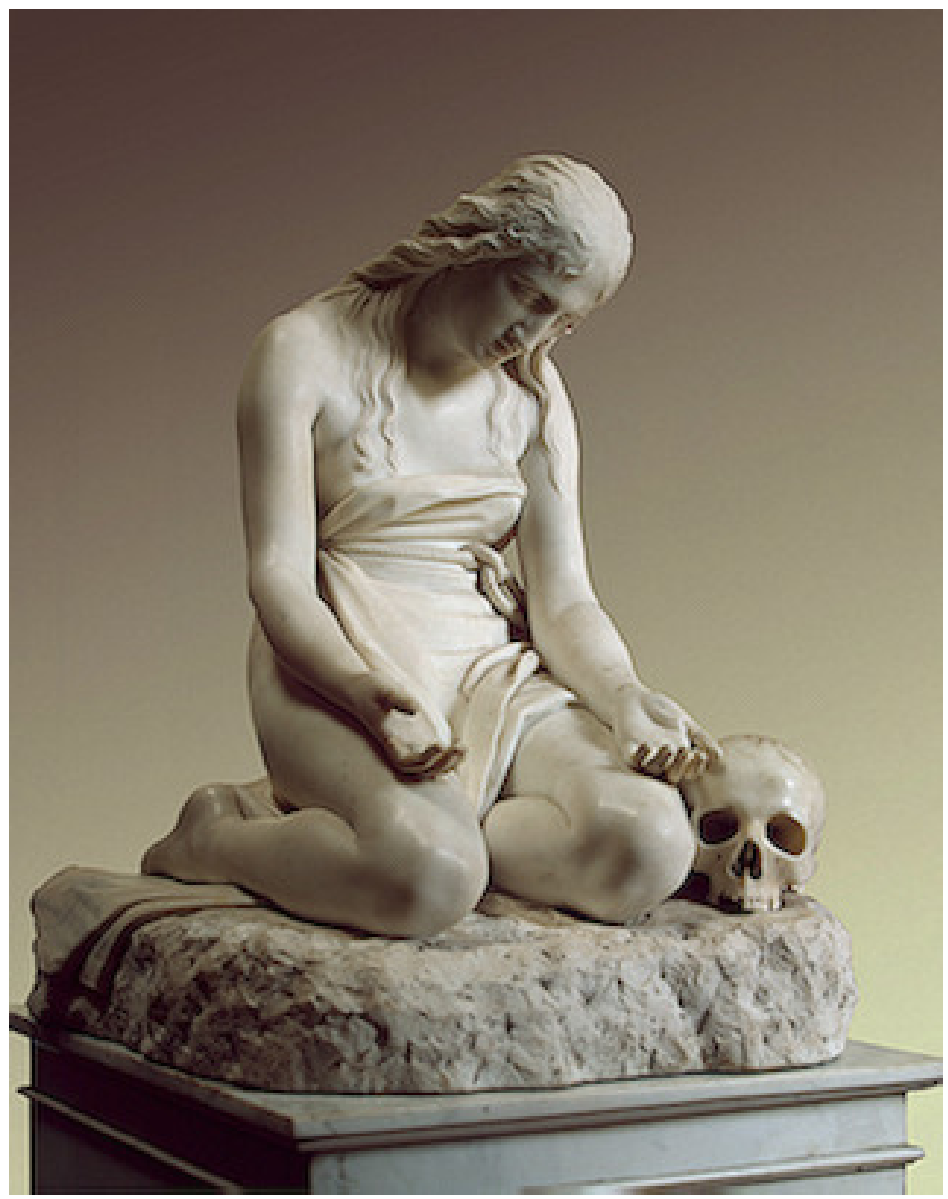

Figura 55: Maria Madalena penitente, de Antonio Canova, 1809.

$\overline{170}$ Donato di Niccolò di Betto Bardi. 
se com o Mestre, afinal já chorara demasiadamente durante sua vida;

b) Meditação espiritual, pois con las manos juntas, una contra otra, simbolozándose con ello el efecto de la devoción y la humildad que se encuentra en las personas, continuando y ejerciendo de este modo la medida y alcance de la Meditación Espiritual (Ripa, 1987, p. 64).

Por outro lado, o aspecto desolador da imagem também poderia levar 0 leitor seiscentista a lê-la, inclusive, como indicação de melancolia:

Mujer vieja, muy triste y dolorida, vestida com paño basto y sin ningún ornamento. (...)

Se pinta anciana por ser los jóvenes de ordinario más alegres, y los viejos por el contrario melancólicos, como dice Virgilio (...).

Va mal vestida y careciendo de adornos, a semejanza de los árboles cuando se ven sin hojas y sin frutos; pues nunca levanta su ánimo al melancólico hasta el punto de procurarse las necesarias comodidades, a fin de proveer o rehuir los males que imagine le acechan. (ibidem, p. 65)

O mesmo não se pode dizer da Madalena (fig. 55) do também italiano Antonio Canova (1757-1822), retratada como uma mulher jovem, bonita e sensual que, sentada sobre as pernas posta-se numa atitude, segundo nosso ponto de vista, de adoração, de entrega, de oração. No entanto, a disposição de seu corpo e de seus gestos não corresponderia a nenhuma das ações enumeradas acima, pelo menos segundo a pesquisa que realizamos a partir de Cesare Ripa. Na representação da oração, por exemplo, a mulher

Se pinta de rodillas y con los brazos abiertos para mostrar la reverencia que se debe tener para con Dios, y de modo particular si se estuviese rezando. (ibidem, p. 160)

No entanto, a cabeça deveria estar voltada para o céu:

El llevar levantada la cabeza, mirando hacia la luz que antes dijimos, claramente nos muestra (...), que la Oración no viene a consistir sino en cierta 
elevación o sublimidad de la mente y excitación de nuestro afecto, de manera que el hombre (...) se sincera con Dios (...). (ibidem, p. 160)

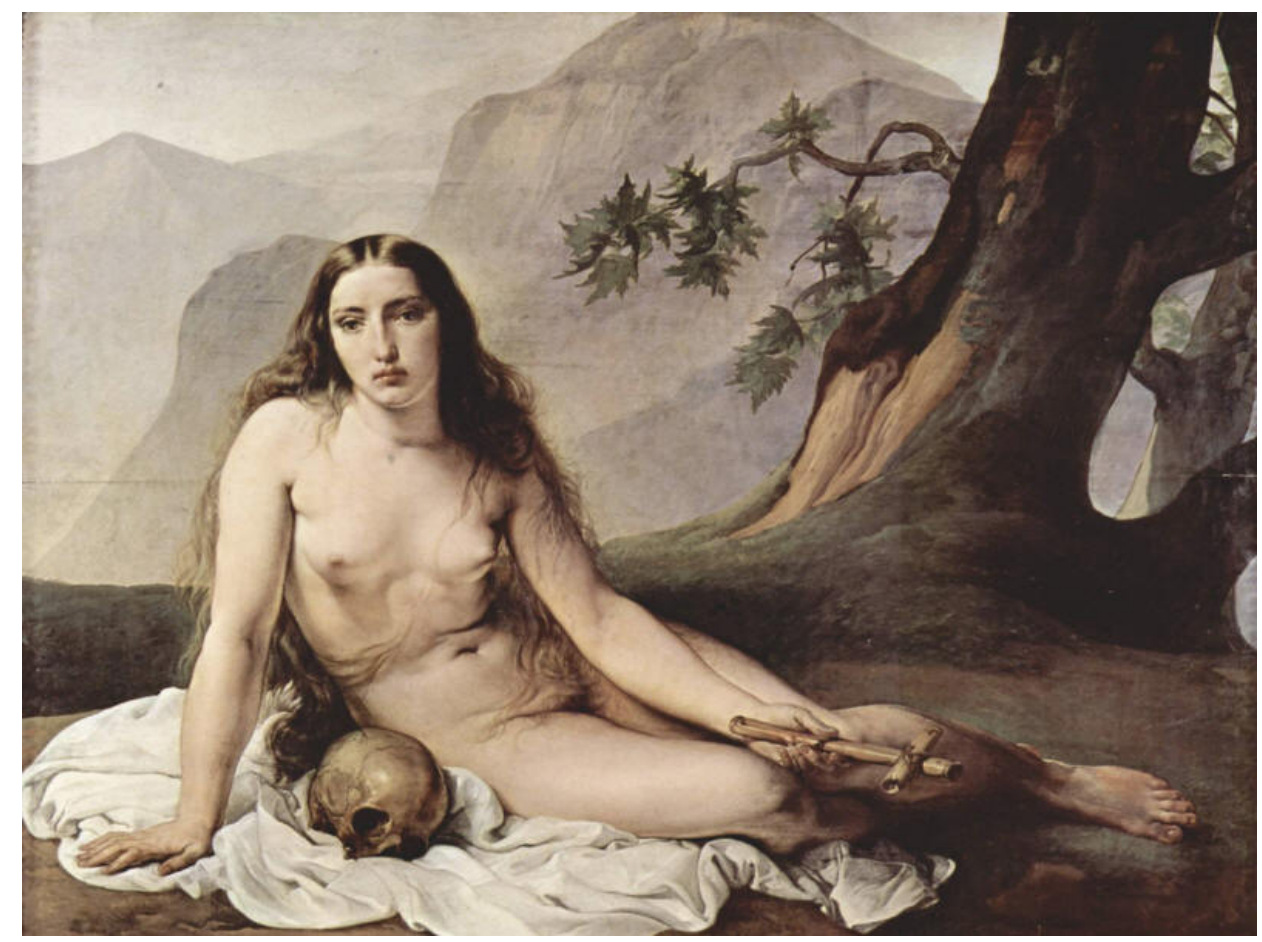

Figura 56: Maria Madalena penitente, De Francesco Hayez, 1825

Os leitores do século XVII, por exemplo, até poderiam ler os olhos baixos de Madalena como sendo sinal de humildade:

Mujer con traje blanco; lleva los ojos bajos, mientras sostiene en brazon un tierno Corderillo.

$(\ldots)$

Ha de ir vestida de saco, mientras que pisote a algunas ropas de aspecto valiosísimo. (ibidem, v.1, p. 499)

No entanto, são, evidentemente, meras especulações. Apesar disso, é possível verificar que a Madalena de Canova possui um vestido cingido por uma corda à semelhança da de Pedro Mena, e que esteja sobre algunas ropas: mas esse sentar-se sobre as pernas não demonstraria a devida reverencia que se debe tener para con Dios.

Provavelmente, o único sinal que remete à penitência seja a idéia de despojamento a que o crânio, ao lado da jovem, possa remeter, conforme os modelos provenientes da emblemática (figs. 17 e 18), conhecidos, 
seguramente, pelo escultor, mas utilizados como mero adorno, pois os outros elementos - digamos essenciais: o cilício, o crucifixo e o estar de joelhos - são ignorados.

Os novos leitores querem vislumbrar a plasticidade da obra, interessamse por sua beleza estética, sua criatividade, sua subjetividade, enfim como o

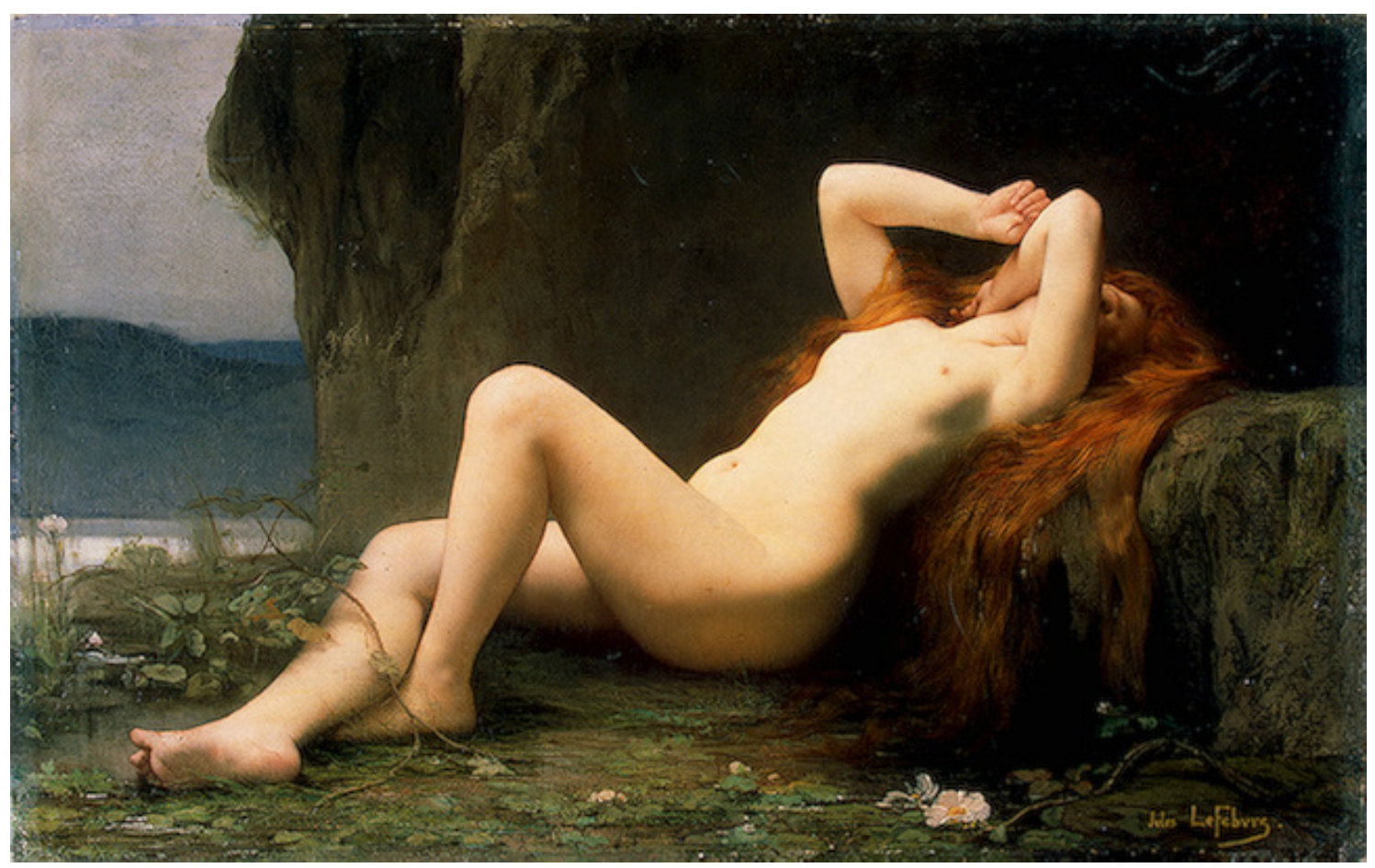

Figura 57: Maria Madalena na gruta, de Jules Josef Lefevre, 1876.

tema foi abordado: os tempos já são outros, ou seja, mesmo que os elementos iconológicos apareçam na obra, sempre serão meros adornos como na fig. $56^{171}$, visto que a leitura de grande parte dos contemporâneos de Francesco Hayez (1791-1882) restringir-se-á ao campo das leituras pré e iconográfica, pois, dificilmente, adentrarão no campo iconológico, afinal esse referencial foi sendo esquecido, coberto por um velame que, ao fortalecer-se, encobre tudo e já não será possível visualizar mais nada (fig. 57), quando já não é mais possível imaginar como teria sido a concepção original da obra. Esta de sacra - a representação de uma santa da Igreja católica -, torna-se pagã, pois poderia ser a representação de qualquer divindade greco-romana: eis o fruto

\footnotetext{
${ }^{171} \mathrm{Na}$ literatura, por exemplo, pode haver a utilização de costumes lingüísticos particulares, seguindo a convencionalidade de uma comunidade ou região como os verificados anteriormente (por exemplo, a palavra pérola) que, acreditamos, estavam de tal forma arraigados na cultura que não puderam - ou não se quis - ser abandonados prontamente.
} 
da liberdade estética e da criatividade, cuja escolha fica na mão do artista, demonstrando que o poder de criação está, agora, em suas mãos.

Essa liberdade criadora e a possibilidade de experimentação no campo das artes, era impensável para o homem dos Seiscentos, atado que estava à

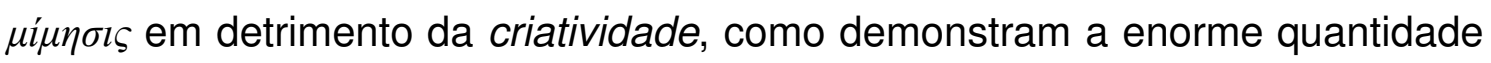
de iconologias que circularam no período, cujos paradigmas deveriam ser seguidos. Por isso a obstinação de Schlegel e dos românticos alemães, para quem a arte tinha de ser produzida por uma subjetividade livre e criadora, ou seja, um eu que fugisse dos modelos preestabelecidos, da mera imitação, e quese voltasse ao individual, ao emotivo, em detrimento do racionalismo coletivo a que a arte estava submetida.

Evidentemente que o século XIX libertou-se da $\mu i ́ \mu \eta \sigma ı \varsigma$, mas não das imagens. Estas expandiram seu campo de ação para além das fronteiras da emblemática e das iconologias - e de toda a tradição da Antigüidade que a acompanhava -, como modelos epistemológicos e paradigmáticos, permeando-se de outros elementos inimagináveis, afinal adentraram no reino da criação pura (da $\pi o i ́ \eta \sigma \iota \varsigma)$, quando o real é criar o não-real, como se verá na arte contemporânea com o rompimento total da relação imagem-texto que havia sido proposta desde a Renascença. Apesar desse rompimento mantiveram-se alguns resquícios, não mais como um preceito a ser obedecido, mas sob a direção e o domínio do artista.

Em A vida de Maria Madalena (fig. 58), Salvador Dalí mescla elementos surreais com os da Renascença - os mesmos das iconologias e da emblemática -, revelados pela figuração dessa tela, utilizadas ao bel prazer do pintor, não por imposição. 


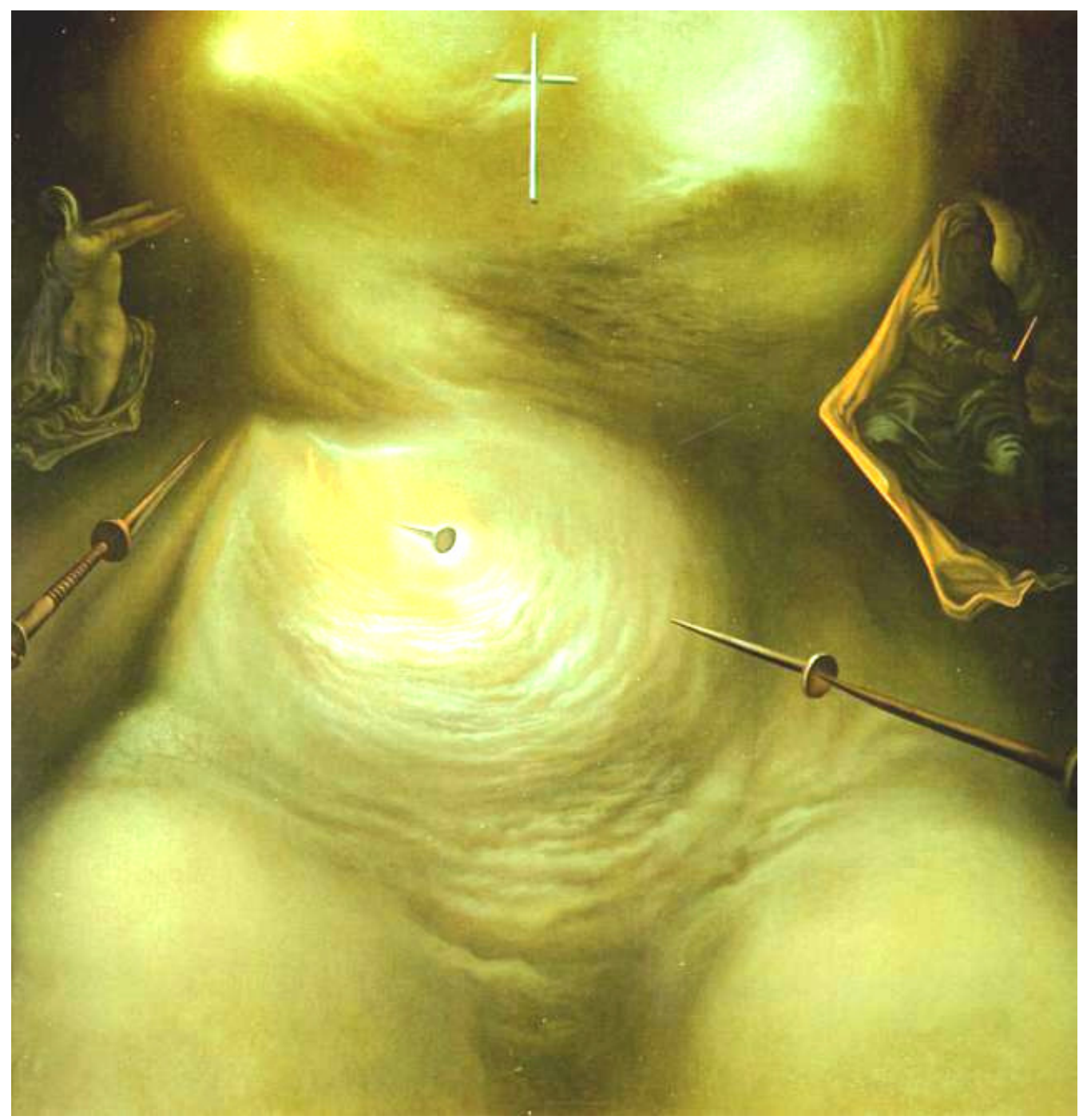

Figura 58: A vida de Maria Madalena, de Salvador Dalí, 1960.

Por isso, quando se afirma que houve um rompimento na interrelação imagem-texto, princípio motor da arte seiscentista, não se quer dizer que a mesma tenha deixado de existir ou mesmo que inexista em nossos dias; pelo contrário, essa relação se expandiu de forma tão explosiva nas ciências humanas, a ponto de a imagem, para alguns teóricos como o estadunidense W. J. Thomas Mitchell, emergir como paradigma no seio dessas mesmas ciências:

a relação entre literatura e imagem já não se limita ao encontro singular da obra literária com a obra visual, mas deve ser vista na perspectiva mais ampla dos estudos das visibilidades, da cultura visual e do desenvolvimento tecnológico de novas formas de representação visual. (Mitchell, apud Schøllhammer, p. 31) 
Dessa forma, poderíamos inferir, por mais paradoxal que possa parecer, que a libertação da pintura em relação à poesia (e vice-versa) foi momentânea; quer dizer, houve, efetivamente, um rompimento da antiga $\varepsilon \pi \iota \sigma \tau \dot{\mu} \mu \eta$ : não se busca mais a representação fidedigna da natureza, da realidade ou, como diz 0 teórico alemão Hans Ulrich Gumbrecht (1948-): os textos literários escritos atualmente voltaram a apresentar "mundos" a seus leitores (Gumbrecht, apud Farinaccio, 2004, p. 11) ${ }^{172}$, ou seja, autores como Gabriel García Márquez (Cem Anos de Solidão) ou Umberto Eco (O Nome da Rosa) não descrevem em suas obras nem a realidade típica caribenha em um, nem o mundo medieval real em outro, sequer propõem ou reivindicam para si fidelidade a quaisquer referentes preexistentes (ibidem, p.12), situação totalmente oposta à dos modelos clássicos que serviram de modelos para os autores dos Seiscentos, para quem a obra deveria ser realista, ou seja, basear-se no real sem, contudo, se preocupar com a história ${ }^{173}$, afinal aqueles autores desconheciam a idéia de forças históricas (Cf.: Auerbach, 2004, p. 28), talvez por isso os textos clássicos, como os de Homero, pareçam-nos sempre lendários, desconexos, irreais apesar de não os serem totalmente:

Enquanto ouvimos ou lemos a sua estória, é-nos absolutamente indiferente saber que tudo não passa de lenda, que é tudo "mentira". (...) Homero (...) não tem necessidade de fazer alarde da verdade histórica do seu relato, a sua realidade é bastante forte; emaranha-nos, apanha-nos em sua rede, e isto lhe basta. Neste mundo "real", existente por si mesmo, no qual somos introduzidos por encanto, não há tampouco outro conteúdo a não ser ele próprio; os poemas homéricos nada ocultam, neles não há nenhum ensinamento e nenhum segundo sentido oculto. (Ibidem, p. 10)

Auerbach demonstra-nos, por exemplo, a diferença de enfoque entre o texto homérico e o bíblico: aquele visava à realidade - por meio da imediatez, fluidez e simplicidade narrativa - enquanto este, exclusivamente, à verdade, devido a seu caráter religioso e a sua pretensão à universalidade histórica (Cf.:

\footnotetext{
${ }^{172}$ Em relação ao Realismo do século XIX, por exemplo, citado adiante: Mas diferentemente do Realismo do século XIX, eles não estão obcecados com a preocupação de dignificar estes mundos literários pela insistência sobre o seu status de representações. (Gumbrecht, apud Farinaccio, p. 11)

${ }^{173}$ Enquanto ciência que estuda a ação do homem ao longo de um tempo determinado.
} 
ibidem, p. 13). Um texto pretende agradar e encantar - como o homérico -, enquanto um outro doutrinar e prometer - como no bíblico, em especial o Antigo Testamento -, daí seu caráter obscuro e metafórico (Cf.: ibidem, p. 12) que perpassará a Antigüidade e será reaproveitado na Idade Média, no Renascimento e no Barroco, como atesta o gênero emblemático com suas preceptivas moralizantes.

Como herdamos, no Ocidente, tanto a cultura helênica quanto a hebraica, podemos ser tentados a inverter o fim a que cada gênero se propõe, ou seja, queremos ler a seriedade e a realidade num texto clássico; ou, de uma forma doutrinária e fantástica o texto clássico; ou ainda, acreditar encontrar a verdade em ambos. Evidentemente, não conseguiremos nenhuma das proposições apresentadas. Ainda citando Auerbach, este nos mostra que

$\mathrm{Na}$ literatura moderna, qualquer personagem, seja qual for o seu caráter ou posição social, qualquer acontecimento, fabuloso, político ou limitadamente caseiro, pode ser tratado pela arte imitativa de forma séria, problemática e trágica, e isto geralmente acontece. Na Antigüidade isto é totalmente impossível. (Ibidem, p. 27)

Essa impossibilidade é devida à separação dos estilos, ou seja, para nós qualquer questão representada via literatura ou via pintura, independente de a personagem concebida pertencer a uma classe social alta ou baixa, pode-nos levar à comoção, à meditação. Isso nunca ocorreria com os antigos, para quem a representação de

qualquer ofício, posição social quotidiana - comerciantes, artesãos, camponeses, escravos -, qualquer cenário quotidiano - casa, oficina, loja, campo -, qualquer costume quotidiano - casamento, filhos, trabalho, alimentação - numa palavra, o povo e sua vida (ibidem, p. 27)

jamais poderiam ser, literalmente, levados a sério, pois nunca abandonam o campo do cômico. Um indivíduo assim representado nunca teria vez numa sociedade em que havia uma separação clara entre o que poderia ser representado pela classe elevada e por aquelas consideradas inferiores, além disso, por não existir o conceito da ação de forças históricas, as pessoas eram vistas a partir de outros valores: os antigos interessavam-se, sobretudo, pela 
problemática moral - que só residiria na aristocracia -, por isso o individual prevalecia sobre o coletivo:

A crítica dos vícios e dos excessos, por mais que sejam muitas as pessoas retratadas como viciosas ou ridículas, coloca o problema de forma individual, de modo que a crítica da sociedade nunca leva ao desvendamento das forças que o movem. (ibidem, $\mathrm{p}$. 28)

Essa mesma separação estendia-se para aquilo que consideravam belo e feio. Restringiam-se, às classes inferiores, o feio e o grotesco (baixo estilo); à classe elevada, o belo e o virtuoso (estilo elevado). A esse respeito, diz-nos um teólogo do século XVII:

toda a intenção de um poeta, toda a finalidade do seu trabalho, é que sejamos, como o seu herói, apaixonados pelas belas pessoas, que as sirvamos como divindades; em uma palavra, que lhes sacrifiquemos tudo, afora, talvez a glória, cujo amor é mais perigoso que aquele que temos pela própria beleza. (ibidem, p. 351)

Nós, pelo contrário, hoje, pelo contrário, podemos encontrar verdades e beleza nas palavras de um cozinheiro, de um balconista, de um garçom: essas independem de quem esteja sendo representado ou protagonizado, podemos ser atingidos do mesmo modo: eis que o Corcunda de Notre Dame, apesar de seu aspecto, parece-nos amável, torna-se belo, passível de nos produzir $\pi \alpha ́ \theta o \varsigma$ (pathos): para os clássicos, tal representação seria impossível, ou seja, a personagem de Victor Hugo nunca os levaria à comoção, mas ao riso: já se faz sentir, no século XIX, uma grande transformação do modelo anterior que não se restringiria apenas ao campo temático (rompimento total dos estilos, por exemplo), nem mesmo à formação e representação imagéticas, mas ao próprio olhar e observação humanas.

Esses não seriam mais os mesmos e o papel de destaque se deve à concretização da fotografia, termo/partida de uma onda de transformações verificadas ao longo daquele século e, quando dizemos um termo, queremos falar que ela foi o limiar de transformações processadas não só no século de seu aparecimento como também nos subseqüentes e cujo resultado foi, inclusive, a mudança na forma de o ser humano ver a si mesmo e o mundo por 
que está rodeado. Essas transformações levariam, segundo Jonathan Crary, inclusive, ao rompimento do predomínio da visão renascentista, cujo vértice estava, segundo esse autor, no ponto de vista da câmara escura.

Por intermédio desta, parâmetro mimético por excelência, desconsiderava-se a interferência humana na produção imagética que se submetia, dessa forma, às rígidas leis físicas da refração e da reflexão em cujo poder não competiria ao homem interferir, mas apenas aceitá-lo: havia uma relação de exterioridade entre o sujeito e seu objeto de observação, ou seja, o ato de ver é alijado do corpo físico do observador:

At the same time, another related and equally decisive function of the camera was to sunder the act of seeing from the physical body of the observer, to decorporealize vision. The monadic viewpoint of the individual is authenticated and legitimized by the camera obscura, but the observer's physical and sensory experience is supplanted by the relations between a mechanical apparatus and a pre-given world of objective truth. (Crary, 1992, pp. 39-40)

Anteriormente, a própria autoridade da câmara escura não permitia ao homem interferir no processo físico da criação imagética devido às leis físicas da propagação da luz, afinal as imagens que se projetavam no fundo escuro da câmara eram decorrentes do efeito de leis naturais que independiam do corpo contingente e cambiante do homem. (Cf.: Ferraz, 2005, p. 50)

Não obstante, a rigidez imputada, desde o Renascimento, à arte e o conseqüente emprego da matemática e das ciências exatas para explicar a formação imagética (conceitos de luz, refração, reflexão), novas idéias filosóficas começaram a modificar essa Weltanschauung racionalista já em finais do século XVIII; temos, como exemplo, a importância da subjetividade para o reconhecimento do mundo em que os homens estão inseridos. Essa busca pela subjetividade que vê, sente e interfere na visão como algo não meramente externo ao homem, pôde ser vista, inclusive, em Kant, em sua obra Crítica da razão pura (1787), quando afirma que

(...) nossa representação das coisas como nos são dadas [devem ser guiadas] (...) não por estas como coisas em si mesmas, mas que estes objetos, como 
fenômenos, muito antes se guiem pelo nosso modo de representação. (Kant, 1999, p. 40)

Ainda segundo o filósofo alemão, conhecemos o que é possível passar pelo crivo de nossa sensibilidade, logo pelo nosso olhar, sem o qual é, simplesmente, ignorado:

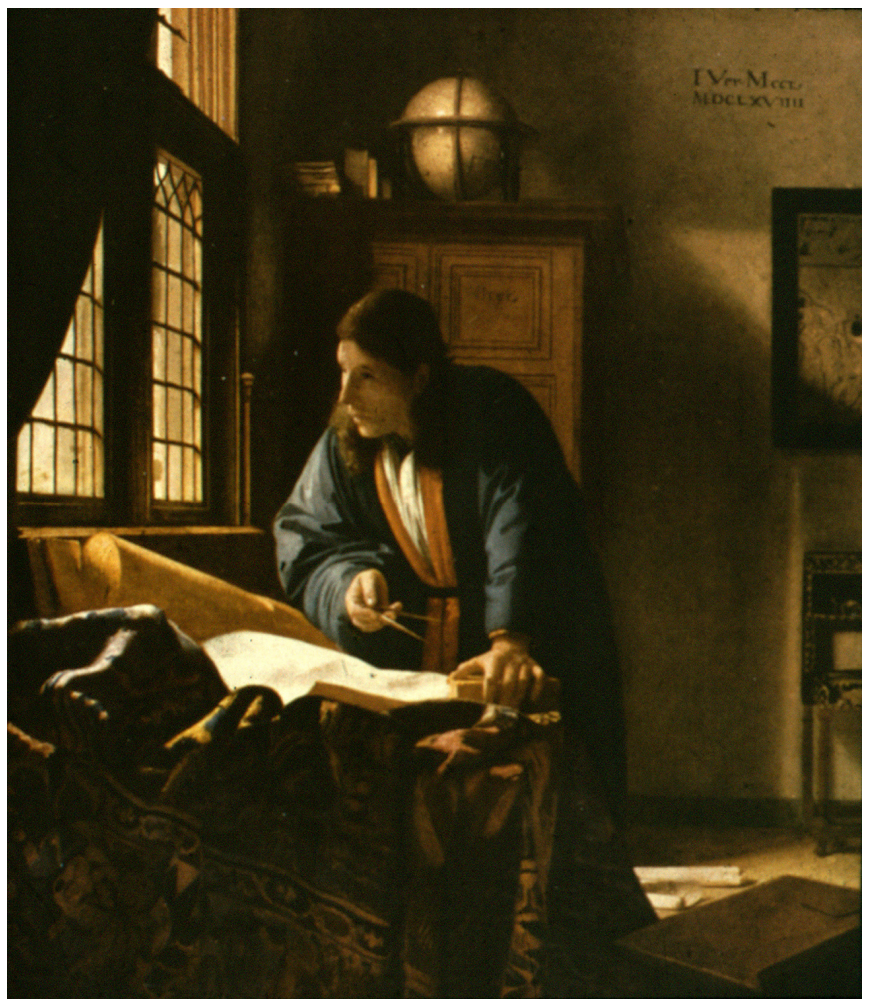

Figura 59: O geógrafo, de Jan van Vermeer, 1668.
(...) nossa intuição não é senão a representação de fenômeno: que as coisas intuímos não são em si mesmas tal qual as que intuímos nem que suas relações são em si mesmas constituídas do modo como nos aparecem e que, se suprimíssemos o nosso sujeito ou também apenas a constituição subjetiva dos sentidos em geral, desapareceriam toda a constituição, todas as relações dos objetos no espaço e no tempo, e mesmo espaço e tempo. Todas essas coisas enquanto fenômenos não podem existir em si mesmas, mas somente em nós. (...) os objetos em si e separados de toda esta receptividade da nossa sensibilidade, permanece-nos inteiramente desconhecidos. Não conhecemos senão o nosso modo de percebê-los, o qual nos é peculiar e não tem que concernir necessariamente a todo ente, mas sim a todo homem. (ibidem, p. 83)

Crary demonstra-nos, metaforicamente, a importância da câmara escura no período anterior, ou seja, no período abordado por esta Tese, utilizando-se de duas obras de um pintor muito conhecido do período, o holandês Jan van Vermeer (1632-1675), cujas telas O astrônomo (1668) e O geógrafo (1668/69 fig. 59) representam cada uma os estudiosos que as nomeiam. Vê-se cada um deles, absorto em seus afazeres, encerrados em seus ambientes de estudo, 
onde se vêem objetos que traduzem seus ofícios: em um há um globo celeste, noutro cartas náuticas:

Each has his eyes averted from the aperture that opens onto the outside. The exterior world is known not by direct sensory examination but through a mental survey of its "clear and distinct" representation within the room, the somber isolation of these meditative scholars within their walled interiors is not in the least an obstacle to apprehending the world outside, for the division between interiorized subject and exterior world is a pre-given condition of knowledge about the latter. (Crary, 1992, p. 46)

À continuação, Crary demonstra-nos a relação entre o mundo interno - o ambiente de estudo/trabalho - com o mundo externo - representado pelo globo, pelos mapas, pelas cartas náuticas -; como se as pinturas pretendessem evidenciar a reconciliação da função da câmara escura, cujo interior seria a interface entre aquilo que Descartes considerava como termos dissimilares: res cogitans e res extensa; esta seria o domínio da matéria; aquela, da mente, do espírito. Uma a visibilidade do mundo exterior, a outra como essa mesma é visualizada a partir da individualidade de cada um. Por meio da luz que entra no ambiente interno - à semelhança do orifício por onde a luz penetra no interior da câmara escura - o estudioso pode conhecer 0 mundo externo, representado por mapas, cartas, imagens, pelo globo, sem ter a necessidade de ter de sair de sua clausura: tem-se acesso, portanto, a uma projeção do mundo, interage com ele sem, contudo, poder interferir nele, sem poder modificá-lo, numa atitude passiva diante do deslumbramento do mundo formado internamente. Sua atitude é de mera contemplação, apesar de palpável, de real: está diante do mundo exterior representado pelo globo estelar, pelas cartas náuticas, pelos mapas, enfim da res extensa, porém essa contemplação só é possível, porque sua mente interfere no processo, a res cogitans, daí a não reconciliação entre os dois termos cartesianos que, aparentemente, a câmara escura rompe:

The production of the camera is always a projection onto a two-dimensional surface - here maps, globes, charts, and images. Each of the thinkers, in a rapt stillness, ponders that crucial feature of the world, its extension, so mysteriously unlike 
the unextended immediacy of their own thoughts yet rendered intelligible to mind by clarity of these representations, by magnitudinal relations. (ibidem, p. 46)

Goethe, no entanto, começa a pôr em xeque - a partir da obra Zur Farbenlehre (1810) - essa relação de distanciamento entre o homem e o mundo proporcionada pela câmara escura, propondo uma experiência simples,

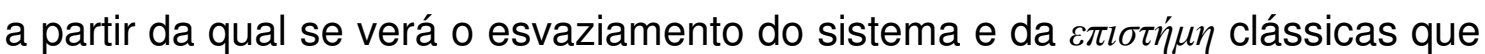
alijavam a imagem do corpo:

In einem Zimmer, das möglichst verdunkelt worden, habe man im Laden eine runde Öffnung, etwa drei Zoll im Durchmesser, die man nach Belieben auf und zudecken kann; durch selbige lasse man die Sonne auf ein weißes Papier scheinen und sehe in einiger Entfernung starr das erleuchtete Rund an; man schließe darauf die Öffnung und blicke nach dem dunkelsten Orte des Zimmers, so wird man eine runde Erscheinung vor sich schweben sehen. Die Mitte des Kreises wird man hell, farblos, einigermaßen gelb sehen, der Rand aber wird sogleich purpurfarben erscheinen. (Goethe, § 40)

Goethe mostra-nos que ao se fechar o orifício da câmara, os olhos vêem na escuridão, pois divisarão várias imagens de cores diversas, provenientes não mais dos raios luminosos externos ao corpo, mas a partir do próprio corpo:

Es dauert eine Zeitlang, bis diese Purpurfarbe von außen herein den ganzen Kreis zudeckt, und endlich den hellen Mittelpunkt völlig vertreibt. Kaum erscheint aber das ganze Rund purpurfarben, so fängt der Rand an blau zu werden, das Blaue verdrängt nach und nach hereinwärts den Purpur. Ist die Erscheinung vollkommen blau, so wird der Rand dunkel und unfärbig. Es währet lange, bis der unfärbige Rand völlig das Blaue vertreibt und der ganze Raum unfärbig wird. Das Bild nimmt sodann nach und nach $a b$, und zwar dergestallt, daß es zugleich schwächer und kleiner wird. Hier sehen wir abermals, wie sich die Netzhaut durch eine Sukzession von Schwingungen gegen den gewaltsamen äußern Eindruck nach und nach wieder herstellt. (ibidem)

Observações demonstram que não é mais a física, nem a lógica matemática e externa ao homem que presidem a visão, mas o próprio olho com 
sua fisiologia inerente que percebe o mundo ele mesmo, não mais como uma realidade externa imposta, sem sua efetiva participação:

Quando a própria produção de imagens pode ser desvinculada de um "mundo" exterior, fixado, estável, seguro, desestabilizaram-se, simultaneamente, as certezas concernentes tanto ao sujeito quanto ao objeto; no mesmo gesto, os processos de percepção e conhecimento passam, necessariamente, a ser alvo de experimentação, observação, descrição e ciência. (Ferraz, 2005, p. 50)

Para isso, faz-se necessária a participação do eu-observador que participará, efetivamente, na construção imagética, não mais de forma passiva, mas ativamente, por isso Crary afirma, a partir dos conceitos abordados por Goethe, que:

The corporeal subjectivity of the observer, which was a priori excluded from the concept of camara obscura, suddently becomes the site on which an observer is possible. The human body, in all its contingency and specificity generates "the spectrum of another colour", and thus becomes the active producer of optical experience. (Crary, 1992, p. 69)

Vê-se, portanto, um conhecimento/desenvolvimento significativo da fisiologia óptica, pois, a partir do estereoscópio ${ }^{174}$, por exemplo, o corpo passa a ser um componente intrínseco da própria máquina, quando por meio do instrumento óptico a pessoa não só tem uma visão binocular como também tridimensional da imagem. Diante dessa participação do homem, seu ato de olhar deixa de ser apenas passivo, a de mero espectador da cena/imagem

\footnotetext{
174 Instrumento óptico que permite ver efeitos de relevo em imagens planas, a partir de fotografias (ou de desenhos) obtidas do mesmo objeto, tiradas de posições ligeiramente diferentes, cuja separação pode ser semelhante à que existe entre os olhos, posssibilitando, portanto, uma visão binocular e a percepção da tridimensionalidade dos objetos. A imagem que se forma na retina de cada olho é plana, mas como há uma pequena diferença entre elas e os olhos estão separados uns 5 a 8 centímetros. O cérebro se encarrega de "fundir" essas duas imagens em uma só, resultando no efeito tridimensional. Esse efeito tridimentsional pode ser simulado, mesmo sem o aparelho, usando-se duas figuras planas, ligeiramente diferentes, como as que seriam projetadas em cada retina, separadamente. Só que, nesse caso, os próprios olhos devem se encarregar de "misturar" as imagens, antes de enviá-las ao cérebro. Para isso, é necessário fazer convergir os olhos de modo a obter uma imagem nas retinas que combine as duas imagens planas das figuras. Algumas pessoas, no entanto, têm dificuldades para isso, já que não conseguem fazer esse movimento forçado de "trocar os olhos". Nesses casos, o uso do esteresocópio resolve o problema, já que projeta uma imagem diferente em cada olho, dispensando a necessidade de fazê-los convergir à força.
} 
vinculada à passividade e à mera assistência, conforme se pode constatar no modo como se concebe o espectador do teatro clássico (Machado, 2002, p. 228); passando a ser ativo, a de observador, ou seja, alguém que vê no âmbito de um conjunto de possibilidades, alguém que está constrangido por um sistema de convenções e limitações. (ibidem, p. 229) A imagem estereoscópica, portanto, rompe com a perspectiva renascentista a partir de um único ponto de fuga,

Por conseqüência, ela modifica o conceito tradicional de "ponto de vista", ou seja, aquela particular relação de um observador com o objeto de sua visão, em torno da qual a significação foi estabelecida durante séculos. Não havendo ponto de fuga ou ponto de vista únicos, não há também hegemonia de um código perspectivo unilocular, como aquele que norteou toda a história ocidental a partir do século XV. (ibidem, pp. 230-231)

É mister, nesse momento, retornar àquilo que foi dito em relação à paradoxalidade do rompimento dos gêneros pictórico e poético para que possamos dar prosseguimento a este estudo, cujo vértice é, precisamente, a fotografia. Poderíamos inferir que essa ruptura não se deu totalmente, mas à semelhança de um pré-vanguardismo, já que foi, num primeiro momento, somente uma mudança de direção. Para a concretização vanguardista, por exemplo, faz-se necessário um período de encetamento ${ }^{175}$ (conforme visto nas figuras 55, 56 e 57), indispensável para haver o rompimento - de forma abrupta e revolucionária (fig. 58) - com o status quo, possibilitando, a posteriori, conhecer-se, de forma mais profunda, seu objeto de estudo ou emprego - as cores, a luz, as sombras na pintura; as palavras, a sintaxe, a métrica na literatura -, para que se possa explorar nele, e dele, todas as possibilidades estéticas possíveis, inclusive utilizar-se de elementos da própria iconologia como, provavelmente, faz Dalí, não de uma forma impositiva, mas como um mote a ser utilizado.

Evidentemente, no século XIX, esse movimento foi incipiente, ainda não seria esse o momento que veríamos o rompimento total com os modelos

175 Que corresponde, exatamente, ao período em questão, o século XIX, em relação às inovações concretizadas no início do século XX. 
antigos, pois o que se vislumbrou, efetivamente, foi o pouco tempo de liberdade que ambas as estéticas - a escrita e a pictórica - tiveram uma em relação à outra, afinal assistimos, simplesmente, a uma troca de eixo com a entrada de um terceiro elemento que não só se imiscui em ambas como também as influencia que foi a fotografia. Dessa forma, não só o lugar da poesia em relação à pintura não ficou vago durante muito tempo, como também o inverso, a pintura enquanto modelo da poesia. (Cf. Praz, 1982, p. 4) $)^{176}$

É possível verificar que, mesmo no século XIX, a fotografia foi tomando o papel que pertenceu à pintura em séculos anteriores, pois a nova técnica

longe de se opor a toda tradição pictórica, não faz senão apostar em sua perpetuação, na medida em que petrifica os arquétipos que a sustentam. (Machado, 1984, p. 150)

Mas, mesmo assim, seu espaço foi sendo conquistado e, à diferença do modelo anterior, não mais como um paradigma a ser seguido e emulado, mas como uma nova opção de retratar a natureza de forma, aparentemente, precisa

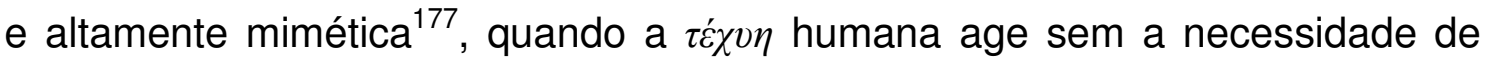
mãos humanas, criando uma pintura técnica ou uma arte técnica ${ }^{178}$ por excelência ${ }^{179}$.

Portanto, esse deslocamento poesia $x$ pintura $\rightarrow$ poesia $x$ fotografia, seria uma conseqüência natural do avanço humano e do emprego de sua $\tau \dot{\chi} \chi v \eta$, por isso devemos observar que

a) na primeira relação (poesia $x$ pintura), cujo princípio norteador era a $\mu i ́ \mu \eta \sigma \iota s$, empregavam-se iconologias, a imagem (pictórica e

\footnotetext{
${ }^{176}$ Assim diz Praz: O grau de prestígio alcançado pela Pintura, graças aos grandes mestres italianos da Renascença, deu azo a que obtivesse uma vitória sobre sua arte irmã, a Poesia; testemunham-no os incansáveis esforços dos poetas de emular os pintores na sensualidade de suas descrições. (Praz, 1982, p. 4)

${ }_{177}$ Veremos que somente nos primórdios da fotografia isso aconteceu, pois se verificou depois a possibilidade de se retocar e modificar o mimeticamente perfeito.

${ }_{178}$ Apesar da redundância que esse termo teria se levássemos em conta a etimologia da palavra $\tau \dot{x} \chi v \eta$ vista no início deste trabalho.

${ }_{179}$ Vale salientar que a fotografia absorve aspectos da composição imagética pictural como a iluminação, a disposição da(s) pessoa(s) dentro da moldura ou mesmo o termo enquadrar, termos e conhecimentos que os primeiros fotográfos já dominavam, afinal em sua grande maioria eram pintores, afinal a câmara era (...) um mecanismo óptico complicado e só rendia imagens nítidas e significativas se fosse manobrada por um perito em representação visual; é por isso (...) que a produção fotográfica primitiva seguiu comodamente as determinações do gosto pictórico reinante. (Machado, 1984, p. 31)
} 
escultórica) estava submetida à tutela do hóros que as direcionava. Havia, dessa forma, uma via de mão única: das iconologias (incluindo os livros de emblemas) para a obra artística

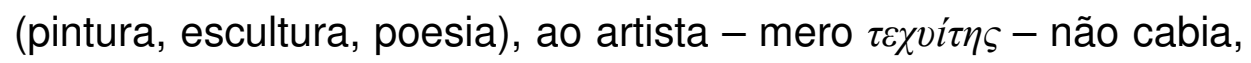
portanto, criatividade, cujo conceito era-Ihe desconhecido;

b) na outra relação (poesia $x$ fotografia) o gérmen mimético desaparece, apesar de a fotografia ser, a priori, mimética por excelência; empregam-se iconofotologias, no entanto essas não existem de per si como compilações a serem observadas, estudadas e/ou empregadas, mas como um acervo individual construído ao longo dos anos por uma pessoa, bem como por uma determinada comunidade em que esteja inserida. Há, portanto, uma via de mão dupla: já que o artista pode partir tanto da natureza como de si mesmo, de seu próprio acervo iconofotológico, ou seja, das imagens fotográficas que permeiam sua memória. A escolha agora deixa de ser uma imposição, passando a depender de sua criatividade, de sua intenção e daqueles a quem pretende chegar.

Evidentemente que, nessas duas relações, tais princípios estendem-se também a seus respectivos leitores, ou seja, se tratarmos do modelo epistemológico em que o barroco estava inserido, os leitores do período tinham de ter acesso à chave cognitiva para que pudessem compreender as obras do período sem a qual seria impossível a apreensão do que seus autores pretendiam. Isso fica claro quando, em período ulteriores, tais obras - bem como seus autores - foram consideradas obscuras ou incompreensíveis: faltará, portanto, aos leitores de períodos históricos posteriores manuais para a sua compreensão. 
$\mathrm{Na}$ passagem do medievo para a modernidade, verificou-se, em uma das muitas alterações cognitivas por que o ser humano passou, o deslocamento de sua percepção sensorial que, de auditiva e táctil, se converte em visual. Maravall, ao discorrer acerca do emprego dos meios visuais empregados pelo Seiscentismo, mostra-nos que

Vinha do mundo medieval a disputa sobre a superioridade do olho ou do ouvido para a comunicação do saber aos outros. Enquanto no mundo medieval se optou pela segunda via, o homem moderno torna-se adepto da primeira, ou seja, da via do olho. (Maravall, 1997, p. 391)

Essa querela, porém, não foi exclusiva da Idade Média - mesmo com sua tradição oral / auditiva / mnemônica de um lado; Santo Agostinho, de outro, afirma, no livro $X$ das Confissões, que os olhos têm primazia sobre os outros sentidos -, mas remonta à Grécia antiga - Platão, em $A$ República, considerava a visão a mais perfeita das sensações, enquanto Aristóteles, em Da Alma, dava o mérito à audição, na medida em que tem a ver com o discurso que é causa da aprendizagem ${ }^{180}$-, chegando ao Renascimento. A partir deste período, a visão se consolida como o sentido humano preponderante principalmente no Ocidente.

Afirmar que o ouvido já foi o sentido por excelência - num mundo dominado por imagens como o nosso - pode até parecer um contrasenso, afinal temos a idéia de a visão ser não só o mais importante sentido que o homem possui - uma metonímia para todos os outros sentidos -, como também de ser uma metáfora para o próprio conhecimento humano: conhecer é ver.

Há, no entanto, um ensaio de Ginzburg, "Ticiano, Ovídio e os códigos da figuração erótica no século XVI" em que o teórico italiano exemplifica-nos essa mudança ao tratar a questão do pecado, segundo alguns manuais para

\footnotetext{
${ }^{180}$ Apesar de na Metafísica afirmar o oposto: preferimos la vista, por decirlo así, a todos los otros [sentidos]. Y la causa es que, de los sentidos, éste es el que nos hace más, y nos muestra muchas diferencias. (Aristóteles, 1987, p. 3)
} 
confessores da Igreja católica. Ele aponta-nos que, por volta de 1540, o pecado mais abordado por esses compêndios era o da avareza, seguido pelo da luxúria. Este último, naquele momento, ainda se manifestava, particularmente, por meio do tato e da audição (Cf.: Ginzburg, 1991, pp. 138-139), revelando a importância que o ouvido possuía não só na tradição medieval, como também até meados do século XVI, por isso

a visão quase não é mencionada. As ocasiões sociais que favorecem a transgressão do mandamento "não fornicarás" são, sobretudo, as danças e as canções. Fazer (...) canções ou sonetos (...) para provocar lascívias torpes $e$ impudicas é pecado mortal, escrevia no seu confessionário Bartolomeo Caimi. Não advertia contra as imagens impudicas - simplesmente porque a sua difusão devia ser mínima ou inexistente, a não ser entre as classes elevadas. (Ginzburg, 1991, p. 139)

O homem do medievo poderia, portanto, receber pelos ouvidos

a) tanto a virtude - Deus expressava-se por meio da leitura das Escrituras, cujo som emanado pela boca do sacerdote era a própria corporificação da voz divina que, no Antigo Testamento, fazia-se também presente via sons e ruídos, mas, conforme São Paulo, deveria ser ouvida nos confins do mundo ${ }^{181}$;

b) quanto à dissipação e à concupiscência que chegavam

- às camadas populares - por meio de cantigas, poesias e encenações de cunho erótico;

- a alguns meios universitários medievais do século XIII - por meio de doutrinas (...) que louvavam a vida sexual natural, (...) a vida sexual impulsiva e promoviam a sua liberdade (Auerbach, 2004, pp. 196-197);

- a uma classe social que (...) de nível elevado, ainda que não feudal (...) sente um prazer culto com a realidade colorida da vida (ibidem, p. 190) ao ouvir novelas (como as de Boccaccio) que, à semelhança do próprio Decamerão, serviam ao divertimento de um círculo de pessoas jovens, distintas e cultas, damas e cavaleiros que se deleitam. (ibidem p. 188)

${ }^{181} \mathrm{Rm} 10,17-18$. 
No entanto, se a difusão imagética era inexpressiva até o final do medievo, tornar-se-á significativa com o advento da modernidade, encerrando o predomínio da verdade auditiva, cujos reflexos fazem-se sentir ainda hoje: desconfiamos daquilo que ouvimos, afinal "uma imagem vale por mil palavras". Alguns fatores foram preponderantes para que a virtù visiva ocupasse o centro da percepção humana bem como a disseminação e a valorização imagética, sejam eles diretos como

c) o perspectivismo de Alberti e a visão unilocular;

d) o aprofundamento da alegorização da sociedade, quando se buscava aliar as sentenças dos auctoritas - compiladas durante a Idade Média - a imagens, as quais buscavam não só descrevê-las, mas também interpretá-las;

e) a inclusão dos pintores nas artes liberais (ars liberae);

ou indiretos como

f) a imprensa de Gutemberg, cujo resultado foi a divulgação das idéias iconográficas e iconológicas em massa;

e, podemos ainda destacar:

g) a Reforma protestante com sua iconoclastia e o conseqüente avanço imagético católico, que se tornará seu antípoda.

Lutero, ao fixar suas 95 teses na igreja de Wittenberg não tinha como preocupação evidente a condenação imagética, tampouco o emprego das imagens nas igrejas - apesar de considerar a quantidade das mesmas um exagero -, afinal estava mais preocupado em atacar o Papa e a venda de indulgências. Entretanto, ao radicalizar-se a Reforma, esta saiu do controle de seu mentor e alguns de seus membros passaram, simplesmente, a destruir imagens religiosas ${ }^{182}$ : esse, sim, foi o start para que o culto às imagens não só

182 O mentor reformista do iconoclatismo foi Andreas Bodenstein von Karlstadt que, aproveitando a ausência de Lutero de Wittenberg, no inverno de 1521/22, publica um opúsculo, cujo título Da Eliminação das Imagens, já demonstava seu intento. Para o reformista, não se podiam tolerar imagens nas igrejas, pois afrontam o primeiro mandamento, dessa forma não incitou somente à destruição de esculturas como também de pinturas, os ídolos de óleo colocados sobre os altares, por também serem considerados invenção do demônio. Lutero classificou o ato de Karlstadt como lamentável, típico episódio de destruição e vandalismo, pregando, inclusive, que as imagens são recordações e testemunhos da Igreja e, por isso mesmo, deviam ser toleradas. 
fosse intensificado como também se tornasse o maior trunfo propagandístico para a manutenção do status quo católico, corroborado pelo Concílio de Trento, em 1563.

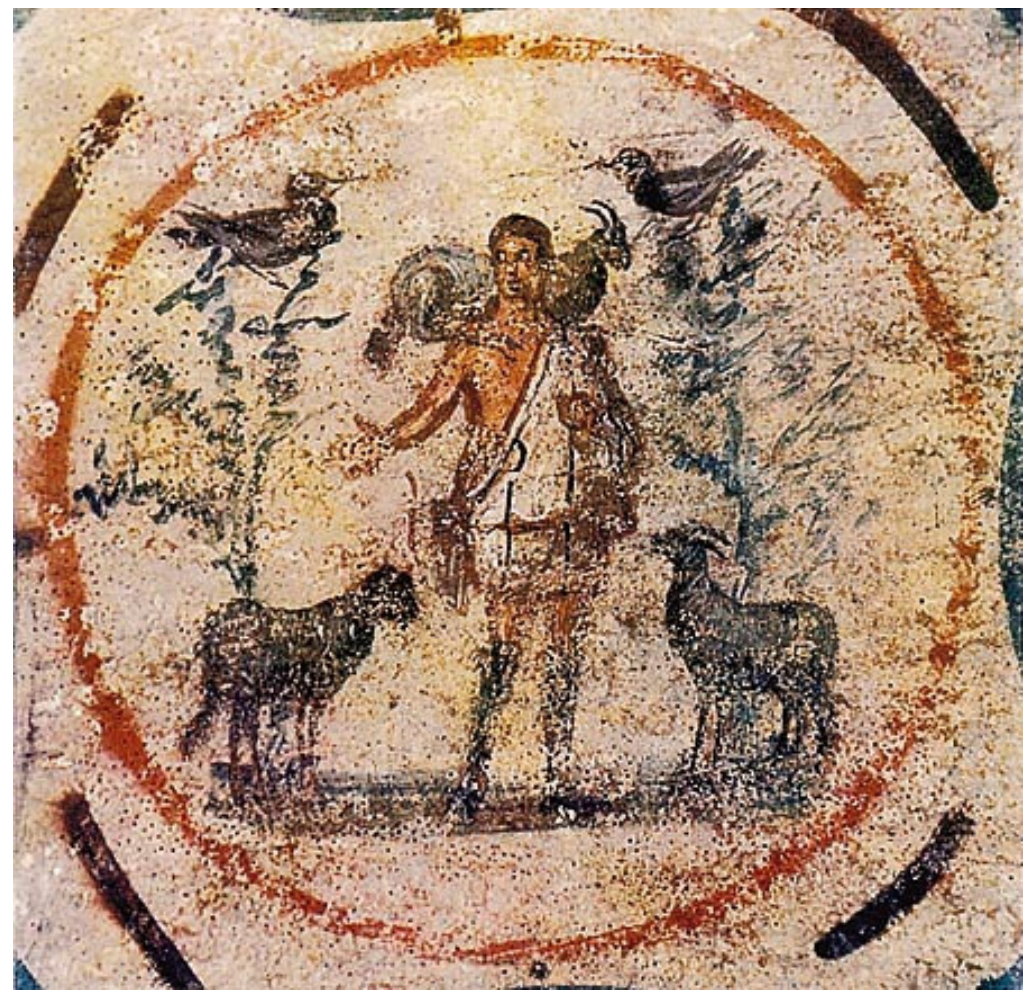

Figura 60: $O$ bom pastor, pintura do interior da catacumba de Santa Priscila, segunda metade do século III, Roma.
Em uma de suas sessões, ratificaram-se, oficialmente, a função intermediária dos santos, dos anjos e da Virgem Maria e a importância das imagens como instrumento da prática devocional em oposição às idéias iconoclastas protestantes. Este reconhecimento fundamentava-se na

tradição estabelecida nos primórdios da era cristã, legitimada pelo Concílio de Nicéia de 787, que estabelecera a tríplice função das imagens na ortodoxia cristã: a) reavivar a memória dos fatos históricos; b) estimular a imitação daqueles que eram representados; c) permitir sua veneração". São Boaventura, já no século XIII, também reiterava a tradição imagética católica:

As imagens não foram introduzidas na igreja sem causa razoável. Elas derivam de três causas: a incultura do simples, a frouxidão dos afetos e a impermanência da memória. A incultura dos simples, que não podendo ler o texto escrito utiliza as esculturas e pinturas como se fossem livros para se instruir nos mistérios de nossa fé... A frouxidão dos afetos, para que aqueles cuja devoção não é estimulada por intermédio dos ouvidos, sejam provocados pela contemplação dos olhos... já que na realidade o que se vê estimula mais os afetos do que o que se ouve. Finalmente, por causa da impermanência da memória, já que o que se ouve é mais facilmente esquecido do que o que se vê... assim, por um dom divino, as imagens foram 
executadas nas igrejas para que as vendo nos lembremos das graças que recebemos e das obras virtuosas dos santos. (Oliveira, 2000, p. 247)

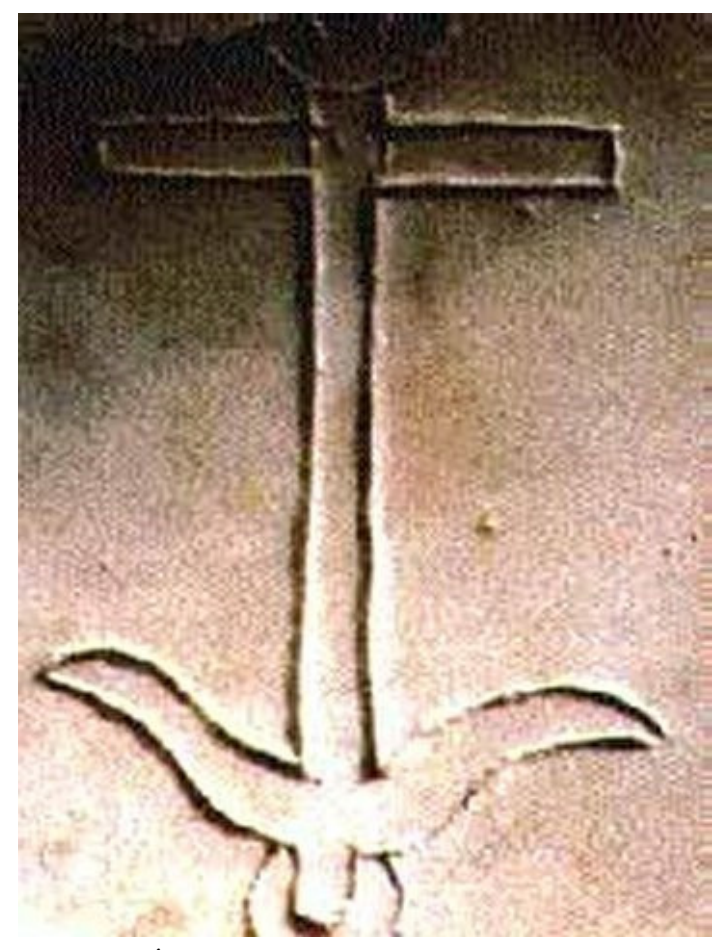

Figura 61, Âncora como representação da cruz, Catacumba de Santa Domitila, Roma

Portanto, a utilização de imagens e de símbolos sacros pela Igreja Católica sempre foi uma constante em sua trajetória, cujos alicerces remontam

a) à própria tradição imagética do Império Romano que, para representar seus vários deuses ${ }^{183}$, fazia largo emprego de imagens, das quais 0 cristianismo absorveu o modelo e a utilização - sendo substituídas, evidentemente, pelas representações de Jesus Cristo, da Virgem Maria e dos santos $^{184}$

b) à própria proto-Igreja das catacumbas, quando Cristo é representado como o Bom Pastor (fig. 60) imagem cuja importância para os primeiros cristãos corresponderia ao crucifixo dos séculos posteriores, pois, como já havíamos assinalado, os primeiros cristãos não conseguiam ver a cruz como símbolo religioso, preferindo estilizá-la por meio de outros símbolos como a âncora (fig. 61).

Diante do embate em que se viu inserida com o advento da Reforma, a Igreja Católica tinha consciência do poder que detinha em suas mãos e que havia aperfeiçoado durante séculos: o poder imagético. Precisava, portanto, adotar uma atitude não só de auto-afirmação como também de propaganda contra uma doutrina que buscava centrar-se no vazio da concretude imagética - exterior ao sujeito -, apoiando-se somente no logocentrismo bíblico.

\footnotetext{
${ }^{183}$ Que havia em todas as esferas de sua sociedade, não só em caráter público, mas também privado, quando se encontravam vários deuses de usos particulares.

${ }^{184}$ Evidentemente, a Igreja Católica absorve muitos aspectos da própria estrutura do Império Romano como as construções dos templos para o culto - as Basílicas -; a divisão de um território episcopal, a diocese - que no Império Romano era divisão judicial de suas províncias -; como também sua própria língua de culto, o latim, que substituiu o grego de seu início.
} 


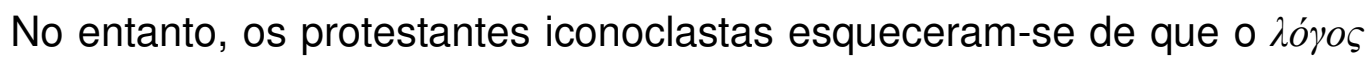
também é imagem, e que ambos possuíram uma fonte comum, a natureza.

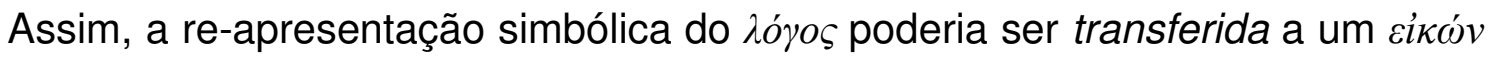
correspondente - também ele uma re-apresentação -, afinal não seria por seu meio que os mais simples - diga-se: analfabetos, aqueles que não dominam a

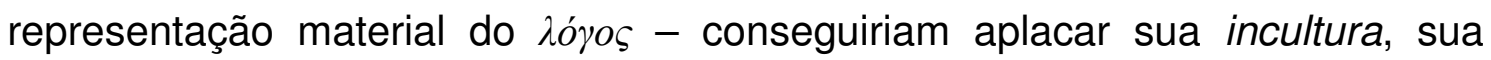
inaptidão diante do todo construído pela humanidade, incluindo o transcedente,

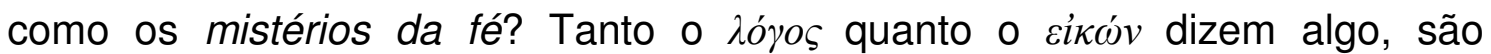
representações (logo, imagens) só que o גóyos transmite-nos a informação de forma literal: linha após linha, demandando um espaço de tempo maior em

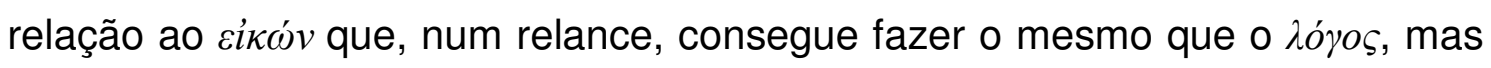
com maior rapidez. Há, além disso, algo importante: tanto na imagem logocêntrica quanto na pictórica, temos a figura do leitor que, devido a seu repertório interno vai direcionar aquilo que será possível, ou não, compreender daquilo que será dado. Sem repertório, não bastarão belos discursos, ou textos perfeitamente construídos para que haja compreensão, pois essa não se concretizará como se pretende (a menos que se deseje exatamente isso!). Iser, por exemplo, afirma que

O que a linguagem diz é transcendido por aquilo que ela revela, e aquilo que é revelado representa o seu verdadeiro sentido. Assim, o sentido permanece relacionado ao que o texto diz, mas não é fruto arbitrário do leitor, pois este o produz na representação (...). (Iser, 1999, pp. 66-67)

Como representar aquilo que se desconhece de forma mais eficiente do que a utilização de uma imagem para tentar demonstrá-lo? Isso faz muito mais sentido em se tratando da representação daquilo que não vemos, ou seja, quando tratamos do sentimento religioso e de sua experiência: como enxergar o que não se sabe, o que não se imagina? Precisa-se da luz para que seja possível discernir, mas o que se fez com a supressão imagética iconoclasta foi cercar o homem de trevas para que pudesse, ele sozinho, tentar atingir 0 inimaginável, como reconhecer o rosto de seus entes queridos sendo cego e, pior, sem poder tocá-los: eis a visão de um Deus desfaciado. Entretanto, seu 
$\lambda o ́ \gamma o s$ torna-se concreto, palpável e mostra sua face, então por que permanecer nas trevas se

Tudo foi feito por meio dela [palavra, do hóosos divino], e de tudo o que existe, nada foi feito sem ela. Nela estava a vida e, a vida era a luz dos homens. Essa luz brilha nas trevas e as trevas não podem apagá-la. (Jo 1,3-5)

Eis o poder evocado pelo גóyos divino: tornar-se imagem real e perceptível daquilo que não é possível enxergar devido às trevas da ignorância humana. Entende-se ignorância em seu sentido etimológico de não conhecer (in + noscere). Se Deus se faz conhecer por meio de sua própria imagem encarnada, seu próprio $\lambda o ́ \gamma o \varsigma$, por que, então, cortar a luz que dissipa as trevas do não conhecimento, da ignorância - cujo elemento básico e confirmador é a representação imagética religiosa, enquanto essência do pensamento simbólico -, privando o homem do acesso perceptível do divino que é a mesma representação imagética? Esse é o resultado da iconoclastia ao se abolir a imagem religiosa, pois acabar com sua representação simbólica, torna-se mais escuro o liame que separa a realidade da transcedência, já que

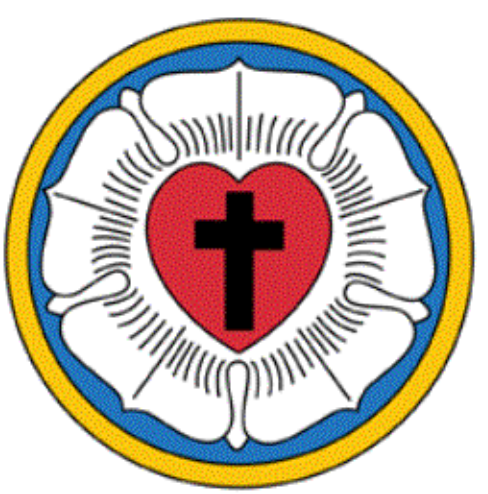

Figura 62: Brasão de Lutero .

com a retirada das imagens do interior das igrejas

protestantes destruiu-se o pensamento simbólico tão constitutivo para o cristianismo. E o pensamento simbólico é pensamento religioso propriamente dito. É na linguagem simbólica que se expressa a experiência do espiritual. Quando essa forma de pensamento não-conceitual deixa de ser usada ou é ridicularizada, produz-se a destruição de uma das disposições religiosas do ser humano. Quando se destruíram as imagens, destruiu-se o elemento que deixa o que é cristão transformar-se em sentimento. A imagem provoca e confirma o pensamento simbólico, sem o qual não se pode imaginar religiosidade viva. Observando imagens religiosas aprendemos a sentir simbolicamente. (Dreher, 2001, p.31)

Lutero viu, provavelmente com apreensão, a onda iconoclasta que se espalhara em meio aos reformados, pois sabia da importância do simbolismo 
da imagem para a fé, conforme atesta o brasão (fig. 62) por ele utilizado ${ }^{185}$, também repleto de suportes simbólicos. Estes pressupõem a capacidade de ver em uma coisa o que ela não é, de vê-la diferente do que é (Castoriadis, 1982, p. 154), por isso Lutero podia enxergar na cor branca a representação simbólica de uma rosa, cuja significação - para o reformador e seus seguidores - seria alegria, conforto e paz. O simbólico, portanto, pressupõe um acordo entre as partes, entre uma coletividade. Torna-se, deste modo, arbitrário em relação àqueles que lhe são estranhos - da mesma forma que o signo é arbitrário - por isso nem todos podem compreendê-lo. Necessita-se de códigos e chaves comuns, sem as quais sua decodificação não é possível:

o simbolismo supõe a capacidade de estabelecer um vínculo permanente entre dois termos, de maneira que um "representa" o outro. Mas é somente nas etapas muito desenvolvidas do pensamento racional lúcido que estes três elementos (o significante, o significado e seu vínculo sui generis) são mantidos como simultaneamente unidos, e distintos, numa relação ao mesmo tempo firme e flexível. (ibidem, p.155)

Essa diferença entre o ser e o representar minimiza a não compreensão do mítico, pois podemos apoiar-nos no simbólico para visualizar o transcendente para que possa nos servir como espelho da divindade. Diante do crucifixo, por exemplo, pode-se entrar em êxtase, apesar de se saber que o

\footnotetext{
${ }^{185} \mathrm{E}$ a explicação dada por Lutero, em uma carta, a respeito da simbologia de seu Brasão é a seguinte: "Graça e paz por parte do Senhor. Como você deseja saber se o selo pintado, que você me enviou, acertou o alvo, devo responder de forma amigável e lhe dizer sobre meus pensamentos e razões originais porque meu selo é um símbolo da minha teologia. Primeiro, deve haver uma cruz preta dentro de um coração - o qual retém a sua cor natural - para que eu seja lembrado que a fé no Crucificado nos salva. Pois quem crê de coração será justificado (Rm 10,10). Embora seja uma cruz preta, que mortifica e que também deve causar dor, ela deixa o coração em sua cor natural. Ela não corrompe a natureza, isto, ela não mata, mas mantém vivo. "O justo viverá por fé" (Rm 1,17), mas pela fé no Crucificado. Tal coração deve estar no meio de uma rosa branca, para mostrar que a fé dá alegria, conforto e paz. Em outras palavras, ela coloca o crente em uma rosa branca, de alegria, pois esta fé não dá paz e alegria como o mundo dá (Jo 14,27). É por isso que a rosa deve ser branca, e não vermelha, pois o branco é a cor dos espíritos e dos anjos (conforme Mt 28.3; Jo 20,12). Tal rosa deve estar numa área de azul celeste, simbolizando que tal alegria em espírito e fé é o começo da futura alegria celestial, que já começa, mas é obtida em esperança, pois ainda não é revelada. Ao redor dessa área está um círculo dourado, simbolizando que tal bênção no céu dura para sempre; é sem fim. Tal bênção vai além de toda a alegria e bens, assim como o ouro é o melhor metal, o mais valioso e precioso. Este é o meu compendium theoligae [o sumário da teologia]... (fonte: www.luterano.com.br/rosa.htm)
} 
mesmo não é, na realidade, Jesus Cristo. Eis porque chamar as imagens

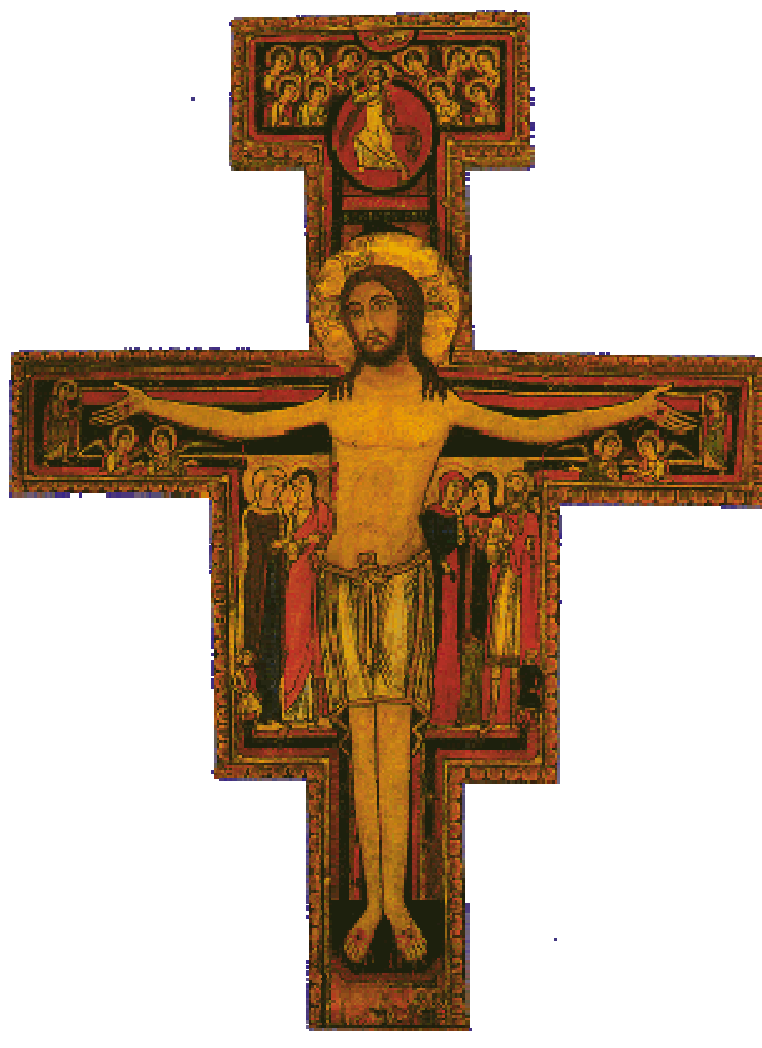

Figura 63: Crucifixo de São Damião, autor desconhecido, aproximadamente século XII. católicas de ídolos é absurdo: elas estabelecem, simbolicamente, o que querem representar, buscam recordar o que se convenciona dizer Cristo crucificado, a Virgem Maria ou qualquer outro santo, não se diz que as imagens sejam elas mesmas o Cristo crucificado, a Virgem Maria ou Santo Antônio, por exemplo.

Outro ponto a se observar é que essas imagens sacras são codificadas segundo o momento em que estão inseridas, ou seja, também participam de uma convenção social a que estão submetidas, sofrendo, muitas vezes, mudanças na forma como são representadas, principalmente no Ocidente. No Oriente, por outro lado, a confecção de ícones utilizados pela Igreja Ortodoxa ainda segue os mesmos procedimentos de seu início como arte sacra: nunca é assinada, não há feixe de luz externo que incida sobre a imagem em nenhum dos lados ${ }^{186}$, a luz deve emanar do próprio Cristo, representando sua divindade (Jo 1,5) há, portanto, uma interpretação metafísica da estrutura do corpo humano (Panofsky, 2004, p. 128), já que a proporção estava ligada a aspectos alegóricos, não visuais, valorizando aspectos alegóricos em detrimento dos visuais - diferente de nosso padrão fotográfico ${ }^{187}$-, por isso, muitas vezes, o ícone ortodoxo não nos atinge: para nós, não representa a realidade que gostaríamos de ver.

\footnotetext{
${ }^{186}$ Vide, por exemplo, como van Veermer trabalha a incidência de luz na fig. 58.

187 Provindo da visão unilocular da Renascença.
} 
Se olharmos para o crucifixo da Igreja de São Damião, em Assis, em estilo bizantino

(fig.

63), provavelmente não seremos levados à comoção, mas para quem se interessa por arte - a uma mera análise plástica do momento em que fora criado, talvez em busca de elementos pictográficos distintos dentre as obras que faziam parte daquele fazer artístico -, ou em busca de elementos novos ou especificidades novas que pudessem permitir uma correlação com as obras que conhecemos hoje.

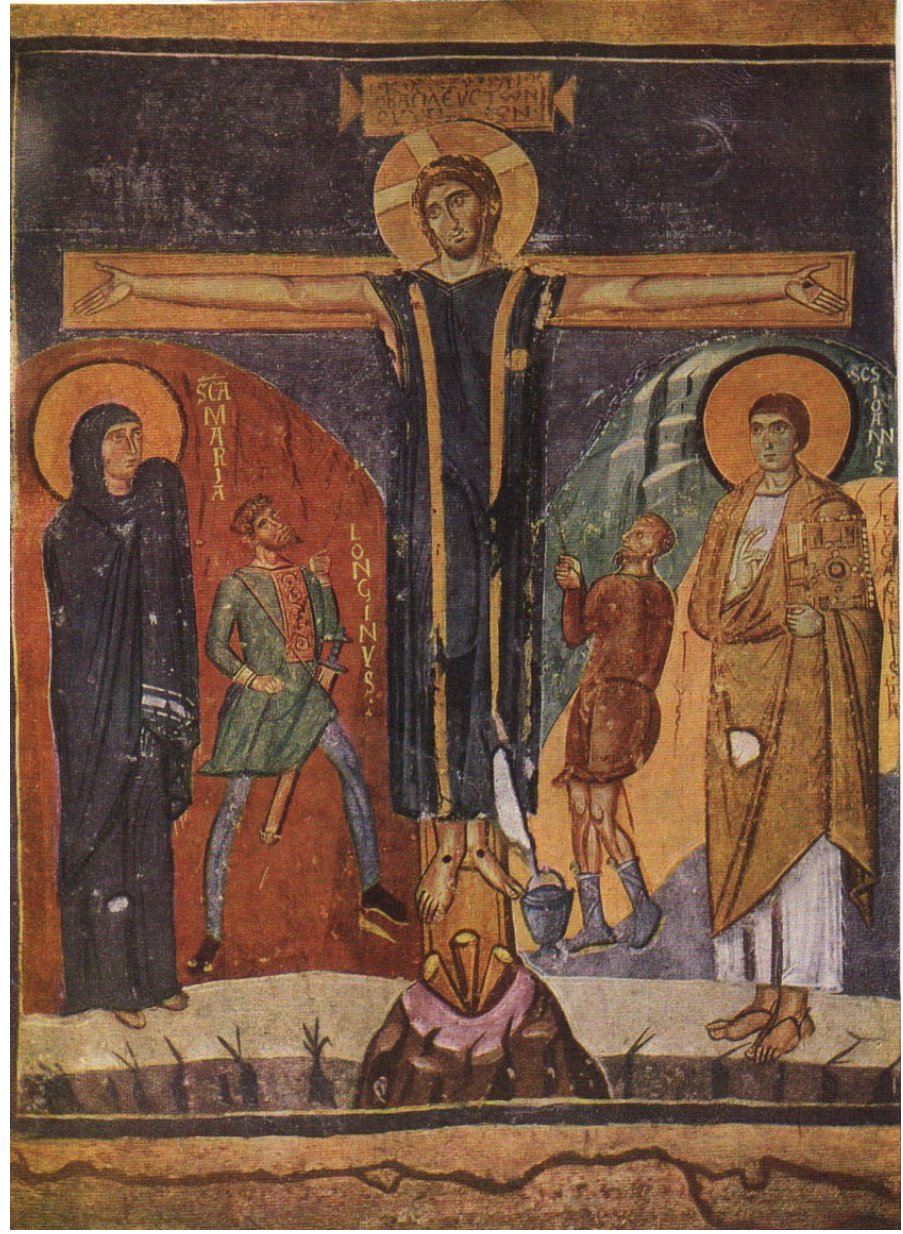

Figura 64: Crucificação de Cristo, afresco romano do século VIII, Roma.

Foi exatamente a contemplação dessa imagem, de sua expressão e linguagem simbólica, que levou São Francisco de Assis a seu arrebatamento e conversão, ou seja, por meio dela - daquilo que ela transmitia simbolicamente - que se expressou sua experiência espiritual. Dessa forma, depreende-se que a expressão realidade mimética como mera cópia e simulacro do real, podia não atingir o homem do medievo, seu olho e olhar não estavam codificados para ver pela janela o mundo em perspectiva, afinal a ratio medieval era transcedente não ligada ao mundo fenomenológico, muito menos ao racionalismo renascentista que o substituiria.

Assim, o crucifixo de São Damião, como representação de Cristo, reflete aquilo que seus leitores queriam e podiam ver, tem legitimidade diante de uma sociedade que ainda não está interessada em ver no Cristo crucificado um homem das dores, mas Deus que, apesar da morte, ressucitou, vencendo-a: as primeiras imagens de Jesus crucificado, por exemplo, mostravam-no de olhos 
abertos, vestido como sacerdote, em toda sua divindade (fig. 64). A partir do século XII, porém, tem início a representação do sofrimento, da dor, quando atingem o ápice da angústia no século XVII: vemos estampado no Cristo crucificado o desespero pelo abandono na cruz e a angústia diante da morte. No entanto, não é essa a imagem da cruz de São Damião; provavelmente, uma imagem barroca seria execrada pela sociedade medieval, que não veria nela a representação de Cristo: não podia enxergar um Jesus das dores, mas um glorioso. Corrobora-se, portanto, que a imagem sacra, como um ícone ortodoxo, é legitimada pela cultura em que está inserida, produz efeito naqueles que enxergam nela muito mais do que tinta e um pedaço de madeira, mas a própria emanação do divino que representa. Não há imitação fidedigna, cópia da realidade, afinal não há a menor preocupação com as proporções, mas com a alegorização.

Dizer que o Renascimento foi um período de desenvolvimento econômico, cientificista, cuja visão antropocêntrica retirou o homem da escuridão medieval, centrada que estava numa visão simbólica e deturpada do mundo é deveras simplista. Primeiramente, porque parte das transformações que se deram nesse período foram decorrentes dos estudos medievais, mesmo que tenham sido no campo das humanidades e com o intuito de racionalizar a fé cristã, apesar de não haver unidade na busca por modelos e explicações do conhecimento pagão. Se, por um lado, temos São Jerônimo, buscando exemplos na literatura pagã, por outro temos Santo Agostinho não as aceitando totalmente (Curtius, 1996, pp. 75-76): mas reside aí o embate de idéias que formará o pensamento intelectual e conceitual da Idade Média que atravessará o medievo, prolongando-se até o Barroco. Tais estudos procuravam, inclusive, demonstrar a própria dinâmica da Bíblia,

escrita numa linguagem artística, elaborada segundo as normas gramaticais (e isso quer dizer poética também), [ou seja]: as artes são indispensáveis para [sua] compreensão. (ibidem, p. 82) 
Por isso não se contentavam em restringir seu conhecimento a um mero embate teológico, inseridos em um campo determinado, mas ir além, em busca do conhecimento

das figuras de retórica, tropos e outros elementos semelhantes, [pois] ninguém pode duvidar de que o leitor tanto mais depressa lhes compreenda o sentido espiritual quanto mais cedo se tenha instruído no estudo das letras. (ibidem, p. 85)

Cada vez mais, os autores da Antigüidade tornavam-se essenciais para se compreender tanto a língua (latina) quanto a literatura na Idade Média. No entanto, o fato de a seleção dos autores didáticos pelos estudiosos medievais abranger tanto escritores pagãos quanto cristãos, além de não distinguirem, claramente, a poesia da época de Augusto e a do fim da Antigüidade (Cf.: ibidem, p. 88), é uma demonstração que ainda thes faltava consciência histórica e crítica (Cf. ibidem, p. 89) - refletida no anacronismo artístico, por exemplo -, fato análogo ao que já se verificava na Antigüidade:

O teatro antigo tinha pouco motivo para desenvolver esta consciência, porque 0 círculo dos seus objetos era demasiado limitado e porque o público antigo não considerava nenhuma forma de vida e cultura, a não ser a própria (...). Durante a Idade Média, perdeu-se até o conhecimento prático de culturas estranhas e de outras condições de vida; embora duas delas, pertencentes ao passado, a antiga e a judeucristã, tivessem grande importância no contexto das culturas medievais e fossem, sobretudo a judeu-cristã, representadas freqüentemente na Literatura e na Arte, a consciência perspectivo-histórica faltava, na medida em que os acontecimentos e os seres humanos daquelas longínquas épocas eram transferidos para as contemporâneas formas e condições de vida: César, Enéias, Pilatos, tornavam-se cortesãos; José de Arimatéia, burguês, e Adão, um camponês do século XII ou XIII. (Auerbach, 2004, p. 285)

Não havendo, evidentemente, discernimento do anacronismo no medievo devido à falta de consciência histórica, autores da Antigüidade são elevados à categoria de autoridades, possuem um valor semelhante, tornandose atemporais. Na Idade Média seu prestígio beirava a cegueira, além de serem incontestes, buscava-se nos auctores aquilo que ainda não possuíam: a 
autoridade científica (pelo menos em nossa acepção moderna), por isso deixam de ser uma simples fonte de consulta, já que

não são somente fontes de saber; são um tesouro da ciência e filosofia da vida. Encontravam-se nos poetas antigos centenas e milhares de versos que condensam experiências psicológicas e regras de vida. (...) que se guardavam de cor, colecionamse, dispõem-se em ordem alfabética, para fácil consulta. (Curtius, 1996, p. 95)

Essas regras, experiências e todas as informações catalogadas formam mais do que uma mera coleção de apotegmas, constituem um núcleo de conhecimentos - muitos dos quais imagéticos - que servirão como base para muitos preceitos e explicações nos quais as iconologias e os livros de emblemas beberão. Ripa, por exemplo, ao exemplificar suas alegorias, vale-se do vasto material propiciado por essas sentenças, conforme podemos comprovar meio de suas referências a Homero, Horácio, Ovídio, Virgílio e Aristóteles.

Tem início, no século XII, o aprofundamento da obra de Aristóteles, que chega à Europa via Averróis (1126-98), maior aristotélico árabe medieval. O pensamento do Estagirita é, num primeiro momento, condenado, provavelmente devido à necessidade de se recorrer a eruditos e comentadores judeus a aqueles escritos, pois os mesmos estavam em árabe, oriundos do grego a partir de uma versão síria. (Cf. ibidem, pp. 92-93) Aristóteles, contudo, foi reabilitado por um dos maiores pensadores medievais: São Tomás de Aquino, que procurou conciliar a doutrina cristã com o pensamento filosófico pagão. No entanto, a influência do Doutor Angelicus foi além do campo religioso, uma vez que sua leitura aristotélica foi utilizada por outros autores como Dante Alighieri (Cf.: Auerbach, 2004, p. 158, 165); além disso, Aristóteles terá uma grande influência no pensamento dos autores e teóricos do Renascimento - como Alciato e Ripa - adentrando e atravessando o século XVII:

La crítica ha puesto de manifiesto que el pensamiento literario se caracterizó por responder a un paradigma teórico compuesto, en el que Aristóteles, por razones 
de prestigio intelectual, ocupó un lugar preeminente, pero en el que otros pensadores tuvieron un papel nada desdeñable. Así Aristóteles, Horacio y Platón componen el triunvirato de auctoritates máximas del Renacimiento, y el cruce de las tres corrientes de pensamiento generadas de cada uno de ellos, independientemente de otras aportaciones menores, alimentó el grueso del pensamiento moderno sobre el hecho literario y sus gêneros. (Sanchez Laílla, 2000, p.10)

Dessa forma - e apesar do embate pela aceitação ou não de doutrinas pagãs pelo cristianismo -, a partir do século XIII, a doutrina filosófica e teológica de Santo Agostinho passa a ser compartilhada juntamente com a de Aristóteles, cujos princípios eram hauridos por muitos estudiosos em antologias ou Auctoritates. (Cf. Nunes, 2001)

Como já mencionado anteriormente, os auctores tornam-se autoridades científicas não só para a Idade Média como também até meados do século XVIII; além disso, acreditava-se que tanto a obra de Platão, quanto a de Aristóteles, como as de outros filósofos da Antigüidade, expressavam, mesmo de forma velada, revelações que anunciavam a chegada de Cristo ao mundo ${ }^{188}$. Assim, obras consideradas herméticas, com conhecimentos encobertos e de difícil interpretação poderiam expressar, naquele momento, verdades ocultas não só concernentes ao homem, mas também de acesso à divindade. Foi exatamente essa leitura que os teóricos do Renascimento fizeram da obra de Horapolo, que chegara a Florença em 1419 e que, em pouco tempo, se tornaria um anseio intelectual e levaria o europeu a entranharse numa busca de tudo aquilo que se referisse ao Egito - manuscritos, papiros, obeliscos -, para que também a ele fosse possível ter acesso a essa chave sígnica.

Dessa forma, vê-se como o pensamento iconológico renascentista foi se compondo: de um lado já havia todo um acervo de sentenças, de apotegmas e de exempla (paradeigma) dos auctoritas, provindos da Idade Média. (Cf.: Curtius, 1996, pp. 96-97) O que corresponderia a uma fonte segura de conhecimentos, adquiridos pela humanidade desde tempos remotos; além

\footnotetext{
${ }^{188}$ Poderíamos dizer que fosse algo semelhante à interpretação figural de Auerbach, só que de uma forma estendida para além do plano bíblico. Vide nota 126.
} 
desses, já havia os tratados medievais sobre animais - bestiários - e sobre as plantas - herbanários -, cuja tradição remonta às versões latinas do Phisiologus grego; de outro, o interesse pelo hermetismo imagético propiciado pelos hieróglifos egípcios, decorrentes da Hieroglyphica de Horapolo: faltava apenas o enlace desses sistemas sígnicos, o que foi efetivado com Alciati, em 1531, com sua obra Emblematum Liber.

Alciati, seguramente, deu corpo àquilo que já fazia parte do ambiente cultural na Europa desde inícios do século XV (Cf.: Zárate, 1989), quando se amalgamavam todas essas figuras alegóricas - provenientes das sentenças, dos hieróglifos, dos bestiários -, concedendo-Ihes além de textos elucidativos uma forma visual. Isso se difundiu e permeou grande parte dos fazeres artísticos do período - e dos outros que se seguiriam, chegando ao século XVIII -, quando se verifica que tais imagens trancendem o meramente estético e convertem-se em tratados de significações doutrinais. Dessa forma, a arte ultrapassa aquilo que poderíamos enxergar como realismo aparente, maneira como a arte renascentista (e depois a barroca) é, muitas vezes, visualizada:

bajo el aparente "realismo" que caracteriza tópicamente a la pintura y escultura barrocas, realismo entendido falsamente, como transcripción literal pero exclusiva de lo que percibe el ojo, late una serie de alusiones y referencias a las verdades de orden espiritual, moral y religioso que convierte la lectura de las obrsa del arte barroco en un fascinante juego. La clave de esta actitud barroca ante la realidade inmediata habría que buscarla en el manejo incesante por parte de aquella lejana sociedade, tan poco parecida a la nuestra, de una copiosa literatura sobre divisas, emblemas y jeroglíficos que había comenzado a entusiasmar desde mediados de la centuria anterior. (Ceballos Gutiérrez, apud Zárate, op. cit.)

Para corroborar essa utilização imagética empregada pelos séculos $\mathrm{XV}$, XVI e, em especial, pelo XVII, e tendo em mãos apenas a obra de Horapolo, faremos uma leitura iconológica (superficial, só dos animais presentes na cena) de uma obra de Mantegna, Oração no Jardim das Oliveiras (fig. 65), em que se vêem Pedro, Tiago e João - que dormem profundamente, apesar de estarem ali para vigiar -, juntamente com Jesus que, num morro, está em oração diante de cinco anjos-meninos que seguram uma cruz. Do lado oposto a essa cena, 
vê-se Judas Iscariotes chegando com uma turba para prender Jesus. Aqui não nos interessa fazer nenhuma análise da construção plástica da obra, mas somente nos ater aos animais nela expostos: um abutre, lebres e cegonhas.

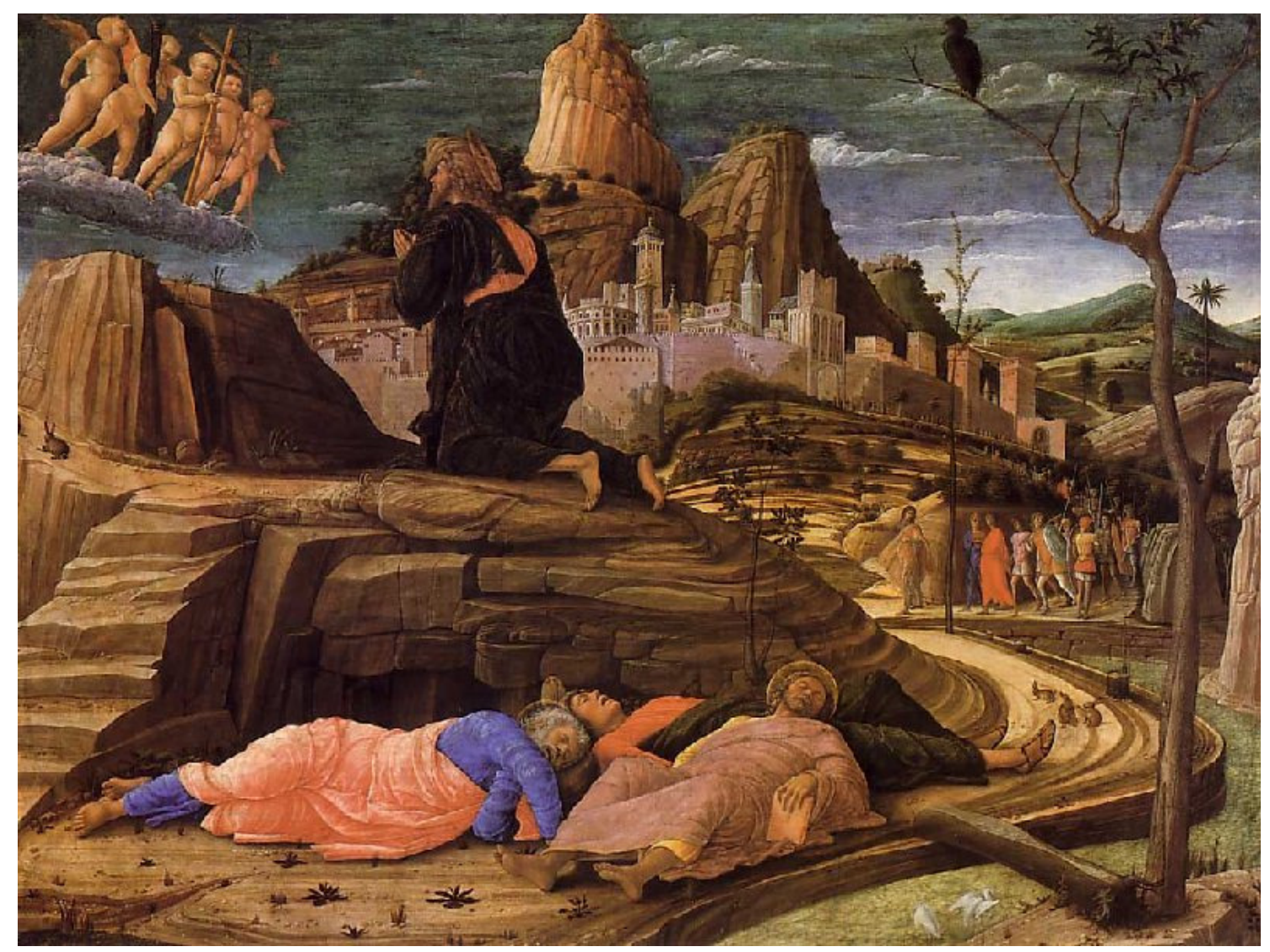

Figura 65: Oração no Jardim das Oliveiras, de Andreas Mantegna, 1460.

O abutre, do alto de uma árvore, lança seu olhar para Jesus que está ajoelhado. Segundo nosso senso comum, o abutre pode representar a morte, já que é um animal que se alimenta dela, no entanto não é essa a visão iconológica que Mantegna quer passar-nos, mas a dada por Horapolo, que via no abutre a clara imagem de Deus, já que não precisa de nada nem de ninguém para procriar-se - acreditava-se, naquele momento, que essas aves eram hermafroditas e se reproduziam por meio do vento. (Cf.: Horapolo, 1991, pp. 92-93) Dessa forma, a imagem do abutre quer dizer-nos que, apesar do sacrifício iminente, Cristo é Deus e seu sacrifício não será em vão, pois reunirá céu e terra novamente.

No caminho que vai dar aos apóstolos, que dormem, como também próximo a Jesus, é possível vermos lebres que, segundo Horapolo, 
representavam a vigilância, isso devido ao fato de esses animais sempre permanecerem com os olhos abertos. Exatamente o que Jesus havia pedido a seus apóstolos:

Então Jesus foi com eles a um lugar chamado Getsêmani. E disse aos discípulos: "Sentem-se aqui, enquanto eu vou até ali para rezar". Jesus levou consigo Pedro e os dois filhos de Zebedeu, e começou a ficar triste e angustiado. Então disse a eles: "Minha alma está numa tristeza de morte. Fiquem aqui e vigiem comigo." (Mt $26,36-38)$

Mas, apesar do pedido, os apóstolos caíram num sono profundo. Não obstante o torpor dos apóstolos, há três lebres próximas aos discípulos que continuam alertas, assim como a que está ao lado de Jesus que, apesar da agonia deste, vigiava a seu lado.

Jesus levanta-se e ao dirigir-se aos apóstolos, demonstra decepção:

Voltando para junto dos discípulos, Jesus encontrou-os dormindo. Disse a Pedro: "Como assim? Vocês não puderam vigiar nem sequer uma hora comigo? Vigiem e rezem, para não caírem na tentação, porque o espírito está pronto, mas a carne é fraca." (Mt 26, 40-41)

Ao lado oposto dos apóstolos, é possível vermos duas cegonhas. Para Horapolo, essa ave representa aquele que ama seu pai (Horapolo, 1991, p. 375), porque cuida deles e respeita-os quando estão velhos (ibidem, p. 175). Mantegna, portanto, mostra-nos a total obediência de Jesus à vontade do Pai, ou seja, sabe que aquilo tem de ser feito, portanto está pronto para realizá-lo:

Jesus foi um pouco mais adiante, prostrou-se com o rosto por terra, e rezou: "Meu Pai, se é possível, afaste-se de mim este cálice. Contudo, não seja feito como eu quero, e sim como tu queres." (Mt 26, 39)

Com a consolidação imagética proporcionada a partir da obra Hieroglyphica de Horapolo e a conseqüente concretização emblemática, por Alciati, esses livros tornaram-se uma febre na Europa. Várias edições baseadas no Emblematum Liber seguiram-se, quando vários autores não só o 
imitavam, como também esses se imitavam, sempre tendo o livro do teórico italiano como norte:

A cultura do livro de emblema cresce e multiplica de tal modo, e tantos livros de emblema são criados, traduzidos e publicados, que em determinado momento os leitores europeus estão já perdidos numa inflação de símbolos, hieróglifos, marcas secretas, e códigos herméticos de todo tipo. Nesse instante, surge um livro de emblemas que é diferente, mas que também é absolutamente necessário: um livro com as "chaves" para todos os milhares de emblemas que se multiplicam, para as infinitas simbologias que proliferavam, fazendo com que o universo emblemático parecesse ter se transformado num pesadelo de significados aleatórios à la Jorge Luis Borges. Com tanto simbolismo, o discurso visual, sobrecarregado, ficou afetado. (Grieco, 2003, p. 89)

É nesse contexto que surge a obra de Cesare Ripa, publicada em 1593, ou segundo Panofsky:

"a chave das alegorias dos séculos XVII e XVIII", explorada por artistas e poetas tão ilustres quanto Bernini, Poussin, Vermeer e Milton. (Panofksy, 2004, p. 216)

Ripa, portanto, estabeleceria o elo necessário para que a Iconologia se firmasse como um modelo epistemológico. Para o teórico italiano, a função de sua obra seria uma descrição fundamentada das imagens - exatamente aquilo que Panofksy denominaria iconografia. Poder-se-ia inferir que para Ripa ainda não estava claro o próprio significado da palavra iconologia, fato que somente foi realizado após sua morte, na edição de 1630, quando é possível encontrar a referência etimológica do termo.

Consideraremos, nesta Tese, a obra de Cesare Ripa como a constituição de um modelo iconológico ${ }^{189}$, devido a seu alcance e a sua importância para

\footnotetext{
189 Deve-se, mais uma vez, salientar que houve outras compilações no período como a Hieroglyphica (1556) de Piero Valeriano (1477-1558) - baseada em Horapolo - que complementavam, inclusive a obra de Ripa.
} 
(...) oradores, predicadores, poetas, pintores, escultores, dibujantes, y para todos los estudiosos en general, así como para idear Conceptos, Emblemas y Empresas, para disponer cualquier tipo de cortejo nupcial, funeral o triunfal, para representar poemas dramáticos, y para dar forma con los más apropiados símbolos a cuanto pueda caber en el pensamiento humano. (Ripa, 1989, v. 1, p. 39)

Assim, Ripa inicia a página de rosto de sua obra de 1613, demonstrando que, mais do que uma mera compilação de imagens e palavras, sua Iconologia trataria das regras que as regem (ibidem, p. 45); ou seja, estabeleceria uma metodologia de aplicação de $\operatorname{conceitos}^{190}$ alegóricos aos mais diversos fins de que a sociedade, em que estava inserido, tinha necessidade. Para isso, opta pelo método aristotélico a partir da Lógica e da Retórica, já que desta retirará a base teórica da metáfora; daquela, a técnica da definição.

Mas, muito mais do que um emprego conceitual da Antigüidade, é dela que retirará parte do repositório ideológico de que a obra disporá, como seu modelo, obtido a partir das medalhas empregadas no Império Romano - essas possuíam além de uma imagem, um conceito alegorizante -; além disso, utiliza a mitologia pagã para demonstrar conceitos alegorizantes: Marte, por exemplo, representava a guerra; Mercúrio, a indústria. Mas, Ripa não permanecerá somente nas alegorizações de origem latina, também utilizará a filosofia grega, de onde retirará aportes para suas definições, bem como a egípcia, da obra de Horapolo, cuja importância já havíamos assinalado e da qual Ripa não poderia prescindir. Além da Antigüidade - Homero, Horácio, Ovídio, Virgílio -; merecem destaque na composição da obra de Ripa o material compilado durante a Idade Média - as sentenças, as exempla -, bem como seus teóricos e poetas Santo Agostinho, São Tomás de Aquino, Dante, Petrarca -; do material propiciado pela emblemática - Ripa cita, várias vezes, Alciato.

Havia, para Ripa, dois conceitos possíveis para se alegorizar:

a) os naturais, que corresponderiam às imagens dos deuses da Antigüidade;

b) os inerentes ao próprio homem.

\footnotetext{
${ }^{190}$ Convém assinalar o que significa para Ripa a palavra conceito: Téngase en cuenta que entendemos por conceptos, sin entrar em mayores sutilezas, todos cuantos pieden ser representados mediante las palabras, pudiéndoseles dividir a su vez en dos clases, para mayor comodidad. Una de ellas consiste en afirmar o negar alguna cosa respecto de alguién, mientras que la outra no lo hace así. (Ripa, 1989, v. 1, p. 46)
} 
Os naturais já possuíam uma codificação própria repassada pelos clássicos, visto que cada deus corresponderia a um ou mais fenômenos; os referentes ao homem poderiam ser simbolizados de várias formas: ou valorizando, individualmente, o conceito ou repelindo-o.

Ripa, no proêmio da obra, cita-nos a máxima que diz ser o homem a medida de todas as coisas, por isso na imagem, segundo o propósito por ele estabelecido na Iconologia, tem de haver a figura humana (cf.: ibidem, p. 46), afinal é dela que se pretendem particularizar as contradições morais. Dessa forma, seria inapropriado que o corpo do qual se define algo não aparecesse na definição proposta para o mesmo. (cf.: ibidem, pp. 46-47)

A partir desse momento, Ripa pontua como definir a alegorização, a partir de dois princípios básicos:

a) disposição, ou seja, a expressão física adequada daquilo que se quer retratar:

Así, encuanto a la disposición adecuada, la cabeza podrá adoptar diversas posturas, yendo alta o baja, alegre o melancólica, descubriéndonos con ello otras muchas pasiones, tal como la apariencia del rostro nos las transmite en el Teatro. Deberá notarse también su disposición en brazos y manos, pies y piernas, trenzas y vestidos, así como un otra multitud de detalles; y según la posición que se adopte, claramente descrita y definida, todo el mundo ha de poder comprender por sí mismo su significado, sin necesidad de extenderse en explicaciones, tomando ejemplo de los antigos romanos que observaron siempre las disposiciones que digo. (ibidem, p. 47)

b) qualidade, ou o conjunto de elementos essenciais que diferenciam algo ou alguém:

(...) cada figura podrá ser blanca o negra, proporcionada o desproporcionada, gruesa o magra, joven o vieja (...). Mas se há de advertir que todas estas cualidades, siendo partes de un todo, han de compenetrarse unas con otras con tal armonía que su descripción nos haga conocer al mismo tiempo la correlación que las une y el buen juicio del que supo ordenarlas y disponerlas juntas de modo que resulte de todas ellas una sola cosa, y aun ésta deleitosa y de la mayor perfección que alcanzarse pueda. (ibidem,p. 47) 
À continuação, Ripa nos diz que quase todas as imagens desenhadas pelos Antigos possuíam essas características, quando levavam em consideração a significação das cores e as características da fisionomia humana; e, para isso, cita a autoridade de Aristóteles. (Cf. ibidem, p. 47) E é baseando-se no Estagirita que demonstra a necessidade de se observar os quatro princípios de uma definição:

a) a matéria, os atributos que constituirão os fundamentos para a formação da alegoria;

b) a eficiência, o ser ou não possível a representatibilidade da matéria por meio de uma alegoria;

c) a forma, a construção da imagem mediante seus atributos;

d) o fim, a percepção visual do conceito abstrato que se pretende alegorizar.

A partir desse momento, o autor da Iconologia mostra-nos que, ao se elaborar uma alegoria, não deve haver uma simples analogia entre a idéia alegorizante e seu atributo simbólico, o que demonstraria falta de engenho, além de pouco valor, como representar o Desespero com alguém com uma corda amarrada ao pescoço, ou Amizade, quando se vêem duas pessoas que se abraçam. (ibidem, p. 48)

Deve ser abordado ainda o fato de Ripa dar extrema importância à nomeação das alegorias:

También me parece que es buena cosa y digna de seguirse observando el inscribir bajo ellas sus nombres, excepto cuando se trate de algún Enigma, pues sin tener noticia de su denominación no es posible alcanzar el conocimiento de la cosa significada, a no ser en el caso de Imágenes triviales, que por el uso repetido son reconocidas por todos a primera vista. (ibidem, p. 50)

Vê-se, portant, que a Iconologia constitui-se em

um dos projetos mais ambiciosos para buscar as fontes das personificações e das alegorias que chegaram ao homem do Renascimento, sem que se soubesse [muitas vezes de forma precisa] de que esfera cultural da Idade Média elas provinham. 
A Iconologia de Ripa é a obra que estabelece parâmetros que por muito tempo vão vigorar na interpretação da simbologia das representações. (Rosa, 2007, p. 247)

Dessa forma, a Iconologia tornar-se-ia muito mais do que um manual de imagens e sentenças - visto que essas também pretendem moralizar, não simplesmente entreter -, ou mesmo de uma taxionomia de virtudes e de vícios acompanhados de suas alegorias visuais. Como foi possível depreender, sua lógica imagética era duplamente articulada, fosse como uma técnica construtiva, fosse como técnica interpretativa (Hansen, 1986, p. 87-88), ou seja, sua utilização só seria possível por aqueles que detivessem a chave sígnica que abriria as portas da interpretação, já que é isso que demonstraria engenho, seja para o autor - que não perdeu tempo enquanto escrevia (cf.: Ripa, s/d, v. 1, p. 50) -, seja para o leitor - que terá prazer quando, na contemplação da obra, identificar o que se pretendia dizer. (Cf.: Aristóteles, 1996, p. 33)

Da forma como foi concebida por Ripa, a lconologia constituiu-se em um manual a ser observado, cujas raízes remontam à Antigüidade, impregna-se da Idade Média, atravessa o Renascimento, norteia o pensamento do homem barroco e chega à Era da Razão, quando cai em descrédito:

Ripa, a pesar de su erudición, carece de gusto, y para convencerse de ello es suficiente ojear esa multitud de figuras monstruosas que deben ser proscritas de la pintura y de las que Horacio se mofa (...). (Ripa, s/d, v. 1, p. 21)

Afinal, parte dos conceitos de Ripa, bem como da emblemática, estavam ligados à Weltanschauung medieval - que foram execrados durante o Século das Luzes, daí a criação do epíteto que a Idade Média recebera do período de Idade das Trevas -, além, é claro, da interpretação fantástica perpetrada por Horapolo à figuração egípcia:

La mentalidad ilustrada del siglo XVIII comenzó a cuestionar estos importantes códigos de información para artistas e intelectuales, comprendió que el fundamento del Emblema era netamente fantástico por cuanto partía de premisas falsas apuntadas por Horapollo, figura enigmática que compuso la Hieroglyphica hacia el siglo IV, obra que llegaría a Florencia en el XV y que estimuló las mentes más preclaras del 
Humanismo dando origen a esta literatura que hemos llamado Emblemática. (Zárate, p. 256,1999$)$

No início deste trabalho, falamos do papel da $\tau \dot{\varepsilon} \chi v \eta$ no desenvolvimento do homem, na mudança de seus conceitos e na forma de ver e de agir diante do mundo que o cerca. Isso, agora, fica claro no futuro em que estamos inseridos e diante das vertiginosas transformações por que estamos passando. Conceitos como velocidade e reprodutibilidade fazem parte de nosso dia-a-dia e sequer nos damos conta disso, no entanto também foram decisivas para a instauração do predomínio europeu mundial, para o desenvolvimento do capitalismo - e da burguesia - e, finalmente, para a disseminação de novas idéias e novas formas de arte.

As transformações sócio-econômicas e culturais por que passou a Europa em meados do século XV, levaram aquela sociedade a desenvolver pesquisas em busca de formas mais eficientes e duradouras para se registrar os éditos reais, notariar custos e gastos, inclusive os acontecimentos e informações diversas diante da sofisticação e da complexidade que se verificou em comparação ao período anterior. O desenvolvimento no fabrico do papel, por exemplo, tornou-o mais barato e acessível, não só facilitando seu emprego como também o universalizando, promovendo, inclusive, o acesso de um

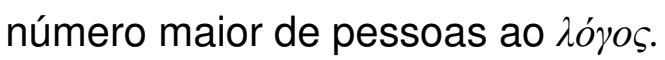

Essa dinamicidade cria condições favoráveis para que Johannes Gutenberg (1390?-1468) criasse a imprensa e seus tipos móveis de chumbo. Tal acontecimento mostrou-se revolucionário, já que por seu meio, a velocidade e a reprodutibilidade de idéias, de teorias e de conhecimentos, atingiram um nível jamais visto na sociedade humana anteriormente. Dessa forma, a grande perdedora foi a Igreja, que perde o status de detentora exclusiva do conhecimento humano, quando se retira dela o poder de

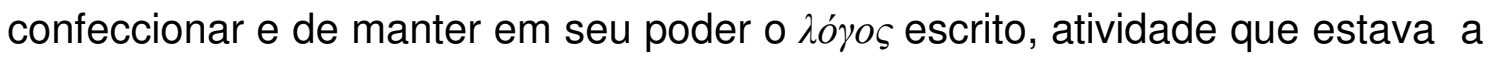
cargo de monges copistas. Assim, esse material manuscrito permanecia na mesma Instiuição de onde proviera, mantendo-se sempre numa auto-gestão. Além disso, essas obras (entre elas a Bíblia) não se destinavam a outros segmentos da sociedade, já que além de não ser permitido que todos as 
tivessem, poucos poderiam, efetivamente, fazer uso delas, afinal a grande maioria da população era analfabeta.

Diante da novidade proporcionada pela imprensa, houve, evidentemente, a rejeição inicial da Igreja, principalmente no que diz respeito à possível popularização da leitura de textos proibidos - inclusive a própria Bíblia, que constava em seu Index Librorum Prohibitorum. No entanto, ao enxergar vantagens em sua utilização para propagar sua doutrina e manter seu status quo, a Igreja não só aceita a novidade como a empregará de várias maneiras. No entanto, o acesso a um número cada vez maior de textos e a rápida propagação de novas idéias filosóficas e religiosas dão início a um questionamento constante da própria hegemonia religiosa, desencadeando discussões que levariam à não aceitação da Igreja Católica como única guardiã da verdade espiritual e que culminariam não só com a Reforma de Lutero, como também com uma nova visão cientificista do mundo:

A revolução científica que viria a questionar as verdades à guarda da lgreja foi igualmente uma consequência directa da tecnologia da impressão. O princípio científico da repetibilidade, garantido pela verificação imparcial de resultados experimentais, estabeleceu-se como paradigma, graças à rápida e ampla disseminação, pela imprensa, de reflexões e descobertas científicas. Acelerando a troca de ideias, estimulou a produção de conhecimento científico, contribuindo para o nascimento de uma comunidade científica que funcionasse sem constrangimentos geográficos. Sistematizaram-se assim metodologias e acrescentou-se sofisticação ao pensamento racional. À medida que mais e mais livros se tornavam acessíveis, $o$ corpo de conhecimentos expandiu-se, originando o surgimento de índices e de sistemas de referência cruzada como formas de possibilitar a gestão da informação disponível, bem como para associar criativamente ideias e assuntos aparentemente distantes e sem qualquer relação. (Bacelar, 1999, p. 4)

No entanto, mais do que questionar, a imprensa levou a mudanças expressivas que contribuíram, inclusive, para ampliar e universalizar as inovações trazidas pelo Renascimento como a visão unilocular - devido à disseminação da teoria albertiana -; a divulgação de tratados e obras da Antigüidade que, em muitos casos foram traduzidas para o vernáculo (que, em contrapartida, acabaram por auxiliar sua própria sistematização); a propagação 
e a disseminação sem igual da nova teoria imagética propiciada pelo gênero emblemático e pelas idéias iconológicas de Ripa; sem contar, evidentemente, com a revolução na comunicação humana e sua propagação que seriam vistos, nessa amplitude, apenas séculos depois:

A tecnologia da impressão desencadeou uma revolução nas comunicações que viria a tocar muito fundo nos modos de pensar e nas interacções sociais. A impressão, em conjunto com a linguagem falada, com a escrita e os meios electrónicos, é considerada um dos marcos de mudanças fulcrais na história da comunicação e que viriam por sua vez a influenciar as mudanças sociais e intelectuais subsequentes. (ibidem, p. 4)

Com a propagação do $\lambda o ́ \gamma o \varsigma$ escrito, teremos o pleno domínio da visão e o rompimento de parte da interação comunitária, pois o homem foi substituindo, lentamente, o ouvir em grupo para o ler individual, ou mesmo a interação do contador de histórias - que troca experiências entre o grupo - para o orador que somente se dirige, quando muito, a um grupo -, o reino do ouvir estava cedendo espaço para o do ver:

A cultura oral passa de geração em geração através de uma atmosfera de interacção pessoal emotiva e sensorial. A escrita facilita a interpretação e a reflexão, uma vez que a memorização já não é tão essencial para a comunicação e o processamento das ideias. A história registada pode ser acrescentada e actualizada ao longo dos tempos. O texto manuscrito originou uma variação nas tradições orais: 0 hábito comunitário de contar histórias, associando à palavra a expressão corporal, a dança, etc., transforma-se na leitura do texto, por um orador, para o grupo. (ibidem, p. 4)

Poderíamos inclusive inferir que essa busca pelo individual assemelhouse ao boom verificado pela expansão imagética que se verificou no Renascimento. As imagens, na Idade Média, tinham, forçosamente, de se dirigir à multidão, tinham de tocar o todo, daí o nivelamento de sua representação, devido à maioria da população ser analfabeta. Facilitava-se com isso, o seu direcionamento, ela iria aonde seus senhores quisessem; além 
disso, a idéia do indivídual era relativa, já que se pensava coletivo (e no coletivo).

Quando se pensa em leitura no período, lembramo-nos dos monges copistas que executavam seu trabalho na privacidade das salas comunais e de estudo dos mosteiros medievais, quando falar nem sempre era permitido; o contrário se via nos campos, quando a faina normalmente era acompanhada de música ou de longas conversas para minimizar o esforço de que, muitas vezes, sequer se tinha juízo - afinal se estava condicionado para isso e não podiam enxergar uma outra realidade que não fosse essa ${ }^{191}$. Com o advento da imprensa, por exemplo, a própria privacidade monacal ganha em amplitude e chega àqueles que podem dar-se ao luxo de lerem tanto o hóyos ali estampado, como também as imagens que possam estar geminadas a ele, ilustrando-o e sendo por elas ilustrado, como em um processo de iniciação: o $\lambda o ́ \gamma o \varsigma$ ainda sente necessidade do cikcóv para se firmar, para clarificar, já que a tradição escrita, apesar de longa, esteve, durante séculos, restrita a uns poucos. Para que essa ruminação logo-icônica fosse possível, a privacidade era necessária:

A impressão, por seu lado, estimulou a procura da privacidade. Livros mais baratos e portáteis levaram à leitura silenciosa e solitária. Esta orientação para a privacidade integra-se num movimento mais amplo de conceptualização e reivindicação de direitos e liberdades individuais, cujo surgimento a imprensa estimulou e contribuiu para divulgar. A impressão impregnou a cultura ocidental com os princípios da estandardização, da verificabilidade e da divulgação de idéias e conhecimentos, a partir de uma fonte, e sua disseminação por muitos receptores dispersos geograficamente. (Bacelar, 1999, p. 4)

Essa estandardização, contudo, não deve ser entendida como aquela que havia no medievo, pois aqui ela é direcionada ao indivíduo via $\lambda o ́ \gamma o \varsigma ;$ à diferença daquela, voltada ao coletivo e por meio exclusivo do sikćv existente nas grandes catedrais (ou mesmo nas igrejas locais). Apesar disso, ambas podem doutrinar, à diferença de que aqueles que têm perfeito domínio do $\lambda o ́ \gamma o \varsigma$ possuem maior liberdade para a escolha, tanto para dominar o mundo como

${ }^{191}$ Algo que nos lembraria o mito da Caverna de Platão. 


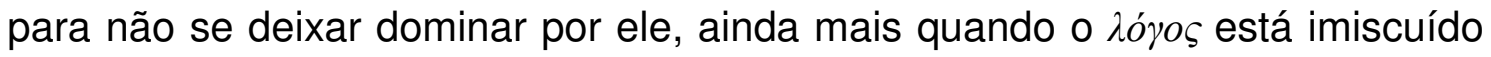
com o sikóv.

Tal como influenciou profundamente a reforma do pensamento religioso e do método científico, as inovações da imprensa desafiaram igualmente o controle institucional. A imprensa estimulou a procura e o credo numa verdade fixa e verificável, assim como abriu caminho aos homens para o livre arbítrio e ao direito de escolher individualmente percursos intelectuais e religiosos. (ibidem, pp. 4-5)

De certa forma, a Igreja tinha razão de temer a imprensa, já que essa abriu novas possibilidades de se ler o mundo em que se está inserido e de se questionar o status quo. No entanto, se houve baixas no lado católico, também houve ganhos, principalmente quando se verificou que o mesmo $\lambda o ́ \gamma o \varsigma$ é que se tornou a própria força da Igreja Católica, quando utilizada por sacerdotes que podiam dominar os recursos oratórios e retóricos em busca de embates para a

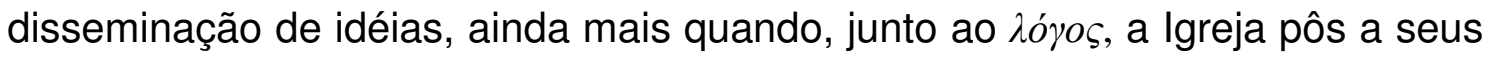
serviços o cikćv. Exemplo desse sucesso foram os jesuítas e seu trabalho ao redor do mundo, pois mal o globo havia sido descoberto, lá estavam os jesuítas com seus livros, sua capacidade cognitiva, seus papéis - e toda a rede epistolar de que dispunha a ordem - e suas imagens: cuja função era ad majorem gloria Dei. ${ }^{192}$

Entretanto, o tempo passou e essa visão e emprego iconológicos desapareceram, assim como o gênero emblemático, apesar disso, as imagens não se dissiparam, só o homem já não necessitava mais do cikćv para compreender o גójos, este se tornara livre. O vernáculo, por exemplo, estabelecera-se em busca de novos caminhos mais refinados, o que se verificou no jogo poético com suas construções imagéticas ${ }^{193}$. Hoje, evidentemente, não há mais espaço para compêndios iconológicos, o mundo mudou e o tempo absorve-nos: cada vez mais, 24 horas é pouco para o homem do futuro, muito menos para sair em busca de motes para a criação, ou de modelos para serem, simplesmente, copiados.

\footnotetext{
${ }^{192}$ Ideal da Companhia de Jesus (jesuítas): Para a maior glória de Deus.

${ }^{193}$ Como no experimentalismo da poesia moderna.
} 
Quando os movimentos vanguardistas do século XX romperam com 0 conceito mimético, abriram surpreendentes possibilidades para o fazer artístico, antes preso a modelos que deveriam ser simplemente seguidos, afinal não enxergavam outra possibilidade de se fazer arte sem a busca por uma referencialidade que lhe era externa, sem a busca pura e simples da $\mu і \mu \eta \sigma \iota \varsigma$ : não havia liberdade de criação.

$\mathrm{Na}$ primeira parte desta Tese, verificou-se que não dispomos mais de um múltiplo referencial que poderia nos servir de repertório, dessa forma temos, continuamente, de criar nossa própria fonte provedora, de forma individual e única. Assim, quando nos depararmos com textos que são alheios a nossa própria Weltanschauung, teremos de redirecionar a construção dessa leitura icônica para outros modelos que não os seiscentistas, já que não os possuímos mais, ou seja, para aqueles que fomos construindo ao longo dos séculos $X X$ e do $X X I$.

O texto seiscentista, por exemplo, sempre apontava para um manancial iconológico predeterminado, logo o jogo entre o escritor e o leitor consistia em verificar em que grau aquele conseguia tornar seu texto mais engenhoso para este, estimulando no leitor o prazer em solucionar uma dificuldade, ou segundo o jesuíta Baltasár Gracián:

La verdad, cuanto más dificultosa, es más agradable: y el conocimiento que cuesta, es más estimado. Son noticias pleiteadas, que se consiguen con más curiosidad, y se logran con mayor fruición, que las pacíficas. Aquí funda sus vencimientos el discurso, y sus trofeos el ingenio. (Gracián, 1987, p. 44)

Ao ruir esse sistema, e ao optar-se pelo novo, pelo inédito, a leitura de mundo tem de ser construída continuamente. O mesmo, evidentemente, se dá com a leitura de poemas e das imagens por eles evocadas, já que esses têm como função apontar:

(...) cada frase que pretende "dizer" algo só tem êxito quando aponta para algo. Como isso vale para todos os textos ficcionais, seus correlatos constamente se entrecruzam e assim alcançam a plenitude semântica à qual visam. Tal resultado, 
porém não se realiza no texto senão no leitor que "ativa" a interação entre os correlatos, pré-estruturada na seqüência das frases. (Iser, 1999, p. 15)

Agora, não é possível apontar para aquilo que não existe mais, ou seja, isso tem de ser substituído por um correspondente, ou por aquilo que nós, enquanto leitores, colocarmos em seus lugares, para que seja possível ativar uma correlação semântica entre aquilo que foi lido com o mundo a que pertencemos. Dessa forma, ao se lerem textos seiscentistas, verificar-se-á que teremos diante de nós um abismo, pois essas correlações que pudermos fazer serão, normalmente, artificiais demais, ocasionando, dessa maneira, aborrecimento, pois as imagens evocadas não se fecham em elos coesitivos, ou se perdem em interpretações non sense.

Quebra-se, portanto, a protensão esperada pelo texto, e as expectativas em relação a ele. Frustra-se, inclusive, o que dizia Gracián, afinal não haverá fruição nessa leitura, pois se está diante de um referencial que não é o nosso: o fato que se acreditava e era esperado, não o é realmente de fato: o navio que afunda antes de chegar ao porto, não é um navio, nem porto é um local para ancoragem! Essa realidade é verificada todos os dias por aqueles que ainda se propõem a ensinar literatura nas escolas e mesmo no ensino superior: para nossos alunos, assim como para a maioria das pessoas, navio sempre será navio, nunca a vida humana! Por isso ao ler um texto seiscentista, acredita-se que o mesmo seja ou infantil demais - com suas descrições simples, sem sentido (afinal a maioria está alegorizada) - ou difícil demais - não devido à não capacidade de se abrir a chave sígnica da alegoria, mas ao preciosismo da língua, às palavras desconhecidas, ou a uma sintaxe mais rebuscada.

Diante disso, verifica-se o interrompimento do fluxo contínuo da leitura. Essa descontinuidade, no entanto, não é a mesma que se verifica nos textos ficcionais contemporâneos, que são, muitas vezes, aguardados, pois é essa quebra da expectativa que revela a maestria, ou não, do escritor, afinal deve haver algo por trás daquilo que não esperávamos:

(...) as seqüências de frases de textos ficcionais não são apenas ricas em mudanças inesperadas; são exatamente essas surpresas que se esperam daquelas. 
Assim, o fluxo contínuo da seqüência pode até assinalar que existe algo escondido a ser revelado. (ibidem, p. 18)

Verifica-se que a fruição pretendida por Gracián - e que permeará todo os Seiscentos - consistia no prazer proporcionado pela revelação do oculto, em sua dificuldade, no entanto para nós tal prazer advém muito mais dos momentos de protensão e retenção, quando

(...) cada correlato de enunciação consiste ao mesmo tempo em intuições satisfeitas e em representaçõe vazias. (...) Quando um novo correlato começa a preencher a representação vazia do correlato anterior no sentido da antecipação, produz-se uma satisfação crescente da expectativa evocada. (ibidem, p. 16)

Essa satisfação, portanto, advém da dedução daquilo que, se sabe, virá num ato contínuo. Esse fruir, no entanto, só será totalmente possível quando se está inserido dentro de um grupo com o qual se partilham idéias comuns; caso contrário, não será decodificado plenamente, já que pode haver ruídos em sua transmissão.

Pergunta-se, portanto, como essa satisfação pode existir na leitura de textos extemporâneos, na contemporaneidade, se não nos é possível completar esse ciclo em que cada correlato individual de enunciação se abre a um outro, a partir do qual a idéia do anterior é completada? Reside exatamente aí o fastio que se tem com textos do período barroco, pois esse ciclo não se fecha e o elo sígnico está sempre rompido:

(...) cada momento da leitura representa uma dialética de protensão e retenção, entre um futuro horizonte que ainda é vazio, porém passível de ser preenchido, e um horizonte que foi anteriormente estabelecido e satisfeito, mas que se esvazia continuamente; desse modo, o ponto de vista em movimento do leitor não cessa de abrir os dois horizontes interiores do texto, para fundi-los depois. Esse processo é necessário porque somos incapazes de captar um texto num só momento. (ibidem, $\mathrm{p}$. 17)

Esse horizonte vazio somente existirá, se o outro também tiver sido preenchido anteriormente, caso contrário, o fluxo da leitura já haveria sido 
interrompido anteriormente. Agora, se pensarmos em um texto poético - muitas vezes construído por meio de imagens que se sobrepõem e que podem, inclusive, ressaltar os lampejos do inconsciente de um eu lírico - e se delimitarmos o período em que esse esteja inserido, como o barroco, veremos que haverá muitos momentos vazios ao longo de seus versos, não só no devir, mas nas relações verso-verso ou imagem-imagem.

Esses espaços vazios têm de ser preenchidos, a fim de que se possa manter pelo menos um mínimo de fluídez possível na leitura. Esse preenchimento, dessa forma, dar-se-á não com imagens que não pertenciam àquele momento, mas com as que pertencem ao leitor, pois

(...) aqueles leitores que não compartilham o código reproduzido [num determinando momento] se deparam com grandes dificuldades para compreender 0 texto. Se o ponto de vista do leitor é cunhado pelas concepções de um determinado público histórico, ele apenas se avivará se reconstruirmos os códigos históricos que esse público dominara - a não ser que adotemos uma postura crítica em relação ao ponto de vista (...). (ibidem, p. 83)

Dessa forma, acrescentaríamos nesses espaços vazios durante a leitura de textos extemporâneos - e são vazios também por nos faltarem elementos com que possamos preenchê-los, devido ao não conhecimento dos pressupostos que regiam aquela sociedade como as icononologias -, imagens retiradas de um acervo individual do leitor, que chamamos de iconofotológico, cuja fonte seria um acervo fotográfico virtual, construído durante toda nossa vida. Isso se torna necessário, porque a dicronia faz com que o $\lambda o ́$ jos não se mantenha o mesmo durante o correr dos anos, já que não é matéria amorfa e estanque; dessa formaa, as imagens, por ele evocadas, ao sofrerem trambém elas modificações sígnicas diacrônicas, não transmitirão 0 mesmo conceito/idéia que transmitiam, pois

Cada palavra materializa a prática social do grupo ou classe social que a utiliza e que a modifica permanentemente no seu cotidiano, a partir de suas vivências. (Baccega, 2005, p. 2) 
Dessa forma, em nossas leituras do século XVII, e por não dispormos mais das iconologias, de que dispunham os artistas daquele período como apoio, necessitaremos (se tentarmos ler tais textos) de outros suportes imagéticos, para que possamos substituir aquelas imagens, adequando seus dados imagéticos ao momento por que estamos passando, tornando-os legíveis no presente. Isso, evidentemente, será possível por meio do acervo iconofotológico de que dispomos hoje.

O passado está sempre atuallizado no presente, reconfigurado em novas práticas, servindo de base - presente e passado - para planejar o futuro, que, afinal, aí está virtualmente contido. (ibidem, p. 6)

É a esse estoque que temos de recorrer para preencher aqueles espaços vazios durante a leitura que, na realidade, representariam apenas 0 devir significativo que teríamos de preencher com base naquilo que o autor escrevera, e com base em nosso próprio repertório, mas que, devido ao vínculo sígnico - do lido com o que vai ser lido - vislumbraríamos a idéia anteriormente, gerando a fruição por ver o não visualizado ainda, ou seja, deduzindo o fato antes de o mesmo acontecer. Como, normalmente, será mais difícil preenchermos esses espaços em textos de momentos literários tão distantes do nosso - por falta daqueles elementos sígnicos de que não dispomos mais -, isso ficará a cargo de nossas próprias iconofotologias, já que essas seriam o acervo de que dispomos hoje, não mais de cunho coletivo e impositivo - apesar de também provir dessa fonte ${ }^{194}$ coletiva -, mas cujo alcance é bem maior do que a limitação retórica imposta pelos Seiscentos, devido, exatamente, à liberdade de escolha individual.

As iconologias dirigiam-se ao coletivo, formando um acervo também coletivo e de conhecimento de todos aqueles que eram partícipes daquela sociedade. Por outro lado, as iconofotologias possuem também uma fonte coletiva, visto que são extraídas de seu meio, porém sua escolha é individual. Há, sem dúvida, uma grande pressão social para que se escolha essa ou aquela imagem, devido ao poder da propaganda, por exemplo, porém nem todos se deixam levar pelas imagens que lhe são impostas. Como

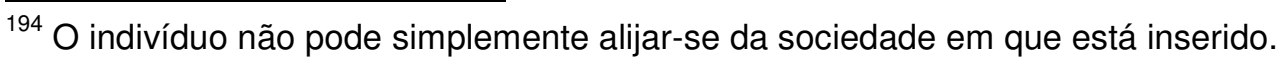


conseqüência, verifica-se que uma leitura feita por um eu pessoal sempre será diferente daquela feita por um outro, já que há uma Weltanschauung individual em meio a uma coletiva: esse é o poder da individualidade que o $\lambda o ́ \gamma o \varsigma$ escrito nos legou, quando de sua universalização, ao libertar-se do sikẃv, como havíamos visto anteriormente, mas que teve sua origem na sociedade burguesa e cujo ápice deu-se nossa. Isso equivaleria dizer que nos deixamos influenciar pelas imagens se, realmente, assim o quisermos, não por imposição do sistema político, social ou econômico, apesar de estarmos, constantemente, sendo influenciados e direcionados por eles ${ }^{195}$ : não somos uma sociedade de estratificada. É possível, inclusive, vermos, atualmente, uma constante divisão social em tribos, cujos membros podem, à medida que os anos passam, transferirem-se de umas a outras, sem nenhum prejuízo individual.

Algo totalmente diverso do conceito seiscentista, para quem não havia individualidade e liberdade de escolha: todos tinham de cumprir um papel determinado, todos eram personagens em uma peça teatral, cujo palco era o mundo dessa forma, não havia por que reclamar do papel designado a cada um, já que

somente se goza ou se sofre durante uma representação. (...) o rodízio na distribuição de papéis [é clara], de maneira que o que hoje se é, um outro o será amanhã. (...) Sua condição aparencial, nunca substancial, de modo que aquilo que se aparenta ser - sobretudo para o consolo dos que sustentam os papéis inferiores - não afeta o núcleo último da pessoa, mas fica na superfície do aparente, freqüentemente em flagrante contradição com o ser e o valer profundos de cada um. Com todas essas implicações, o tópico "grande teatro do mundo" converte-se em um instrumento imobilista da maior eficácia: não há por que levantar-se em protesto pelo destino que coube a alguém; não há por que lutar violentamente para mudar as posições designadas aos indivíduos, já que, por si só, na ordem dramática (não geométrica, à maneira de uma órbita ou ciclo) está assegurada a rápida sucessão das mudanças. (Maravall, 1997, p. 255)

\footnotetext{
${ }^{195}$ Evidentemente que tanto a sociedade quanto a política têm uma força persuasiva incríveis em nossas sociedades, principalmente quando sabem empregar a propaganda a seu favor, basta, para isso, termos em mente o papel exercido pelo nazismo na Alemanha. Agora, é inconteste também o poder de coerção dos meios econômicos sobre a sociedade capitalista, na qual estamos inseridos. No entanto, teríamos a possibilidade de libertar-nos se quiséssemos devido ao livre-arbítrio, fato que dificilmente ocorreria no Barroco e seu poder coercitivo muito maior que permeava toda aquela sociedade.
} 
Essa individualidade e opção de escolha é que faz com que nossa iconofotologia seja sempre diferente da do outro, por mais que vivamos na mesma sociedade e que sejamos, igualmente, influenciados por ela e pela infinitude de imagens que a cercam. Cabem aqui, por exemplo, os conceitos de punctum e de studium de Barthes, para quem nem todas as fotografias têm a mesma recepção pelo eu individual, ou seja, damos atenção mais a algumas, enquanto, simplesmente, passamos rapidamente por outras.

Dependendo do conhecimento individual, bem como da familiaridade com determinado tema ${ }^{196}$, algumas fotografias chamam nossa atenção em detrimento de outras, ou seja, algo nos impele para que, ao passarmos por elas - via revista, livro, internet -, tenhamos, pelo menos, de deter-nos e contemplálas:

O que experimento em relação a essas fotos tem a ver com um afeto médio, quase um amestramento (...) é o studium, que não quer dizer, pelo menos de imediato, "estudo", mas a aplicação a uma coisa, o gosto por alguém, uma espécie de investimento geral, ardoroso, é verdade, mas sem acuidade particular. É pelo studium que me interesso por muitas fotografias, quer as receba como testemunhos políticos, quer as aprecie como bons quadros históricos: pois é culturalmente (essa conotação está presente no studium) que participo das figuras, das caras, dos gestos, dos cenários, das ações.(Barthes, 1984, p. 45)

É pelo studium que veremos nosso olhar se cruzar com o do fotógrafo, à semelhança da pintura albertiana, quando o pintor forçava-nos a buscar o que pretendia:

Reconhecer o studium é fatalmente encontrar as intenções do fotógrafo, entrar em hamonia com elas, aprová-las, desaprová-las, discuti-las em mim mesmo, pois a cultura (com que tem a ver o studium) é um contrato feito entre os criadores e os consumidores. O studium é uma espécie de educação (saber e polidez) que me permite encontrar o Operator, viver os intentos que fundam e animam suas práticas, mas vivê-las de certo modo ao contrário, segundo meu querer de Spectator. (Ibidem, p. 48)

${ }^{196}$ Cuja codificação também é algo imposto via cultura, dentro de uma determinada sociedade. 
Isso quer dizer que, por meio do studium, lemos, racionalmente, as fotografias que temos pela frente. Analisamo-nas, buscamos encontrar nelas intencionalidades; diante delas, sequer demonstramos prazer ou pesar, mas curiosidade, além disso, nós as dominamos, na medida em que estão a serviço de nossa ratio, isso quer dizer que podemos descartá-las quando quisermos. É pelo studium que refletimos: essa tomada foi ou não proposital? Essa fotografia é ou não uma montagem? Algo parecido quando se tem, diante dos olhos, uma cena como a fotografia 5 , quando se vê a tomada de Berlim pelos soviéticos que hasteiam a bandeira vermelha sobre o Reichstag.

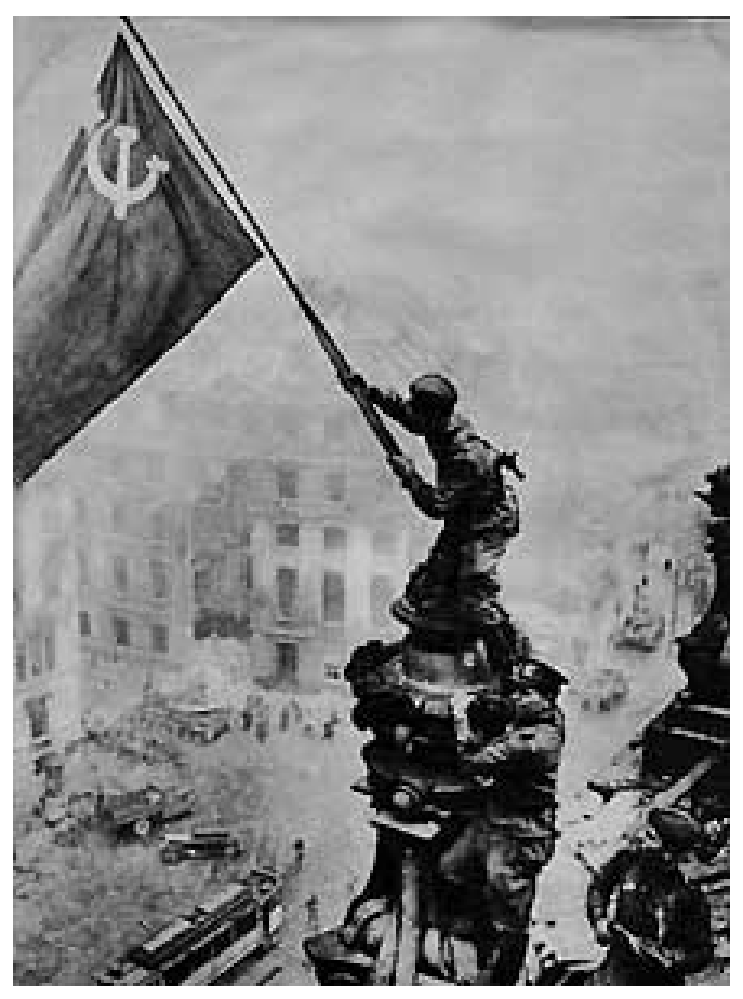

Foto 5: Hasteamento da bandeira vermelha no Reichtag, após a capitulação alemã, 1945.

Há, porém o outro conceito barthiano por que nos deixamos dominar, o punctum:

(...) não sou eu que vou buscálo (como invisto com minha consciência soberana o campo do studium), é ele que parte da cena, como uma flecha, e vem me transpassar. (...) O punctum de uma foto é esse acaso que, nela me punge (mas também me mortifica, me fere). (Ibidem, p. 46)

Ou ainda, segundo Barthes, o campo do studium é diversificado, do gosto inconseqüente, do gosto/ não gosto, do / like/ I don't like, enquanto o do punctum seria específico, não geral, não voltado ao to like, mas ao to love. (Cf.: ibidem, pp. 47-48)

Muitas vezes, será o punctum que nos forçará a reter determinadas imagens em detrimento de outras, visto que, ao sermos atingidos por elas, somos impelidos a permanecer mais tempo diante das mesmas, analisando-as, 
encontrando a origem da seta que nos atingiu ${ }^{197}$. Isso, evidentemente, se deve a vários fatores de ordem sócio-cultural, ou seja, uma pessoa cuja família tem tradição religiosa islâmica, por exemplo, dificilmente se deixaria pungir por uma fotografia de uma missa católica celebrada pelo já debilitado Papa João Paulo II, quando muito se deixaria atrair pelo studium; o mesmo vale para um católico diante de uma fotografia do Muro das Lamentações, ou da Caaba: o efeito, enquanto punctum, seria quase nulo.

Enquanto as iconologias serviam aos artistas e poetas como modelos epistemológicos nos Seiscentos, hoje são as imagens fotográficas, das quais nos valemos como um repertório imagético pronto - apesar de ter sido construído ao longo de cada vida individual - e disponível não só em nosso imaginário, mas também no mundo em que estamos inseridos e de onde as retiramos, continuamente, via jornal, livros e, de modo especial, via internet.

Guimarães nos diz que o narrador é o sujeito das imagens por ser ele o mediador entre elas e a significação que queira dar as mesmas. (Cf.: Guimarães, 1997, p. 78) Poderíamos, porém, transferir essa autoridade exatamente para o eu leitor em relação a um eu lírico criador dessas imagens, visto que é aquele que reordenará as imagens propostas por este, a partir de seu próprio mundo. Se o narrador/ eu lírico nos apresentar algo que não estamos preparados, ou que está fora de nosso campo de conhecimento, pouco valerá tal indução, visto que o leitor não será capaz de decodificar conforme o enunciador queria. Iser nos diz que

Embora eles [os livros] desenvolvam os pensamentos de outrem, o leitor se transforma durante a leitura em sujeito desses pensamentos, desse modo desaparece a cisão entre sujeito e objeto, cisão tão importante para o conhecimento e a percepção geral. (Iser, 1999, p. 85)

No entanto, quando se dá essa cisão, o leitor ocupa-se com os pensamentos do autor; aquele se abandona diante deste e de seus

\footnotetext{
197 Barthes nos faz uma digressão sobre a escolha desse nome, indicando sua origem etimológica como ferida, picada, marca feita por instrumento pontudo, assim como as fotos que, por meio de determinadas marcas, como feridas, atingem determinadas pessoas e não outras. (Cf. Barthes, 1984, p.46)
} 
pensamentos (cf.: Ibidem, p. 88) e, quando a fusão sujeito x objeto é rompida, é que se permitem as experiências extra-pessoais na leitura textual, quando a memória do leitor entra em ação, e seu acervo iconofotológico permeará sua leitura, principalmente de textos não contemporâneos, visto que nos hodiernos ainda persistem muitos elementos de contato entre o escritor e o leitor ${ }^{198}$. Por outro lado, esse fato não se verifica de forma tão clara em um poema, cujo autor, por exemplo, está muito distante do receptor que terá a obra em suas mãos.

Dessa forma, para que o start da compreensão imagética seja acionado - não só para uma possível interpretação, mas também para que fosse possível, mesmo num primeiro momento, sua leitura - deve haver um ponto de contato, um elo perceptivo. Esse está, exatamente, nas imagens, as mesmas que ultrapassam a percepção por todos os lados (Bergson, 1999, p. 268), mas não aquelas que estão perdidas num passado distante, que fazem com que tenhamos prazer se dispomos de seu referencial, mas as que temos hoje diante de nossa memória virtual formada por nosso acervo iconofotológico.

Falando dessa maneira, temos de valer-nos das palavras de Foucault e de sua arqueologia proposta em As palavras e as coisas, quando nos diz que se

não houvesse na representação o obscuro poder de tornar novamente presente uma impressão passada, nenhuma jamais apareceria como semelhante a uma precedente ou dessemelhante dela. Esse poder de lembrar implica ao menos a possibilidade de fazer aparecer como quase semelhantes (como vizinhas e contemporâneas, como existindo quase da mesma forma) duas impressões, das quais uma porém está presente enquanto a outra, desde muito talvez, deixou de existir. Sem imaginação não haveria semelhança entre as coisas. (Foucault, 2007, p. 95)

Dessa forma, somente por meio de uma nova representação (não no sentido epistemológico que havia nos Seiscentos) seria possível uma leitura de textos barrocos, devido à inexistência de um referencial acessível, bem como

\footnotetext{
${ }^{198}$ Quando o escritor tem um poder de aliciamento muito maior sobre o leitor, levando-o aonde quer durante a leitura, apesar de, mesmo assim, o leitor fazer uso de seu acervo iconofotológico que sempre diferirá daquelo do escritor, afinal não existem duas pessoas iguais no mundo, ou seja, as imagens construídas por um, nunca corresponderão àquelas lidas e compreendidas por outros.
} 
de uma vontade para fazê-lo. Assim, verificamos ser natural o avizinhar termos, mesmo que não correspondam ao que pretendia seu autor: a palavra pérolas, por exemplo, ser lida como adorno, como jóia, não como lágrimas. Assim, representaríamos o que lemos por imagens que estejam a nosso alcance - via imaginação -, para que pudéssemos estabelecer outras relações, mesmo que incipientes com o mundo pesquisado, no caso, a poética de um momento específico, conhecido por Barroco.

Bergson, por sua vez, fala-nos que

uma imagem pode ser sem ser percebida; pode estar presente sem estar representada; e a distância entre esses dois termos, presença e representação, parece justamente medir o intervalo entre a própria matéria e a percepção consciente que temos dela (...). (Bergson, 1999, p. 32)

Para Bergson, a representação tem de abandonar algo de si para que possa representar, assim pérola tem de deixar de ser um material orgânico duro, produzido por ostras, para se tornar lágrima. Mas, mais do que isso, é necessário

suprimir de uma só vez o que a segue, o que a precede, e também o que a preenche, não observando mais do que sua crosta exterior, sua película superficial. (...) Eu a converteria em representação se pudesse isolá-la, se pudesse sobretudo isolar seu invólucro. A representação está efetivamente aí, mas sempre virtual, neutralizada, no momento em que passaria ao ato, pela obrigação de prolongar-se e de perder-se em outra coisa. (ibidem, p. 33)

Dessa forma, Tränen des Vaterlandes [Lágrimas da Pátria] pode ser qualquer lágrima, aquela que nos escorre no rosto quando estamos tristes ou alegres, ou mesmo o sofrimento por um erro efetuado, ou ainda o arrependimento pelos pecados cometidos; ainda mais, isolada, Tränen pode representar-nos qualquer choro, de qualquer pessoa, via iconofotologia, que também não deixará, evidentemente, de ser a representação de uma representação. Não é necessário muito para que se efetive essa mudança conceitual, esse deslocamento do signo, principalmente por parte do poeta, 
cujo objetivo maior é, exatamente, jogar com o גóyos. Assim, mais do que isolar o objeto imagem, esse não deve destacar-se nem iluminar-se,

mas ao contrário obscurecer certos lados dele, diminuí-lo da maior parte de si mesmo, de modo que o resíduo, em vez de permanecer inserido no ambiente como uma coisa, destaque-se como um quadro. (ibidem, pp. 33-34)

E o que é um poema senão quadros feitos de palavras (Carone Neto, 1974, p. 71), os quais se abrem diante de nós para que sejam visualizados e causem-nos prazer nos moldes da fotografia? 
De um modelo iconofotológico ao poema fotográfico

Como já se demonstrou, a relação entre a imagem pictórica e a poética já possui longa tradição. Ambas caminharam juntas durante séculos, apesar dos paragoni que buscavam ressaltar a predominância de uma sobre a outra. O objetivo desta Tese, no entanto, será tentar estabelecer uma possível relação entre a leitura de textos literários, restritos à poesia descritiva, cujo corpus será formado por poemas do século XVII alemão, e a fotografia. Obviamente, essa relação não se dará por meio dos pressupostos retóricos daquele período, afinal haveria um total anacronismo, mas a partir da recepção imagética que fazemos hoje das imagens, aparentemente, descritivas daquele momento.

Como nos séculos anteriores, na contemporaneidade, faz-se uso distinto das regras retóricas e de suas imposições, o que não significa que as figuras retóricas tenham sido abolidas, afinal constituem a essência do fazer poético:

(...) não há poesia sem figuras, conquanto se entenda 'figuras' num sentido suficientemente amplo: toda mensagem literária é necessariamente ritmada, rimada, assonante, graduada, cruzada, oposta, etc. Mas, evidentemente, há figuras sem poesia (...). (Dubois, 1974, p. 41)

A partir do Modernismo, a arte pictórica e a literária ampliam seus horizontes por meio de uma verdadeira revolução. Parte desse processo deveu-se ao advento da fotografia no século XIX, cuja repercussão fez-se sentir não só naquele século como em todo o século $X X$, afetando, inclusive nossa relação com o mundo imagético, seja no campo da artes pictóricas seja no da literatura.

Há também, no início do século XX, uma reaproximação entre a palavra e a pintura, como demonstram os experimentos vanguardistas. Hoje, por sua vez, palavra e imagem (em sua grande maioria fotográfica) são largamente empregadas, por exemplo, na linguagem publicitária. No entanto, diante do domínio da imagerie que estamos presenciando, vêm-nos algumas questões que já se tornaram, inclusive, lugares-comuns: pode a imagem sempre superar 
o גóyos na apreensão do mundo que nos cerca? Ou ainda: Uma imagem vale por mil palavras...

O hóóc tem o poder de representar-se e de representar aquilo que está a nossa volta e, mesmo diante do assédio que o turbilhão imagético-fotográfico proporciou-nos, continua demonstrando sua hegemonia, já que diante de uma fotografia - seja em revistas, jornais, outdoors - necessitamos, muitas vezes, da legenda para que, por meio desta, possamos explicar aquela e torná-la mais legível ou mesmo inteligível, pelo menos sob o ponto de vista de nossa racionalidade.

Essa busca pela inteligibilidade resulta ainda do fato de haver, por parte de muitas pessoas, a convicção de ser a imagem fotográfica uma cópia fiel da realidade. No entanto, hoje, devido às inúmeras possibilidades auferidas pelos recentes softwares de edição de imagens, esse mito vem, pouco a pouco sendo desfeito, já que se tem consciência de que a fotografia pode passar por várias possíveis manipulações.

Devido à facilidade da propagação imagética, atualmente, muitas pessoas já têm o hábito de desconfiar do que vêem: realmente é a fulana que está aqui? Aquela foto não é uma montagem ? $^{199}$ Esse desconfiar do imagético está se tornando constante ${ }^{200}$ (deve-se ter em mente que uma das funções da fotografia era, exatamente, o contrário, a comprovação), principalmente devido à infinita possibilidade proporcionada pelas imagens na internet, que nos leva, inclusive, a uma idolatria, mesmo que nós não nos demos conta disso.

Surge daí a necessidade comprobatória da legenda que negará ou afirmará uma possível manipulação efetuada numa imagem, ou mesmo naquilo que ela possa significar, afinal

cada fotografia é um fragmento, o seu peso moral e emocional depende do conjunto em que se insere. Uma fotografia muda em função do contexto em que é vista: por isso, as fotografias de Smith ${ }^{201}$ sobre Minamata parecerão diferentes numa

\footnotetext{
${ }^{199}$ Como havíamos visto anteriormente, as montagens fotográficas sempre existiram, porém não havia consciência dela fora de seu meio profissional ou de seus aficionados.

${ }^{200}$ Evidentemente, para aqueles que têm uma visão mais crítica daquilo que vêem.

${ }^{201}$ William Eugene Smith (1918-1978), fotojornalista estadunidense que retratou os horrores da Segunda Guerra Mundial por meio de sua lente. Minamata é uma vila da cidade japonesa de
} 
prova de contacto, numa galeria, numa demonstração política, num arquivo policial, numa revista de fotografia, numa revista de actualidades, num livro, numa parede da sala de estar. Cada uma destas situações sugere um uso diferente para as fotografias, mas nenhuma pode fixar seu significado. (Sontag, 1986, p. 99)

Devem-se estabelecer os limites sígnicos da fotografia e, para que isso seja possível, faz-se necessário o uso do $\lambda o ́ \gamma o s:$

Ocorre em relação a cada fotografia o que Wittgenstein afirmava sobre as palavras: o significado é o uso. E é por isso mesmo que a presença e a proliferação de todas as fotografias contribui para a erosão da própria noção de significado, para estilhaçar a verdade em verdades relativas, o que hoje é aceite sem reservas pela consciência liberal moderna. (ibidem, p. 99)

Isso faz com que acabemos sendo impelidos a acreditar no que temos diante de nossos olhos. Fazemos isso, no entanto, não devido à imagem em si, mas às palavras que a explicam. Segundo Flusser, foi exatamente o contrário que se verificou no século XIX, quando os textos passaram a ser inimagináveis diante do alto grau alcançado pela textolatría:

En el sentido más estricto, este fue el fin de la historia, la cual, en este sentido estricto, es la transcodificación progresiva de las imágenes en conceptos, la explicación progresiva de las imágenes, el progresivo desencantamiento, la conceptualización progresiva. Donde los textos ya no son imaginables, no hay nada más qué explicar, y la historia cesa.

Precisamente en esta etapa crítica, en el siglo XIX, se inventaron las imágenes técnicas a fin de hacer los textos nuevamente imaginables, para colmarlos de magia $y$, así, superar la crisis de la historia. (Flusser, 1990, pp. 14-15)

Com isso, queremos simplesmente dizer que paradigmas podem (e devem) ser quebrados e aquilo que o senso comum afirma, pode e, muitas vezes, deve ser contestado. O mesmo se dá em relação ao poder imagético e ao fato de a nossa sociedade preferir, incontestavelmente, as imagens às 
palavras. Estas, no entanto, não estão mortas e devido a sua logicidade, a imagem, muitas vezes, não pode prescindir da palavra para se clarificar; isso se faz necessário para que se possa depreender da imagem muito mais do que pigmentação, incidência da luz, ou aquele/aquilo que se retratou, assim

O mundo das imagens não é, necessariamente, imagem de mundo, mas cópias mal-ajambradas de visões de mundo estereotipadas e tacanhas. Daí a facilidade com que a lógica do texto se impõe, inclusive nos forçando a olhar o mundo apresentado por imagens com desconfiança maior do que o mundo apresentado por textos. (Bonfiglioli, 2008, p. 7)

Logicamente, tal afirmação quebra o lugar-comum que nos expõe a possibilidade de as imagens prescindirem do $\lambda o ́ \gamma o s$, só que se esquece de que vindas de uma fonte comum, a natureza - via $\mu i ́ \mu \eta \sigma l \varsigma$ - acabam se completando, inclusive imiscuindo-se - como no gênero emblemático, e mesmo nos movimentos vanguardistas do século $X X$-; além disso, a imagem também deve ser lida, bem como sua tessitura desmontada, à semelhança do texto escrito, a fim de que seja possível sua interpretação, quando se depreenderá todos seus elementos constitutivos - como na leitura iconológica de Panofsky.

Para que isso seja possível, é importante o papel do leitor que, à semelhança do texto logocêntrico, também tem de se relacionar com a obra e, a partir de sua Weltanschauung ter possibilidade, ou não, de ler uma imagem. Dessa forma, não é sua aparente objetividade que atuará naquele que lê, mas a leitura que o leitor faz da imagem, ou seja, para que seja possível essa interpretação, bem como sua visualização, necessita-se da intermediação do eu observador, para que possa ele mesmo construir a imagem a partir de sua realidade:

O processo da simulação não é o da imagem em si, mas o da relação com o sujeito. (Xavier, 1998, p. 379) 
A leitura/interpretação é um processo que passa pelo $\lambda o ́ \gamma o \varsigma$, afinal vê-se que ele estabelecerá a clareza sígnica, levando-nos aos meandros do texto imagético, por isso dificilmente há imagem que esteja alijada de palavras, seja na forma de legenda, de comentário, de subtítulo ou mesmo de diálogos. (Cf.: Barthes, 2005, p. 97)

Exemplo dessa relação pode ser estabelecida a partir da figura 66, quando vemos um crucifixo posicionado sobre o capô de um carro de luxo (exatamente no lugar onde se costuma colocar o símbolo da empresa que fabrica o mesmo) numa atitude que pode suscitar algumas ponderações: alguns verão, na imagem, uma obra artística; outros, uma de mau gosto, de profanação da imagem religiosa. Essa leitura, porém, dependerá daquele que

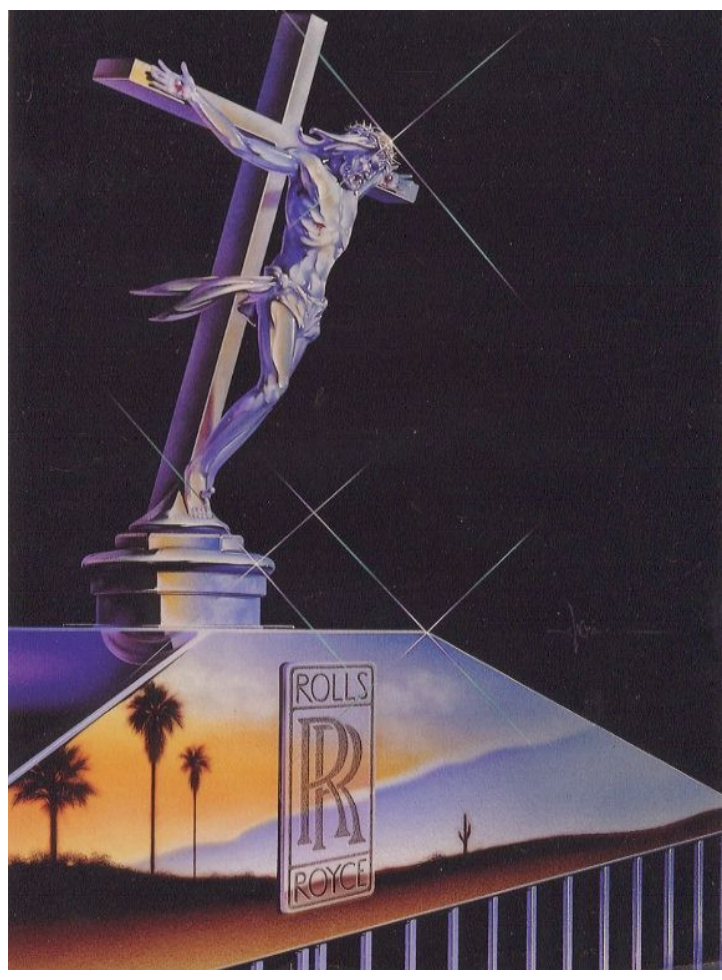

Figura 66: Entre o luxo e o lixo: a publicidade sacraliza o consumo e diviniza a posse. Playboy, 1988. Retirado de $\underline{\text { www.multiculturas.com/retorica/introd.htm }}$ pretende decodificá-la, pois poderá enxergar nela ou a) uma obra genial e ilustrativa das novas divindades fabricadas por nossa sociedade atual (quando a própria Divindade, representada pelo Cristo crucificado, está a serviço do consumo e do dinheiro, cujo símbolo está sob a cruz: a marca Rolls Royce); ou b) uma propaganda de extremo mau gosto que pretende denegrir a imagem de Jesus, ou mesmo usá-la como amuleto. A legenda, nesse caso, é que fará o diferencial entre o profanar e o moralizar, podendo inclusive aplacar os ânimos referentes à utilização de um símbolo religioso em uma propaganda, a fim de se moralizar uma visão consumista de nossa sociedade, em que o mais importante não é o ser mas o ter.

Por outro lado, as palavras - em especial, os poemas construídos por elas - também podem evocar imagens, devido à geminação entre os dois sistemas sígnicos, e é sob esse viés que pretendemos trabalhar. Ora, se nos 
Seiscentos os dois sistemas compartilhavam um mesmo gênero, o emblemático, também é possível verificar essa relação, em nossa contemporaneidade, com duas grandes diferenças: a codificação social e sua mobilidade. Hoje, é possível que um código seja empregado de diversas formas em um curto espaço de tempo e, mesmo que haja um direcionamento específico para um determinado estrato social, isso não indetermina que um outro não possa ter acesso a sua chave sígnica (o que não ocorria no Barroco, por exemplo). O mesmo se dá em relação a sua mobilidade ou estaticidade: o signo hoje não é estanque, devido ao próprio dinamismo de nossa sociedade. Dessa forma, modismos lingüísticos são, continuamente, criados e modificados num espaço de tempo cada vez menor, quando são ignorados pelas novas gerações que não os consegue mais decodificar, causando, inclusive, um efeito de estranhamento naquele que o utilizou diante da não compreensão do outro.

O mesmo se dá, evidentemente, com determinados empregos imagéticos em detrimento de outros: depreende-se, portanto, que a linguagem - seja verbal ou não verbal - é significado e, como tal relativo:

Todos os sistemas de comunicação vivem no mundo das referências e dos significados relativos. Daí que sejam conjuntos de signos dotados de certa mobilidade.(...) Outro tanto ocorre com a linguagem, só que a sua gama de mobilidade é muito superior às de outros processos de significação e comunicação. Cada vocábulo possui vários significados, mais ou menos conexos entre si. Esses se ordenam e se precisam de acordo com o lugar da palavra na oração. Os outros desaparecem ou se atenuam. (Paz, 2005, p. 44)

O mesmo pode ser dito em relação à imagem:

Las imágenes son superfícies significativas. En la mayoría de los casos, éstas significan algo "exterior", y tienen la finalidad de hacer que ese "algo" se vuelva imaginable para nosotros, al abstraerlo, reduciendo sus cuatro dimensiones de espacio y tiempo a las dos dimensiones de un plano. A la capacidad específica de abstraer formas planas del espacio-tiempo "exterior", $y$ de re-proyectar esta abstracción del "exterior", se le puede llamar imaginación. (Flusser, 1990, p. 11) 


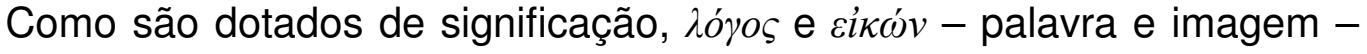
são suscetíveis à interpretação, ou seja, não possuem existência sem que um olhar neles se detenha e decodifique a intenção que o eu lírico ou pictórico tinha em mente, apesar das possíveis distorções anacrônicas que tal ato possa suscitar. Dessa forma, o ato adentra na temporalidade:

Mientras la mirada registradora se desplaza sobre la superfície de la imagen, va tomando de ésta un elemento tras otro: establece una relación temporal entre ellos. También es posible que regrese a un elemento ya visto y, así, transforme el "antes" en un "después". Esta dimensión temporal - como se reconstruye mediante el registro - es por tanto, una dimensión de regreso eterno. La mirada puede volver una y otra vez sobre el mismo elemento de la imagen, estableciéndolo como centro de significado de la imagen, el registro establece relaciones llenas de significado entre los elementos de la imagen. (ibidem, pp. 11-12)

Que fazemos, afinal, quando lemos um poema e vemo-nos diante das imagens construídas pelo eu lírico? É próprio da linguagem poética esse ir e vir, o deter-se diante de suas imagens e ficarmos como que diante de um quadro, tentando depreender o que havíamos visto antes e o que vemos depois para que possamos construir seu significado, já que

As imagens do poeta tem sentido em diversos níveis. (...) possuem autenticidade: o poeta as viu e ouviu, são a expressão genuína de sua visão e experiência do mundo. (Paz, 2005, p. 45)

Pouco nos importa que a verdade do poeta seja apenas de ordem psicológica (cf. ibidem, p. 45), correspondente ao ato criativo, à emanação de seu $\lambda o ́ \gamma o \varsigma$ criador, porque, enquanto obra factível, torna-se real e objetiva:

essas imagens constituem uma realidade objetiva, válida por si mesma: são obras. Uma paisagem de Góngora não é a mesma coisa que uma paisagem natural, mas ambas possuem realidade e consistência, embora vivam em esferas distintas. São duas ordens de realidade paralelas e autônomas. (...) o poeta faz algo mais do 
que dizer a verdade; cria realidades que possuem uma verdade: a de sua própria existência. (ibidem, p. 45)

O poeta, portanto, além de criar o tempo próprio do poema, adentra numa outra dimensão: a da espacialidade. Esta não pertence sequer ao próprio criador, nem ao eu lírico, mas tão-somente à própria realidade da obra enquanto obra. É nela que a realidade se funde em tempo e espaço, mas essa realidade é mágica, pertence ao mundo feérico:

tal relación espacio-tiempo reconstruida a partir de las imágenes es propria de la magia, donde todo se repite y donde todo participa de un contexto pleno de significado. El mundo de la magia difiere estructuralmente del mundo de la linealidad histórica, donde nada se repite jamás, donde todo es un efecto de causas y llega a ser causa de ulteriores efectos. (Flusser, 1990, p. 12)

A mágica maior, porém, é poder vislumbrar mundos novos sem que os mesmos tenham existido concretamente enquanto substância material, ou trazer mundos concretos e distantes para a palma da mão. Eis a magia que 0 $\lambda o ́ \gamma o \varsigma$ nos propicia via literatura: tornar o virtual concreto, palpável, factível; no entanto, o mesmo poder podemos conferir ao ato fotográfico, via $\tau \dot{\chi} \chi v \eta$, quando executa o ato de forma contrária: fazer da concretude, do tangível, do visível, virtual: seja no papel fotográfico, seja no écran de uma tela de computador. Eis que o fotógrafo também é poeta, na medida em que nos impele a ler suas metáforas imagéticas, na medida em que se torna um eu fotográfico-lírico:

Aquilo que antes só podia ser visto por olhos inteligentes pode agora ser visto por todos. Instruída pelas fotografias, qualquer pessoa é capaz de visualizar este conceito que era puramente literário, a geografia do corpo: por exemplo, fotografando uma mulher grávida de modo a que pareça um monte, ou um monte de forma a parecer uma mulher grávida. (Sontag, 1986, p. 94)

Por isso, não basta dizer que só o poeta é um fingidor, sendo um criador; o mesmo podemos afirmar do fotógrafo, afinal ele não é apenas um meio de que se vale um instrumento tecnicista para, unicamente, captar a luz emanada pelos seres, pela natureza, ou ainda pelos homens: também ele é 
criador de realidades diversas, na medida em que sua criação leva os outros a outros mundos que não sejam mais o seu: seja nas viagens temporais por um tempo que não existiu, seja numa viagem espacial, para locais que somente permanecem em nossas próprias memórias.

Assim, podemos estabelecer relações entre a fotografia - enquanto expressão artística de um eu - e a literatura - que há muito já é considerada essa expressão -, levantando, inclusive, pontos de contatos entre as duas $\tau \varepsilon ́ \chi v \alpha l$ que poderão auxiliar na interpretação (recepção) literatura/ fotografia, a partir da relação mimética com o mundo. Para tanto, faz-se necessário estabelecer uma relação entre a moldura fotográfica - como um fragmento da realidade percebida por esse eu - e a moldura estabelecida por um poema um soneto, por exemplo - em que os quadros de palavras, fragmentados muitas vezes, estão delimitados pela métrica.

O fazer do eu fotográfico coincide, dessa forma, com o do eu lírico na criação imagética, na medida em que aquele também utilizará subjetividade em sua criação, em suas fotografias como este. Dentre vários ângulos e pontos de vista que poderiam ser empregados, por exemplo, apenas um foi escolhido ${ }^{202}$. À semelhança de um poeta que tem de escolher, no léxico oferecido pela língua, as palavras que melhor se encaixam para representar as imagens desejadas $^{203}$ - como no ato de catar feijão, segundo João Cabral de Melo Neto -, o fotógrafo também procura em seu campo de visão, que é o mundo, as melhores tomadas, registrando aquilo que os outros não vêem ou passaria despercebido. Dessa forma, a fotografia fixa o real, mas a partir de uma seleção subjetiva do conjunto de imagens que é o mundo. Afinal, também não seria essa uma das prerrogativas da poética?

(...) depois de ter sido definida, durante muito tempo, como arte do verso, a poesia acabou por ser reconhecida, também, como arte da imagem (...) o poema, não apenas carrega as significações que atuam sobre os vocábulos por ele reunidos, mas

\footnotetext{
${ }^{202}$ Mesmo que para isso, tenha de ter tirado muitas chapas para considerar apenas uma. Mas, não é da mesma forma que trabalha o poeta ou o escritor?

${ }^{203}$ Num poema, o poeta também dispõe de várias palavras que oferecem inúmeras possibilidades para dizer o que quer - isso quando quer dizer algo, ou seja, quando não deixa, simplesmente, que as palavras fluam de suas mãos -, entretanto a escolha é sempre aquela não uma outra.
} 
ainda os organiza num assunto, diríamos mesmo: numa cena, no sentido pictórico de ambos os termos. (Grupo $\mu, 1980$, pp. 80-81)

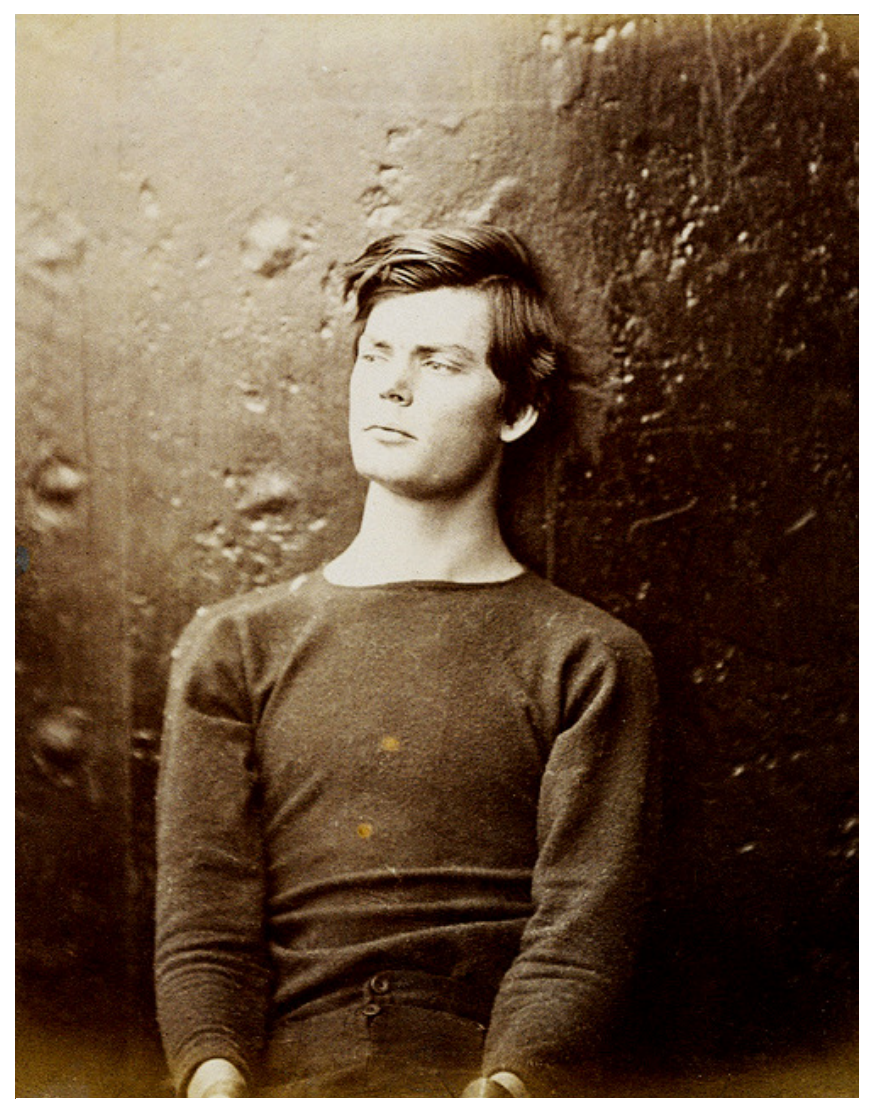

Foto 6: Fotografia de Lewis Payne, de Alexander Gardner, 1865.
Mas, um dos pontos mais importantes tanto na criação poética quanto na fotográfica é o da recordação, pois as imagens construídas por ambas têm o poder de fazer-nos ir a um tempo que não é mais o nosso, de rever os que não estão mais conosco, de visualizar aquilo que não existe mais:

A imagem reproduz 0 momento da percepção e força $O$ leitor a suscitar dentro de si o objeto um dia percebido. $O$ verso, a fraseritmo, evoca, ressuscita, desperta, recria ou, como dizia Machado: não representa, mas apresenta. Recria, revive nossa experiência do real. Não vale a pena assinalar que essas ressurreições não são somente as de nossa experiência cotidiana, mas as de nossa vida mais obscura e remota. O poema nos faz recordar 0 que esquecemos: o que somos realmente. (Paz, 2003, p. 46)

Assim, fotografia e poesia fazem ressurgir aquele presente que estava ausente tanto de nosso inconsciente quanto o da sociedade, o mesmo que queria permanecer oculto, apesar de sabermos que está ali, na memória, mas num passe da mágica poética e fotográfica, é despertada e ressurge das cinzas, fazendo com que aquele presente ressurja novamente. No entanto, esse ressurgir não se dá de forma clara e ordenada, mas é construído.

O compromisso da poesia com o concreto e com a autonomia da linguagem é paralelo ao compromisso da fotografia com a visão pura. Ambos implicam 
descontinuidade, formas desarticuladas e unidades compensatórias: arrancar as coisas ao seu contexto (para que possam ser vistas de um modo novo), reuni-las elipticamente de acordo com as exigências imperiosas e por vezes arbitrárias da subjectividade. (Sontag, 1986, pp. 90-91)

É isso o que acontece quando nos deparamos com a fotografia de Alexander Gardner (foto 6), em que vemos Lewis Payne, à espera de seu enforcamento:

A foto é bela ${ }^{204}$, o jovem também: trata-se do studium. Mas o punctum é: ele vai morrer. Leio ao mesmo tempo: isso será e isso foi; observo com horror um futuro anterior cuja aposta é a morte. Ao me dar o passado absoluto da pose, a fotografia me diz a morte no futuro. (Barthes, 1984, p 142)

Pelo fato de ser bela e de ele ser belo, a fotografia foge ao lugar-comum daquilo que cremos ser um assassino, com isso nos desviamos de seu intento $^{205}$; temos, portanto, de subjugar nossa subjetividade, desviar nosso olhar dos olhos de Lewis e entrar na temporalidade que a fotografia retoma: ele vai morrer, mas já está morto.

Quando nos propomos a fazer uma análise de um poema do período conhecido por Barroco, vem-nos sempre a indagação: até que ponto podemos ou não utilizar essa ou aquela imagem - a partir da ótica do século XXI, em que estamos inseridos -, pois, como foi abordado anteriormente, não dispomos mais das preceptivas retóricas daqueles autores. No entanto, o que pretendemos com este trabalho é tentar demonstrar como se dá a recepção dessas mesmas imagens em nossos dias, pois querer que as mesmas sejam decodificadas a partir do referencial daquele momento resultaria - para a maioria dos leitores de hoje - em anacronismo, afinal não dispomos mais daquelas determinações. Pretendemos, portanto, demonstrar que a recepção imagética das imagens formadas por aqueles poetas dá-se, hoje, de forma fotográfica, pois é por seu meio que criamos um álbum virtual dos

\footnotetext{
${ }^{204}$ A fotografia analisada por Barthes não é a mesma empregada na tese: quis mudar o ângulo, apesar de o condenado e seu fotógrafo serem os mesmos.

${ }^{205} \mathrm{O}$ de sua imagem servir de exemplo para que outros não cometessem o mesmo crime.
} 
acontecimentos que nos cercam, constituído por anos de bombardeamento de imagens técnicas via mídia impressa ou visual. É como se esse corpus virtual e latente ficasse à espera de um estímulo externo - como uma imagem evocada num poema, por exemplo - para que pudesse reaparecer, pois

Diante de uma experiência sensível (uma determinada variação do regime de luz, a percepção de um cheiro, o desenho formado por uma mancha de leite), atingimos um fragmento do passado que julgávamos esquecido ou perdido. (Guimarães, 1997, p. 180)

A fotografia, portanto, passa a ter a importância de monumento, enquanto reminiscência do que foi, pois para nós, sua função é a de tornar sempre claro, frente a nossos olhos, determinado período, acontecimento, pessoa ou pessoas. É como se nos dissesse: você não pode esquecer isso! À semelhança de um totem, o monumento religaria os dois extremos temporais de um grupo social, tornando-se uma ponte entre o presente e o passado, que não deixa as lembranças por ele evocadas serem destruídas. Por ser rocha, 0 totem duraria o suficiente para que aquelas pessoas ou fatos dos quais não se queria esquecer fossem lembrados por gerações, até que se extinguissem todas as lembranças do motivo primeiro que o originou; quando, finalmente, ninguém mais saberá quais pessoas ou fatos os autores do monumento quiseram perpetuar. Dessa forma, uma das particularidades do monumento é a idéia de perpetuação, por isso

As sociedades antigas procuravam fazer com que a lembrança, substituto da vida, fosse eterna e que pelo menos a coisa que falasse da Morte fosse imortal: era o Monumento. Mas ao fazer da fotografia, mortal, o testemunho geral e como que natural 'daquilo que foi', a sociedade moderna renunciou ao Monumento (...) a Fotografia é um testemunho seguro, mas fugaz (...). (Barthes, 1984, p.139)

Perpetuar, portanto, um acontecimento também é uma forma de evitar que ele se repita se for contraproducente; ou que será rememorado, se benéfico; daí a importância de seu registro, seja fotográfico ou mesmo poético. 
A fotografia passa a ser combustível que reaviva a chama não só de nossa memória, como também de nossas emoções, pois, apesar de sua fugacidade daí sua dessemelhança em relação ao totem, cuja aparência dá testemunho de perenidade (enquanto existir), também existirá com ela uma outra realidade. $O$ tempo pode passar, certas pessoas podem não ter vivenciado a cena retratada, mas à vista de uma fotografia, há a extemporização do momento, semelhante a uma viagem no tempo, por meio das imagens por ela evocadas. Além disso, pode não só nos revelar aquilo que estava na cena, como o que havia, provavelmente, por trás da mesma. As mais corriqueiras atitudes passam a ser dignas de crédito quando fotografadas, mesmo a posteriori, ou seja, o mais banal dos acontecimentos reveste-se de grande importância ${ }^{206}$.

A omnipresença das câmaras sugere persuasivamente que o tempo só compreende acontecimentos interessantes que vale a pena fotografar. O que, por sua vez, nos leva facilmente a sentir que qualquer acontecimento, uma vez precipitado (...) deveria ir até ao fim, para que assim possa surgir mais alguma coisa: a fotografia. Quando o acontecimento tiver acabado, a fotografia ainda existirá, o que confere ao acontecimento uma espécie de imortalidade (e importância) que de outro modo nunca teria. (Sontag, 1986, p. 21)

Justamente esse fato de que tudo vale a pena fotografar reforça seu aspecto trivial e fugaz, de algo sem importância, principalmente em uma sociedade repleta de imagens sem deferência. Todavia, essa falta de importância é uma demonstração de sua presentificação, ou seja, retrata o momento em que se está inserido e que corresponde ao presente retratado na fotografia. No entanto, essa relação mudará com o passar dos anos, pois tal foto, ao ser visualizada certo tempo depois, não trará só a banalidade de um instante congelado, mas também a totalidade de um momento que não estará exposto naquele papel-imagem que, no entanto, será reativado na memória de quem passou por aquele instante, ou mesmo por quem sempre dele ouviu falar. Quantas vezes pessoas ouviram histórias de um momento qualquer que

\footnotetext{
${ }^{206}$ Para compreendermos essa relação, bastaria lermos, por exemplo, fotos antigas da cidade de São Paulo, quando da colocação dos trilhos dos bondes pela Light. Aquilo que era uma trivialidade - operários trabalhando na colocação de trilhos na cidade (São Paulo já possuía bondes à tração animal) - transformou-se para nós em um documento histórico de grande importância.
} 
fora retratado numa foto e ao vê-la, in loco, são capazes de enxergar além de seu enquadramento, sem ter estado lá, à semelhança de um déjà vu? Dessa forma, a fotografia impele-nos ao saudosismo, à rememoração, à busca de um elo perdido, já que

(...) promove intensamente a nostalgia. A fotografia é uma arte elegíaca, uma arte crepuscular. A maior parte dos temas fotografados são, pelo simples facto de serem fotografados, afectados pelo pathos. Um tema feio ou grotesco pode ser comovente por ter sido dignificado pela atenção do fotógrafo. Um tema belo pode provocar sentimentos de compaixão por ter envelhecido, perdido importância ou já não existir. (ibidem, p. 24)

Semelhante ao valor testemunhal evocado pela fotografia e seu propósito de perpetuar-se no tempo como um monumento, temos a linguagem poética. Esta, diferentemente da linguagem comum, tem como atributo próprio o fato de durar. (Cf. Levin, 1975, p. 103) Enquanto a comum - centrada na função referencial - não se mantém, visto que a partir do momento que compreendemos o que se diz ela

é substituída em nossas mentes pelo que significou (ibidem, p. 103)

torna-se, portanto, sem valor e é apagada.

Em poesia, tanto a forma quanto a impressão permanecem. Por outras palavras, as mensagens poéticas desfrutam uma permanência que a linguagem comum não desfruta. Por permanência não queremos dizer o fato de um poema perdurar por gerações ou séculos (permanência geral), mas antes o fato de ter a faculdade de permanecer na mente individual; ele é memorável. (ibidem, p. 103)

Assim sendo, o poema também teria uma função de monumento, religaria o presente ao passado e, sendo memorável, perpetuar-se-ia na memória, na recordação e na lembrança da posteridade. Dessa forma, tanto o 
poema quanto a fotografia poderiam ser indicadores de autenticidade de um tempo que já está distante do nosso, e à semelhança da Bíblia, ser de outro modo comunicadores históricos em meio à função retórica. Quantos não empregaram suas vidas para tentar provar que as imagens bíblicas eram uma cópia fidedigna da realidade passada? Entretanto, esses haviam se esquecido de que o Livro não é meramente histórico, mas poético e que nem todos seus poemas são, segundo nossa Tese, fotográficos.

Um dos liames, por exemplo, que aproximam a fotografia da arte barroca e que suscitara, inclusive, esta Tese é a edificação da morte que se encontra nas duas. Contudo, a morte não em seu sentido de término, mas como perpetuação, uma constante ressurreição daquilo que foi fotografado ou daquilo que foi descrito num poema. Ambas as imagens detêm o tempo, quando a temporalidade do objeto separa-se daquela do sujeito (Virilio, apud Guimarães, 1997, p. 48), ou seja, imortaliza o que é mortal

Todas as fotografias são memento mori. Fotografar é participar na mortalidade, vulnerabilidade e mutabilidade de uma outra pessoa ou objeto. Cada fotografia testemunha a inexorável dissolução do tempo, precisamente por seleccionar e fixar um determinado momento. (Sontag, 1986, 24)

Ao selecionar um momento qualquer, é como se disséssemos a ele: tenha vida eterna! Viva. Viva ainda mais do que seu próprio referente, de sua própria emanação primeira; porque o ato de fotografar é dedicar-se à captura da morte:

Pois é preciso que a Morte, em uma sociedade, esteja em algum lugar; se não está mais (ou está menos) no religioso, deve estar em outra parte: talvez nessa imagem que produz a Morte ao querer conservar a vida. Contemporânea do recuo dos ritos, a Fotografia corresponderia talvez à intrusão, em nossa sociedade moderna, de uma Morte assimbólica, fora da religião, fora do ritual, espécie de brusco mergulho na Morte literal. A Vida / a Morte: o paradigma reduz-se a um simples disparo, o que separa a pose inicial do papel final. (Barthes, 1984, p. 138) 
Vê-se, portanto, a renúncia do monumento dos antigos para celebrar a morte, ou ainda toda uma visão iconológica cujo tema é exatamente o mesmo, mas os recursos são totalmente diversos. Com a fotografia a morte existe (e reside) a partir do presente perpétuo; já no Barroco, por exemplo, a morte é retratada exatamente pelo seu futuro, ou seja, a descarnação total do ser: o esqueleto.

Se o século XV havia mostrado uma verdadeira obsessão pela morte, o XVII (...) supera-o e consegue dar uma versão ainda mais temível e impressionante: se na Idade Média a morte é, na arte e no pensamento, uma idéia teológica, e no espetáculo popular das danças macabras se apresenta com um caráter didático geral e impessoal, agora é tema de uma experiência que afeta a cada um em particular e causa uma dolorosa convulsão. (Maravall, 1997, p. 268)

Quando Maravall fala-nos em espetáculo, tais palavras não podem soar como metafóricas, visto que a tópica do palco do mundo também encontra eco no momento derradeiro:

Selbst in den letzten Stunden fühlt das Ich sich nicht allein; stets stehen die anderen als Zuschauer herum, nach deren Beifall man verlangt. So endet das Leben, wie es überhaupt empfunden und geführt wurde: als Schauspiel. Selbst noch im Tode, ja noch drüber hinaus im Grabstein. (Flemming, 1937, p. 26)

[Mesmo em seus últimos momentos, o eu não se sente sozinho; sempre há outros como espectadores a seu lado, que desejam aplaudir. Assim, finalmente termina a vida, como foi sentida e dirigida: como palco. Assim como na morte, assim como fora, na lápide.]

Tanto a fotografia quanto a poesia barroca acabam tratando, mesmo que não diretamente, do memento mori: uma porque perpetualiza o momento (embalsamando-o), outra porque essa própria tópica já faz parte da Weltanschauung do momento. Assim, como olhando em um espelho, em que, de um lado, víssemos refletido nosso presente; e de outro, concomitantemente, o futuro e o passado de outrem ou o nosso. Evidentemente, não nos é permitido ver 0 futuro, dessa forma, temos de restringir esse olhar para 0 
presente, enquanto realidade que já passou, ou seja, o período posterior àquele verificado e concretizado pela fotografia.

Pode-se considerar a poesia como um reflexo especular tanto da linguagem humana - por apresentar os níveis fônico e semântico -; quanto da alma humana - por refletir aquilo de que o homem está impregnado: a totalidade de seu ser, seus pensamentos e emoções.

Se se pode, portanto, considerar a poesia como portadora de reflexo especular, que dizer, então, da fotografia que há muito não só reflete o que está diante de uma câmera, como também tem o poder de fixá-lo? Isso já seria suficiente para que pudéssemos começar a cotejar a poesia com a fotografia em relação à especularidade de sua reprodução imagética, afinal a foto além de aprisionar a imagem que tem diante de si também revela as minúcias que se querem (ou se queriam) manter escondidas.

Há, além disso, o fato de ambas, por sua própria estrutura e emprego, manterem-se perenes, eternizadas por meio do papel - algo extremamente frágil e perecível. Que é o homem senão a totalidade de um ser perecível - seu corpo - juntamente com um imortal - sua alma? Mesmo que não exista Deus, nem religião, nem uma alma eterna, o homem já seria eterno, por poder perpetuar-se por meio de sua obra, de sua $\tau \dot{\chi} \chi v \eta$ e de seu $\lambda o ́ \gamma o s$.

Vê-se, portanto, que o liame que une a poesia e a fotografia não é tão tênue a ponto de romper-se tão facilmente quanto poderia parecer inicialmente,

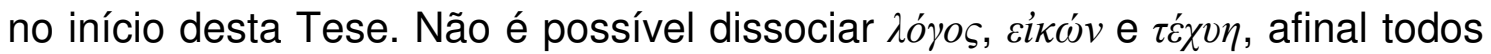
fazem parte de uma trindade constitutiva do espírito ${ }^{207}$ do homem que o torna um ser diferente dos outros por meio da ratio que lhe é inerente.

Diante disso, não se constituiria um contra-senso chamar um poema de fotográfico, nem uma fotografia de poética, como propusemos nesta Tese. Assim, poderíamos chamar de fotográfico um poema, cujo poeta não tenha tido ele mesmo a influência direta da fotografia, mas aquele cujo leitor tenha sofrido a influência dela, já que são as imagens verbais contidas nessa estrutura

\footnotetext{
${ }^{207}$ A alma humana é espiritual e possui três capacidades ou potências: a) a capacidade de entender (a inteligência); b) a capacidade de querer (a vontade); e c) a capacidade de sentir (a sensibilidade). A sensibilidade é que nos permite sentir alegria, tristeza, raiva, simpatia: estes sentimentos da alma estão sempre ligados ao corpo; a inteligência e a vontade são as potências de nossa alma que nos tornam imagens de Deus, por isso são menos dependentes do corpo.
} 
lingüística que revelam, justamente as imagens fotográficas que permeiam nossa memória, ou seja, nosso acervo iconofotológico. Essas também nos fazem refletir a respeito da própria obra poética e do mundo em que está inserida, via contemplação imagética que não passa de uma atividade orientada para a captura da significação, a qual não é imanente a uma obra, tampouco dependente de uma única leitura, mas entendida como um

conjunto de processos de decodificação, (...) de associação com uma série indefinida de mensagens, lembranças, afetos, multiplicidades intensivas ou qualidade existenciais (...). (Lévy, apud ALMEIDA, 2006, p. 89)

É inconteste que esse start em nossa memória não se dê somente via imagens visuais, mas também por meio de imagens acústicas - quando determinada música nos faz lembrar de um momento perdido no tempo, mas que está guardado em nosssa inconsciência - ou palativo-olfativas - quando um perfume, a fragrância de uma flor, o cheiro de terra molhada, ou a essência de um determinado tempero produzem-nos efeito semelhante.

Para o neurocientista Jean-Pierre Changeux, por exemplo, tanto na contemplação como no que se convencionou chamar prazer estético intervêm processos distintos que vão da a) pura sensação - apreensão da superfície colorida e das formas -, passando pela b) percepção - atividade de reconhecimento de formas e figuras -, que despertará, em ressonância com as imagens internas armazenadas pelo espectador (a memória), uma síntese significatica da obra (compreensão). (Cf.: ibidem, p. 89)

Assim, contemplação e prazer estético

Implicam, portanto, distintas operações e faculdades, recrutando, neurologicamente, tanto estados de atividade do sistema límbico (o "cérebro das emoções") como representações mais sintéticas do córtex frontal (relacionado ao raciocínio e à razão). (ibidem, p. 89) 
A contemplação, portanto, seria orientada para capturar sentidos sígnicos que não são imanentes à obra ${ }^{208}$, mas que pressupõem a utilização de nosso acervo iconofotológico (memória), de onde retirararíamos imagens que preencheriam as que vão se formando durante a leitura que fazemos por meio do hóros (poemas ou romances, por exemplo), a fim de que possamos visualizar o todo proposto pelo autor. É evidente que esse todo proposto pelo autor será lido de forma subjetiva e nunca corresponderá àquilo que o mesmo concebera originalmente.

Quem lê, despretensiosa e mecanicamente, um texto poético qualquer, sem nenhuma dedicação para apreendê-lo, poderá não ter aguçada sua memória fotográfica ${ }^{209}$, a menos que alguma imagem evocada punja-o e retireo do texto - servindo-Ihe de punctum - e leve-o a procurar seu correspondente na própria memória; mas, para isso, a imagem precisa ser retirada do meio em que está inserida ou disposta, por meio da supressão daquelas que lhe são contíguas. (Cf. Bergson, 1999, p. 24) É nesse momento que ocorre a ativação da memória, a ressurreição de um passado que não existe mais, visto que já estava morto:

Desaparecidas a terra de origem e sua língua, é a narração que se torna ela própria uma terra que faz renascer (Guimarães, 1997, p. 150) 'os últimos restos, remanescentes e cacos de algo que estava irrecuperavelmente perdido e não poderia mais ser recomposto por nenhum artifício do mundo.' (Handke, apud Guimarães, p. 150)

Tais cacos, portanto, podem ressurgir, mas de forma sempre individual, por meio da literatura, por meio de poemas fotográficos. Esses são aqueles cujas imagens têm trânsito em diversos tempos, ou seja, aparentemente não demonstram ser somente inerentes a um determinado período. No entanto, como há uma mudança do signo lingüístico ao longo dos anos, aquilo que

\footnotetext{
${ }^{208}$ Poderíamos dizer também que a contemplação seria algo próximo ao conceito de leitura pré-iconográfica, seguindo o modelo de Panofsky; ou ainda, ao ler um poema e inteirar-se de suas imagens e conteúdo, algo parecido ao studium de Barthes.

${ }^{209}$ Já que é por meio da fotografia quando se inauguram mundos imagéticos escondidos nos pequenos detalhes (Cf. Benjamim, 1991, p. 222) e que nos faz perceber as minúcias antes escondidas, agora reveladas.
} 
parecia óbvio num determinado momento, não será mais em outro; dessa forma, o que parecia diacronia, não passa de uma ilusão sincrônica.

A leitura de poemas fotográficos, portanto, sempre é iconofotológica, visto que é efetuada a partir da sincronia, desde que as palavras/imagens empregadas pelo poeta sejam de livre acesso temporal, ou seja, perfeitamente perceptíveis em qualquer tempo, por isso os poemas que indicam catástrofes e guerras - inerentes ao todo humano - normalmente são fotográficos. 


\section{DA PINTURA À FOTOGRAFIA: ENCETAMENTO DO POEMA FOTOGRÁFICO}

Das iconologias paradigmáticas a uma iconofotologia particular

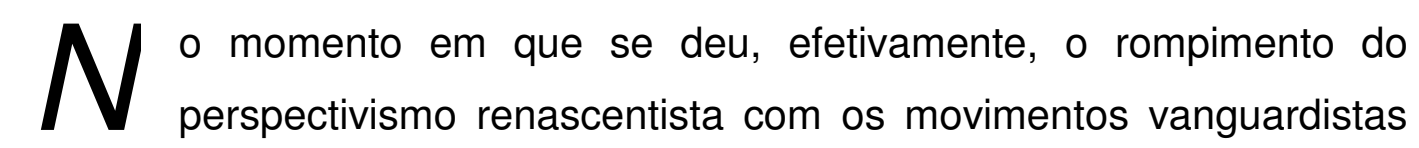
no século $X X$, tem início o que se convencionou chamar Modernismo. Se, antes disso, tínhamos um ponto de vista único que uniformizava o espaço imagético, quando cada ponto representado na tela corresponderia a um outro no espaço do artista que, por sua vez, o passaria para o espaço do leitor; centralizava-se, dessa forma, uma base de reversibilidade do trajeto indo da coisa vista à imagem e da imagem à coisa vista (Couchot, 2003, p. 30) em uma relação especular; vê-se, agora, uma maneira nova de o homem ver e sentir a arte: temos a quebra definitiva da coerência do espaço figurativo, é como se o espelho em que se calcava a obra pictórica tivesse sido quebrado, levando-nos a uma visão pluriocular, heterogênea de maneira que

a distância entre o olho do pintor, o objeto a pintar e o quadro parecem se reduzir, se contrair. A projeção ótica do contorno dos objetos não passa mais por um centro organizador. O plano de projeção grandemente fissurado por Cézanne, se rompe. O "contínuo plástico" se estilhaça "em mil surpresas de fogo e sombra". O véu de Alberti se rasga, a vidraça de Leonardo da Vinci se quebra. (ibidem, p. 51)

Os cacos do espelho rompido fazem com que o espaço que antes era amplo, apesar de limitado pela perspectiva, se reduzisse. Mas, essa redução não representou uma visão diminuta das coisas e do mundo, pelo contrário, procurou-se traduzir a pluralidade de olhares do artista na tela e os movimentos de seus olhos para a mesma (Cf.: ibidem, p. 51) que, ao eliminarem a idéia tridimensional da tela, oferecem-nos vários ângulos daquilo que se quer retratar. O questionamento da virtù visiva era, na realidade, ir contra a restrição 
imposta à direção visual única a partir do vértice piramidal que Alberti havia imposto ao olhar, limitando seu alcance, fazendo com que o lado escuro da lua nunca fosse visualizado, apesar de sua eventual possibilidade. Picasso não passa um rolo compressor sobre suas personagens para sufocá-las nem para submetê-las a seu poder, mas para nos possibilitar passear por seu entorno apesar de o mesmo não poder nos fornecer essa possibilidade de forma

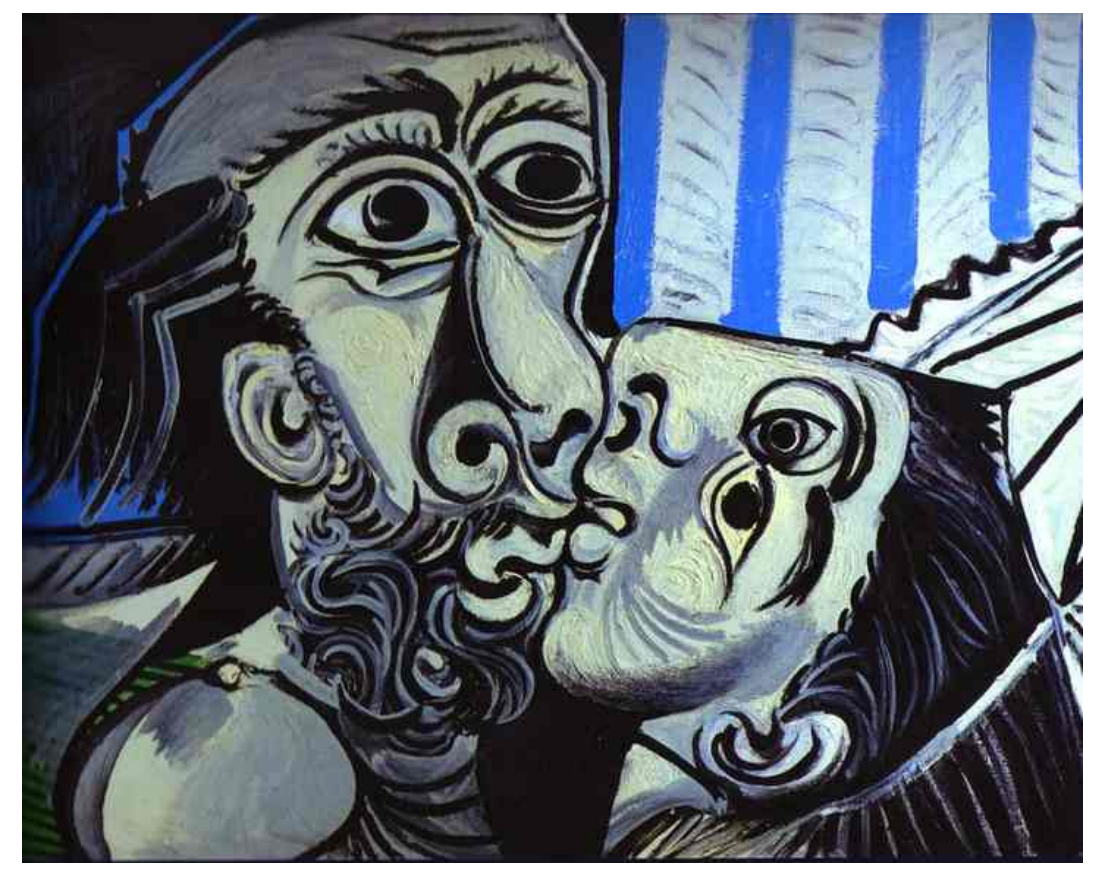

Figura 67: O beijo, de Pablo Picasso, 1969.

completa -, mantendo-as em liberdade e dando-nos a mesma que ele próprio se conferiu (fig. 67). A despeito disso, essa liberdade teve um preço pago pelos leitores, pois, na medida em que ela nos possibilita passear pelo entorno da obra, dando-nos profundidade sem o perspectivismo, rompe a relação de intersubjetividade que ligava o pintor ao observador, afinal sua obra não representa mais o mundo, não há mais $\mu i \mu \eta \sigma \iota \varsigma$ - o único erro possível em arte é a imitação (ibidem, p. 52) -, mas apresenta um novo mundo inscrito e fragmentado na tela:

O observador perde, na operação, a possibilidade de entrar em coincidência com o olho do pintor, como o ponto de vista único e central que a perspectiva lhe permitia. Ele ainda deve trabalhar: restabelecer ele mesmo a unidade dos planos estilhaçados, encontrar os deslocamentos do olho e da mão do pintor. (ibidem, p. 64) 
Há, portanto, o rompimento do liame que prendia o leitor ao artista, quando pouco a pouco se instaura um abismo entre os dois e o acervo comum que os unia desaparece. O leitor sabia, exatamente, o que o artista iria dizer, afinal tudo era mimético, os auctores eram conhecidos por todos, seus olhares confluíam não só devido à perspectiva fria e direta da matemática, mas também devido ao acervo comum que os unia e permeava sua sociedade. Com esse rompimento, o leitor fica órfão na medida em que tem de trilhar sozinho o caminho que vai de si mesmo para o outro que se expõe na tela, tem de especular, imaginar e deduzir o que o outro quis dizer: a criatividade configura-se como preceptiva principal da arte, o artista deixa de se submeter a preceitos e mandos de outrem. Assim, diante do poder conferido por sua nova fertilidade criativa - distante da pura $\mu i ́ \mu \eta \sigma \varsigma$-, o artista brinca com o leitor, velando a significação imagética de sua obra - não mais nos moldes engenhosos de Góngora -; induz o leitor a ler sua obra não só pelo crivo da visão, mas para além da relação ocular antes estabelecida entre pintor $x$ observador, forçando-o, muitas vezes, a deslocar essa visão para os outros sentidos, a fim de que também possam participar da leitura dessa nova imagem que se apresenta.

A visão deixa de parecer o sentido mais seguro ou mais preciso para construir uma imagem do mundo. Ela mantinha os objetos, todo o real, muito à distância, e isso era um atributo mais próprio da imagem fotográfica e do cinema com seus automatismos. Para os pintores, a perspectiva, com seu sistema de retas convergentes, não mais parecia apta a "despertar uma idéia de profundidade". Para estabelecer o espaço pictural, é preciso recorrer (...) às sensações táteis e motoras e a todas as nossas faculdades". É o corpo inteiro, enquanto órgão perceptivo, e não mais exclusivamente a visão que participa da pintura. (Couchot, 2003, pp. 49-50)

Daí muitas obras de arte modernistas apresentarem materiais não pictóricos em suas telas como areia, serragem, pedaços de espelho, de jornais, de tecidos: a tela pede para ser tocada, apalpada, manipulada e sondada sob vários pontos de vista sensoriais: táteis, auditivos, olfativos. Muitas vezes, abrem-se várias possibilidades artísticas pelo amalgamento entre a arte e outras habilidades humanas, como a técnica, com a qual está se imiscuindo 
cada vez mais, abrindo-se várias possibilidades e inovações. Nesse sentido, encontramos, cada vez mais, um elo entre arte e $\tau \dot{\varepsilon} \chi v \eta$, quando se verifica um retorno daquela em relação a esta, ou seja, a um momento (há muito perdido) em que ambas partilhavam um mesmo campo semântico. É possível ver que

(...) a arte, desde o início do século (XX), substitui o real pela sua imagem (colagens, ready-mades) e abre-se a todas as técnicas, a todos os materiais possíveis, sem nenhuma interdição em princípio, recusando a encerrrar-se em uma especificidade seja ela qual for. Esta recusa se justifica, parcialmente, pela necessidade de introduzir na arte certas habilidades que solicitam outras percepções além da visão, sem interditar as técnicas visuais. A associação das mídias mais diversas, sonoras, visuais, textuais, torna-se uma prática corrente facilitada pela eletrônica (diríamos, informática). Esta desespecificidade contribui, também para a abertura de todos os azimutes. Por sua vez, as fronteiras entre a arte e a técnica se interrompem. (ibidem, p.141)

Apesar de os vanguardistas da segunda metade do século XX não quererem considerar suas obras como arte - como Duchamp -, essas acabaram tornando-se paradigmas. Mas, longe de serem modelos seguidos nos moldes dos Seiscentos, tornaram-se vazios em si mesmos, afinal seu princípio motor era o de chocar, mas esse se saturou, rapidamente, pois aquilo que chocava o público há alguns anos, hoje tem um efeito inócuo.

Quais são as pretensões da arte? Voltar a ter um paradigma que pudesse seguir? Indubitavelmente, não há mais espaço para paradigmas hoje, a arte tem de estar constantemente em luta pelo novo, por aquilo que, inclusive, choque e que atinja o público - apesar de pouco importar-se com ele $e^{210}$-; mas, devido a essa necessidade vital e de subsistência, condena-se ad aeternum e - à semelhança do primeiro hieróglifo de Horapolo - a arte permanecerá sempre numa contínua autofagocitose, pois já não possui um referencial de onde alimentar-se.

\footnotetext{
${ }^{210}$ Evidentemente, esse fazer artístico não se refere à arte popular que surge de seu próprio meio e, a priori, a ele mesmo se destina. Falamos aqui da arte que quer (e precisa para se manter assim) ser simplemente inovação, diferente, à semelhança dos desfiles de modo em que vemos as modelos com uma indumentária tão extravagante que nunca será utilizada por ninguém, mas se presta à passarela (e aos aplausos que serão recebidos por seu criador).
} 
Devido à recusa incondicional da $\mu i ́ \mu \eta \sigma l \varsigma$, a arte deve apropriar-se continuamente de si mesma; resulta daí um aparente paradoxo que é o fato de não querer (poder) representar mais nada, mas de ter sempre de apresentar 0 novo. Como ela não consegue conciliar esses extremos, pois a imagem que transmite é uma não-imagem, tem de ser substituída, pois esses artistas esqueceram-se do fundamental: a imagem é cifra da condição humana (Paz, 2005 , p. 38), por isso as pessoas - as mesmas a quem a arte não quer se dirigir, devido ao pedestal em que acredita se encontrar -, que querem sempre se lembrar de algo, vêem-se instigadas a evocar suas lembranças, a compartilhar seu olhar, sentimentos e emoções com aqueles que lhe pareçam próximos, mesmo que esses sejam simulacros de papel, ou imagens de gesso; mesmo os sonhos remetem a algo, representam a res que buscamos descobrir e que acreditamos serfeita a nossa imagem e semelhança: poucos conseguem enxergar isso na pintura moderna, principalmente a figural, pois não representam nada, somente - quem sabe? - um momento de explosão solitário do artista, do seu mais puro sentimento egoístico, quando o mais importante é seu momento, é ele mesmo enquanto ser, não o outro. No entanto, não é isso o que queremos.

Aspiramos, novamente, à representação das coisas para que possamos co-participar nela, de forma especular, com nossos próprios olhares frente ao mundo, nossas próprias angústias e sentimentos, mas que, enganando-nos ao vê-las ali espelhadas, acreditemos que pertençam somente a nós mesmos: queremos acreditar que sejam momentos únicos - também egoístas como os do artista -, feitos exclusivamente para nós ou, quando muito, compartilhado pelo artista que pinta/escreve só para mim. A pintura perdeu essa posição,

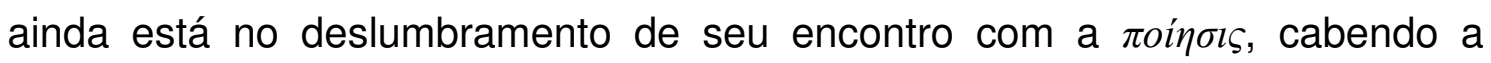
representação do mundo - que nos rodeia e permeará nossa memória - à fotografia.

Tange a ela, portanto, o ressurgimento da capacidade de ver-se representado como se é, ou se acredita ser, nem que para isso seja necessário posar, várias vezes, em frente ao fotógrafo como se fazia, antigamente, em frente ao pintor, mas com um grande diferencial: nós próprios podemos participar do processo de criação, visto que é possível manipular seu resultado, 
daí falarmos em ser como é, ou mesmo acreditar ser, sem, contudo, termos de ouvir que a fotografia é artificial.

O artista pictográfico, por outro lado, ao apagar nossos defeitos e exaltar nossas qualidades, também poderia demonstrar artificialismo ou falta de capacidade mimética - apesar de, para Aristóteles, o artista poder imitar as coisas como são, ou piores, ou melhores, desde que respeite a verossimilhança -, mesmo se prendendo a preceitos preestabelecidos, no entanto poderia não agradar a todos, poderia tornar-se uma imitação pouco crível, motivo de escárnio, tanto para aqueles que estimam e convivem (ou não) com o retratado, quanto para aqueles que não o suportam. Por outro lado, não se deve esquecer de que uma pintura não tem a obrigação de ser perfeita: é uma arte, exclusivamente, subjetiva.

O mesmo não ocorre com a fotografia, pois mesmo sendo manipulada e subjetiva não carrega esse fardo, afinal ela é técnica, a outra meramente manual, uma ars mechanicae, por isso e apesar dos avanços na Renascença, a arte moderna queria, efetivamente, libertar-se do mero manual, do qual os artistas queriam fugir: já haviam dominado as leis de perspectiva, suas obras já pareciam cópias da realidade: haviam chegado ao topo, precisavam galgar outros territórios, libertar-se. Isso se efetiva com a fotografia, cuja participação fora fundamental na expressividade da arte pictórica e em sua libertação mimética, quando acaba assumindo, para si, a função documental e referencial que pertencera à pintura durante mais de quatro séculos. Apesar disso, a fotografia também se emancipou, não aceitou ser mera coadjuvante do ato artístico - como havia preconizado Baudelaire - para também se introduzir no

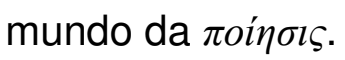

A $\tau \varepsilon ́ \chi v \eta$ atua de forma singular na fotografia, traçando um caminho inverso ao da pintura - pelo menos no que se refere a sua recepção pelas pessoas -: não só a fotografia está cada vez mais presente em suas vidas - à diferença de outras expressões artísticas, cada vez mais distantes do público -, proliferando-se por todos os segmentos sociais como nunca havia ocorrido até então, como também as próprias pessoas extraem dela todas as possibilidades artísticas possíveis, devido aos recursos da informática disponíveis hoje, seja para retocá-la, pintá-la, encobri-la, descolori-la, escolhendo de dentro da moldura o que mais lhe agrada e montando-o com outros de outras molduras 
quase num ato sem fim. Seu resultado, à semelhança de um mosaico, cujas peças elas próprias são fragmentos da realidade individualizada e particularizada, é montar uma sucessão de presentes, talvez como o pintor que cria, do espaço vazio, sua própria realidade. Dessa forma, e apesar de se tecnologizar cada vez mais - sem nunca ter deixado de fazer parte das $\tau_{\varepsilon}^{\prime} \chi v \alpha l-$, a fotografia ainda é utilizada como base memorialista: não só devido aos inúmeros álbuns que insistimos em manter em casa, como também pelo gigantesco acervo virtual que as pessoas montam atualmente, devido às novas possibilidades trazidas pela fotografia digital. Além disso, a fotografia mantémse ainda, pelo menos por enquanto, como critério básico para a identificação das pessoas em todos os níveis da sociedade - nas escolas, nas empresas, em agremiações sociais e na esfera pública -, isso equivale a dizer que, sem ter sido fotografada pelo menos uma vez na vida, uma pessoa não pode ser considerada alguém em nossa sociedade.

Somos impelidos a voltar à pintura, para que possamos levantar duas questões hipotéticas:

$\left.1^{a}\right)$ seria possível, se quiséssemos, adotar a pintura modernista como paradigma - nos moldes das iconologias - para estabelecermos (ou mantermos) um repertório de lembranças visuais calcada em bases pictográficas?

$2^{\mathrm{a}}$ ) se isso fosse possível, poderia esse repositório seguir algumas das preceptivas das iconologias existentes nos Seiscentos para que pudéssemos utilizá-los como modelo ou fonte de pesquisa? ${ }^{211}$

Certamente, nenhuma dessas possibilidades seria plausível, pois, conforme levantamos até o momento,

a) se quiséssemos utilizar a iconografia barroca mesmo como um start para novas iconologias, sem ter posse de todas as preceptivas do período seria muito difícil, já que não bastaria criarmos uma lista de imagens e seus significados para consulta prévia, pois toda a carga semântica que subjaz a elas não teria o menor sentido para nós: já

${ }^{211}$ Evidentemente, sem toda a carga epistemológica presente naquele momento, mas como paradigmas imagéticos, cuja função seria mais um acervo da memória do que modelos para serem seguidos. 
não dispomos mais de toda a bagagem cultural e aristocrática do período, afinal vivemos hoje sob os auspícios da burguesia ${ }^{212}$. Logo, se não nos é possível compreender o período, como tentar utilizar-se dele para adotar uma nova iconologia para nós, no futuro, mesmo que fosse somente para servir de alicerce para que pudéssemos nele inscrever nossa nova fórmula? Simplesmente não é possível, conforme revelam o desdobramento de seus fatores anacrônicos sejam sócio-culturais e econômicos, sejam mítico-religiosos;

b) no futuro, não podemos falar que abandonamos as iconologias, pois sequer as conhecemos, nem mesmo seus modelos epistemológicos que, para nossa sociedade seriam considerados pura crendice e, em alguns aspectos, inclusive, politicamente incorretos ${ }^{213}$, arcaicos, já que sua argumentação científica fundamentava-se em dados supersticiosos de uma empiria absurda ${ }^{214}$, baseada numa filosofia excludente, preconceituosa e cega que seguia preceitos e modelos antigos (auctores) e ultrapassados;

c) nossa sociedade, por rechaçar tudo que é passadiço, tem dificuldade para compreender o que não se refere a ela. Dessa forma, ou prefere idealizar o passado por meio do cinema, quando vemos a mistura de classes sociais que seriam impensáveis naquelas sociedades, mas que na tela torna-se real (normalmente sob a ótica romântica), ou então demonstrar valores hodiernos, diga-se, burgueses, em suas personagens aristocráticas: eis que Alexandre Magno, aos olhos de

${ }^{212}$ A própria burguesia utilizou-se desse expediente anteriormente, no período literário que chamamos de Arcadismo, que não passava de uma imitação de parte das preceptivas aristocráticas, mas que logo foram abandonadas com o advento do Romantismo.

${ }^{213}$ Somente a título de ilustração e sem nos atermos a uma leitura alegórica, podemos citar a representação de Ripa para o pecado, simbolizado por um negro cingido por uma serpente.

${ }^{214}$ Foucault mostra-nos que também a ciência é algo passível de mudança, cuja expressão reflete a sociedade e o tempo em que se insere. Isso fica claro, quando exemplifica as analogias que havia no Cinquecento, para isso cita dois teóricos da época: Pierre Belon e Aldrovandi. Aquele traçou uma tábua de comparação entre o esqueleto humano com o dos pássaros - seguindo as preceptivas vigentes e codificadas naquela sociedade que consistiam na analogia entre o homem e a natureza criada - que se poderia, hoje, considerar precisa, só comparada com aquilo que seria feito somente no século XIX; este outro, por seu lado também seguindo os moldes impostos pela epistéme do período, compara as partes inferiores do homem aos lugares infectos do mundo, ao Inferno, às suas trevas, aos condenados que são como excrementos do Universo. (Foucault, 2007, pp. 30-31) Ambos os teóricos seriam recebidos, em nossos dias de forma diferente: Belon seria o genial, o que vislumbra o futuro; Aldrovandi, o fantasioso, cuja superstição lembraria mais a ldade das Trevas do que a iluminação renascentista. No entanto, ambos pertencem, dentro do momento em que estavam inseridos, à mesma cosmografia analógica cujo princípio norteador era a comparação. 
muitas pessoas, simplesmente é homossexual, ou Maria Madalena, uma prostituta.

Vivemos em uma sociedade imediatista e superficial que não consegue, portanto, estabelecer relações temporais, na medida em que não pode (ou não quer?) enxergar as outras realidades de modo diferente da que vemos hoje;

e, finalizando, diríamos que

d) a drástica ruptura que se verificou na expressão pictórica modernista 1) com o fim do perspectivismo albertiano; 2) com a negação parcial e total da $\mu \dot{\mu} \mu \eta \sigma \iota \varsigma^{215}$; 3) com o fim da interrelação autor x leitor, fez com que o período perdesse a referencialidade.

Como um período cuja arte prescinde do referencial que o minimiza e descarta poderia servir de repositório para outros fazeres artísticos? Seria algo impraticável, pois seguiria o mesmo continuum em que já se estabelecera a própria arte, a partir da segunda metade do século XX: a busca por sua renovação perpétua.

Sem referencialidade, por exemplo, não é possível sequer haver a interrelação entre o artista e o leitor, afinal este se tornou órfão e aquele, um deus intocável. Essa interrelação funcionava, por exemplo, na pintura do Classicismo, como fator de intersubjetividade, quando autor e leitor, partilhavam o mesmo olhar, e sua eficácia

se sustentava (...) na possibilidade de qualquer espectador ocupar, ele também, o poder da pirâmide visual e de aí reencontrar a posição originária do autor. (...) O sujeito observador entra então em coincidência retrospectiva, ou ainda "em ressonância", com o sujeito instaurador da imagem. (Couchot, 2002, p. 31)

Havia, dessa forma, uma estreita aquiescência entre o passado e 0 futuro a partir do eixo do presente. (ibidem, p.31) Mas, com a concretização do rompimento perspectivista do Renascimento e o incremento da visão pluriocular, heterogênea, esqueceu-se de que, apesar de o ponto de vista único

${ }^{215}$ Dizemos parcial, pois mesmo na arte cubista, por exemplo, via-se uma representação da natureza, mesmo que a partir de figuras geométricas; o mesmo não poderia ser dito da arte abstracionista, que abandona toda referencialidade . 
homogeneizar o espaço e delimitar uma localização precisa em relação à imagem, ao pintor e ao objeto representado, é também onde se projeta o olho do artista e a pintura imaginada por ele, ou seja, colocar em perspectiva tanto pode ser copiar quanto imaginar (Cf.: ibidem, pp. 30-31); mais do que isso, levar a imaginar, sair de si mesmo, do eu individual, para participar de um outro eu, tornar-se coletivo, multifacetado e, portanto, passível de múltiplas interpretações, mesmo que delimitado dentro da convenção. Essa consonância é clara nos Seiscentos quando, mais do que o mesmo olhar e imaginar, partilhavam-se imagens comuns, inseridas num tempo comum, mas que se introjetava de um tempo já distante, como no dos auctores.

Apesar de estar embasada dentro dessa perspectiva temporal, a própria pintura já mantém, intrinsecamente, com o tempo uma relação anacrônica que a diferenciará da fotografia -, na medida em que sustenta com esse uma ligação de composição: a imagem não surge de um instante a outro como no ato fotográfico ${ }^{216}$, já que o pintor a constrói, lentamente, pincelada a pincelada:

a tela a ser pintada só pode receber progressivamente a imagem que vem lentamente nela se construir, toque por toque e linha por linha, com paradas, movimentos de recuo e aproximação, no controle centímetro por centímetro, com esboços, rascunhos, correções, retomadas, retoques, em suma, com a possibilidade de o pintor intervir e modificar a cada instante o processo de inscrição da imagem. (Dubois, 2006, p. 167)

O passado e o futuro estariam não só nas mãos do pintor que cria a obra a partir de vários presentes - já que não é possível fazê-lo num único momento - como também do leitor que, no futuro, lerá a obra a partir de sua própria Weltanschauung, quando procura, se a obra the tocar como num punctum, saber as razões que levaram o artista a compô-la. Evidentemente, os olhares do artista e do leitor se cruzarão, na medida em que o passado (os vários

\footnotetext{
${ }^{216}$ Não há dúvida de que também haja, no processo fotográfico, esse procedimento, principalmente quando se torna necessária uma maior exposição da câmera à luz (como nas fotografias noturnas, de livros, ou mesmo as microscópicas). Nesse caso, é necessário que o obturador esteja aberto o maior tempo possível, a fim de que se possa controlar a velocidade e a exposição da luz; e, dependendo do tempo empregado haverá, inclusive, o registro de sobreposições no resultado final da fotografia. Contudo, não nos ateremos a essa particularidade fotográfica nesta Tese.
} 
presentes da execução pertencente ao pintor) de um se encontrará com o olhar, no futuro, de um outro; não importa que o motivo, a razão e a intenção do artista tenham desaparecido no tempo, da mesma forma que tenham se dissipado suas práticas discursivas, suas preceptivas, sua intencionalidade; enfim, que o período em que o artista esteve inserido, não passe de uma mera sombra temporal há muito tempo extinta, pois cada vez que um leitor se postar diante de sua obra, também verá a cena a partir do vértice dado pelo outro como pistas a serem seguidas. Ao leitor, porém, não restará muito mais do que isso - além da curiosidade de saber, por exemplo, o que poderia ter motivado tal obra: encomenda, prazer, necessidade -, pois a limitação anacrônica fará o restante, ou seja, manterá o leitor alijado da total intencionalidade estética do momento.

$\mathrm{Na}$ fotografia, por sua vez, vê-se uma tomada sincrônica, cujo traço distingue-se, radicalmente, da pintura (Cf.: Ibidem, p. 167), sua imagem é formada por inteiro - um recorte de um instante, de um lapso temporal - sem a interferência do fotógrafo no processo. ${ }^{217}$ Apesar dessa sincronia, o referente fotográfico estará sempre no passado, formado não mais de vários presentes, como na pintura, mas de um único momento, de uma única emanação de luz, indicando que alguma coisa passou diante do pequeno orifício de uma câmera fotográfica. (Cf.: Barthes, 1984, p. 117) Mais do que isso, se o leitor vir uma foto sua ou uma em que ele esteja presente, cruzará seu olhar não só com o do fotógrafo, mas também com sua própria emanação visual, a mesma que partiu de seus próprios olhos no momento em que o clique congelou aquele instante, revelando alegria ou pesar, capturados pelo instante fotográfico.

Ao dizermos emanação referimo-nos ao reflexo causal, que consiste na capacidade que temos em estabelecer relações a partir de pontos de contato entre o que vemos no presente a partir de imagens que retratam o passado. Por exemplo, um detalhe em uma fotografia - que passaria despercebido a qualquer pessoa - pode servir-nos (a nós que o vivenciamos ou que tivemos contato com aqueles que a vivenciaram) - de link para restabelecermos, em nosso presente, uma viagem para um outro presente, o imobilizado pelo instante fotográfico, cuja realidade desapareceu - mas está mumificado - no

\footnotetext{
${ }^{217}$ Há, evidentemente, o controle do período de exposição ou da velocidade do obturador, e
} mesmo o de fazer clique, por exemplo. 
momento de sua imobilização. Assim, o reflexo causal deixa de ser a simples emanação dos raios luminosos do retratado para o papel, mas aquilo que a câmera capta e somente nossa subjetividade pode ler num momento temporalmente distante do fato - um sorriso, um gesto, um olhar enviesado, cujos sinais pertencem somente a nós e que, ao serem revisualizados na imagem fotográfica, trazem-nos à tona sua rememoração, sua extra-moldura. Portanto, não se quer dizer que o reflexo emanado pela imagem fotográfica seja fidedigno àquela luz emanada há instantes, dias ou anos, já que aquela se perdeu na emulsão fotográfica, quando os sais de prata deixaram-se sensibilizar. Teríamos, com o reflexo causal algo semelhante ao punctum barthiano, mas que somente estariam presentes em nossas fotografias, naquelas que nos dizem respeito como as familiares ou as sociais das quais participamos direta (como retratado ou como operator ${ }^{218}$ ) ou indiretamente (a partir de relatos a seu respeito seja por familiares, seja por amigos ou conhecidos).

Não se deve esquecer de que, apesar de estar inserida no campo técnico, a fotografia também possui suas particularidades artísticas - assim como muitas atividades humana -; entretanto, essas não interferem na recepção que o leitor faz dela, nem na relação estabelecida entre leitor $x$ fotografia, pois não importa o meio do processo, mas seu produto final e a relação deste com seus leitores. Isso demonstra, por exemplo, que para a fotografia - inserida em dois campos da $\tau \dot{\chi} \chi v \eta$ humana, a artística e a técnica -, podem se levantar problemas teóricos e conceituais de ordem técnica, como o suscitado pela palavra emanação, sem que isso, insistimos, prejudique o objeto deste estudo, já que nos ateremos a seu caráter artístico, apesar de seu caráter epistemológico. No entanto, pelo fato de ter a fotografia também algo de tautológico, esquece-se de que a imagem formada na câmara escura não surge do vazio, como mero reflexo especular, mas depende do aparato que lhe serve de intermediário, que transforma, ele mesmo, aquilo que o operator vê, nas imagens que nós veremos, mas que nunca corresponderá àquilo que o eu fotográfico viu, ou pretendeu captar: deve-se parte dessa transformação à própria reflexão óptica que ocorre quando os raios luminosos ultrapassam a lente. Dessa forma, a constituição imagética, formada na câmara escura,

${ }^{218}$ Barthes chama o fotógrafo de operator, como veremos adiante. 
depende de uma série de processos físico-químicos aleatórios, muitas vezes, imprevisíveis que, efetivamente, receberão e formarão a imagem a partir das emanações de luz desprendidas dos corpos, por isso

Emanações luminosas do referente só podem resultar imagens fotográficas após elas terem sido transformadas pelo dispositivo óptico câmera. Claro que a construção de uma imagem na superfície da película depende sempre de um referente que posa diante da câmera (...). Mas não se pode daí tirar a conclusão de que a imagem fotográfica seja apenas a fixação do seu "reflexo" e, por conseqüência, o correspondente mais exato e fiel do modelo que o gerou. Ao penetrar na câmera, a informação luminosa é codificada e se deixa reestruturar para conformar-se à convenção do sistema pictórico. (Machado, 1984, p. 39)

Essa colocação é pertinente, pois não se deve esquecer de que a técnica é própria da constituição fotográfica como é de outras expressões artísticas - basta lembrarmos de todo aparato técnico empregado pela pintura da Renascença.

No entanto, da mesma forma que se considerou a fotografia durante muito tempo somente por seu aspecto de imagem técnica - não como elogio, mas como demonstração de preconceito não tanto à técnica fotográfica em si, mas àqueles que viram na fotografia algo mais do que servir às ciências e às artes de maneira subserviente e humilde como propusera Baudelaire -, não é possível retirar, hoje, seu papel de expressão artística imagética com todas as implicações que a imagem proporciona ao homem. Dessa forma, se se aceita dizer que a fotografia somente representa a técnica - com o uso corrente dessa palavra e não na abrangência da $\tau \dot{x} \chi v \eta$-, retiraríamos dela não só todas suas possibilidades de expressão artística, como também todo o referencial e a identidade de gerações que encontraram nela o que em nenhuma outra arte foi possível: a si mesmo a partir do outro. Esse foi o motivo de termos explanado, no início desta Tese, a relação semântica da palavra $\tau \dot{\chi} \chi v \eta$ e suas implicações, para que pudéssemos demonstrar a inserção, de fato, da fotografia no objeto que chamamos arte, que passa a ser algo indissociável e natural a ela; dessa forma, a técnica passa ser uma conseqüência.

Encontramos, assim, no ato fotográfico, 
a) aspirações de ordem poética, se quisermos utilizar o lugar-comum que vê, nos poetas, aqueles cujo poder é transformar os sonhos em realidade utilizando-se do גóyos; a foto é como um sonho que se torna factível: a $\tau \dot{\varepsilon} \chi v \eta$ imprime o sonho no papel, torna-o concretude imagética, eternizam-se o presente, o momento, 0 instante que não querem esvair-se; mesmo aqueles que queríamos nunca ter passado, ou termos por ele passado, tornam-se perenizados pelo ato fotográfico. Que é o poema, senão a eternização de um momento, e eternizado porque não queremos olvidá-lo? Dizemos poema, exatamente, porque foi nessa estrutura que os grandes mitos da humanidade foram construídos, quando se buscava eternizar cada acontecimento que se cria único e digno de permanecer na posteridade. Por que deixamo-nos fotografar, senão para que a posteridade aponte: este é aquele, este foi um grande homem. Os solitários dizem não gostar da foto exatamente por esse motivo: não há ninguém para quem deixar suas imagens, então para que deixá-las? Não admitiriam ouvir um quem é esse aí?

b) aspirações de ordem técnica ou mesmo, diríamos, alquímica, se pensarmos que poderíamos colocar a revelação fotográfica no mesmo nível da pedra filosofal e do elixir da longa vida, almejado pelos alquimistas desde a Idade Média.

Que seria a revelação fotográfica senão uma transformação alquímica, semelhante àquelas buscas incessantes do homem pela eternidade? Vemos a transformação do banal, do trivial, em algo memorável, inesquecível; eis os poderes da pedra filosofal: transformar objetos sem valor em ouro; paralelamente, vemos que junto à beleza e ao reluzir do ouro vem uma de suas mais notáveis características: a perenidade, a tendência para seu eterno brilho: eis o elixir da longa vida, quando o momento fugaz propiciado pelo presente, torna-se eterno dentro do mesmo presente!

Aquilo com que os egípcios sempre sonharam e temiam era voltar à casa dos vivos e não conseguir reconhecer seu 
próprio corpo: daí as máscaras mortuárias, a incessante busca por retratar a luz, para que, quando viessem também em luz, pudessem reencontrar-se a si mesmos e, assim, tornar o brilho comum; além de recuperar, dessa forma, seu próprio reflexo causal, por meio de sua própria fotografia impressa em ouro em seus próprios sarcófagos. Os alquimistas tentaram na Idade Média, mas foi somente graças à $\tau \dot{\chi} \chi v \eta$ que o sonho de muitos tornou-se realidade, factível; agora, é possível falar em eternidade, quando os instantes únicos e reais perenizam-se no papel e, devido também à técnica, podemos vislumbrar o onírico esmaecido nas paredes da memória que, muitas vezes, a arte pictórica não conseguia lograr.

Esse quê de eternidade próprio da fotografia tem o poder de reviver o passado e, auxiliado pelo reflexo causal, fará brotar parte da sensação vivenciada naquele presente distante e ausente, mas presente no momento, apesar de partir de um buraco do tempo (Cf.: Dubois, 2006, p. 164), instante em que se faz uma varredura na parede da memória em busca daquelas percepções diversas do mesmo objeto que se oferecem a nossos sentidos, mas que, ao se reunirem, não constituirão sua imagem completa. (Cf.: Bergson, 1999, p. 49) Dubois nos fala que para que fosse possível preencher o buraco do instante vazio colocado por sua memória fotográfica, seria necessário que ele mesmo fosse retirado de sua própria fotografia

tirando-me de meu corte e mergulhando-me numa memória que não é mais a minha, recosturando de fora e depois o tempo cortado, isto é, fazendo dessa reconstituição uma ficção, um metafantasma. (Dubois, 2006, p. 164)

No entanto, quando isso se efetiva - o ser retirado e ser reintroduzido -, a exterioridade faz com que as lembranças advindas daí não sejam verdadeiras, mas artificias, pois nos provêm prontas de terceiros com uma codificação que nos é desconhecida, ou seja, sem aval de nosso reflexo causal constituído até aquele momento. Como se ao vir uma fotografia alguém nos dissesse que aquela criança ali retratada fôssemos nós mesmos, apesar de 
não nos reconhecermos nela, já que não nos deixamos tocar nem nos reconhecer por meio de nosso próprio reflexo causal, este sim rememorador e construído ao longo de nossa história enquanto pessoas.

A iconofotologia de nossa própria identidade - a mesma que constituiu nosso reflexo causal - é construída à semelhança de um espelho em que pudéssemos ver, concomitantemente, todas as fases e faces de nossas vidas diga-se, imagens que temos de nós mesmos -, quando bem quiséssemos. Essas são constituídas, a partir das primeiras fotografias que nos retratam, transmitidas por meio de nossos pais que as vão indicando, ao longo de nossa primeira infância - quando nossa representação começa de forma impessoal (Cf.: Bergson, 1999, p. 46) -, e formarão essa base iconofotológica, cujo expoente principal é o fato de, normalmente, reconhecermo-nos mesmo que sejamos irreconhecíveis para as outras pessoas: esse sou eu. Aqueles, porém, que nunca tiveram alcance a esse acervo fotográfico por privação, relapso dos pais - ou por não terem tido condições de relegar à posteridade uma pequena peça do mosaico da vida incipiente de seus filhos -, não conseguirão reconhecer-se frente ao passado, não possuirão seu reflexo causal apurado para aquela determinada fase de suas vidas, mas, provavelmente, o possuirão de outras. Assim, o retirar-se de um corte foto-temporal e ser reintroduzido, posteriormente, como tendo sido aquele bebezinho, faz com que acabemos por tomar essa nova imagem apresentada como paradigmática e aceitarmos ser aquilo que está retratado como sendo o que fomos um dia: o presente ressurge por meio de um totem dos mortos que é a fotografia, mesmo que ela não seja, realmente, nossa própria retratação. Agora, porém, o será de fato.

Diante do exposto, poderíamos refletir sobre o quadro de Bailly apresentado na primeira parte deste trabalho, quando o eu pictográfico apresenta-se a si mesmo, retratando-se no presente. $O$ jogo imagético alcançado pelo pintor não passaria, segundo o que propomos, realmente de um jogo, pois o mesmo não teria como retratar-se quando jovem, pois a imagem que temos de nós mesmos vai esmaecendo-se todos os dias diante do espelho: vivemos, constantemente um eterno presente; ou seja, para Bailly ele era realmente o senhor de suíças apresentado por um jovem ele mesmo, que foi idealizado pelo homem maduro. Isso, porém, pode até ser possível quando 
fazemos leituras fotográficas ${ }^{219}$ de nosso filhos - se os tivermos -, quando tentamos nos enxergar nos mesmos. Daí dizermos fotográficas, ou seja, vermo-nos filhos como se eles próprios pudessem ter sido nosso reflexo imagético de onde retiraríamos os traços que faltavam de nossa imagem esmaecida pelo tempo e por nossa memória. Vê-se, portanto, o retornar do mosaico, quando as partes vão sendo coladas pouco a pouco com a cola do tempo e daqueles que temos a nosso lado. Eis o grande papel da fotografia: mostrar-nos quem somos, fazer-nos reconhecer nos parentes distantes, mesmo que chegássemos a imaginar não pertencermos a determinada família devido à dissimilitude com nossos pais e irmãos, mas devido ao totem fotográfico, veríamos que tudo é possível: eis aqui a fotografia de minha tiaavó, ela tem os mesmos olhos e sobrancelhas que as minhas! Revelar não só o diminuto, aquilo que o movimento não nos permitiria, mas também os traços do passado, as cicatrizes: Odisseu reaparece, não importa que pareça velho ou carcomido pelo tempo, a cicatriz mostra, aponta: é ele. Eis a fotografia apontando, criando e formando nossa memória, fazendo-nos, destarte, descobrir quem somos, ou quem querem que sejamos: uma vez instalada em nossa memória fotográfica, em nossa iconofotologia, só mesmo uma força maior para dissuadir-nos de sermos aquilo que nos imputaram.

Criamos paradigmas e imputam-se-nos, constantemente, vários outros modelos, mesmo que não percebamos, que agem sobre nós como sua ação virtual, que concerne aos outros objetos e se desenha nesses objetos (ibidem, p. 59), pois para que pudéssemos perceber com a consciência teríamos de aceitar uns e descartar outros. Para isso teríamos, segundo Bergson, de dispor de nossos sentidos, mas por meio de sua educação, já que

Nem a visão nem o tato chegam imediatamente a localizar suas impressões. Uma série de aproximações e induções é necessária, através das quais coordenamos pouco a pouco nossas impressões umas às outras. (ibidem, p. 48)

O mesmo se dá com o acréscimo de informações imagéticas de que dispomos, ou seja, na relação entre o sentir e o perceber o mundo que está a

\footnotetext{
${ }^{219}$ No sentido de rememoração imagética ou mesmo iconofotológica que, evidentemente, não era o caso de Baiily.
} 
nossa volta, entre a ação real e a virtual que levarão à percepção - que mede o poder refletor do corpo a partir dos objetos e desenhando-se neles - e à afecção - quando se vê a percepção efetivada no próprio corpo (Cf.: ibidem, pp. 58-59):

Isto equivale novamente a dizer que minha percepção está fora de meu corpo, e minha afecção, ao contrário, em meu corpo. Assim como os objetos exteriores são percebidos por mim onde se encontram, neles e não em mim, também meus estados afetivos são experimentados lá onde se produzem, isto é, num ponto determinado de meu corpo. (ibidem, p. 59)

Assim temos, num primeiro momento, uma ação virtual, quando fotografias são verificadas, analisadas e, apesar de nos ser um corpo estranho, percebidas e lidas. Muitas acabam, finalmente, sendo impressas em nossa memória, deixam de ser meramente percebidas para serem sentidas, passam a concretizar-se, a uma ação real, pois ao manuseá-la e ao lê-las buscamos mais do que escanear informações que possam nos ser úteis, buscamos, dependendo de sua ação sobre nós, retê-las, para que se tornem parte de nosso acervo iconofotológico.

Essa performance advém, muitas vezes, do fato de junto a algumas fotografias estar presente uma legenda, principalmente naquelas cujo veículo de circulação sejam jornais, revistas ou livros. No entanto, o diferencial não é a

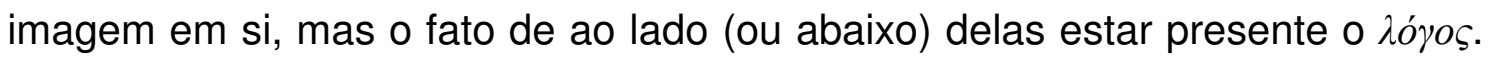
Este dá voz, sentido e autonomia às imagens fotográficas, por isso mais do que

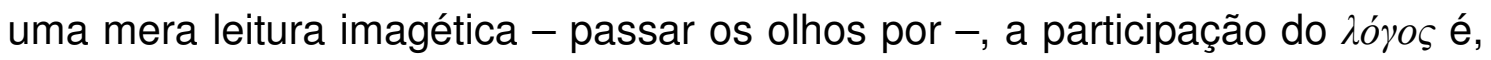
muitas vezes, essencial para deixarmo-nos, ou não, envolver pela imagem fotográfica.

De facto, as palavras falam mais alto que as imagens. As legendas tendem a sobrepor-se a evidência do nosso olhas; mas não há legenda que possa de modo permanente restringir ou fixar o significadeo de uma imagem. 
O que os moralistas ${ }^{220}$ exigem a uma fotografia é aquilo que ela nunca poderá fazer: falar. A legenda é a voz ausente e de que se espera a verdade. (Santag, 1986, p. 101)

Por seu meio, uma imagem insignificante ganha destaque, outra espetacular perde sua singularidade: resulta dessa relação o fato de fotografias triviais tornarem-se artísticas, simplesmente devido à legenda que o fotógrafoartista dá a ela; o mesmo serve para as artísticas que podem perder seu valor por necessitarem mais do que a própria imagem para nos tocar. Benjamim também observa esse poder da câmera de transformação:

\section{É agora incapaz de} fotografar um casebre ou um monte de lixo sem os transfigurar. Para já não falar numa barragem ou numa fábrica de cabos eléctricos: perante essas coisas a fotografia só pode dizer: "que bonito" (...). Mesmo a pobreza mais abjecta, ao ser tratada de uma maneira actual e tecnicamente perfeita, é transformada num objecto de fruição. (Benjamim, apud Sontag, op. cit. p. 100)

Muitas obras da arte

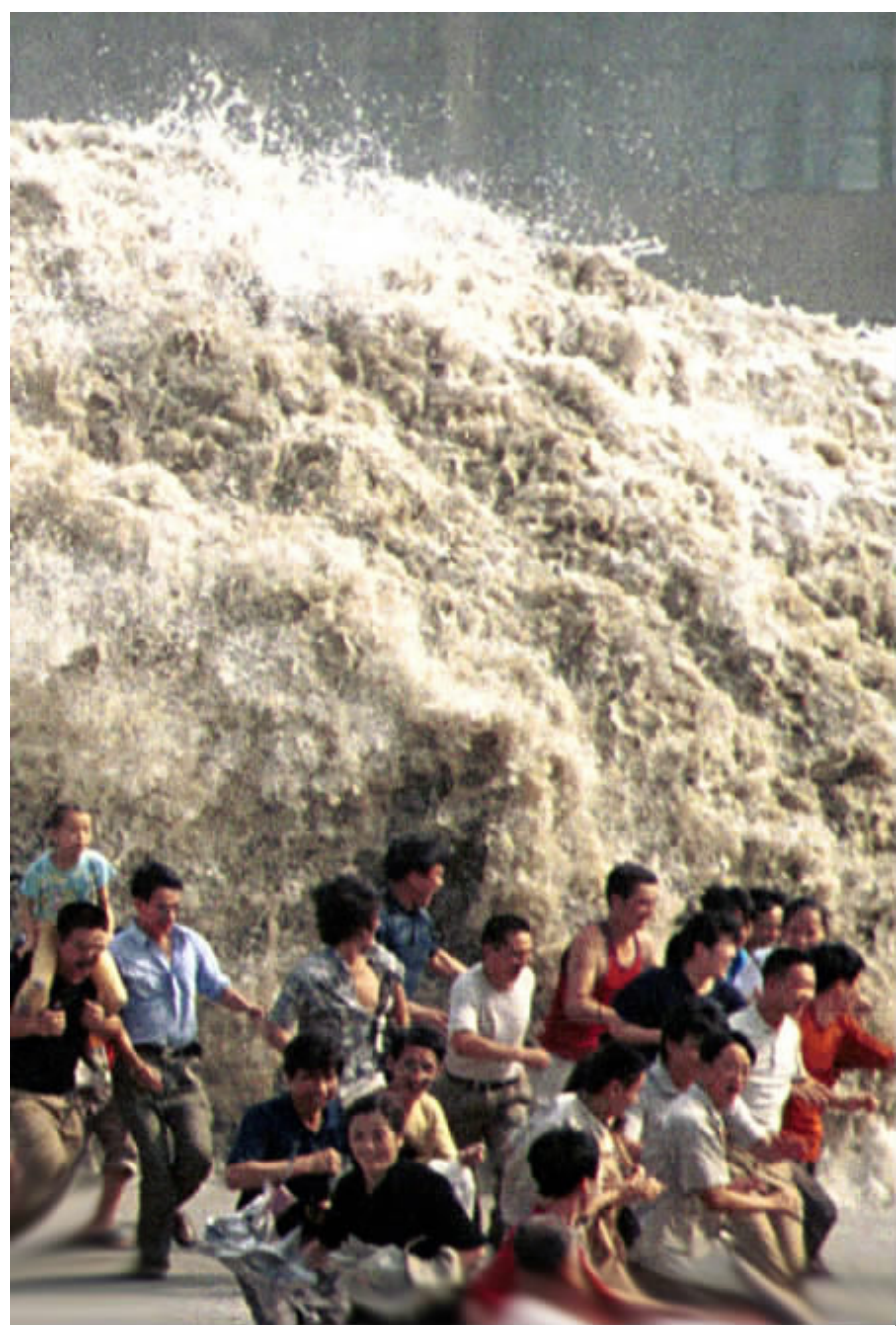
moderna foram, inclusive, compreendidas - ou se Foto 7: Macaréu do rio Qiantang, China, 2002. Esta foto, juntamente com outras semelhantes, havia sido veiculada pela internet como sendo retiradas no deixaram compreender momento do tsnunami de 26 de dezembro de 2006, no entanto, foram desacreditadas por uma emissora de televisão da Austrália.

devido à legenda, cujo papel corresponderia a uma espécie de chave sígnica para seu desvendamento, pois ao lê-la, poderíamos tentar compreender aonde

${ }^{220}$ Para Sontag esses moralistas eram os marxistas ou pseudomarxistas fascinaddos pela fotografia, mas perturbados pelo modo como ela inexoravelmente embeleza. (Sontag, 1986, p. 100) 
o artista queria chegar e se ele conseguiu atingir seus objetivos de fazer-nos perceber e discernir sua obra, apesar da sua total falta de referencialidade:

Perceber todas as influências de todos os pontos de todos os corpos seria descer ao estado de objeto material. Perceber conscientemente significa escolher, e a consciência consiste antes de tudo nesse discernimento prático. As percepções diversas do mesmo objeto que oferecem meus diversos sentidos não reconstituirão, portanto, ao se reunirem, a imagem completa do objeto. (ibidem, p. 49)

Bergson nos diz que para que essa visualização seja completa é necessária uma educação dos sentidos, restabelecendo uma continuidade rompida pela própria necessidade das diversas partes de nossos corpos e dos sentidos que lhe são correspondentes. Algo, portanto, que a arte moderna quis explorar, quando buscava essa aproximação de diversos materiais para formar seu objeto artístico. Ou, seguindo nossa linha de pensamento, ser retirado do recorte em que se está inserido - para que nos dêem novas imagens, novas lembranças - para ser, novamente, nele introduzido - repleto de lembranças dadas por outrem. Isso seria algo parecido com o filho cuja mãe, de repente, dissesse que toda sua história de vida não é como ela havia dito: seu pai não havia morrido em um acidente de carro, seu casamento não fora em determinada igreja, que seus avós... Como se num átimo, todas as suas lembranças, as imagens formadas ao longo de um tempo, suas idealizações fossem, abruptamente, arrancadas e a pessoa ficasse só, esperando ser resgatada dos escombros de seu próprio prédio que ruiu e, ao ser retirada, visse que seu mundo havia sido transformado em outro: novas verdades, novas lembranças teriam de ser formadas, assim como um novo acervo iconofotológico.

Poderíamos utilizar essa metáfora da ruína para exemplificarmos a renovação de nosso próprio acervo iconofotológico. Assim, aquilo que, continuamente, vemos ruir, faz parte da acomodação de nosso patrimônio iconofotológico, quando novas imagens tomam o lugar de outras num ato 
quase contínuo ${ }^{221}$; assim, teríamos uma adequação de nosso acervo, a fim de que possamos, quando necessário, utilizá-lo. Serão essas novas lembrançasimagens que se tornarão nossos novos paradigmas iconofotológicos, aos quais se juntarão outras imagens, que, todavia, permanecem como base desse mesmo patrimônio. Dessa forma, pode-se dizer que algumas das antigas imagens - parte de nosso acervo iconofotológico - acabam atualizando-se, quando serão recompostas, transferidas ou substituídas; outras, no entanto, se tornarão, efetivamente, novas, como a visão das ondas gigantescas do tsunami que passaram a fazer parte do acervo iconofotológico de parte da humanidade, devido aos efeitos devastadores ocasionados por essa catástrofe; ou a fotografia dos novos caçadores de cabeças (foto 14) da Indonésia que, por seu ineditismo para nossa contemporaneidade - além de transmitir-nos um excesso de primitivismo -, abre-se-nos como novo modelo imagético, (em substituição às cenas do martírio dos cristãos da proto-Igreja ou das cenas pictográficas da guilhotina que, eventualmente, poderiam permear nossa imaginação ${ }^{222}$ ) e torna-se, devido à sua singularidade, parte de nosso novo acervo iconofotológico.

Um ponto ainda deve ser observado quanto à aquisição de novas imagens para nosso acervo iconofotológico. Muitas do tsnumani, por exemplo, foram veiculadas, exaustivamente, durante alguns meses e sempre a partir de um novo ângulo ou tomada diferente, o que nos poderia fazer acreditar que, pouco a pouco, as pessoas fossem revelando ao mundo aquilo que elas mesmas vivenciaram. Essas imagens, portanto, acabam sendo inseridas em nossa memória e são incluídas em nosso acervo iconofotológico, entretanto parte das que foram veiculadas como tendo sido tiradas durante a catástrofe transmitidas, normalmente, via internet -, não correspondiam, verdadeiramente, ao tsunami de 2006, mas a outras fotografias, a cuja legenda

\footnotetext{
${ }^{221}$ Nem sempre nos é interessante a mudança de paradigmas iconofotológicos, ou seja, podemos manter as imagens de nosso acervo por tempo ilimitado, desde que suas imagens possam nos satisfazer quando de seu emprego.

${ }^{222} \mathrm{E}$ por serem pinturas tornaram-se o que são: meras pinturas, ou seja, não nos toca com o realismo que tocava o homem dos séculos XVI e XVII, com as pinturas da decapitação de Carlos V, na Inglaterra, a de Holofernes por Judite, a de São João Batista, ou ainda Perseu segurando a cabeça da Medusa morta; agora, ao vermos cenas parecidas via fotografia, não há como não se impressionar: vemos que é verdade, tal fato aconteceu, e eis que a cena ficará permanente em nossa memória, mesmo que queiramos esquecê-la, não que as outras não tenham sido - à exceção da morte de Medusa (talvez por já termos a consciência de constituirse mitologicamente) -, mas a pintura não nos atinge mais.
} 
não se fazia referência. Isso serve para ilustrarmos que, mesmo sabendo, a posteriori, que muitas daquelas imagens veiculadas naquele e em outros momentos, como sendo desse grande tsunami devastador, sequer retratavam, efetivamente, a hecatombe que se abateu sobre a Ásia; apesar disso, acabamos tomando-as como se tivessem sido autênticas. Quando, tais fatos se repetirem - novos tsunamis, novas lutas religiosas seja na Indonésia ou no interminável conflito no Oriente Médio -, provavelmente não terão o mesmo apelo imagético como da primeira vez em que o visualizamos - via fotografia e que perdurarão em nosso acervo iconofotológico ou serão, simplesmente, substituídos por outros mais recentes.

Vê-se, portanto, que essa alteração do (no) acervo iconofotológico pode tanto dar-se como:

a) um acréscimo: aquisição de uma imagem/conceito realmente novo, como a do tsunami, afinal sabia-se do fato, mas não havia uma consciência imagética coletiva do mesmo, muito menos de sua magnitude, fato que ficou claro até mesmo no emprego do vocábulo por crianças e adolescentes - durante um período curto após o incidente - como sinônimo de turbilhamento (numa piscina, por exemplo) ou de bagunça;

b) uma substituição: quando as imagens vão sendo substituídas por outras mais recentes; pode-se, por exemplo, incluir aí, o padrão de beleza instituído em uma sociedade em um determinado período, quando é possível verificar sua mudança.

Normalmente, tal substituição ocorre quando imagens pretéritas são postas de lado por outras mais impactantes que insistirão em manterem-se no lugar das mais antigas, as quais vão sendo elididas aos poucos.

Digamos, inicialmente que, se colocarmos a memória, isto é uma sobrevivência das imagens passadas, estas imagens irão misturar-se constantemente à nossa percepção do presente e poderão inclusive substituí-la. Pois elas só se conservam para tornarem-se úteis: a todo instante completam a experiência presente enriquecendo-a com a experiência adquirida; e, como esta não cessa de crescer, acabará por recobrir e submergir a outra. (Bergson, 1999, p. 69) 
Um exemplo dessa substituição imagética que acaba sendo submersa é a do Edifício Joelma em chamas em São Paulo nos anos 70: a cena de pessoas pulando em direção à morte marcou muitas pessoas durante anos; entretanto, a imagem das Torres Gêmeas em Nova lorque em chamas aliada aos mass media, impuseram-nos uma mudança paradigmática, ou seja, iconofotológica, já que acabamos abandonando uma grande tragédia regional presa a um determinado tempo - para assumirmos como paradigmática uma gigantescamente maior, não só devido à altura das torres, à quantidade de vítimas, mas também ao espetáculo oferecido a todo o globo.

A cena do WTC serve-nos também para abrirmos um parêntese em relação ao fato fotográfico, já que muito se fala do, inegável, poder do vídeo e do cinema na aquisição de uma memória fotográfica. Realmente a imagem em movimento dá-nos uma impressão maior, de movimento, de instantaneidade e de continuidade temporal: não há uma tomada, um recorte tempo-espacial como na fotografia, mas uma sucessão de recortes. Mas, acreditamos que a estaticidade imagética tem um poder maior de sedução devido, exatamente, ao recorte da particularidade: queremos ver o exato momento. Não nos basta mais vermos os aviões chocando-se contra as torres, nem mesmo sendo engolidos por elas, ou ainda as explosões que se seguiram. Queremos congelar 0 momento, ver passo a passo, cada detalhe da tétrica hecatombe que se verificou: agora o que se vê é verdadeiro, é real! Não há necessidade do detalhe na ficção, afinal ela é entretenimento. Mas, o fato que se deu em 11 de setembro é verdadeiro: eis a diferença. Assim, como se deu a penetração do avião no prédio? E a explosão? O vídeo passa-nos a impressão de que tudo não passou de ficção: já nos habituamos a desgraças piores do que essa no cinema, por isso queremos ver o registro do instante fotográfico, ainda acreditamos mais nele do que nas imagens em movimento. Evidentemente as imagens vidiáticas e cinematográficas servem-nos como alimentadoras de nossas iconofotologias individuais, não por seu movimento, mas por sua particularização, pelo detalhe à moda da fotografia. Apesar de não ser possível tratarmos desse assunto nesta Tese - o que esperamos ocorra num momento oportuno -, devemos ainda utilizar-nos da imagem cinematográfica para 
abordarmos o que chamamos de extra-moldura, que Deleuze nomeia de extracampo:

A imagem movimento corresponde ao plano e possui duas faces: uma voltada para os objetos (é o enquadramento); outra voltada para o todo (é a montagem) resta agora o extracampo. Deleuze concederá a esse termo dois sentidos. Diante de um conjunto enquadrado e, portanto, visto, há sempre um conjunto maior ou um outro com o qual o primeiro forma um maior, o qual pode ser visto assim que se forme um novo extracampo, e assim sucessivamente. Segundo esse sentido, o extracampo concerne a uma virtualidade do visível. Já o segundo sentido guarda um aspecto absoluto, "através do qual o sistema fechado [o quadrado, i.e., aquilo que é visto sob a ação do enquadramento] se abre para uma duração imanente a todo universo (...). (Guimarães, 1997, p. 106)

Para Deleuze, no cinema, vê-se que a imagem pode voltar-se para o enquadramento e para a montagem, sendo que aquele está voltado para o objeto, particularizando-o, enquanto esta para o todo, algo como a generalização. No entanto, entre esse dois elementos haveria ainda o extracampo para o qual o filósofo estabelece duas relações: 1ํ) sempre haverá um conjunto maior que pode ser maior ainda ao se completar num outro sucessivo, formando, portanto, uma virtualidade daquilo que se vê; $2^{\circ}$ ) quando o enquadramento guarda um sentido absoluto e se abre para uma duração imanente ao todo do universos, que não é mais um conjunto e não pertence à ordem visível. (Deleuze, apud ibidem, p. 106)

Enquanto na pintura, calcada no perspectivismo, há um único ponto de fuga que direciona nosso olhar para o centro da tela, somos obrigados a abandonar (e esquecer) de ver (e imaginar) tudo o que está extra-moldura: esta acaba não nos interessando pela falta total de elementos significativos que nos levem a eles: inconscientemente, sabemos que aquilo é uma composição manual, emanada da mente do artista, cuja previsibilidade já estava preestabelecida dentro do contorno da moldura: sabemos que não há nada fora de seus limites, apesar de podermos avançar para além deles, mas isso nos enfastia: não, lá não há nada! Além dessa apatia frente ao óbvio, também há o fato de nossa visão estar presa em duas direções: 
a) seja na patética pose das obras renascentistas que, devido à imobilidade assumida pelas personagens, realmente parecem estar fazendo pose para serem retratadas pelo artista - e que será assumido pelo ato fotográfico de estúdio dos primeiros momentos;

b) seja no todo movimento das obras barrocas que, diferentemente, das renascentistas e devido à sugestão de movimento e ao excesso de detalhes, prendem-nos a ler seus detalhes, esquecendo-nos do extra-quadro.

O mesmo não pode ser dito da fotografia, seja ela pessoal - incluída nos álbuns de família -, seja documental (jornalística ou histórica), pois a mesma tem o poder, ao contrário da pintura, de nos levar para fora da moldura. $\mathrm{Na}$ medida em que estamos diante da contemplação de uma fotografia familiar, por exemplo, somos levados, via memória, a rememorar aquilo que ela não nos permite visualizar, como se fosse uma caixa de surpresas a nos brindar com o passado: ela retira-nos de sua letargia de res para que nos envolvamos naquela atmosfera eclipsada pela moldura.

Em se tratando da lembrança, o corpo conserva hábitos motores capazes de desempenhar de novo o passado; pode retomar atitudes em que o passado irá se inserir; ou ainda, pela repetição de certos fenômenos cerebrais que prolongaram antigas percepções, irá fornecer à lembrança um ponto de ligação com o atual, um meio de reconquistar na realidade presente uma influência perdida: mas em nenhum caso o cérebro armazenará lembranças ou imagens. Assim, nem na percepção, nem na memória, nem, com mais razão ainda, nas operações superiores do espírito, 0 corpo contribui diretamente para a representação. (Bergson, 1999, p. 264)

É pela foto que a representação vai se tornar nossa lembrança (Cf.: Dubois, 2006, p. 90), porque, a partir do momento em que vivenciamos algo, esse desaparece para sempre devido à trivialidade de certos detalhes da vida cotidiana, imperceptíveis, mas que captados receberam uma nova roupagem a posteriori. Poderíamos dizer, juntamente com Barthes, que a fotografia torna-se uma realidade inconteste: isso é (Barthes, 1984, p. 14), diante dela não dizemos Esse fui eu, mas Esse sou eu: à semelhança do espelho, sempre nos reconheceremos diante de nossas fotos como num constante presente, afinal 
diante do espelho não vemos as marcas que o tempo nos dá: somos sempre iguais. Apesar disso e, paradoxalmente, a própria fotografia nos mostra os estragos do tempo, é ela que nos possibilita comparar-nos com nós mesmos, além de compararmo-nos como mundo que nos rodeia: William Fox Talbot já assinalara, no final dos anos 30 do século XIX, a capacidade de a câmera fotográfica registrar os estragos do tempo, mas como acrescenta Susan Sontag:

Fox Talbot referia-se ao que ocorre em relação a edifícios e monumentos. Para nós, os desgastes mais interessantes não são os da pedra, mas os da carne. Através da fotografia acompanhamos do modo mais íntimo e perturbador a realidade do envelhecimento de uma pessoa. (Sontag, 1986, p. 70)

A despeito de seu estar sempre no presente, nós caminhamos com o tempo, não é possível pará-lo senão pararíamos com ele, por isso a fotografia, enquanto corte não só temporal, mas também espacial, indica, refere-se a, quer dirigir-nos também, mas para isso necessita do passado, não para exaltálo, mas para comprovar sua existência, por isso o noema da fotografia para Barthes é o isso foi, existiu, alguém estava lá:

isso foi (...) isso que vejo encontrou-se lá, nesse lugar que se estende entre o infinito e o sujeito (operator ou spectator); ele esteve lá, e todavia de súbito foi separado; ele esteve absolutamente, irrecusavelmente presente, e no entanto já diferido. (Barthes, 1984, pp. 115-116)

É o eu vi, mas como isso cada vez diz menos em nossa sociedade iconofílica (todos já vimos tudo!), há um troféu comprobatório: a fotografia, que de res passa a $\varepsilon \succsim \delta \omega \lambda o v$, fetiche da busca permanente pelo presente estampado ali, mas que já se foi; de um tempo que por não existir mais foi o melhor de sua vida. Isso se deve à sincronia do ato fotográfico, quando vemos o encapsulamento do presente, devido ao corte possibilitado pela $\tau \dot{\varepsilon} \chi v \eta$, quando 0 homem consegue superar-se ao imobilizar o tempo e dele fazer emprego posteriormente. Vê-se o despertar de uma nova realidade: pode-se imobilizar o 
tempo em um presente constante, sem, contudo, parar o tempo e estancar a vida.

A fotografia, portanto, possui sua realidade regida pelo Cronos, pois sendo um corte temporal, imobiliza o presente, tornando-o um presente contínuo, ou nas palavras de Deleuze:

De acordo com Cronos, só o presente existe no tempo. Passado, presente e futuro não são três dimensões do tempo; só o presente preenche o tempo, o passado e o futuro são duas dimensões relativas ao presente no tempo. É o mesmo que dizer que o que é futuro ou passado com relação a um certo presente (...) faz parte de um presente mais vasto, de maior extensão ou duração. Há sempre um mais vasto presente que absorve o passado e o futuro. (Deleuze, 2003, p. 167)

A partir dessa realidade, dois aspectos podem ser levantados:

a) a imagem fotográfica como mera técnica, sem valor artístico, já que a relação fotógrafo $x$ fotografia restringir-se-ia a um mero disparar do obturador que captaria a emissão de luz proveniente do objeto que se quer retratar. Residiria aí uma simples automatização da representação, considerada somente sob um viés tecnicista frio e

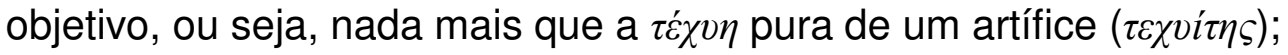

b) a partir da obtenção da fotografia via $\tau \dot{\chi} \chi v \eta$, essa se tornaria muito mais mimética que a própria pintura, afinal consegue captar, a partir da luz emanada do objeto retratado, a própria imagem decalcada via $\mu і \mu \eta \sigma \iota \varsigma$.

A partir desse último ponto e a despeito da $\tau \dot{\chi} \chi v \eta$, na acepção hodierna já haveria subjetividade em uma fotografia, visto que entre vários ângulos/pontos de vista que poderiam ser explorados pelo eu fotográfico e entre várias possibilidades de tomada, somente uma foi empregada. Algo semelhante ocorre em relação ao ato poético, pois o poeta tem a sua disposição inúmeras palavras, no entanto escolhe a que melhor se encaixa a suas pretensões. Dessa forma, ambas produzem imagens, só que a $\tau \dot{\chi} \chi v \eta$ empregada é que diferenciará o resultado final, pois 
toda imagem aproxima e conjuga realidades opostas, indiferentes ou distanciadas entre si. Isto é, submete à unidade a pluralidade do real. (Paz, 2005, p. 38)

Por isso, o insignificante no mundo real passa a ter um significado especial diante da lente que o registrará, que o fará desabrochar para o mundo da arte, quando por meio de um inconsciente óptico se descobrem as minúcias (Cf. Benjamin, 1991, p. 222) que cairiam no esquecimento, apesar de sequer terem vindo à luz do conhecimento humano; eis a magia da fotografia e eis a magia da poesia: tornar o pequeno, grande; o desconhecido, conhecido; a pluma, pedra. Isso fica claro quando um fotógrafo como Alfred Stieglitz (18641946) faz um estudo fotográfico - em quase uma década (1923-1932) -, cujo motivo era, unicamente, retratar nuvens: eis a pluralidade tornando-se unidade. A trivialidade das nuvens - motivo para brincadeiras infantis, ou demonstração do estado de espírito de muitos poetas -, também pode transformar-se em mote para um aparato tecnicista, frio e objetivo, mas que, nas mãos de um Fotógrafo, torna-se arte. Este, à semelhança do $\tau \varepsilon \chi v i ́ t \eta \varsigma$ grego que trazia à luz uma matéria informe como o mármore e cuja arte era contemplada, demonstrava que o belo poderia tentar chegar ao Belo, mas seu artífice permanecia na onscuridade(assim como, em muitos casos, o fotógrafo também o é, afinal sua obra pode passar para a história, porém ele, o criador, muitas vezes sequer é conhecido). Tal colocação não é de se estranhar, visto que Jakobson nos diz que

É evidente que muitos dos procedimentos estudados pela Poética não se confinam à arte verbal. (...) numerosos traços poéticos pertencem não apenas à ciência da linguagem, mas a toda a teoria dos signos, vale dizer, à Semiótica geral. Esta afirmativa, contudo, é válida para a arte verbal como para todas as variedades de linguagem, de vez que a linguagem compartilha muitas propriedades com alguns outros sistemas de signos ou mesmo com todos eles (traços pansemióticos). (Jakobson, 2005, p. 119)

Dessa maneira, Jakobson corrobora que a relação entre o $\lambda o ́ \gamma o \varsigma$ e 0 mundo não se restringe apenas ao verbal, mas a todas as espécies de 
discursos (Cf.: Ibidem, p. 119). Ora se tivermos em mente que o גóyos é a força

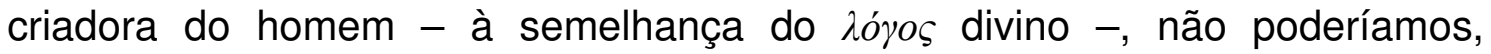
evidentemente, restringir-nos apenas ao discurso verbal, mas a todo discurso que possa nos transmitir uma informação, uma idéia, um objetivo, ou mesmo prazer estético, inclusive um discurso fotográfico, já que este também está construído

no pólo do enunciador (pessoas, empresas, instituições), com o objetivo de persuadir, de convencer, de tornar único um ponto de vista, de transformar em verdade uma única interpretação histórica, sempre atendendo a objetivos que quase nunca contemplam a maioria. (Baccega, 2005, p. 2)

Afinal, toda fotografia, à semelhança do discurso verbal, também é intencional por mais que se apresente trivial, além disso, extrapola a representação de uma mera imagem única (apesar do pleonasmo) para se tornar a concretização de várias outras imagens formadas a partir de nossa própria imaginação. Isso é possível quando, a partir de um momento retratado pelo instante fotográfico, viajamos para além do enquadramento, para um tempo/espaço alijado do simples papel fotográfico, mas que está presente em nossa memória, ou mesmo na memória do coletivo que foge ao controle consciente, já que é um fragmento, cujo peso moral e emocional depende do contexto em que está inserido, em que é visualizado. (Cf.: Sontag, 1986, p. 99) Uma foto equivaleria a um ponto disperso entre outros pontos que estariam à nossa disposição no mundo material, mas que seria captado por nossa consciência, por meio de uma escolha, ou como dizia Bergson, pelo discernimento. (Cf.: Bergson, 1999, p. 36) Mesmo que não seja captado, tornase destaque quando, em meio a tantas outras fotografias, escolhemos uma que nos chama a atenção; além disso, e de novo à semelhança do discurso verbal, possui sempre uma intenção, já que também é parte de um discurso.

Partindo desse pressuposto discursivo e valendo-se do fato de que o discurso fundamenta-se na intenção de um emissor que pretende chegar a um receptor a respeito de um referente, podemos valer-nos das três práticas empregadas por Barthes para trabalharmos o discurso fotográfico: 
uma foto pode ser objeto de três práticas (ou de três emoções, ou de três intenções): fazer, suportar, olhar. O Operator é o Fotógrafo. O Spectator somos todos nós, que compulsamos, nos jornais, nos livros, nos álbuns, nos arquivos, coleções de fotos. E aquele ou aquela que é fotografada, é o alvo, o referente, espécie de pequeno simulacro, de eídolon emitido pelo objeto, que de bom grado chamaria de Spectrum da fotografia, porque essa palavra mantém, através de sua raiz, uma relação com o "espetáculo" e a ele acrescenta essa coisa um pouco terrível que há em toda fotografia: o retorno do morto. (Barthes, 1984, p. 20)

Não se pode, portanto, enxergar a (e na) fotografia um mero decalque de um referente qualquer, deve-se abandonar seu estereótipo de simples cópia técnica não intencional, afinal por meio de um operator a fotografia terá uma intenção: seja o álbum das crianças, uma lembrança da formatura, a recordação da festa de casamento ou uma simples viagem de passeio; em todas há um traço comum: ninguém realmente demonstra ser o que é diante da objetiva, todos fazem pose, buscam ser diferentes, mais bonitos ou mais caricaturais como nas fotos de encontro de amigos, de forma mais relevante após o advento da fotografia digital, quando os instantes fazem-se presentes via caricatura: todos querem mostrar que têm línguas compridas, narizes enormes, ou sabem mostrar o dedo do meio, afinal nessas fotos tudo é possível, principalmente devido à facilidade que as câmeras digitais e os celulares proporcionaram à humanidade, fato impensável há alguns anos, quando havia todo um ritual para ser fotografado ou para fotografar.

A pose ou as poses também nos lembram a arte, a arte pictórica, a arte escultórica: efetivamente, a fotografia também faz parte do mundo da $\pi \circ i ́ \eta \sigma \iota \varsigma$, pois ninguém está livre da intencionalidade fotográfica de seu operator, que não precisa mais gritar xis: todos nós já sabemos a pose que temos de tomar. $E$, quando formos nós mesmos tomar o resultado fotográfico em nossas mãos, quando formos seu spectator procuraremos ver como nos portamos, como o outro se portou e como o operator captou-nos naquele instante. Então ou o elogiaremos - se a foto nos agradar, ele terá sido um grande profissional - ou faremos o contrário - se não agrada, ele não sabe o que faz -, apesar de ser aquele spectrum ali captado nossa própria luz emanada. Vemo-nos ali, quer gostemos ou não, quer lancemos mão do impropério da nossa não aceitação: 
também nós cremos no decalque mimético da fotografia, apesar de, no fundo, não o aceitarmos. Barthes nos diz isso quando afirma que há na fotografia um campo cerrado de forças:

Quatro imaginários aí se cruzam, aí se afrontam, aí se deformam. Diante da objetiva, sou ao mesmo tempo: aquele que eu gostaria que me julgassem, aquele que o fotógrafo me julga e aquele de que ele se serve para exibir sua arte. (Barthes, 1984, p. 27)

Como não aceitar, portanto, a intencionalidade do ato fotográfico se ele é claramente intencional desde o início da fotografia? As primeiras décadas após seu surgimento foram extremamente profícuas, gerando verdadeiras obras de arte. É singular o fato de que grande parte dos primeiros fotógrafos era pintor e lançou mão de seu conhecimento pictórico na arte incipiente. Essa, no entanto, diante de sua particularidade abriu-se, rapidamente, para outros campos por meio de processos empíricos de experimentação. Poderíamos, inclusive, valer-nos do próprio conceito platônico de empiria como mera privação de racionalidade ( $\alpha \lambda o \gamma o \varsigma)$ - evidentemente, não no sentido negativo que o filósofo the havia imputado -, mas para demonstrarmos que mesmo no campo árido da $\tau \dot{\varepsilon} \chi v \eta$ haveria (e há) espaço para o subjetivo, para a explanação do eu, mas aí nos vem a pergunta que sempre se faz desde que a fotografia surgiu e que chegou até ao futuro em que estamos inseridos: a fotografia é ou não uma arte mimética? Até que ponto pode-se considerar a fotografia uma arte da fidelidade em relação a seu spectrum?

Essa concepção advém, exatamente, da mecanicidade do ato fotográfico que, ao empregar a $\tau \dot{\chi} \chi v \eta$, criou o conceito de automatismo da gênese técnica, usando o conceito empregado por Dubois. (Cf.: Dubois, 2006, p. 25) Além disso, a fotografia satisfaz em nós a vontade de ver para crer, é uma espécie de prova, um atestado, uma comprovação. Euclides da Cunha mostra-nos isso, quando retrata a exumação de Antônio Conselheiro, cujo cadáver fora desenterrado, cuidadosamente, afinal era uma 
Dádiva preciosa - prêmio único, únicos despojos opimos de tal guerra! faziam-se mister os máximos resguardos para que se não desarticulasse ou deformasse, reduzindo-se a uma massa angulhenta de tecidos decompostos.

Fotografaram-no depois. E lavrou-se uma ata rigorosa firmando sua identidade: importava que o país se convencesse bem de que estava afinal extinto, aquele terribilíssimo antagonista. (Cunha, 1998, p. 498)

Com essas palavras, Euclides da Cunha encerra sua obra acerca de uma guerra impiedosa e vergonhosa, mas que teve participação ativa da fotografia, seja para retratar os infames monstros impiedosos de Canudos feitos prisioneiros, seja para comprovar a derrocada de seu líder - ainda que o mesmo tenha morrido antes do final do conflito e tivesse de ter sido exumado para que, a partir de uma fotografia, todo o Brasil pudesse testemunhá-lo: afinal, a fotografia não pode mentir!

Em sua obra $O$ ato fotográfico, Phillippe Dubois desconstrói o mito que afirma ser a fotografia uma cópia fidedigna da realidade, a partir dos aspectos que serviram de pressupostos epistemológicos para que ela pudesse ter se tornado um paradigma do real. Para isso, o autor enumera o percurso da mimeticidade atribuída ao ato fotográfico: a) como espelho do real; b) como transformação do real; c) como um traço do real.

A especularidade do ato fotográfico tem como embasamento seu automatismo técnico, quando, a partir da $\tau \dot{\chi} \chi v \eta$, a imagem impregna-se na chapa ou no papel, prescindindo-se do artista. Vê-se o momento de magia, quando o homem aprisiona uma imagem (ou a sua mesma) num espelho: a fabulação torna-se realidade, a imaginação (cantada pela literatura no correr da humanidade) converte-se em fato. Diante do prodigioso ato do aprisionamento imagético há o despertar do medo e da atração: uns sentiam sua alma sendo roubada - à semelhança do que ocorria com alguns povos tribais -; outros procuravam conhecer-se a si mesmos, vendo o que só eles poderiam vislumbrar: suas particularidades, sua beleza ou feiúra, afinal não havia a participação de mãos humanas em sua elaboração, aquela era a realidade da qual não se poderia fugir! Eis que estamos novamente no Éden e buscamos nos divinizar, queremos conhecer o que está somente ao alcance da própria 
divindade: conhecer 0 oculto, conhecer a verdade. Baudelaire chama Daguerre, por exemplo, de Messias de um deus vingador que castiga os homens, exatamente, por querer se tornar à sua semelhança, saciando-os com a trivialidade de imagens exatas, prontamente exaltadas pela multidão que diz para si:

"Como a fotografia nos proporciona todas as garantias desejáveis de exatidão (eles acreditam nisso, os insensatos!), a arte é a fotografia." A partir desse momento, a sociedade precipitou-se, como um único Narciso, para contemplar sua imagem no metal. Uma loucura, um fanatismo extraordinário apoderou-se de todos esses novos adoradores do sol. (Baudelaire, apud Dubois, 2006, p. 28)

Apesar da crítica que tecia a respeito da fotografia, Baudelaire já tinha a consciência de a fotografia não ser expressão pura da mímesis, pois somente os insensatos viam isso no ato fotográfico. 


\section{LEITURAS ICONOFOTOLÓGICAS DA POÉTICA BARROCA ALEMÃ}

C omo já havíamos assinalado, anteriormente, a guerra foi um dos motes mais antigos empregados pela poética como atestam a Ilíada e a Odisséia ${ }^{223}$ de Homero; a Eneida de Virgílio; a Canção de Rolando; ou Orlando furioso de Ariosto; só para citar os épicos. Isso implica dizer que todos esses poemas, bem como aqueles que neles se basearam, possuem uma visão aristocratizante da guerra não aquela que consideraríamos real, já que desconheciam aquilo que entendemos, hoje, por realidade histórica. Isso equivaleria a dizer que tal representação não era natural (no sentido de habitual, segundo aquilo que entendemos hoje por habitual, e mesmo por aquilo que eles entendiam acerca desse conceito, pois no front real não havia heróis invencíveis, mas homens de carne e osso que pereciam em meio a combates cruéis e inumanos como as guerras têm de ser. No entanto, tais atos de torpeza, de carnificina nunca poderiam ser retratadas via literatura, mas abrandadas o que, para nós, significaria uma representação artificial, não verossimilhante. Auerbach dá-nos um exemplo, retirado do teatro clássico francês, do que se considerava natural e habitual no século XVII: a expressão pura da classe parasita que orbitava em torno ao rei, quando diz

Natural era sinônimo de razoável e decente. Neste sentido, sentia-se (...) que se estava em harmonia com os tempos áureos da cultura antiga (...). Com base nesta concepção, segundo a qual o natural se apresenta como produto da cultura e da criação, continuou-se a construir, e mais tarde foi tido por natural aquilo que (...) comove o coração dos homens: seus sentimentos e as suas paixões. O natural era ao mesmo tempo também o naturalmente humano; e acreditava-se que o eternamente humano aparecesse de forma mais clara e sem mistura nas alturas isoladas da vida

\footnotetext{
${ }^{223}$ Mesmo esta não retratando uma guerra em si, envolve seu protagonista em várias pequenas guerras para poder regressar a sua Ítaca, quando tem de lutar contra os pretendentes de seu trono e de sua mulher.
} 
do que a baixa e confusa balbúrdia histórica. Através disso, porém foi fixada (...) uma limitação do eternamente humano; só as "grandes" paixões podiam ser tomadas como objeto (...). (Auerbach, 2004, p. 348)

Lêem-se, evidentemente, grandes paixões, aquelas de uma determinada classe social, a dominante, a aristocrática, que não enxergava nos movimentos sociais $^{224}$ nada além de agitações vis, orgiásticas e ilegais (ibidem, p. 33) que visavam tão somente - segundo acreditavam - a romper a ordem natural das coisas, à destruição do status quo e dos valores tidos como verdadeiros e inabaláveis. O que os clássicos queriam exprimir - quando exprimiam - não eram forças ou paixões arrebatadoras e revolucionárias nos moldes do Romantismo, mas, sobretudo, vícios e erros, e mesmo assim, esses problemas nunca eram colocados sob um ponto de vista espiritual nem histórico-evolutivo, mas moralista (ibidem, p. 32); além disso, esses textos nunca se dirigiam a multidões, mas ao deleite de uma elite social e literária que observa as coisas de cima, impassível e fruidora. (ibidem, p. 40)

Assim, se juntarmos o fato de o povo não ter tido acesso à escolaridade - era uma massa de iletrados -, à dominação de uma elite ciosa de sua posição e cultura, pouco se saberá sobre o sofrimento que as guerras causaram a grande maioria da população, pelo menos sob o ponto de vista da literatura dita oficial, ou seja, aquela que chegou até nós ${ }^{225}$, afinal as guerras serviram de mote poético ao longo dos séculos: para a exaltação bélica de um povo e de suas conquistas - como nos poemas da Antigüidade -, não para

\footnotetext{
${ }^{224}$ Não na acepção politicista hodierna que a expressão pode, por exemplo, suscitar, mas como movimentos mais ou menos organizados, em que determinados grupos sociais reivindicaram em momentos singulares como o espartacismo, no Império Romano; ou a Revolta dos Camponeses, no século XVI de nossa Era. Que tais movimentos teriam em comum? A forma como a Aristocracia dominante debelou-os, massacrando os insurrectos, afinal era inaceitável para essas classes movimentos revolucionários. Essa estamentização social, como não poderia deixar de ser, influenciou a literatura, quando se verifica a escolha dos estilos, quando o próprio escritor vê de cima o mundo que retrata e seu livro é um produto da mais elevada cultura, e espera de seus leitores uma formação social e literária à altura de compreender imediata e naturalmente todas as nuanças das infrações sociais, da vulgaridade do falar e do gosto. Por mais vulgar e grotesco que seja o assunto, a representação nada tem da grosseira comicidade das farsas populares. (Auerbach, 2004, p. 40)

${ }_{225}$ Pode-se refutar tal afirmação, quando se pensa que a tradição popular permaneceu viva por muito tempo via oralidade, no entanto essa literatura popular, acreditamos, mesclou-se com a literatura oficial, sendo, portanto, por essa corrompida por jogos de interesses e propagandas da mesma classe social que mantinha o poder. A esse respeito, por exemplo, já havíamos assinalado Maravall, quando aborda o tema. (Cf.: Maravall, 1997, p. 389ss)
} 
expressar dor e pesar por vidas, vilas e cidades destruídas. Assim, como a história é sempre contada pelos vencedores, a poética também usava dessas preceptivas ufanistas, mesmo antes de a efetivação do Estado.

Desse modo, se um eu lírico, se propusesse, hipoteticamente, a ser um filtro social de que determinada sociedade necessitasse para esboçar, por meio de palavras, sua indignação, revolta e lamento, ou ainda suas impressões de momentos de penúria e de desesperação, deveria haver uma mudança total em sua postura de artista, bem como da sociedade que consumia sua arte: essa sociedade, à vista do que foi demonstrado acima, não poderia estar inserida naquilo que se convencionou chamar clássica - com todas suas vertentes, inclusive a barroca.

Os gritos de indignação, tais quais os conhecemos hoje por meio de uma literatura combativa e com uma visão socializante da sociedade, são frutos da própria sociedade burguesa, cujo início remonta ao Romantismo - a Victor Hugo -, ao pós Romantismo - como na obra de Zola -, bem como a nossa própria sociedade com suas preocupações sociais. Já no ancien régime os valores eram outros: a guerra, por exemplo, era uma atribuição da nobreza, cujos filhos, tinham de freqüentar academias militares, onde se ensinavam jovens aristocratas estouvados exercícios de praça de armas, esgrima e equitação avançada (Keegan, 2006, p. 437). Eram eles que iam para a frente de batalha levar suas tropas à vitória ou à derrota, no entanto, já em meados do século XVII com a ascensão de um novo modelo sócio-econômico-cultural, muitos nobres esquivavam-se de suas obrigações militares, pagavam para outros irem em seu lugar: o mundo já não era o mesmo.

Para iniciarmos nossa análise literária, utilizaremos um excerto de um poema de Bertolt Brecht cujo tema gira em torno da Primeira Guerra Mundial (a Grande Guerra, como era chamada então), a fim de que possamos comparar a utilização imagética que o poeta e dramaturgo alemão do século $X X$ pertencente ao Modernismo - utilizou para que possamos confrontar com um outro do século XVII. 


\section{Bertolt Brecht}

\section{Der belgische Acker}

An den Grenzen Mord, Schlachten und Dörfer in Brand.

Aber nachts flackert der Feuerschein

Rot und lodernd ins belgische Land hinein

Spiegelt in blanken Äckern sich, im endlos blühenden Land.

Geschützdonner brüllt

Dumpf überrollt vom Sturmglockenklang

Tage und Nächte den wirkenden Frühling lang

Über Altflanders sprossendes Friedhofgefild.

[O campo belga

À fronteira assassinatos, batalhas e aldeias em chamas./ Mas, à noite, o clarão vermelho cintila Flamejante no interior da terra belga. /Espelha-se em campos nus, na florescente terra sem fim. / Trovão de artilharia grita/ Abafado passa a repicar de assalto/ Dias e noites agindo ao longo da primavera/ Sobre a paisagem tumular brotejante da velha Flandres.]

Als der Frühling aus dem Meere quillt

Schreiten über die Äcker und Straßen in wimmelden Zügen

Deutsche Soldaten über die Höfe und Wiesen und Flächen

Mit flatternden Eggen und wühlenden Pflügen

Malmen und brechen

Die springenden Schollen

Werfen aus vollen

Fäusten, die heiß vom Gewehrlauf noch und geschwollen

Klingendes Fruchtkorn über die bräutliche Erde.

Tag und Nacht grub der Pflug Acker und Ackerrain.

Straße und Garten und Anger, Verhaue und Brüche von Stein...

Verschonte keine Grenzmark, keinen Feldergang

$$
\text { (...) (Brecht, 1990, pp. 9-11) }
$$

[Quando brotou do mar da primavera/ Caminham nos campos e ruas em fervilhante marcha/ Os soldados alemães em fazendas e pastos e campos/ Com arados tremulantes e arados revoltos/ Trituram e quebram/ Os torrões erguidos/ Lançam fora dos punhos/ Repletos, os quais ainda intumescidos e quentes devido aos canos dos/ Fuzis, sementes tinindo sobre a terra pretendida./ Dia e noite cava o arado o campo e seus limites/ Rua e jardim e prado, cercas e cacos de pedra... / Nenhuma marca de limite respeitada, nenhuma trilha (...).] 
Quando efetuamos uma leitura superficial no texto de Brecht, algo salta a nossos olhos: o eu lírico fala de desgraça ou de esperança? O mesmo acontece quando nos mostra a imagem dos soldados marchando com arados... mas a função dos soldados é fazer guerra, ou seja, matar e morrer: é a nefasta lógica que rompe o nexo racional da humanidade, ou seja, o homem tem de matar para impor-se e dizer que é superior aos demais que, subjugados, curvam a cabeça frente a seus opressores.

Vê-se que a arte moderna pôde-se dar ao luxo de tratar a guerra dessa forma, então, por que não os soldados arando a terra? Por que não os soldados levando flores nos canos de seus fuzis em lugar dos projetis mortais, afinal não eram eles, os soldados, alimentados por aqueles a quem defendiam?

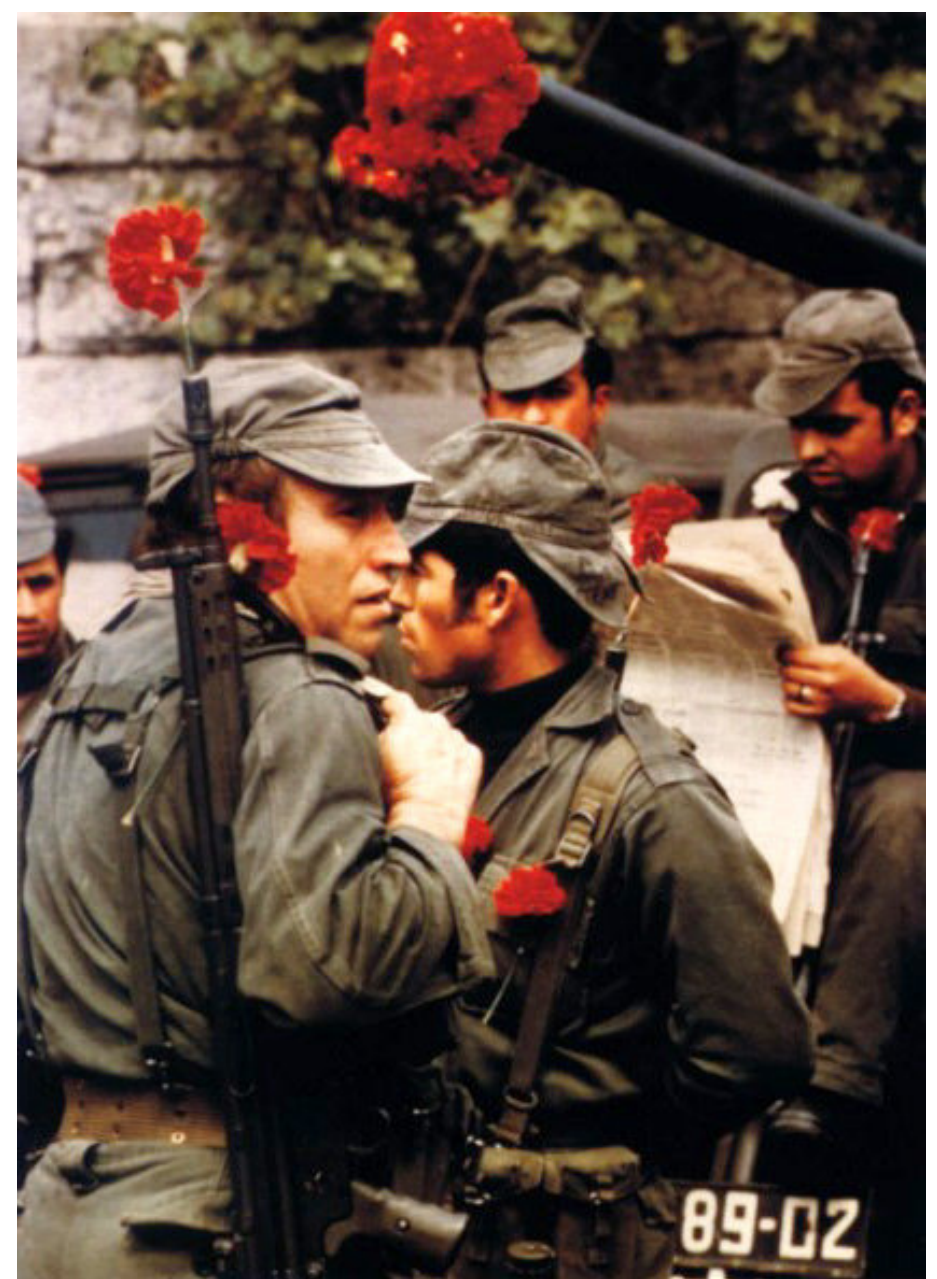

Foto 8: Revolução dos Cravos, 25 de abril de 1974, Portugal, s/autor.
Todas as civilizações devem suas origens ao guerreiro; suas culturas nutrem os guerreiros que as defendem, e as diferenças entre elas farão os guerreiros de uma muito diferentes externamente dos da outra. (Keegan, 2006, p. 17)

Assim como foi possível à arte moderna modificar a imagem que a sociedade possuía do soldado, tal procedimento poderia ser extendido também, não só ao guerreiro, mas também à guerra $e$ à relação estabelecida entre ambos. Dessa forma, o Modernismo 
traduziu aquilo que não teria sido possível em outros momentos artísticos como no Classicismo, quando um mote como a guerra limitava-se a tipificar o herói.

A luta pelo poder era a expressão de uma classe social - a nobreza que detinha seu monopólio - bem como o monopólio artístico - por isso se voltava a si mesma crendo-se como expressão máxima da sociedade, mesmo que sua importância política - dentro dos incipientes Estados nacionais absolutistas - tornava-se cada vez menor - apesar de ainda manter certo prestígio que possuía. (Cf. Auerbach, 2004, p. 350)

Com a libertação da arte mimética, tornou-se possível quase tudo em termo de arte, inclusive inverter a lógica estrutural da guerra bem como da parcela social por ela retratada, quando o soldado não só mata, mas pode levar a vida. Essa foi uma transformação da mentalidade do homem, decorrente da mudança de pressupostos e paradigmas sócio-culturais e econômicos que tornariam realidade, no século $X X$, o fato de populares colocarem flores nos canos dos fuzis dos soldados como se viu na Revolução dos Cravos, em 1975, em Portugal (foto 8).

Vemos que o poema de Brecht ao nos passar essas imagens, leva-nos, inclusive, a crer em sua verossimilhança, ou na possibilidade de que o impossível é possível de acontecer. Sentimos nelas a criação artística do poeta, sabemos que o mesmo faz arte e sentimos prazer com as imagens que ele evoca. Podemos, inclusive, até nos deixar levar por esses mesmos pensamentos que, queremos acreditar, sejam únicos, inclusive vivenciados mesmo que na mente criadora do poeta -, portanto, dignos de crédito. Sabemos o que são soldados, e que esses, ao marcharem pelos campos vão destruindo aquilo que Ihes parece sinal do inimigo, apesar de suas mãos poderem se abrir para esse mesmo campo e dele fazer com que a semente dê frutos. Dessa forma, o poeta faz com que acreditemos em suas palavras, transmite-nos esperança em tempos de destruição e morte como na Grande Guerra que assombrou o mundo no começo do século $X X$ e frustrou as esperanças da burguesia da belle époche, apesar de vermos An den Grenzen Mord, Schlachten und Dörfer in Brand. O poeta dá-nos alento e esperança quando se vê que Tag und Nacht grub der Pflug Acker und Ackerrain: eis o 
grande antagonismo da poesia moderna criar verossimilhança onde só haveria inverossimilhança:

A idéia cardeal do movimento revolucionário da era moderna é a criação de uma sociedade universal que, ao abolir as opressões desenvolva simultaneamente a identidade ou semelhança original de todos os homens e a radical diferença ou singularidade de cada um. O pensamento poético não tem sido alheio à vicissitudes e aos conflitos dessa empresa literalmente sobre-humana. (Paz, 2005, pp. 95-96)

Podem-se ler no poema de Brecht características de cunho social, ou tendências marxistas que nos explicitariam as imagens construídas por ele, quando se busca dar adeus ao mundo velho e à esperança de transformá-lo em poesia. (ibidem, p. 98) Evidentemente, essa não era uma característica de todos os poetas do período, ou seja, cada um possuía a sua própria, levandonos a ler seus poemas também sob um ponto de vista individual e, muitas vezes, único.

\section{Andreas Gryphius}

\section{Threnen des Vatterlandes/ Anno 1636}

Wir sindt doch nuhmer ganz/ ja mehr den ganz verheret! Der frechen völcker Schaar/ die rasende Posaun Das vom blutt fette Schwerdt/ die donnernde Carthaun Hatt aller Schweis/ und fleis/ und vorraht auff gezehret.

Die Türme stehn in glutt/ die Kirch ist umbgekehret. Das Rahthaus ligt im graus/ die starcken sind zerhawn. Die Jungfrawn sindt geschändt/ und wo wir hin nur schawn Ist fewer/ pest/ und todt der herz undt geist durchfehret.

Hier durch die Schanz und Stadt/ rint alzeit frisches blutt. Dreymal sindt schon sechs jahr als unser ströme flutt Von so viel leichen schwer/ sich langsam fortgedrungen.

Doch schweige ich noch von dem was ärger als der Tod. Was grimmer den die pest/ undt glutt undt hungers noth Das nun der Selen schatz so vielen abgezwungen. 
Inteiros ainda estamos, no entanto roídos!/ Da gente insolente a trombeta arrebatada,/ O canhão estridente, a espada ensangüentada;/ O esforço e o estoque e o suor foram destruídos! As torres flamejam; os templos revolvidos;/ A prefeitura, pó; as forças lancinadas;/ E para onde olharmos há virgens violentadas,/ Fogo, peste, morte, coração e alma partidos.

Sempre aqui escorre sangue entre o fosso e a cidade./ Três vezes seis anos: nossos rios com esforço,/ Obstruídos de corpos lentos escorriam...

Porém silencio: foi, pois, pior que a morte,/ Que a ferocidade do fogo, fome e peste/ E até o tesouro espiritual extorquiram. ${ }^{226}$ ]

Se, ativermo-nos agora ao soneto de Gryphius, veremos que sua construção imagética, apesar de uma temática, superficialmente, afim revela uma outra realidade de construção que não se restringe apenas à estrutura fixa empregada pelo autor do século XVII, nem nos versos livres de Brecht, mas no emprego imagético utilizado por ambos - como o fato de um ser diacrônico enquanto o outro mais sincrônico.

É, exatamente essa relação imagética - estabelecida entre diacronia e sincronia - que faz com que esse soneto de Gryphius sirva-nos para demonstrar aquilo que chamamos de poema fotográfico. É possível verificar que suas imagens possuem - a partir da sincronia -, uma aparente utilização denotativa do signo lingüístico e, devido a sua justaposição, dão-nos hoje a impressão de visualisarmos a realidade imposta às pessoas que viviam na Silésia em plena Guerra dos Trinta Anos, quando a região não passava de um palco de lutas, aquartelamentos, pilhagens, devastações, maus-tratos, crueldades e mortes. (Cf. Mauser, 1976, p. 110) Essa pseudo aparência denotativa deve-se ao fato de essas imagens parecerem-se facilmente decodificáveis, à semelhança do texto prosaico, ou seja, são diretas, claras, objetivas e pertencentes a nosso momento: não têm aparência metafórica nem alegórica.

Como em uma fotografia, em que temos a certeza de o fotógrafo ter estado na cena retratada e, devido a sua escolha de uma, particularizando-a, em relação a outras, demonstra não só uma tomada de posição, uma opção por determinado ângulo ou enquadramento, mas também uma intencionalidade, um objetivo - como chocar, sensibilizar, comprovar -; também somos levados a acreditar que o eu lírico tenha presenciado as cenas

\footnotetext{
${ }^{226}$ Transcriação poética de Brandão, 2003, p. 130, no entanto para que efetuemos a análise do textos, valer-nos-emos da tradução quase literal, simplesmente para efeito didático.
} 
construídas, que as tenha descrito para demonstrar-nos não só que esteve presente lá, que as tenha visto, mas que tenha tomado uma posição, talvez intencional, em sua escolha imagética - mesmo que não as tenha visto ${ }^{227}$ nem delas ter participado. Para nós, sequer importa que seu texto seja, tão somente um poema elegíaco (como é, seguindo os moldes clássicos a que estava submetido). Entretanto, não é essa a impressão que temos dele, mas a de estarmos diante de uma realidade concreta, fotográfica:

Na fotografia, a presença da coisa (em um certo momento passado) jamais é metafórica; quanto aos seres animados, o mesmo ocorre com sua vida, salvo quando se fotografam cadáveres; e ainda: se a fotografia se torna então horrível, é poque ela certifica (...) que o cadáver está vivo, enquanto cadáver: é a imagem viva de uma coisa morta. (...) Assim, vale dizer que o traço inimitável da Fotografia (seu noema) é que alguém viu o referente (mesmo que se trate de objetos) em carne e osso, ou ainda em pessoa. (Barthes, 1984, p. 118)

Esta é a grande diferença entre a imagem textual e a fotográfica: nesta o objeto se entrega em bloco e a vista está certa disso (ibidem, p. 157), naquela outras percepções me dão o objeto de uma maneira vaga, discutível (ibidem, p. 157), incitam-me a desconfiar daquilo que acredito ver. Isso, porém, não se aplica ao poema, não se aplica ao poeta, já que esse tem plena consciência de que

A imagem explica-se a si mesma. Nada, exceto ela, pode dizer o que quer dizer. Sentido e imagem são a mesma coisa. Um poema não tem mais sentido que as suas imagens. Ao ver a cadeira, apreendemos instantaneamente seu sentido: sem necessidade de recorrer à palavra, sentamo-nos. O mesmo ocorre com o poema: suas imagens não nos levam a outra coisa, como ocorre com a prosa, mas nos colocam diante de uma realidade concreta. (Paz, 2005, p. 47)

\footnotetext{
${ }^{227}$ Apesar de, no caso de Gryphius, ter vivenciado os horrores da Guerra dos Trinta Anos in loco.
} 
Dá-nos a impressão, em Tränen des Vaterlandes ${ }^{228}$, que o eu lírico faznos viajar à pós-batalha como que munido de uma câmera fotográfica:

a) quer registrar tudo aquilo que passa diante de seus olhos;

b) não faz uso de metáforas para minimizar o que vê, afinal não quer velar nada, pelo contrário, quer revelar: cria tal impacto para atrair a atenção;

c) faz propaganda (do latim propagare = disseminação de idéias), assume, inclusive, uma atitude política (Mauser, 1976, p. 9), denunciando a verdade.

Indubitavelmente, podemos ser levados a pensar dessa maneira, pois nossa noção de arte é diversa daquela do período em que o poeta se encontrava, afinal o mesmo:

a) não só faz uso de metáforas como trabalha em grande parte do texto com figuras alegóricas;

b) realmente quer criar impacto, não para expressar seu sentimento e indignação, mas para transmitir $\pi \dot{\alpha} \theta o \varsigma$ (patos);

c) denunciando a verdade... mas, que verdade? A nossa ou a dele? Seria possível se falar em uma verdade ou em pontos de vista, imputados pela cultura.

Como fizemos até este momento, temos de reafirmar que esses aspectos devem ser levados em conta quando procuramos analisar as imagens de um poema do século XVII, mesmo sem nos ater, preliminarmente, a sua expressão formal e rítmica, apenas à semântica, pois advém dessa particularidade o fato de o poema ser ou não considerado fotográfico, algo que seria plausível há muito tempo, pois corresponderia ao período que a fotografia domina nossa construção imagética. Além disso, a própria poesia depois de

\footnotetext{
${ }^{228}$ Atualizando para a ortografia contemporânea que será utilizada no decorrer da tese no lugar de Threnen des vatterlandes, conforme o emprego de Gryphius.
} 
ter sido definida, durante muito tempo, como a arte do verso, (...) acabou por ser reconhecida, também, como arte da imagem (...). O poema constitui uma imagem (com ou sem "imagens"). (Grupo $\mu, 1980$, p. 80)

Para muitas pessoas, ainda hoje há certa confusão nos conceitos de poesia e verso, além de esquecerem que o ato de fazer poemas abrange dois níveis da linguagem: o fônico e o semântico, sendo que o semântico é privilegiado. (Cf.: Cohen, 1978, p. 46) O mesmo se pode dizer da prosa e da poesia; aquela busca a coerência e a claridade conceitual, enquanto esta tende a manifestar-se por meio de imagens não de conceitos. (Cf. Paz, 2005, p. 12) Além disso,

o poema se apresenta como uma ordem fechada, a prosa tende a manifestarse como uma construção aberta e linear. (...) a figura geométrica que simboliza a prosa é a linha (...) sempre para diante e com uma meta precisa. (...) O poema, pelo contrário, apresenta-se como um círculo ou uma esfera: algo que se fecha sobre si mesmo, universo auto-suficiente e no qual o fim é também um princípio que volta, se repete e se recria. (Ibidem, pp. 12-13)

Afinal, também não é essa a mesma idéia da fotografia? Imagem fechada e recorrente em si mesma que nos leva a várias leituras e releituras, mas que sempre acaba voltando para um mesmo ponto? Há, na fotografia, uma limitação de espaço e de tempo; o congelamento de um momento particularizado por um olho entre tantos outros, daí a subjetividade fotográfica. Essa limitação é-nos demonstrada pela moldura, vista aqui não como um adorno, mas como seu enquadramento (= colocar dentro de um quadro). Busca-se a particularidade, um átimo captado pela lente; temos, enfim, uma fragmentação da realidade. No soneto, à semelhança da fotografia, também há um emolduramento das imagens: duas quadras e dois tercetos unidos formam um bloco uno, em que não há somente diferenças de cor, luz, sombras, figuras superpostas; há, antes, palavras, mais especificamente quadros feitos de palavras. (Carone Neto, 1974, p. 71) Tais quadros têm como tarefa remeter 0 objeto diretamente à imaginação e ao desfrute do leitor (Ibidem, p. 71), pois as 
mensagens poéticas desfrutam de uma permanência que a linguagem comum não desfruta (...), pois o poema é memorável (Levin, 1975, p. 103), levando o leitor a ver aqueles quadros sob várias facetas, pois não existe uma resposta definitiva e única em relação à percepção que se tem da realidade.

Tränen des Vaterlandes está como que emoldurado em três planos de visão que nos remetem, inclusive, a outras sensações - auditivas, por exemplo -, quando somos retirados de seu enquadramento e levados à extra-moldura, abrindo-nos o campo, a partir do eu lírico:

1. A conscientização da desgraça presente e que atinge a todos (os quatro primeiros versos): Wir sindt doch nummehr gantz/ ja mehr denn gantz verheeret!; como também impressões auditivas: Der frechen Volcker Schaar/die rasende Posaun/das vom Blutt fette Schwerdt (o tilintar das espadas e, como conseqüência, o sangue que nelas escorre)/ die donnernde Carthaun; quanto emotivo-psicológicas: Hat

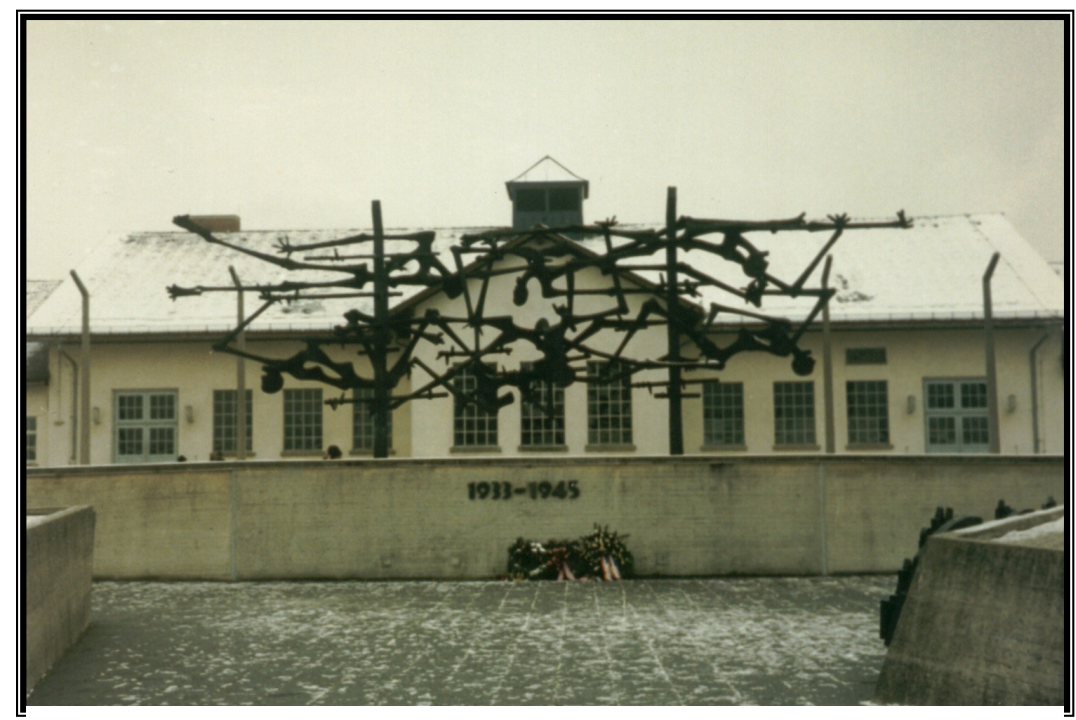

Foto 9: Monumento às vítimas do Campo de concentração de Dachau, próximo à Munique (foto de Antônio Jackson S. Brandão, 1994)

aller Schweiz/ und Fleiß/ und Vorrath auffgezehret.

2. Vemos, agora, o resultado da destruição causada por tropas após uma batalha em uma cidade ou vila. Se não fosse a data no título do poema, uma referência temporal no segundo verso do primeiro terceto (do segundo ao décimo-primeiro versos): Dreymal sindt schon sechs jahr (a guerra teve início em 1618), ou mesmo a linguagem empregada (glutt por Glut, umbgekehret por umgekehrt entre outras) diríamos que 
o poema é atemporal, podendo ser o resultado das inúmeras batalhas travadas em toda a humanidade: Die Turme stehn in glutt/ die Kirch ist umbgekehret. / Das Rathaus ligt im graus/ die Starcken sind zerhaun/ Die Jungfrawn sindt geschändt/ und wo wir hin nur schawn/lst fewr/pest/undt todt der herz undt geist durchfehret.

3. Há, portanto, como resultado, a desolação dos homens frente à destruição que restou (o último terceto), entretanto o lamento, o grito maior é o "calar-se": schweige ich, pois pior que a destruição material foi a espiritual, que acaba com as esperanças e a vontade de reerguer tudo novamente.

Temos diante de nós um quadro de lágrimas amargas de desesperança e de desprazer, reconhecíveis na Weltanschauung barroca, pois o homem dos Seiscentos é um indivíduo em luta, com toda a comitiva de males que essa luta traz, mas que sente até prazer em presenciar atos sanguinolentos. Dessa forma, chegava-se ao objetivo para o qual se orientava todo o delineamento patético e pessimista do século XVII: o de pôr às claras a condição humana para dominá-la, contê-la e dirigi-la. (Cf.: Maravall, 1997, p. 268) Veremos, portanto, que a inserção de Gryphius é em uma Europa cuja existência é sombria: perdem-se vidas e arruínam-se propriedades, destroem-se casas ou abandonam-se oficinas. A tristeza impera por todos os lados e com ela a difusão da tópica da loucura do mundo, que tão próxima está das manifestações artísticas do Barroco (Cf.: ibidem, p. 248), pois numa sociedade em que a violência é explícita sócio, política e religiosamente temos junto a ela o medo e a loucura.

Poder-se-ia dizer que, em Tränen des Vaterlandes, há a edificação fotográfica da morte, pois produz em nós um êxtase estranho: não podemos aceitar a miséria humana, queremos esquecê-la, mas precisamos perpetuá-la para que tal fato não mais ocorra. As sociedades antigas procuravam com que as lembranças, como substitutos da vida, fossem eternas e aquilo que falasse da Morte deveria, portanto, ser imortal. (Barthes, 1984, p. 139) Diante disso, vêem-se espalhados hoje pela Alemanha monumentos às vítimas do Holocausto, as paredes que cercam Dachau (Foto 9), e seu monumento à 
entrada do museu, que não nos deixam esquecer daqueles que por ali passaram e lá pereceram.

O soneto de Gryphius é fotográfico, pois suas imagens ainda estão presentes e reais; vemos os acontecimentos como se estivessem estampados num papel fotográfico, vemos em seus versos nossa contemporaneidade, necessária para que nós, leitores do século XXI, possamos compreender sob nosso ponto de vista, independente de preceitos retóricos do século XVII, esses versos, mesmo que Gryphius não quisesse imprimir a seu texto, obviamente, um valor de monumento, apesar de sê-lo (pelo menos para nossa percepção). Seu texto é de valor elegíaco, ou seja, temos um eu que não expressa, evidentemente, a visão psicológica do autor, mas nos mostra uma experiência típica de dor pela aplicação de um $\dot{\eta} \theta o \varsigma$ (ethos) triste e lamentoso que nos leva a paixão, melancolia, angústia, ou seja, ao $\pi \dot{\theta} \theta o \varsigma$ (pathos). Gryphius consegue chegar ao que queria via cvó $\rho \gamma \varepsilon l \alpha$, ou seja, mesmo que nós não leiamos seu texto com as preceptivas retóricas do século XVII, deixamonos levar pelas imagens vivas que o eu lírico nos impôs, a ponto de acreditarmos que tenham sido verdadeiras (mesmo o sendo) e não meras preceptivas retóricas. Sendo seu texto, portanto, um totem - algo inconteste e de valor perene cujas cenas já passaram - perdurarão como uma fotografia, já que essa também confere aos acontecimentos uma espécie de imortalidade. (Cf.: Sontag, 1986, p. 21)

As lágrimas não pertencem ao eu lírico, mas a toda a nação. Cada vez que lemos o texto, a cena se renova: os canhões com seus estrondos, o fogo a consumir as torres (por que não as torres gêmeas do World Trade Center de Nova York?), as igrejas destruídas; as virgens são novamente violentadas; não há mais estoques, não há mais suor, não há mais esforço; mas vemos o sangue fresco escorrendo além dos muros das cidades e nas espadas; olhamos os corpos abandonados ao sabor das águas dos rios... Entretanto, tudo já está morto! Esse é o poder fotográfico de Tränen des Vaterlandes: ressuscitar o passado no presente; ele não apenas rememora o passado, seu efeito não é o de restituir o abolido, mas de atestar que aquilo que vemos realmente existiu (Cf. Barthes, 1984, p. 123), foi fato, foi História. Assim, Gryphius não descreve simplesmente cenas, não cria fatos, não reproduz 
simplesmente uma pintura, não quer ser um pintor, cujo papel no Barroco é "fingir o natural", pois copiar um modelo natural é impossível, além do que sua intervenção sempre terá um caráter ativo, introduzindo elementos novos e transformando o objeto para deixá-lo entrar no mundo da arte (Maravall, 1997, p. 402); diante das cenas fotográficas de Gryphius, somos levados a acreditar nele, da mesma forma que não questionamos uma foto, sabemos que o fotógrafo estava lá. Não relutamos em acreditar no poeta e em seu passado, pois seu soneto fotográfico

faz cessar essa resistência: o passado é tão seguro quanto o presente, o que se vê no papel é tão seguro quanto o que se toca. (Barthes, 1984, p. 130)

Eis porque a relação diacronia X sincronia torna Tränen des Vaterlandes um soneto fotográfico: ele é crível a nossos olhos, em nossa leitura préiconográfica (valendo-nos do conceito de Panofksky), sentimo-lo sincrônico devido a sua aparente simplicidade imagética. No entanto, a partir de uma análise iconológica, verificaremos exatamente o contrário, pois é a diacronia que permeará o texto, tornando-o diferente de nosso presente, pois o signo aparenta ser o que, efetivamente, não o é mais, mas que nós não somos capazes de perceber devido à aparência sincrônica que a obra nos passa. Veremos, além disso, que as imagens nesse soneto também suscitam a transitividade imagética, devido ao impacto perpassado pelas imagens que tratam de vicissitudes sofridas pelos homens, e por serem essas as mais exploradas pelos meios midiáticos em nossos dias: sempre somos bombardeados por imagens que retratam o sofrimento humano, sejam decorrentes da guerra ou de calamidades; dessa forma, as imagens transitivas de Gryphius fazem-nos adentrar no mundo de nosso presente, via leitura iconofotológica.

Vê-se, portanto que, apesar de o eu lírico também ter, à semelhança da imagem fotográfica, mumificado seu presente, seu referencial - o presente no texto poético - tornou-se anacrônico, já que as imagens armazenadas em nossa memória - nosso acervo iconofotológico construído via mídia - acabam 
sendo invocadas para ler esses poemas fotográficos que, inclusive, poderíamos chamar de históricos, ou que nos passem a impressão de sê-los.

Prosseguiremos nossa análise, lendo o soneto - verso a verso - a partir do acervo fotográfico de que dispomos, buscando evocar nosso acervo iconofotológico a partir das imagens criadas pelo poeta, para que possamos contrapor à iconologia da época. Evidentemente, essa leitura é uma leitura dirigida e pessoal, de um acervo pessoal - mesmo que, neste caso, tenha havido pesquisas fotográficas -, isso quer dizer que poderíamos ter inúmeras leituras iconofotológicas de um mesmo verso, já que essa dependeria de vários fatores como

a) estar ou não em sintonia com os acontecimentos do mundo;

b) estar, ou não, informado a respeito de vários aspectos por que passa a humanidade;

c) ter acesso contínuo a imagens que tratam desses acontecimentos, cujo acesso está aberto a todos. Atualmente, isso foi facilitado sobremaneira devido às novas mídias, em especial à popularização da internet;

ou ainda

d) não ler, absolutamente nada a esse respeito, mantendo um total alijamento do mundo.

Além disso, convém ressaltar o óbvio: essa leitura é, como foi dito acima, dirigida, ou seja, trabalhará com a legenda à semelhança da notícia jornalística ${ }^{229}$; do artista moderno que, ao compor uma obra, a nomeia, induzindo-nos a enxergar aquilo que quer que vejamos na mesma; ou do fotógrafo que, ao nomear uma fotografia trivial, a transforma em arte.

\footnotetext{
${ }^{229}$ Frase curta que possui, geralmente, duas funções: descrever a fotografia (ou ilustração) da matéria jornalística a que se refere, e dar-lhe apoio, fornecendo outros dados sobre o assunto noticiado. Normalmente, emprega verbos no presente e não utilizam ponto final.
} 
Threnen des Vatterlandes. Anno 1636 é um dos sonetos mais conhecidos de Andreas Gryphius, no entanto seu título original era Trawklage des verwüsteten Deutschlandes [Lamento da Alemanha destruída], pertencente aos Lissaer Sonette ${ }^{230}$. Poderíamos especular acerca da mudança do título do mesmo, mas demandaríamos tempo, no entanto devemos nos ater a detalhes

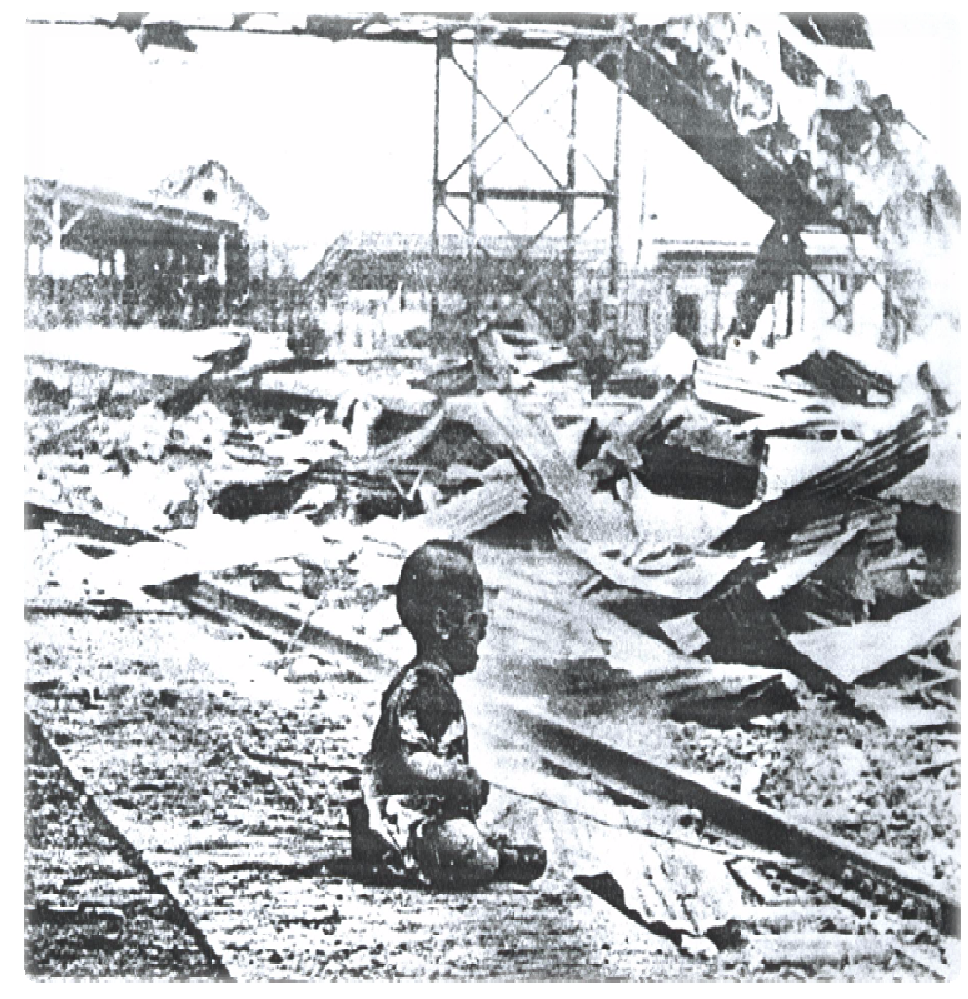

Threnen des Vatterlandes

Foto 10: Time Life Books, 1971

Legenda original: Seconds after his mother was killed by Japanese bombs, a Chinese baby sits crying at a Shangai railroad station in 1937. The attack was filmed by one of Hearst Metrotone's starnewsreel photographers with a $35 \mathrm{~mm}$ movie camera, this frame, reproduced in magazines and newspapers, stirred up international outrage at the slaughter of Chinese civilians que cremos ser pertinentes.

Quando se fala
em lamento pela destruição de um país, é possível que essa carga semântica não fosse tão expressiva, segundo as preceptivas barrocas ${ }^{231}$, quanto ao fato da utilização da palavra lágrimas e toda sua conotação metafórica, como já havíamos levantado anteriormente, ao analisarmos a obra de Pedro Mena.

A palavra lágrimas perpassa 0 sentido de tristeza e alegria e adentra,

no período seiscentista, à purgação dos pecados, à limpeza da alma que, arrependida é levada à compunção.

\footnotetext{
${ }^{230}$ Primeira coletânea de sonetos de Andreas Gryphius publicada no início de 1637, na cidade polonesa de Lissa, daí ser conhecida como Lissaer Sonette.

${ }^{231}$ Talvez pelo fato de a idéia de Estado ainda não existir nas fronteiras do Sacro Império Romano Germânico.
} 
Evidentemente que, no caso do soneto, toda a pátria tem de ser levada à essa amargura, a fim de que também ela possa encontrar a paz desejada. Não aquela em que as armas cessarão de se alimentar da morte, mas aquela em que a paz do espírito se revelará, afinal se choram é porque têm de pagar por algo que cometeram de errado, à semelhança do povo hebreu que, devido a seus pecados e à não obediência a Javé, era, muitas vezes, levado à escravidão:

Torrentes de lágrimas me descem dos olhos, porque não cumprem a tua vontade. $(\mathrm{SI} 119,136)$

Mas, no fim, as lágrimas trarão a bonança para que tudo possa se restabelecer, pois

O cordeiro que está no meio do trono será o pastor deles; vai conduzi-los até às fontes de água da vida. $E$ Deus Ihes enxugará toda lágrima dos olhos. (Ap 7, 17)

Ao lermos o título do soneto, estaremos propensos a esperar que o eu lírico encaminhe-nos à descrição da tristeza ocasionada pela dor da perda, pela dor da guerra, quiçá à semelhança

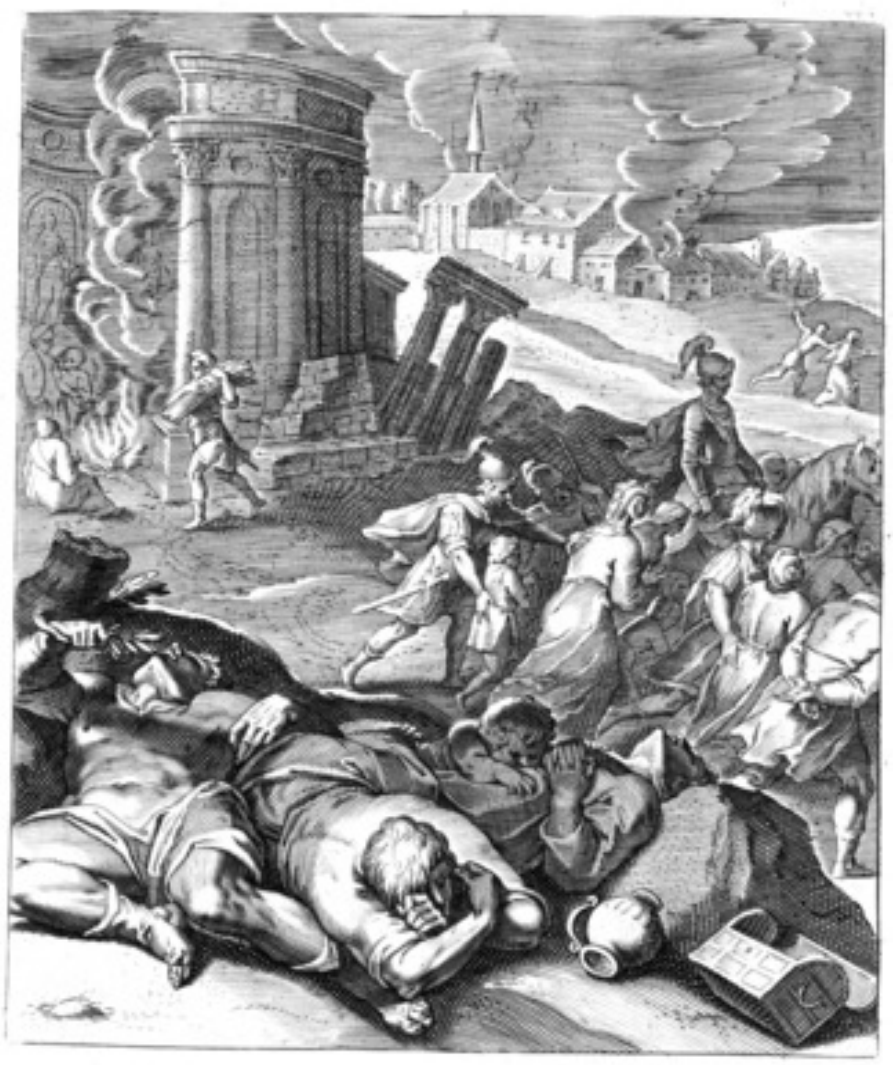

Figura 68: Emblema 86, Neglectae religionis poena multiplex, de Otto Vaenius, 1612 da criança na fotografia 10 que chora e que poderia representar parte do povo chinês, perseguido e massacrado pelos japoneses durante a Segunda Guerra Mundial. Além disso, e devido à transitividade da fotografia somos impelidos também à observação: alguém pôs essa criança ali, toda chamuscada, 
simplesmente para tirar essa foto? Onde estariam realmente seus pais, em especial sua mãe que, segundo a legenda nos diz que foi morta há pouco? A destruição que a foto nos mostra, poderia ser interpretada como a destruição descrita por Gryphius? Essas lágrimas poderiam ser interpretadas à semelhança das lágrimas no Barroco e estendidas a todo o povo chinês (que, talvez tivesse tido a necessidade de ser sido purgado naquele momento)?

Evidentemente, que a guerra por si só nos leva a vários questionamentos, mas hoje seria inadmissível crermos que um povo qualquer

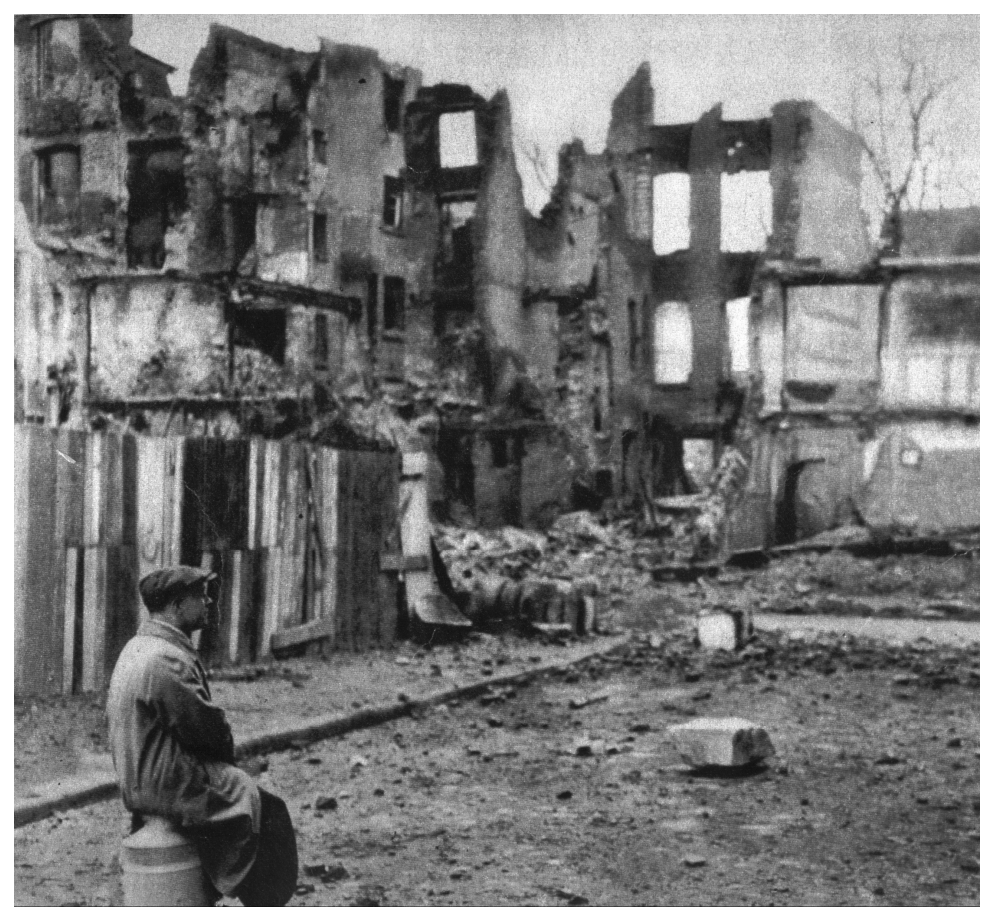

Wir sindt doch nuhmer ganz/ ja mehr den ganz verheret!

Foto 11: A Segunda Guerra Mundial. 1966, p. 18. Legenda original: Um subúrbio da cidade de Colônia, na Alemanha, mostra os efeitos da luta e a devastação levada a cabo pelos bombardeios prévios da aviação aliada mereça ser purificado por seus erros, seja quais forem eles, se é que esses existiram algum dia. Logo, verificamos que nossa leitura iconofotológica do título do soneto já nos levaria a uma interpretação distorcida daquela pretendida pelo autor. Ficaria clara aqui a relação entre a imagem criada pelo poeta e aquela que nós temos acerca do tema, ou seja, apesar de sua aparente facilidade interpretativa, vemos que, logo no título, nossa leitura iconofotológica desvirtuaria toda a interpretação que teríamos de ter do soneto (se nossa intenção fosse, evidentemente, compreendê-lo à luz da intencionalidade daquilo que o poeta pretendera, quando construiu essas imagens), afinal o poema remete-nos a uma outra conceitualização interpretativa pelo fato de ser fotográfico.

Segundo Gryphius, a destruição que se verifica e que se nos apresenta à contemplação, seria semelhante àquela que vemos no emblema de Vaenius 
(fig. 68), quando este a apresenta como resultado do abandono humano aos preceitos religiosos e à vontade divinos. Para isso, o emblemista cita Cícero na alma do emblema (mantive o original):

Que Reynos en el mundo tan gloriosos,

Que villas, que ciudades tan nombradas,

Que personas jamas tan leuantadas,

No cayeron con fines lastimosos.

Por solo despreciar los sonorosos

Ecos de religion, y las sagradas

Ceremonias antiguas, heredadas

De aquellos padres, por virtud famosos;

$Y$ es la mayor miseria, que podemos

Mostrar (o gran desdicha) aquestos daños,

Sinque otro exemplo alguno aqui se trayga.

Al cielo le pidamos, y roguemos

De à entender à los vnos sus engaños,

$Y$ alque estuuiere en pie, guarda, no cayga.

No corpo do soneto, o eu lírico trabalhará com uma sucessão de imagens, que não passavam de metáforas e alegorias. Apesar disso, não nos é possível as enxergarmos assim, pois nos são próximas se não fosse, por exemplo, a diacronia verificada nos arcaísmos empregados em sua ortografia.

No primeiro verso do soneto, Wir sindt doch nuhmer ganz/ ja mehr den ganz verheret! [Nós todos estamos, de agora em diante, mais do que completamente destruídos!], somos propensos a imaginar a destruição decorrente da Guerra dos Trinta Anos (1618-1648), mote do soneto. No entanto, a destruição, nesse caso, vai muito além da mera destruição física de pessoas, vilas e cidades, mas chega a sua destruição moral. 
A mesma que nos levaria a indagar: por que merecemos isso? Ou

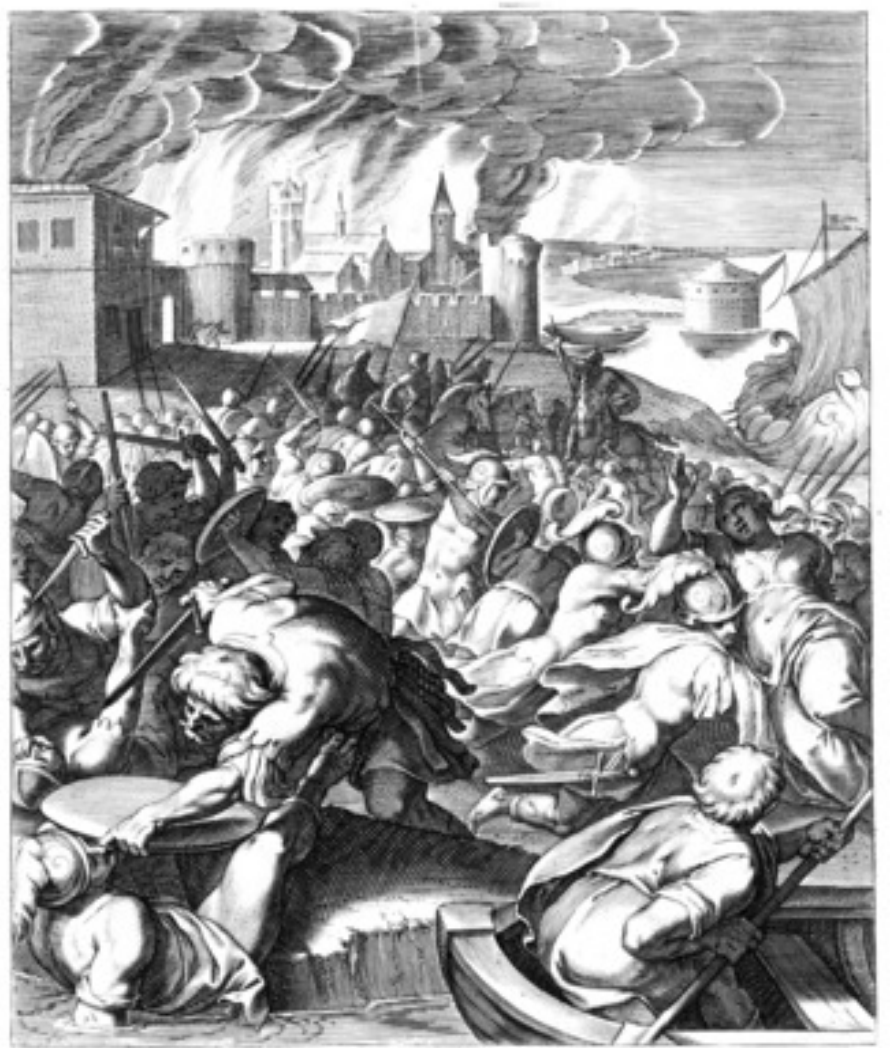

Figura 69, emblema 88 Principum delicta plebs luit, de Otto Vaenius, 1612. mesmo no plano individual: qual foi minha culpa? Ou, a partir da leitura da fotografia 9: valeu a pena termos seguido ao Führer, onde estarão as esperanças que o futuro nos prometia? Mais uma vez vemos que a transitividade da fotografia em questão nos abre espaço para acompanharmos o olhar do homem que, sentado, contempla a destruição que vê à sua volta: estamos completamente destruídos! Sejam nossos sonhos de há pouco - os de esplendor, de grandeza, de vitória -, seja a concretude visível de tudo o que possuíamos nossas casas, móveis, roupas. Onde estará a família desse homem? Existirá, ou ele foi o único sobrevivente em meio a essa destruição?

Essa fotografia, juntamente com o verso do soneto, remete à idéia do emblema 88 de Vaenius (fig. 69), quando nos diz que, devido a uma só pessoa, a morte se espalha e transmite seu horror tanto a justos como injustos, a inocentes e culpados, afinal todos perdem muito com ela, inclusive o bem mais precioso: a vida. Vaenius fala-nos na alma desse emblema, citando o exemplo dado pela Guerra de Tróia que, devido ao rapto de uma mulher, muitos tiveram de ver suas vidas abruptamente modificadas:

Per l'amoroso rapto d'vna Greca, Gran pianto, e sangue Grecia, e Troia sparse.

E populo innocente, e turba cieca

Perì fra mura sanguinose, \& arse.

Cosi l'error d'vn solo à molti arreca 
Rouine, e morti non di sangue scarse,

E del fallo d'vn Re, che non s'afriena,

Il sudito meschin soffre la pena.

O eu lírico leva-nos, em seguida, a visualizar como todo o esforço, suor, economias foram subtraídas e destruídas. Para isso, mostra-nos o valor da turba: Der frechen völcker Schaar [Da insolente turba popular]. Aqui convém salientar que a palavra alemã Schar (Gryphius grafava Schaar) significava originalmente um destacamento do exército (Heeresabteilung), mas sua acepção foi estendendo-se à multidão, à sociedade, ou mesmo a uma reunião de seres vivos como as aves. O eu lírico, por sua vez, precisa o termo ao dizer völcker Schaar, ou seja, grupo de populares, uma turba que, em português, poderíamos dizer tratar-se de populacho, de povaréu, quando esse faz, exatamente, o que o verbo correspondente, em português, quer expressar: desequilibrar, desorganizar, perturbar.

Anteriormente, já havíamos assinalado como aquelas sociedades aristocráticas viam os membros do povo - pessoas sem valor, submersas em sua total ignorância -, menosprezando-os, mas enaltecendo-se a si mesmos nas figuras principescas e nobres, sempre em detrimento das classes mais baixas. Isso fica claro quando verificamos a busca incessante pela separação dos estilos que se fará presente durante todo o século XVII. Dessa forma, Gryphius desloca a atenção da vileza e baixeza não para as classes aristocráticas, mas à turba, pois ela, segunda aquela concepção, que é capaz de cometer os atos mais insanos, como se isso tivesse sido possível sem o aval das classes dominantes.

Essa acepção de turba remete aos grupos que pretendem vingar-se da sociedade em que estão inseridos, buscando para seu consolo destruir aqueles que consideravam diferentes, enxergando neles um bode espiatório de seus próprios males. Exemplos dessa procura por culpados vimos em toda a história da humanidade: na perseguição aos cristãos no tempo do Império Romano quando fora imputado aos cristãos o incêndio de Roma -; a perseguição de mulheres e pessoas com deficiência física na Idade Média - por suas ligações demoníacas pela mesma Igreja católica que já fora perseguida -; no 
acossamento de judeus na Alemanha nazista - por conspirarem contra a estabilidade da nação -; na expulsão dos palestinos de suas casas para a efetivação do Estado de Israel - eles não aceitariam ser submetidos por um povo estrangeiro -; e, mais recentemente, o fanatismo religioso que aflora de novo em todo o mundo, conforme exemplo da foto 12, quando o simples fato de ser cristão num país muçulmano como a Indonésia era motivo para ser barbaramente assassinado.

Essa mesma foto, claramente transitiva, mostra-nos como a turba excitase diante da câmera: como se já não bastasse o fato de o homem estar nu, morto e ter sido lançado em uma lixeira (equiparado à imundície), insiste em destruir o que já está destruído, ou seja, a vida humana, o bem mais precioso de que dispomos. Vemos num primeiro plano mãos que querem agarrar a outra que não se contenta com a morte pura e simples, mas quer desfigurar. O olhar do homem em direção à vítima é de calcular, exatamente, o que vai fazer. Mas, o que pretendem as outras mãos? Evitar a transfiguração do morto, fazê-lo parar diante da câmera que o está captando, ou elas mesmas fazerem o que o outro insiste, tão decididamente, em praticar?

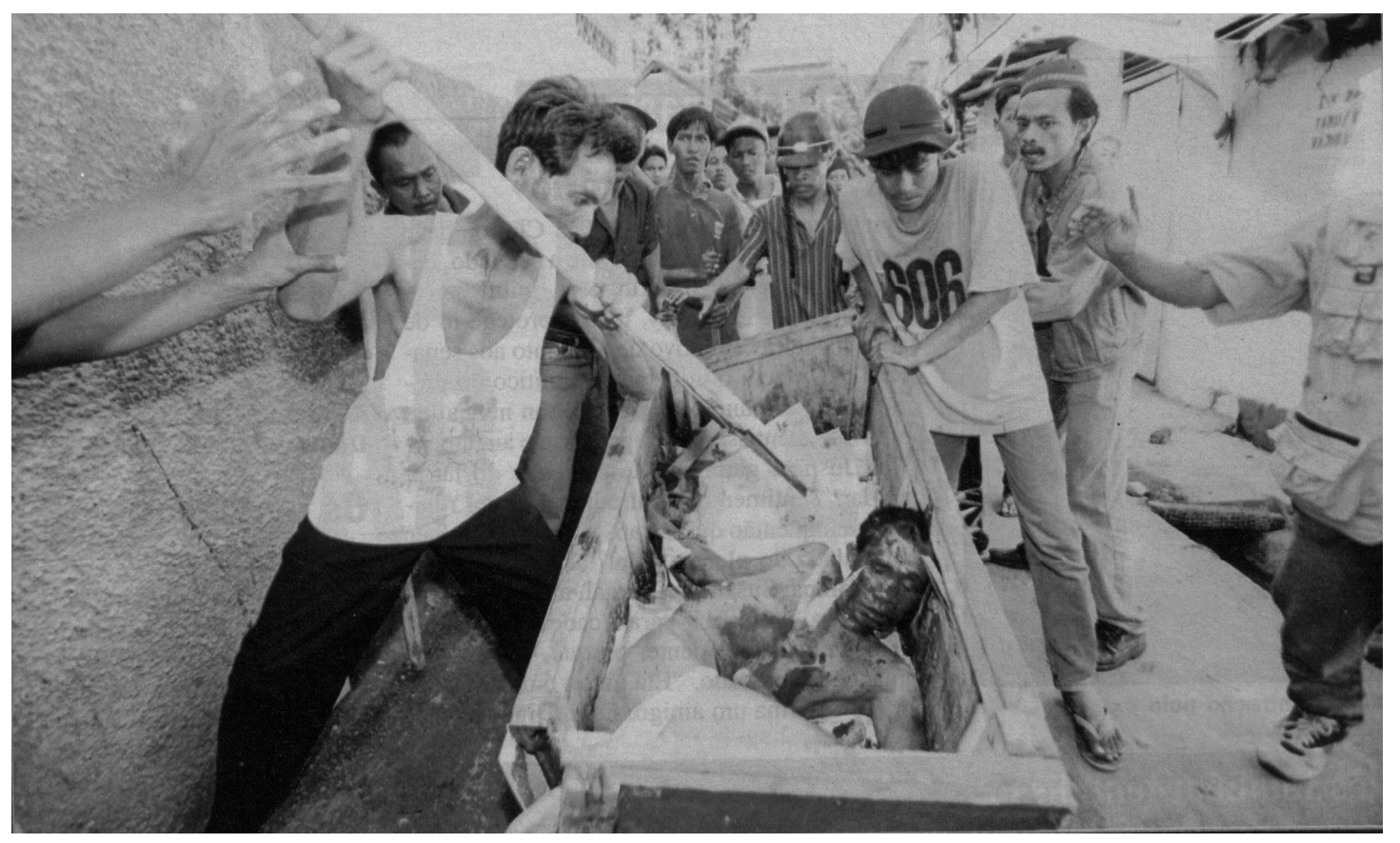

Der frechen völcker Schaar

Foto 12 Veja (ed. 1584) 1999, p. 53 (foto de Paula Bronstein/Liaison).

Legenda original: (há outra foto além desta no mesmo quadro) Cristão refugiados numa igreja em Ambon, na Indonésia, para escapar de linchamentos como o da foto ao lado (acima): 65 mortos em janeiro [daquele ano] 
Vê-se que o primeiro hemistíquio do segundo verso do soneto também nos abre a essa transitividade imagética, afinal o genitivo representado por ele impõe-nos isto: algo pertence a algo, algo foi criado a partir de algo ou, de outra maneira, algo se deriva de algo. Assim, tem início a enumeração daquilo que é proveniente da turba. Entretanto, o segundo hemistíquio abrenos com uma imagem pouco reconhecida por nós: a da trombeta.

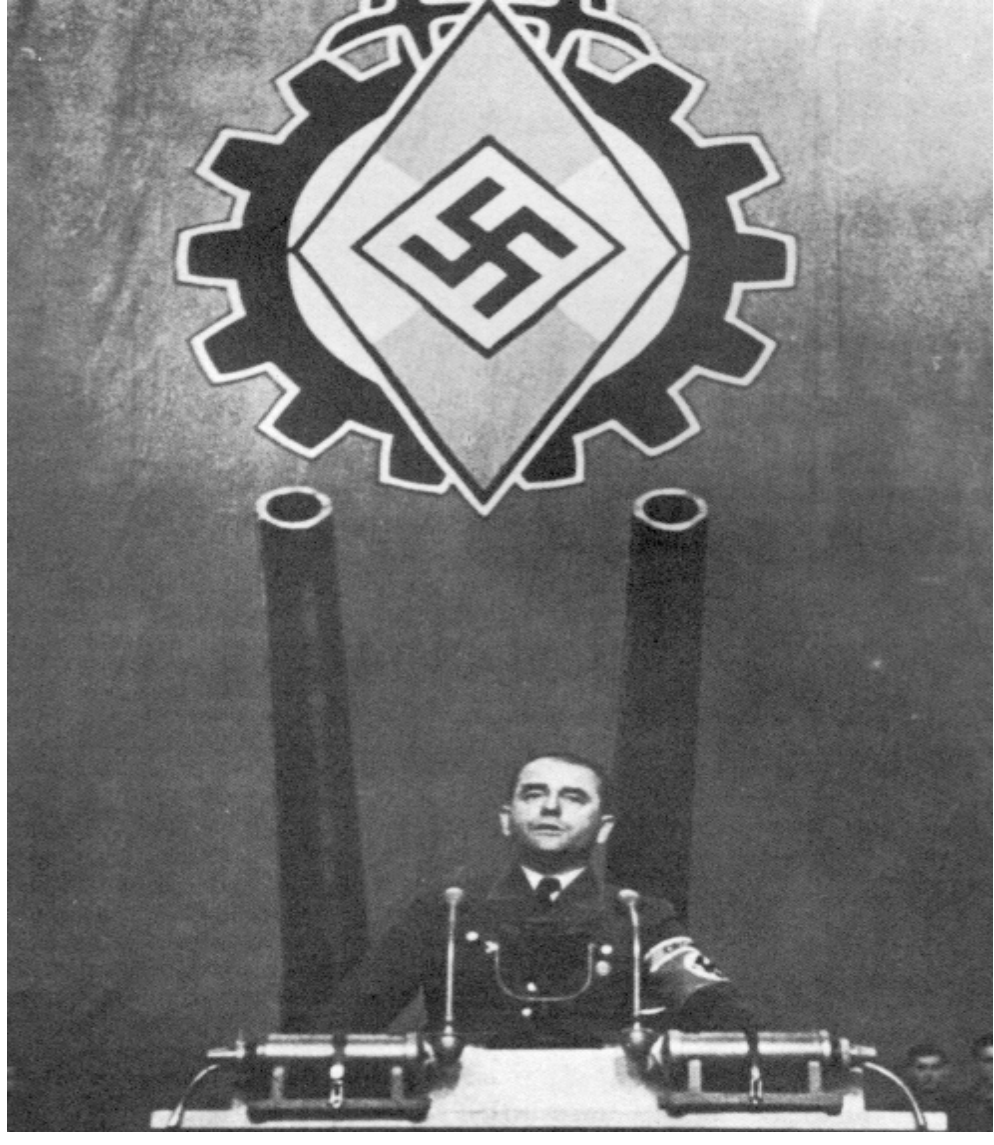

Die rasende Posaun

Foto 13: FÄRBER, Matias. p. 241. (O fotógrafo não é citado)

Legenda original: „, Reichsappel 1943 “. In einem Berliner Rüstungswerk spricht Albert Speer zur „, schaffenden Jugend“. „Wenn ich mir vergegenwärtige“, sinnierte Speer nach dem Krieg in seiner Spandauer Zelle, „da $\beta$ unter meiner Leitung als

Rüstungsminister bürokratische Fesseln, die die Produktion von 1942 behinderten entfernt wurden und daraufhin in nur zwei Jahren die Zahl der gepanzerten Fahrzeuge fast auf das Dreifache, der Geschütze auf das Vierfache stieg, wir dir Zahl der Flugzeuge mehr als verdoppelten und so weiter - dann wird mir schwindlig "
Esta talvez seja lembrada por aqueles que estiveram na caserna, ou mesmo por aqueles que assistiam a filmes de far west, quando era tocada estridentemente para indicar 0 ataque de índios. Gryphius utiliza, exatamente, essa idéia: die rasende Posaun [a trombeta estridente]. A idéia da trombeta, porém, é bíblica e

remete ao Antigo Testamento, à Schofar hebréia ${ }^{232}$ :

Três dias depois, pela manhã, houve

trovões e relâmpagos e uma nuvem espessa desceu sobre a montanha, enquanto $o$ toque da trombeta soava fortemente. $O$ povo que estava no acampamento começou a tremer. (Ex 19,16)

${ }^{232}$ Eine eintönige Signaltrompete, aus dem altjüdischen Schofar - einem Widderhorn entstanden, das beim Marsch durch die Wüste, beim Nahen von Feinden oder bei der Gottesoffenbarung am Berg Sinai ertönte und beim Jobel- oder Erlaßjahr den Sklaven die Freiheit verkündete. (Biedermann, 1998, p. 860) 
Rememora o momento em que Moisés encontra-se com Javé, simboliza a revelação divina ao homem, prenunciando a aliança que será estabelecida entre Deus e o povo hebreu. No entanto, Gryphius não utiliza a palavra para indicar o encontro com o divino, ou mesmo para indicar os anjos chamando os mortos para o Juízo Final (fig. 70), mas em outra acepção, que nos remete ao Novo Testamento, como prenúncio de desgraças apocalítpticas:

E os sete Anjos com as sete trombetas se prepararam para tocar. (...) nessa hora vi e ouvi uma Águia voando no meio do céu, e gritando em alta voz: "Ai! Ai! Ai! Dos que vivem na terra! Ainda faltam três toques de trombeta. $E$ os anjos estão prontos para tocar." (Ap 8,6 e 13)

Se a trombeta é prenúncio de desgraças iminentes, por que não poderíamos representá-la, iconofotologicamente, por meio do microfone e dos grandes discursos de conclamação da população

para uma causa - nobre ou

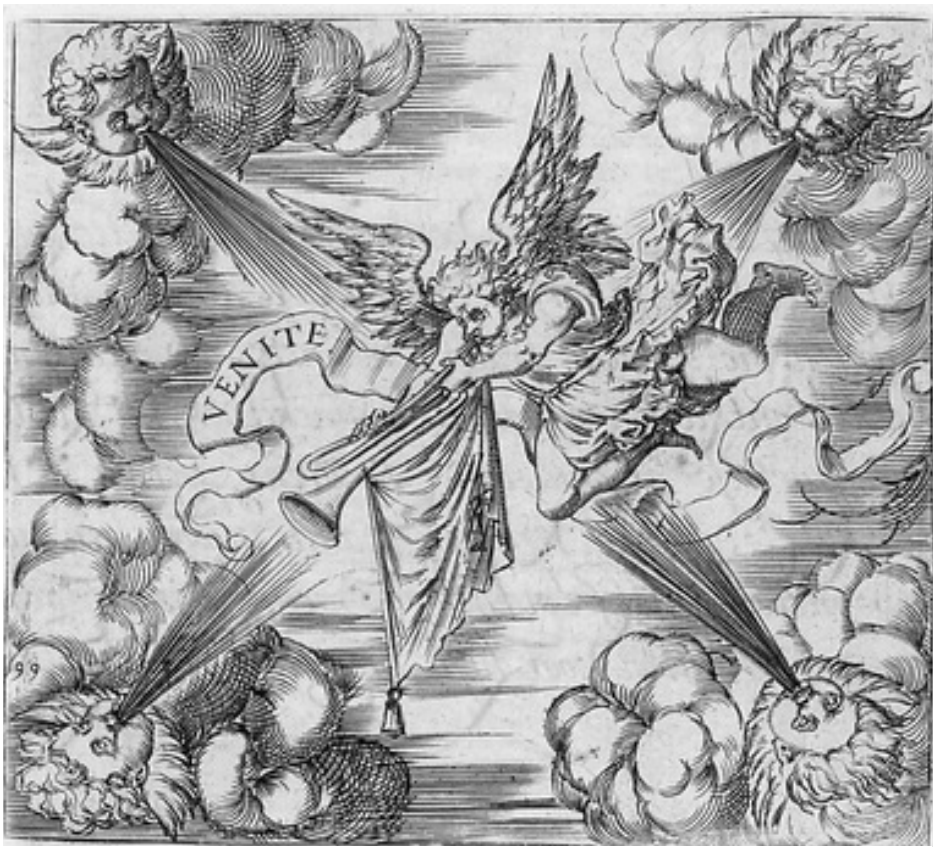

Figura 70: Emblema 99, Venite [Vem!], de Georgete de Montenay, 1615.

não tão nobre assim, como

os discursos de Hitler em Nurembergue - à semelhança de um deus que se dirige a seu povo escolhido? Há uma fotografia, porém, que nos passa essa mensagem, quando vemos Albert Speer diante não de um, mas de dois microfones, conclamando para que haja um aumento na produção da máquina de guerra. Atrás do ministro, vêem-se dois canhões como que nos mostrando a abertura das trombetas que rugiam e anunciavam o que estava acontecendo e o que ainda estava por vir: a adoção total da nova revelação, que traria junto a si mais mortes e destruição. Eis que junto a essa nova manifestação, viriam os quatro Cavaleiros apocalípticos. 
O eu lírico prossegue sua descrição falando-nos, no terceiro verso, da diferença entre o passado e o presente, entre como a guerra era e em que se tornou, para isso nos apresenta duas imagens distintas, paradigmáticas, de como se faz guerra: uma por meio da espada (Schwerdt), outra por meio do canhão (Carthaun), e como ambos participam da destruição do homem, de seus bens e de sua dignidade.

A espada como ato continuado do sofrimento, da dor, da ante-morte: prolonga a agonia, faz com que a vida se esvaia lentamente, e o homem perca sua individualidade diante dos outros, já que o ato acontecia no tete-à-tete com o inimigo; o canhão, cujo alvo de destruição seriam, a priori, as construções, não as vidas que nele se abrigam, assemelhava-se às catástrofes naturais que atingem o homem em conjunto, quando se perece, muitas vezes, sem sequer ter tido consciência, à semelhança de um terremoto.

Encontramos, novamente, nesse soneto de Gryphius, imagens do Apocalipse:

Ouvi o primeiro dos quatro Seres Vivos falar como estrondo de Trovão: "Venha!" (...)

Apareceu então outro cavalo, era vermelho. $\mathrm{Seu}$ cavaleiro recebeu poder para tirar da terra a paz, a fim de os homens se matarem uns aos outros. $E$ entregaram para ele uma grande espada. (Apo 6, 1b e 4)

A espada representava para a Antigüidade muito mais do que uma arma, possuindo simbologia própria em várias culturas, inclusive

Das vom blutt fette Schwerdt

Legenda original: Os cortadores de cabeça da ilha Bornéu, 1999

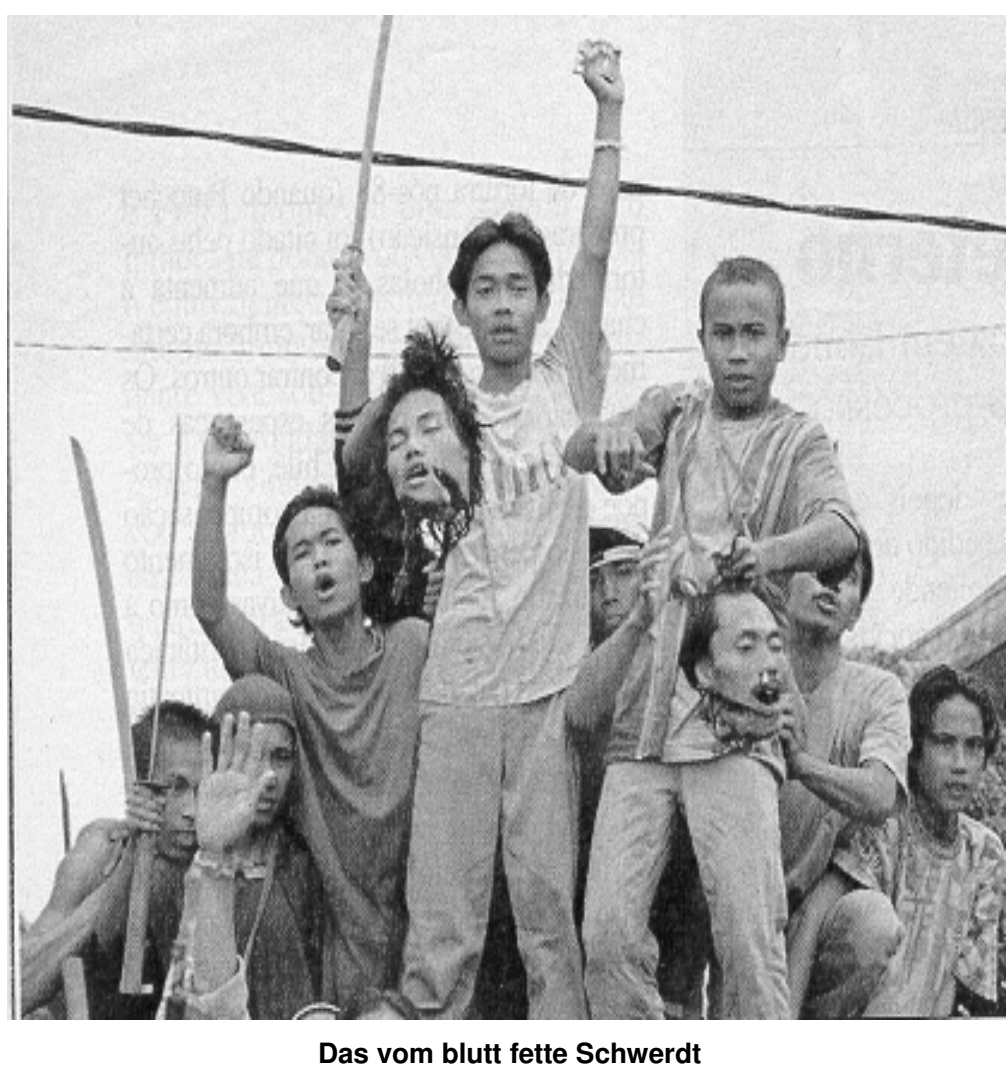


nome próprio. Na mitologia nórdica, por exemplo, havia a Balmung que fora forjada após a queda de um meteoro enviado pelos deuses e com a qual Siegfried matara o dragão Fafnir; há a Excalibur do Rei Artur que remonta às tradições célticas; na Idade Média, podia também significar castidade se interposta entre um homem e uma mulher; na tradição hebraico-cristã, vemos seu emprego já no primeiro livro da Bíblia, o Gênesis, quando Javé expulsa o homem do Éden e deixa a sua porta querubins com uma espada flamejante para guardá-lo. (Gn 3, 24)

Como arma, sua representação/efetivação da morte é mais do que conhecida, apesar de, muitas vezes, esquecermo-nos de a enxergamos em seu sentido cruel e inumano, exatamente por não nos representar, de forma efetiva, a morte como em outras épocas ${ }^{233}$. Apesar disso, restou como adordo simbólico utilizado, por exemplo, nas forças armadas pelo oficialato, simbolizando sua autoridade, ou na cavalaria montada, como simples adorno; há também seu emprego em esportes como a esgrima e o quendô. Aquilo que pode provar nossa visão romântica em relação à espada é o fato de a vermos desde crianças por meio dos seriados de televisão e de filmes, quando assistimos a nossos heróis travarem duras batalhas para conquistar algo ou para buscar e salvar seu amor ${ }^{234}$, além disso desde a primeira infância, vêemse meninos - inclusive meninas - brincando de espada com cabos de vassouras, pedaços de galhos de árvores, ou qualquer objeto que a lembre: essa imagem, portanto, tornou-se, para nós, não mais a figuração de algo mortal, muito menos a representação de status social - havia diversos tipos de espada: do reles soldado a de um rei ou imperador -, mas uma brincadeira, uma mera figuração romântica: é como se quiséssemos esquecer toda a crueldade que tal suplício proporcionou à humanidade e na história.

O eu lírico, seguindo as preceptivas do período, desloca a mera idéia unilateral da morte, bem como de sua crueldade, redirecionando seu foco das

\footnotetext{
${ }^{233}$ Esse encargo foi transmitido aos vários tipos de armas de fogo empregadas hoje.

${ }^{234}$ Ainda seguindo os ideais românticos, no entanto não se deve esquecer de que tais ideais remontam à tradição medieval dos ideais da cavalaria. O amor (...) é um dos temas mais discutidos da história da literatura medieval (...). É preciso lembrar que a forma (...) na qual se pensa (...) em amor cortês - a amada como senhor, ccujos favores o cavaleiro quer obter através de feitos heróicos e da dedicação total, escravizada - não é a única forma de amor que aparece no tempo do florescomento da épica cortesã, nem é a que predomina. (Auerbach, 2004)
} 
mãos da aristocracia para a da turba que se inebria com o sangue inimigo. Além disso, não se vê, nesse segmento social, a representação daquilo que poderíamos chamar de sofrimento real. Este sempre é limpo, elegante e heróico. A plebe, por sua vez, quando muito, poderia ter a vantagem de ver/sentir seu sofrimento que era real aplacado por um golpe de misericórdia, executado por alguma bondosa alma cristã que minimizasse sua agonia.

Um outro ponto interessante é como a espada é-nos apresentada, já que não fala da lâmina, nem do fio, ou mesmo do brilho da morte que advém do aço nela contida, mas do resultado do uso contínuo e constante, resultante do ato de matar: vom blutt fette [engordurada de sangue]. Mas, por que fett e não rot [vermelho]? Sabe-se, por exemplo, que o perído em que se deu a Guerra dos Trinta Anos foi um período de dificuldades econômicas e de penúria em toda a Europa, logo fett poderia representar aqueles que a tinham em excesso, os soberbos e mesmo os poderosos, visto que a Guerra não poupou ninguém fosse no front fosse por meio da peste que assolou e matou populações inteiras.

Vemos que realmente há uma distância grande entre essas imagens que o eu lírico nos passa e um possível acervo iconofotológico, no entanto na esteira das novas guerras de religião que se tem verificado ultimamente e nas disputas de espaço por etnias e grupos rivais, está ressurgindo o lado animalesco do homem que há muito estava reservado aos livros históricos ou de lendas, como o caso dos caçadores de cabeças da Indonésia. Verificou-se nesse país, bem como em todo o mundo islâmico, uma onde de belicosidade frente a tudo o que seja ocidental, cujos reflexos se fazem sentir nos aspectos religiosos. A foto 14 impressiona-nos duplamente:

a) é difícil para nós crermos que tais atos ainda sejam possíveis em nossos dias, ainda mais com a brutalidade como seus troféus foram exibidos ${ }^{235}$;

b) a foto quase não nos impele para fora dela, devidos aos vários detalhes contidos, a ponto de per si nos satisfazer com seus

\footnotetext{
${ }^{235}$ Evidentemente, houve algo parecido com a suposta Guerra ao Terror, quando terroristas, em represália, capturavam reféns que eram decapitados frente às câmares e cuja imagem correu os cinco continentes via internet, no entanto eram atos furtivos (apesar de seu efeito dominó), feitos às escondidas, não abertamente como as cenas vistas em Bornéu.
} 
elementos mórbidos, representados pelas cabeças de dois homens e pelo instrumento decapitador: suas espadas.

Estas, por exemplo, fogem, inclusive, do padrão de espada que conhecemos e demonstram ser do padrão oriental, semelhantes àquelas dos samurais que já permeiam nossa memória - seja por meio de filmes, desenhos animados e mesmo pinturas.

Para a turba, não basta o decapitar, deve-se fazer um ritual para vilipendiar os cadáveres, algo que grande parte das culturas abomina, mesmo aquelas em que haja a antropofagia - ela própria uma homenagem, por mais que não consigamos compreender essa relação. Um fato que nos chama a atenção também é 0 de os protagonistas da cena serem todos jovens, ou seja, estariam muito

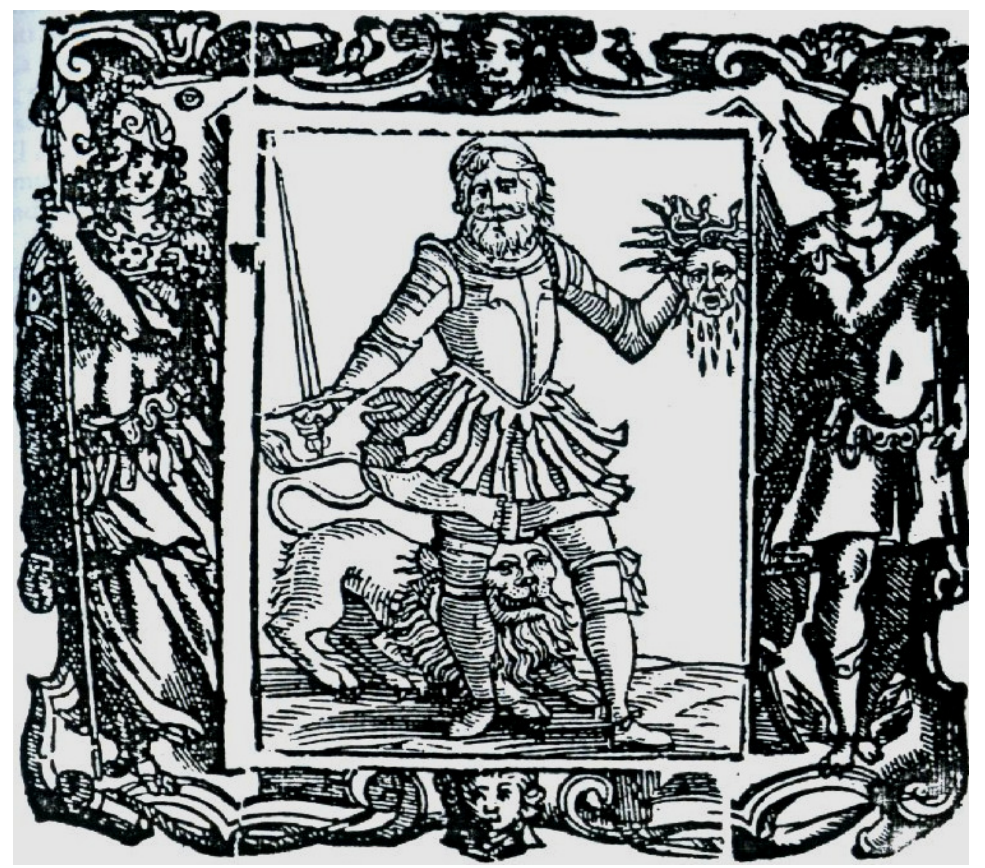

longe da tradição que tentam resgatar, a de seus ancestrais belicosos.

Talvez resida aí a semelhança que encontramos nessa imagem fotográfica e a de Gryphius, pois este nos mostra que as espadas estão repletas de fett, mas aqueles que a utilizaram - a turba - estariam longe dessa condição (a da saciedade também representada pela própria fett); a foto, por sua vez, mostra-nos jovens - talvez da periferia que não tinham as mesmas condições de seus supliciados - bem mais velhos e, provavelmente, com melhores condições financeiras. O provável líder dessa turba juvenil tem em uma de suas mãos a cabeça de um supliciado; em outra, aquilo que parece ser um maço de cigarros; além disso, está numa atitude que nos lembra a da conquista. Nenhum dos jovens está fumando, não temos elementos que nos mostrem o porquê (sequer é-nos possível saber se o jovem segura, realmente, 
um maço de cigarros!): preceitos religiosos, purismo, não querer se misturar com os defeitos daqueles que eles próprios mataram?

A certeza de que temos é que a outra cabeça possui algo que nos parece ser um cigarro enfiado em uma das narinas, talvez num ato de repúdio por esse deleitar-se com o fumo ou por esse vício demonstrar que ambos os supliciados pertencessem a uma classe social diferente daquela a que aqueles jovens pertenciam, ou mesmo como parte desse rito macabro (muitas fotos desse período têm esse traço comum). Provavelmente, poderiam dizer - como o eu lírico de Tränen des Vaterlandes - que também suas espadas estivessem repletas vom blutt fette, ou seja, da mesma gordura (enquanto representação da fartura) de que careciam.

Ripa, por exemplo, em sua alegorização do Espanto (fig. 71) utiliza imagens que nos lembra a fotografia 14, quando se vê um homem que segura uma espada com uma mão e uma cabeça com a outra. No entanto, a idéia central da alegoria não está nem na cabeça da meduza nem na espada, mas no leão que está sob o homem que se espanta. A cabeça da Medusa, por sua vez, era empregada pelo imperador Domiciano que a utilizava para subjugar o povo. Afinal, que faziam aqueles jovens com as cabeças de seus desafetos,

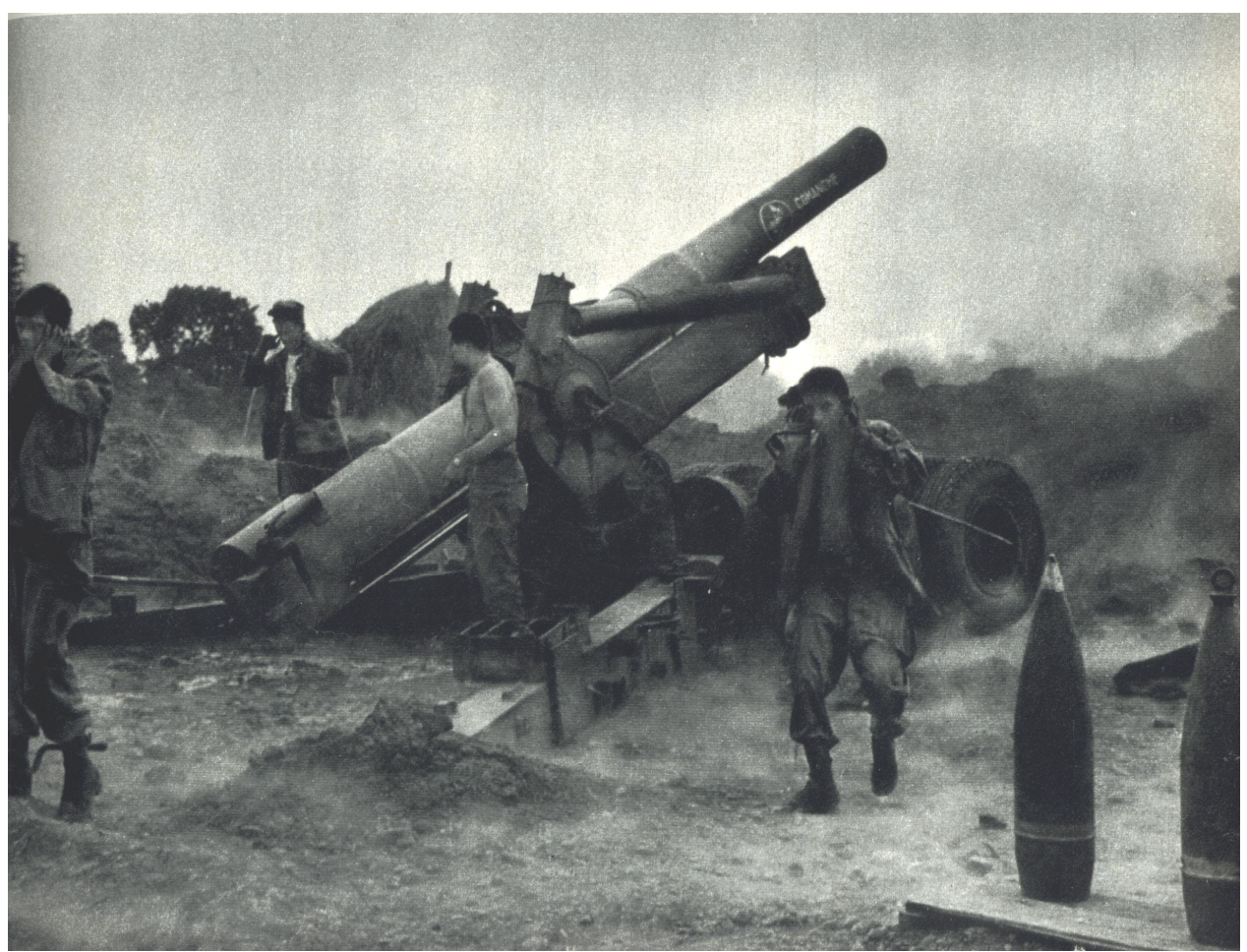

die donnernde Carthaun

Foto 15: Färber, p. 186. (O fotógrafo não é citado)

Legenda original: Uma peça de grosso calibre da artilharia norte-americana dispara contra as posições japonesas 
senão levar o terror e o medo a seus adversários?

Os fenômenos naturais sempre assustaram os homens desde antes da criação do $\lambda o ́ \gamma o \varsigma$ - e da formação de sua ratio - como também nas ditas civilizações adiantadas ${ }^{236}$, quando se buscava explicá-los como forma da revelação ou da ira divinas, criando-se, destarte, todo um mundo mítico para que pudessem, se não compreendê-los, saber porque temê-los.

Com a invenção do canhão, o homem conseguiu criar uma arma mortífera a cujo poder de destruição acrescentava-se algo: o estrondo divino do trovão. Gryphius mostra-nos que, apesar de o toque da trombeta anunciar a iminente destruição, ouvia-se também die donnerende Carthaun [o canhão troante].

Um fato curioso chama-nos a atenção em relação a essa peça de artilharia que é o de os primeiros canhões de bronze terem sidos produzidos por sineiros,

únicos artesãos que sabiam moldar metal em fôrmas grandes (técnica desenvolvida no século VIII), até que, no século XVI começaram as experiências com ferro fundido. (Keegan, 2006, p. 398)

Eram os mesmos sineiros que fabricavam sinos para as igrejas, cuja tradição remonta à Igreja catacumbática - feitos de prata e, evidentemente, com um tamanho menor (Cf.: Biedermann, 1998, p. 408) -, e que, durante grande parte do medievo, orientou a vida das comunidades cristãs: chamandoos à missa, soando alarmes, lamentando as pestes, acompanhando os féretros.

Dessa forma, o eu lírico mostra-nos como o humano interfere no divino: o homem quer também ser deus, usa dos artifícios da divindade para dominar e conquistar - não se contenta apenas com o fogo dado por Prometeu, quer ir além. Adquire para si o poder do trovão e do raio, a luz que voa com sua bola de fogo: eis que as tropas estão chegando como Deus outrora:

\footnotetext{
${ }^{236}$ Segundo, é claro, os padrões preconceituosos de nossa sociedade, visto que não deveria haver a elevação de cultura em detrimento de outra, daí chamarmos uma de primitiva (inferior) e outra civilizada (superior).
} 
O trovão anuncia a chegada dele, e a sua ira se acende contra a injustiça. Ao ver tudo isso, o meu coração treme e salta fora do peito. Atenção! Ouçam o trovão de sua voz e o estrondo que sai de sua boca. Seu relâmpago brilha do céu, atingindo a extremidade da terra. Depois dele, sua voz estronda, ribombando com fragor majestoso. Nada detém os seus raios, depois que se ouve o seu trovão. (Jó 36, 33 e $37,1-4)$

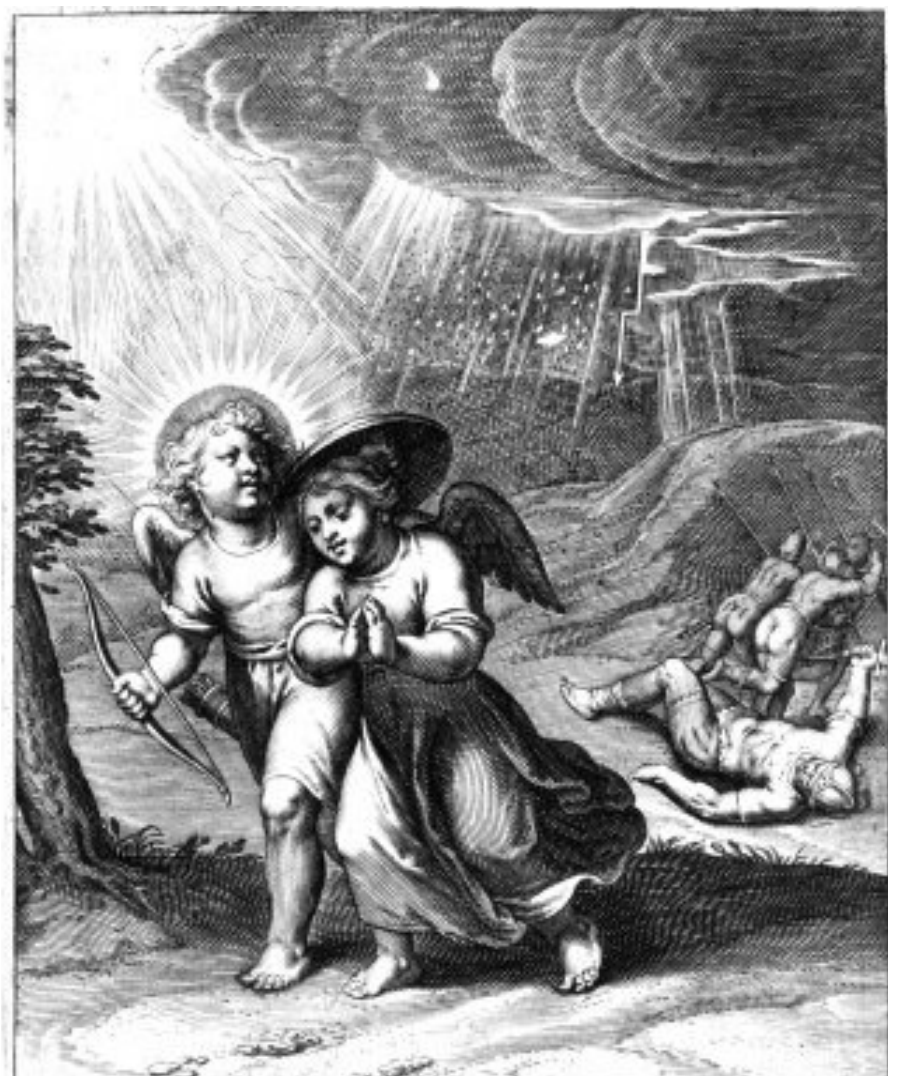

Figura 72, emblema 21 A malu tuetur, de Otto Vaenius, 1615.

Mas, à diferença do homem, a cuja chegada trará morte a justos e injustos, a bons e maus, o Amor divino vem aplacar a sede por justiça em meio às injustiças: eis que o eu lírico sabe disso, acredita nisso. Pouco importa se donnern traz junto a si os raios da luz da morte vindas por mãos humanas, o braço do Amor divino o protegerá:

Ele livrará você do laço do caçador, e da peste destruidora. Ele o cobrirá com suas penas, e debaixo de suas asas você se

refugiará. O braço dele é escudo e armadura. (SI 91,4)

É exatamente disso que trata a alma do emblema 21 de Vaenius $A$ malo tuetur [O Amor nos protege do mal] (fig. 72), ou seja, o eu lírico mostra-se confiante no Amor divino e sabe que pouco a pouco seus inimigos cairão, que o mal não triunfará apesar do trovão artificial do homem e de seu efeito mortífero. Ele sabe que o fogo que avançará não será mais o das bombas que cospem a morte com seu fogo (foto 15), nem mesmo o fio da espada com seu aço frio, mas o próprio Javé que o libertará: 
Trevas e nuvens o envolvem, Justiça e Direito sustentam o seu trono. À frente dele avança um fogo, devorando seus inimigos ao redor. Seus relâmpagos deslumbram o mundo, e, ao vê-los, a terra estremece. (SI 97 2-4)

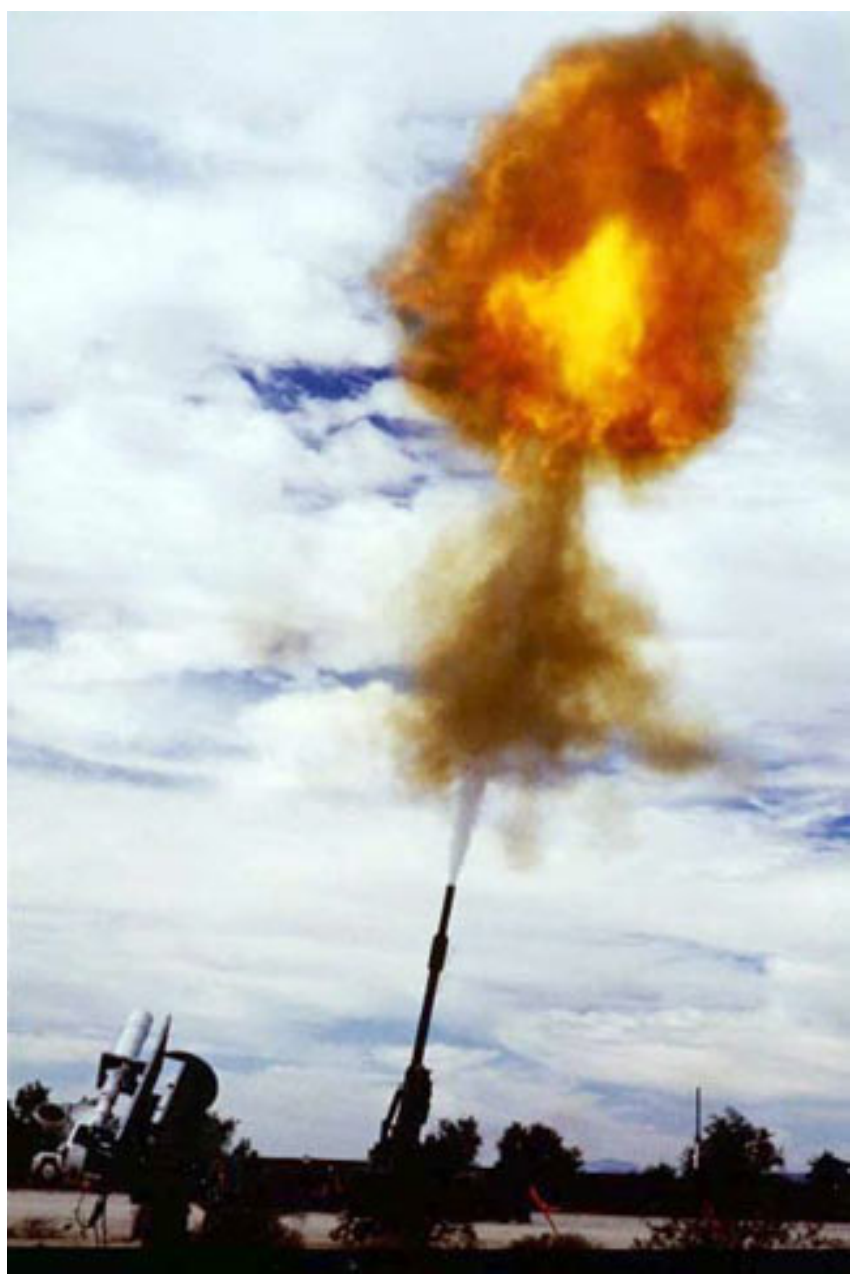

Foto 16. Teste do exército americano,

Legenda original: The U.S. Army tested ammunition during World War II, Korea, Vietnam, and the Persian Gulf War, retirado de www.jpgheritage.org
Nós, ao vermos a imagem expressa pelo eu lírico no segundo hemistíquio, die donnerende Carthaun, somos levados a uma leitura iconofotológica semelhante à da fotografia 15, quando vemos soldados disparando contra posições inimigas, mas tendo de fechar as orelhas para suportar o estrondo a seguir. Algo parecido ocorre, quando na iminência de uma tempestade vemos um raio cruzar o céu e aguardamos o trovão em seguida. O punctum que nos chama a atenção é o fato de o soldado mais próximo não estar tapando as orelhas como os outros. Será que já

está surdo, ou não se importa com mais nada? Provavelmente, não quer mais se importar com nada, ignora, inclusive, a presença do fotógrafo ali, sequer se vira para participar com os outros da tomada. Por outro lado, se atentarmos um pouco mais à leitura da fotografia, veremos que dois dos soldados olham para o fotógrafo como se fizessem pose, ou estão na iminência de que se concretizasse a explosão, cujo estrondo deve ser não só ensudercedor como também enlouquecedor. O interessante é que insistem em manter os olhos abertos para fazerem-se ver pelo fotógrafo: insistem em participar da ação, querem perpetuar-se naquele que pode ser o último ato de suas vidas: não, 
não nos é possível enxergar nada de divino ou de salvífico em meio a esse donnern, os soldados sabem que enviam projetis e fogo para um lado e podem receber os mesmos do outro.

A única certeza que se tem diante de canhões, espadas, trombeta e

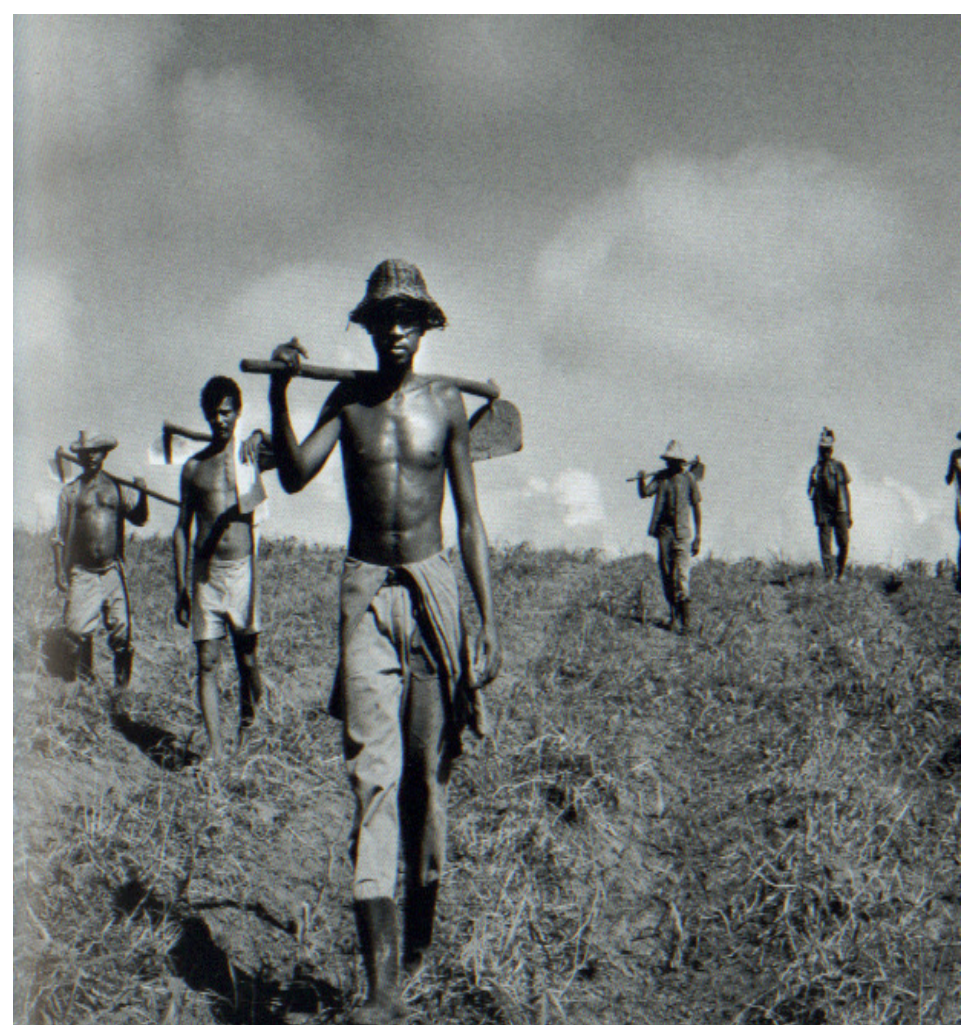

schweis

Foto 17. Salgado, p. 303 (fotógrafo Sebastião Salgado).

Legenda original: Camponeses voltando do trabalho no assentamento de Santa Clara, em Sergipe, Nordeste do Brasil. Sergipe, Brasil, 1996.

turba é dada pelo próprio eu lírico, pois cada um desses elementos Hatt aller Schweis und fleis und vorraht auff gezehret [consumiu todo suor e esforço e provisões]. Vemos a bela fotografia de Sebastião Salgado que nos mostra trabalhadores voltando de sua labuta no campo trazendo sua dignidade às costas representada pela enxada e pelas camisas presas à cintura. Vemos o suor como algo que dignifica o homem, pouco importa qual atividade esse exerça, apesar de ainda se encontrar, em nossa sociedade, o depreciamento de determinadas atividades como sendo inferiores. Tal concepção advém da formação de nossa base social calcada na escravidão, quando o simples ato de carregar um pacote era depreciativo. É, exatamente, sob esse ângulo que temos também de ler os Seiscentos e toda a concepção aristocrática que nele está envolvido.

Não devemos esquecer que o texto poético de que tratamos pertence ao século XVII, portanto essa pseudo beleza advinda do trabalho braçal não era vista como algo tão digno e construtivo para a vida humana, pelo menos segundo a visão aristocrática de mundo, refletida no desprezo que essa classe 
social nutria tanto pelas classes dominadas quanto pela própria burguesia. $\mathrm{O}$ trabalho não era visto como algo que desse bem-estar ou dignidade ao homem, mas em sua acepção etimológica - tripallium: instrumento com que se castigavam os escravos no Império Romano -, ou seja, como algo negativo à qual algumas pessoas foram condenadas e que recaía sobre os menos favorecidos pela sorte.

Talvez essa idéia pudesse ser reflexo da expulsão do homem do Paraíso e sua conseqüente condenação, após seu ato de desobediência:

Você comerá seu pão com o suor do seu rosto, até que volte para a terra, pois dela foi tirado. Você é pó, e ao pó voltará. $(\mathrm{Gn} 3,19)$

Algo como uma predestinação: de um lado, os justos e escolhidos por Deus para serem os que guiam o povo - logo não tinham de suar, de penar, enfim trabalhar -; de outro,

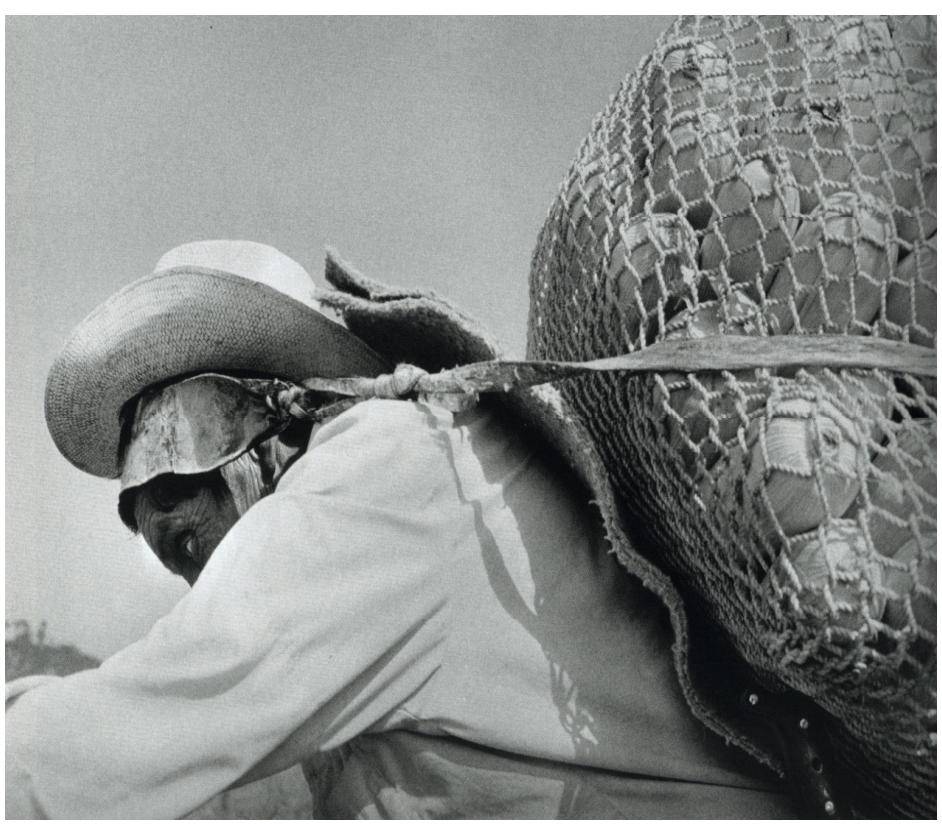

fleis

Foto 18. (Ibidem, p. 282, foto de Sebastião Salgado).

Legenda original: Colheita de milho em Santa Rita, antiga fazenda particular de 6 mil hectares que em 1994 foi ocupada por trabalhadores rurais de San Miguel, comunidade próxima da floresta de Lacandón. $O$ milho é o alimento básico em todo o México. Aqui, parte da colheita era reservada para o consumo dos trabalhadores da fazenda e suas famílias, e o excedente vendido nas aldeias vizinhas. Chiapas, México, 1998 aqueles que tinham de pagar pelo fato de não terem nascido em uma família nobre - tinham de perpetuar a condenação dada ao homem quando de sua expulsão do Paraíso. Apesar disso, ao pobre era-lhe ensinado que, apesar da dureza que o trabalho se lhe imputava, esse lhe serviria como meio para sua salvação futura, revestindo-se, portanto, de satisfação.

Evidentemente, que o mesmo pode ser dito a respeito de fleis [esforço], já que esse pressupõe trabalho por parte daquele que almeja algo e tem de lutar por isso. Etimologicamente, esse era uma das acepções da palavra em alemão que para nós, em português, segundo o Houaiss (2007) significa intensificação das forças físicas, intelectuais ou morais para a realização de 
algum projeto ou tarefa; aquilo que se faz com dificuldade e empenho; trabalho, empreendimento, obra.

Se tomarmos, por exemplo, um emblema do século XVII com características parecidas à foto de Sebastião Salgado (foto 18), veremos que a

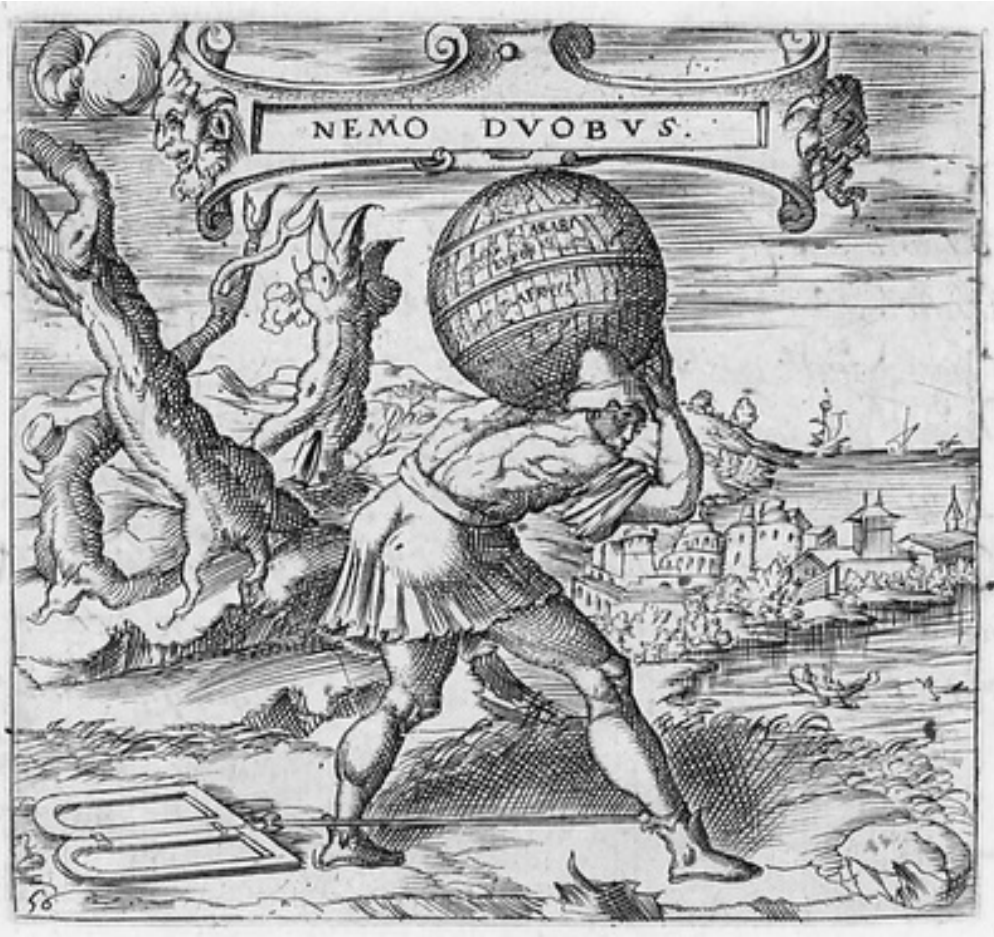

Figura 73: Emblema 56 Nemo Duobus, de Georgette de Montenay/Anna Roemer Visscher, 1615. acepção que aqueles intelectuais possuíam da noção que temos de esforço, não condiz com aquela que temos, ou que podemos ler em suas imagens. Georgette de Montenay, em seu emblema 56 (fig.: 73), mostra-nos um homem, à semelhança de Atlas, que carrega algo semelhante a um globo em suas costas $e$, amarrado a seus pés, arrast as tábuas da Lei. A inscriptio, porém, mostra-nos o que a emblemista quer transmitir-nos: Nemo duobus [ninguém pode servir a dois senhores], mote bíblico retirado do Evangelho de Mateus:

Ninguém pode servir a dois senhores. Porque, ou odiará a um e amará a outro, ou será fiel a um e desprezará o outro. Vocês não podem servir a Deus e às riquezas. (Mt 6, 24)

Vê-se, portanto, que a imagem representa apenas conceitos morais e religiosos, não o valor do esforço e do trabalho como se poderia supor ou, inclusive, relacionar com a fotografia de Sebastião Salgado. $O$ homem que carrega o mundo, seus encantos e suas virtudes - representados pelo globo terrestre às costas - sente a Lei e os preceitos religiosos - representados pelas tábuas amarradas aos pés - um fardo, mas que se tem de carregar. 
No primeiro dístico da segunda estrofe do soneto, o eu lírico nos aponta para três imagens que evocam importantes aspectos da sociedade dos Seiscentos e que acabam possuindo relações entre si: Kirch [igreja], Rathhaus [prefeitura], Turm [torre]. Se, por um lado, a igreja é o centro do poder espiritual, temos na prefeitura o centro do poder temporal local; em ambos externamente -, fazendo parte de sua construção, encontramos a torre.

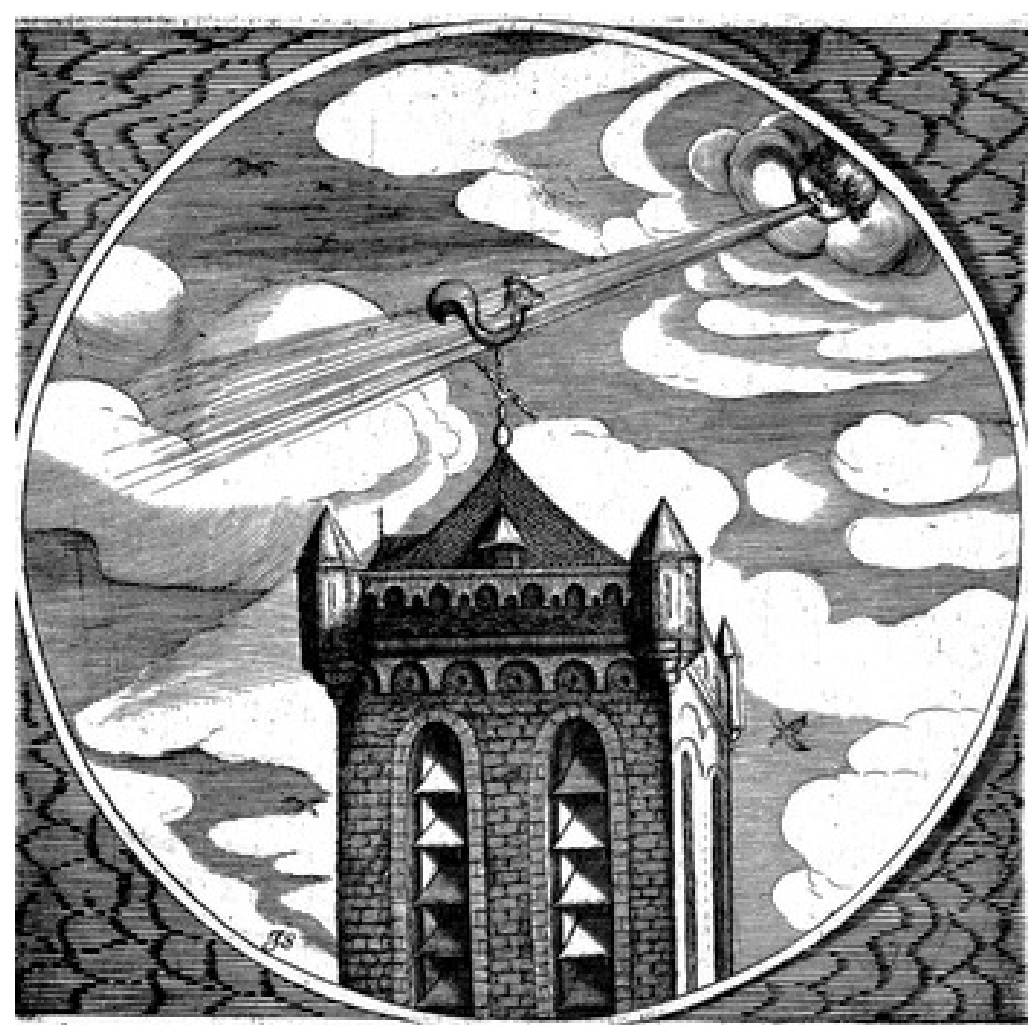

Figura 74: Emblema 29 Domine, quo me vocat, aura, de Jacob Cats, 1627.

Esta pode ser vista como uma forma de se alcançar a Deus - devido a sua busca contínua pela altura -, quando se corrobora a glória e o poder divinos; por outro lado, também poderia ser uma afronta ao divino, quando 0 homem quer fazer-se deus - representado pela mítica Torre de

Babel. Devido à imponência de suas formas externas, a torre também pode demonstrar esplendor, domínio e poder de um cardeal ou príncipe, os quais se compraziam em exteriorizá-los em seus palácios e catedrais. Assim, o poder e a glória do senhor que tem domínio sobre o burgo ou a cidade também poderiam ser representados pela torre, já que essa resguardava seu poder, ao propiciar um posto de vigilância avançado e ser instalada em pontos-chave para a defesa em caso de ataques; além disso, também poderiam ser lançados dentro de suas paredes aqueles que eram considerados inimigos do Estado como na Bastilha na França. A partir dessa idéia, poderíamos ver a torre tanto como uma metonímia para Igreja 
quanto para Estado, representando tanto o poder espiritual quanto o temporal; a igreja e o palácio.

Há também, na emblemática, uma acepção que, muitas vezes, nos remete à torre: a indicação da direção e do caminho que se deveria ou não seguir, quando vemos sobre seu telhado um cata-vento - a figura de um animal, um galo, por exemplo - que nos mostra a direção do vento. Essa representação, contudo, quer 75). em suas estruturas inabaláveis. demonstrar-nos a inconstância do amor humano que, muitas vezes, deixa-se levar por idéias novas (fig.

Convém salientar que a torre também transmitia a idéia da firmeza e da segurança (fig. 74), pois mesmo assolada por tempestades e ventos, não se deixaria abalar, desde que, solidamente, construída. Dessa forma deveriam ser a alma e o caráter humanos: sólidos, firmes e seguros, para que, diante das transformações e mudanças mantivessem-se seguros

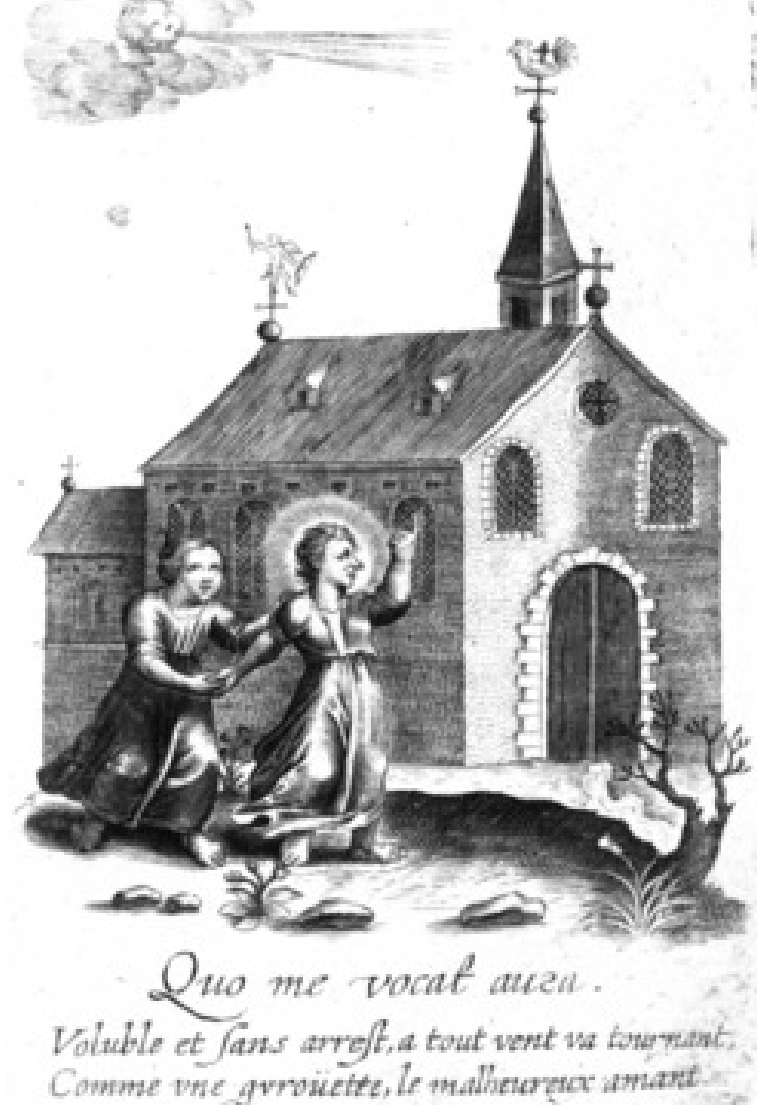

Quando o eu lírico, em Tränen Figura 75: Emblema 39 Inconstancia amoris, de Ludovicus van Leuven, 1629.

des Vaterlandes mostra-nos que as

torres estão em brasas, vê-se que a firmeza e sua solidez, enquanto representação de instituições sólidas, foram quebradas, abalaram-se não só os poderes temporal ou espiritual como também a própria constância e firmeza da alma humana. Diante desse abalo, têm de ser purificados pelo fogo, daí o fato de estarem em brasa, purgando-se - tema fartamente explorado na Bíblia:

Ainda que me sondes o coração, e de noite o examines; ainda que me proves com o fogo (SI 17, 3);

(...) porque o ouro é provado no fogo e as pessoas escolhidas, no forno da humilhação. (Eclo 2, 5). 
Hoje, ao lermos essa imagem poética, vem-nos à mente, seguramente, a imagem das torres gêmeas do World Trade Center de Nova lorque, afinal a palavra Turm [torre] para nós não tem a mesma representação daquela que tem para alguém que mora em pequenas cidades européias medievais que são

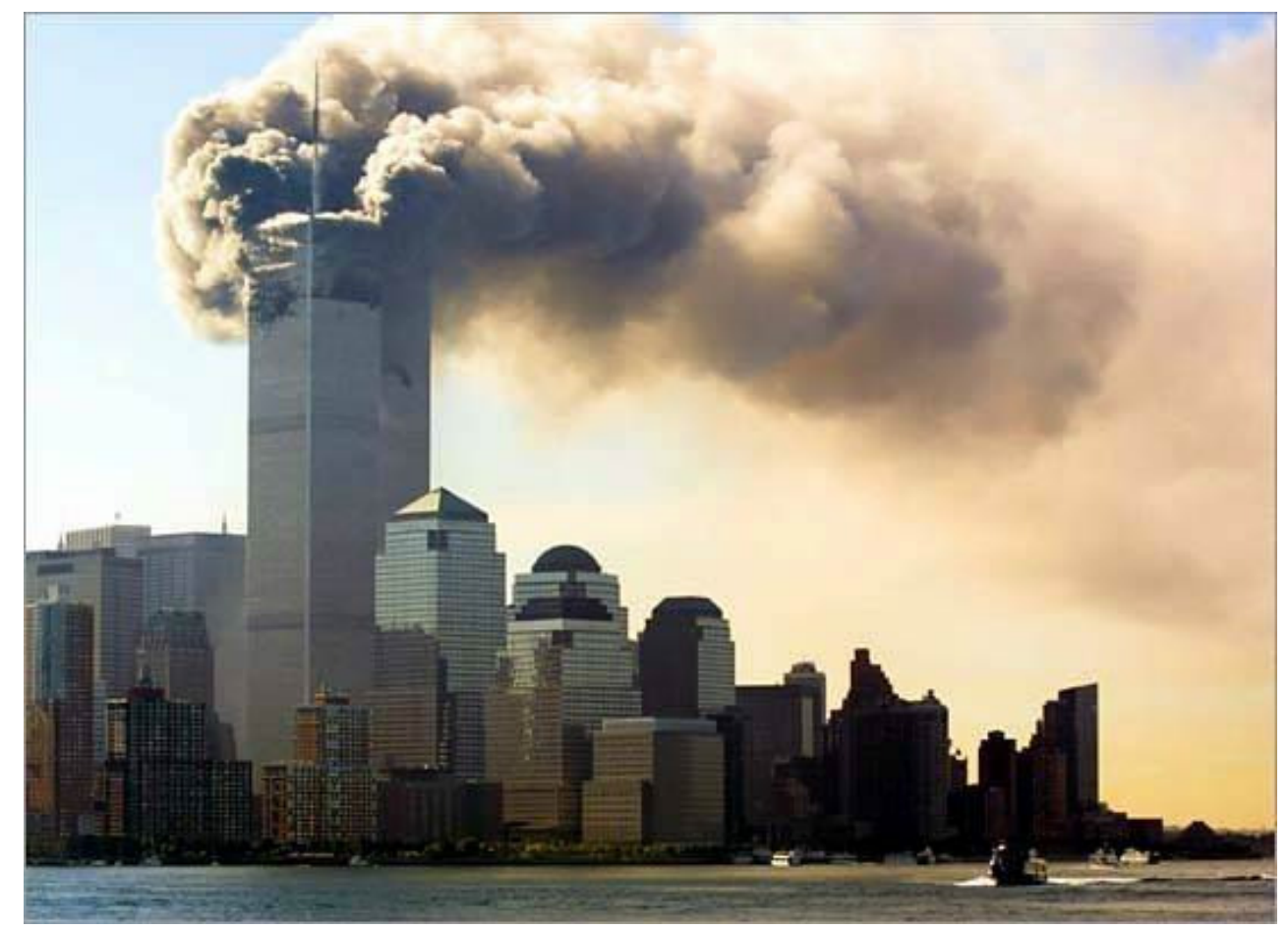

Die Türme stehn in glutt (a)

Foto 19: Atentado ao World Trade Center, em Nova York, 15/09/2001 (não foi possível determinar o fotógrafo)

cercadas por muralhas com suas torres de vigilância. No máximo, lembraríamos das torres de antigas igrejas. No entanto, após o fatídico 11 de setembro de 2001, fomos bombardeados à exaustão pela mídia com imagens das torres gêmeas em chamas sob vários ângulos (fotografia 19).

Que representa, afinal, a cena do choque dos aviões contra os prédios do WTC senão o abalo tanto do poder temporal - representado pelo domínio e status da nação mais poderosa da Terra, centro financeiro do mundo capitalista com seus 110 andares e com quase $527 \mathrm{~m}$ de altura ${ }^{237}$ (algo inimaginável sequer para a mítica Torre de Babel), quanto do espiritual - representado pela crença dos terroristas partícipes daquela hecatombe de que foram mártires em sua Guerra Santa contra o grande Satã, representado pelos EUA.

${ }^{237}$ Exatos 526, $3 \mathrm{~m}$ até o final de uma antena instalada em uma das torres. 
Eis que as imagens construídas por Gryphius são, para nós, totalmente transitivas, é possível vê-las claramente, mas não com sua idéia original, já que a refração diacrônica impossibilita-nos, modificando sua significação em cada

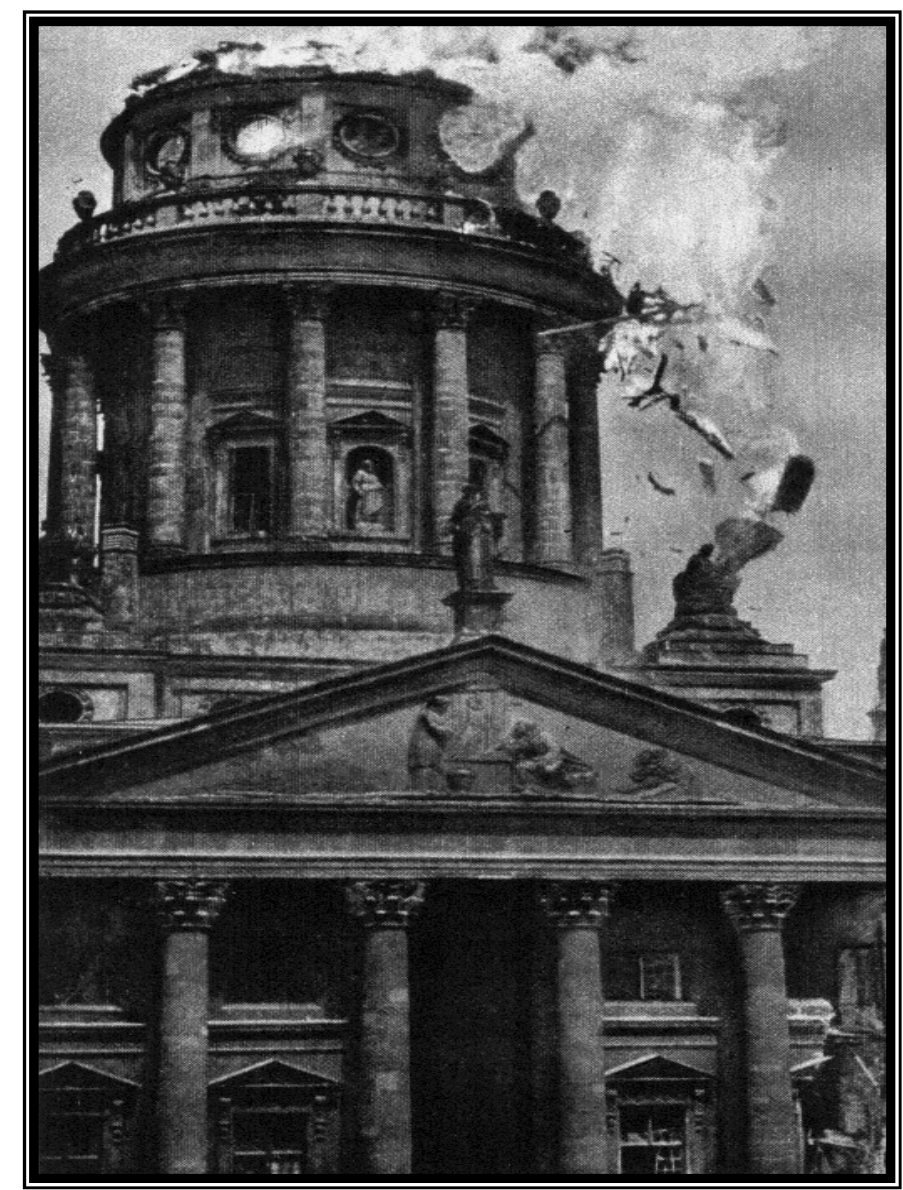

Die Türme stehn in glutt (b)

Foto 20. A Segunda Guerra Mundial (vol.10), 1966, p. 236 Legenda original: No coração da Alemanha, os incêndios provocados pelos bombardeios destroem edifícios de grande valor, juntamente com bairros residenciais e zonas fabris. momento particular em que é lida no decorrer da História. No período do pós Segunda Guerra Mundial, poder-se-ia fazer, por exemplo, uma possível leitura iconofotológica do hemistíquio conforme 0 visto na foto 207 , ou seja, teríamos de resgatar uma outra imagem de um momento próximo temporalmente. É possível exemplificar isso, utilizando ainda a imagem da torre, pois se o texto de Gryphius fosse, por exemplo, lido em meados do século XX, evidentemente, a imagem do WTC em chamas não teria sido utilizada como modelo iconofotológico devido a seu anacronismo (sua inauguração foi em 1971); poderíamos, hipoteticamente, deslocar essa imagem para o Empire State Building, cuja construção se deu em 1931. Mas, nesse deslocamento hipotético ainda restaria uma pergunta: como acreditar que os EUA seriam tão duramente atingidos em seu solo se conseguiram vencer o Eixo, tornando-se uma superpotência, sem nunca travar uma batalha em seu solo? Eis o elo de que necessitamos para identificar a idéia de Gryphius: a torre em brasas representa o poder que é atingido em sua base, sem uma preparação prévia e quebrando a base estável em que estava inserida a sociedade seiscentista, cuja representação era dada pela torre. $O$ poeta alemão já demonstrara algo parecido, quando escrevera a tragédia 
Ermordete Majestät oder Carolus Stuardus (1649), sob o impacto causado pela execução do rei inglês Carlos I, quando demonstrou toda sua indignação pelo ato $^{238}$, e que se verificaria, também de modo assustador, durante a Revolução Francesa, quando os nobres europeus viram que suas Casas poderiam ruir à semelhança do que ocorrera com Luís XVI e Maria Antonieta.

Guardadas as devidas proporções, tal comoção verificou-se quando da destruição das torres gêmeas e o emprego político que se fez dela por autoridades estadunidenses, quando não só ruíram as paredes e a estrutura de aço daquilo que parecia ser indestrutível,

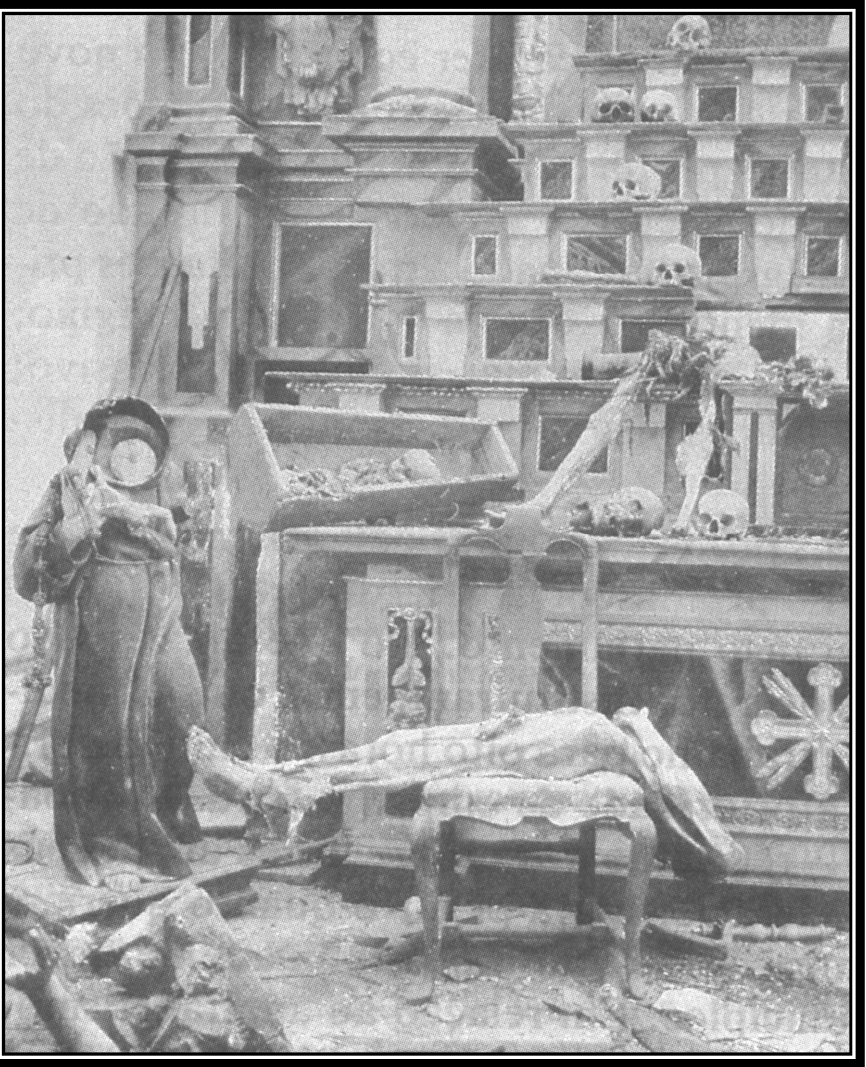
Die die Kirch ist umbgekehret.

como também aquilo que acreditávamos ser a base de

Foto 21: BEIGUELMAN-MESSINA 1994, p 30 (O fotógrafo não é citado). Legenda original: Saque e profanação de igreja e campo santo. A identificação da Igreja com o Estado oligárquico espanhol fez com que uma das marcas da violência da Guerra Civil fosse a queima e a destruição dos espaços que a simbolizavam.

\footnotetext{
${ }^{238}$ Trauerspiel escrita poucos dias após a execução do rei inglês, ocorrida em 30 de janeiro de 1649, por um Gryphius profundamente consternado pela execução do rei. Devido à rapidez com que elaborou a trama, o enredo não foi um dos melhores que o autor escrevera até aquele momento. Não se deve esquecer de que essa consternação de Gryphius é reflexo da base ideológica do Seiscentismo, que era absolutista, acreditava na origem do poder divino do rei característica marcante, principalmente, dos estados protestantes - e por isso na limitação da soberania popular. O crime de lesa-majestade era visto como um dos mais abomináveis que existiam, pois era o mesmo que atentar contra a pessoa de Deus, de quem o soberano era um espelho. (Brandão, 2001, p. 61) Heinrich Hildebrandt - quem melhor explanou o pensamento político de Gryphius, segundo Mauser - nos diz: Aufruhr und Königmord zerstören die Fundamente staatlichen Lebens, heben die menschlische Gemeinschaft auf und stürzen das Reich in ein heilloses Chaos. (MAUSER, 1976, p. 13) [Revolução e regicídio destroem os fundamentos da vida do estado, anulam a sociedade humana e viram o reino num caos sem salvação.]
} 
nossa segurança e liberdades individuais, devido ao crescente terrorismo por parte dos fundamentalistas islâmicos e do governo estadunidense em sua guerra contra o terror.

O mesmo serve para o segundo hemistíquio: die Kirch ist umbgekehret [a igreja está invertida]. Seguramente, Gryphius não estava preocupado em nos mostrar que a igreja - o templo enquanto estrutura material - estivesse revolvida, destruída, de pernas para $o$ ar, mas que a Instituição sofrera ela mesma um abalo, mais moral que material.

A imagem empregada pelo eu lírico nos faz remeter a uma fotografia, em que nos é mostrada a profanação de igrejas e cemitérios em plena Guerra Civil Espanhola (foto 21), quando se vêem, mais do que imagens sacras destruídas e bancos queimados, cadáveres de religiosos enterrados no local, mas que foram vilipendiados pelos republicanos. É possível ver na foto, em primeiro plano, o corpo de um religioso ainda não totalmente descarnado, além de vários esqueletos à semelhança de um quadro barroco que retratasse a vanitas. Algo, além de macabro, que envolve essa foto é o fato de tais atos terem sido praticados por cristãos $^{239}$ - pelo menos estavam inseridos dentro de uma sociedade e tradição cristãs -, não por terroristas islâmicos.

Mais uma vez, vê-se que o embate deveu-se a fatores de ordem política, quando nacionalistas - de direita e apoiados por Hitler, Mussolini e Salazar -, liderados por Franco, tentavam manter o controle do país, e enfrentavam os republicanos - que detinham o apoio da antiga União Soviética, logo de Stálin -, os quais queriam retirar a Espanha do atraso em que se encontrava e cujos fatores eram sua sociedade agrária, o obscurantismo da Igreja católica e o Exército. Die Kirch ist umbgekehret pode ser, portanto, inserida dentro do contexto da guerra civil espanhola como demonstrado pela fotografia, pois, mais do que uma mera destruição do templo, solidificadamente construído, vêse a destruição de relações arraigadas não só na religião, mas em toda a sociedade que não queria modernizar-se.

Diante do caos instalado, não bastou aos poderosos seu poder; nem mesmo a padres, freiras, sua fé; ou armas aos militares, já que todos esses eram sumariamente assassinados pelas milícias de esquerda, da mesma forma

239 Já que eram, em sua maioria, espanhóis, além do auxílio das Brigadas Internacionais (estrangeiros voluntários que lutaram ao lado dos republicanos). 
que professores, sindicalistas e intelectuais - Federico García Lorca, por exemplo - não foram poupados pelas forças nacionalistas.

Se se destróem os valores ditos morais e éticos de uma sociedade, essa perde sua identidade e sente-se acéfala. Dessa forma, não há mais valores para serem respeitados, não há mais autoridade digna de crédito, nem líderes a serem seguidos. Isso é representado no soneto Tränen des Vaterlandes pelo hemistíquio Das Rathaus ligt im graus [a prefeitura, a casa do conselho - local onde se reúne os membros do poder temporal - está em chamas], metonímia que demonstra que 0 poder temporal também fora abalado juntamente com o espiritural, representado pela igrejatemplo.

Um exemplo iconofotológico é 0 da fotografia 22 , quando se vê um soldado alemão diante do Reichstag. A foto é muito expressiva e impele-nos, inclusive, a vê-la como uma montagem. Há dois fatos que nos chamam a atenção:

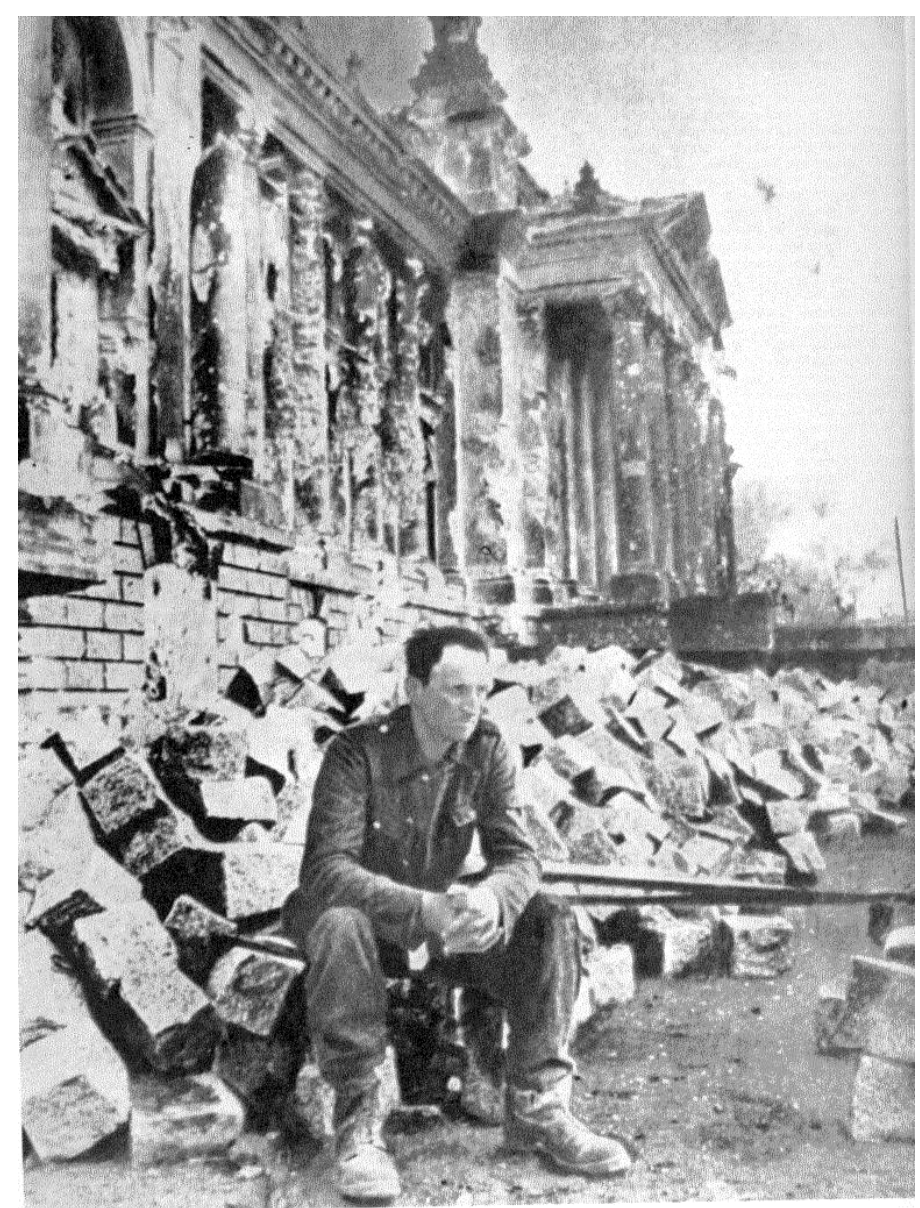

Das Rathaus ligt im graus

Foto 22: FÄRBER, 1990, p. 580 (O fotógrafo não é citado). Legenda original: Ein deustscher Soldat Überlebender der Schlacht in Berlin vor der Ruine des Reichstagsgebäudes.

a) o fato de as paredes do prédio estarem totalmente alvejadas por vários tiros, além de uma grande quantidade de pedras - como paralelepípedos - estar diante do prédio. Eis que o studium põe-se em ação, já que elas não parecem terem sido resultado dos bombardeiros: estão muito simétricas para isso. Terão sido utilizadas em barricadas para defender o prédio? Ou foram colocadas lá para algum propósito? 
b) o outro é o fato de um soldado alemãoficar, desarmado, diante do prédio numa iminente (ou concretizada) derrota, sabendo que os aliados estavam próximos e que poderia ser alvejado por tiros.

Eis que o verso de Gryphius salta, transitivamente, para além da moldura do soneto em que está inserido e se mostra também nessa foto. $O$ Reichstag era o símbolo da Alemanha moderna e democrática, foi por meio dele que Hitler sobe ao poder, pois após a tentativa inóqua do Putsch (1924) havia prometido que ascenderia ao poder via democracia, pelo voto. Ao conquistar a Chancelaria, um acontecimento foi o estopim para sua perseguição a seus principais inimigos, os comunistas: o incêndio do mesmo Reichstag. Aproveita-se do fato para ganhar poderes ilimitados e perseguir os inimigos do Estado e impor-se diante de sua sociedade.

Alguns anos depois, todo o esplendor de seu poder, de suas vitórias fulminantes sind zerhawn [foram despedaçadas, cortadas em pequenos pedaços], como as pedras diante do Reichstag, como na cena de um soldado desolado, observando que die donnernde Carthaun Hatt aller Schweis/ und fleis/ und vorraht auff gezehret [o troante canhão alimentou-se de todo suor, esforço e provisões]: o soldado representa exatamente isso os fortes foram destruídos, não thes resta mais nada a fazer que abaixar a cabeça e ver-se diante do palco que havia sido o orgulho da Pátria, seu fictício Parlamento. Seguramente, essa foto foi montada pelas tropas de ocupação, afinal representa muito. Um soldado não ficaria posando para fotos diante do caos instalado nos momentos finais da guerra, a não ser que fosse obrigado a isso: Dem deutschen Volk [Ao povo alemão] restaria isso: escombros.

O eu lírico de Tränen des Vaterlandes continua sua construção imagética e mostra-nos agora virgens estupradas - Die Jungfrawn sindt geschändt [As virgens são violadas] diante do caos instalado. Mais uma vez, a imagem evocada deve ser lida dentro de um contexto maior. A virgindade é uma tradição do cristianismo desde seus primórdios, quando garotas ofereciam-na a Jesus, imitando sua mãe, Maria. No entanto, não fora a religião cristã que criara a consagração das virgens, isso remonta à Antigüidade, talvez 
uma referência às vestais, sacerdotisas do culto de Vesta (Héstia para os gregos), deusa romana do lar.

Eram escolhidas entre as principais famílias romanas e encarregadas de uma das mais altas, nobres e importantes funções de Roma: a conservação do fogo sagrado. Possuíam tanto prestígio entre os romanos que, em assuntos de justiça, sua palavra era por si só digna de todo crédito. Eram iniciadas por volta dos seis a dez anos, tinham de manterem-se virgens e castas até os trinta anos e se violassem o voto de castidade, eram enterradas vivas. Haveria nesse caso, a quebra do pacto divino, pois aquelas que deveriam velar pela paz nos lares e ser as intermediárias entre o povo e a deusa foram violadas: é como se a chama inextinguível, que representava a vida e era protegida pelas vestais, houvesse também sido lançada para as torres pelo furor dos deuses, afinal Die Turme stehn in glutt.

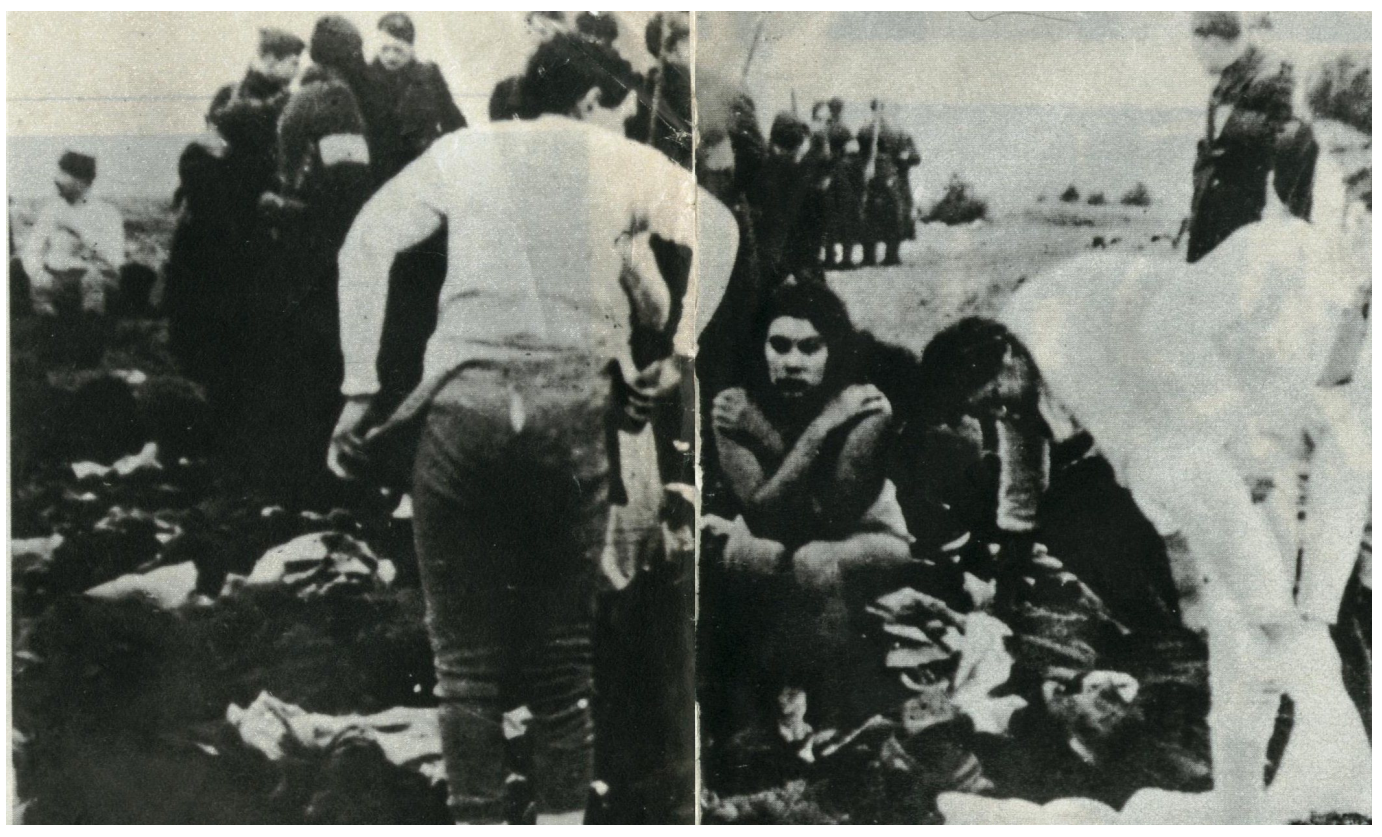

Die Jungfrawn sindt geschändt

Foto 23: Revista Der Spiegel, Nr.39/1988, p.158.

Legenda original: Entkleidung jüdischer Frauen vor einem Mordkommando (...)

Dificilmente encontraríamos fotos de estupro, nem seria nossa intenção, apesar de havermos uma referência iconofotológica veiculada na imprensa, durante a guerra de Kossovo. Essa mostrava mulheres em campos de refugiados da antiga lugoslávia chorando por terem sido violentadas por vários soldados sérvios, a fim de manchar seu sangue kosovar. No entanto, há uma fotografia que mesmo não tratando do tema, remete-nos a ele indiretamente, 
pois trata daquilo que o estupro tem de mais pernicioso: a violação não só da integridade física do ser humano enquanto ser único e com direito a privacidade, como também da violação da própria vida de forma humilhante.

À semelhança de um estupro, a mulher vê-se obrigada a despojar-se de suas roupas para entregar-se a alguém, nesse caso, ao Mordkommando [pelotão de fuzilamento]. A cena que vemos na fotografia 23 revela isso, vêemse vários soldados armados e mulheres que são obrigadas a desnudar-se. Mas para quê? Que passava na cabeça dessas mulheres, vendo-se desveladas diante não do marido, mas de homens desconhecidos e armados dessa forma?

O punctum dessa imagem é a mulher que, estando nua, cobre-se diante do fotógrafo: tenta não deixá-lo invadir sua privacidade, cobre os seios numa atitude pudica, apesar disso vê que não poderá resguardar sua intimidade que está sendo violada, assim como sua honra: que representa esses conceitos senão o sentido etimológico de estupro? Mesmo que alguns possam dizer que se cobre devido ao frio, demonstrado pelos pesados casados exibidos pelos soldados presentes no local. Vêem-se roupas espalhadas pelo chão, a mulher no primeiro plano dá as costas para o fotógrafo, também ela não quer ter sua intimidade velada, ou se envergonha de ter em sua calça de baixo um rasgo que também deixará de ser velado, mas que se revela a todos agora?

Vê-se que os soldados não demonstram nenhum interesse por essas mulheres nuas: conversam entre si, não olham para seus corpos... Não seriam elas atraentes para seus olhos? Não demonstrariam viço e a rigidez decorrente do frio? Não as enxergam como mulheres por um único motivo: são judias, um povo inferior, não digno de atração, muito menos de compaixão.

Despem-se, portanto, não para serem estupradas - algo inconcebível e rechaçado pelo regime nazista, não devido à moral ou à ética, mas porque a pureza do sangue ariano não admitiria manchas desse tipo -, mas para serem executadas diante de um fosso: não basta a morte, tem-se que tê-la por meio da humilhação, da perda da identidade, da humanidade, representada pela extirpação das roupas que temos e que nos cobrem e protegem-nos do mundo externo, tornam-nos individuais e senhores de nossas particularidades.

Eis o estupro levado a mais alta ignomínia, vê-se em seu objeto de desejo, uma forma abjeta, cujo destino é o de perder-se em meio a tantas 
outras pessoas que caíram na vala comum sem direito a identidade alguma: arranca-se a vida humana, antes mesmo que os projetis o façam com o corpo.

Como se não bastassem os poderes espiritual e temporal terem sido subjugados e junto a eles tanto os fortes quanto aos fracos (Die Jungfrawn - a virgens), o eu lírico ainda nos faz olhar em torno, a fim de que possamos enxergar ainda mais a desolação que presencia e com ela sua visão apocalíptica: und wo wir hin nur schawn/lst fewer/ pest/ und todt [e para onde olhamos é fogo, peste e morte].

Vi aparecer um cavalo esverdeado. Seu cavaleiro era a Morte. (...) Deram para ele poder sobre a quarta parte da terra, para que matasse pela espada, pela fome, pela peste e pelas feras da terra. (Ap 6, 2-8)

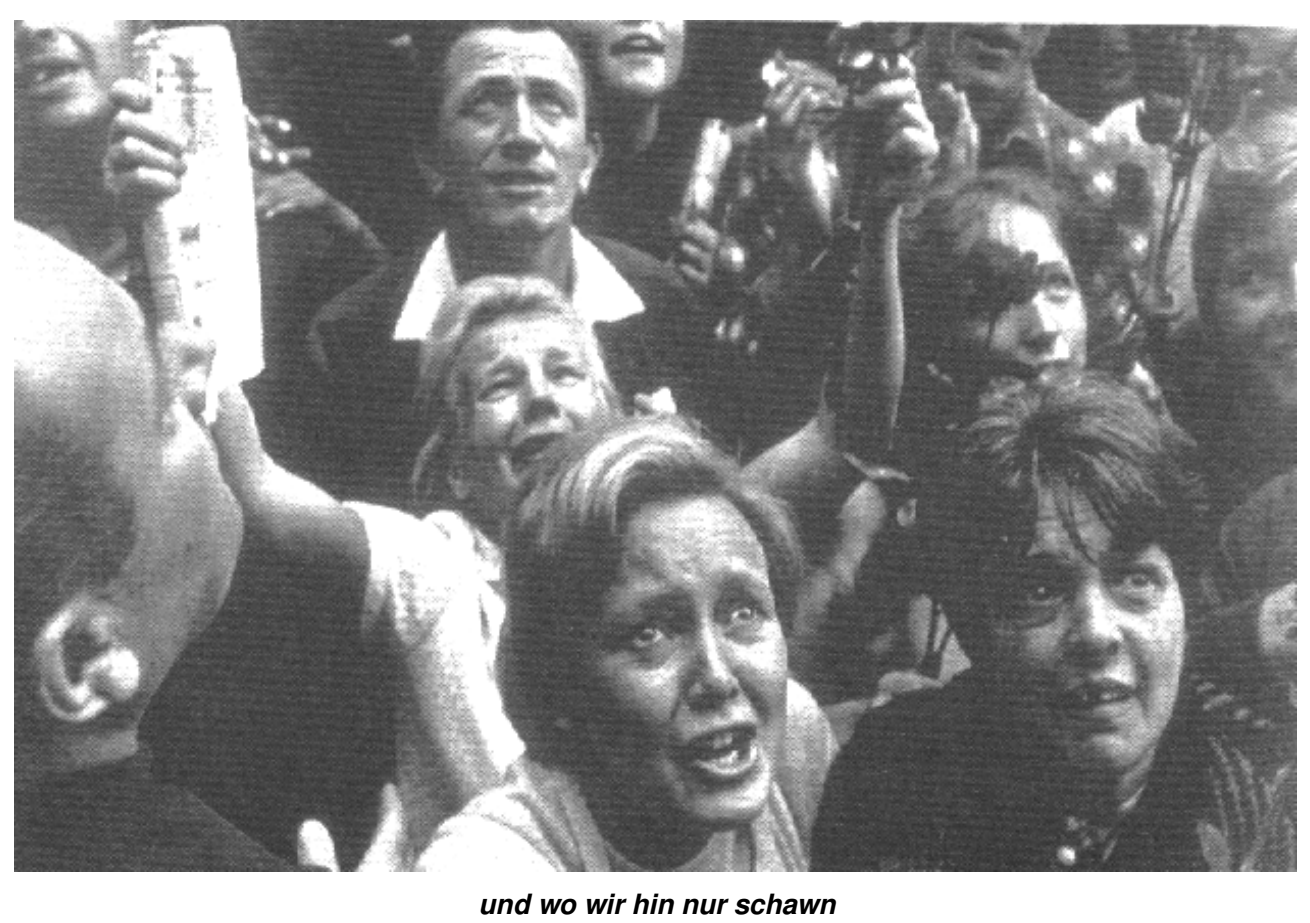

Foto 24: ARBEX JR. 1997, p.102.

Legenda original: Em Praga, jovens estampam nas faces a angústia causada pela invasão de tanques soviéticos, em 1968.

O cavaleiro da morte deixa seu rastro por onde passa - a peste e a morte assolam em todos os locais, não se intimidam frente a títulos, honrarias, família, riqueza ou pobreza: não escolhe ninguém, mas avança sobre todos e ceifa seu bem mais precioso: a vida - e, pior que sua passagem destruidora é o fato de aniquilar também o que antes ainda permanecia: a esperança, 
quando ainda se cria que o pior já havia passado e que a vida restante poderia ser diferente.

É possível sentir isso, quando se vê a fotografia 24, cuja legenda nos mostra que as esperanças (o ato de esperar algo em si) podem ser simplemente destruídas. A Primavera de Praga tornou-se um sonho mais rápido do que as esperanças daquelas pessoas puderam usufruir, pois mal abriram os olhos depois de uma noite de sono, viram diante de suas casas os tanques soviéticos demonstrando que o pesadelo seria muito pior do que o mal que acreditavam tinha se ido: lançam o olhar para suas esperanças destruídas, sentem que seu olhar dirige-se para o fogo que redobra de seus corações e almas partidos.

Eis que a mulher no centro da foto ergue os olhos e braços para os céus e clama para que o pesadelo acabe e que se minimize seus efeitos: para eles as flores nas mãos foram inóquas, fizeram pouco caso das mesmas: romperam-se as esperanças de liberdade, rompeu-se, portanto, o coração, destruiu-se o espírito.

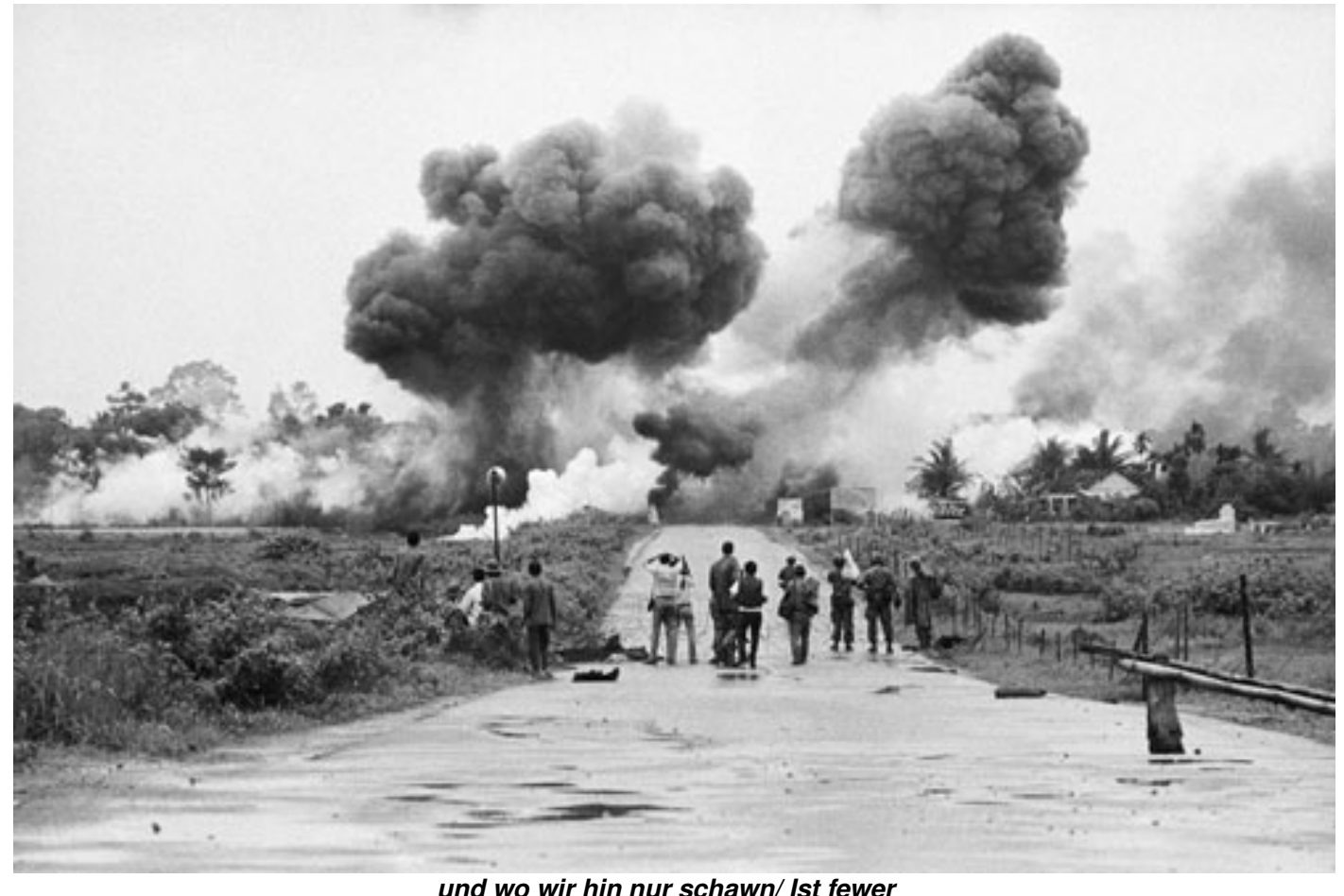

Foto 25 (fotógrafo desconhecido)

Legenda original: Das Bild eines unbekannten Fotografen zeigt die erste Reihe von 12 Reportern, die den Luftangriff auf Trang Bang am 8. Juni 1972 fotografieren. In den nächsten Sekunden gerät ihnen die Gruppe um Kim Phúc in den Blick der Objektive. 
Eis para onde as pessoas estão olhando e para onde o eu lírico nos convida a olhar: para o porvir, por isso os olhares de espanto, de desespero, de riso (como acreditar que o ontem deixou de existir e junto com ele a liberdade que se supunha ter no outro dia?). Aquilo que preocupa o eu lírico na terceira estrofe é o tempo, mas para isso nos mostra o que restou da passagem da Morte por seu meio, além da desesperança: Fewr [fogo], Pest [peste] e a própria personificação da Todt [morte].

Aviões sobrevoam a vila vietnamita de Trang Bang onde, provavelmente, as pessoas já estavam acostumadas a ouvi-los continuamente. $\mathrm{O}$ ano era 1972; o dia, 8 de junho. Acostumados a explosões, não esperavam que do céu caísse algo pior do que as bombas que destroem e matam, conheceram o que era o napalm, ou parafraseando Camões: fogo que arde sem se ver. Não, ele não representava o amor, mas o ódio contra um povo que se mostrava, cada vez mais, difícil de se vencer de forma tradicional.

Vimos, até este momento, várias acepções para fogo empregadas por Gryphius em seu soneto. Poderíamos dizer também que, para nós, também poderíamos ver o fogo de várias maneiras, afinal vários são nosso modelos

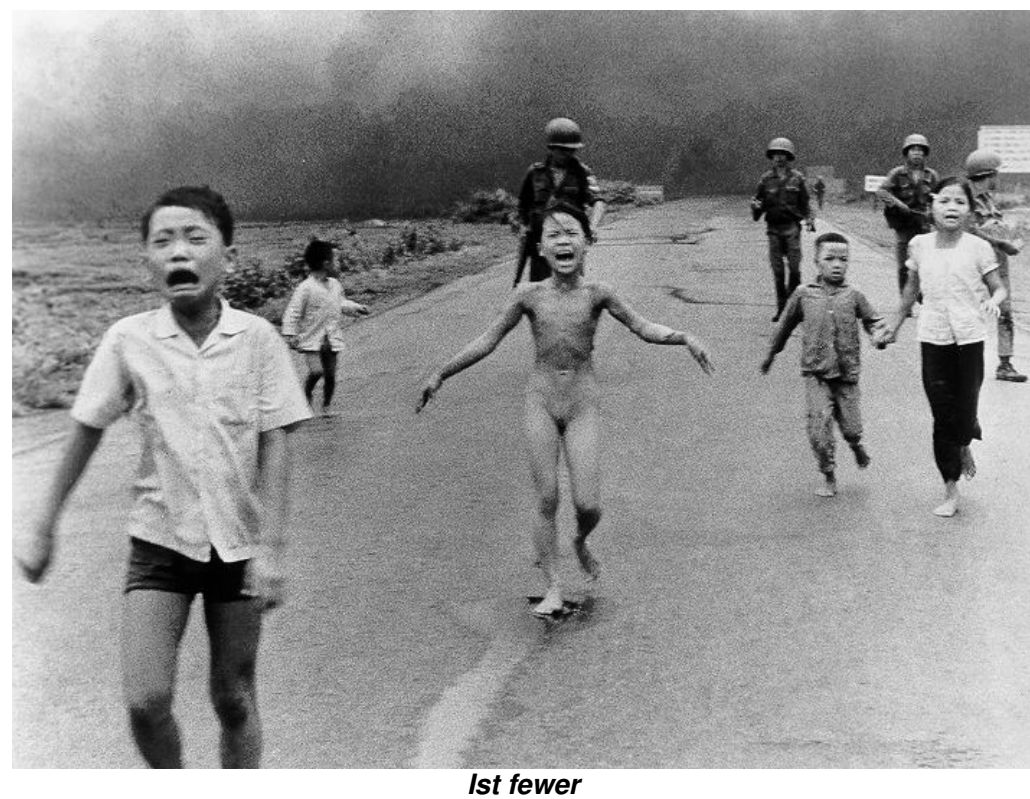

Foto 26: LESTER, 1991, p. 52 (foto de Nick Ut)

Legenda original: Many readers were upset at seeing children run in torment after an accidental napalm attack

iconofotológicos que

nos fazem retomar essa imagem tão comum para nós. Mas, há uma imagem que, dificilmente, as pessoas que tenham vivenciado os últimos anos do século XX não tenham tido contato: a de uma menina correndo, nua, desesperada, gritando e fugindo do horror de ver e sentir na própria pele os efeitos do fogo 
que não se vê mais que se sente (foto 26), já que, uma vez lançado, o agente químico prende-se à pele e não há como fugir dessa insanável dor.

Momentos antes do ataque aéreo, vários fotógrafos posicionavam-se para registrar as cortinas de fumaça e fogo que se elevavam ao céu, quase que, momentaneamente, viam as pessoas correndo de suas casas para fugir do pânico, do caos, da dor. (foto 25)

Gryphius, novamente, dirige-se a nós e aos fotógrafos e diz wo wir hin nur schawn/lst fewer só que com esse olhar vem a dor de saber que lá reside a morte e a peste que os ronda. Nosso olhar se cruza também com o do fotógrafo à semelhança do que víamos com as obras pictóricas miméticas: também nós ficamos esperando para ver o que vai acontecer depois do bombardeio. Sairá alguém da mata? Todos estão lá esperando para ver o que ocorrerá... e, de repente, acontece: crianças correm desesperadas, não há mais como esconder-se. Um fato serve-nos de studium: onde estariam os adultos? Todos mortos, escondidos, com medo de serem capturados? Isso não poderia ficar distante da leitura de Threnen des Vatterlandes, afinal as lágrimas renovam-se nessas crianças assustadas que correm desesperadas em busca de proteção, em busca de salvação; uma menorzinha olha para trás, talvez procurando a mãe, uma arrasta o menor pela mão: o fogo destrói mais do que os campos e a pele, rompe laços que ficam para trás, daqui por diante. Que prenderá essas crianças a seu passado senão as lembranças emanadas por seu próprio reflexo causal estampados em seu grito de dor?

Dirijamos nosso olhar para o mês abril de 1994, quando o mundo assombrou-se com a grande hecatombe genocida ocasionada por lutas étnicas em Ruanda, na África: de um lado hutus, de outro tutsis que, em pouco mais de um mês, ocasionaram a morte de quase um milhão de pessoas que pereceram com requintes de crueldade em ambos os lados.

O genocício nos faz voltar ao verso Die Kirch ist umbgekehret, pois o lugar sagrado foi, mais uma vez, profanado. Agora não são as imagens que foram destruídas - quase não havia muitas por lá -, não foram os bancos quase não os tinha -, nem seus grandes vitrais - desconhecidos por seus fiéis, mas homens, mulheres, crianças que para lá acorreram em busca de proteção, 
mas encontraram o terror, a morte, o abandono e a ferocidade da turba. Esta também se dirigiu para lá a fim de extrapolar seus sentimentos mais perversos e brutais, cujo resultado é possível ver na foto 27 - mais barroca impossível -, quando nos mostra o resultado da morte de milhares de pessoas profanadas em sua dignidade dentro do templo que agora se tornou museu.

No entanto, essa imagem é muito diferente da representada por Vaenius na figura 76, quando vemos que a morte é o termo de tudo e diante dela se deixa tudo que se conquistou: poder, glória, riqueza... Vaenius nos diz na alma do emblema:

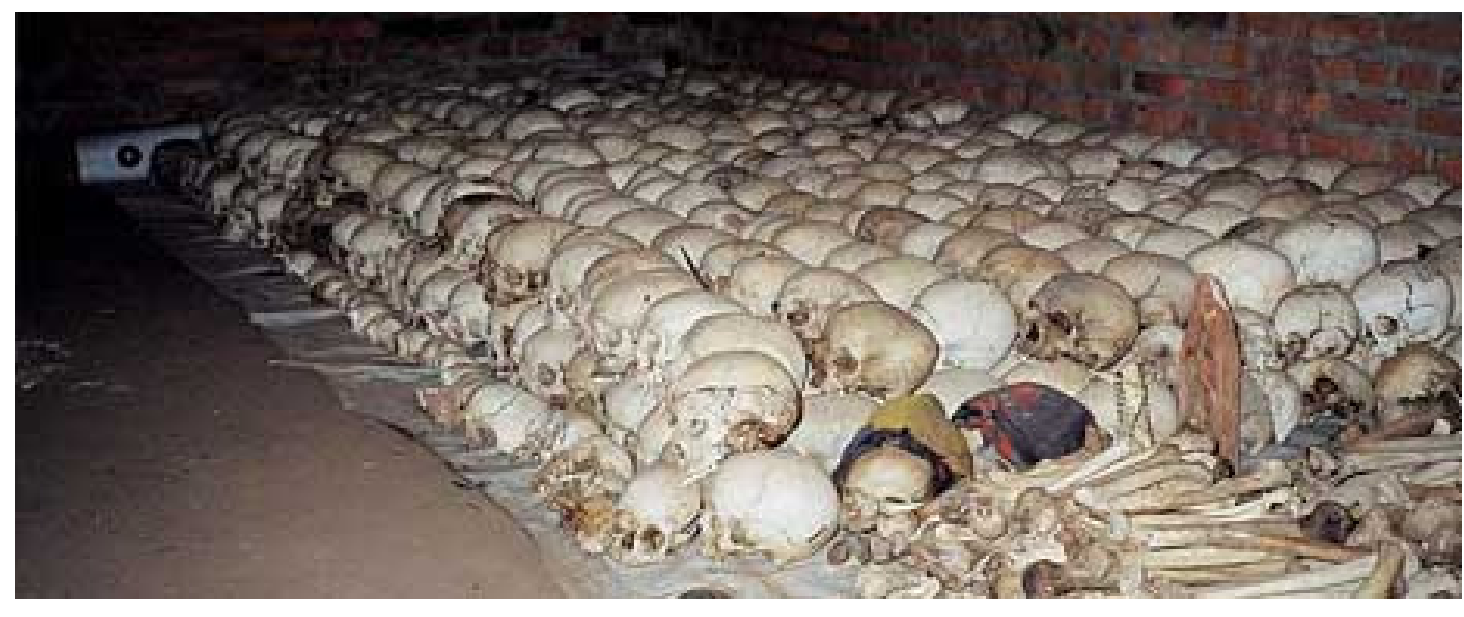

und todt

Foto 27: Retirada da internet (sem autor)

Legenda original The Church of Giterma, which was the site where more than 5,000 Tutsis victims sought refuge

Todo lo dexa el hombre juntamente,

Quando al termino muerte llega, y quādo

Dexa de andar aqui peregrinando,

Boluiendo [volviendo] al poluo [polvo], su primera fuente;

Que es ley del cielo, y ley, que no cōsiente,

Excepcion por riqueza, triumfo, ò mando,

Las virtudes tan solo eternizando,

Que es lo que el cielo guarda eternamēte,

Estas al fin esperan la corona,

Cantando al fin la gloria en dulce canto,

Pues viue [vive] el hombre solo en su memoria;

$Y$ yo tambien dexando la Elicona, 
Por lo bueno diziendo sancto sancto,

Al fin eterno cantarè la gloria

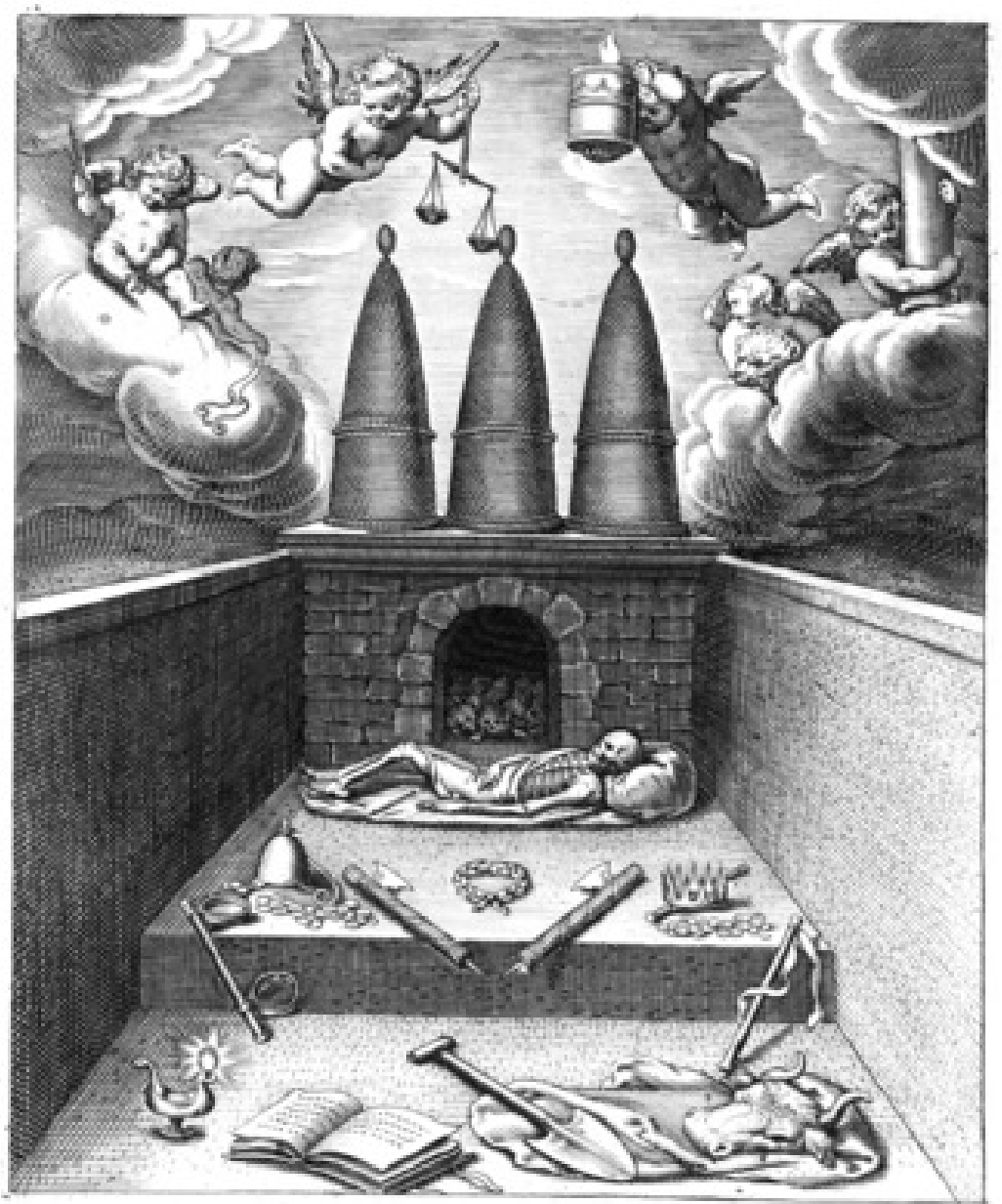

Figura 76: emblema 103 Mors ultima linea rerum est, de Otto Vaenius, 1612
A morte é verdadeira, natural, digna, repouso para as vicissitudes da vida: vemos que 0 esqueleto repousa diante do ossário - à semelhança da fotografia 24 , repleta de crânios - em uma atitude de alívio, de conformação diante do inevitável que vem coroar as virtudes tidas em vida.

Os crânios da fotografia, por outro lado, foram pessoas que não se tiveram como descansar, viram simplemente a luz de suas vidas se apagar diante do altar para Al fin eterno cantar la gloria a Deus.

Muitos de seus assassinos também foram massacrados numa onda insana, num círculo macabro que levou à morte muitos outros devido às inúmeras epidemias que se verificariam: eis que a peste rondou a todos. Enormes covas tiveram de ser escavadas, às pressas, para tentar dar um fim a esse contínuo ciclo mortal. (foto 28) Impassíveis, os sobreviventes assistiam à cena dos grandes sepultamentos coletivos antiteticamente: uns com uma mescla de prazer - pelos inimigos mortos -, outros com pesar - pelos parentes e amigos que se foram. 
Vê-se que o século XVII e seu deleite pela morte não estão assim tão distantes do homem de nosso tempo, nem os homens mudaram tanto daquele momento para cá, afinal sua paradoxalidade ainda permanece presa à tensão

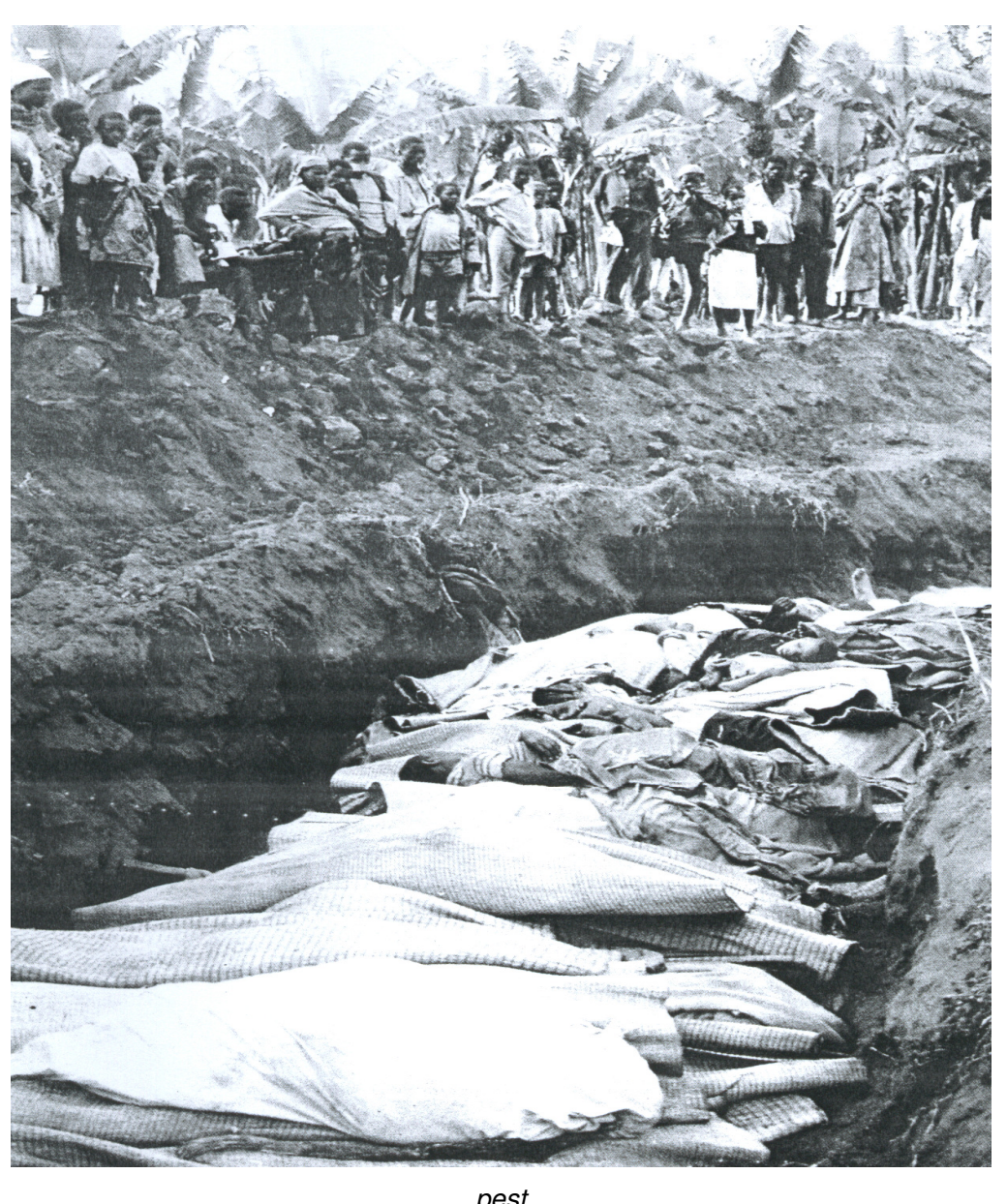

pest existencial da vida humana com suas contradições entre vida-morte, ou na extrapolação de seus sentimentos mais contraditórios como o olhar de ternura e os acessos de ódio incontidos.

Esses sentimentos, portanto, permanecem OS mesmos, principalmente os mais primitivos, aqueles que se refletem diretamente em nossa Foto 28: 100 Photos pour la liberté de la presse, 1995, p. 81. (Foto de Cunningham-Reid) sobrevivência como 0 Legenda original: Fossee comunes.

ódio e o medo. Diante daquilo que nos ameaça, do que nos é desconhecido, do receio de perder aqueles que nos são caros - os filhos, os pais, os companheiros, bem como de perder nossa própria vida - assumimos atitudes que podem nos surpreender: ou a passividade incontida que nos prende os membros e não nos deixa fazer absolutamente nada, ou ainda a fúria após esse primeiro momento de letargia. 


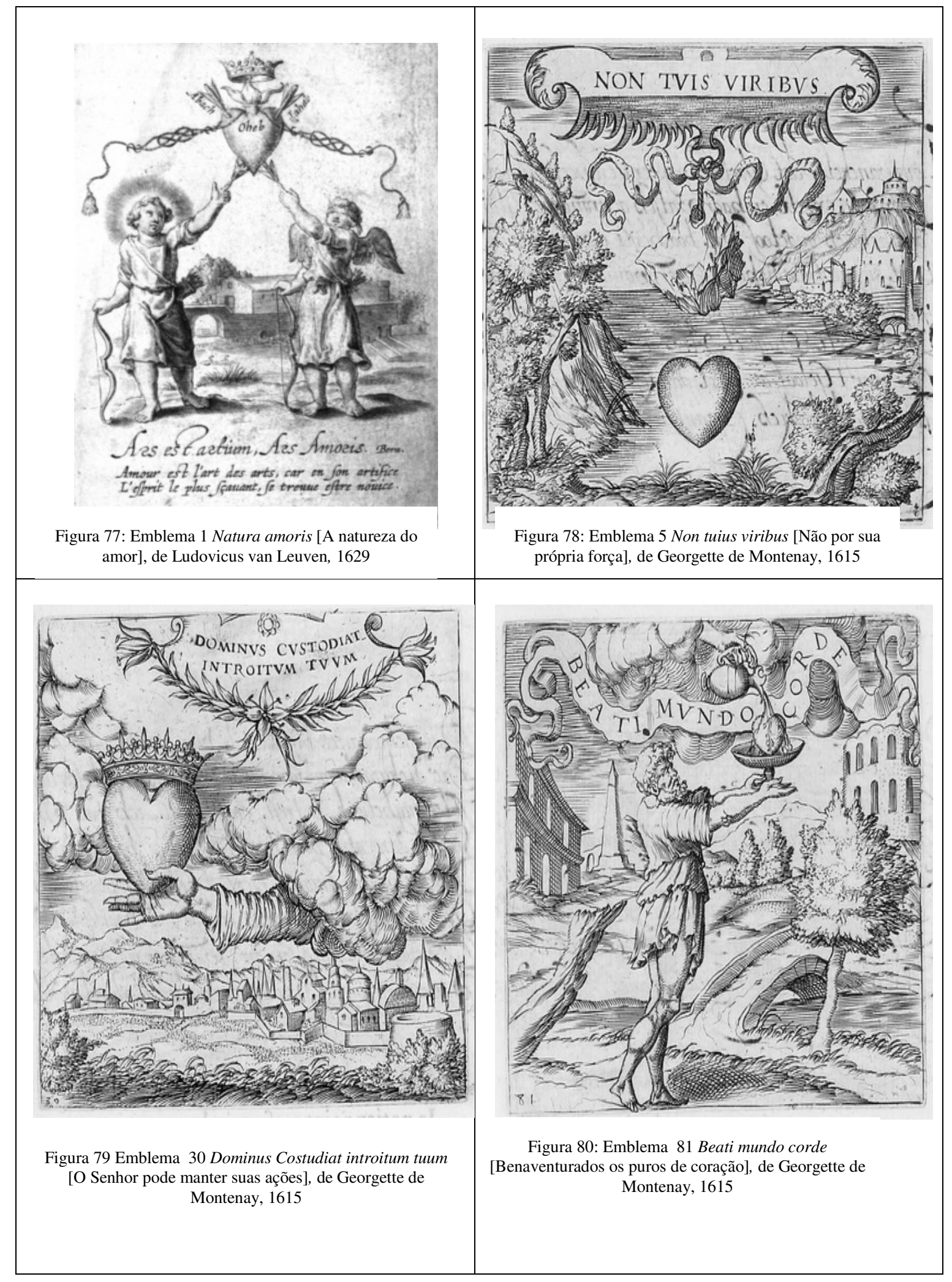

Tabela comparativa 1: várias acepções e empregos da imagem coração. 
No segundo momento, ou seja, quando tomamos uma atitude, seja de revidar, de gritar ou mesmo de fugir, verificamos um aumento da descarga de adrenalina no sangue e com ela uma mudança brusca nos batimentos cardíacos. Diante dessa reação, não compreendida pelo homem em seus primórdios, este associou o coração com seus sentimentos sejam eles positivos - como o amor, o afeto, o carinho - sejam negativos - como o ódio e a inveja. Essa relação, portanto, entre o coração e os sentimentos foi estabelecida, pelos seres humanos, há milhares de anos e é encontrada em em todas as culturas. Dessa forma, o coração tornou-se para nós o senhor de nossos sentimentos, quando à semelhança de um tambor de guerra, nos impele a alguma ação: seja amar, seja lutar.

O coração, no século XVII, em especial na emblemática, pode assumir vários significados, entre eles, o do amor divino. Há, no entanto, vários emblemas que utilizam sua figuração como a representação da natureza do amor (fig.: 77); como a de um ímã divino que atrai tudo para junto de si (fig.: 78); o coração do rei que é dirigido por Deus (fig.: 79); o mesmo seguindo os preceitos evangélicos dos puros de coração (fig.: 80). Dessa forma, quando Gryphius emprega herz [coração], sua significação extrapola aquela que temos em nossos dias, cuja representação iconográfica, normalmente, representaria o amor humano.

Ripa, por exemplo, mostra-nos o coração como parte da representação da Amizade (Ripa, 1987, v. 1, p. 85), da Quinta Bem-aventurança (ibidem, p. 151), da Consciência (ibidem, p. 207), do Conselho (ibidem, pp. 221-222), da Boa Fama (ibidem, pp. 396-397), da Caridade (ibidem, pp. 161-162), da Lealdade (Ripa, 1987, v. 2, p. 14). Como se pode verificar, o emprego que fazemos da imagem do coração - quase que exclusivamente para representar o amor - não era tão empregada nos Quinhentos nem nos Seiscentos. Quando, por exemplo, empregavam-se dois corações juntos - que para nós representaria a união entre um casal - significaria, para aqueles leitores, Fraude (ibidem, pp. 445-446). Ripa faz apenas um emprego do coração em nossa acepção hodierna, mas de uma maneira direta e em poucas linhas para demonstrar o Tormento de Amor, quando se vê o coração transpassado por um dardo e rodeado por duas serpentes que os envolvem. (Ripa, 1987, v. 2, p. 362) 
Dessa forma, vemos que a imagem empregada por Gryphius é muito mais do que nossa representação de coração, podendo ser compreendida numa amplitude muito maior. Iconofotologicamente, porém, é-nos possível recorrer a uma imagem que saia um pouco do lugar-comum para tentarmos compreender, superficialmente, o que quis nos passar o eu lírico em Threnen des vatterlandes.

Uma imagem que poderia nos servir para isso é a da mãe que se preocupa com filhos, netos, marido, enfim com a família e acredita poder sempre os proteger de todas as formas, entretanto em tempos de guerra surge aquilo por que não esperava: a impotência diante de uma situação que lhe foge totalmente do controle: os filhos vão ao front, o marido, provavelmente também, e essa situação se espalha no meio em que está inserida, restando-lhe apenas a companhia de outras mulheres que sofrem a mesma situação e das crianças que, provavelmente, permanecerão órfãs. Essa é a dor que punge o coração das mães e que não é possível cicatrizar durante toda sua existência: a perda de seu filho.

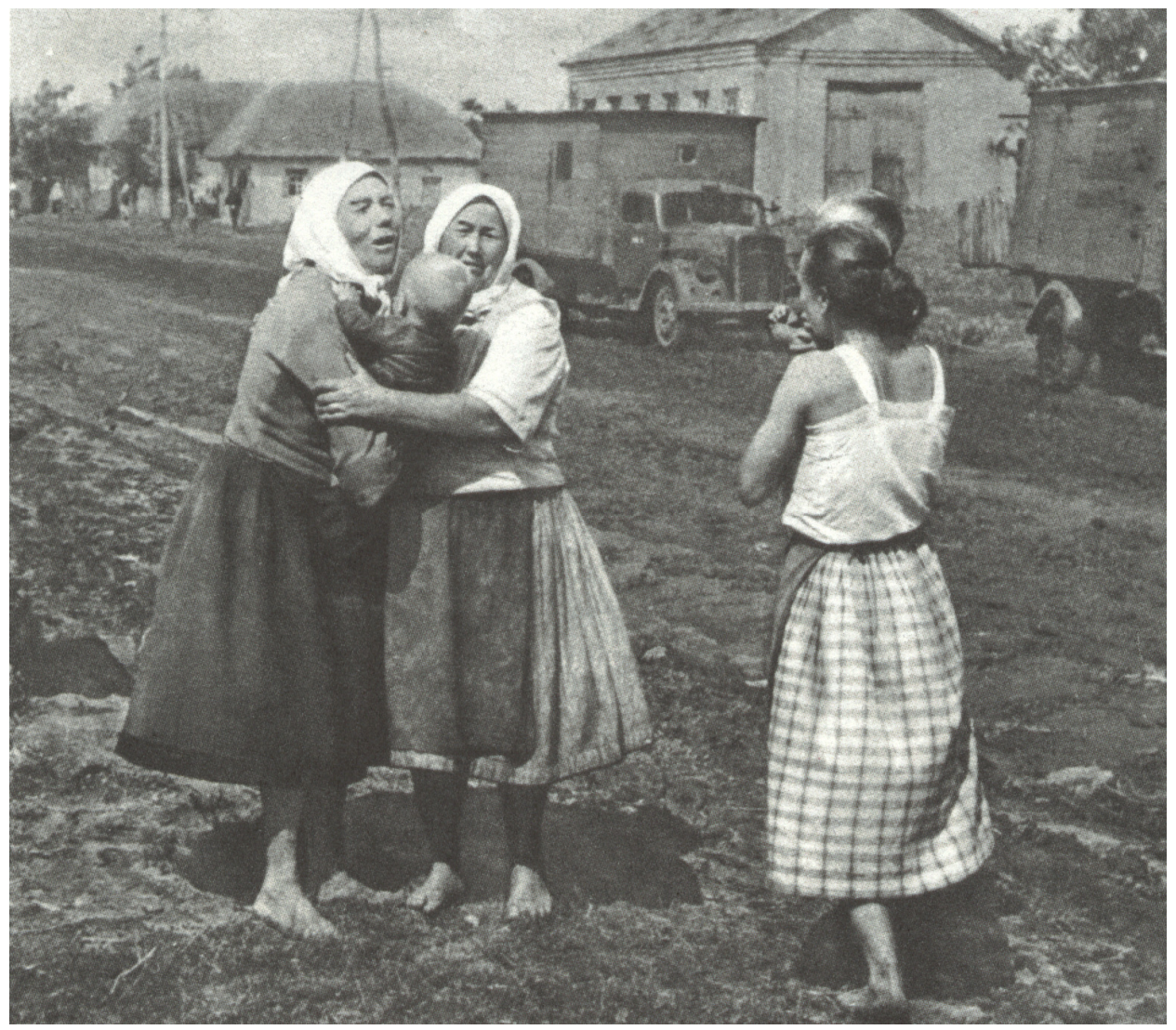

der herz

Foto 29: FÄRBER, op. cit. p. 266.

Legenda original: Die Zivilbevölkerung lebte in ständiger Angst vor Bomben und Tieffliegern. 
A fotografia 29 com toda sua transitividade mostra-nos isso: ao vermos três mulheres, sendo que duas - as mais idosas, avós, provavelmente - tentam se consolar mutuamente e trazem ao colo um bebê, sendo vista por uma mais jovem que ao dirigir-se a elas, leva as mãos à boca numa atitude de comiseração. O grito da provável avó ecoa pela rua de terra: terá recebido a tão temida notícia da morte de um dos seus, ou já não agüenta mais o ronco dos aviões sobre suas cabeças a despejar a morte? Seu grito é o grito de seu coração, cuja aflição não pode mais suportar sozinha, precisa das companheiras de dor, de luta e de sofrimento, sai à rua e pouco se importa com seus pés descalços na lama, a mão da amiga que lhe aperta o braço alivia a dor que consome seu coração.

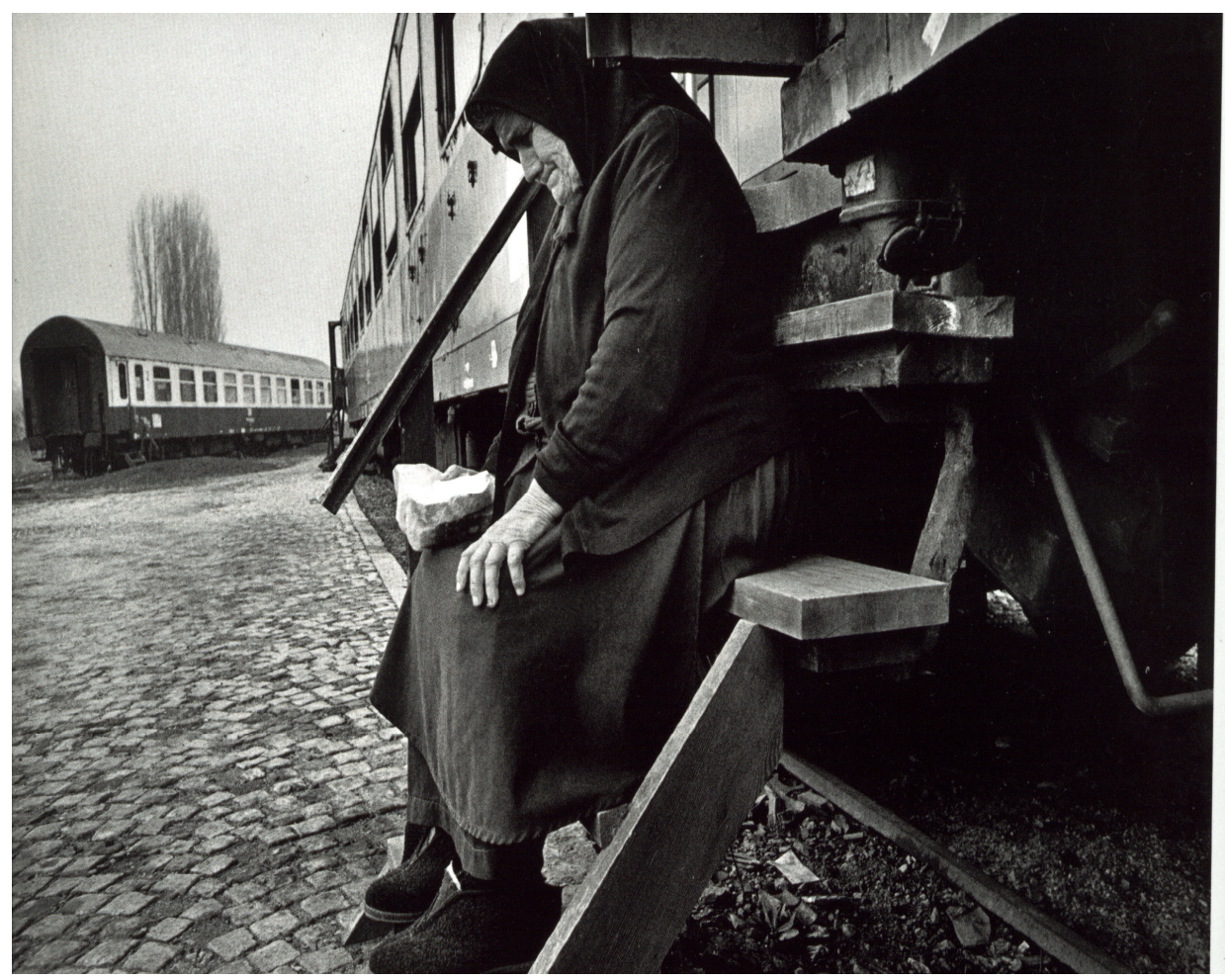

geist durchfehret.

Foto 30: SALGADO. p. 118 (foto de Sebastião Salgado).

Legenda original: No campo de Vinkvci, 150 pessoas vivem em dois trens. Vinkovci já foi um dos maiores entroncamenteos ferroviários da Europa, o ponto de encontro dos trens que ligavam a Europa Ocidental e a Oriental. Vinkovci, Croácia, 1994

Nem todos, porém, podem ter um abraço amigo no momento de dor com quem possa dividir sua tristeza e agonia, apesar de todas estarem feridas de morte em seus corações e em suas almas: der herz undt geist durchfehret. Vêse, dessa forma, que a dor perpassa o coração - como expressão corpórea do 
ser - e adentra na alma - expressão que liga a humanidade à divindade, ao transcedente.

A mulher que vemos na fotografia 30 mostra-nos isso ao encontrar-se sozinha diante daquilo que seria sua nova casa - um vagão de trem abandonado -, não há ninguém a seu redor, ninguém que console sua dor: sente-se sem forças para sequer levantar-se: há muito sua dor ultrapassou as fronteiras do coração, instalando-se em sua alma que, poderímos dizer, refletese nas roupas lutosas que traz. Traz em uma das mãos um embrulho. Para quem seria? Seria para algum filho, uma merenda, que ele não poderia mais comê-lo por não mais existir? Talvez ela pretendesse dar-lhe aquilo que já não é mais possível devido à guerra? Essa fotografia é de uma beleza indescritível, já que aqui, apesar de não haver braços e mãos amigas que a ajudem a agüentar sua dor, há o meio em que está inserida: até o céu fecha-se para ampará-la, bem como a árvore atrás do outro vagão que, seca - devido ao inverno -, solidariza-se com a mulher, cuja dor da alma pertence ao cenário frio, vazio e limpo, apesar do tempo de guerra e de destruição.

O eu lírico, agora na terceira estrofe, propõe-nos uma demarcação temporal daquilo que quer que vejamos, demonstrando-nos o continuum do sofrimento: alzeit [todo momento], dreymal sechs jahr [três vezes seis anos], $a^{240}$ [desde], langsam [lentamente]: o sofrimento não tem fim, sua duração parece infinita.

Não importa onde se esteja: se no campo ou na cidade, se na trincheira ou nas ruas, a morte está sempre à procura daqueles com quem se fartar. Seria simples se pudéssemos acreditar em uma entidade Morte que quisesse nos perseguir e devorar! No entanto, esquecemo-nos - pelo menos fingimos isso - de que tal entidade não é que faz isso, mas o próprio homem com sua perversidade e falta de razão.

Não são poucas as vezes que essa mortandade ocorre, o eu lírico é claro: alzeit - a todo momento - corre lentamente o precioso líquido da vida: frisches blutt. O momento se aproxima, o pelotão de fuzilamento está a postos, faltam somente os oficiais que se dirigem para vilipendiar os ultrajantes

${ }^{240}$ No sentido do seit, seitdem. 
rebeldes que ousaram ir contra a manutenção do status quo, os mesmos - que queriam sua liberdade e de seu povo de volta - também já estão a postos, de joelhos para serem executados: nenhum deles está com as mãos amarradas, não temem o que está por vir, crêem em seu ideal, a morte não lhes roubará seu sonho de liberdade (foto 31 ).

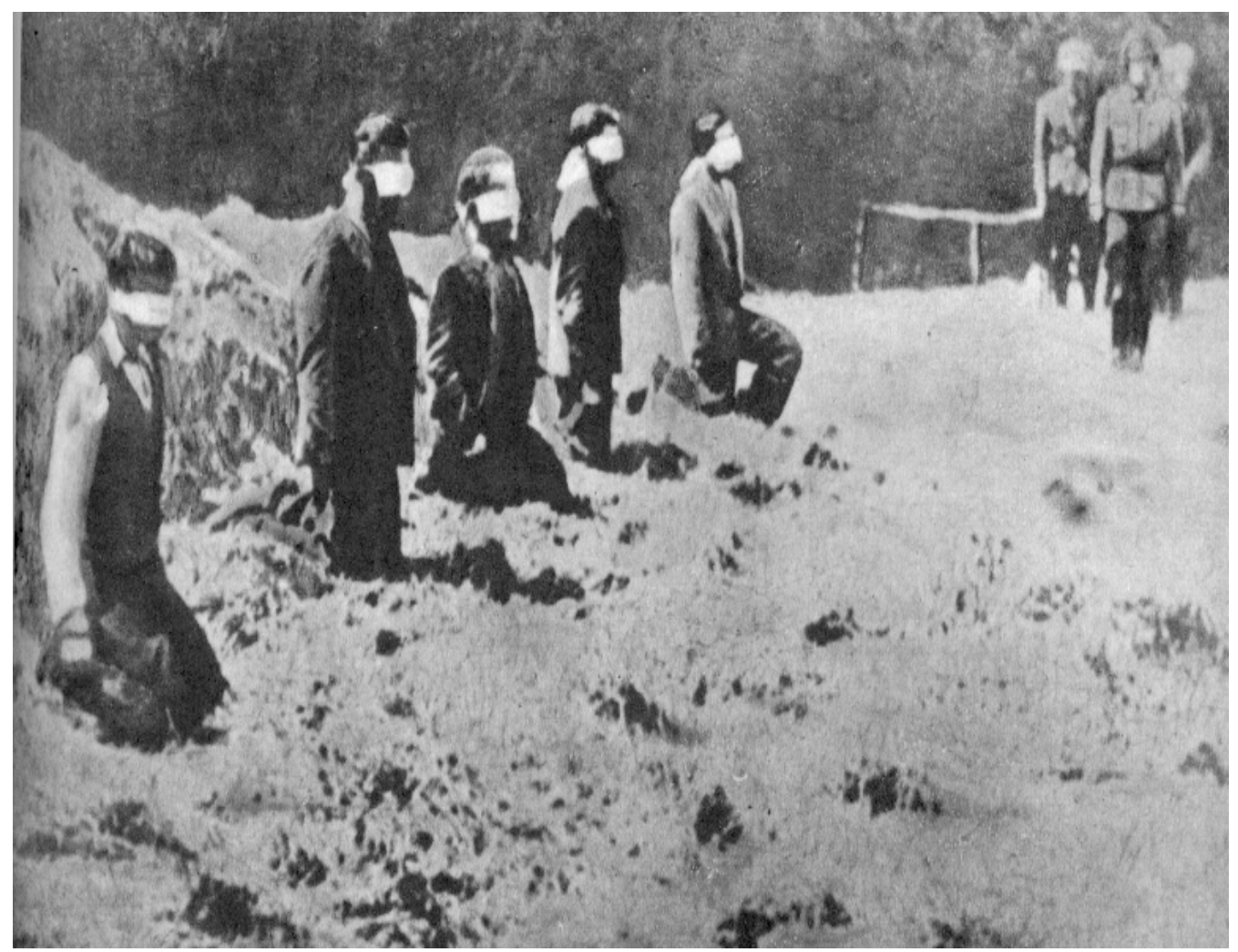

Hier durch die Schanz

Foto 31 FÄRBER, p. 371.

Legenda original: Erschißung von Partisanen. „Freischärler, so der Befehl für das Unternehmen „Barbarossa“, „, sind durch die Truppe im Kampf oder auf der Flucht schonunungslos zu erledigen. “

O mesmo já não é possível falar do soldado que sucumbe em pleno combate em meio à cidade em escombros (fotografia 32). Mas o que há em comum é o fato de que a máquina da guerra não pára e tem, cada vez mais, uma sede insaciável por sangue, cujo odor férrico alimenta suas entranhas. 
O grito do eu lírico ainda hoje ecoa: Hier durch die Schanz und Stadt/ rint alzeit frisches blutt. Que mudanças tivemos daquele momento para hoje? Provavelmente, a eficiência e a limpeza da morte, ou seja, não é mais necessário destruir todo o homem por meio de espadas, lanças, basta um simples tiro certeiro, como os que levaram os jovens da fotografia 31. Não, não é essa a preocupação do eu lírico, mas o fato da constância, da continuidade, da interminável guerra que ceifa cada vez mais não só a vida, mas as esperanças dos vivos.

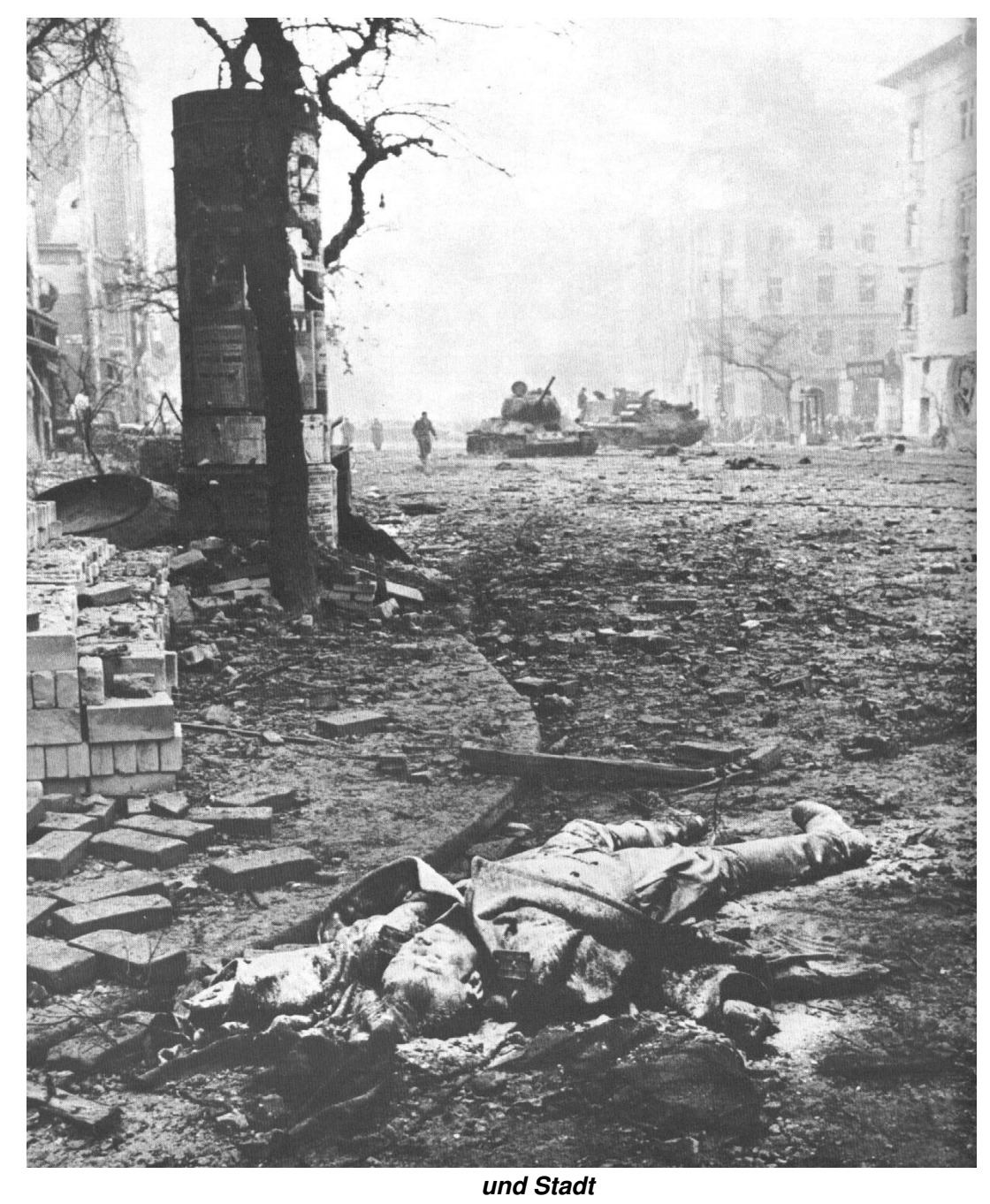

Foto 32. História do século 20, p.

No próximo verso, temos o desalento do eu lírico: Dreymal sindt schon sechs jahr [Três vezes seis anos]..., ou seja, há 18 anos que a destruição não tem fim, conforme está estampado no título do poema: Anno 1636, já que a guerra dos Trinta Anos teve início em 1618. Além do óbvio que é a mera 
contagem temporal, outro detalhe surge com a utilização desses três números. Segundo Marian Szyrocki, o número 6 corresponderia ao número da vanitas para Gryphius (Cf.: Szyrocki, 1964, p. 57), ou seja, tudo o que foi dito anteriormente refletiria a idéia da brevidade das coisas que permeará grande parte da arte dos Seiscentos. Vê-se, dessa forma, que o eu lírico não nos dá, simplesmente, a conhecer a passagem do tempo, nem o fato de a guerra ainda estar em curso, mas o da brevidade dos atos humanos: suas construções, conquistas, esforços, enfim sua própria vida.

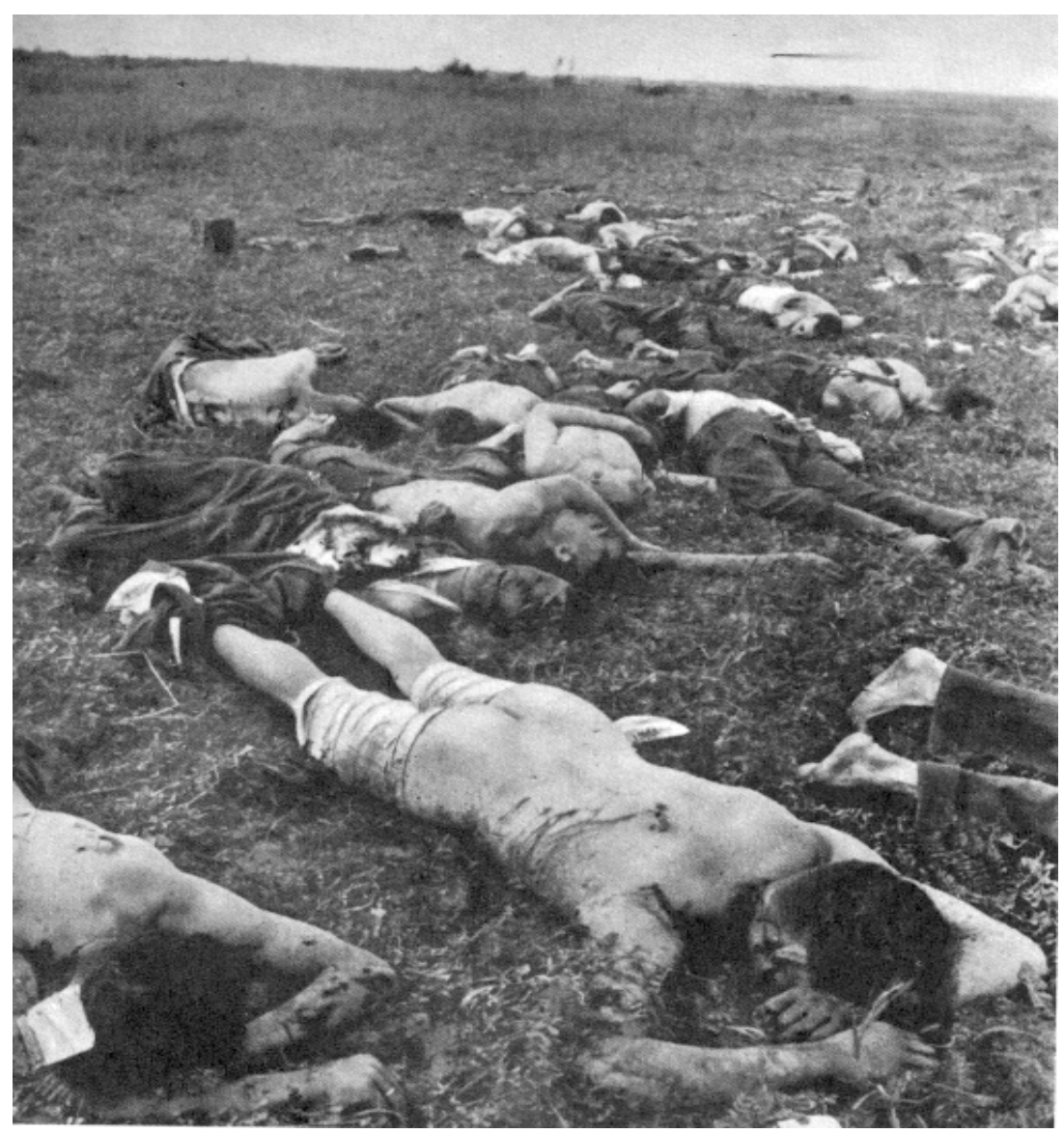

rint alzeit frisches blutt.

Foto 33: FÄRBER, Matias. p. 370. (O fotógrafo não é citado.)

Legenda original: Erschlagen und ausgeplündert fand das vorübergehend zurückgenommene Bataillon eines deutschen Schützenregiments im Juli 1941 bei Dubno (Wolhynien) nach erfolgreichem neuem Vorsto $\beta$ die verwundet oder gefangen dort zurückgelassenen Kameraden.

Vemos agora, o assombro do eu lírico diante de uma realidade, naquele momento absurda: unser ströme flutt von so viel leichen schwer [nossos cursos d'água, nossos rios, estão pesados, repletos de de cadáveres] tamanha foi a mortandade que se vê por todos os lados. O assombro é real, afinal o rio tem uma função vital, tem de trazer a vida - para dele se beber, para dele se alimentar - não a morte - fato que nos habituamos, na modernidade, com a 
poluição que conseguiu matar grande parte dos cursos d'água ao redor do mundo, mas era desconhecido pelo eu lírico -, daí o espanto e o prolongamento do fato não em um hemistíqui, mas em dois versos de uma mesma estrofe. O rio não corre seu curso natural, é impedido pela concretude da morte que não apenas o cerca, mas impede seu caminho. Eis mais um paradoxo: da via que traria vida, vem a morte.

Ripa mostra-nos, na representação iconológica da Bondade, um rio que flui mansamente, ao lado de uma árvore em que sempre serão vistos frutos. Essa imagem foi retirada do Salmo 1:

Ele [o homem] é como árvore plantada junto d'água corrente: dá fruto no tempo devido, e suas flores nunca murcham. (SI 1, 3)

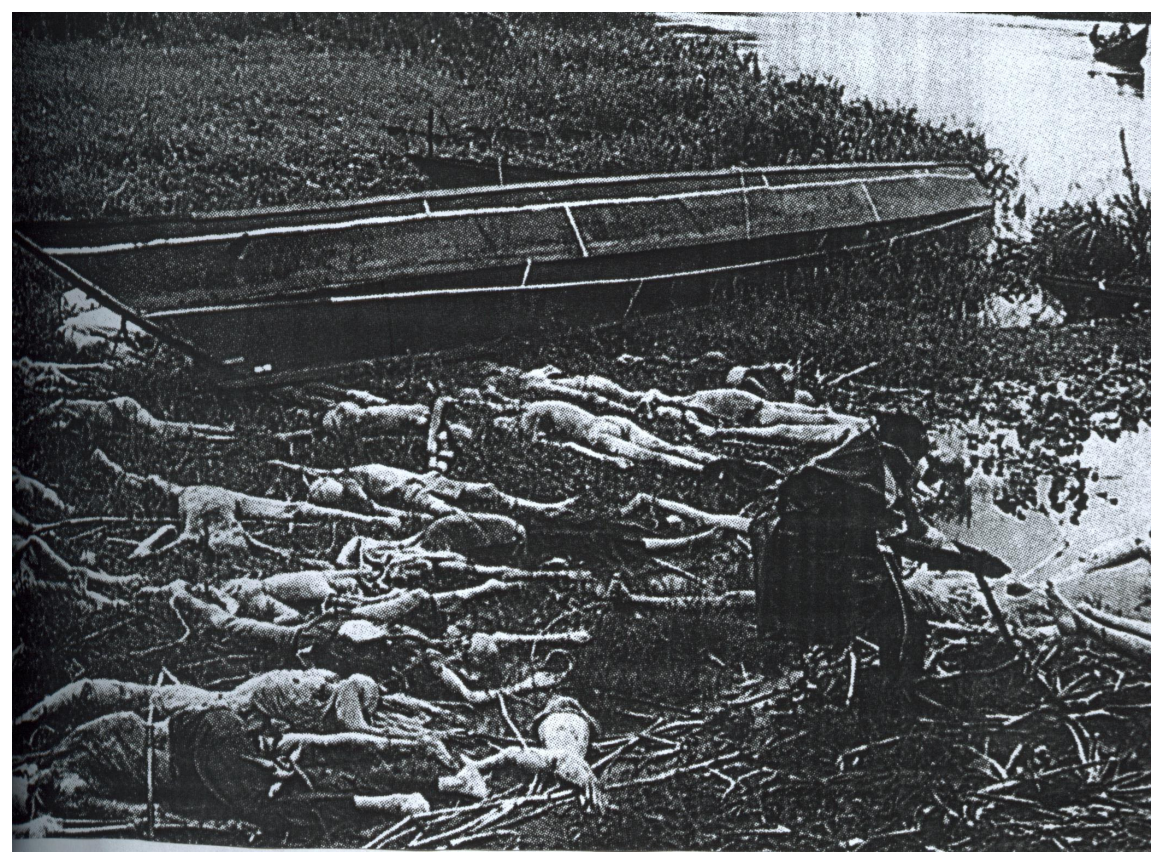

Dreymal sindt schon sechs jahr als unser ströme flutt Von so viel leichen schwer/ sich langsam fortgedrungen

Foto 34: Revista Time, 6/6/1994, p. 34. (Foto de David Blumenkrantz)

Legenda original: The thousands of Rwandan bodies that have washed 60 miles downriver into Lake

Victoria could start massive epidemics if Uganda cannot swiftly remove the grisly corpses.

No entanto, o que o eu lírico transmite-nos foge, completamente, dessa visão edílica e adentra numa macabra, numa antivisão: não se vê bondade, pelo contrário, vê-se crueldade. Não há como não se lembrar da imagem de rios repletos de cadáveres após a hecatombe ocorrida em Ruanda, quando, mais do que corpos em decomposição, se verificou a contaminação da água, 
causando um desastre ambiental de grandes proporções em vários países da região, cujo resultado foi a impossibilidade de acesso à água potável; a morte de peixes e de outros animais; além de epidemias - contra que, aqueles que conseguiram sobreviver, tiveram de lutar - em meio ao caos instaurado na região. Vemos, na fotografia 34 , a imagem que nos remete, iconofotologicamente, a esse fato.

Apesar de tudo isso, apesar de todas as desventuras denunciadas e enumeradas pelo eu lírico, apesar da continuidade do sofrimento, ele inicia a última estrofe com um doch [apesar disso, contudo]: ou seja, ainda há algo bem pior do que tudo o que foi enumerado. Mas, como pode haver algo pior do que a morte, a peste, a fome?

Antes da enumeração acima, o eu lírico faz uso do verbo schweigen [calar-se]: como expressar 0 inexpressável,

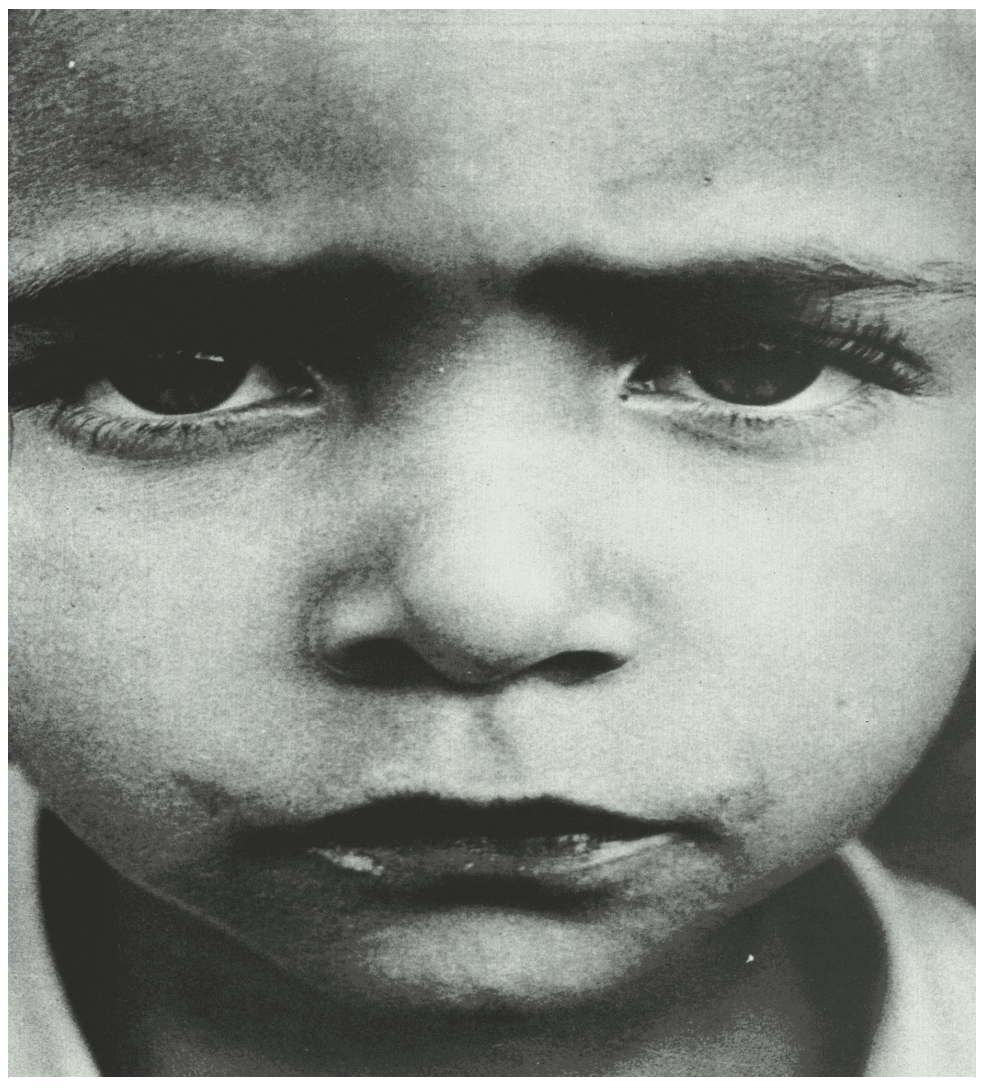

Doch schweige ich (a)

da criança, por exemplo, torna-se punhal para aqules que estão do outro

Foto 35: Curso completo de fotografia: série prática (A fotografia profissional), p. 47 (foto de Armando Prado).

Legenda original: Na página ao lado (acima), Prado, ao captar o olhar triste da criança, coinseguiu a imagem perfeita que sintetiza a violência policial.

lado da trincheira, ou seja, para aqueles que querem impor-se frente aos outros. Num assalto, por exemplo, pode haver qualquer motivo para que assaltantes, cujos nervos já estão à flor da pele, percam controle e, simplesmente, atirem. Verifica-se isso também na guerra e de forma pior em guerras étnicas, quando os instintos mais elementares do ser humano - como 
a de proteger as crianças, os bebês - desaparecem, já que foram substituídos pelo ódio e pelo desprezo ao outro.

A foto de Armando Prado transmite-nos um calar que faz com que nós não nos calemos, que nos impele a saber mais sobre o menino que se deixou fotografar: que tristeza leva uma criança a ficar assim numa mescla de raiva e desconhecimento? Que faz com que uma criança deixe de ser criança e deixe de ter em seus lábios o sorriso que deveria ser-lhe natural?

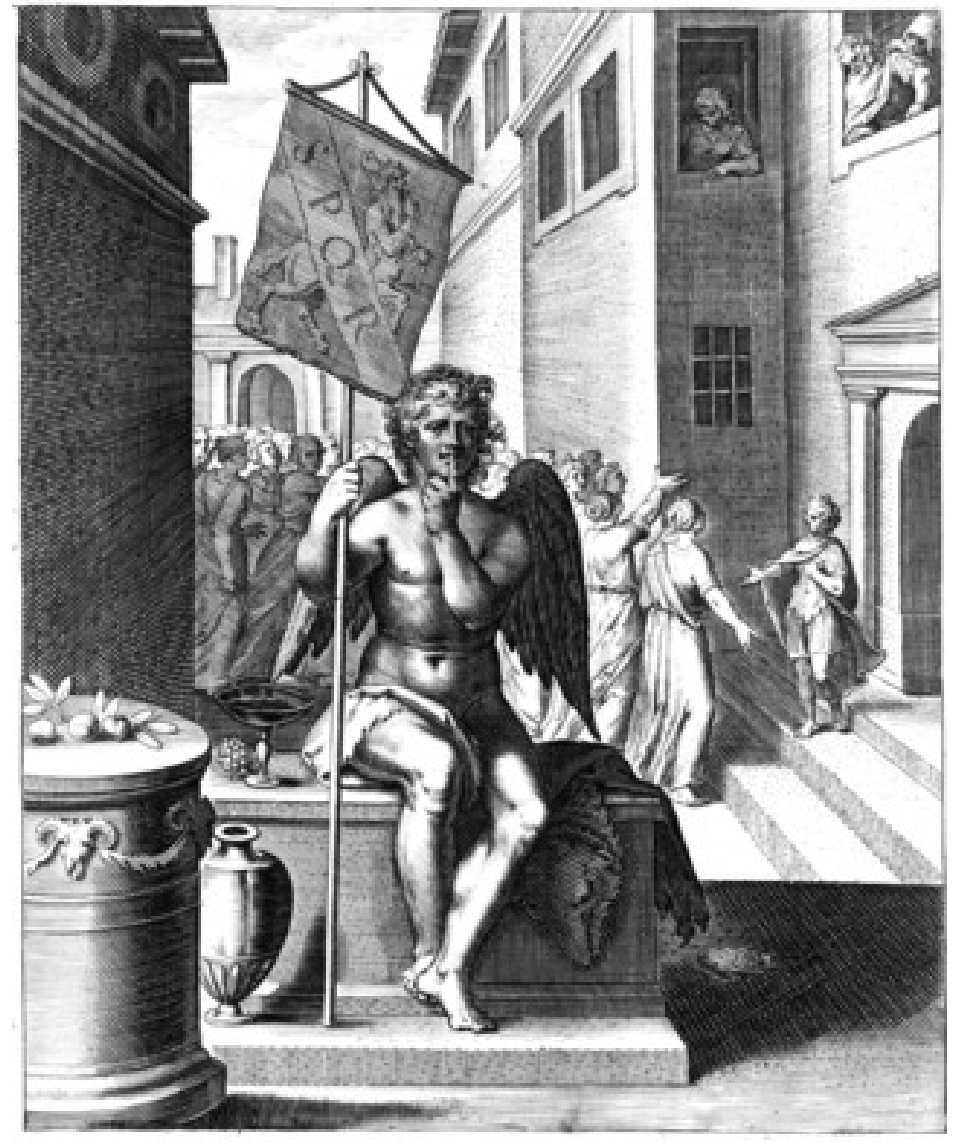

Figura 81: Emblema 28 Nihil silentio utilius [Nada é mais útil que o silêncio], de Otto Vaenius, 1612.

Há uma outra fotografia que também nos mostra isso (fotografia 36), quando vemos um soldado diante de um menino que, de joelhos, clama por algo - pelo pai que fôra preso pelas tropas de ocupação americanas na segunda guerra do Iraque. O choro do menino é compungido, não expresso, tenta ainda manter uma ombridade que não deveria existir

nessa idade. Retém as lágrimas, tenta convencer pelo olhar que revela seu sentimento, mas é ignorado por aquele que está a sua frente, por isso se cala e seu calar-se tenta dizer que tudo aquilo é errado, é um equívoco, que o pai é inocente: que será dele e de sua família? Nada vai mudar a impassibilidade do outro que, simplemente, observa o garoto como se fizesse parte das areias do deserto.

Para a emblemática (fig. 81), representa-se guardar silêncio por um um anjo sentado em meio a uma taça de vinho de um lado e por uma cabeça de urso de outro, sendo que atrás dele é possível ver uma multidão que discute algo com um homem defronte a um palacete. $\mathrm{O}$ anjo segura em uma mão um 
estandarte ${ }^{241}$, onde se vê um centauro; com a outra, leva o dedo indicador diante dos lábios, demonstrando pedir silêncio (a mesma representação que temos em nossos dias).

O urso, na iconologia de Ripa, é o símbolo da ira, da raiva, da irritação (Cf.: Ripa, v. 1, pp. 538-539), enquanto o excesso de vinho representa o homem que tem desprezo pelas virtudes, um tolo, um néscio, alguém que deixa ofuscar seu engenho (Emblema 17 de Otto Vaenius Crapula ingenium offuscat [A embriaguês ofusca o engenho]); ou, segundo Ripa, faz os homens tornarem-se débeis e envelhecidos com maior rapidez. (ibidem, p. 316) Há, ainda, a figura do centauro que, para Ripa, representa a velocidade da vida humana. (Cf.: Ripa, v. 2, p. 390)

$\mathrm{Na}$ alma do emblema Nihil silentio utilius, Vaenius nos diz, em espanhol:

\section{El Silencio está sentado}

Entre el furor, y entre el vino,

Para dezir [decir], que es diuino

[divino],

Si con qualquier es callado;

A quien jamás le ha pesado

De callar? y de hablar no?

Porque nunca, el que callo,

Dexo [dejó] de lograr sus años,

$Y$ siempre sintió los daños

Del hablar, quien mucho habló.

Vaenius mostra-nos que o anjo é, na verdade, o deus Harpócrates que, para os gregos e romanos, representava o silêncio $^{242}$ e 0 discernimento. Esse deus era concebido, na iconologia de Ripa

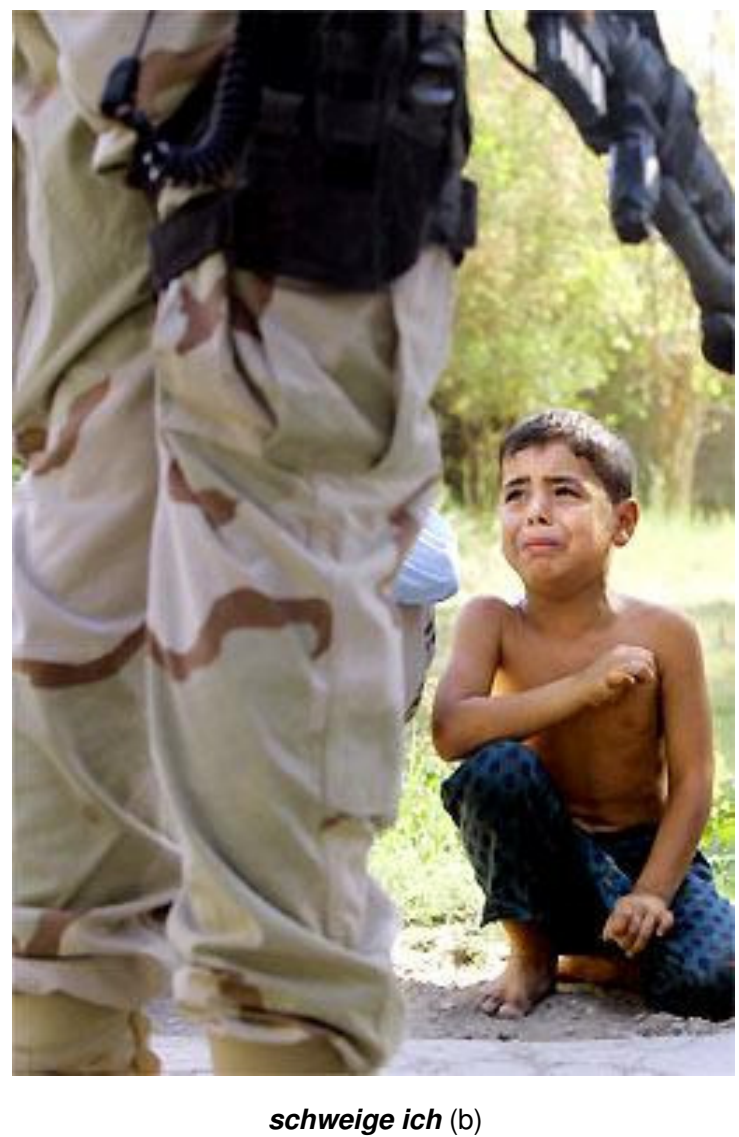

Foto 36: Folha online (foto de Andrea Comas). Legenda original: Meninos choram a ver seu pai ser detido por americanos.

${ }^{241}$ Com as iniciais do Império Romano SPQR, Senatus Populusque Romanus [O Senado e o Povo Romano].

${ }^{242}$ Essa divindade proveio do Egito, mas não possuía a qualidade de representar o silêncio. $O$ fato de o mesmo ter o dedo na boca, demonstrava que o mesmo era um menino, Hórus 
como um joven com alas y com el rostro negro, pues el silencio, como dicen los Poetas, es amigo de la noche (ibidem, p. 315)

parecido também com outra representação do silêncio, também segundo Ripa de um

muchacho (...) con un dedo en la boca, y unas negras alas que nacen de sus espaldas. Además habrá de estar sentado (...). (ibidem, p. 315)

Ao estar sentado entre o vinho e o urso, Vaenius mostra-nos que apesar da bebida e da irritação, deve-se saber manter o silêncio que nos faz alcançar aquilo que almejamos com o tempo e com os anos

con el fin de vencerlos [nuestros afanes] más fácilmente, gozando a continuación de uma vida muy alegre y agradable. (ibidem, p. 314)

por isso,

que el saber callar a tiempo ofrece grandes ventajas, por lo que nunca debe el hombre que es prudente gastar o consumir su tiempo con palabras vanas y sin fruto; antes bien, sabiéndose callar, deberá considerar todas las cosas con gran cuidado antes de manifestarse. (ibidem, p. 314)

Essa é a grande lição do silêncio para os Seiscentos: quem o mantém, cultiva não só sua paz interior como a dos outros - o contrário do que é visto, no emblema 28 de Vaenius, atrás de Harpócrates, quando se vê a multidão de ânimos acerbados devido o muito falar de alguém -, na medida em que não espalha aquilo que deve ser velado de forma iníqua: sabe guardar segredo para viver, destarte, uma vida longa e aprazível, já que dissimular suas preocupações para vencê-las mais facilmente.

Vê-se, portanto, que o eu lírico precisa de um tempo para poder analisar a situação com que se defronta, por isso cala-se, não grita, porque gritar é ir 
contra aquilo que os céus the impuseram, pois se isso the ocorreu, ele pode passar por essa tribulação. Há uma resignação estóica no eu lírico, mas muito mais que o preceito pagão, encontra-se na Bíblia seu manancial:

O injusto arruína o próximo com a boca, mas os justos se salvam pelo conhecimento que possuem.

(...)

A cidade prospera com a bênção dos retos, mas se destrói pela boca dos injustos.

Quem despreza o próximo não tem bom senso; o homem prudente guarda silêncio.

Quem fala demais espalha segredos; o homem de confiança mantém a discrição. (Pr 11, 9, 11-13)

No entanto, esse silêncio pode transmitir-nos também o assombro do eu lírico frente aquilo que para ele é pior que todas as desgraças por ele

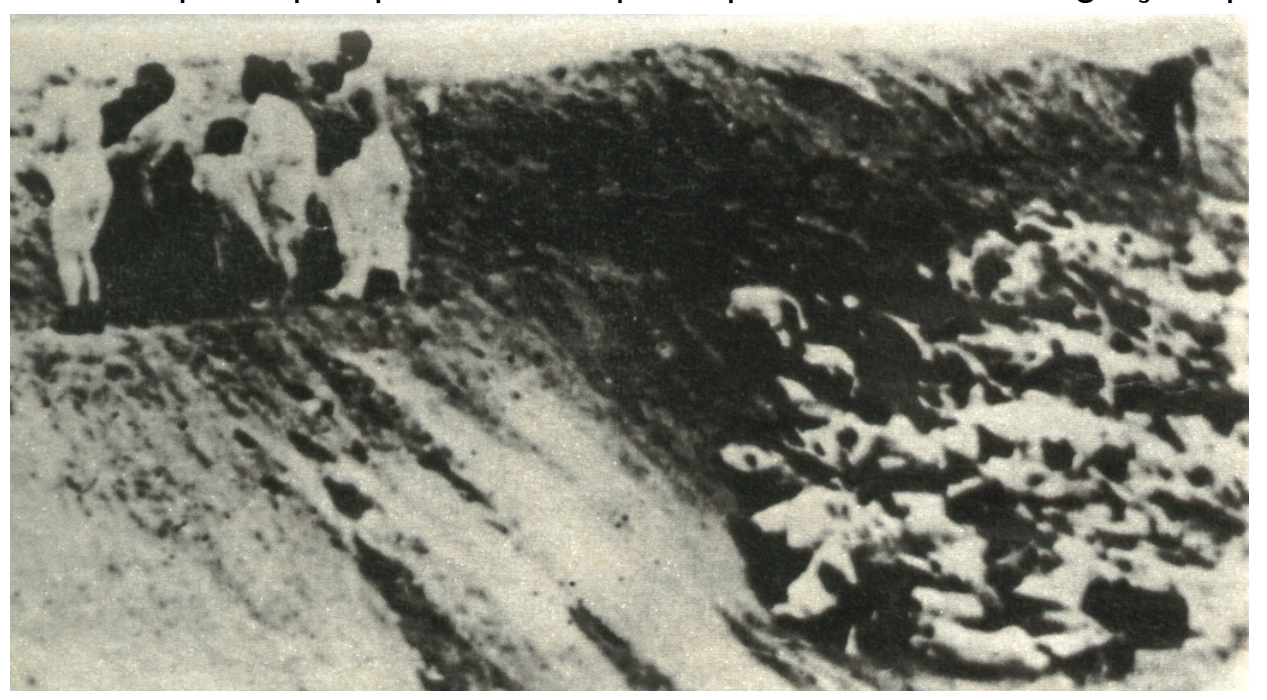

noch von dem was ärger als der Tod.

Foto 37: Revista Der Spiegel, $\mathrm{n}^{\circ} 39 / 1988$, p. 158. (O fotógrafo não é citado.)

Legenda original: Jüdinne vor der Erschießbung, am Massengrab, Fangschuß unbekannte Angehörige eines Sonderkommandos: „Die Leichen wurden regelrecht geshichtet.

vivenciadas. Algo pior do que a morte, como a que vê diante de si a garota da foto 37 que, apesar de estar diante de um pelotão de fuzilamento, ainda tem tempo para olhar para trás, para a grande vala onde jazem vários outros corpos, cujas pessoas tiveram o mesmo fim inglório, inumano que a espera. Ou ainda daquela que agonizando já na vala, fica à espera de algo que abrevie sua lenta agonia, da sensação de vazio: nua, inerte, respirando a terra onde jaz e sentindo o odor da morte e dos corpos dos entes queridos que estão a seu 
lado: Deus existe? Deus nos abandonou? Onde estás, ó Javé, o Eu Sou (Ex 3, 14)? Nós que não somos mais clamos a Ti...

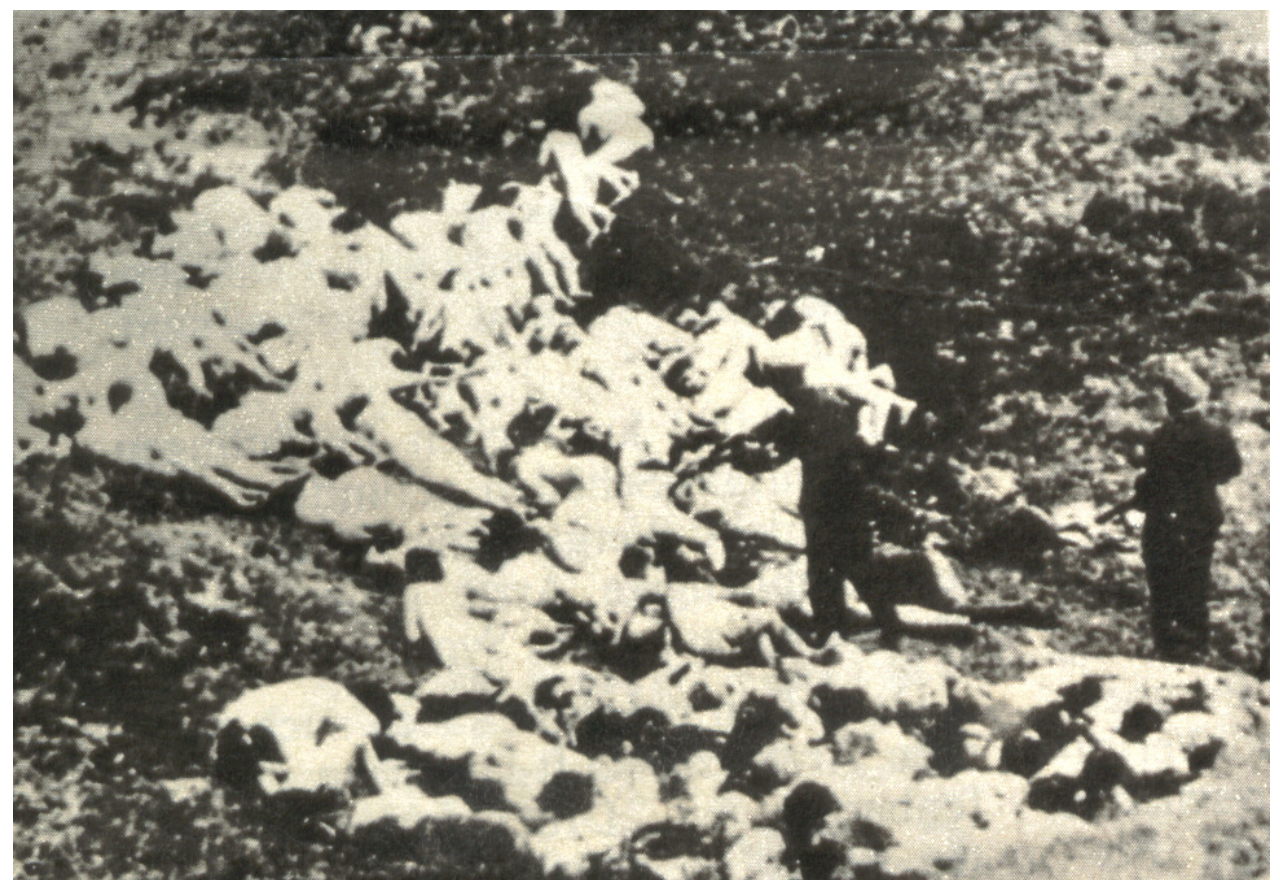

noch von dem was ärger als der Tod.

Foto 38: Revista Der Spiegel, nº 39/1988, p. 159. (O fotógrafo não é citado.)

Para o eu lírico, ainda havia algo pior que a ferocidade da peste - Was grimmer den die pest, quando em meio a batalhas, a pilhagens, a invasões de turbas esfomeadas ${ }^{243}$ e sem direção, cidades e aldeias (fig. 82) transformavamse em palco de carnificinas sem lógica e sem razão (como se houvesse alguma

\footnotetext{
${ }^{243}$ Havia, em plena Guerra dos Trinta Anos, muitos soldados que eram contratados em meio a marginais que sequer sabiam o que era disciplina militar; outros que por não receberem seu soldo regularmente, viam-se no direito de, simplemente pilhar tudo e todos que viam à sua frente; além disso, havia exércitos independentes - como o de Wallenstein - que agiam de acordo com os interesses do contratante. Em suma, que se podia esperar daqueles que diziam ser o que na verdade não eram? Há um texto interesante a esse respeito que nos mostra os resultados do porquê do desvio e conduta dos soldados no século XVII. Dem Soldates stand man mißtrauisch gegenüber undgering war seine soziale Weertung und Stellung. Es haftete am Soldaten das ganze Jahrhundert lang der Makel des Entgleister oder Untauglichen zu bürgerlicher Beschäftigung und Ehrbarkeit. Schon lange hatte sich dis Soldateska aus unteren Schchten ergänzt. Der bereits erwähnte sächsische Musterungsbericht rät, „böse Buben, Landhäufer und solch Gesindel" anzuwerben. Im Laufe des großen Kriegs wurde das nicht besser. Ausgeraubte Bauern, heruntergekommene Adlige gesellten sich den von Natur abenteuerlichen Elementen zu; allmählich sammelte sich der Abschaum Europas in diesen Regimentern, die schlißlich mehr Räuberbanden glichen, der Soldatenberuf war das unsicherste aller Handwerke; den schon nach einigen monaten oder doch nach ein paar Jahren wurden die Regimenter aufgelöst und sa $\beta$ der Söldner oft mit Weib und Kind auf der Straße, dem Elend preisgegeben. Als dann die stehenen Heere eingerichtet wurden, brauchte der Soldadrt nicht tägtaglich Dienst zu tun; er wurde monatelang nach Hause entlassen und konnten Landarbeiter sein oder einem Handwerk nebenbei nachgeben. (Fleming, 1937, p. 142)
} 
em meio a guerra!), cujo resultado eram corpos espalhados pelo chão que necessitavam ser recolhidos, nem tanto devido ao preceito cristão para se enterrar os mortos, mas por extrema necessidade, tamanho era a pestilência nos campos, nos vales e nas cidades.

Aquilo que havia sido um corpo humano, no entanto, transforma-se, na companhia de outros, em uma pilha amórfica de seres, muitas vezes, irreconhecíveis. Alguns podiam até seram conhecidos, mas tinham de ser ignorados, deixados de lado para que se pudesse preservar ou - pelo menos tentar - salvar a própria vida. Correr para tentar se salvar... mas de quê?

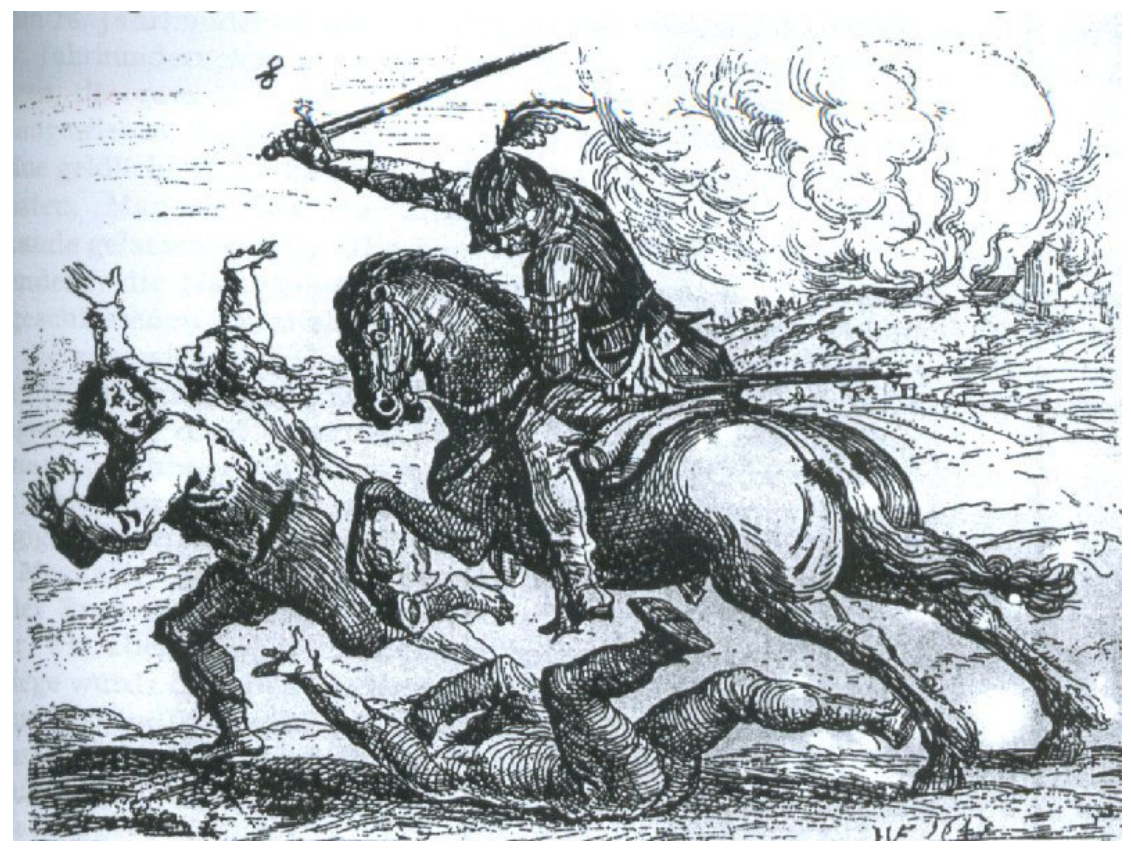

Figura 82: Brandschatzung eines Dorfes durch plündernde Soldaten [Devastação de uma aldeia por meio de soldados saqueadores]. Ilustração de Ulrich Frank, 1645.

Que se fez para merecer-se tamanha comiseração? O eu lírico faz com que nos lembremos disso hoje. Também somos impelidos a buscar em nosso acervo iconofotológico imagens que retratem seu sofrimento, como a fotografia 39, em que vemos a disformidade - aquilo foi gente que ria, brincava, trabalhava, amava - sendo arrastada como terra e misturada a ela. Os soldados que participam da operação utilizam-se de máscaras: não se pode suportar o odor da pestilência, sob elas e em suas narinas ungüentos de cânfora e mentol, sem os quais também eles não conseguiriam estar ali. 


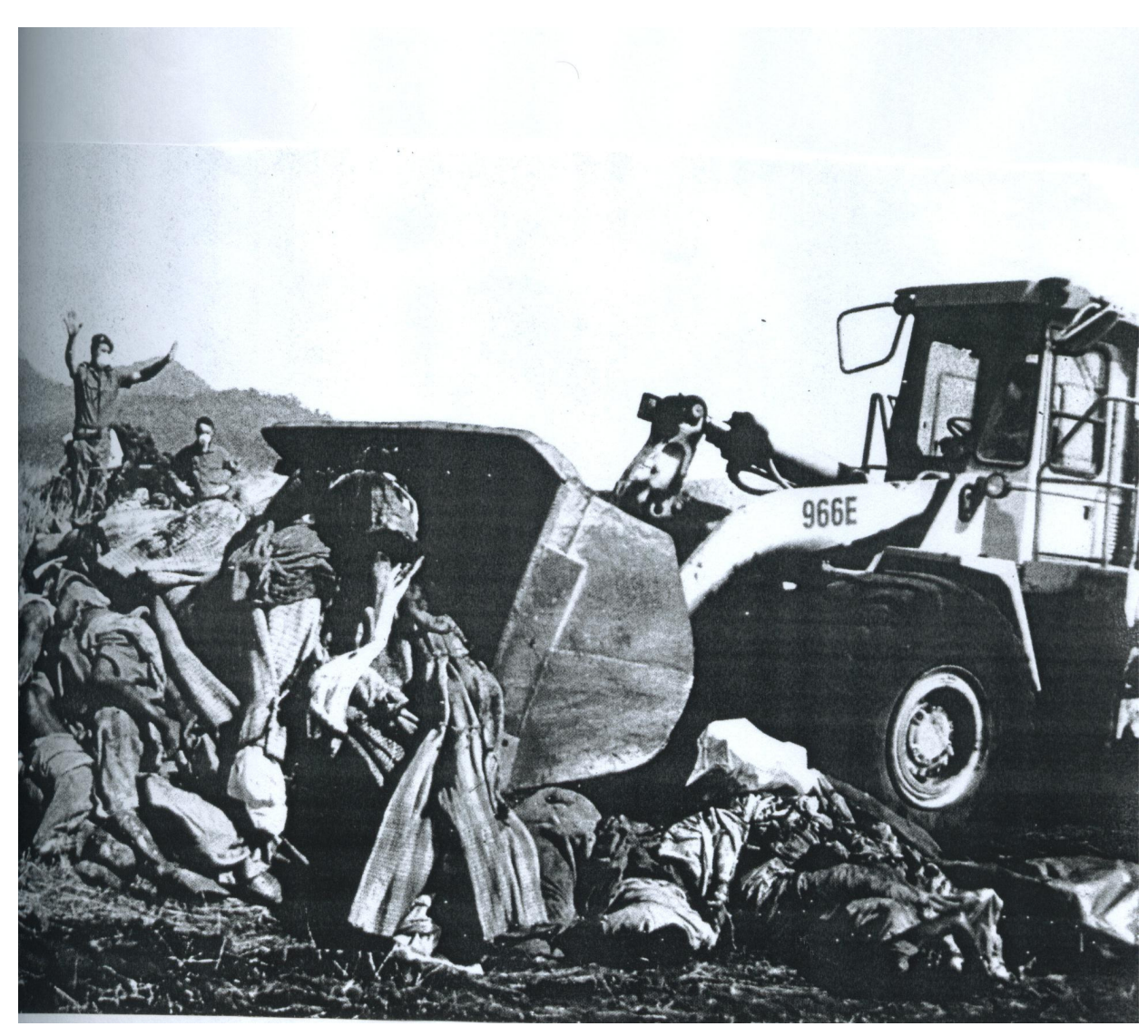

Was grimmer den die pest

Foto 39: 100 Photos pour la liberté de la presse, 1995, p. 79. (Foto de Jacqueline Arzt.) Legenda original: Camp de Kitumba. L'épidémie de choléra fait des dizaines de milliers de morts. L'armée française enterre lês cadavres.

Mesmo sem termos passado por situações semelhantes em que a peste - e mesmo seu valor - pudesse ser factível para nós, poderíamos, no máximo, conseguir nos aproximar via epidemias, por exemplo. Quando, hoje, falamos nelas, sabemos qual ou quais são seus transmissores, suas causas. Temos 0 exemplo da dengue, ou mesmo da febre amarela: sabemos que o culpado é o mosquito Aedes aegypti: bastaria exterminá-lo. No entanto, grande parte desse conhecimento foi somente adquirido pela humanidade na segunda metade do século XX. Nosso sofrimento, portanto, poderia, em tese, ser minimizado pois saberíamos qual é o motivo/transmissor daquilo que nos faz mal. Mas, e no século XVII, que tais conhecimentos eram desconhecidos, apesar de seus avanços no campo científico? Restaria, portanto, só o lamento, a deprecação aos homens e aos céus. 
O eu lírico cala-se diante daquilo que considera ser pior que a própria morte, que a ferocidade da peste, e pior que o fogo devorador. O mesmo que consome e constrói, aquele que com seu ardor, reduz tudo a cinzas: prédios, florestas, casas e pessoas...

Ao pensar nas palavras do eu lírico, ressurge a idéia da turba e de sua

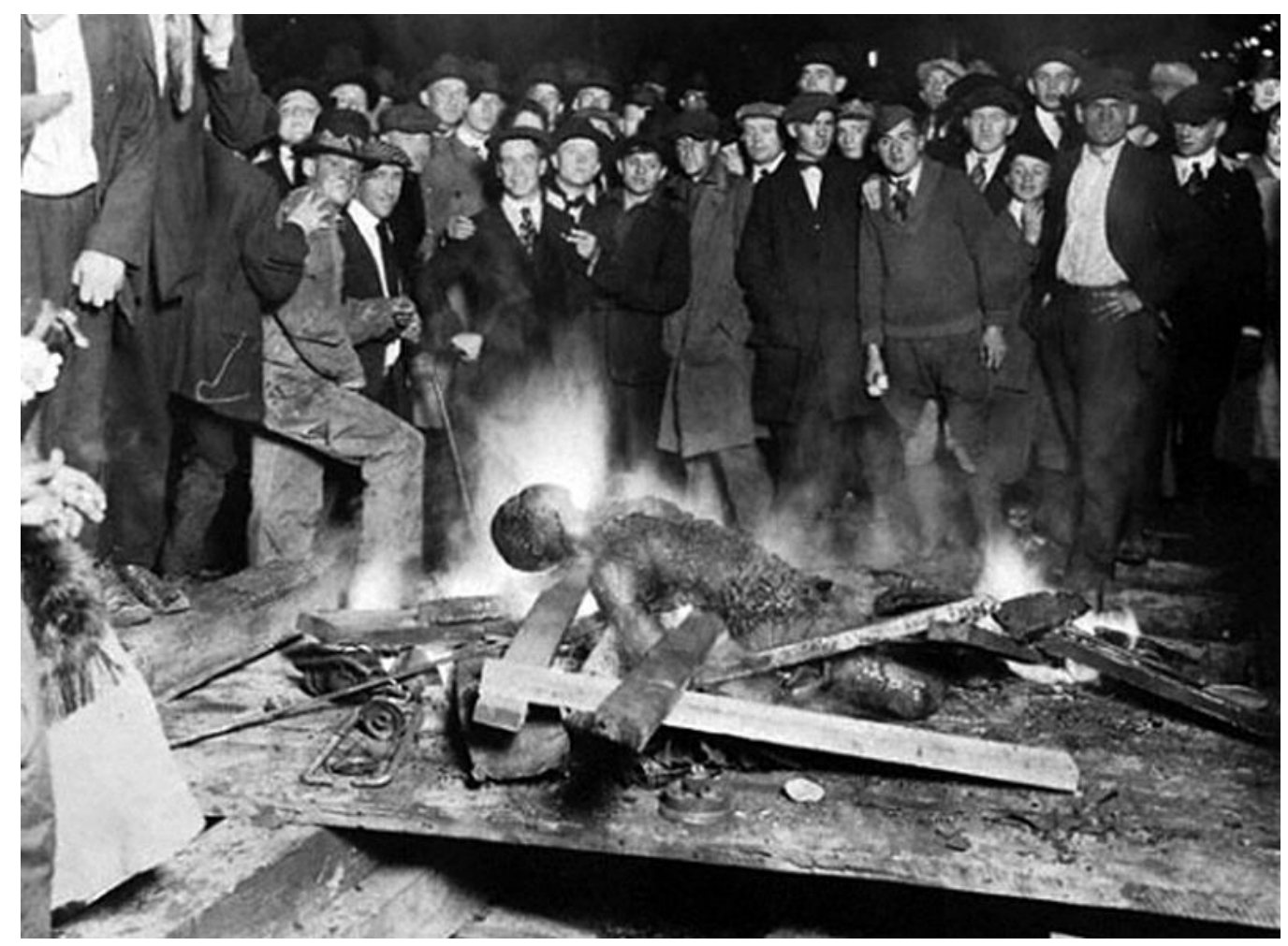

undt glutt

Foto 40: Após o linchamento e sua mutilação, o corpo do negro Will Brown é carbonizado para deleite da turba que o arrancara da prisão em Omaha, EUA, em 28/09/1919.

total inconseqüência diante de determinados fatos que fazem com que as pessoas larguem por completo o emprego da ratio. Que se pode dizer de uma multidão que acorre aos milhares a uma prisão, retira uma pessoa acusada de ter estuprado alguém - simplesmente pelo fato de a mesma ser negra, sem saber se é ou não culpada pelo crime que dizem ter cometido - lincha-a, mutila-a e depois the ateia fogo? Pior que tudo isso é dizer que se fez justiça à moça que havia sido estuprada! $\mathrm{E}$ as chamas consomem o homem que não tinha, provavelmente, relação alguma com o crime de que fora acusado, mas satisfizeram a busca por catarse da turba. A fotografia 40 é extremamente transitiva e chocante: primeiro por vermos uma multidão ao redor de um cadáver humano em chamas, apesar disso fazem pose para o fotógrafo. Fazem questão de mostrarem-se para a posteridade pelo ato humano que 
fizeram; segundo, pior do que a cena em si é o olhar de satisfação de todos aqueles que dela fazem parte, olhar e pose de dever cumprido, como se estivessem diante de uma obra construída e estivessem contemplando o resultado de seus esforços; nenhum dos presentes demonstra estranhar aquilo que, provavelmente, estranharíamos: o odor de carne humana sendo

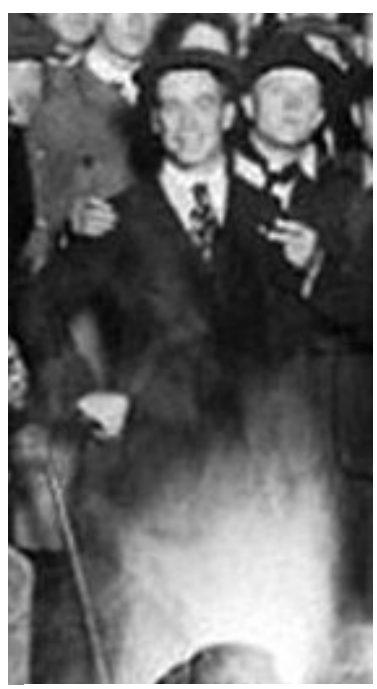

Recorte 1 incinerada. Há um rapaz mais à direita da cena que nos serve de punctum (recorte1) com sua atitude de vencedor, mão ao lado e cujo sorriso chega a ponto de gargalhar. Não há como não se impressionar com sua atitude. Esta é altamente constrangedora e não foi fotografada numa aldeia longínqua da África, nem em meio à guerra (a Grande Guerra já acabara há quase um ano 11/11/1918). Apesar disso, a cena deve ser lida dentro do contexto e da sociedade em que está inserida:

eles realmente acreditavam numa superioridade racial branca diante de outras etnias, consideradas inferiores, como a negra, daí a satisfação mórbida de ter a seus pés - literalmente - a carbonização daquele que quis (como se fosse possível dizer algo contrário diante da turba) enfrentar seu status quo.

Ante essa imagem, surge-nos outra, retirada da emblemática, que nos demonstra a relação do fogo com aqueles que o utilizaram de modo tão vil, a fim de que possamos compreender melhor aquilo que pensava o eu lírico. Vemos, na figura 83, lobos vestidos de monges, e corvos que não só ateiam fogo a uma pira cavada no chão como também a alimentam; da árvore ao lado jorra sangue sobre o fogo, extinguindo-o.

A imagem do lobo é muito presente na cultura ocidental como representação do mal ou associado a ele desde a Antiguidade. Desde a Renascença há muitas alusões a esse animal. Horapolo nos mostra que o lobo expressa o homem incomodado por seus inimigos (p. 271) ou mesmo aversão (p. 489). Nesta acepção, também foi visto como imagem do inimigo, já que não se intimida em enfrentar e destruir membros de sua própria espécie (p. 490); há, também em Horapolo, a utilização do corvo, porém aquilo que ele chama de corvo noturno é, na realidade, uma coruja. Para Ripa, a figura do lobo pode 
estar associada a várias representações de, em sua maioria, atitudes negativas: no volume 1 encontramos Carro de Marte (p. 168), Conselho - em representação com outras três cabeças: do cachorro (virada para a direita); do leão (no meio); do lobo (virada para a esquerda, representa o passado) - (p. 218), Dúvida (p. 297), Interesse próprio (p. 535); no volume 2, Peste ou Pestilência (p. 205), Rapina (p. 245), Silêncio (p. 314) e Voracidade (p. 432). Ripa, em relação ao corvo nos traz no volume 1: Indecisão (p. 515), Infortúnio (p. 523); no volume 2, Vingança (p. 391). Vê-se que vários elementos do emblema poderiam ser lidos na fotografia 35 sem que fosse necessário criar

metáforas para isso.

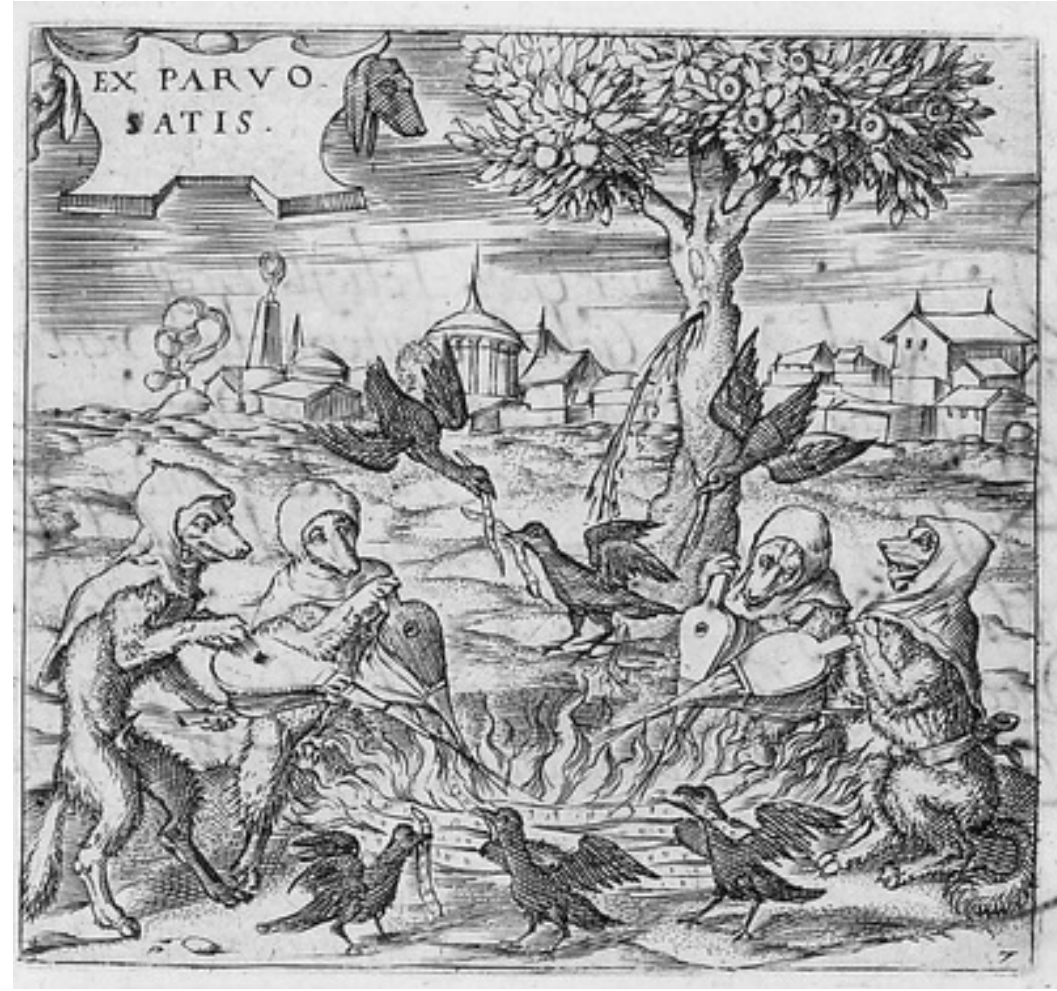

Figura 83: Emblema 7 Ex parvo satis, de Georgette de Montenay, 1615.

Os lobos no

emblema poderiam representar os homens que se inebriam diante do cadáver incinerado na pira criada por eles, demonstrando insaciável avidez em acompanhar a desgraça dos outros para fazer emprego dela - à semelhança dos lobos seguindo os exércitos (Ripa, 1989, v. 1, pág. 168) - como na demonstração soberba na foto que serve de propaganda para seus atos; estes demonstram interesses egoístas para demonstrar seu poder - daí a fotografia do jovem em pose sarcástica diante do corpo em chamas -, cuja fome foraz (ibidem, p. 535) o faz buscar culpados para seus atos, a fim de poder saciar suas próprias vontades. Vêm-nos, dessa forma, as palavras de Plauto - homo homini lupus [o homem é o lobo do homem] -, aforismo muito utilizado no século XVII retomado por Hobbes em Leviatã (1651): 
Por lo general el lobo, debido a su forma de vida basada em la rapiña, ha sido considerado como imagen de la maldad. Debido a su ferocidad se le asocia con lo meralmente bestial, es decir, con la guerra; de ahí que se encuentre entre los símbolos propios de marte, como lo señala Ripa en su "Carro de Marte". (Horapolo, 1991, p. 271)

Ávidos por vingança - cuja representação para Ripa emprega o fogo, a chama para significar a turbulência da alma que agita e ferve o coração dos homens, levando-os ao ódio e à ira sem limites -, simbolizado, no emblema, pelo corvo que, para Ripa, pica um escorpião. (ibidem, v. 2, p. 391)

Dessa forma, pouco restaria ao infeliz do negro que fora imolado em Omaha, se não fosse pelo detalhe do sangue que jorra da árvore sobre a pira no emblema -, que representa o próprio sangue de Cristo, único capaz de aplacar as chamas que, de outra forma, não sucumbiriam à constante alimentação fornecida pelos lobos e corvos. Poderíamos ver que não há árvore alguma próxima às labaredas que saem do corpo do homem morto e incinerado, mas um detalhe chama-nos a atenção: a posição do mesmo no chão e em sua pira. O rapaz está numa posição que lembra o próprio Cristo crucificado com um patibulum que passa sob seus braços... a própria cabeça, voltada para cima, lembra também o Cristo que grita: Pai perdoa-Ihes! Eles não sabem o que estão fazendo! (Lc 23, 34) para depois gritar mais forte: Pai, em tuas mãos entrego meu espírito! (Lc, 23, 46)

Segundo a alma do emblema, a árvore também representaria a cruz de Cristo e o sangue que dela jorra é o mesmo que jorrou de seu lado após a crucificação, o único capaz de aplacar aquelas chamas:

Feralem struxere focum coruique lupique:

Nec tamen, accenso fomite, ligna calent.

Nēpe sacra manās Christi cruor arbore, flāmas

Obruit, \& sterili lumina falsa rogo.

[Os corvos e os lobos fazem um fogo extravagante. Nada, porém, pode apagar o fogo depois de este ter sido ateado na madeira. Pelo sangue de Cristo que jorra da árvore sagrada as chamas do falso fogo da pira estéril são extintos.] 
Que dizer, que falar diante de uma cena como a da fotografia 41? Diante dela não temos palavras, também nos calamos. Como é possível ainda hoje a morte de milhões devido à fome? A foto de Sebastião Salgado salta diante de nós, ainda mais quando vemos que o rapaz traz um terço ao pescoço e nele vemos a cruz. É, exatamente, essa cruz que nos aproxima desse rapaz, não podemos dizer que ele não tenha algo que nos ligue a ele, a cruz grita por ele que, também calado, famélico, apesar disso tem um olhar e expressão

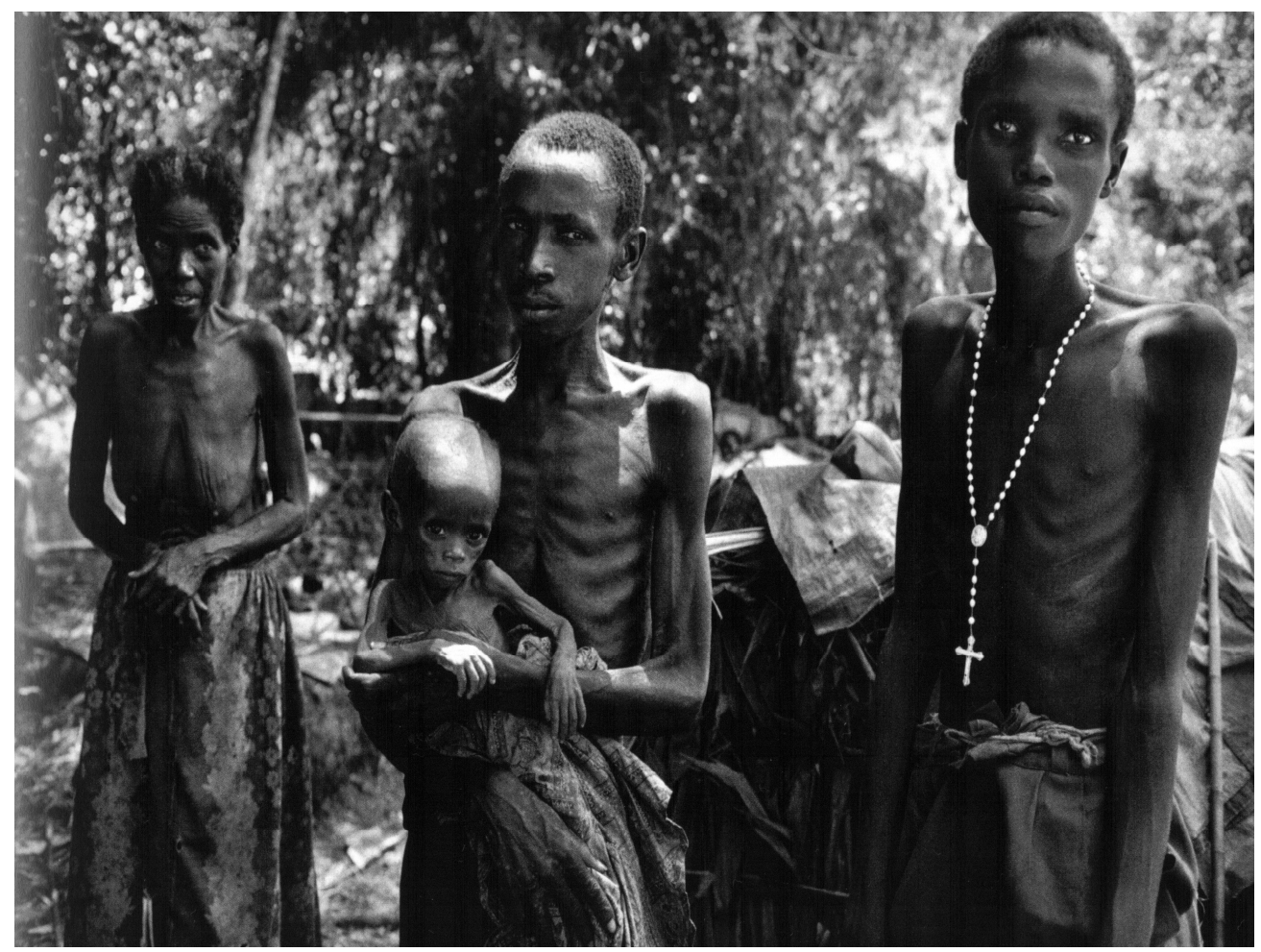

und hungers noth

Foto 41: SALGADO, Sebastião. Op. cit. p. 213 (foto de Sebastão Salgado).

Legenda original: (refere-se também a outras fotos) Dia 31 de março de 1997, na aldeia de Biaro. A Cruz Vermelha zairense foi convocada pelas forças de Kabila para enterrar os mortos ( a fim de evitar a propagação de doenças) e fazer uma contagem dos órfãos (cerca de mil). Estes eram enfileirados ao longo das linhas férreas, sob o falso pretexto de que seriam distribuídos alimentos. Outros refugiados exaustos ou agonizantes, jaziam no chão perto de um improvisado centro médico. Esperavam em vão, pois não existiam remédios. Por isso, haviam sido deixados ali para morrer ao sol; os encarregados da remoção dos corpos muitas vezes não tinham a certeza se a pessoa estava de fato morta ou ainda respirava. (...)

incomum. Que esperança tem seus olhos? Não há como desviar nossos olhos de seu contemplar: é ele que nos contempla, é ele que nos questiona, mas seus olhos não nos pedem nada, passam-nos serenidade. Será a serenidade da fé, representada pela cruz em seu peito? Com o cordão amarrado àquilo que podemos chamar de calças, lembra-nos tanto a Madalena de Mena - pelo cordão à cintura como também pela cruz que traz junto a si -, quanto à de Donatello - por sua esqualidez não por sua aparente feiúra. Não há feiúra 
nessa fotografia, toda ela é transitiva, força-nos a nos reconhecer, mesmo o homem do meio que segura a criança com seu olhar de soslaio e suas costelas à mostra, como à mostra também estão os seios da mulher atrás. Há algo ainda pior do que as chamas e do que a penúria da fome...

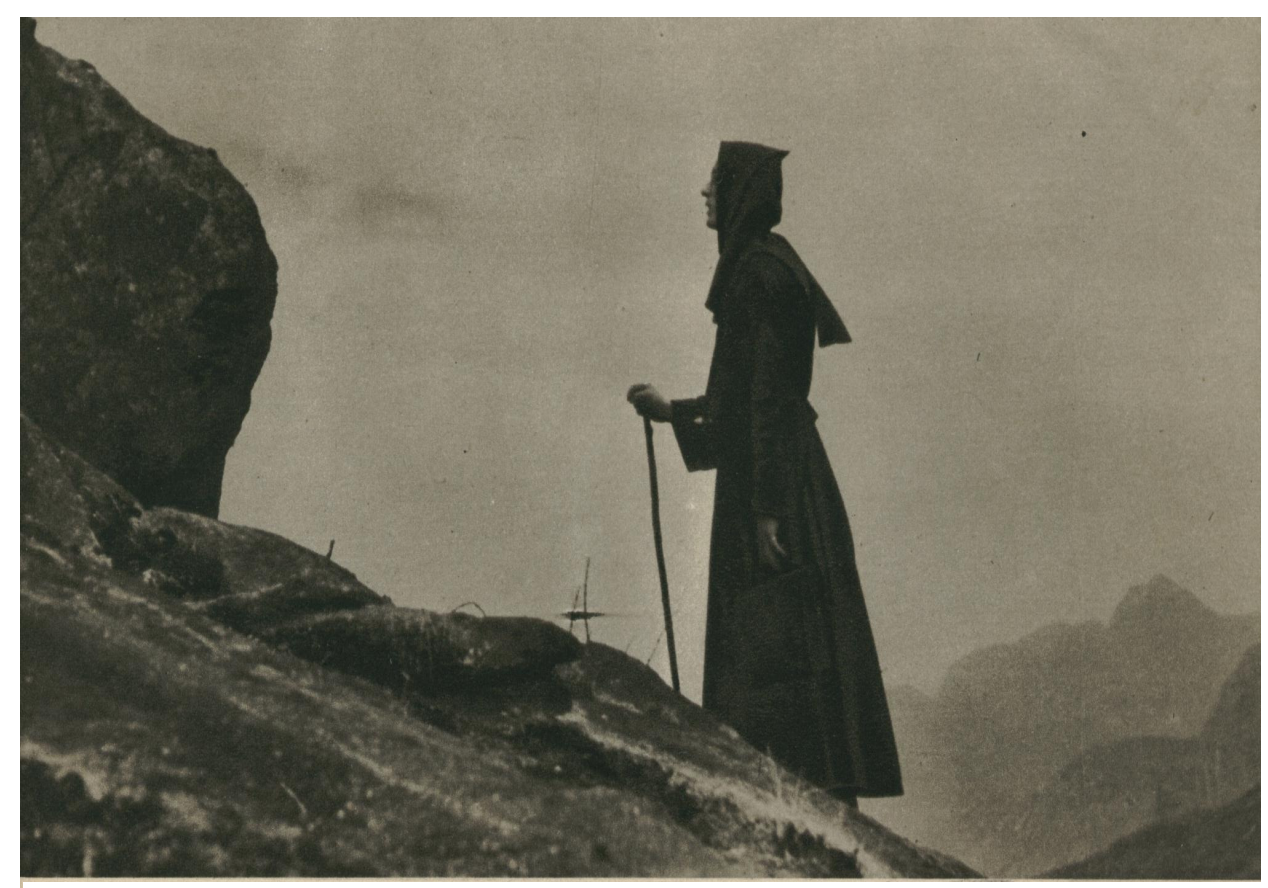

Das nun der Selen schatz/ so vielen abgezwungen.

Foto 42: Pescador de almas. São Paulo, s/d, antepenúltima página. Legenda original: Todos subimos a montanha de nossa vida, ao encontro de Deus.

Pior que todas as desgraças vistas e presenciadas é o fato de ter arrancada, à força, a última de todas as esperanças para aquele que crê: sua própria fé. Sua crença em que todas as vicissitudes são passageiras, já que se crê que há um lugar para onde lançar o olhar, há a esperança de que após a montanha haja um vale florido onde se poderá descansar. O eu lírico clama exatamente por isso: até mesmo do Selen schatz(es) [o tesouro do espírito] é obrigado a abdicar, não de uma forma livre, consciente, pessoal, mas sob pressão, por imposição, daí o verbo abzwingen (abgezwungen) - extorquir, arrancar, usurpar.

Diante do quadro traçado e concretizado pelo eu lírico, remete-nos, iconofotologicamente, à fotografia 42 - que parece, inclusive, uma pintura -, quando lemos um frade que sobe uma montanha e nada leva em suas mãos, a 
não ser um cajado que facilita sua subida. Subir ao monte ${ }^{244}$ tem muitas significações, uma delas é a da aproximação de Deus e pode tanto ser encontrada no Antigo quanto no Novo Testamento. É um lugar particular, de encontro com a divindade, no entanto demanda esforço que vai além do físico, mas do espiritual, quando se busca, a partir de um esforço interior e individual, libertar-se do peso das atribulações diárias e que se possa - após a purgação - colocar-se diante do criador.

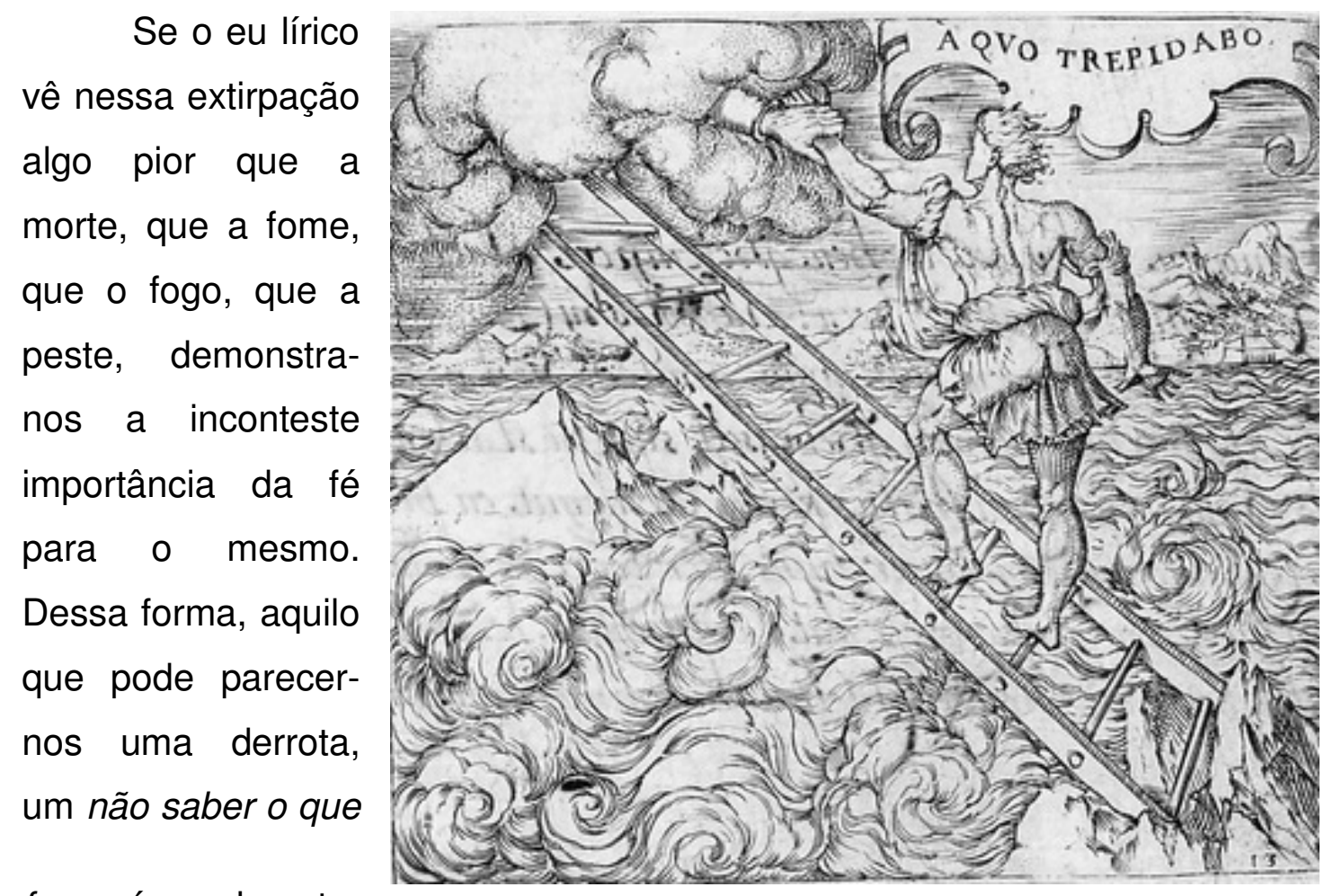

fazer é, realmente, um alento maior, Figura 84: Emblema 13 A quo trepidado [diante de quem tremerei], de Georgette de Montenay, 1615.

um momento de felicidade em que pode provar-se sua fé e sua esperança, um subir ao monte e poder gritar como o salmista:

\footnotetext{
${ }^{244}$ Há inúmeras passagens bíblicas que tratam do tema, quando se vêem dois momentos: o de revelação e o da paixão. No Antigo Testamento temos: o monte Moriá, onde Abraão foi posto à prova, com o sacrifício de Isaac; Monte Horeb (ou Sinai), lugar onde Moisés teria recebido as Tábuas da Lei; o Monte Carmelo, onde o profeta Elias provou que Javé era um Deus verdadeiro frente aos sacerdotes do deus Baal; monte Sião, o Monte do Templo do Senhor, escolhido por Davi, para nele colocar a Arca da aliança, onde ficava o Templo de Jerusalém e, por extensão, onde ficava a própria cidade. No Novo Testamento, normalmente, referem-se à vida de Jesus: o monte da tentação, o monte do Sermão da Montanha, resumo da doutrina de Jesus; o monte Tabor, lugar da Transfiguração do anúncio da cruz e da paixão, da glória e da ressurreição, lugar onde Jesus é revelado como Filho de Deus; o Calvário, monte da agonia, da crucificação e morte; e o monte da Ascensão.
} 
Javé é minha luz e salvação: de quem terei medo? Javé é a fortaleza da minha vida: frente a quem tremerei? $(\mathrm{SI} 27,1)$

Há, na emblemática, muitos exemplos em que nos é mostrado o homem que diante das adversidades não se entrega ao desespero, mas se segura nas mãos de Deus (fig. 84). 
Para continuarmos nossa análise, deter-nos-emos naqueles poemas que, segundo nossa visão hodierna, consideraríamos como demonstração de fenômenos naturais, quando um eu lírico demonstra seu clamor diante das ações efetuadas pela natureza em forma de catástrofes.

Efetuaremos, portanto, uma leitura iconofotológica de alguns versos, visto que, a título de ilustração, não será mais necessária uma abordagem mais detalhada, como havíamos feito no poema anterior. Priorizaremos, dessa forma, os versos que demonstrem terem sofrido refração diacrônica e, se necessário, recorremos à emblemática e à Iconologia de Cesare Ripa para que possamos contrastar aquilo que vemos, iconofotologicamente, com aquilo que pretendiam os autores daquele momento particular.

Die auff ein starckes Ungewitter erfolgte Stille

Die auff ein starckes Ungewitter erfolgte Stille [O ímpeto de uma tempestade seguida de calmaria] é um longo poema de Barthold Heinrich Brockes (1680-1747), pertencente à obra Irdisches Vergnügen in Gott, edição contendo poemas e traduções do autor em nove volumes, cujo mote principal é a natureza, suas belezas e sua utilização como forma de refletir a criação divina e sua relação com os homens.

O subtítulo, como veremos, mostra-nos em quem o autor baseou-se para escrever o poema, no Livro de Jó, quando este descreve que Deus utilizase dos fenômenos naturais tanto para demonstrar a bondade que sente pelos homens quanto para castigá-los:

Ele enche as nuvens de unidade e espalha as nuvens de tempestade. Estas guiadas por ele, giram e circulam, para cumprir todas as suas ordens no mundo inteiro. Ele as envia aos povos da terra para castigá-los ou para beneficiá-los. (Jó 37, 11-12) 


\section{Barthold H. Brockes}

\section{Die auf ein starckes Ungewitter erfolgte Stille} Job. XXXVII, 5-11.

Gott donnert mit Seinem Donner gräulich, und thut grosse Dinge. - Die dicken Wolcken scheiden sich, daß helle werde, und durch den Nebel bricht Sein Licht.

Nachdem die Sonne jüngst, seit zweymahl funfzehn Tagen,

Die neu-beblühmte Welt beständig angelacht;

Schwamm alles, was man sah, in Wollust und Behagen.

Die Gluht, die alles hell, die alles lebhaft macht,

Befloß so Stadt als Land, bedeckte See und Flüsse.

Sie senckte sich so tief in Tellus Schooß hinein,

Daß Feld und Felsen glüht'; es gläntzte Sand und Stein;

Man kennete fast nicht die feuchten Wolcken-Güsse,

Bis endlich sich einmahl, bey schwühlen Mittags-Stunden,

Ein kleines Wölckchen zeigt', und, in dem Augenblick,

Sich auszuspannen schien. Die Luft ward plötzlich dick;

Das Licht ward allgemach vom Schatten überwunden;

Es stieg ein grauer Duft und Nebel in die Höh';

Des Tages Gold erbleicht'; es schwand das heitre Blau;

Die dicke, dunckle Luft beschattete die See;

Die Bäche schienen schwartz, die Flüsse braun und falbe;

Der gantze Luft-Kreis ward von Duft und Regen schwer;

Kein Vogel war zu sehn, die auch schon scheuche Schwalbe

Schoß nur allein, jedoch gantz niedrig, hin und her.

[O ímpeto de uma tempestade seguida de calmaria

Jó 37, 5 e 11

Deus troveja com voz prodigiosa e realiza maravilhas que não compreendemos. - As pesadas nuvens partem-se, para que se se torne claro e através da névoa brilhe Sua luz.]

Depois que o sol há pouco, desde duas vezes quinze dias/ O novo-reflorido mundo sorriu estável;/ Absorve tudo, o que se vê, em volúpia e deleite./ O calor que tudo ilumina, que faz tudo vivo,/ Flui na cidade assim como no campo, cobre lagos e rios./ Ele mergulha profundamente dentro do seio de Telo, / Que fumega campo e rochedo; brilha areia e pedra,/ Quase nunca se conhece as nuvens úmidas e carrefagas,/ Até que, finalmente, uma vez, no mormaço do meio-dia/ Uma pequena nuvenzinha mostra-se e num momento/ Parece se 
desatrelar. O ar, de repente, torna-se pesado/ A luz, aos poucos, é dominada pelas sombras;/ Às alturas sobem cheiros e névoas tenebrosos/ Empalidece o ouro da tarde; desaparece o azul sereno;/ O pesado e escuro ar encobre o mar/ Os regatos parecem pretos, os rios marrons e amarelentos/ Toda a atmosfera ficou pesada pela neblina e chuva;/ Não há nenhum para se ver, as andorinhas também se afugentaram

É possível ver que Brockes inicia seu poema exibindo-nos imagens que demonstrem placidez e constância: vemos que die Sonne [o sol] não só ilumina os campos, os rios, como vai além, ao prórprio seio da Terra: Sie senckte sich so tief in Tellus Schooß hinein [penetra, tão profundamente, no próprio interior da

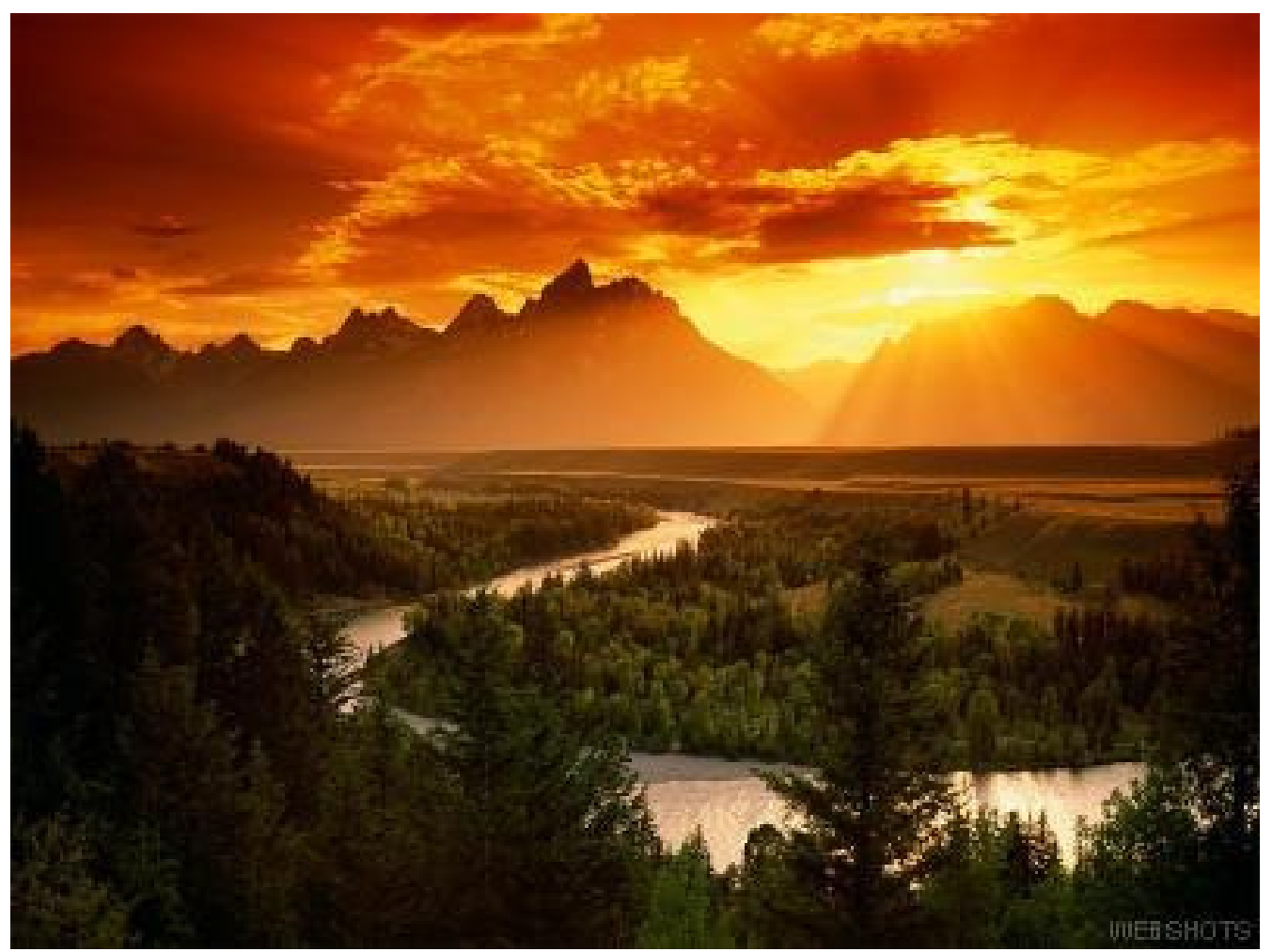

Nachdem die Sonne jüngst, seit zweymahl funfzehn Tagen

Foto 43: Snake River, Grand Teton National Park, Wyoming, retirado de www.webshots.com (C) Super Stock, Inc.

terra, no seio de Telo, da Terra Mater]. Suas palavras estão repletas de bucolismo que nos remete a uma profunda serenidade, à contemplação, como se estivéssemos sobre uma montanha após o esforço da subida e pudêssemos admirar, do alto, o vale embaixo: a mais completa recompensa pelo esforço realizado. 
É possível ler esses versos, iconofotologicamente, a partir da fotografia 43, quando se pode vislumbrar não só o findar de um outro dia (ou seria o recomeço de outro?), como também o término de um mês zweymahl funfzehn Tagen (duas vezes quinze dias).

No entanto, o que enxergamos como bucolismo, como contemplação da exuberância da natureza, não corresponderia, exatamente, à imagem pretendida pelos leitores dos Seiscentos, com aquilo que buscavam ou enxergavam, principalmente quando falamos na contemplação vinda do alto.

Há, na figura 85, uma idéia próxima da que descrevemos anteriormente: vemos a representação de uma pessoa no alto de um monte que aponta para um vale. A seu lado, é possível ver um chapéu e uma cabaça atada a um cajado: esses são os sinais

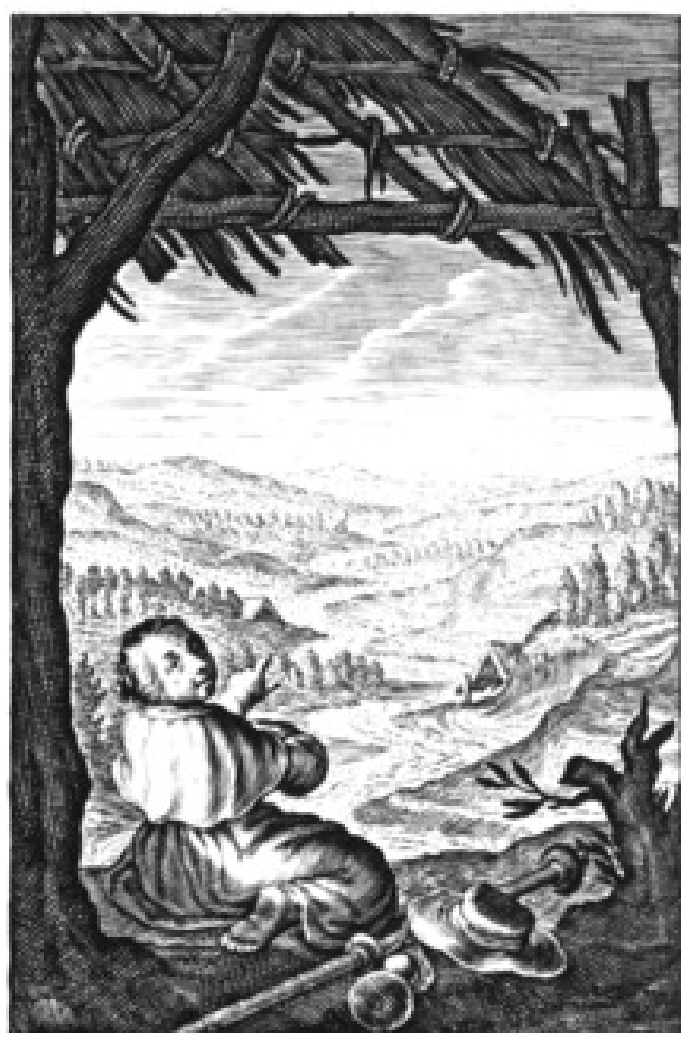

Figura 85: Emblema 37, Heu mihi quia in colatus meus prolongatus est! [Ai de mim, exilado (...) acampado nas tendas !], de Justus Harduwijn, 1629. do peregrino. A inscriptio do emblema é retirado do Salmo 120 que nos mostra o sofrimento do estrangeiro em terras estrangeiras, daí a representação emblemática de um peregrino, ou seja, aquele que está somente de passagem e que, provavelmente, aponta em direção a seu caminho, a sua terra.

À continuação, o eu lírico mostra-nos que devido ao schwühlen MittagsStunden [mormaço do meio-dia], aquilo que era uma Wölckchen [nuvenzinha] transforma-se: Das Licht ward allgemach vom Schatten überwunden [A luz, aos poucos, é dominada pelas sombras], a tempestade aproxima-se (fotografia 38) e com ela a destruição que fustiga o homem, mas que faz com que os animais também se amedrontem. 
A tempestade que se aproxima tem a mesma significação que havíamos visto anteriormente em relação ao fogo purificador por que o homem tem de passar para provar se tem ou não confiança em Deus, se segue os não seus preceitos:

Vocês recusaram os meus conselhos e não aceiratam o meu aviso. Por isso, eu também vou rir da desgraça de coces. Vou zombar, quando o terror cair sobre vocês como tempestade, a desgraça chegar como furacão, e a angústica e afliação os alcançar, então vocês vão me chamar, mas eu não reponderei. Vocês vão me procurar, mas não me encontrarão. ( $\mathrm{Pv} 1,25-28)$

Porque, aqueles que não o fazem, sentem o braço poderoso de Deus que se abate sobre eles. O profeta Naum mostra-nos, por sua vez, que a tempestade é a demonstração da ira de Javé:

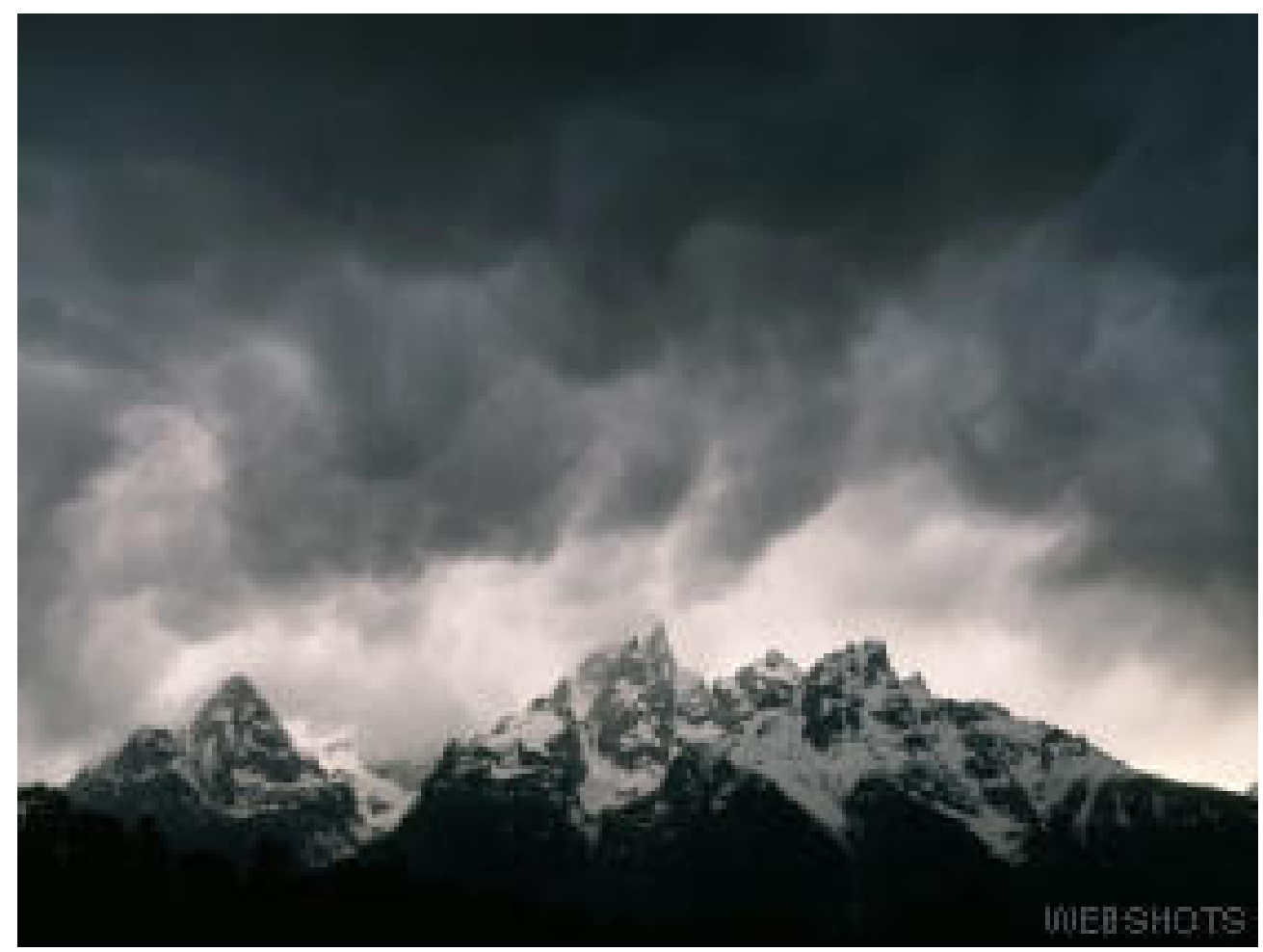

Das Licht ward allgemach vom Schatten überwunden

Foto 44: Storm Clouds Over the Teton Range, Wyoming, ( ) Willard Clay 
Javé é lento para a ira e muito poderoso, mas não deixa ninguém sem castigo. Borrasca e tempestade fazem o caminho dele; as nuvens são a poeira de seus passos. Ameaça o mar, e o mar seca; ele enxuga todos os rios. ( $\mathrm{Na} \mathrm{1,3-4)}$

No entanto, vemos, no Novo Testamento, que quem está com Deus não deve temer as piores tempestades que possam se abater sobre os homens;

$E$ eis que houve grande agitação no mar, de modo que a barca estava sendo coberta pelas ondas. Jesus, porém estava dormindo. (Mt 8,24$)$

Eis que o eu lírico
quer nos passar a
confiança em Deus, a
única capaz de nos
fazer passar pelas
trevas que se nos põe
diante de nossas vidas,
é ela que nos faz
chegarmos sãos à outra
margem do mar em

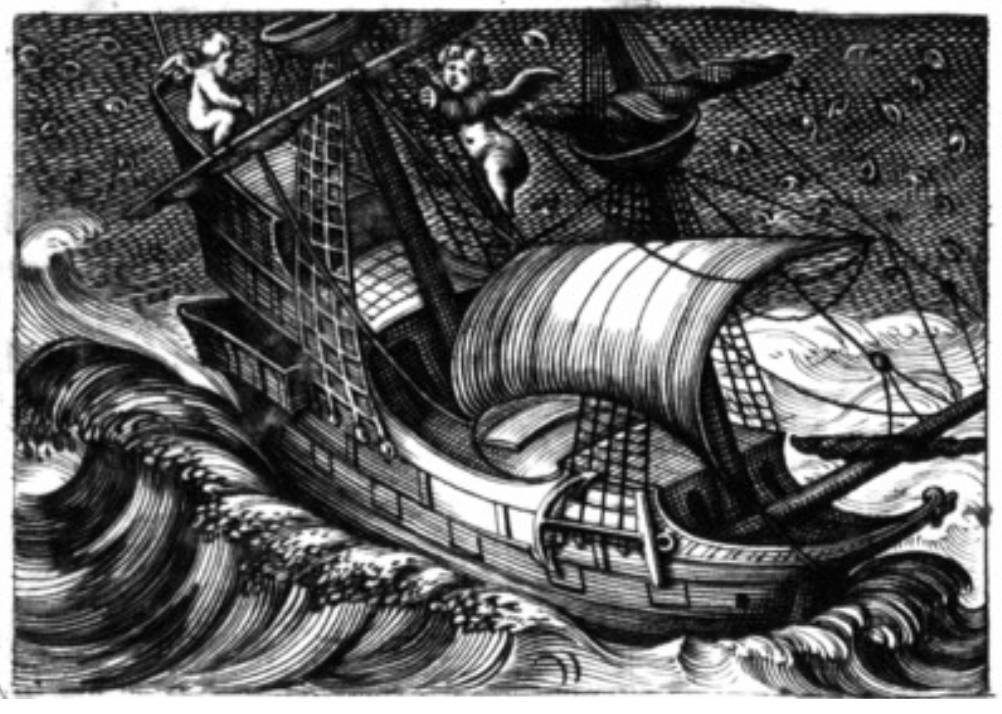

Figura 86: Emblema 11 In tenebris lucem, de Daniël Heinsius, 1616.

meio ao turbilhão da borrasca que quer nos pôr para fora de nosso navio (nossa vida); por isso que Jesus simplemente dorme em meio à tempestade, enquanto seus apóstolos desesperam-se temendo pelo pior.

A fotografia 44 mostra-nos o que é, para nós, as sombras que cobrem a luz do sol. A grande semelhança com o eu lírico é o fato de também mantermos o medo diante daquilo que não conhecemos, por mais que já saibamos como as tempestades são formadas, como sugem os furacões e tufões, ainda os tememos, pois nem sempre podemos acreditar que estamos salvo de suas conseqüências. Prova disso foi o furacão Katrina que destruiu a cidade de Nova Orleãs em agosto de 2005, levando destruição, pânico e morte a várias pessoas que, acreditavam, estarem protegidas. 


\section{CONCLUSÃO}

Procuramos, neste trabalho, discorrer sobre um dos períodos mais surpreendentes da história da arte que foi o Seiscentismo, apesar de ter sido depreciado durante anos como um momento obscuro, ininteligível e de mau gosto. No entanto, cada vez mais verificamos que essa visão distorcida rompida no início do século $X X$ - não passava de desconhecimento da chave sígnica que abriria o sentido do período, mas que se perdera, quase totalmente, quando da inovação propiciada pelo Romantismo. É exatamente essa névoa sígnica que esta Tese procurou explorar.

Esta exploração, no entanto, apesar de adentrar na imagerie daquele período, teve como pressuposto sua recepção não mais a partir dos modelos epistemológicos do período, representados pelas iconologias ou pelos livros de emblemas - verdadeiros manuais -, mas por aquilo que podemos considerar sua substituta: a imagem fotográfica, via o que nomeamos de iconofotologia.

É, exatamente, a partir da propagação da fotografia na sociedade, a partir do século XIX, que nossa Weltanschauung passa a adotar outro escopo. Sua gênese influenciou não só nosso olhar o mundo, como também nos abriu a possibilidade de conhecer e aguçar nossa visão de outros mundos (perceptível ou imperceptível).

Evidentemente, trabalhar com duas tendências artísticas que, na aparência, não confluem é uma tarefa penosa, principalmente por estarem em campos diferentes do saber. Para isso, tivemos de recorrer à etimologia para demonstrarmos que esses campos, pelo menos em sua origem, não se repelem, mas confluem.

Dessa forma, algumas palavras se tornam chave neste trabalho como $\lambda o ́ \gamma o \varsigma$ e $\tau \dot{x} \chi v \eta$. Aquela por ter-nos dado a racionalidade, esta por nos abrir a possibilidade de trabalhar com aquilo que a outra nos forneceu: dominar 0 mundo, dominando-nos primeiramente. Outra relação importante estabelecida

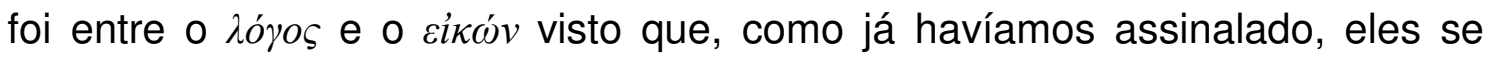
imiscuíam profundamente no período barroco, sob os auspícios da $\mu \dot{\mu} \mu \eta \sigma \varsigma$ : afinal tudo era imitação no período e como não havia a idéia de originalidade, 
aquela sociedade acabava se refletindo nela mesma e buscando os auctores para poderem-se também refletir neles. Vê-se que tal sociedade orbitava em torno de si mesma, já que não havia possibilidade de abertura para outras idéias à semelhança do ancien régimen.

O tempo, porém, fez com que a casca que recobria essa sociedade se inseria, fosse rompida e seus cacos se espalhassem nos momentos seguintes. Fragmentado, tal conhecimento se perdeu, por isso nossa dificuldade de ler as suas obras, sejam elas pictóricas, poéticas ou escultóricas.

Para isso, valemo-nos, nesta Tese, do método de análise de Panosfsky, a fim de que também nos fosse possível abrir a chave sígnica para a compreensão daquele momento para o leitor hodierno. Evidentemente, para que isso fosse possível, tivemos de resgatar pressupostos tanto da arte renascentista - para que pudéssemos cotejá-los com o olhar barroco -, como também de lançar nosso olhar para o medievo, possibilitando uma visão global do fazer artístico do Barroco, como fruto tanto da experiência clássica quanto da medieval.

A partir desse momento, vimo-nos na obrigação de trabalhar de forma paralela: ora falando do $\lambda o ́ \gamma o \varsigma$ ora do sikẃv para que, finalmente, chegássemos à fotografia e a nossa Tese, propriamente dita.

Aproveitando esse trabalho comparativo, dividimos a Tese em duas partes: a primeira procurou situar o leitor na Weltanschauung seiscentista, quando se levantaram aspectos daquela epistéme, sem os quais seria impossível a compreensão do período, como a idéia do anacronismo, a da representação, do gênero emblemático. Concomitante a esses, inseriram-se também aspectos da linguagem fotográfica e as possíveis analogias com a linguagem poética.

Com base nesses pressupostos, fizemos uma leitura tanto de uma escultura quanto de um quadro do período, sob o ponto de vista alegórico, contrastando-os com excertos poéticos, verificando a relação estabelecida

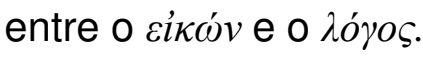

O resultado da compilação demonstra que é muito difícil, senão impossível algumas vezes, lermos as imagens extemporâneas de um período como o Barroco sob nosso olhar. Para isso, fazem-se necessários alguns elementos que possam tornar essas imagens claras diante de nossos olhos. 
No entanto, para que isso fosse possível, seria necessária a leitura de várias obras e tratados do momento, para que pudéssemos ter acesso àquela chave cognitiva, no entanto isso está fora de cogitação numa sociedade como a nossa que, cada vez mais, quer alijar-se da leitura, ainda mais de textos obscuros como os do Barroco.

Aqueles, porém, que se atreverem a ler tais textos, lê-los-ão não sob os auspícios das iconologias - que não existem mais - mas, sob o das iconofotologias que seriam o acervo imagético-fotográfico que formamos durante nossa vida. São essas imagens que colocamos no lugar daquelas propostas pela epistéme seiscentista de que não dispomos mais.

Com base nas iconofotologias, veremos que podemos transferir todas as imagens criadas pela literatura por um correspondente fotográfico e isso se torna mais claro em textos distantes, temporalmente, do escritor, já que o acervo cultural se torna mais tênue com o passar dos anos. Fato, por exemplo, menos provável em textos contemporâneos, visto que a imagem proposta pelo escritor pode também pertencer ao leitor, uma vez que ambos co-participam do mesmo período temporal e pode haver um acervo iconofotológico coletivo comum.

Dessa forma, verifica-se que as leituras iconofotológicas podem tanto ser coletivas quanto individuais, pois pressupõem a aquisição de um acervo imagético compilado ao longo de uma vida sob a influência de vários fatores de ordem sócio-cultural.

Esta Tese limitou-se a trabalhar com a lírica do Seiscentismo de diversos autores e, diante do fato iconofotológico, sentimos a necessidade de explicitar também aquilo que denominamos de poema fotográfico, que seria aquele cujo poeta não tenha tido ele mesmo a influência direta da fotografia, mas aquele cujo leitor, sim, tenha sofrido a influência dela, já que são as imagens verbais contidas nessa estrutura lingüística que revelam, justamente as imagens fotográficas que permeiam nossa memória, ou seja, nosso acervo iconofotológico: esse seria, portanto, um dos traços que nos ligariam, por exemplo, ao período barroco, visto que também nós estamos presos e essas imagens, apesar de não podermos fugir das palavras.

Essa relação fica clara, quando se diz que a imagem por si só se vale. No entanto, verificamos que não é bem assim. Buscamos e temos a 
necessidade de uma legenda que nos torne clara a proposta do fotógrafo e mesmo do pintor (em se tratando da arte moderna, por exemplo, com seu total abstracionismo e ausência do referencial).

$\mathrm{Na}$ parte final desta Tese, portanto, fizemos uma leitura iconofotológica de um poema fotográfico de Andreas Gryphius, concomitantemente a uma análise iconológica do período em que o poeta estava inserido, utilizando-nos para isso de imagens da emblemática. Para que a leitura fosse factível, utilizamos parte de nosso acervo iconofotológico para a mesma o que, não necessariamente, corresponderia à das outras pessoas, visto que é individual.

Sob as imagens fotográficas, inserimos os quadros poéticos do eu lírico, para que pudéssemos direcionar a leitura para nosso propósito, conforme fazem os editores de jornais e revistas, além de demonstrar o poder que o $\lambda o ́ \gamma o \varsigma$ tem de coerção frente ao sikẃv.

Esperamos ter ficado evidente o ineditismo desta Tese. Não nos propusemos tão somente a analisar textos de um período distante, muito menos fazer uma mera interpretação daqueles que escolhemos como corpus. Por esse motivo, não direcionamos, a priori, o trabalho para um único autor, mas para uma seleção de autores representativos.

Com isso, procuramos demonstrar que a chave sígnica de que havíamos falado anteriormente era comum a todos do período Seiscentista, ou seja, havia um léxico comum que remetia a um campo imagético específico, mas que ao se perder no tempo teve de ser substituído. 


\section{BIBLIOGRAFIA}

ALMEIDA, Júlia de. "Entre texto e imagem: título e quadro". In Alceu, v. 6, n. 12, Rio de Janeiro, 28-41, 2006.

ALONSO, Dámaso. Poesia española (ensayo y métodos y límites estilísticos). Madrid, Gredos, 1987.

ARBEX JR. José. Guerra Fria: Terror de Estado, política e cultura. São Paulo, Moderna, 1997.

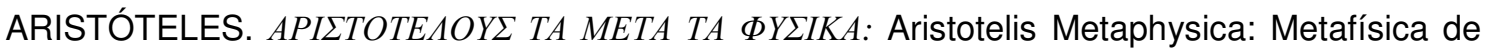
Aristóteles. Madrid, Gredos, 1987. . Os pensadores: Aristóteles. São Paulo, Nova Fronteira, 1996.

ARNIM, Achim von. Ausgewählte Gedichte. In Die digitale Bibliothek der deutschen Lyrik. Berlin, Directmedia, 2003.

ARNOLD, Heinz Ludwig (Hrz.). Text + Kritik: Zeitschrift für Literatur. Heft 7/8 Andreas Gryphius (2. Auflage).München, 1980

AMELANG, J.S. et alii El hombre barroco. (Madrid?), Alianza Editorial, (?)

AUERBACH, Erich. Introdução aos estudos literários. São Paulo, Cultrix, 1970.

Mímese: a representação da realidade na literatura ocidental. São Paulo,

Perspectiva, 2004.

BACELAR, Jorge. "Apontamentos sobrea história e o desenvolvimento da impressão". In (www.bocc.ubi.pt/pag/bacelar apontamentos.pdff), Biblioteca on line de ciências da comunicação. Lisboa (?), 1999.

BACCEGA,M.A.. "Comunicação/ Educação: Linguagem e História". In Anais do Congresso Brasileiro de Ciências da Comunicação, 28., 2005, Rio de Janeiro. São Paulo: Intercom, 2005. Vide (http://reposcom.portcom.intercom.org.br/dspace/bitstream/1904/17960/1/R1040-1.pdf), acessado em 29/09/2007)

BAIER, Lothar. "Persona und Exemplum: Formeln der Erkenntnis bei Gryphius und Lohenstein." Text + Kritik: Zeitschrift für Literatur, München, (7/8): 58-67, março de 1980.

BAITELLO JÚNIOR, Norval. "O olho do furacão. A cultura da imagem e a crise da visibilidade". In http://www.cisc.org.br/portal/biblioteca/furacao.pdf, acessado em 20/02/2007.

BARROS, Diana Luz Pessoa de. Teoria semiótica do texto. São Paulo, Ática, 1990.

BARTHES, Roland. A câmara clara. Rio de Janeiro, Nova Fronteira, 1984. Image, music, text. New York, Hill and Wang, 1994. "Visualização de Linguagem". In: Inéditos, vol.3: Imagem e moda. São Paulo, Martins Fontes, 2004. Roland Barthes por Roland Barthes. São Paulo, Cultrix, 1977.

BENJAMIN, Andrew. OSBORNE, Peter (orgs.). A filosofia de Walter Benjamim. Rio de Janeiro, Jorge Zahar, (?)

BENJAMIM, Walter. Origem do drama barroco alemão. São Paulo, Brasiliense, 1984. Sociologia (org. Flávio R. Kothe) 2ª ed. São Paulo, Ática, 1991. 
Magia e técnica, arte e política: ensaios sobre literatura e história da cultura.

Obras escolhidas Vol. 1. São Paulo, Brasiliense, 1993.

BENZ, Richard. Deutsches Barock. Stuttgart, Reclam-Verlag, 1949.

BERGSON, Henri. Matéria e memória. São Paulo, Martins Fontes, 1999.

BIEDERMANN, Hans. Dicionário de símbolos. São Paulo, Melhoramentos, 1993. Knaurs Lexikon der Symbole. Berlin, Directmedia, 1999.

BIERBAUM, Otto Julius. Ausgewählte Gedichte, In Die digitale Bibliothek der deutschen Lyrik. Berlin, Directmedia, 2003.

BIRKEN, Sigmund von. Geistliche Lieder. In Die digitale Bibliothek der deutschen Lyrik. Berlin, Directmedia, 2003.

BOESCH, Bruno (organizador). História da Literatura alemã, São Paulo, Herder, 1967.

BONFIGLIOLI, Cristina Pontes. "Representação e pensamento: a visibilidade dependente". In Compós: Associação Nacional dos Programas de Pós-graduação em Comunicação. Biblioteca 296, Belo Horizonte, 2008. (www.compos.org.br/data/biblioteca 296.pdf)

BRASSAÏ. Proust e a fotografia. Rio de Janeiro, Jorge Zahar Ed., 2005.

BRECHT, Bertolt. Die Gedichte von Bertolt Brecht in einem Band. Frankfurt, Suhrkamp Verlag, 1990.

BLIKSTEIN, IZIDORO. Kaspar Hauser ou a fabricação da realidade. São Paulo, Cultrix, 1990.

BLOOM, Harold. O cânone ocidental: os livros e a escola do tempo. Rio de Janeiro, Objetiva, 1995.

BURGER, Harald. Sprache der Massenmedien. Berlin, Walter de Gruyter, 1990.

BRANDÃO, Antônio Jackson S. Poesia, Tempo e mar. São Paulo, Plêiade, 2001.

A literatura barroca na Alemanha. Andreas Gryphius: representação, vanitas e guerra. Dissertação de mestrado apresentada à Universidade de São Paulo, 2003.

BRASSAÏ, Gilberte. Proust e a fotografia. Rio de Janeiro. Jorge Zahar, 2005.

BRECHT, Bertolt. Teatro completo em 12 volumes. Vol. VI. Rio de Janeiro, Paz e Terra, 1991.

BRENTANO, Clemens. Ausgewählte Gedichte, In Die digitale Bibliothek der deutschen Lyrik.

Berlin, Directmedia, 2003.

BROCKES, Barthold Heinrich. Irdisches Vergnügen in Gott, In Die digitale Bibliothek der deutschen Lyrik. Berlin, Directmedia, 2003.

BRUMMACK, Jürgen. "Satire". In: Reallexikon der deutschen Literaturgeschichte. (Hrsg. Von Kohlschmidt), Werner und Mohr. 2. auflage. Berlin/New York, 1977, Bd. 3.

BÜCHNER, Luise. Frauenherz. In Die digitale Bibliothek der deutschen Lyrik. Berlin, Directmedia, 2003.

BÜHLER, Johannes. Deutsche Geschichte: Das Barockzeitalter. Berlin, Walter de Gruyter, 1950.

BUYSSENS, Eric. Semiologia e comunicação lingüística. São Paulo, Cultrix, s/d.

CAMPOS, Jorge Lúcio de. "Eis dois cachimbos: roteiiro para uma leitura foucaultiana de Magritte“. In Espéculo, n. 27, Madrid, 2004.

CAÑIZAL, Eduardo Peñuela. Surrealismo: rupturas expressivas. São Paulo, Atual, 1986. 
CARONE NETO, Modesto. Metáfora e montagem. São Paulo, Perspectiva, 1974.

CARONTINI, Enrico. PERAYA, D. O projeto semiótico: elementos de semiótica geral. São Paulo, Cultrix, 1979.

CARPEAUX, OTTO Maria. História da literatura ocidental. Rio de Janeiro. Edições O Cruzeiro, 1960, vol. II.

CARVALHO, Nelly de. Publicidade: a linguagem da sedução. $2^{a}$ ed. São Paulo, Ática, 1998.

CASTORIADIS, Cornelius. A instituição imaginária da sociedade. Rio de Janeiro, Paz e Terra, 1982.

CHAUÍ, Marilena. Convite à Filosofia. $7^{a ̣ a}$ ed. São Paulo, Ática, 2000.

CHRISTEN, Ada. Lieder einer Verlorenen. In Die digitale Bibliothek der deutschen Lyrik. Berlin, Directmedia, 2003.

CHOMSKY, Noam. Reflexões sobre a linguagem. São Paulo, Cultrix,1980.

COHEN, Fritz G. "The Strategy of Variants: An Analysis of Andreas Gryphius' Sonnet 'An eine Jungfraw'”. Simpliciana IV/V, Bern: 143-153, 1983.

COHEN, Jean. Estrutura da linguagem poética. São Paulo, Cultrix, 1978.

COELHO, Nelly. Literatura e linguagem. $3^{\text {a }}$ ed. São Paulo, Quíron, 1980.

COSTA LIMA, Luiz (org.). A literatura e o leitor. Rio de Janeiro, Paz e Terra, 1979.

CRAIA, Eladio C. Pablo. Gilles Deleuze e a questão da técnica, 2003, Tese (Filosofia), Unicamp, Campinas.

CRARY, Jonatahn. Techniques of the observer: On vision and modernity in the nineteenth century. Cambridge \& London, MIT Press, 1992.

CUNHA, Celso Ferreira da. Gramática da Língua Portuguesa. Rio de Janeiro, FENAME, 1982.

CUNHA, Euclides da. Os sertões: campanha de Canudos. São Paulo, Ática, 1998.

CURTIUS, Ernst Robert. Literatura européia e Idade Média Latina. São Paulo, Hucitec/Edusp, 1996.

DACH, Simon. Geistliche Lieder. Trostgedichte., In Die digitale Bibliothek der deutschen Lyrik. Berlin, Directmedia, 2003.

DEHMEL, Richard. Aber die Liebe In Die digitale Bibliothek der deutschen Lyrik. Berlin, Directmedia, 2003.

DELEUZE, Gilles. Lógica do sentido. São Paulo, Perspectiva, 2003.

DERRIDÁ, Jacques. A escritura e a diferença. São Paulo, Perspectiva, 1995.

DREHER, Martin N. "Palavra e imagem: a reforma religiosa do século XVI e a arte". In Revista de Ciências Humanas, Florianópolis, v. 30, p. 27-41, 2001.

DROSTE-HÜLSHOFF, Anette von. Gedichte (Edição de 1844) In Die digitale Bibliothek der deutschen Lyrik. Berlin, Directmedia, 2003.

DUARTE, Rodrigo. FIGUEIREDO, Virgínia (org.) Mímese e expressão. Belo Horizonte, Ed. UFMG, 2001.

DUBOIS, J. Et allii. Retórica geral. São Paulo, Cultrix-Edusp, 1974.

Retórica da poesia: leitura linear, leitura tabular. Cultrix-Edusp, 1980.

DUBOIS, Philippe. O ato fotográfico. Campinas, Papirus, 2006. 
ECO, Umberto. Tratado geral de semiótica. São Paulo, Perspectiva, 2003.

EICHENDORFF, Joseph von. Gedichte (Edição de 1841) In Die digitale Bibliothek der deutschen Lyrik. Berlin, Directmedia, 2003.

ENTLER, Ronaldo. "O corte fotográfico e a arepresentação do tempo pela imagem fixa." In Studium, Campinas, v. 18, 2004. (www.studium.iar.unicamp.br/18/03.html)

ERMATINGER, Emil. Barock und Rokoko in der deutschen Dichtung. Leipzig, B.G, Teubner, 1928.

FAIRCLOUGH, Norman. Language and Power. London/New York, Longamann, 1995.

FARINACCIO, Pascoal. A questão da representação e o romance brasileiro contemporâneo, 2004, Tese (Teoria Literária), Unicamp, Campinas.

FÄRBER, Mathias. Zweiter Weltkrieg in Bildern. Sttutgart, Unipart Verlag, 1990.

FERRAZ, Maria Cristina Franco. "Tecnologias, memória e esquecimento: da modernidade à contemporaneidade", Revista FAMECOS, Porto Alegre, 49-57, 2005.

FIGUEIREDO, Fernando Antônio. Curso de Teologia Patrística l: a vida da Igreja primitiva (séculos I e II). Petrópolis, Vozes, 1986.

FIGUEIREDO, Fidelino de. A luta pela expressão: prolegômenos para uma filosofia da literatura. $3^{\underline{a}}$ ed. São Paulo, Cultrix, 1973

FLEMING, Paul. Deutsche Gedichte. In Die digitale Bibliothek der deutschen Lyrik. Berlin, Directmedia, 2003.

FLEMMING, Willi. Deutsche Kultur im Zeitalter des Barock. Potsdam, Akademische Verlagsgesellschafte Athenaion, 1937.

FLUSSER, Vilém. Hacia una filosofía de la fotografía. México, Trillas-Sigma, 1990.

FOERSTER, Rolf H. Die Welt des Barocks. Max Hueber Verlag, München, 1977.

FOUCAULT, Michel. As palavras e as coisas. Lisboa, Portugália-Martins Fontes, 1966.

FRICKE, Gerhard. Deutsche Barockforschung. Köln, Kiepenheuer und Witsch, 1970.

FRIEDELL, Egon. Kulturgeschichte der Neuzeit: Die Krise der europäischen Seele von der schwarzen Pest bis zum ersten Weltkrieg. München, Beck, 1969.

FREUND, Michael. Deutsche Geschichte. München, Paul List Verlalg, 1969.

GAEDE, Friedrich."Gryphius und Grimmelshausen als Kritiker des endlichen Verstandes". Simpliciana II, Bern: 43-52, 1980.

GARCIA, Alicia Olabuenaga. "De la Tecnica a la Techne". In A Parte Rei. Revista de Filosofía no 1, Madrid, 1997. (http://serbal.pntic.mec.es/ cmunoz11/techne.html)

GERHARDT, Paul. Gedichte. In Die digitale Bibliothek der deutschen Lyrik. Berlin, Directmedia, 2003.

GEISS, Imanuel. Geschichte griffbereit. Band 5: Staaten: die natiole Dimension der Weltgeschichte. Hamburg, 1987.

GOMES, Álvaro Cardoso. O poético: magia e iluminação. São Paulo, Perspectiva, 1989.

GONÇALVES, Márcia C. F. "A recusa da teoria da mímesis pelas teorias estéticas na virada dos séculos XVII e XIX e suas conseqüências". In DUARTE, Rodrigo. FIGUEIREDO, Virgínia (org.) Mímese e expressão. Belo Horizonte, Ed. UFMG, 2001. 
GONZÁLES DE ZÁRATE, Jesús María. "Lo emblemático, lo mitológico y lo onírico en la pintura de Goya: el pintor y la visión del Príncipe". In Cuadernos de arte e Iconografía. Tomo VIII - 16, Madrid, 1999.

GRACIÁN y MORALES, Baltasar. Agudesa y arte de ingenio. Madrid, Castalia, 1987.

GREEN, Vivian H. Hooward. Renascimento e Reforma: a Europa entre 1450 e 1660. Lisboa, Publicações Dom Quixote, 1984.

GREIFFENBERG, Catharina Regina von. Geistliche Sonnette, Lieder und Gedichte, S. 198.

GREIMAS, Algirdas J. Semiótica e ciências sociais. São Paulo, Cultrix, 1981.

Ensaios de semiótica poética. São Paulo, Cultrix-Edusp, 1975.

GRIEGO, ALFREDO. "Comunicação por imagem fotográfica na internet: mudança de paradigma". In Alceu, v. 6, n. 12, Rio de Janeiro, 99-114, 2006.

"Livro de emblemas: pequeno roteiro de Alciati à Iconologia de Cesare Ripa". In

Alceu, v. 3, n. 6, Rio de Janeiro, 79-92, 2003.

GRILLPARZER, Franz. Gedichte, In Die digitale Bibliothek der deutschen Lyrik. Berlin,

Directmedia, 2003.

GRYPHIUS, Andreas. Gesammtausgabe der deutschsprachigen Werke (hrsg. Marian Szyrocki): Sonnete. Tübingen, Max Niemeyer, 1963, v.1, 273 p.

Gesammtausgabe der deutschsprachigen Werke (hrsg. Marian Szyrocki) : Oden und Epigramme. Tübingen, Max Niemeyer, 1964, v. 2, 244 p.

Gesammtausgabe der deutschsprachigen Werke (hrsg. Marian Szyrocki) :

Vermischte Gedichte. Tübingen, Max Niemeyer, 1964, v. 3, 217 p.

Werke in einem Band. Leipzig, Aufbau Verlag, 1987.

Wenn mir der Himmel bleibt - Gedicht. Köln, Verlag Jacob Hegner, 1962.

Weltgeschick und Lebenszeit: Ein schlesicher Barockdichter aus deutscher und

polnischer Sicht (hrsg. Von der Stiftung Gerhart-Hauptmann-Haus). Düsseldorf, Droste Verlag, 1993.

HANSEN, João Adolfo. Alegoria: construção e interpretação da metáfora. São Paulo, Atual, 1986.

HEGEL, Georg W. Friedrich. Os pensadores: Hegel. São Paulo, Nova Cultural, 1999.

HEINE, Heinrich. Buch der Lieder. In Die digitale Bibliothek der deutschen Lyrik. Berlin, Directmedia, 2003.

HELBO, André. Semiologia da representação. São Paulo, Cultrix, 1980.

HENNIG, Friedrich-Wilhelm. Das vorindustrielle Deutschland 800 bis 1800 . Paderborn, Ferdinand Schöningh, 1974.

HENSEL, Luise. Lieder (Edição de 1879) . In Die digitale Bibliothek der deutschen Lyrik. Berlin, Directmedia, 2003.

HERDER, Johann Gottfried. Gedichte, In Die digitale Bibliothek der deutschen Lyrik. Berlin, Directmedia, 2003.

HOFFMANNSWALDAU, Christian Hoffmann von. Gedichte aus Neukirchs Anthologie, v. 1. In Die digitale Bibliothek der deutschen Lyrik. Berlin, Directmedia, 2003. 
Sinnreiche Heldenbriefe. In Die digitale Bibliothek der deutschen Lyrik. Berlin, Directmedia, 2003.

ISER, Wolfgang. O ato de leitura: uma teoria do efeito estético. Vol. 2. São Paulo, Ed. 34, 1999. JAKOBSON, Roman. Lingüística e Comunicação. São Paulo, 2005.

JAUSS, Hans Robert et alii. A literatura e o leitor: textos de estética da recepção. Rio de Janeiro, Paz e Terra, 1979.

JÖNS, Dietrich Walter. "Das sinnen-Bild": Studien zur allegorischen Bildlichkeit bei Andreas Gryphius. Stuttgart, J.B. Metzlersche Verlagsbuchhandlung, 1966.

KANT, Immanuel. Os pensadores: Kant. São Paulo, Nova Cultural, 1999.

KEEGAN, John. Uma história da guerra. São Paulo, Cia das Letras, 2006.

KENKEL, Konrad O. "Was liefert dir die Welt? Rauch, Nebel, und Gedichte: Die Lyrik des Andreas Gryphius." Text + Kritik: Zeitschrift für Literatur, München, (7/8): 85-93, março de 1980. KLAJ, Johann. Redeoratorien. In Die digitale Bibliothek der deutschen Lyrik. Berlin, Directmedia, 2003.

KLEIN, Johannes. Geschichte der deutschen Lyrik. Wiesbaden, Franz Steiner Verlag, 1957.

KRAUSS, Rolf. H. Photographie \& Literatur. Zur photographischen Wahrnehmung in der deutschsprachigen Literatur des neunzehnten Jahrhunderts. Ostfildern, Hatje Cantz Verlag, 2000.

KUHLMANN, Quirinus. Der Kühlpsalter, v. 1. In Die digitale Bibliothek der deutschen Lyrik. Berlin, Directmedia, 2003.

LADEIRA, Julieta de Godoy. Criação de propaganda. 4ª ed. São Paulo, Global, 1997.

LAÍLLA, Luis Sánchez. "'Dice Aristóteles': la reescritura de la Poética en los Siglos de Oro". in Criticón. Número 79, Madrid (?), CVC - Centro Virtual Cervantes, 2000.

LAUSBERG, Heinrich. Elementos de retórica literária. Lisboa, Fund. Calouste Gulbenkian, 1993.

LESSING, Gotthold E. Laocoonte ou sobre as fronteiras da pintura e da poesia. São Paulo, lluminuras, 1998.

LEVIN, Samuel. Estruturas lingüísticas em poesia. São Paulo, Cultrix, 1975.

LIMA, Oliveira. Histórica da civilização. São Paulo, Melhoramentos, 1922.

LOGAU, Friedrich von. Sinngedichte In Die digitale Bibliothek der deutschen Lyrik. Berlin, Directmedia, 2003.

LOHENSTEIN, Daniel Caspar. Gedichte. In Die digitale Bibliothek der deutschen Lyrik. Berlin, Directmedia, 2003.

LOPES, Ruy Sardinha. A imagem na era de sua reprodutibilidade eletrônica. Dissertação de mestrado apresentada à Universidade de São Paulo, 1995.

LOTMANN, Jurij M. Die Struktur literarischer Texte. München, Wilhelm Fink Verlag, 1981. HORAPOLO. Hiroglyphica. Madrid, Ediciones Akal, 1991.

MACHADO, Arlindo. A ilusão especular: introdução à fotografia. São Paulo, Brasiliense, 1984. "A emergência do observador", in Galaxia no 3, São Paulo, 2002. 
MANGUEL, Alberto. Uma história da leitura. São Paulo, Companhia das Letras, 1997.

MARAVALL, José Antonio. A cultura do Barroco: análise de uma estrutura histórica. São Paulo, 1997.

MARTINS, Wilson. História da inteligência brasileira: (1550-1794). São Paulo, Cultrix, 1978, v. $1,585 p$.

MATOS, Gregório de. Obra poética vol. 1 (Ed. James Amado). Rio de Janeiro, Record, 1990. .. Obra poética vol. 2 (Ed. James Amado). Rio de Janeiro, Record, 1990.

MAUSER, Wolfram. Dichtung, Religion und Gesellschaft im 17. Jahrhundert: Die Sonnete des Andreas Gryphius. München, Wilhelm Fink Verlag, 1976.

MENDES, Norma Musco. "As relações políticas entre o Princepse o Populus Romanum através do 'transcrito público'”. In Hélade 2 (1) 2001.

(http://www.heladeweb.net/N1\%202001/norma musco mendes 2001.htm)

MCEVEDY, Colin. Atlas da História Medieval. São Paulo, Verbo, 1990.

MICHELSEN, Peter. "Vom recht auf widerstand in Andreas Gryphius' Aemilius Paulus Papinianus". Simpliciana XVII, Bern: 45-70, 1995.

MOISÉS, MASSAUD. A criação literária. São Paulo, Melhoramentos, 1975.

A criação poética. São Paulo, Melhoramentos/EDUSP, 1977.

Dicionário de termos poéticos. São Paulo, Cultrix, 1992.

A literatura portuguesa através dos textos. São Paulo, Cultrix, 2000.

MURICY, Kátia. Alegorias da dialética. Rio de Janeiro, Relume Dumará, 1999.

NEUKIRCH, Benjamim. Gedichte. In Die digitale Bibliothek der deutschen Lyrik. Berlin, Directmedia, 2003.

NIEL, André. A análise estrutural de textos (literatura, imprensa, publicidade). São Paulo, Cultrix, 1978.

NUNES, Ruy Afonso da Costa. "São Boaventura e Aristóteles." In Cadernos de História e Filosofia da Educação, v. IV. FEUSP, São Paulo, 2001.

NUSSBAUM, Martha C.. La fragilidade del bien: Fortuna y ética en la tragedia y la filosofía griega. Madrid, Visor, 1995.

OLIVEIRA, Carla Mary. S. "Dobras e redobras: uma discussão sobre o Barroco e suas interpretações". In Política e trabalho. №. 15, João Pessoa, 1999.

OLIVEIRA, Myriam Andrade R. de. "A escultura devocional na época barroca - aspectos teóricos e funções". In Revista Barroco, Belo Horizonte, v. 18, p. 247-267, 1997

PANOFSKY, Erwin. Significado nas artes visuais. São Paulo, Perspectiva, 2001.

PAZ, Octavio. Signos em rotação. São Paulo, Perspectiva, 1976.

PEIRCE, Charles S. Semiótica. São Paulo, Perspectiva, 2005.

PERVY, Marvin. Civilização Ocidental: uma história concisa. São Paulo, Martins Fontes, 1985.

PESSOA, Fernando (org). Arte no pensamento. Vitória, Fundação Vale do Rio Doce, 2006

PLATÃO. Os pensadores: Platão. São Paulo, Nova Cultural, 1999.

PRAZ, Mário. Imágenes del Barroco (estúdios de emblemática). Madrid, Ed. Siruela, 1989. Literatura e artes visuais. São Paulo, Cultrix, 1982. 
QUEVEDO, Francisco de. Antología poética. Madrid, Espasa, 1975.

RANKE, Leopold von. Deutsche Geschichte im Zeitalter der Reformation. Wien, PhaidonVerlag, s/d.

REBOUL, Olivier. O slogan. São Paulo, Cultrix, s/d.

RIFATERRE, Michael. Estilística estrutural. São Paulo, Cultrix, 1973.

RIPA, Cesare. Iconología (Prólogo de Adita Allo Manero). Tomo I. Madrid, Akal, s/d. Iconología. Tomo II. Madrid, akal, 1987.

ROSA, Ronel Alberti et alii. "Pintando o Deus verdadeiro - Boaventura, Ripa, Pachco - e a teologia da imagem." In Teocomunicação, v. 37, Porto Alegre, 2007.

ROSENFELD, Anatol. Teatro alemão: história e estudos. São Paulo, Brasiliense, 1968.

RÜCKERT, Friedrich. Wanderung. In Die digitale Bibliothek der deutschen Lyrik. Berlin, Directmedia, 2003.

SANGIRORGI, Osvaldo. "Cibernética no mundo contemporâneo". In Scientia, São Paulo, 1991. SILESIUS, Angelus. Cherubinischer Wandersmann. In Die digitale Bibliothek der deutschen Lyrik. Berlin, Directmedia, 2003.

Heilige Seelenlust oder geistliche Hirtenlieder, In Die digitale Bibliothek der deutschen Lyrik. Berlin, Directmedia, 2003.

TAROT, Rolf. "Recht und Unrecht im barocken Trauerspiel, am Beispiel des Carolus Stuardus von Andreas Gryphius“. In Simpliciana IX, Bern: 215-237,1987.

TERSTEEGEN, Gerhard. Geistliches Blumengärtlein. In Die digitale Bibliothek der deutschen Lyrik. Berlin, Directmedia, 2003.

THEODORO, Janice. América barroca: temas e variações. São Paulo, Edusp/Nova Fronteira, 1992.

QUEVEDO, Francisco de. Antología Poética. Madrid, Espasa-Calpe, 1975.

SANCHEZ LAÍLLA, Luis. "Dice Aristóteles: la reescritura de la Poética en los Siglos de Oro". In Criticón 79, Toulose, 9-36, 2000.

SANTAELLA, Lúcia. NÖTH, Winfried. Imagem: cognição, semiótica, mídia. São Paulo, lluminuras, 1998.

SAUSSURE, Ferdinand de. Curso de lingüística geral. São Paulo, Cultrix, 2006.

SELIGMANN-SILVA, Márcio. "Friedrich Schlegel e Novalis: poesia e filosofia". In Terceira Margem: Revista do Programa de Pós-Graduação em Ciência da Literatura, v. 10. Rio de Janeiro, 95-111, 2004.

SHEARMAN, John. O maneirismo. São Paulo, Cultrix, 1978.

SCHILLING, Heinz (et alii). Mitten in Europa. Deutsche Geschichte. Berlin, Wolf Jobst Siedler Verlag, 1987.

SCHØLLHAMMER, KARL. E. "Regimes representativos da modernidade". In Alceu, v. I, n. 2, Rio de Janeiro, 28-41, 2001.

SCHREIBER, Hermann. Die Welt in einem Augenblick. Tübingen/Basel, Horst Erdmann Verlag, $\mathrm{s} / \mathrm{d}$. 
SILVA, Franklin Leopoldo e. Descartes: a metafísica da modernidade. São Paulo, Moderna, 1993.

SIMANKE, Richard. Metapsicologia lacaniana: os anos de formação. São Paulo, Discurso Editorial, Editora UFPR, 2002.

STELZER, Otto. Arte y fotografia: contactos, influencias y efectos. Barcelona, Gustavo Gili, 1981.

STRICKLAND, Carol. Arte comentada: da pré-história ao pós-moderno. Rio de Janeiro, Ediouro, 2002.

SZYROCK, Marian. Andreas Gryphius: Sein Leben und Werk. Tübingen, Max Niemeyer, 1964. TAPIÉ, Victor-Lucien. O barroco. São Paulo, Cultrix, 1983.

TAROT, Rolf. "Die Kunst des Alexandriners im barocken Trauerspiel Andreas Gryphius Papinian“. In Simpliciana XIX, Bern: 125-154, 1997.

TENBROCH, R. Hermann. Historia de Alemanía. München, Max Hueber Verlag, 1968.

VON DER HEYDE, Claudia Brinker. „Freundschaft und grimmer Haß Oder: Die Macht des Wortes im Leo Armenius von Andreas Gryphius“. In Simpliciana XX, Bern: 293-305, 1998.

VISTARINI, Antonio Bernat. "Imago Veritatis. La circulación de la imagen simbólica entre fábula y emblema". In Studia Aurea 1 (2007). Revista de Literatura española y teoría del Renacimiento y Siglo de Oro. ( http://www.studiaaurea.com/pdf/070625110849 ImagoVeritatis.pdf )

WITTGENSTEIN, Ludwig. Investigações filosóficas. Série: Os pensadores. São Paulo, Nova Cultural, 1999.

XAVIER, Ismail. "Cinema: revelação e engano". In NOVAES, Adauto (org). O olhar. São Paulo. São Paulo, Cia. das Letras, 1988.

ZÁRATE, Jesús María González. "Los Hieroglyphica en el contexto cultural y artístico europeo de época moderna". In Cuadernos de arte e iconografía, tomo II - 3, Fundación Universitaria Española, Madrid (?), 1989. (http://www.fuesp.com/revistas/pag/cai0343.html) . "Lo emblemático, lo mitológico y lo onírico en la pintura de Goya: el pintor y la visión del príncipe." In Cuadernos de arte e iconografía, tomo VIII - 16, Fundación Universitaria Española, Madrid (?), 1999. (http://www.fuesp.com/revistas/pag/cai16a.pdf)

ZEENDEN, Ernst Walter. Das Zeitalter der Glaubenskämpfe: 1555-1648. München, Deutscher Taschenbuch Verlag, 1978.

ZILLES, Urbano. "A Iconoclastia". In Revista Teocomunicação, vol. 27, Porto Alegre, 1997. 


\section{BIBLIOGRAFIA ICONOGRÁFICA}

BEIGUELMAN-MESSINA, Giselle. A guerra civil espanhola: 1936-1939. São Paulo, Scipione, 1994.

FÄRBER, Matias. Zweiter Weltkrieg in Bildern. Stuttgart, Unipart Verlag, 1990.

LESTER, Paul. Photojornalism: a ethical approoach. Hielsdale, Lawrence a Erlbaum, 1991.

SALGADO, Sebastião. Exxodos: Sebastião Salgado. São Paulo, Companhia das Letras, 2000.

A Segunda Guerra Mundial (Vol. 1 a 12). Rio de Janeiro, Grolier, 1966.

100 Photos pour la liberté de la presse, Paris (?) 1995.

100 Photos pour la liberté de la presse, Paris, (?), 1998.

Curso completo de fotografia: A fotografia profissional. Rio de Janeiro, Rio Gráfica e Editora, $\mathrm{s} / \mathrm{d}$.

16 años de fotoperiodismo. Madrid/Barcelona, Lunwerg, 1993.

Life library of Photography: Photojornalism. Life Books, Alexandria, 1971.

Revista Der Spiege/ no 39/1988.

Revista Time, de 6/6/1994.

Revista Veja: edições: 1584 (10/02/1999), 


\section{SITES CONSULTADOS}

http://alecrim.inf.ufsc.br/bdnupill/

www.bocc.ubi.pt/

www.bowdoin.edu/dept/library//mc/span311/estrofas.htm

http://www.cisc.org.br

www.compos.org.br

www.cotianet.com.br/photo/hist/

http://diglib.hab.de/

www.digital-designs.de/fabian.ahrendts/downloads/handout.vortrag.digitalfotografie-

geschichte technik aesthetik.pdf

www.diglib.hab.de/drucke/

www.ditzelphotography.com/essays robinson.html

http://edoc.hu-berlin.de

http://emblems.let.uu.nl

www.fotolab.com.br/interna.asp

www.fotoreal.com.br/historia.htm

http://www.fuesp.com

www.gargoris.cpd.um.es

www.glatt.com.br/tec lito.asp

http://greciantiga.org

www.hs-augsburg.de/ harsch/a alpha.html

www.heladeweb.net

www.herbario.com.br/cie/universi/teoriacont/0103fot03.htm

http://images. library.uiuc.edu:8081/cdm4/document.php?CISOROOT=/emblems\&CISOPTR=10 $\underline{35 \& R E C=17}$

www.kodak.com/BR/pt/fotografia/historia/tehistoria01.shtml

www.maxwell.lambda.ele.puc-rio.br

www.members.tripod.com/fotografia.htm

http://media.library.uiuc.edu/projects/oebp/SPT--Home.php

www.mnemosyne.org/

www.motivaete.com/cap01.html

www.multiculturas.com/retorica/introd.htm

www.mun.ca/alciato/

http://omega.ice.edu.mx

www.ph-freiburg.de/deutsch/texte/wichert.htm

http://pintura.aut.org/

www.psiqweb.med.br/cursos/linguag.html

http://reposcom.portcom.intercom.org.br/

www.rediris.es/rediris/boletin/38/ponencia6.html 
http://html.rincondelvago.com/historia-de-lacomunicacion-audiovisual.html

http://rosalia.dc.fi.udc.es/emblematica/

www.studiaaurea.com/pdf/070625110849 ImagoVeritatis.pdf

www.studium.iar.unicamp.br

www.sbmri.org.br/page7ptadao.htm

www.textlog.del

www.tsunamis.com/tsunami-pictures.html

www.ucm.es/info/folchia/lecturas.htm

www.uni-essen.de/literaturwissenschaft-aktiv/Vorlesungen/poetik/arpoetik.htm

www.uni-mannheim.de/mateo/desbillons/symbol.html

www.user.gwdg.de/ sbarbar/szyrocki.pdf

www.utem.cl/trilogia/volumen 12n/p 12 2.htm

www.waste.informatik.hu-berlin.de/mtg/archiv/1 amelunx.htm

www.zonezero.com/exposiciones/fotografos/jurado/libro/pag1sp.html 